\title{
Modernidade, \\ Cinema e Temporalidade
}

000000000000000000000000000000

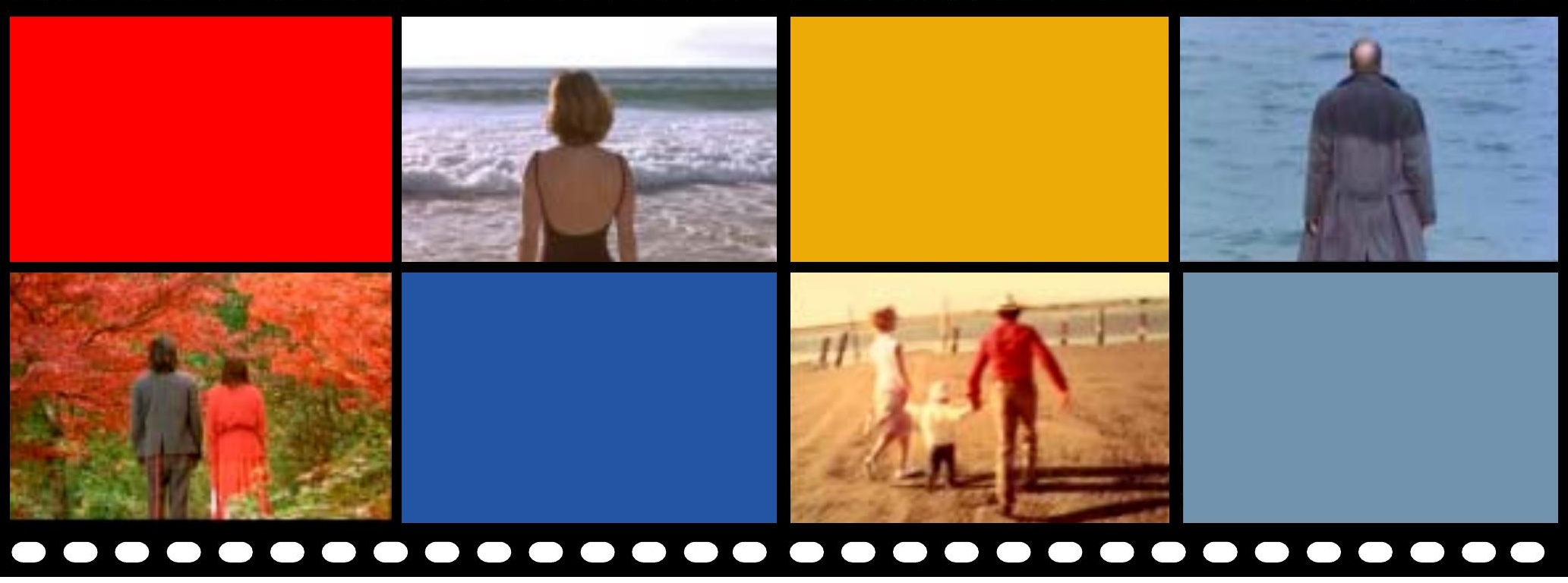

MAÍRA SARUÊ MACHADO

Faculdade de Filosofia, Letras e Ciências Humanas

Universidade de São Paulo 
UNIVERSIDADE DE SÃO PAULO

FACULDADE DE FILOSOFIA, LETRAS E CIÊNCIAS HUMANAS

DEPARTAMENTO DE SOCIOLOGIA

PROGRAMA DE PÓS-GRADUAÇÃO EM SOCIOLOGIA

MAÍRA SARUÊ MACHADO

Modernidade, cinema e temporalidade 
MAÍRA SARUÊ MACHADO

Modernidade, cinema e temporalidade

Dissertação apresentada ao Departamento de Sociologia da Faculdade de Filosofia, Letras e Ciências Humanas da Universidade de São Paulo para a obtenção do título de Mestre.

Orientador: Prof. Dr. Paulo Menezes

São Paulo

2007 
contato: mairasarue@yahoo.com.br 
Viajo para conhecer minha geografia.

A todos aqueles que, desraigados, conseguem, em busca de si, rodar o mundo numa vida errante. 
Saber orientar-se numa cidade não significa muito. No entanto, perder-se numa cidade, como alguém se perde numa floresta, requer instrução. Nesse caso, o nome das ruas deve soar para aquele que se perde como o estalar do graveto seco ao ser pisado, e as vielas do centro da cidade devem refletir as horas do dia tão nitidamente quanto um desfiladeiro. Essa arte aprendi tardiamente; ela tornou real o sonho cujos labirintos nos mata-borrões de mens cadernos foram os primeiros vestígios.

Walter Benjamin, "Tiergarten" 


\section{Agradecimentos}

Muitas pessoas foram fundamentais durante o processo de elaboração desta pesquisa. A lista é extensa, mas sempre resta alguém num esquecimento temporário, e desde já me desculpo.

Agradeço ao Paulo Menezes, que me orientou e me incentivou, enriquecendo assim meu percurso acadêmico.

À minha mãe, Yvonne, que me apoiou desde o início, me incentivando em todas as etapas. E que leu carinhosa e atentamente todos os capítulos de cada etapa desta pesquisa. À minha irmã, Joana, que parecia mais feliz do que eu com meu ingresso no Mestrado, e que por fim enredou para esse caminho acadêmico. Ao meu pai, Cleber, que me incentivou e me acompanhou, dialogando nos encontros possíveis entre a Arquitetura e a Sociologia. Às minhas avós, que às suas maneiras tão distintas - me deram força: à Ely pela acolhida nos feriados e fins-de-semana finais, dando-me todo o cuidado que eu precisava naquele momento. E por levar pipoca enquanto eu escrevia. À Gerty pelos filmes e livros que me deu, e pelo constante interesse nesta minha caminhada. A Lita, Osmar e Shlomo, que me inspiram a cada lembrança. Agradeço também àqueles que se juntaram à minha família, e que me são igualmente essenciais: Bacha, Yasuko e Alex.

Aos amigos de todas as horas, presentes desde os primeiros passos: Gustavo, Galiana, Cristina, Débora, Daniel A., Smeg, Rodrigo, Guilherme. Aos amigos dos últimos tempos, mas igualmente fundamentais: Dmitri, Célia, Aninha (a quem sou enormemente grata pela ajuda na reta final), Lili, David, Maurício, Sara, Marie, Diego, André, Leo S. À Rita, que me introduziu no universo da Psicanálise. A Dilma, Elba e Elzi. À Ruth Simis pelo livro e interesse; ao Leo N. pelos filmes; ao Marinho pelas cópias; ao Adriano pelas discussões acadêmicas e gramaticais fortuitas, e pela revisão da qualificação; ao Renato, pela acolhida; ao Daniel B. pela ajuda e incentivo.

Ao G.E.I. e ao "grupo do Paulo", sobretudo Anderson, Edilson, Marina, Daniela, Michelle. Ao Alexandro.

Aos professores com quem tive aula no Mestrado: Sedi Hirano, Flavio Pierucci e José Sérgio Carvalho. Aos professores José Carlos Bruni e Mauro Rovai pelos cuidadosos comentários no exame de qualificação.

Por fim, agradeço às funcionárias do Departamento de Sociologia da USP: Ângela, Irani e Juliana

E à Capes, pelo financiamento da pesquisa. 


\title{
Resumo
}

Esta pesquisa tem por objetivo entender, por meio da análise fílmica, as formas como a temporalidade está presente no imaginário social na modernidade. Para isso, foi inicialmente elaborada uma abordagem histórica da constituição da temporalidade moderna, refletindo sobre a perda da narrativa, e da tradição e as mudanças no significado da morte.

A análise dos filmes Dolls, Paris, Texas, Sob a areia e A eternidade e um dia vêm mostrar formas de temporalidade que se apresentam como contraponto àquela hegemônica na modernidade. Em seus temas, são abordados os elementos de ruptura: a errância, o desenraizamento, o luto e a rememoração.

Palavras-chave: temporalidade; modernidade; Sociologia do Cinema; Walter Benjamin; errância

\begin{abstract}
This thesis seeks to understand, through filmic analysis, the ways in which temporality is present in the social imaginary of modernity. To do so, it initially elaborates a historic approach to the construction of modern temporality, reflecting on the loss of narrative, tradition and the changing meaning of death.

The analysis of the four films Dolls, Paris, Texas, Under the Sand and Eternity and a Day demonstrates forms of temporality that are presented as a counterpoint to that which is hegemonic in modernity. The key themes approached are elements of rupture: wandering, uprooting, mourning and remembering.
\end{abstract}

Keywords: temporality; modernity; Sociology of Cinema; Walter Benjamin; wandering 


\section{Sumário}

Apresentação

03

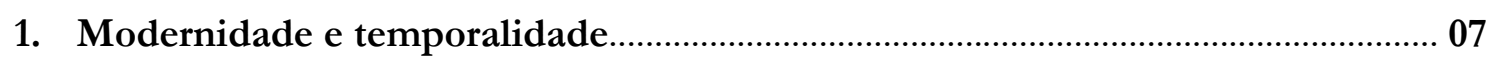

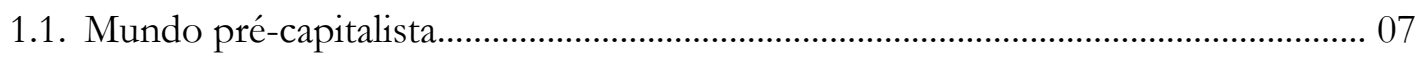

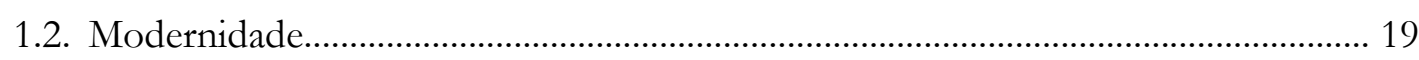

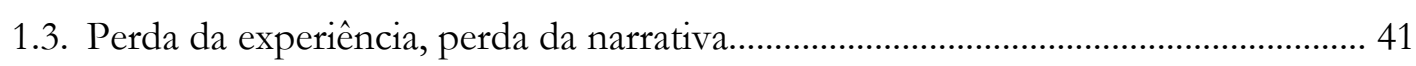

2. Espera e errância - saída da temporalidade moderna em Dolls............................ 47

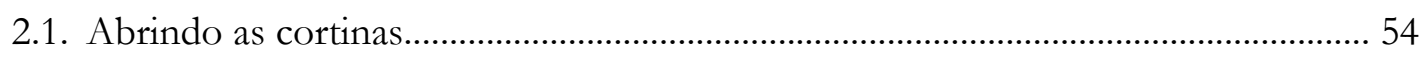

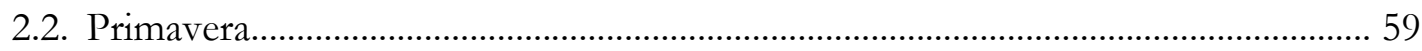

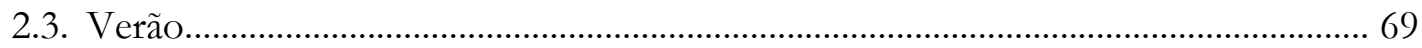

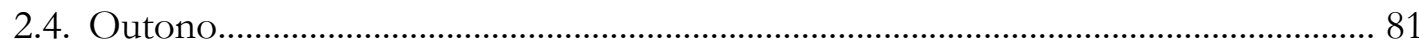

2.5. Inverno

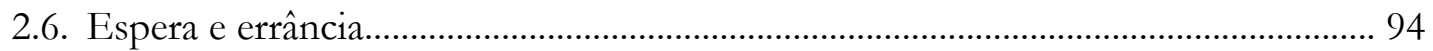

3. Errância, itinerância, melancolia e silêncio: bem-vindo a Paris, Texas ............... 98

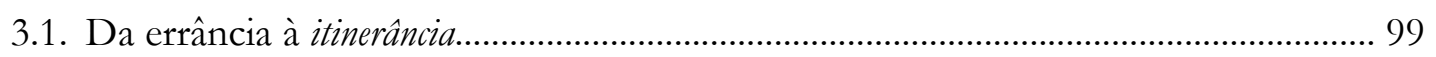

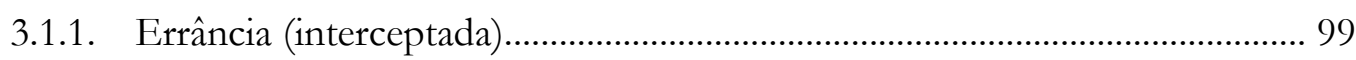

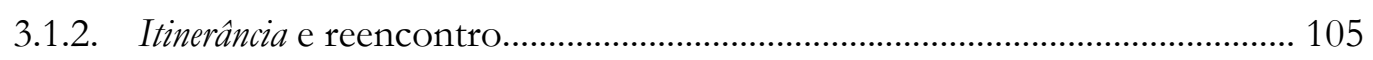

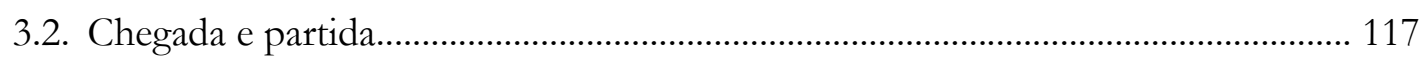

3.2.1. Chegada pela estrada...................................................................................... 117

3.2.2. Reconstrução da família pela imagem................................................................. 120

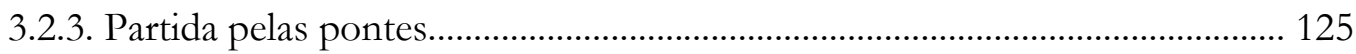

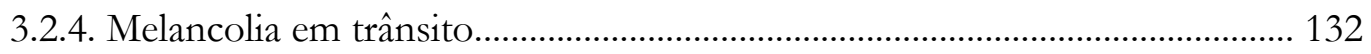

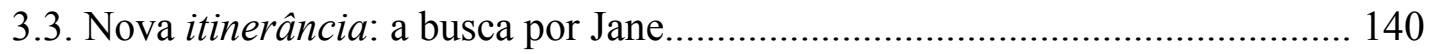

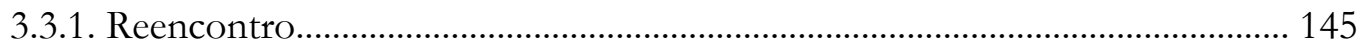

3.3.2. Comunicação permeada pela técnica................................................................... 151

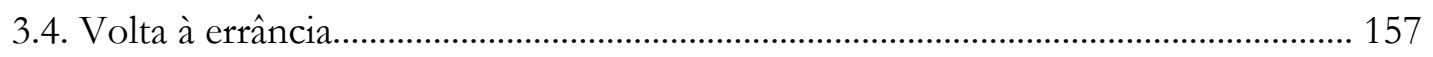




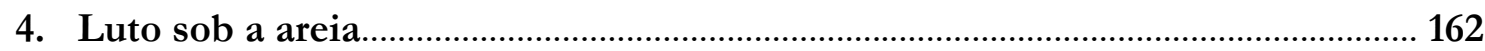

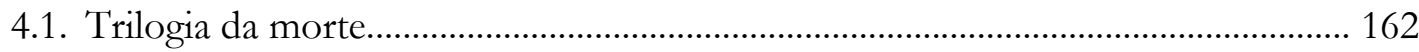

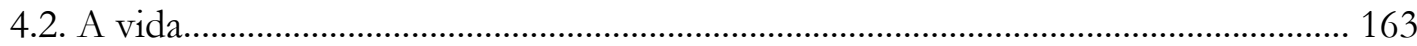

4.3. "Já não são as crianças que nascem dentro de repolhos, mas os mortos que desaparecem por entre as flores".................................. 169

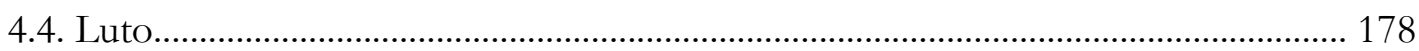

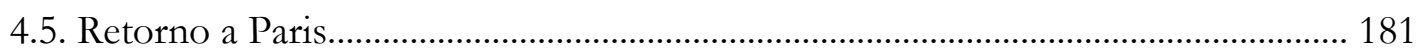

4.6. Morte sem corpo................................................................................................................ 203

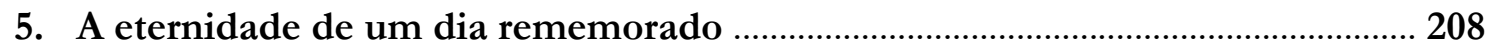

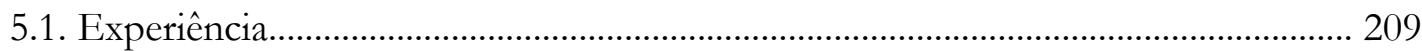

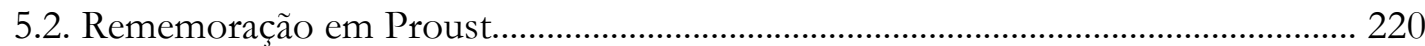

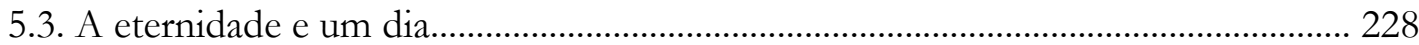

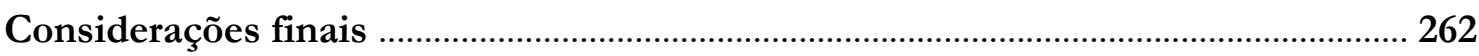

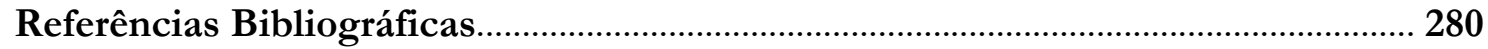

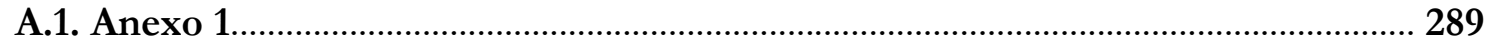

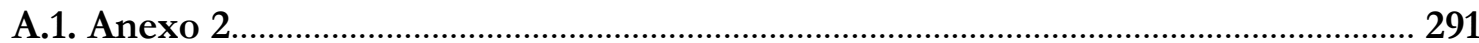

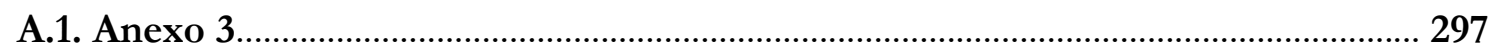

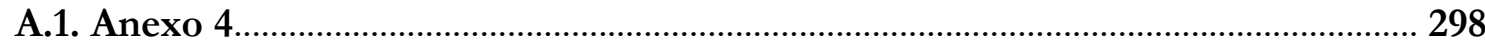




\section{Apresentação}

No mundo moderno, com freqüência ouvimos queixas sobre a escassez de tempo, e somos mesmo acometidos por um sentimento de que nunca conseguimos fazer tudo aquilo que gostaríamos. Mas nem sempre nos perguntamos: por que o tempo corre?

As pessoas, hoje, têm a percepção de que "o tempo voa". A celeridade do tempo tornou obsoleto, senão quase impossível, o planejamento do futuro: da mesma maneira, acabou por impedir quase totalmente o aproveitamento bem sucedido da experiência passada. O agora converteu-se em absoluto, o que exaspera a necessidade de consumi-lo exaustivamente. "Ganhar" tempo e não "perdê-lo" tornou-se uma obsessão das pessoas: elas são esmagadas pelos ritmos e pelos programas que se lhes impõem através de todas as malhas sociais, tanto no trabalho quanto fora dele. A necessidade de uma boa gestão do tempo é internalizada, como o são todas as regras sociais mais importantes. Converte-se em imperativo. $[\ldots]^{1}$

"O tempo passa rápido demais", pensamos, sem nos darmos conta de que essa percepção nada mais é do que reflexo da temporalidade sob a qual vivemos, que não é um dado da "natureza", mas um fenômeno socialmente construído.

Foi a intenção de compreender a relação do homem moderno com o tempo em incessante aceleração que despertou o interesse inicial desta pesquisa. Essa inquietação fez-nos pensar sobre a possibilidade de se viver sob uma outra temporalidade, na qual não há pressa e sobra espaço para uma relação mais íntima com o passado. Nesse sentido, o cinema surgiu como espaço interessante para essa busca, pois a própria ida à sala de exibição já condensa uma temporalidade diferente da moderna: entramos na sala para esquecermo-nos de nós mesmos, de nossos problemas, de nossos atrasos.

Jean-Claude Carrière, roteirista que gravou diversos filmes com Buñuel, disse que, no cinema, "acreditamos que estamos vendo e ouvindo, mas parasitas nos invadem, intrusos nos corrompem, e, sem perceber, somos enganados" e, assim, "acabamos tendo prazer na ilusão"2. Por isso é que "consentimos, em geral alegremente, em sermos

\footnotetext{
1 Augusto, Maria Helena Oliva. "O moderno e o contemporâneo: reflexões sobre os conceitos de indivíduo, tempo e morte". In: Tempo Social - Revista de Sociologia da USP. São Paulo, 6 (1-2), 1994 (editado em jun. 1995), p. 98.

${ }^{2}$ CARriÈre, Jean-Claude. A Linguagem Secreta do Cinema. São Paulo: Nova Fronteira, 1995, p. 56.
} 
enganados"3. Ou seja, entramos na sala de cinema para adentrar a vida de cada personagem, para atribuir "realidade" a tudo o que vemos na tela.

Quando estamos na sala de exibição, embora nos esqueçamos do mundo exterior, envelhecemos. E, durante esse período de exibição, esquecemos inclusive que, enquanto estamos lá dentro, o tempo passa, em seu fluxo inexorável, do lado de fora da sala.

[...] Quando saímos para a calçada, no fim da tarde, nos surpreendemos ao ver a noite que se aproxima e as luzes da rua já acesas.

Então, de um salto, envelhecemos. Alcançamos o tempo passado, ou perdido. A ilusão se fende. Foi tudo um engano. ${ }^{4}$

Percebemos, assim, que se expressava no cinema um indício para nos questionarmos sobre uma possibilidade de ruptura temporal na modernidade, de resistência à temporalidade predominante. $O$ passo seguinte foi pensar, sociologicamente, como essa ruptura com a temporalidade moderna poderia estar contida filmicamente. Foi então que passamos a buscar, nos filmes, formas de expressão da temporalidade que se diferenciassem daquela hegemônica na modernidade; formas de representação fílmica dessa ruptura presente no imaginário social.

Primeiramente, procuramos situar historicamente a temporalidade a que estamos submetidos, pensando desde sua construção inicial até sua configuração atual. Para que encontrássemos a formação histórico-social da temporalidade moderna, nos empenhamos inicialmente no estudo acerca da constituição da modernidade. A essa tarefa está dedicado o Capítulo 1 desta dissertação. Tentamos, assim, "desnaturalizar" a percepção de que a temporalidade que vivenciamos existe por si; buscamos caracterizar a temporalidade moderna, à qual estamos subjugados, e situá-la historicamente partindo inicialmente da narrativa benjaminiana e da vida à época de ouro da narrativa, quando se dava a experiência coletiva e uma relação mais intensa com o passado.

Esse empenho serviu também para nos elucidar que a característica aporética que comumente se atribui ao mundo contemporâneo é fruto de um desenraizamento que acomete seus indivíduos. Como não temos mais a narrativa, transmitida de geração em

\footnotetext{
${ }^{3}$ CARrière, Jean-Claude. A Linguagem Secreta do Cinema. op. cit., p. 57.

${ }^{4}$ CARriÈre, Jean-Claude. A Linguagem Secreta do Cinema. op. cit., p. 123.
} 
geração, para indicar uma tradição que nos oriente, não vivemos mais uma experiência coletiva, mas, antes, um agrupamento de fatos sem sentido.

Nos filmes escolhidos, esse desarraigamento é, entretanto, ambíguo, pois ao mesmo tempo gera a possibilidade da liberdade de se desvincular do local de origem, e uma perda de referências que pode levar o indivíduo a uma profunda solidão. Esse desenraizamento pode se expressar, também, na desvinculação do indivíduo da temporalidade dominante na modernidade - e aqui foi que buscamos pontos de resistência à temporalidade hegemônica.

Com o posterior estudo da instauração da modernidade, pudemos situar a quebra dessa relação temporal no século XIX. Buscamos nos aprofundar na pesquisa sobre a implementação do paradigma da modernidade a partir de Paris, cidade que julgamos exemplar de uma aceleração do ritmo temporal que seguia preceitos vindos do Iluminismo e foi disseminada pelo mundo.

Passamos, então, a buscar nos filmes a possibilidade de expressão de uma temporalidade distinta daquela que prevalece na modernidade - que a própria ida ao cinema, como vimos, propõe ao espectador, com a pausa por (no mínimo) uma hora e meia para a crença em uma história que se sabe ficcional. Buscamos, então, no objeto fílmico, a expressão de uma ruptura com a temporalidade do incessantemente novo sob a qual vivemos - e, para isso, selecionamos uma amostra com filmes cuja narrativa constrói uma articulação temporal diferente daquela do progresso.

Os filmes que encontramos tratam de uma temporalidade vivida como resistência à aceleração temporal hegemônica da modernidade, a partir sobretudo do desenraizamento dos protagonistas.

Dolls apresenta a temporalidade de um presente imediato baseado na perda da memória e na errância dos protagonistas. Os personagens errantes se misturam às paisagens que mudam a cada nova estação do ano.

Em Paris, Texas a errância também está presente, é fruto do desenraizameto do protagonista que, embora evoque elementos de seu passado, tem seu cotidiano preso essencialmente à temporalidade do presente.

Já Sob a areia mostra uma relação temporal na qual a insistência em um dos elementos do passado é mantida, a despeito de diversos elementos da realidade provarem o contrário. Assim, sem a presentificação dessa falta, a temporalidade fica aberta à dimensão passada, diferenciando-se daquela corrente na modernidade. 
No último filme aqui analisado, A eternidade e um dia, traçamos um paralelo entre o conceito benjaminiano de experiência e a rememoração, de modo que o capítulo mostrasse a possibilidade de se transformar o presente no qual vivemos através de sua abertura temporal.

Esta dissertação mostra-se, pois, como uma possibilidade de entendermos de algumas das representações sociais que rompem com o ciclo irrefreável da modernidade, como uma operação de resistência humana frente à vinda do incessantemente novo. 


\section{Modernidade e temporalidade}

\subsection{Mundo pré-capitalista}

É queixa comum, hoje, o sentimento de uma aceleração do tempo e de que a vida está esvaziada de sentido. Tais sensações resultam das mudanças ocorridas ao longo da modernidade; apontando seu surgimento histórico, é possível perceber que tais sentimentos nem sempre existiram - há uma série de fatores (históricos, políticos, sociais, etc.) que contribuíram para formar tal percepção social. Observar o período que antecede a modernidade ajuda a identificar os elementos que mudaram com a sua instauração.

Como eixo para essa discussão, será abordado o filósofo Walter Benjamin, mais precisamente seu ensaio chamado O Narrador - Considerações sobre a obra de Nikolai Leskov $^{1}$, no qual Benjamin caracteriza o período pré-industrial pela existência de uma experiência que dotava as comunidades de uma relação com o tempo diferente da atual. A forma de comunicação literária marcante nesse período que precede a emergência da modernidade é a narrativa oral. Benjamin se dedica à narrativa e à figura do narrador em seu ensaio sobre Nikolai Leskov ${ }^{2}$ para tocar em uma conseqüência fundamental que a modernidade - com suas exaustivas mudanças e valorização da técnica - acarretou: a perda da experiência. Benjamin destaca características expressivas do período em que se transmitiam as narrativas, como o senso de coletividade presente na vida social, o lento ritmo com que ocorriam as mudanças (a vida não mudava tanto a cada geração) e uma relação com a morte que tinha fundamento coletivo, sem o atual isolamento dos moribundos. Na presença desses elementos, por meio da narrativa transmitia-se a experiência de geração em geração.

As narrativas eram histórias contadas oralmente, coletivamente criadas e ouvidas, que transmitiam um saber por todos partilhado. Tiveram sua época áurea quando o tipo

\footnotetext{
1 Tal ensaio foi escrito em 1936. Foram consultadas, para esta pesquisa, duas traduções da obra: BENJAMIN, Walter. "O Narrador - Considerações sobre a obra de Nikolai Leskov". In: Obras escolhidas, volume I-Magia e técnica, arte e política. São Paulo: Brasiliense, 1994, pp. $197-221$ e BENJAMIN, Walter. "O Narrador - Observações sobre a obra de Nikolai Leskow". In: BENJAMIN, Horkheimer, Adorno et Habermas. Textos escolhidos. Coleção “Os pensadores”. São Paulo: Abril Cultural, 1975, pp. 63-81. Para simplificar a leitura, as referências seguem a edição contida nas Obras escolhidas.

${ }^{2}$ Considerado por Benjamin um narrador, Nikolai Leskov nasceu na Rússia, em 1831, e lá morreu em 1895. Embora Leskov tenha escrito romances, ao analisá-lo Benjamin refere-se apenas às suas narrativas (Cf. BENJAMIN, W. “O Narrador - Considerações sobre a obra de Nikolai Leskov”. op. cit., p. 197).
} 
de trabalho predominante era o artesanal, ou seja, antes da industrialização moderna, quando a produção de mercadorias era manual e se dava nas oficinas.

Os antigos narradores transmitiam um conhecimento ao contarem histórias dotadas de uma sabedoria que vinha da experiência coletiva, oralmente comunicável de pessoa a pessoa. No narrador interpenetravam-se duas figuras: o homem que fizera uma longa viagem, e que portanto tinha o que contar sobre lugares distantes, e aquele que pouco saíra de onde nasceu, e que portanto conhecia a fundo as histórias de sua terra, e tinha o que contar sobre ela ${ }^{3}$. Ou seja, o narrador (um dos "inúmeros narradores anônimos"4 que contavam as histórias para um grupo) era um homem que, em sua viagem - no tempo ou no espaço -, colhia ensinamentos para narrar, e por isso tinha algo a dizer para uma comunidade de ouvintes.

Ao contrário do que ocorre nos dias de hoje com a informação - que deve ser comprovada científica ou factualmente para que seja validada - era a própria distância que dotava a narrativa de autoridade. Um saber que vinha de longe, o conteúdo narrado dispensava qualquer tipo de comprovação e não perdia sua validade; diferente da informação, a narrativa não se exauria mesmo depois de passado muito tempo ${ }^{5}$.

Assim como a história contada pertencia ao narrador e aos ouvintes, eles a essa pertenciam. A marca do narrador ficava impressa em sua narrativa, e cada ouvinte mergulhava a história em sua própria existência vivida, para depois recontá-la. Isso porque, para não se perder, as narrativas deveriam ser recontadas quantas vezes fossem possíveis e, para tal, seus ouvintes (futuros narradores) deveriam memorizá-las. Para facilitar sua gravação por um ouvinte, era desejável que a história não tivesse muitas explicações psicológicas, o que também permitia sua validade mesmo depois de passado muito tempo desde seu surgimento. Metade da arte de narrar estava aí - na privação de explicações enquanto ela era (re)produzida. Nas palavras de Benjamin:

Nada facilita mais a memorização das narrativas que aquela sóbria concisão que as salva da análise psicológica. Quanto maior a naturalidade com que o narrador renuncia às sutilezas psicológicas, mais facilmente a história se gravará na memória do ouvinte, mais completamente ela se assimilará à sua

\footnotetext{
${ }^{3}$ Cf. Benjamin, W. "O Narrador - Considerações sobre a obra de Nikolai Leskov". op. cit., pp. 198-199.

${ }^{4}$ BENJAMIN, W. "O Narrador - Considerações sobre a obra de Nikolai Leskov". op. cit., p. 198.

${ }^{5}$ Cf. BENJAMIN, W. "O Narrador - Considerações sobre a obra de Nikolai Leskov". op. cit., p. 204.
} 
própria experiência e mais irresistivelmente ele cederá à inclinação de recontá-la um dia. $[\ldots]^{6}$

Tal ausência de amarrações psicológicas, típica da narrativa, é o que Jeanne Marie Gagnebin nomeia a dimensão da abertura, que aproxima Benjamin da teoria da "Obra Aberta" de Humberto Ecco. Para ele e para Benjamin, de acordo com a autora, a profusão dos sentidos da obra viria de seu "não-acabamento essencial". Gagnebin situa esse movimento de abertura na própria estrutura da narrativa tradicional ${ }^{7}$.

A narrativa podia ser utilitária e aconselhar porque tinha como base uma experiência que era partilhada pelo narrador e seus ouvintes, construída coletivamente: “O narrador retira da experiência o que ele conta: sua própria experiência ou a relatada pelos outros. E incorpora as coisas narradas à experiência dos seus ouvintes" ${ }^{\prime 8}$. A transmissão da sabedoria vinda da experiência dava à narrativa uma utilidade, presente de forma clara ou oculta, que poderia aparecer em forma de lição de moral, indicação prática, provérbio ou norma de vida ${ }^{9}$.

O conselho era uma proposta oral à continuidade da história que estava sendo narrada; surgia das experiências comunicadas durante a narração. Para que se pudesse aconselhar era preciso, evidentemente, que primeiro se soubesse narrar:

Essa noção de conselho que implica no fato de que uma história possa ser dita, colocada em palavras, supõe antes uma memória, isto é, a ancoragem dos sujeitos numa história constitutiva de si próprios. E se esta história colocada em palavras se faz de uma maneira não definitiva nem exaustiva, mas implicando uma abertura para "seqüências diferentes" e "conclusões desconhecidas", é porque ela supõe a possibilidade de reconstruções dessa história com base em outros pontos de vista. $[\ldots]^{10}$

A assimilação da narrativa pelo ouvinte ficava mais propensa a ocorrer quando o ouvinte estava descontraído, sem seu estado de atenção desperto. O tédio, "ponto mais

\footnotetext{
${ }^{6}$ Benjamin, W. “O Narrador - Considerações sobre a obra de Nikolai Leskov”. op. cit., p. 204.

${ }^{7}$ Cf. GAGNEBIN, Jeanne-Marie. "Prefácio - Walter Benjamin ou a história aberta". In: BENJAMIN, Walter. Magia e técnica, arte e política - Obras escolhidas, volume I. op. cit., pp. 12-13.

${ }^{8}$ BENJAMIN, W. “O Narrador - Considerações sobre a obra de Nikolai Leskov”. op. cit., p. 201.

${ }^{9}$ Cf. Benjamin, W. “O Narrador - Considerações sobre a obra de Nikolai Leskov”. op. cit., p. 200.

${ }^{10}$ CARDoso, Irene. "A narrativa silenciada". In: CARDOSO, Irene et SILVEIRA, Paulo (orgs.). Utopia e mal-estar na cultura: perspectivas psicanalíticas. São Paulo: Hucitec, 1997, p. 176.
} 
alto a que chega a distensão psíquica" ${ }^{\prime 1}$, era a forma marcante da psique no tempo do trabalho artesanal, quando a transmissão da experiência ocorria, por meio da narrativa, enquanto se trabalhava. Quanto mais o ouvinte se esquecia de si durante a narração, mais ele guardava as histórias, e por isso a narrativa é marca de uma época em que o modo de produzir predominante não era industrial, mas sim manual. Os artesãos narravam enquanto produziam seu trabalho. A forma distendida de mentalidade das pessoas sob o domínio dessa temporalidade permitia ao conteúdo narrado obter rápido acesso à dimensão (hoje nomeada como) inconsciente dos ouvintes, que atribuíam significado à história ouvida de acordo com aquilo que haviam vivido anteriormente. $\mathrm{O}$ conteúdo vivido pelos ouvintes era, entretanto, bastante semelhante nessa época, e pouco mudava a cada geração, já que havia pouco espaço para as novidades.

Benjamin vê a própria narrativa como uma forma de comunicação que, em certo sentido, era artesanal. Isso porque cada narrador, como um oleiro com a argila de seu vaso, imprimia suas marcas na narrativa antes de retransmiti-la ${ }^{12}$. Não importava tanto o acontecimento transmitido pela narrativa, mas esse processo no qual ela era recontada ao longo do tempo. Isso porque não havia pressa em concluir a narrativa - era uma época em que o tempo não corria.

É como se, a cada nova vez que se (re)contasse uma história, ela fosse aperfeiçoada pela transmissão de um ensinamento de caráter social. E, nesse processo, a celeridade não era um fator de importância, pelo contrário, era a vasta sobrevivência de uma narrativa (ou seja, sua recontagem exaustiva) que a tornava mais bem-acabada. As narrativas seriam como "pérolas imaculadas, vinhos encorpados e maduros, criaturas realmente completas" ${ }^{\prime 13}$ - produtos formados por uma cadeia de causas que só se rompe quando chega à perfeição.

Benjamin buscou em Paul Valéry a metáfora que aplicou ao processo de recontagem da narrativa:

\begin{abstract}
Iluminuras, marfins profundamente entalhados; pedras duras, perfeitamente polidas e claramente gravadas; lacas e pinturas obtidas pela superposição de uma quantidade de camadas finas e translúcidas... - todas essas produções de uma indústria tenaz e virtuosística cessaram, e já passou o tempo
\end{abstract}

\footnotetext{
${ }^{11}$ BENJAMIN, W. “O Narrador - Considerações sobre a obra de Nikolai Leskov”. op. cit., p.204.

${ }^{12}$ Cf. Benjamin, W. “O Narrador - Considerações sobre a obra de Nikolai Leskov”. op. cit., p. 205.

13 Benjamin, W., referindo-se à passagem de Paul Valéry. In: Benjamin, W. "O Narrador Considerações sobre a obra de Nikolai Leskov". op. cit., p. 206.
} 
em que o tempo não contava. $\mathrm{O}$ homem de hoje não cultiva o que não pode ser abreviado. ${ }^{14}$

A lenta superposição de "camadas finas e translúcidas" citada por Valéry representa para Benjamin "a melhor imagem do processo pelo qual a narrativa perfeita vem à luz do dia, como coroamento das várias camadas constituídas pelas narrações sucessivas" ${ }^{15}$. Isso porque a cada vez que a mesma história era contada, ela ganhava mais uma fina camada, translúcida, que a dotava de maior perfeição, já que havia passado por mais pessoas. Dado o caráter coletivo da narrativa, quanto mais pessoas estivessem envoltas por uma mesma história (que se transformava adquirindo novas camadas, mas cuja essência era a mesma), mais bem-acabada - mais próxima da perfeição - ela estaria. Assim como o oleiro não faz um vaso tão belo se o fizer às pressas, a narrativa precisava de tempo para se aperfeiçoar, a distensão temporal da narrativa não permitia que ela se abreviasse.

A temporalidade socialmente dominante à época da narrativa, que antecedeu a produção industrial, portanto, era a desse tempo que não se apressava, temporalidade distendida que se combinava com o ritmo de feitura do produto do trabalho artesanal. As narrativas demorarem a formarem-se não era um problema para seus contadores e ouvintes, pois elas levavam o tempo necessário para isso, sem que as desejassem completas com maior celeridade.

O tempo das narrativas, diferente do atual, era dotado de eternidade, isto é, por trás das camadas finas e translúcidas nomeadas por Valéry havia a idéia de um tempo eterno - posto que fora da linha temporal unidirecional que hoje predomina - sem início ou fim, não progressivo. Eterno era o que estava "fora do tempo", portanto, uma duração fora da temporalidade corrente ${ }^{16}$.

\footnotetext{
${ }^{14}$ VALÉRY, Paul. Apud: BenJAmin, W. "O Narrador - Considerações sobre a obra de Nikolai Leskov". op. cit., p. 206.

${ }^{15}$ Benjamin, W. “O Narrador - Considerações sobre a obra de Nikolai Leskov”. op. cit., p. 206.

${ }^{16}$ Embora igualados no senso comum e mesmo em alguns de seus sentidos, eternidade e imortalidade se diferem na proposição aqui tratada. Das definições encontradas em dicionários, selecionaram-se as que mais se aproximam da idéia aqui trabalhada, explicitada ao longo do texto. Cf. HoUAISS, Antonio; VILlar, Mauro; et Mello-Franco, Francisco. Dicionário Houaiss da língua portuguesa. Rio de Janeiro: Objetiva, $1^{\text {a }}$ edição, 2001:
}

Eternidade: 1. característica, atributo, qualidade do que não tem início ou fím; 2. duração que não tem começo nem fim, que prescinde de qualquer determinação cronológica. (...), p.1270. Eterno: 1. Fora do tempo, sem início ou fim; 2. Que tem começo mas não tem fim. (...), p.1270.

Imortalidade: 1. Qualidade ou condição de imortal, do que não perece; eternidade (...), p. 1577. Imortal: 1. Que não está sujeito à morte, não mortal; perpétuo, eterno. 2. Que dura ou parece durar infinitamente, infindável; permanente., p. 1577. 
Tomando a Grécia Antiga como foco de estudo, Hannah Arendt define os conceitos de eternidade e imortalidade, bastante distintos à época, mas que, nos dias de hoje, parecem ter o mesmo significado:

Imortalidade significa continuidade no tempo, vida sem morte nesta terra e neste mundo, tal como foi dada, segundo consenso grego, à natureza e aos deuses do Olimpo. Contra este pano de fundo - a vida perpétua da natureza e a vida divina, isenta de morte e de velhice - encontravam-se os homens mortais, os únicos mortais num universo imortal mas não eterno, em cotejo com as vidas imortais dos seus deuses, mas não sob o domínio de um Deus eterno. [...] Inserida num cosmo onde tudo era imortal, a mortalidade tornou-se o emblema da existência humana. Os homens são "os mortais", as únicas coisas mortais que existem porque, ao contrário dos animais, não existem apenas como membros de uma espécie cuja vida imortal é garantida pela procriação. A mortalidade dos homens reside no fato de que a vida individual, com uma história vital identificável desde o nascimento até a morte, advém da vida biológica. Essa vida individual difere de todas as outras coisas pelo curso retilíneo do seu movimento que, por assim dizer, intercepta o movimento circular da vida biológica. É isto a mortalidade: mover-se ao longo de uma linha reta num universo em que tudo o que se move o faz num sentido cíclico ${ }^{17}$.

Assim, imortal era a espécie humana, dada sua continuidade pela procriação. Os homens, entretanto, eram mortais por serem dotados de vida individual. Embora mortais, os homens podiam produzir feitos eternos, que não seriam apenas deles, mas de toda a humanidade, feitos que transcendessem a mortalidade e ingressassem no mundo da eternidade, coletivo e não-perecível:

[...] Contudo, se os mortais conseguissem dotar suas obras, feitos e palavras de alguma permanência, e impedir sua perecibilidade, então essas coisas ao menos em certa medida entrariam no mundo da eternidade e aí estariam em casa, e os próprios mortais encontrariam seu lugar no cosmo, onde todas as coisas são

Cf. FerreIRA, Aurélio B. H. Novo Aurélio Século XXI: o dicionário da língua portuguesa. Rio de Janeiro: Nova Fronteira, $3^{a}$ edição, 1999:

Eternidade: 1. Qualidade ou caráter de eterno. 2. A vida que, para crentes, principia após a morte; a vida eterna. (...), p. 848. Eterno: 1 . Que não tem princípio nem fim; que sempre existiu e existirá. (...) 5. De duração indefinida. (...), p. 848. (Os verbetes imortalidade e imortal foram suprimidos porque pouco se diferem da definição supracitada).

17 ARENDT, Hannah. A Condição humana. Rio de Janeiro: Forense-Universitária; Rio de Janeiro: Salamandra; São Paulo: Edusp, 1981, pp. 26-27. 
imortais, exceto os homens. A capacidade humana para realizá-lo era a recordação, Mnemósine, considerada portanto como mãe de todas as demais musas ${ }^{18}$.

O período descrito por Arendt está mais próximo daquele em que a épica a que Benjamin se refere compunha a forma de comunicação predominante, e não a narrativa. É, entretanto, da epopéia que deriva a narrativa ${ }^{19}$, e a temporalidade de ambas se parece. Isso porque a grande quebra temporal se deu com a modernidade, no século XIX, e não antes disso.

A narrativa, mantendo-se transmissível, era uma forma de ensinamento que podia ser dotada dessa eternidade. Seu início e término tampouco eram fixos ou determináveis:

À temporalização inerente à narração e ao conselho supõem-se simultaneamente uma memória e uma abertura para seqüências desconhecidas, supõe por isso mesmo que neles não existem nem um começo, nem um fim delimitados. $^{20}$

A morte de um homem é a perda de um mortal individual, mas se nesse momento se origina uma história que se transformará em narrativa por sua retransmissão, tal história transcenderá a mortalidade da vida, que invade os feitos humanos, para entrar na eternidade de um mundo que segue outra temporalidade, que é dotado de coisas eternas. A narrativa, em sua cadeia de transmissão, era um ensinamento sobre o mundo que carregava a experiência partilhada por todos aqueles que a ouviam. A experiência, que tinha a temporalidade da eternidade, transcendia a mortalidade do homem para se fixar em um tempo outro, transcendia a vida para entrar em um mundo cuja temporalidade era eterna. Era uma espécie de acervo cultural de todos que a compartilhavam: todos a detinham, e também a formavam. Os narradores recorreriam a essa experiência para colher o material a ser transmitido:

[...] Comum a todos os grandes narradores é a facilidade com que se movem para cima e para baixo nos degraus de sua experiência, como numa escada. Uma escada que chega até o centro da terra e que se perde nas nuvens - é a imagem de uma experiência coletiva, para a qual mesmo o mais profundo choque da

\footnotetext{
${ }^{18}$ ARENDT, Hannah. Entre o Passado e o Futuro. São Paulo: Perspectiva, $5^{\text {a }}$ edição, 2000, p. 72.

${ }^{19}$ Nas palavras de Benjamin: "[...] a epopéia propriamente dita, contém em si, por uma espécie de indiferenciação, a narrativa e o romance" - BENJAMIN, W. "O Narrador - Considerações sobre a obra de Nikolai Leskov". op. cit., p. 211.

${ }^{20}$ CARDOSO, Irene. "A narrativa silenciada”. op. cit., p. 177.
} 
experiência individual, a morte, não representa nem um escândalo nem um impedimento $^{21}$.

Como aquilo que é eterno, a morte está situada "fora do tempo"22, é um acontecimento sem início ou fim. Para os antigos, a possibilidade de saída para o problema da mortalidade estava colocada justamente na morte: pela herança de feitos eternos que deixasse à humanidade, o homem poderia ter seu ingresso na eternidade.

"A idéia da eternidade sempre teve na morte sua fonte mais rica" ${ }^{, 23}$, diz Benjamin. A narrativa, que enquanto perdurava pertencia à eternidade, surgia das palavras que o moribundo balbuciava momentos antes de sua morte. Era nesse momento que, para essa sociedade que não vivia sobre os ditames do progresso técnico irrefreado em que se busca adiantar o futuro, o homem atingia o maior grau de sabedoria em vida: acabava no momento imediatamente anterior à morte o processo de acumulação de experiência e vivência de uma pessoa.

O pressuposto do acúmulo de sabedoria no idoso é marca da forma de vida que precede a modernidade, quando as mudanças não ocorriam de modo tão acelerado e não se seguiam preceitos cientificistas. O idoso não era considerado alguém anacrônico, porém sábio:

Abrão ou os camponeses de outrora morreram "velhos e plenos de vida", pois que estavam instalados no ciclo orgânico da vida, porque esta lhes havia ofertado, ao fim de seus dias, todo o sentido que podia proporcionar-lhes e porque não subsistia enigma que eles ainda teriam desejo de resolver. Podiam, portanto, considerar-se satisfeitos com a vida. ${ }^{24}$

Além da plenitude da satisfação com sua vida e sabedoria adquirida, o moribundo tinha outro ponto a lhe favorecer a transmissão do conselho que fundava a narrativa - diz Benjamin:

[...] é no momento da morte que o saber e a sabedoria do homem e, sobretudo sua existência vivida - e é dessa substância que são feitas as histórias - assumem

\footnotetext{
${ }^{21}$ BENJAMIN, W. "O Narrador - Considerações sobre a obra de Nikolai Leskov”. op. cit., p. 215.

${ }^{22}$ Parte da definição do verbete "eterno" disponível em HouAISS, A., ET Alli. Dicionário Houaiss da língua portuguesa. op. cit., p. 1270.

${ }^{23}$ Benjamin, W. “O Narrador - Considerações sobre a obra de Nikolai Leskov”. op. cit., p. 207.

${ }^{24}$ WeBer, MAX. “A Ciência como vocação”. In: Ciência e política: duas vocações. São Paulo: Cultrix, 1993, p. 31.
} 
pela primeira vez uma forma transmissível. Assim como no interior do agonizante desfilam inúmeras imagens - visões de si mesmo, nas quais ele se havia encontrado sem se dar conta disso -, assim o inesquecível aflora de repente em seus gestos e olhares, conferindo a tudo o que lhe diz respeito aquela autoridade que mesmo um pobre-diabo possui ao morrer, para os vivos em seu redor. Na origem da narrativa está essa autoridade. ${ }^{25}$

A morte é o fim de tudo o que uma pessoa pode experimentar, viver e contar, e daí advém a autoridade da palavra do moribundo - é a última vez que ele se pronunciará $^{26}$. A morte é sua última viagem, e as palavras de quem está na fronteira entre o mundo dos vivos e o desconhecido mundo dos mortos engendravam uma narrativa sobre um limiar misterioso aos ouvintes.

As palavras dos moribundos eram duráveis e transmitidas "como um anel, de geração em geração" 27 . Sabia-se narrar, aos moribundos era atribuída sabedoria, e havia quem os escutasse - quem estava ao seu lado neste momento ouvia o conselho enigmático no qual o moribundo condensava sua existência vivida. Desses conselhos surgiam as narrativas, que espalhavam socialmente os ensinamentos da tradição.

Isso era possível porque, de modo geral, o momento da morte de alguém era assistido por outras pessoas. O caráter público da morte nas sociedades em que Norbert Elias denomina "pré-industriais" é enfatizado pelo autor: nessas sociedades, a família permanece ao lado dos membros que envelhecem e dos moribundos. Essas sociedades eram predominantes no período da narrativa, quando o envelhecimento e a morte podiam ser acompanhados de perto pela família extensa, e algumas vezes também pelos vizinhos do convalescente ${ }^{28}$.

Se a morte era uma questão mais pública que hoje, colaborava fortemente para isso o fato de que não havia o hábito de estar-se sozinho, a vida como um todo tinha um caráter mais público (inclusive em momentos como o nascimento e a morte):

[...] Pode-se dizer que antes do século XX, ou talvez do XIX, a maioria das pessoas morria na presença de outras apenas porque estavam menos acostumadas a viver e estar sós. Não havia muitos cômodos onde uma pessoa pudesse ficar só.

\footnotetext{
${ }^{25}$ BenJAmin, W. “O Narrador - Considerações sobre a obra de Nikolai Leskov”. op. cit., pp. 207-208.

${ }^{26}$ Cf. Benjamin, W. "O Narrador - Considerações sobre a obra de Nikolai Leskov". op. cit., p. 208.

${ }^{27}$ BENJAMIN, Walter. "Experiência e pobreza". In: . Magia e técnica, arte e política - Obras escolhidas, volume I. op. cit., p. 114.

${ }^{28}$ Cf. ELIAS, Norbert. "Envelhecer e morrer: alguns problemas sociológicos". In: A Solidão dos moribundos: seguido de "Envelhecer e morrer". Rio de Janeiro: Jorge Zahar, 2001, pp. 84-85.
} 
Os moribundos e os mortos não eram tão flagrantemente isolados da vida comunitária como é geralmente o caso nas sociedades avançadas. $[\ldots]^{29}$

A principal diferença a possibilitar o surgimento da narrativa nos momentos que antecediam a morte era o fato de ela ocorrer em um ambiente onde a presença dos outros era constante. Morria-se em casa, e não no isolamento asséptico de um quarto de hospital.

Surgida no momento imediatamente anterior à morte, a narrativa tinha que ser transmitida para que não se perdesse, uma vez que a "a relação ingênua entre o ouvinte e o narrador é [era] dominada pelo interesse em conservar o que foi narrado"30. Para que fosse retransmitida uma história, entretanto, era necessário que houvesse uma memória que a preservasse e uma tradição que a mantivesse.

A musa da narrativa é, de acordo com Benjamin, a memória, enquanto a do romance é a rememoração. Ambas teriam origem comum na reminiscência da epopéia, já que as duas formas literárias têm sua origem na poesia épica. Mas seria a narrativa herdeira legítima dessa reminiscência, que acaba por unir as narrativas todas:

A reminiscência funda a cadeia da tradição, que transmite os acontecimentos de geração em geração. Ela corresponde à musa épica no sentido mais amplo. Ela inclui todas as variedades da forma épica. Entre elas, encontrase em primeiro lugar a encarnada pelo narrador. Ela tece a rede que em última instância todas as histórias constituem entre si. Uma se articula na outra, como demonstraram todos os outros narradores, principalmente os orientais. Em cada um deles vive uma Scherazade, que imagina uma nova história em cada passagem da história que está contando. Tal é a memória épica e a musa da narração. $[\ldots]^{31}$

Não é de se estranhar que Scherazade, musa narradora de As mil e uma noites, seja citada por Benjamin, já que esta é uma narrativa na qual, além da articulação com outras narrativas, posto que carrega tradição, diferentes histórias se articulam no interior da mesma obra. Hoje As mil e uma noites são conhecidas em sua forma escrita, mas as histórias existiam, na forma de narrativa oral, antes do livro. Muitas das histórias que compõem o livro homônimo chegaram ao Ocidente antes de sua publicação escrita, por

\footnotetext{
${ }^{29}$ ELIAS, Norbert. "Envelhecer e morrer: alguns problemas sociológicos". op. cit., p. 87. Grifos do autor.

${ }^{30}$ BENJAMIN, W. “O Narrador - Considerações sobre a obra de Nikolai Leskov”. op. cit., p. 210.

${ }^{31}$ BENJAMIN, W. "O Narrador - Considerações sobre a obra de Nikolai Leskov". op. cit., p. 211. Grifos do autor.
} 
meio dos relatos de viajantes e comerciantes. Existem diferentes versões escritas para a obra provavelmente porque os diferentes escritores que as "transcreveram" fizeram-no de acordo com o que ouviram (o modo específico como o narrador lhes contou) e com o que puderam memorizar (que varia de acordo com o ouvinte) ${ }^{32}$.

Jorge Luis Borges diz que a origem de As mil e uma noites é oculta, essa narrativa seria como as catedrais "malamente llamadas góticas" 33 : obras construídas não por um indivíduo específico, mas por gerações de homens. A diferença é que os artesãos das catedrais sabiam bem o que estavam fazendo, enquanto a narrativa surge de modo misterioso. As mil e uma noites é uma obra de milhares de autores que não pensavam estar edificando uma obra ilustre, diz Borges ${ }^{34}$, ou - pode-se acrescentar uma obra coletiva que transmitia uma experiência viva, sem que seus narradores se dessem conta disso.

Jamil Haddad se indaga sobre o valor da narrativa em As mil e uma noites:

[...] o que é que As mil e uma noites ensinaram ao mundo? Isso é cousa séria, pois é o que determina que o mundo não pare, determina que o mundo não se estagne. As mil e uma noites trazem a grande lição do Sonho. ${ }^{35}$

Esse Sonho é a experiência, a tradição transmitida de geração em geração, sempre re-significada, típica em uma sociedade marcada pela temporalidade qualitativa, e não quantitativa. É a transmissão da experiência que dá eternidade à narrativa:

Tenho em casa os dezessete volumes da versão de Burton [um dos principais tradutores de As Mil e uma noites]. Sei que nunca os terei lido todos mas sei que aí estarão os dezessete volumes; aí estará essa espécie de eternidade de As Mil e uma noites do Oriente. ${ }^{36}$

\footnotetext{
${ }^{32}$ Não se levam em conta, aqui, versões como a de Galland, que adaptou o livro original a que teve acesso aos costumes franceses de sua época. Fala-se de tradutores que, procurando ser o mais fiel possível à narrativa ouvida, chegaram a resultados diferentes por encontrarem originais diferentes, e mesmo por darem mais importância à memorização de determinados trechos, em detrimento de outros.

${ }^{33}$ Borges, Jorge Luis. "Las Mil y una noches". In: . Obras Completas III; Barcelona: Emecé Editores, 1989, p. 236.

${ }^{34}$ Cf. Borges, J. L. "Las Mil y una noches". op. cit., p. 236.

${ }^{35}$ HADDAD, Jamil Almansur. Interpretações das Mil e Uma Noites. In: Collatio, $\mathrm{n}^{\mathrm{o}}$ 6, Centro de Estudos Árabes da FFLCH-USP, São Paulo, junho de 2001. Disponível online em http://www.hottopos.com/collat6/jamyl.htm, acessado em 07/08/2006.

${ }^{36}$ Borges, J. L. "Las Mil y una noches". op. cit., p. 237. Tradução livre de: "Tengo en casa los diecisiete volúmenes de la versión de Burton. Sé que nunca los habré leído todos pero sé que ahi estarán los diecisiete volúmenes; ahi estará esa especie de eternidad de Las mil y una noches del Oriente."
} 
Refletindo sobre As mil e uma noites, Gagnebin equipara sua estrutura, na qual uma história chama outra, a um movimento infinito de memória ${ }^{37}$. Entrelaçada à memória, a narrativa podia ser recontada infinitamente, o que a dotava de uma temporalidade oposta à do progresso. O conselho transmitido pela narrativa vinha de uma história do passado, era recriado no momento presente em que a história era narrada, e se projetava para o futuro, pois se tornava constitutivo da vida dos ouvintes, que a recontariam. Essa articulação entre os tempos do passado, presente e futuro determinava a temporalidade entrecruzada das narrativas. Tratava-se, assim, de um tempo entrecruzado e eterno; a narrativa vivia enquanto fossem recontadas suas histórias - que já não eram mais as mesmas após cada recontagem.

A narrativa existia quando havia a experiência: desta se alimentava o narrador em suas histórias, dessa se contaminava a narrativa para espalhá-la socialmente. A narrativa tirava ensinamentos da experiência, que eram passados aos ouvintes. Assim, para que houvesse a narrativa, deveria haver experiência a ser transmitida, ao passo que para que a experiência pudesse ser transmitida, a narrativa desempenhava papel fundamental.

A narrativa podia ter tom benevolente ou ameaçador. Por meio de histórias contadas se indicavam caminhos a seguir em uma forma de vida que lhes era comum aos ouvintes e a seus antecessores. Benjamin ilustra esse ensinamento por meio de uma parábola:

Em nossos livros de leitura havia a parábola de um velho que no momento da morte revela a seus filhos a existência de um tesouro enterrado em seus vinhedos. Os filhos cavam, mas não descobrem qualquer vestígio do tesouro. Com a chegada do outono, as vinhas produzem mais que qualquer outra na região. Só então compreenderam que o pai lhes havia transmitido uma certa experiência: a felicidade não está no ouro, mas no trabalho. $[\ldots]^{38}$

Nessa parábola, a morte do pai é presenciada por seus filhos. A parábola existe porque um pai que está morrendo fala algo. Não apenas a família está reunida no momento da morte do progenitor, que certamente ocorreu em casa, como o pai lhes conta uma parábola que servirá de ensinamento. Pai e filhos teriam na vida a mesma ocupação - cuidar do vinhedo. O pai moribundo e os filhos partilham uma mesma

\footnotetext{
${ }^{37}$ Cf. Gagnebin, J. M. "Prefácio - Walter Benjamin ou a história aberta”. op. cit., p.13.

${ }^{38}$ BenJAMIN, W. "Experiência e pobreza". op. cit., p.114.
} 
temporalidade, há na parábola palavras cujo sentido é compartilhado entre as gerações tal narrativa ganha, assim, uma função prática, porque se entende a palavra dita.

Quem contasse essa parábola transmitiria, além de um ensinamento prático e moral, uma experiência, mas para isso era preciso que houvesse uma tradição e uma história comuns, "que garantiam a existência de uma experiência coletiva, ligada a um trabalho e um tempo partilhados, em um mesmo universo de prática e de linguagem" 39 .

Mas isso logo se perderá. Com a emergência do modo de produção fabril da modernidade, há uma subjugação à temporalidade daí decorrente que finda uma dimensão mais "natural" então existente com o tempo. A passagem do tempo na anedota citada se dá pela "chegada do outono". O tempo fabril é mais recortado e subjugado aos segundos, não há tempo para o aconselhamento das narrativas, para a percepção da alteração das estações do ano. Com a perda da narrativa, emergem o romance e, sobretudo, a informação.

\subsection{Modernidade}

Walter Benjamin escreveu, já em 1936, que "a arte de narrar está em vias de extinção", isso porque cada vez menos pessoas sabiam narrar devidamente ${ }^{40}$. Narrativa e experiência estavam atreladas na época de ouro da narrativa, e assim a decadência de uma é por Benjamin associada à perda da outra - a narrativa transmitia uma experiência que decai junto a ela. Diz Benjamin: "as ações da experiência estão em baixa, e tudo indica que continuarão caindo até que seu valor desapareça como um todo",41.

O termo usado por Benjamin para se referir à experiência - "ações" que "estão em baixa" - se parece com o jargão dos investidores da Bolsa de Valores. Pois os investimentos bancários são boa expressão para marcar uma mudança fundamental trazida pela modernidade: a celeridade do ritmo temporal. Celeridade ligada ao ritmo de vida fabril, industrial, e não mais artesanal, na qual o tempo é calculado em cifras.

\footnotetext{
${ }^{39}$ Gagnebin, J. M. "Prefácio - Walter Benjamin ou a história aberta”. op. cit., p. 11.

${ }^{40}$ Cf. Benjamin, W. “O Narrador - Considerações sobre a obra de Nikolai Leskov”. op. cit., p. 197.

${ }^{41}$ BENJAMIN, W. "O Narrador - Considerações sobre a obra de Nikolai Leskov”. op. cit., p. 198. Em outra tradução, lê-se: “a experiência caiu na cotação. E a impressão é de que prosseguirá na queda interminável” - BENJAMIN, W. "O Narrador - Observações sobre a obra de Nikolai Leskow”. op. cit., p. 63.
} 
Na Idade Média, a temporalidade corrente era a da Igreja, marcada por práticas cristãs "caracterizadas pela representação da eternidade, pela repetição ritual do sacrifício do filho de Deus, pela idéia de que o tempo pertence a Deus, e o que a ele pertence não pode ser profanado, isto é, não pode ser atribuído um preço e ser vendido" $"$. Tendo Le Goff como quadro de referência, José Carlos Bruni situa no fim da Idade Média uma primeira ruptura temporal, quando o tempo dos mercadores passou a se diferenciar do tempo da Igreja.

A prática da usura, corrente quando se dá o desenvolvimento de uma rede comercial, teria invertido a característica medieval do tempo pois, com o empréstimo a juros, o tempo, antes considerado uma "dádiva de Deus", passou a ser visto como "objeto lucrativo" 43 . As instituições bancárias, cuja linguagem Benjamin utiliza para se referir à queda da experiência, estão ligadas à quebra da usura como algo socialmente inaceitável porque contrária aos preceitos religiosos; a dinâmica bancária, fundamental para o comércio, está ligada ao lucro sobre o tempo - que então deixou de ser condenável. A perda da experiência ocorre quando há essa nova relação com o tempo, a experiência vai 'caindo na cotação' até praticamente perder-se com o avanço da modernidade nos séculos XIX e XX.

$\mathrm{O}$ advento do progresso teria levado a bruscas mudanças na temporalidade corrente. Embora o apogeu da idéia de progresso seja localizado por Bruni entre 1750 e 1950, o autor destaca o século XIX como momento decisivo. ${ }^{44}$ Nas oficinas de trabalho artesanal, antes do século XIX, o controle do tempo urgia menos, havia mais tempo para a conversa, para o acaso, e menos previsibilidade e serialização do trabalho ${ }^{45}$, situação que viria a se inverter na modernidade, tornando a temporalidade voltada para o futuro.

Há diversos marcos para o início da modernidade. Não é objetivo desta pesquisa delimitar seu exato início e abrangência, mas situar na implantação do projeto moderno uma guinada na temporalidade corrente, que fez com que se perdesse a referência da experiência vivida como tradição e se acelerasse o ritmo temporal. O que marca a

\footnotetext{
${ }^{42}$ BRUNI, José Carlos. "Tempo e trabalho intelectual". In: Tempo Social - Revista de Sociologia da USP. São Paulo, 3 (1-2): 1991, p. 157.

${ }^{43}$ Cf. LE GofF. Apud: BRUNI, J. C. "Tempo e trabalho intelectual". op. cit., pp. 157-158.

${ }^{44}$ Cf. BRUNI, J. C. "Tempo e trabalho intelectual". op. cit., p. 160. Neste artigo, Bruni faz uma oposição entre o tempo do "trabalho manual/industrial" e o tempo do trabalho intelectual. A expressão "trabalho manual/industrial" não é, entretanto, decorrente de uma equiparação entre o trabalho manual e o industrial, mas fruto da busca por especificidades do trabalho intelectual, foco do estudo apresentado, que leva Bruni a diferenciá-lo dos demais tipos de trabalho.
}

${ }^{45}$ Cf. BRUNI, J. C. "Tempo e trabalho intelectual”. op. cit., p. 162. 
modernidade são as mudanças que ocorrem velozmente e em grande quantidade, tendo como base uma temporalidade voltada para o futuro. Esse anseio desenfreado pelo desenvolvimento, que impele os indivíduos ao futuro, tem origem no ideário iluminista de progresso.

Mudanças sociais e culturais sempre existiram - mesmo na Europa, antes da modernidade chegar com força no século XIX. Seu ritmo era, entretanto, mais lento, a temporalidade seguia um ritmo mais natural, a vida estava ligada a um mundo mágico e a um tempo cíclico. Fazia-se visível, ainda entre os séculos XVI e XVIII, a presença de uma cultura tradicional, que foi marcante na Europa agrícola:

[...] Tratava-se sobretudo de um universo voltado para o mundo mágico e calcado na concepção de um tempo cíclico, repetindo entre os homens o caminhar das estações do ano. Por isso várias das festas populares se recobrem do significado de um rito de passagem: carnaval (renascimento do ano cristão), fertilidade da terra (rituais de agricultura), mobilidade de um grupo de idade para o outro (passagem da adolescência para o mundo adulto). [... $]^{46}$

Essa relação temporal começou a mudar com a implantação de um projeto iluminista segundo o qual, tendo em vista o notável aprimoramento das capacidades humanas no então presente, e partindo de uma lógica temporal de continuidade e estabilidade, havia a crença positiva (e positivista) no progresso da civilização. Acreditava-se que uma consciência reflexiva acompanharia tal desenvolvimento, o que daria ao homem total domínio sobre esse processo ${ }^{47}$. O futuro era pensado como conseqüência de um presente marcado por um notável avanço - sobretudo técnico e científico -, o que garantia ao Século das Luzes a expectativa de um porvir mais próspero para a humanidade ${ }^{48}$.

Seguindo os preceitos positivistas, houve uma forte valorização do conhecimento técnico-racional. Desde então, o progresso, no que concerne a seu aparato técnico e científico, não cessou, mas tampouco ocorreu de maneira reflexiva. Aniquilou-

\footnotetext{
${ }^{46}$ ORTIZ, Renato. Cultura e Modernidade - A França no século XIX. São Paulo: Brasiliense, $1^{\mathrm{a}}$ edição, 1991, p. 32.

47 Cf. SILVA, Franklin Leopoldo (2001). "O mundo vazio: sobre a ausência da política no contexto contemporâneo". In: Silva, Doris Accioly e MARRACH, Sonia Alem (orgs.). Maurício Tragtenberg Uma vida para as Ciências Humanas. São Paulo: Ed. Unesp, 2001, p. 242.

${ }^{48}$ Cf. SilvA, F. L. "O mundo vazio: sobre a ausência da política no contexto contemporâneo". op. cit., pp. 239-240.
} 
se a reflexão do processo de avanço da humanidade e o progresso tornou-se um mero acúmulo técnico-científico ao qual o homem se subordinou.

O progresso, que ficou relacionado à rapidez da produção industrial, seria:

[...] o avanço da produtividade do trabalho, isto é, a elevação do volume de produção e do desempenho por pessoa e por unidade de tempo. O progresso na provisão de bens e o progresso social são neste caso grandezas derivadas. [...] $\mathrm{O}$ progresso técnico, aumento da produtividade do trabalho, ganha, em intervalo de tempo ganho, um novo intervalo de tempo, do qual o progresso técnico ganha um intervalo de tempo, do qual ganha-se tempo, etc. (...) O tempo permanece, mesmo depois da divisão, aquilo que ele era: um todo, mesmo que seja a metade do todo originário. O tempo é novamente um completo intervalo de tempo que pode propiciar novo intervalo de tempo para a fabricação de um produto, a superação de uma distância, a transmissão de uma notícia. Ele contém, mesmo depois da divisão ínfima, o caráter de algo novamente divisível. ${ }^{49}$

Tal idéia de progresso, de acordo com Bruni,

[...] Funciona como idéia-síntese: nela vêm se aninhar os conceitos de evolução, crescimento, desenvolvimento, organização, planejamento, figuras todas devedoras de um imaginário que privilegia o futuro como dimensão temporal mais plena, mais intensa, mais "real" do que o passado ou o presente, representação inteiramente coerente com a "fantasia de onipotência" do tempo pensado e praticado como infinitamente produtivo. Pois a produtividade do tempo abstrato da nossa sociedade está ligada ao processo da divisão infinita dos intervalos de tempo de uma determinada atividade em unidades cada vez menores, sem que, em princípio, nenhum limite possa a isso se opor ${ }^{50}$.

Mas a reflexão não acompanhou o desenvolvimento da técnica, e essa - que deveria ser um meio para o fim que seria a melhoria de toda a humanidade - se autonomizou, subordinando o homem a seu domínio. Ainda assim, continuou-se desejando o progresso - agora mero acúmulo de técnica autonomizada. Passou-se então a adiantar o futuro para a obtenção sempre mais veloz de um nível cada vez mais

\footnotetext{
${ }^{49}$ RinderSPACHER \& ERMERT. Apud: BRUNI, J. C. “Tempo e trabalho intelectual”. op. cit. p. 160.

${ }^{50}$ BRUNI, J. C. "Tempo e trabalho intelectual". op. cit., p. 160.
} 
elevado de progresso (técnico): o futuro, assim, invadiu o presente, e passou-se a viver em um futuro presentificado ${ }^{51}$.

O progresso da produtividade do trabalho tem base técnico-científica, e não representa uma melhoria da humanidade. Trata-se do progresso pós-quebra dos preceitos iluministas, apartado da reflexão que supostamente o acompanharia no caminho à Razão, mas que se põe no mundo ainda como algo que leva ao bem-estar de todos.

A idéia do progresso significa que aquilo que veio depois é necessariamente melhor do que o que veio antes; ela nos oculta a diferença entre desenvolvimentos técnico-científicos e a regressão da sociedade, porque a noção de progresso, como algo idêntico a si mesmo, esconde a barbárie da qual esse progresso é portador, o que faz com que acreditemos que os progressos da ciência são progressos da humanidade enquanto tal ${ }^{52}$.

De meio para obtenção de uma melhoria da humanidade, o progresso técnico foi transformado em fim, por isso se diz uma técnica autonomizada, que se autonomiza em relação a seus fins, tornando-se ela própria um fim. Como decorrência desse processo, houve uma aceleração na temporalidade: o futuro passou a ser o tempo forte.

Se, para Ortiz, o mundo até o século XVIII era explicado por crenças mágicas e um tempo cíclico, é justamente no Século das Luzes que se localiza a ruptura. Recorrendo à tese de Keith Thomas ${ }^{53}$ para pensar as mudanças que ocorrem de maneira mais intensa a partir desse período, Ortiz observa um recuo das crenças mágicas - fato que pode ser remetido ao conceito weberiano de desencantamento do mundo - que não decorre das conquistas tecnológicas ou científicas, mas de uma mudança de mentalidade que tem como origem a reforma intelectual ocorrida no Iluminismo.

Promovendo a racionalidade, o Iluminismo "seria a antítese da irracionalidade das práticas populares" ${ }^{54}$, o que teria levado a um ceticismo crescente. Exemplo disso teria ocorrido na Inglaterra, em 1736, quando deixaram de existir processos formais contra feitiçaria. Tal dado não demonstra o desaparecimento de todo tipo de feitiçaria no país, mas sua descriminalização revela uma mudança na mentalidade das autoridades

\footnotetext{
${ }^{51}$ Cf. Silva, F. L. "O mundo vazio: sobre a ausência da política no contexto contemporâneo”. op. cit., pp. 239-245.

${ }^{52}$ MAtTos, Olgária. “Memória e história”. A Terceira idade - Revista do SESC-SP. Ano 4, n.6, out/1992, p. 7.

53 Apud: OrTIZ, R. Cultura e Modernidade - A França no século XIX. op. cit., p. 34.

${ }^{54}$ Renato OrTIZ referindo-se a Keith ThOMAS: ORTIZ, R. Cultura e Modernidade - A França no século XIX. op. cit., p. 35.
} 
judiciárias - como os "homens educados" que controlavam a máquina judiciária não acreditavam mais na matéria que seria julgada, a prática da feitiçaria deixou de ser considerada crime para ser pensada como uma ilusão causada pela ignorância do povo ${ }^{55}$.

Ortiz comenta as constatações de Thomas, lembrando que o projeto iluminista, embora pudesse prever a melhoria da humanidade como um todo, tinha uma atuação restrita às elites:

[...] Não tenho dúvidas de que o movimento de racionalização da sociedade tem implicações sobre a objetividade das crenças mágicas (embora isso necessariamente não leve a seu desaparecimento). Mas não se pode perder de vista que não existe um Iluminismo das massas: quando Keith Thomas fala no declínio da magia, ele está se referindo à regressão da consciência mágica de uma elite. Podemos dizer que esse racionalismo é dominante, no sentido de que "faz" a história do mundo ocidental, mas ele é certamente minoritário e inexpressivo diante do conjunto da população. $[\ldots]^{56}$

Ainda assim, como decorrência do Iluminismo, embora se tenha deixado de esperar a melhoria da humanidade, manteve-se um acúmulo técnico-científico a impelir os homens ainda mais para frente, sempre para o futuro, tempo esse que ocupa o lugar do passado e retira a densidade do presente.

Subordinamo-nos ao acúmulo externo de meios e produtos tecnológicos, acúmulo que é visto como progresso, mas que representa também um processo que nem sempre esteve acompanhado pela reflexão. É isso que significa dizer que nos apropriamos do futuro de maneira "irreflexiva e irrefletida". Tudo é nosso, é tudo produto de nossa atividade, mas ao mesmo tempo nos escapa. A partir dessa separação entre conhecimento, ação e reflexão, não podemos mais manter a esperança iluminista de que essas realizações se inscrevam efetivamente num projeto de aprimoramento histórico dos indivíduos e da sociedade [...] O progresso deixa de ter o sentido pedagógico que o Iluminismo lhe atribuía ${ }^{57}$.

Decorrem da autonomia da técnica e da valorização do progresso técnico a busca pelo futuro e o desejo de adiantá-lo, situação na qual deixou de fazer sentido a

${ }^{55}$ Renato ORTIZ referindo-se a Keith ThOMAs: Cf. ORTIZ, R. Cultura e Modernidade - A França no século XIX. op. cit., p. 35.

${ }^{56}$ ORTIZ, R. Cultura e Modernidade - A França no século XIX. op. cit., p. 35.

${ }^{57}$ SILVA, F. L. "O mundo vazio: sobre a ausência da política no contexto contemporâneo”. op. cit., p. 243. 
transmissão coletiva de uma experiência que remeta ao passado. Cada nova geração passou a entrar em um mundo que é novo, um mundo que muda com tal freqüência, que os ensinamentos que poderiam lhe fornecer seus antepassados não mais têm validade, tornaram-se ultrapassados. À narrativa, que era um ensinamento vindo do passado, não restou espaço nesse mundo que transforma suas paisagens e idéias a todo instante, tentando sempre adiantar o futuro. Fonte das histórias narradas, as últimas palavras do moribundo perderam assim a sabedoria que lhes era atribuída, ficando também desprovidas de ouvintes.

O ápice do progresso científico foi colocado no infinito, de modo que para quem vive sob essa lógica há sempre a possibilidade de um novo avanço. Como a vida individual do homem moderno foi imersa nesse progresso, a morte deixou de ser um acontecimento que pode encerrar sentido, pois quem morre não terá jamais alcançado o pico infinito do progresso. O homem velho, assim, se tornou socialmente um anacrônico, e não mais um sábio.

O moribundo podia dar um conselho (fonte de origem da narrativa benjaminiana) a partir do qual a experiência seria transmitida porque ele era considerado sábio, uma vez que detinha plena posse do sentido da vida. Com a modernidade, sob a lógica da ciência e do progresso técnico, o conhecimento que um homem adquire na vida é superado a cada nova descoberta científica, e logo se torna ultrapassado. Se o indivíduo moderno pode sentir-se cansado da vida, certamente não se sentirá pleno dela ${ }^{58}$.

Desenvolvimento técnico sempre houve, marca a modernidade o fato de essa técnica estar autonomizada e atrelada ao progresso, que tem o infinito como ápice. Diz Ortiz: "o progresso econômico passa necessariamente pelo progresso técnico; o progresso técnico só pode ser a passagem de um sistema técnico para outro sistema técnico" ${ }^{59} \mathrm{O}$ autor ainda lembra que, até a Revolução Industrial, as técnicas evoluíram, sim, porém empiricamente, de modo apartado da ciência. Seria uma característica moderna, entretanto, do final do século XIX e início do XX, a técnica como prolongamento da ciência ${ }^{60}$.

\footnotetext{
${ }^{58}$ Cf. WeBER, M. “A Ciência como vocação”. op. cit., p. 31.

${ }^{59}$ OrTIZ, R. Cultura e Modernidade - A França no século XIX. op. cit., p. 28.

${ }^{60}$ Cf. OrtiZ, R. Cultura e Modernidade - A França no século XIX. op. cit., p. 27.
} 
Novas tecnologias implicam, para além de mudanças técnicas e econômicas, em

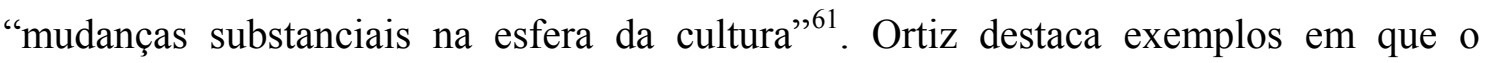
desenvolvimento tecnológico gerou profundas mudanças nessa área:

[...] O automóvel redimensiona o uso do tempo pelas pessoas, que podem agora se deslocar a uma velocidade maior sem mais ter de fazer uso dos fiacres ou de transportes coletivos como o trem ou a diligência. A eletricidade propicia um padrão de conforto (elevadores, iluminação das casas) desconhecido até então. Dentro desse contexto, a própria sociabilidade dos indivíduos é reorganizada. Um exemplo é a difusão do telefone. Utilizado pelos homens de negócio, ele é certamente um instrumento de trabalho, mas sua função extrapola o universo das transações comerciais. Ao colocar em contato as pessoas, ele modifica as noções de proximidade e distância. $[\ldots]^{62}$

A constante superação pelo novo é marca da modernidade - com a rapidez das mudanças tecnológicas, dá-se a celeridade do ritmo do tempo social, pois cadeias de mudanças têm início. A diminuição da noção de distância entre as pessoas, seja pelo automóvel ou pelo telefone, certamente abalou a temporalidade corrente. Se antes se levavam horas (ou dias) para falar com alguém em outra cidade, fosse por troca de correspondências, fosse pela viagem ao encontro dessa pessoa, com o telefone isso passou a ocorrer de forma muito mais veloz. Desse modo, a modernidade, para além de implicar em uma séria mudança de hábitos, causou mudanças em outro elemento da cultura vigente: a sensação do tempo, usualmente atrelada ao espaço.

O desenvolvimento do progresso levou à mecanização da produção - passou-se a produzir objetos em velocidade muito mais acelerada. Acreditou-se, inclusive, que com o desenvolvimento do progresso tecnológico e o uso de computadores, carros e aviões mais velozes, a sociedade estaria pronta a entrar na era do lazer, pois as máquinas executariam diversas tarefas pelos homens, deixando-os, assim, com mais tempo livre ${ }^{63}$. Mas isso certamente não ocorreu. E não poderia mesmo ocorrer nessa vida moderna que tem base em um ideal de progresso no qual é fundamental uma técnica que foi autonomizada. São os homens, entretanto, que a devem produzir. E produzir cada vez mais, pois há um crescimento das necessidades de consumo. Não há

\footnotetext{
${ }^{61}$ OrtIZ, R. Cultura e Modernidade - A França no século XIX. op. cit., p. 28.

${ }^{62}$ OrTIZ, R. Cultura e Modernidade - A França no século XIX. op. cit., p. 28.

${ }^{63}$ Cf. BernARDI. Apud: Bruni, J. C. "Tempo e trabalho intelectual”. op. cit., p. 156.
} 
tempo para o lazer sob a temporalidade de um futuro presentificado, há apenas a busca por esse futuro, no que concerne a seu desenvolvimento técnico.

A técnica foi aplicada à indústria para acelerar a produção - teve início o modo de vida industrial, que pressupõe uma organização social urbana. Assim foi que se arquitetaram metrópoles e as indústrias passaram a compor a vida social como sua base de produção. Grandes cidades européias, em especial Paris e Londres, experimentaram um vertiginoso crescimento demográfico no século XIX, fruto da busca de migrantes por empregos nas novas fábricas. Surgiu, assim, o inédito fenômeno das multidões. Eram multidões de anônimos que despertavam incerteza nos indivíduos (pela imprevisibilidade do comportamento alheio, mas também por não se conhecer, até então, tal fenômeno). Uma vez imerso na multidão, ninguém sabia o que estava por vir, havia apenas uma certeza constante nas metrópoles: a de que, inevitavelmente, tal encontro - com o intenso e caótico fluxo da multidão - ocorreria. ${ }^{64}$

Junto à multidão, surgiu a pobreza como fenômeno social. Nas indústrias, não havia vagas para todos os migrantes à busca de emprego. Era o exército de reserva que estava se formando, uma massa de pessoas que circulava pelas metrópoles em condições de miséria e assustava a burguesia que, orgulhosa de suas cidades, por elas igualmente circulava. Havia encantamento pelas novidades que se observavam, mas havia, por outro lado, espanto pela pobreza que surgia. Foi com esse misto de admiração e medo que os habitantes das grandes cidades, em especial Londres e Paris, reagiram às multidões e à pobreza (ou seja, aos elementos de sua própria modernidade) ${ }^{65}$.

Era tal o encantamento assustador que os autores da época sentiam pelo que observavam, que eles passaram a relatar, em seus escritos, o espetáculo da vida urbana, descrevendo as cenas que assistiam nas ruas ${ }^{66}$. Muitos autores se puseram a escrever sobre as multidões, Engels descreveu exaustivamente as péssimas condições de moradia dos operários em Londres ${ }^{67}$, Baudelaire expressou em seus escritos sua admiração

\footnotetext{
${ }^{64}$ Cf. Bresciani, Maria Stella M. Londres e Paris no século XIX: o espetáculo da pobreza. São Paulo: Brasiliense, 2004, p.12.

${ }^{65}$ Cf. BRESCIANI, M. S. Londres e Paris no século XIX: o espetáculo da pobreza. op. cit., pp. 8- 9.

${ }^{66}$ Cf. BRESCIANI, M. S. Londres e Paris no século XIX: o espetáculo da pobreza. op.cit., pp. 7-8.

${ }^{67}$ Vide: ENGELS, Friedrich. A Situação da classe trabalhadora na Inglaterra. São Paulo: Global, 1985 (primeira publicação em 1845).
} 
contaminada por repulsa em relação à multidão de Paris $^{68}$ - por onde desfilava a burguesia, por onde vagava o pobre, por onde perambulava oflâneur.

Paris, a capital do século XIX ${ }^{69}$, tornou-se palco desse início da modernidade. $\mathrm{O}$ espírito de mudanças e novidades teve a própria cidade como palco, por meio de uma ampla reforma urbanística. O Barão Georges Eugène Haussmann (1809 - 1891), administrador do Sena de 1853 a 1869, foi o prefeito de Paris responsável por essa reforma urbana - a mais importante da cidade -, que teve a mesma duração que seu cargo.

Barão de Haussmann, ou simplesmente Haussmann, como ficou conhecido, se autodenominava o artiste démolisseur (artista demolidor). Destruiu ruelas para abrir largas avenidas, além de destruir, demolir e reconstruir diversos prédios. Foi a reforma de Paris, sob seu comando, que tornou a capital um símbolo dessa modernidade que ia à busca do novo - ainda que para isso fosse necessário demolir parte da cidade.

Durante os anos de poder, Haussmann foi responsável pelas obras viárias que transformaram a cidade de Paris em um espaço mais propício à circulação. Ele executou:

[...] a urbanização dos terrenos periféricos, com o traçado de novas retículas viárias, e a abertura de novas artérias nos velhos bairros, com a reconstrução de edifícios ao longo do alinhamento.

A velha Paris compreendia 384 quilômetros de ruas no centro e 355 nos subúrbios; ele abre, no centro, 95 quilômetros de ruas novas (suprimindo 49) e, na periferia, 70 quilômetros (suprimindo 5). O núcleo medieval é cortado em todos os sentidos, destruindo muitos dos antigos bairros, especialmente aqueles perigosos situados no Leste, que eram foco de todas as revoltas. Na prática, Haussmann sobrepõe ao corpo da antiga cidade uma nova malha de ruas largas e retilíneas, formando um sistema coerente de comunicação entre os principais centros da vida urbana e as estações ferroviárias, garantindo, ao mesmo tempo, eficiência diretora ao trânsito, por cruzamento e por anéis; ele evita destruir os

${ }^{68}$ Ver: BAUdelAiRe, Charles. Les Fleurs du mal. Paris: Booking International, 1993 -, que teve sua primeira edição publicada em 1857, após mais de uma década de elaboração - e BAUDELAIRE, Charles. Pequenos poemas em prosa. Rio de Janeiro: Nova Fronteira, 1980. - Traduzido para o português por Aurélio Buarque de Holanda Ferreira, a primeira publicação do livro foi feita postumamente, por dois amigos de Baudelaire, com o título de Le Spleen de Paris, em 1869 (Cf. LAUREL, Maria Herminia A., "Le Spleen de Paris, Petits poèmes en prose: 'crise de vers', crise de prose”. In: Máthesis, 10, 2001, 137-152. Disponível online em: www4.crb.ucp.pt/Biblioteca/Mathesis/Mat10/mathesis10 137.pdf. Acesso em 11/08/2006).

${ }^{69}$ Paris ficou conhecida como a "capital do século XIX" ainda durante esse século. Em Larousse du XIX siècle, publicado em 1875, sobre Paris, lê-se: "pode ser tomada, incontestavelmente, como a capital do mundo", e ainda "a capital da Europa, o centro do mundo inteiro, a metrópole moderna da civilização". (Larousse du XIX siècle, Apud: SAlgueIro, Heliana Angotti. "Introdução: Da Temática, dos autores e de suas idéias". In: (org.). Cidades Capitais do século XIX. São Paulo: Edusp, 2001, p. 21). 
monumentos mais importantes, mas faz com que fiquem isolados e adota-os como ponto de fuga para as novas perspectivas viárias ${ }^{70}$.

Para além das obras viárias, Haussmann renovou, ainda, as instalações hidráulicas da cidade e a sede administrativa da capital. Desse modo, dotou Paris de maior poder de circulação, maior fluidez, como demandava a produção fabril. Se os monumentos foram mantidos, foi para preservar uma ligação com o passado, pois também constitui a modernidade, para além da incessante novidade, uma nostalgia de tempos idos, que não permite uma reflexão sobre o passado, apenas o evoca rapidamente por símbolos, elegendo heróis de uma história dos vencidos sobre os quais pouco se sabe:

Os monumentos são construídos pelos dominantes para perdurarem e eternizar uma imagem do passado, que é feita para ser creditada e reconhecida pelas gerações na sucessão do tempo. A classe dominante constrói uma tradição através dos monumentos. ${ }^{71}$

Roberto Schwarz percebeu que há uma "poesia que emana de qualquer poder quando ele é passado para trás" ${ }^{72}$. Nesse caso seria uma poesia melancólica mantida por Haussmann como consagração de uma nação francesa que ainda estava em formação e carecia de monumentos que a afirmassem e a dotassem de qualquer tradição.

Muito mais do que pelos monumentos preservados, entretanto, essas obras foram marcadas pela destruição que seguia preceitos da busca pelo novo aparato técnicocientífico. Essa obra representou um fortíssimo marco para a chegada da modernidade às metrópoles, indo primeiro a Paris, com financiamento estatal.

Para que a reforma urbana pudesse coroar a instauração da modernidade, outros fatores fundamentais já vinham ocorrendo na França, permitindo o avanço do capitalismo. Ortiz os relata:

Os estudos mostram que as medidas revolucionárias introduzidas na sociedade francesa são fundamentais para o desenvolvimento do capitalismo: abolição dos direitos feudais; fim do caráter inviolável das corporações e dos privilégios das manufaturas; consagração da propriedade privada; interdição de

70 Benevolo, Leonardo. "Haussmann e o plano de Paris". In: História da arquitetura moderna. São Paulo: Perspectiva, 1976, p.98.

${ }^{71}$ Mattos, O. "Memória e história". op. cit., p.7.

${ }^{72}$ SCHWARZ, Roberto. "Nacional por subtração". In: Cultura e política. $1^{\text {a }}$ edição. São Paulo: Paz e Terra, 2001, p. 116. 
qualquer associação de empregados ou patrões com o intuito de influir nos salários (laissez-faire). É dentro deste contexto que a Revolução Industrial se instala, com a introdução de novas formas de energia (vapor), mecanização das fábricas (sobretudo as indústrias têxteis), crescimento da indústria de construção e de metalurgia e o advento das ferrovias. Esses acontecimentos, que se manifestam no nível da infra-estrutura econômica, têm conseqüências fundamentais na organização da sociedade: criação de grandes empresas industriais e comerciais, desenvolvimento do patronato, do assalariado burguês e da classe operária. Paralelamente a eles, tem-se um movimento de imigração rural, com a população concentrando-se cada vez mais nas cidades. [... $]^{73}$

A faceta urbanística da modernidade influenciava em outras áreas. As mudanças da cidade fizeram com que as classes populares que viviam no antigo centro migrassem para as periferias, onde estavam localizadas as fábricas ${ }^{74}$. As grandes vias facilitavam a circulação pela cidade, acelerando-a. Isso tudo influenciou de modo radical a vida dos habitantes de Paris, cuja relação de identidade com a cidade teve que ser refeita.

Quanto aos motivos que levaram a uma reforma estatal tão ampla em Paris, há diferentes opiniões. Para alguns, a reforma foi fruto apenas de uma necessidade de circulação mais intensa, inerente ao modo de vida industrial; outros a vêem como necessidade de se evitar a insurgência de novas barricadas. Havia, ainda, por trás das reformas, o desejo de higienizar a cidade, sustentado por um ideário científico.

Heliana Salgueiro localiza um percurso histórico a determinar os rumos da crítica sobre as reformas de Haussmann ao longo dos "últimos decênios":

[...] Do simplismo datado e redutor que via na abertura dos bulevards apenas um ato deliberado para facilitar a marcha dos canhões sobre o povo e acabar com as barricadas, passou-se a estudar as respostas que a remodelação geral da cidade dava a representações anteriores e a problemas urbanos prementes de salubridade e circulação, o que significava equipá-la com ruas pavimentadas, praças arborizadas, parques, jardins, escolas, teatros, estações, esgotos, transportes, imóveis padronizados com fachadas em pedra e providos de água, luz e gás, medidas que, independentemente de qualquer ideologia e da especulação inerente a esse processo, trariam novas condições cotidianas de vida. $[\ldots]^{75}$

\footnotetext{
${ }^{73}$ OrTIZ, Renato. Cultura e Modernidade - A França no século XIX. op. cit., p. 14.

${ }^{74}$ Cf. ORTIZ, Renato. Cultura e Modernidade - A França no século XIX. op. cit., p. 21.

${ }^{75}$ SAlgueiro, H. A. "Introdução: Da Temática, dos autores e de suas idéias". op. Cit., pp. 23-24.
} 
A percepção que Benjamin tem da reforma de Paris não se restringe a vê-la exclusivamente pelo âmbito de suas motivações estratégicas. No entanto, ele fundamenta a reforma de Haussmann pela proteção da cidade contra novas barricadas. Em suas palavras:

A verdadeira finalidade das obras de Haussmann era tornar a cidade segura no caso de guerra civil. Ele queria tornar impossível que no futuro se levantassem barricadas em Paris. [...] Haussmann quer impedi-las de duas maneiras: a largura das avenidas deveria tornar impossível erguer barricadas e novas avenidas deveriam estabelecer um caminho mais curto entre as casernas e os bairros operários. Os contemporâneos batizam esse empreendimento de "embelissement stratégique" [embelezamento estratégico] ${ }^{76}$.

Havia o orgulho da cidade reformada, mas havia também o medo burguês causado pelos pobres. E assim configurava-se, com espanto, a satisfação dos habitantes de Paris:

[...] Aqui [na França do século XIX], os parisienses, orgulhosos de sua civilização, temem depredações e o constrangimento do espetáculo das multidões famintas, mas temem, sobretudo, as jornadas revolucionárias. Seu temor se fixa numa imagem de grandeza assustadora: aquela de homens fazendo valer suas exigências através do controle das instituições políticas; pondo, portanto, na ordem do dia, o assédio e a ocupação das praças e dos edifícios públicos. O espectro das multidões incontroláveis dos anos revolucionários faz-se presente a cada momento da vida cotidiana, como força em repouso de uma sociedade que se autoconcebe constituída sobre o marco do acolhimento da pobreza no campo da política.

Não é a pobreza indigente, sem trabalho, o principal interesse do francês ao observar a multidão; sua atividade exploratória das cenas de rua está sempre atenta aos sinais de uma irrupção das forças subterrâneas da sociedade. A metáfora da faísca elétrica prenunciadora das grandes tempestades é usada por Victor Hugo para descrever a ansiedade social anterior às jornadas de 1832 . $[\ldots]^{77}$

A reforma da cidade teria ajudado a apartar esse medo, uma vez que encaminhou a temerosa massa dos pobres às periferias. Assim, Paris tornou-se uma cidade

${ }^{76}$ Benjamin, Walter. "Paris, capital do século XIX". In: Benjamin - Sociologia. São Paulo: Editora Ática, 1985, p. 42. . Kothe, Flávio R. (org.). Walter

${ }^{77}$ Bresciani, M. S. Londres e Paris no século XIX: o espetáculo da pobreza. op. cit., pp. 109-110. Grifos da autora. 
"reformada em seus hábitos, em seus costumes e seus espaços, na qual a multidão dos pobres perde suas próprias raízes" $" 78$.

Se, de fato, entre os objetivos que motivaram Haussmann em sua reforma estava o de evitar novas barricadas, certamente ele não utilizara a técnica mais eficiente. Isso porque, após a reforma, houve a insurgência de barricadas ainda mais fortes e seguras, cruzando as grandes avenidas, com a Comuna de Paris. E é o próprio Benjamin quem constata: "O incêndio de Paris é a digna conclusão da obra de destruição de Haussmann"79.

Além dos motivos já citados, havia, por trás da reforma e mesmo da crítica a seu respeito, um ideal técnico. Paris tinha passado, em 1832, por uma epidemia de cólera. A imprensa local começou a pressionar o Estado para instaurar uma política de grandes obras, de modo a melhorar as condições de higiene da capital e, concomitantemente, dar emprego à população de baixa renda ${ }^{80}$. As obras de Paris empregaram, regularmente, a classe operária por mais de quinze anos, respondendo ao que fora pedido por jornais da época ${ }^{81}$. Reivindicava-se também infra-estrutura básica, como a distribuição de água para toda a cidade ${ }^{82}$. Estudos de sanitaristas e médicos franceses passaram a alertar sobre "doenças determinadas pelas condições ambientais" $" 83$, dando origem à engenharia sanitária em meados do século XIX.

Os engenheiros pediram que o centro de Paris fosse racionalizado. Com isso seriam destruídas pequenas casas da população de baixa renda e seus habitantes teriam que procurar novas habitações - a maioria deles deixaria de morar no centro, o que era tido como um ponto positivo, pois se acreditava que encontrariam melhores condições de salubridade e ventilação no subúrbio, pagando um valor igual ao que gastavam para viver na região central ${ }^{84}$. Tal pensamento supõe que haveria uma melhoria na vida da população de baixa renda, que seria transferida para as periferias, pois considera apenas o fator técnico da habitação - haveria maior ventilação e salubridade -, não levando em

\footnotetext{
${ }^{78}$ Bresciani, M. S. Londres e Paris no século XIX: o espetáculo da pobreza. op. cit., p.121.

${ }^{79}$ BENJAmin, W. "Paris, capital do século XIX". op. cit. p. 43.

${ }^{80}$ Cf. PICON, Antoine. "Racionalidade técnica e utopia: a gênese da haussmannização". In: SALGUEIRO, H. A. (org.). Cidades Capitais do século XIX. op. cit., p. 80.

${ }^{81}$ Cf. SAlgueiro, H. A. "Introdução: Da Temática, dos autores e de suas idéias”. op. cit., pp. 24 - 25.

${ }^{82}$ Cf. PICON, A. "Racionalidade técnica e utopia: a gênese da haussmannização". op. cit., p. 80.

${ }^{83}$ CALABI, Donatella. "O Papel de Paris na urbanística italiana do século XIX: o mito da modernização". In: SAlgueiro, H. A. (org.). Cidades Capitais do século XIX. op. cit., pp. 104-105.

${ }^{84}$ Cf. PICON, A. "Racionalidade técnica e utopia: a gênese da haussmannização". op. cit., p. 81.
} 
conta as distâncias que seriam então percorridas para que essa população pudesse participar de uma nova cidade a ser construída; ou seja, não considerando sua exclusão.

Antoine Picon destaca o pensamento técnico que estava por trás da reforma de Paris, sobretudo o dos engenheiros que, a partir da virada do século XVIII para o XIX, passaram a ocupar-se com questões urbanísticas ${ }^{85}$. Ainda no século das Luzes, as elites idealizavam uma cidade dotada de possibilidade de fluxo - natural e humano - e que pudesse crescer, "uma cidade antiga preservada ao lado dos quarteirões novos concebidos pelos engenheiros" $"$. No século XIX teria surgido, com inspiração sansimonista, um desejo de unir organicidade a eficiência técnica ${ }^{87}$.

De acordo com Benjamin, Haussmann estava mesmo preso a uma lógica do desenvolvimento técnico, marca da modernidade. Ele seguiria a tendência do século XIX de "enobrecer necessidades técnicas fazendo delas objetivos artísticos" via arte nas obras, que as avenidas rasgadas nos antigos bairros medievais, antes de serem inauguradas, eram cobertas por uma lona, do mesmo modo como eram inaugurados os monumentos ${ }^{89}$.

Há ainda pressupostos políticos para a reforma. Leonardo Benevolo a vê, sob esse aspecto, como parte de um movimento de reformas feitas por uma "nova direita, autoritária e popular", representada por Napoleão III na França, que buscava um "controle direto do Estado sobre muitos setores da vida econômica e social" "90, uma resposta aos movimentos de 1848. Luís Napoleão teria, também, interesse nas obras como meio de tornar-se mais popular e, indo na mesma direção de Benjamin, Benevolo acredita que havia a intenção de "tornar mais difíceis as futuras revoluções, demolindo as antigas ruas medievais e substituindo-as por artérias espaçosas e retilíneas propícias aos movimentos de tropas" $" 91$.

Para além dos fatores que a motivaram - um saber técnico somado a motivos políticos -, a reforma de Paris levou a mudanças que extrapolaram o parâmetro urbano, transformando, mais que a cidade, a vida social de seus habitantes. Benjamin observa que, com as mudanças realizadas por Haussmann, os bairros da capital francesa

\footnotetext{
${ }^{85}$ Cf. PICON, A. "Racionalidade técnica e utopia: a gênese da haussmannização". op.cit., pp. 66-67.

${ }^{86}$ PiCON, A. "Racionalidade técnica e utopia: a gênese da haussmannização". op. cit., p. 69.

${ }^{87}$ Cf. PICON, A. "Racionalidade técnica e utopia: a gênese da haussmannização". op. cit., p. 77.

${ }^{88}$ Benjamin, W. "Paris, capital do século XIX”. op. cit. p. 41.

${ }^{89}$ Cf. Benjamin, W. "Paris, capital do século XIX". op. cit. p. 41.

${ }^{90}$ Benevolo, L. "Haussmann e o plano de Paris". op. cit., p. 92.

${ }^{91}$ Benevolo, L. "Haussmann e o plano de Paris". op. cit., p. 96.
} 
perderam sua fisionomia própria. ${ }^{92}$ Com isso, Paris teria se tornado uma cidade estranha a seus próprios moradores, que não mais se sentiam em casa nessa (sua) cidade.

Os usuários dessa "nova cidade" tiveram que dela se (re)apropriar, ainda que pudessem não se dar conta disso. Um novo modo de vida foi implantado com a reforma, transformando Paris na capital do século XIX. Não foi, certamente, apenas a reforma da cidade que fez com que ela se tornasse palco inicial da modernidade; a aplicação urbanística de um ideário de progresso no qual se destrói o antigo para erigir o novo foi, entretanto, marco concreto de uma nova relação dos citadinos com a cidade. Com o aumento da fluidez, ocorreu também uma intensificação na celeridade da circulação, o que modificou a relação dos metropolitanos com o tempo.

Sobre os bulevares da capital do século XIX circulava a burguesia emergente. Paris tornava-se palco da modernidade, da busca pelo novo, e também da moda. Havia uma forte efervescência cultural nessa cidade refeita. E havia também a tensão em relação às massas expulsas para as periferias, como lembra Benjamin, ao se debruçar teoricamente sobre Paris, no início do século XX:

Como formação social, Paris é uma contra-imagem do Vesúvio, como formação geográfica: uma massa ameaçante, perigosa, um Janus da Revolução sempre ativo. E assim como as ladeiras do Vesúvio, graças às camadas de lava que as cobrem, tornam-se pomar paradisíaco, assim também aqui, extraídos da lava da revolução, florescem arte, moda, e existência festiva como em nenhum outro lugar. $^{93}$

Ocorreram tantas transformações, que se tornou quase impossível preservar raízes e tradições nessa cidade cujos hábitos, costumes e espaços passaram a ser reformados sem cessar. Foi também no século XIX que surgiram em Paris as galerias, ou "centros comerciais de mercadoria de luxo" 94 , fruto da alta do comércio têxtil - um marco para o surgimento do intenso estímulo à fetichização da mercadoria.

\footnotetext{
${ }^{92}$ BENJAMIN, W. "Paris, capital do século XIX". op. cit., p. 41.

${ }^{93}$ Benjamin, Walter. Apud: Buck-Morss, Sandra. Dialética do olhar - Walter Benjamin e o Projeto das Passagens. Belo Horizonte: Editora UFMG; Chapecó/SC: Editora Universitária Argos, 2002, p. 96.

${ }^{94}$ Benjamin, W. "Paris, capital do século XIX”. op. cit. p. 31.
} 
Sobre as galerias, Benjamin deixou um trabalho inacabado conhecido como o “projeto das Passagens", Passagen-Werk no original ${ }^{95}$. Benjamin o iniciou em 1927 e nele trabalhou até seu suicídio, em $1940^{96}$. Esse projeto se destinava a estudar as passagens (ou arcadas) parisienses "que, no século XIX, foram a morada dos primeiros mundos de sonho de consumo" 97.

Era o início da era do consumo, e Paris se consagrava enquanto centro de tal prática. “[Na exposição Universal de 1867] O Império está no apogeu do seu poder. Paris se afirma como capital do luxo e da moda"98. A cidade se destacava pelas mercadorias que oferecia, entre elas a moda das vestimentas. E foi justamente "moda" a palavra derivada por Baudelaire para cunhar o termo "modernidade" 99.

Orgulhosa que estava da efervescência que vivia Paris, a burguesia francesa começou a ter como distração a ida às galerias, onde sempre havia novidades entre as mercadorias ofertadas. Seu orgulho pela industrialização se refletia nas exposições nacionais das indústrias, que originaram as Exposições Universais - segundo Benjamin, "centro de peregrinação ao fetiche mercadoria". Com as exposições, "o valor de uso da mercadoria passa para segundo plano. Inauguram uma fantasmagoria a que o homem se entrega para se distrair" ${ }^{\prime 100}$.

As construções arquitetônicas passaram a utilizar os novos materiais que surgiam a partir do uso do ferro nos trilhos dos trens: "Com o ferro aparece, pela primeira vez na história da arquitetura, um material artificial. A isto se subjaz uma

\footnotetext{
${ }^{95}$ A primeira edição brasileira dessa obra foi lançada recentemente com o título de Passagens. Veja: Benjamin, W. et Bolle, Willi (org.) Passagens. Belo Horizonte: Editora UFMG e São Paulo: Imprensa Oficial do Estado, 2006.

${ }^{96}$ Embora haja divergências quanto à data precisa de seu suicídio, parece certo que ocorreu em 1940: "1940 - (...) Suicida-se em 27 de setembro, quando fica sabendo que lhe é impossível atravessar a fronteira franco-espanhola, última chance para escapar à Gestapo" (GAGNEBIN, J. M. Walter Benjaminos cacos da história. São Paulo: Brasiliense, 1982, p. 95); e “(...) el 26 de septiembre de 1940, Benjamin se suicidó en la frontera franco-española, que intentaba atravesar con una visa norteamericana" (SARLO, Beatriz. Siete ensayos sobre Walter Benjamin. Buenos Aires: Fondo de Cultura Económica de Argentina, 2000, p. 13). Grifos meus.

${ }_{97}^{9}$ BuCK-Morss, S. Dialética do olhar - Walter Benjamin e o Projeto das Passagens. op. cit., p.64.

${ }^{98}$ BenJAmin, W. "Paris, capital do século XIX". op. cit., p. 36.

${ }^{99}$ Baudelaire cunha o termo em "O Pintor da vida moderna", ensaio publicado postumamente (em 1869) sobre o desenhista, aquarelista e gravador Constantin Guys (cf. BAUDELAIRE, Charles. Sobre a modernidade. Rio de Janeiro: Paz e Terra, 1996, p. 7). No item IV, intitulado "A Modernidade", lê-se "A Modernidade é o transitório, o efêmero, o contingente, é a metade da arte, sendo a outra metade o eterno e o imutável. [...] Não temos o direito de desprezar ou de prescindir desse elemento transitório, fugidio, cujas metamorfoses são tão freqüentes". (BAUDELAIRE, Charles. Sobre a modernidade. Rio de Janeiro: Paz e Terra, 1996, p. 25).

${ }^{100}$ Benjamin, W. "Paris, capital do século XIX". op. cit., p. 36.
} 
evolução cujo ritmo se acelera no decorrer do século"101. Passou a ocorrer, também, o desenvolvimento da técnica para a elaboração de novos materiais para o uso na arquitetura. A construção em ferro levou a arquitetura a se emancipar da arte e a ser praticada também por engenheiros, como os técnicos de Haussmann e Eiffel, este responsável pela torre homônima.

Fruto dessa capacidade intelectual - técnica - de fabricar peças utilizando novos materiais, prática que se tornou símbolo dessa era em que a constante superação tecnológica é valorizada, a Torre Eiffel foi concluída em 1898 e instalada na cidade de Paris. Sobre o monumento, resultado, portanto, do emprego de novos materiais decorrentes da indústria, observa Benjamin:

Aqui o poder de plasticidade visual é silenciado em favor de uma extraordinária tensão de energia intelectual que a energia do material inorgânico traz para as formas extremamente pequenas e efetivas, unindo-as de maneira mais eficaz [...]. Cada uma das 12.000 peças de metal é precisamente determinada ao milímetro, [assim como] cada um dos dois milhões e meio de rebites $[\ldots] .^{102}$

A técnica vinha se espalhando pelos domínios urbanísticos e arquitetônicos, e Benjamin acredita que o art nouveau representava "a última tentativa de fuga de uma arte sitiada em sua torre de marfim pela técnica" ${ }^{, 103}$. Tal estilo trazia formas da natureza vegetal, mas utilizava os novos materiais da indústria, como o ferro. No século XIX, constituíam-se os primórdios da arquitetura sem adornos. Poucos anos depois, Mies van der Rohe - com seu célebre preceito "less is more" - viria a aplicar na arquitetura, de forma mais incisiva, a transparência do vidro - "material tão duro e tão liso, no qual nada se fixa", "material frio e sóbrio", material que é "o inimigo do mistério". "As casas de vidro não têm aura" ${ }^{104}$, diz Benjamin, referindo-se à arquitetura moderna para ilustrar a aplicação dos frutos do desenvolvimento técnico no exterior das habitações e nas cidades ${ }^{105}$.

${ }^{101}$ Benjamin, W. "Paris, capital do século XIX”. op. cit., p. 31.

102 Benjamin, W. Apud Buck-Morss, S. Dialética do olhar - Walter Benjamin e o Projeto das Passagens. op. cit., p. 105.

${ }^{103}$ Benjamin, W. "Paris, capital do século XIX". op. cit., p. 37.

${ }^{104}$ BENJAMIN, W. "Experiência e pobreza”. op. cit., p.117.

105 Sobre a relação entre a arquitetura de vidro e o pensamento benjaminiano, ver: MISSAC, Pierre. "A Arquitetura de vidro". In: 181-212. . Passagem de Walter Benjamin. São Paulo: Iluminuras, 1998, pp. 
Se a arquitetura seguia essa tendência ao modernismo, a decoração de interiores restava ao homem do século XIX como possibilidade de obter um lar confortante onde ele podia deixar rastros. Assim, em um mundo que passou a seguir um ideário de progresso no qual tudo muda radicalmente e com rapidez, incluindo a própria cidade, o homem foi buscar refúgio dentro de casa:

O interior não é apenas o universo do homem privado, mas também seu estojo. Habitar significa deixar rastros. No interior, eles são acentuados. Colchas e cobertores, fronhas e estojos em que os objetos de uso cotidiano imprimam a sua marca são imaginados em grande quantidade. Também os rastros do morador ficam impressos no interior. ${ }^{106}$

Pois, se nas ruas as galerias faziam da compra de mercadorias uma diversão burguesa, no interior da residência o homem moderno procurava retirar o caráter mercantil dos objetos, substituindo o valor de uso por um valor afetivo ${ }^{107}$ e assim se impregnando da tentativa de, com esses objetos, deixar rastros:

[...] Se entrarmos num quarto burguês dos anos oitenta [1880], apesar de todo o "aconchego" que ele irradia, talvez a impressão mais forte que ele produz se exprima na frase: "Não tens nada a fazer aqui”. Não temos nada a fazer ali porque não há nesse espaço um único ponto em que seu habitante não tivesse deixado seus vestígios. Esses vestígios são os bibelôs sobre as prateleiras, as franjas ao pé das poltronas, as cortinas transparentes atrás das janelas, o guardafogo diante da lareira. $[\ldots]^{108}$

Em um mundo que estava sendo transformado, em que a industrialização chegava com a sua força de padronização, os homens dos anos de 1880 tentavam deixar seus rastros no apego aos objetos de decoração de suas casas. Eles não buscavam, entretanto, novas experiências.

No ensaio ao qual se refere a passagem anterior, "Experiência e pobreza"109, Benjamin aponta a existência de alguns homens que buscavam, pela total ausência de

\footnotetext{
${ }^{106}$ Benjamin, W. "Paris, capital do século XIX”. op. cit., p. 38.

${ }^{107}$ Cf. BenJamin, W. "Paris, capital do século XIX”. op. cit., p. 38.

108 BENJAMIN, W. "Experiência e pobreza". op. cit., pp. 117-118.

${ }^{109}$ BENJAMIN, W. "Experiência e pobreza”. op. cit.,, pp. 114-119.
} 
experiência, transcendê-la ${ }^{110}$ : "aspiram a libertar-se de toda experiência, aspiram a um mundo em que possam ostentar tão pura e tão claramente sua pobreza externa e interna, que algo de decente possa resultar disso" "111. Benjamin lembra, entretanto, que obter algum resultado pela total expurgação de qualquer experiência não é o objetivo, e tampouco o pensamento do homem mediano da modernidade. Deslumbrado pelas incessantes novidades, o homem comum acaba por perder seu lastro com o passado.

Na nova e povoada Paris, onde a novidade se fazia presente inclusive no espaço urbano, andavam as massas de trabalhadores e desfilava a burguesia. Nessa nova cidade também perambulava o flâneur, sujeito que tinha um ritmo diferente do das massas;

[...] O flâneur ainda está no limiar tanto da cidade grande quanto da classe burguesa. Nenhuma delas ainda o subjugou. Em nenhuma delas ele se sente em casa. Ele busca o seu asilo na multidão. [...] Na multidão, a cidade é ora paisagem, ora ninho acolhedor. A casa comercial constrói tanto um quanto o outro, fazendo com que a flânerie se torne útil à venda de mercadorias. A casa comercial é a última grande molecagem do flâneur.

Com o flâneur, a intelectualidade parte para o mercado. Pensa que é para dar uma olhada nele; na verdade, porém, já [é] para encontrar um comprador ${ }^{112}$.

O flâneur se misturava à multidão, mas andava em outro ritmo. A cidade estava rodeada por galerias comerciais, aonde se ia às compras. O flâneur deixava essa sua condição quando, seduzido pelas mercadorias, entrava nas galerias para consumir. Nessa nova Paris, até os que saíam sem intenção de consumo acabavam sendo fisgados pelo encantamento que provocavam as galerias à procura de compradores, até mesmo o flâneur se maravilhava frente ao novo: "A derradeira viagem do flâneur: a morte. Sua meta: o novo. (...) O novo é uma qualidade independente do valor de uso da mercadoria" ${ }^{, 13}$.

A novidade atraía a todos, até mesmo ao flâneur, que acabava por desejar possuí-la. A novidade constante acarreta a destruição de tudo o que estava antes criado. O incansável anseio pelo novo pode igualmente parecer, enquanto mecanismo, regra: a

\footnotetext{
${ }^{110}$ Se em "Experiência e Pobreza" (BENJAmin, W. op. cit.), texto de 1933, Benjamin parece propor uma 'saída' para a situação da perda da experiência, julgando alguns homens capazes de transcendê-la, em "O Narrador - Considerações sobre a obra de Nikolai Leskov" (BENJAMIN, W. op. cit.), de 1936, Benjamin lamenta a perda da experiência em tom quase melancólico, e descreve uma situação de aparente aporia.

${ }^{111}$ BENJAMIN, W. "Experiência e pobreza". op. cit., p. 118.

${ }^{112}$ BenJamin, W. "Paris, capital do século XIX". op. cit., p. 39.

${ }^{113}$ Benjamin, W. "Paris, capital do século XIX". op. cit., p. 40.
} 
"falsa aparência de novidade se reflete, como um espelho em outro, na falsa aparência do sempre-igual" ${ }^{, 114}$.

A esse paradigma moderno somou-se também, de acordo com Simmel, uma forma de sociabilidade específica da metrópole moderna ${ }^{115}$. Tantos são os "estímulos contrastantes" a que seus nervos são subjugados na vida urbana, "em rápidas mudanças e compressão concentrada", que eles “cessam completamente de reagir". Pela "rapidez e contrariedade" das mudanças, os nervos são estirados "tão brutamente em uma e outra direção, que suas últimas reservas são gastas" e, ficando a pessoa no mesmo meio, não há tempo para recuperar sua força. De uma "incapacidade de reagir a novas sensações com a energia apropriada" daí decorrente surge a "atitude blasé"116.

Com a atitude blasé a concentração de homens e coisas estimula o sistema nervoso do indivíduo até seu mais alto ponto de realização, de modo que ele atinge seu ápice. Através da mera intensificação quantitativa dos mesmos fatores condicionantes, essa realização é transformada em seu contrário e aparece sob a adaptação peculiar da atitude blasé. Nesse fenômeno, os nervos encontram na recusa a reagir a seus estímulos a última possibilidade de acomodar-se ao conteúdo e à forma da vida metropolitana. ${ }^{117}$

Submetido o metropolitano a esse tipo de atitude, sua autopreservação frente à cidade grande leva-o a ter uma "atitude mental" para com os outros - uma forma de sociabilidade especial, denominada por Simmel de "reserva" - que lhe faz restringir seus contatos sociais. Caso algum habitante da metrópole desejasse conversar com todos os que aí vivem, e conhecê-los todos, essa pessoa "ficaria completamente atomizada internamente e chegaria a um estado psíquico inimaginável"118. Assim, essa reserva exterior do metropolitano apresenta, em seu aspecto interior, para além da forma da indiferença,

[...] uma leve aversão, uma estranheza e repulsão mútuas, que redundarão em ódio e luta no momento de um contato mais próximo, ainda que esse tenha sido

\footnotetext{
${ }^{114}$ BenJamin, W. "Paris, capital do século XIX". op. cit., p. 40.

115 Cf. SimMel, G. "A metrópole e a vida mental”. In: VelHo, Otávio Guilherme (org.). O fenômeno urbano. Rio de Janeiro: Zahar Editores, 1967, pp. 13-28. O texto foi publicado pela primeira vez em 1902, e tem como principal referência a cidade de Berlim.

${ }^{116}$ SimmeL, G. "A metrópole e a vida mental". op. cit., p. 18.

${ }^{117}$ SimMEL, G. "A metrópole e a vida mental". op. cit., p. 19.

${ }^{118}$ SIMMEL, G. “A metrópole e a vida mental”. op. cit., pp. 19-20.
} 
provocado. [...] A antipatia nos protege de ambos êsses perigos típicos da metrópole, a indiferença e a sugestibilidade indiscriminada. ${ }^{119}$

A atitude blasé e a forma reserva levariam a um maior isolamento dos indivíduos, mostrando que a multidão moderna aumentava apenas a proximidade física entre as pessoas: de acordo com texto publicado pela primeira vez em 1902 por Simmel, o homem metropolitano agiria com a cabeça, e não com o coração; a proximidade física entre os habitantes das grandes metrópoles aumentaria de maneira proporcional à visibilidade de sua distância mental. $\mathrm{O}$ aumento da densidade demográfica nas grandes cidades traria em si, desse modo, o seu oposto - a distância e o isolamento mental dos indivíduos ${ }^{120}$.

Se o século XVIII "encontrou o indivíduo preso a vínculos opressivos que haviam sido destituídos de significação", no século XIX "os indivíduos liberados de vínculos históricos agora desejavam distinguir-se um do outro". E, se a "escala dos valores humanos" antes era constituída pelo “"ser humano geral' em cada indivíduo”, no século XIX ela passa a ser definida pela "unicidade e insubstituibilidade qualitativas do homem". ${ }^{121}$ Como decorrência, os metropolitanos, embora estejam fisicamente mais próximos uns dos outros, individualizam-se e isolam-se cada vez mais. A dimensão coletiva que determinava a base tradicional da sociedade se perde, e tanto os acontecimentos vividos, como o significado que os indivíduos retiram desses (se é que ainda buscam algum significado para a vida), tornam-se muito distintos, individuais.

Nesse contexto, a morte se tornou um episódio cada vez mais particular para os indivíduos. Elias acredita tratar-se de um recalcamento da morte: "a morte parece estar recalcada - um recalcamento que é individual e social". ${ }^{122} \mathrm{Com}$ as mudanças advindas da modernidade, a partir do século XIX, não se vêem mais os mortos, não se acompanham mais os moribundos - eles são isolados em instituições hospitalares, onde são cuidados longe das vistas alheias; a morte perde seu caráter social ${ }^{123}$.

Se a morte dos homens foi recalcada na modernidade, outra forma da morte - a destruição do antigo pela cada vez mais rápida produção do novo - tornou-se presença

\footnotetext{
${ }^{119}$ SIMMEL, G. “A metrópole e a vida mental”. op. cit., p. 20.

${ }^{120}$ Cf. SimMEL, George. “A metrópole e a vida mental”. op. cit., pp. 22-23.

${ }^{121}$ SimmeL, G. “A metrópole e a vida mental”. op. cit., p. 27.

${ }^{122}$ ELIAS, Norbert. “A Solidão dos moribundos”. op. cit., p. 15.

${ }^{123} \mathrm{O}$ tema da morte e as mudanças em sua forma de representação social serão tratados no Capítulo 4 deste trabalho, intitulado "Luto sob a areia".
} 
diária na vida metropolitana. Para Gagnebin, a reforma de Paris oferece boa alegoria a essa morte do novo na modernidade, uma vez que, em seu "gesto arquitetônico", "ruínas e fundações se confundem", de modo que "a morte não habita só os palácios de ontem, mas já corrói os edifícios que estamos erguendo"124.

\subsection{Perda da experiência, perda da narrativa}

A mudança no sentido da morte, acompanhada pelo isolamento dos moribundos, e a desagregação entre velhice e sabedoria, que vêm com a modernidade, já seriam fortes motivos para a perda da narrativa, cujas histórias originárias brotavam das palavras últimas do moribundo. O futuro enquanto tempo forte, que acaba por transformar o tempo presente em um "futuro presentificado", assim como a valorização da novidade expressa em tantos lugares quantos possíveis tampouco são motivos a impulsionar a narrativa; pelo contrário, sob a temporalidade que se impõe na modernidade, os indivíduos acabam se desfazendo do forte vínculo que outrora tinham com o passado e a tradição.

Essa situação tornava iminente a perda da narrativa. Benjamin então atribui um marco para seu definhamento: a Primeira Guerra Mundial (que, à época, ainda não se sabia tratar-se apenas da primeira guerra). Os soldados que foram lutar no front se encontraram, ao voltarem para suas casas, numa situação bastante peculiar. Tinham diante de si um mundo em que quase tudo havia mudado:

[...] Uma geração que ainda fora à escola num bonde puxado por cavalos viu-se abandonada, sem teto, numa paisagem diferente em tudo, exceto nas nuvens, e em cujo centro, num campo de forças de correntes e explosões destruidoras, estava o frágil e minúsculo corpo humano. ${ }^{125}$

Além das inúmeras mudanças, ocorridas em tão pouco tempo, que fizeram com que a paisagem se transformasse de forma rápida e intensa, a situação vivenciada pelos

\footnotetext{
${ }^{124}$ Gagnebin, Jeanne-Marie. História e narração em Walter Benjamin. São Paulo: Perspectiva, 1999, p. 50.

125 BENJAMIN, W. "Experiência e pobreza". op. cit., p. 115. Há uma passagem muito semelhante a essa em "o Narrador": "[...] Uma geração que ainda fora à escola num bonde puxado por cavalos se encontrou ao ar livre numa paisagem em que nada permanecera inalterado, exceto as nuvens, e debaixo delas, num campo de forças de torrentes e explosões, o frágil e minúsculo corpo humano." (BENJAMIN, W. "O Narrador - Considerações sobre a obra de Nikolai Leskov". op. cit., p. 198).
} 
combatentes durante a guerra fora tão terrível que não havia palavras para descrevê-la: "os combatentes voltavam mudos do campo de batalha, não mais ricos, e sim mais pobres em experiência comunicável". ${ }^{126}$ Benjamin usa os combatentes como metáfora para uma pobreza de experiência comunicável que, entretanto, acometera toda a humanidade. Uma sociedade que transmitia oralmente o ensinamento da experiência, através das gerações, sofreu a perda da narrativa. O mundo mudava radical e rapidamente nesse tempo em que se instaurava a modernidade, no qual a herança da experiência já não era mais transmitida, e tampouco carregada pelos indivíduos.

[...] a arte de contar torna-se cada vez mais rara porque ela parte, fundamentalmente, da transmissão de uma experiência no sentido pleno, cujas condições de realização já não existem na sociedade moderna. [... $]^{127}$

A narrativa partia da transmissão da experiência, que precisava de determinadas condições para existir (condições existentes à época de ouro da narrativa e que, decaindo, levam também à decadência da narrativa). Jeanne-Marie Gagnebin aponta condições existentes no modo de vida pré-moderno que possibilitavam a realização da experiência, e que se perdem com a modernidade. Em primeiro lugar, "a experiência transmitida pelo relato deve ser comum ao narrador e ao ouvinte" ${ }^{128}$. Com a modernidade e suas aceleradas mudanças - devidas às quais o antigo se torna logo obsoleto - o mundo e suas relações são contaminados por uma perenidade que faz com que tudo mude muito rapidamente, de modo que conselhos de uma geração não são mais válidos para a geração seguinte. Com a modernidade, perde-se o mundo comum que permite aos jovens obter ensinamentos dos mais velhos.

A segunda condição para que se possa transmitir experiência é o trabalho artesanal ser a forma de produção predominante. Isso porque

[...] O artesanato permite, devido a seus ritmos lentos e orgânicos, em oposição à rapidez do processo de trabalho industrial, e devido a seu caráter totalizante, em oposição ao caráter fragmentário do trabalho em cadeia, por exemplo, uma sedimentação progressiva das diversas experiências e uma palavra unificadora. $\mathrm{O}$ ritmo do trabalho artesanal se inscreve em um tempo mais global, tempo onde ainda se tinha, justamente, tempo para contar. Finalmente, de acordo com

\footnotetext{
${ }^{126}$ BENJAMIN, W. “O Narrador - Considerações sobre a obra de Nikolai Leskov”. op. cit., p. 198.

${ }^{127}$ Gagnebin, J. M. "Prefácio - Walter Benjamin ou a história aberta". op. cit., p. 10.

${ }^{128}$ GAgnebin, J. M. "Prefácio - Walter Benjamin ou a história aberta". op. cit., p. 10.
} 
Benjamin, os movimentos precisos do artesão, que respeita a matéria que transforma, têm uma relação profunda com a atividade narradora: já que esta também é, de certo modo, uma maneira de dar forma à imensa matéria narrável, participando assim da ligação secular entre a mão e a voz, entre o gesto e a palavra. ${ }^{129}$

Por fim, Gagnebin lembra que, para que a narrativa possa aparecer ao ouvinte como um conselho, o narrador e o ouvinte devem estar inseridos em um "fluxo narrativo comum e vivo, já que a história continua, que está aberta a novas propostas e ao fazer junto". 130

Além dessas três condições citadas por Gagnebin, pode-se acrescentar também o já mencionado caráter público da morte, que deixa de existir com o isolamento dos moribundos e sua retirada para instituições hospitalares e asilos. Assim, sem condições propícias à sua existência na modernidade, a narrativa, gênero literário escolhido por Benjamin para representar o período que antecede a produção industrial, perde sua força. As formas de comunicação predominantes passam a ser o romance e a informação.

Oposto à coletividade que marcava a narrativa, o romance "nem procede da tradição oral e nem a alimenta", pois depende totalmente do livro. Ele surge de um indivíduo isolado - "o romancista segrega-se", busca sozinho o sentido da vida, que nada garante que será encontrado, e escreve para um leitor que igualmente persegue tal sentido sozinho, sem garantias de êxito. Contrário também à dimensão de abertura característica da narrativa, o romance se encerra tão logo o leitor percorre a última palavra do livro. ${ }^{131}$

Quem escuta uma história está em companhia do narrador; mesmo quem a lê partilha dessa companhia. Mas o leitor de um romance é solitário. Mais solitário que qualquer outro leitor (pois mesmo quem lê um poema está disposto a declamá-lo em voz alta para um ouvinte ocasional). Nessa solidão, o leitor do romance se apodera ciosamente da matéria de sua leitura. Quer transformá-la em coisa sua, devorá-la, de certo modo. Sim, ele destrói, devora a substância lida, como o fogo devora lenha na lareira. A tensão que atravessa o romance se assemelha muito à corrente de ar que alimenta e reanima a chama. ${ }^{132}$

\footnotetext{
${ }^{129}$ Gagnebin, J. M. "Prefácio - Walter Benjamin ou a história aberta”. op. cit., pp. 10-11.

${ }^{130}$ GagneBin, J. M. "Prefácio - Walter Benjamin ou a história aberta”. op. cit., p. 11.

${ }^{131}$ Cf. Benjamin, W. “O Narrador - Considerações sobre a obra de Nikolai Leskov”. op. cit., p. 201.

${ }^{132}$ Benjamin, W. "O Narrador - Considerações sobre a obra de Nikolai Leskov”. op. cit., p. 213.
} 
Emerge, junto ao romance, a informação. Esta, também marca da comunicação na modernidade, tem um ritmo como o do progresso científico - é superada a cada instante, possui, portanto, curtíssima duração. Desprovida da autoridade que a narrativa possuía por ser um conhecimento que vinha de longe, a informação deve sempre ser passível de comprovação - como a verificação é facilitada por curtas distâncias, tanto mais convincente é a informação quanto mais de perto ela vem:

[...] o saber que vem de longe encontra hoje menos ouvintes que a informação sobre acontecimentos próximos. O saber, que vinha de longe - do longe espacial das terras estranhas, ou do longe temporal contido na tradição -, dispunha de uma autoridade que era válida mesmo que não fosse controlável pela experiência. Mas a informação aspira a uma verificação imediata. Antes de mais nada, ela precisa ser compreensível “em si e para si”. Muitas vezes não é mais exata que os relatos antigos. Porém, enquanto esses relatos recorriam freqüentemente ao miraculoso, é indispensável que a informação seja plausível. Nisso ela é incompatível com o espírito da narrativa. Se a arte da narrativa é hoje rara, a difusão da informação é decisivamente responsável por esse declínio.

Cada manhã recebemos notícias de todo o mundo. E, no entanto, somos pobres em histórias surpreendentes. A razão é que os fatos já nos chegam acompanhados de explicações. Em outras palavras: quase nada do que acontece está a serviço da narrativa, e quase tudo está a serviço da informação. ${ }^{133}$

A temporalidade da informação é compatível com a modernidade, na qual predomina o tempo do "incessantemente novo"; tudo deve ser reconstruído a todo instante, de modo a evitar obsolescência. A informação só tem valor enquanto é nova: "Ela só vive nesse momento, precisa entregar-se inteiramente a ele e sem perda de tempo tem que se explicar nele". ${ }^{134}$ Assim como o romance, a informação já chega ao receptor dotada de conceitos e significados psicológicos - não é dado a seus leitores interpretar o conteúdo que recebem, como faziam os ouvintes da narrativa. Quando as explicações sobre o acontecimento comunicado o acompanham, a interpretação do receptor fica comprometida ${ }^{135}$. A narrativa podia se desenvolver por muito tempo após sua transmissão porque sua explicação era fruto da reflexão de quem a ouvia, em qualquer época.

\footnotetext{
${ }^{133}$ BENJAMIN, W. “O Narrador - Considerações sobre a obra de Nikolai Leskov”. op. cit., pp. 202-203.

${ }^{134}$ BENJAMIN, W. "O Narrador - Considerações sobre a obra de Nikolai Leskov”. op. cit., p. 204.

${ }^{135}$ Cf. BENJAmin, W. “O Narrador - Considerações sobre a obra de Nikolai Leskov”. op. cit., p. 203.
} 
A narrativa era responsável pela transmissão da experiência, mas em um mundo no qual a temporalidade é a do futuro presentificado e se esvaecem as referências ao passado, então visto como tempo da obsolescência, não há mais experiência, e tampouco narrativa. Perdeu-se uma tradição que unia as gerações por meio dos ensinamentos aconselhados pela narrativa, que orientava e dava sentido à vida no mundo, ligando-a ao passado. Nas palavras de Hannah Arendt:

[...] Com a perda da tradição, perdemos o fio que nos guiou com segurança através dos vastos domínios do passado; esse fio, porém, foi também a cadeia que aguilhoou cada sucessiva geração a um aspecto predeterminado do passado. $[\ldots]^{136}$

Talvez o passado agora tivesse coisas inéditas a dizer, mas sem uma tradição ancorada firmemente, que traga à memória a dimensão do passado, a profundidade da existência humana é colocada em perigo:

[...] Estamos ameaçados de esquecimento, e um tal olvido - pondo inteiramente de parte os conteúdos que se poderiam perder - significaria que, humanamente falando, nos teríamos privado de uma dimensão, a dimensão de profundidade na existência humana. Pois memória e profundidade são o mesmo, ou antes, a profundidade não pode ser alcançada pelo homem a não ser através da recordação. $^{137}$

Dialogar com a memória humana não significa buscar um retorno saudosista ao passado, tampouco propor um retorno às condições de vida pré-modernas. Significa, antes, estabelecer, na modernidade, alguma espécie de relação com o passado na qual ele não mais apareça como o tempo do que é obsoleto.

Benjamin identificou no romancista Marcel Proust a experimentação de uma temporalidade que rompia com a da modernidade a partir de um entrecruzamento temporal, fruto de uma rememoração ${ }^{138}$. O cinema parece igualmente capaz de prover seu espectador de uma relação temporal que extravase a temporalidade do futuro presentificado.

${ }^{136}$ ARENDT, H. Entre o Passado e o Futuro. op. cit., p.130.

137 AREndT, H. Entre o Passado e o Futuro. op. cit., p. 131.

${ }^{138}$ Ver Benjamin, Walter. "A imagem de Proust". In: . Magia e técnica, arte e política - Obras escolhidas, volume I. São Paulo: Brasiliense, 1985, pp. $36-49$. Esse assunto será tratado no Capítulo 5 deste trabalho, "A Eternidade de um dia rememorado". 
O exercício dos próximos capítulos será, a partir da análise fílmica, perceber como a temporalidade das obras selecionadas é capaz de romper com a lógica do progresso técnico e da valorização do novo. Isso decorre da proposta de mostrar ao espectador, por meio do aparato tecnológico do cinema, a possibilidade de experimentação de temporalidades distintas da predominante, ainda que sob o jugo da modernidade. 


\section{Espera e errância - saída da temporalidade moderna em}

\section{Dolls}

Após filmar Brother nos Estados Unidos e obter reconhecimento internacional, o diretor Takeshi Kitano voltou ao seu país pátrio, o Japão, para filmar Dolls. Lançado em 2002, o filme retoma elementos típicos da cultura japonesa, como o teatro bunraku. Refere-se, entretanto, a temas universais, uma vez que subverte a temporalidade moderna ao mostrar histórias centradas na errância e na espera. Dolls submete o espectador a uma temporalidade mais lenta que aquela à qual o homem moderno está acostumado. Os caminhos de seus personagens se misturam às estações do ano, cada qual associada a um sentimento, de modo que a construção do filme aponta para uma relação com o tempo que não diz respeito aos ponteiros do relógio.

Uma apresentação do tradicional teatro japonês de bonecos manipuláveis, o bunraku, abre o filme. Em seguida, são mostrados, de modo intercalado, três relacionamentos amorosos vivenciados por personagens humanos. Nessas três histórias, os protagonistas têm uma vida de ruptura com a temporalidade moderna, por fatos trazidos pelo acaso - ou seria pelo destino?

Dolls tem início na primavera, com a paisagem carregada de cerejeiras floridas. No verão, recebem destaque o elemento "água" e a simbologia que o acompanha; no outono a tela é tingida de vermelho pelas folhas caídas e pelo sangue escorrido. Por fim, na branca paisagem do inverno, coberta pela neve, encerra-se esse ciclo.

Cada uma das histórias mostradas em Dolls possui uma trama distinta, mas elas se ligam por sua temporalidade distendida e por rápidos encontros entre os personagens, que não chegam a interagir entre si. Na história central, uma mulher é abandonada por seu noivo, e, como decorrência de uma tentativa de suicídio, perde a memória. Arrependido, ele a busca no hospital e o casal passa a caminhar sem destino, unido por uma corda. A segunda história é marcada pela espera passiva de uma mulher por um rapaz a quem ela diz ser "seu namorado". Esse homem se lembra da antiga promessa de um dia voltar para encontrá-la e o faz, percebendo que ela ainda o espera. Na terceira história, uma famosa cantora sofre um acidente de carro e isola-se em uma praia, à espera de um improvável retorno ao mundo do estrelato, ou mesmo de uma volta ao passado anterior ao ocorrido, e lá recebe a visita de um de seus fãs, que se cegou. 
As tramas variam, mas há um mesmo elemento nas histórias: a espera (na primeira história expressa pela errância), que atua como um mecanismo autonomizado em relação ao objeto inicial. Isso porque, com o passar do tempo, a busca deixa de ter o alvo inicial como objetivo e acaba por tornar-se a atividade central da vida dessas pessoas. A espera torna-se, assim, uma atividade destituída de finalidade, um elemento naturalizado na vida dos protagonistas.

A temporalidade que emerge dessa busca que se encerra em seu próprio mecanismo pode ser pensada como contraponto à temporalidade moderna. Não há pressa em Dolls, a construção fílmica permite ao espectador a contemplação de imagens de intensa duração. No enredo, poucos diálogos, e a predominância de uma linguagem que se difere daquela predominante na modernidade, cuja função é majoritariamente "prático-comunicativa".

Apesar de ser um filme repleto de efeitos de edição, com diversos cortes, o ritmo de Dolls é lento, já que nele se expressa o ritmo de uma busca inalcançável - da espera e da errância sem objeto -, que muito se difere do ritmo do "incessantemente novo" da modernidade.

A trama se passa no Japão, país que possui a segunda maior economia em potência tecnológica do mundo, atrás apenas dos Estados Unidos, e cuja economia é considerada a terceira maior do mundo, atrás dos Estados Unidos e da China ${ }^{2}$. Em Dolls, entretanto, não é esse país moderno e tecnológico que se vê, salvo em rápidas cenas. Quando o Japão inserido na modernidade, dotado de forte apelo tecnológico, aparece no filme, é para, em seguida, ser contraposto à fuga dessa temporalidade da técnica autonomizada. O filme não foi construído de modo a reforçar a temporalidade moderna, mas, ao contrário, o espectador de Dolls é submetido a uma temporalidade baseada na passagem "natural" do tempo, que oscila junto ao clima de cada estação. Cada estação climática traz novos elementos ao filme, que levam o espectador a associá-lo a um sentimento distinto do anterior, já que não apenas a paisagem, mas também as expectativas geradas pela trama, mudam a cada oscilação.

\footnotetext{
${ }^{1}$ Irene Cardoso associa a perda da narrativa benjaminiana à emergência de uma linguagem 'práticocomunicativa', uma linguagem 'instrumental': "o fim da narrativa tem ainda por indício a prevalência de uma linguagem cada vez mais instrumental"; "A prevalência de uma linguagem prático-comunicativa sobre a narração exclui a história e a memória, porque construída sobre o imediatamente presente e o existente". (CARDOSO, Irene. “A narrativa silenciada”. op. cit., p.174 e 175).

${ }^{2}$ Cf. CIA - Central Intelligence Agency. The World Factbook 2006. E.U.A., 2006. Publicação anual disponível em: https:/www.cia.gov/cia/publications/factbook/geos/ja.html\#Econ. Acesso em 13/09/2006.
} 
No Japão, as estações do ano têm clima bem-definido. Como o país está localizado no hemisfério Norte, a primavera é a primeira estação que tem início a cada novo ano. Com a chegada da primavera, florescem as cerejeiras no país. O verão, em seguida, é marcado por chuvas constantes, que vão se espaçando até a chegada do outono - quando as folhas ficam secas, ganham coloração avermelhada e caem das árvores. Segue-se então o inverno, que costuma ser rigoroso, com fortes geadas e neve em grande parte do país.

Cada uma das estações aparece em Dolls de forma a ser possível identificá-las rapidamente. Na primavera, a paisagem está tomada pelas flores brancas das cerejeiras, evocando no espectador a impressão de que dessas flores se colherão bons frutos. Daí se extrai um sentimento de esperança que coincide com a expectativa do público, habituado aos finais felizes no cinema. Essa esperança advinda da primavera dilui-se, entretanto, nas águas que chegam com o verão para dar fim à primavera.

No verão, a tela é banhada por águas em constante movimento: rio, mar e chuva vêm simbolizar, sobretudo, a irreversibilidade dos fatos. Nessa estação, aparecem no filme dois outros casais protagonistas, além do primeiro, que já aparecera na estação anterior.

Em um cenário coberto por folhas vermelhas que voam e se espalham pelo chão, a tela se tinge de sangue e desgraça no outono. Com a morte de dois personagens masculinos, as histórias que tiveram início no verão já chegam ao fim.

A história central do filme, que começou marcada pelo branco das flores de cerejeira da primavera, termina no branco da neve que toma a paisagem no inverno. Ao espectador resta a impressão de que um novo ciclo de estações terá início, e novas esperanças poderão operar na primavera que se segue, já que os elementos que poderiam ter rompido com o curso trágico de Dolls se mostraram inoperantes.

De início relacionada à mudança de estações de ano, a temporalidade predominante em Dolls, aqui chamada de "temporalidade de espera", está mais próxima do ritmo cíclico associado à natureza - que emana da transformação de elementos ditos "naturais", como a água, que assume outros estados até retornar à forma líquida -, do que do tempo rápido do tique-taque de um relógio, o tempo devorador da modernidade, que caminha sobre a repetição exaustiva e exaustivamente veloz da novidade (e, conseqüentemente, da morte que cada novidade traz consigo). 
Os intervalos de tempo entre as mudanças das estações do ano e outras repetições a que se chamam "naturais" parecem ter maior duração do que o intervalo entre os incessantes - e transitórios - eventos da modernidade. A mesma impressão pode surgir da comparação entre o tempo de maturação e o de obsolescência: na natureza, os fenômenos parecem demorar mais para se formar e durar mais tempo do que os acontecimentos modernos. Isso porque na natureza há a possibilidade de criarem-se feitos que se aperfeiçoam por meio de processos de longuíssima duração, para os quais a celeridade é dispensável, ao passo que para a modernidade a celeridade é pensada como valor positivo, e por isso há uma busca por apressar, tanto quanto possível, seus processos.

As águas de um rio podem, entretanto, passar de modo mais veloz do que as novidades e os acontecimentos que surgem na modernidade, e ter-se-á ainda a impressão de que a natureza compõe uma temporalidade mais lenta. Isso ocorre porque a diferença entre a temporalidade da natureza e a da modernidade não está na duração de fenômenos isolados, mas na forma cíclica que à primeira se atribui, contraposta à forma linear da temporalidade moderna.

O que faz com que se atribua caráter circular à temporalidade dos fenômenos naturais, e que à modernidade se atribua caráter retilíneo, está sobretudo no fato de que, na natureza, toda sucessão de eventos, mudanças e repetições ocorridos se fecha e se concatena em uma cosmologia que é dotada de unidade de sentido e que pode ser percebida. Há previsibilidade nos eventos, que podem ser observados como uma totalidade. Espera-se um recomeço, já previsto, ao término de cada ciclo.

Já na modernidade, a sucessão de eventos, mudanças e repetições ocorre de modo exaustivo, sem que haja previsibilidade. A fragmentação dos fenômenos é tamanha, que o indivíduo não consegue estabelecer relações entre os fatores que observa - que operam apenas como estímulos, de forma fragmentária. Como a percepção dos acontecimentos é sempre parcial e provisória, não se pode pensar o mundo moderno como uma totalidade da qual se extraia sentido. Sua temporalidade, progressiva, opera sobre uma reta que caminha invariavelmente para frente, sem que se possa pressagiar.

Uma vez que o ritmo de Dolls é marcado pela mudança das estações do ano, opera no filme a mesma sensação de temporalidade cíclica que opera na natureza ainda que possa haver alguma surpresa, as novas estações são previsíveis. 
Edmund Leach aponta três modos pelos quais se dá a percepção do tempo: a repetição, a entropia e a velocidade. Sobre a primeira, escreve:

Em primeiro lugar, nós reconhecemos a repetição. Gotas d'água caindo do teto; elas não são sempre a mesma gota, mas sim diferentes. Porém, para reconhecê-las como sendo diferentes devemos distinguir primeiramente e portanto definir intervalos de tempo. Os intervalos de tempo, as durações, sempre começam e terminam com "a mesma coisa", uma pulsação, uma badalada de relógio, um dia de Ano Novo. ${ }^{3}$

A entropia seria o reconhecimento humano de que "Todas as coisas vivas nascem, envelhecem e morrem. $\mathrm{O}$ envelhecimento é um destino irreversível de todos nós." 4 Já a velocidade diz respeito à celeridade com que o tempo passa, que para Leach é irregular. Se comparada ao tempo estelar, tal irregularidade se concretiza em fatos como o crescimento de uma planta, que ocorre de modo mais acelerado no início da sua vida do que em seu fim, e a cicatrização de uma ferida, que igualmente se dá mais rapidamente em uma criança do que em uma pessoa idosa ${ }^{5}$.

Esses modos de percepção do tempo mostrariam, segundo Leach, que "a regularidade do tempo não é uma parte intrínseca da natureza; é uma noção fabricada pelo homem, que nós projetamos em nosso ambiente para os nossos próprios objetivos particulares." Isso porque, embora os indivíduos creiam que o tempo é algo concreto, à espera da mensuração humana, "nós criamos o tempo através da criação de intervalos na vida social." 7

Os intervalos que o homem observa na natureza são eles também fruto de uma busca humana por regularidade em fenômenos que aparentemente escapam à vida social. E a totalidade que aí pode ser percebida faz crer que a natureza tem um tempo próprio, a partir do qual o tempo social seria medido. O "tempo social" e o "tempo natural" são um mesmo fenômeno; a temporalidade circular da natureza, dotada de sentido na sua repetição e desprovida de pressa, é que difere da temporalidade do progresso da

\footnotetext{
${ }^{3}$ LEACH, Edmund Ronald. "Cronos e Crono". In: Repensando a Antropologia. São Paulo: Perspectiva, 1974, p. 204.

${ }^{4}$ LEACH, E. “Cronos e Crono". op. cit., p. 204.

${ }^{5}$ Cf. LEACH, E. “Cronos e Crono”. op. cit., pp. 204-205.

${ }^{6}$ LEACH, E. “Cronos e Crono”. op. cit., p. 205.

${ }^{7}$ LEACH, E. "Cronos e Crono”. op. cit., p. 207. Grifos do autor.
} 
modernidade, na qual a percepção se dá por fragmentos e o desejo pela novidade faz com que os eventos ocorram de modo mais acelerado, sendo também mais efêmeros. ${ }^{8}$

O tempo a que estão submetidos os indivíduos modernos (como se buscou explicitar no Capítulo 1) advém de uma valorização da novidade e do progresso que culminou na autonomização da técnica. A temporalidade da modernidade acabou por basear-se no tempo do "futuro presentificado", e não mais no tempo presente com vistas para a dimensão do passado e do futuro. Como essa temporalidade é fragmentada, intervalos de tempo operam de forma que não é possível estabelecer uma relação com o mundo que não seja igualmente fragmentária.

Norbert Elias relaciona, em Sobre o tempo ${ }^{9}$, a evolução do conceito temporal à percepção que o indivíduo tem do tempo - esta, produto de uma síntese cada vez mais elevada, que acaba por impedir que o indivíduo perceba que o tempo é, antes de tudo, uma construção humana, e não um dado "natural".

De acordo com Elias, a "regulação social do tempo" adquire aspecto individual na vida das pessoas desde cedo, colaborando de maneira acentuada para que se consolide uma "consciência pessoal do tempo", a qual ele julga "inabalável"10.

Os homens dotados dessa estrutura de personalidade tendem a apreender todas as seqüências de acontecimentos - físicos, sociais ou pessoais -, em função dos símbolos reguladores temporais utilizados em sua sociedade, como se isso fosse uma característica de sua própria natureza e, em última análise, da natureza humana em geral. Isso nada tem de surpreendente, pois quem tem uma consciência do tempo tão profundamente arraigada, tão uniforme e tão onipresente, sente dificuldade de imaginar que existam outros seres humanos desprovidos dessa necessidade constante de se situarem no tempo. Essa individualização da regulação social do tempo apresenta, em caráter quase paradigmático, os traços de um processo civilizador. ${ }^{11}$

No entanto, quando se sai de um convívio social amplo, submetendo-se a um ritmo de vida que em nada se parece com o moderno, é possível que essa necessidade constante de se situar no tempo desapareça, assim como podem se perder outras

\footnotetext{
${ }^{8}$ Isso não quer dizer, entretanto, que o "tempo natural" seja mais lento do que o "tempo da modernidade", mas que a relação que o homem estabelece com ele e sua repetição regular produz essa impressão de lentidão.

${ }^{9}$ ELIAS, Norbert. Sobre o Tempo. Rio de Janeiro: Jorge Zahar Editor, 1998.

${ }^{10}$ Cf. Elias, N. Sobre o Tempo. op. cit., p. 22.

${ }^{11}$ ELIAS, N. Sobre o Tempo. op. cit., p. 22.
} 
regulações advindas do convívio social, por deixarem de fazer sentido. Esse abandono das regras sociais, consciente ou não, aparece em Dolls como resultado de processos traumáticos (uma tentativa de suicídio, o término de um namoro e um acidente de carro) e pressupõe o isolamento social destes indivíduos (no segundo caso, o isolamento se dá predominantemente no âmbito afetivo). No filme, a "saída do mundo"12 significa a saída da própria sociedade e mesmo de parte de suas regras de convívio, e por meio dessa ruptura os personagens centrais deixam de estar submetidos a essa temporalidade dominante na modernidade.

Mas mesmo essa possibilidade de "saída do mundo" - saída do contexto social é socialmente determinada:

Todo homem, numa certa medida, governa-se a si mesmo. Todo homem, até certo ponto, está sujeito às coerções geradas pelo convívio com seus semelhantes, pela estrutura e evolução de sua sociedade e, finalmente, por necessidades naturais, ao mesmo tempo individuais e comuns, como a necessidade de comer e de beber, ou que provêm da natureza externa, como as ligadas ao calor e ao frio. A margem de decisão dos homens, sua liberdade, repousa no final das contas em sua possibilidade de controlar, de diversas maneiras, o equilíbrio mais ou menos flexível e, aliás, em perpétua evolução entre as diferentes instâncias de onde provêm as restrições. [...] A relação entre esses diferentes tipos de coerção, as formas de equilíbrio e as configurações que eles constituem variam consideravelmente, conforme as diferentes camadas sociais. E a margem de decisão de que dispõem os indivíduos e grupos também varia em conseqüência disso. ${ }^{13}$

Essas margens de manobra de que dispõem os indivíduos, embora reduzidas no que concerne à temporalidade moderna (as sociedades industrializadas), ainda deixam frestas para que o indivíduo consiga, a duras penas (como o citado isolamento social), sair da lógica temporal dominante. Isso não quer dizer, é evidente, que haja valoração de uma ou outra condição temporal, mas que, embora globalizante, a modernidade ainda deixa pequenas brechas pelas quais os indivíduos podem "fugir" de sua lógica totalizante e experimentar outra relação temporal - relação essa que pode ser captada pelo cinema, mais especificamente, que pôde ser captada por Dolls.

\footnotetext{
${ }^{12}$ Referência à frase do amigo de Matsumoto sobre Sawako: "parece que ela está em outro mundo".

${ }^{13}$ ELIAS, N. Sobre o Tempo. op. cit., p. 29.
} 


\subsection{Abrindo as cortinas}

Dolls começa com imagens de um elemento tradicional da cultura japonesa, o bunraku, teatro de bonecos manipuláveis (títeres) cujas apresentações ocorrem no Japão há muitos séculos. O mais conhecido dramaturgo do bunraku é Chikamatsu Monazaemon ${ }^{14}$, que viveu de 1653 a $1725^{15}$. Na primeira cena do filme, o espectador se depara com uma relação temporal que lhe é pouco usual na modernidade - a temporalidade de uma tradição que está consolidada pelo menos desde o início do século XVII ${ }^{16}$ aparece condensada em dois bonecos que serão usados em uma apresentação de teatro bunraku.

No bunraku, cada boneco é manipulado por três homens. Além dos manipuladores, o narrador (aquele que reproduz as falas dos bonecos) e o músico são fundamentais às apresentações. Os titereiros ficam sobre o palco, trajam roupas pretas e podem ser vistos pela platéia. Entregar-se à história que está sendo mostrada é, entretanto, deixar de vê-los e crer na ficção que se passa tendo como personagens os bonecos. Desse modo, durante as apresentações, cabe aos manipuladores, narrador e músico operarem como subterfúgios - de acordo com Jean-Claude Carrière, os subterfúgios seriam elementos capazes de revelar a irrealidade que é própria ao cinema (como as câmeras, microfone, montagem), e por isso não deveriam aparecer nos filmes. Sem que a irrealidade seja mostrada, o cinema ilude o espectador mais facilmente com sua projeção de luzes, sons e silêncios, permitindo que ele se entregue tanto quanto possível à história que está sendo contada ${ }^{17}$. A transposição que aqui se faz da noção de "subterfúgio" utilizada por Carrière a respeito do cinema para o bunraku deve-se ao elemento ficcional presente em ambas as formas artísticas. De acordo com Carrière, em um filme,

[...] O que a platéia não vê é o subterfúgio. A ficção, a própria natureza do filme, as técnicas da filmagem e da projeção - tudo é esquecido, afastado pelo

\footnotetext{
${ }^{14}$ No Japão, o nome de família (sobrenome) precede o nome pessoal. Manteve-se aqui a ordem original do nome do dramaturgo (sobrenome, nome) e, como é de praxe, no momento em que apenas um nome seu for citado para identificar Chikamatsu Monazaemon, será usado seu sobrenome, Chikamatsu. Takeshi Kitano, diretor de Dolls, embora também japonês, consagrou-se internacionalmente pela versão já "ocidentalizada" de seu nome, por isso segue com o nome antes do sobrenome.

${ }^{15}$ Cf. The Columbia Encyclopedia. Sixth Edition, 2006. Verbete "Chikamatsu, Monzaemon" consultado online em http://www.encyclopedia.com/doc/1E1-Chikamat.html. Acesso em 07/06/2006.

${ }^{16}$ Cf. Site da Fundação Japão, São Paulo, disponível online em http://www.fjsp.org.br/bunraku/\#bunraku. Acessado em 18/06/2006.

${ }^{17}$ Cf. CARRIÈre, Jean-Claude. A Linguagem Secreta do Cinema. op. cit., p. 52.
} 
poder físico da imagem falada, aquela máscara barulhenta colocada sobre o semblante da realidade ${ }^{18}$.

A irrealidade do cinema, expressa nas técnicas de filmagem e projeção, é velada pela ocultação desses elementos. No caso do bunraku, os titereiros, o narrador e o músico operam de forma a serem esquecidos durante a apresentação para aumentar o poder de crença na ilusória humanidade dos bonecos (no caso do cinema, a ausência de subterfúgios aumenta a crença de que as luzes projetadas sobre uma tela são a presentificação de uma história, com personagens reais). Evitar os subterfúgios é deixarse iludir, seja no teatro convencional, no bunraku ou, como propôs Carrière, no cinema:

[...] Acreditamos que estamos vendo e ouvindo, mas parasitas nos invadem, intrusos nos corrompem, e, sem perceber, somos enganados. Nossa inteligência hipnotizada se retrai e paralisa, rende-se à emoção e mesmo à sensação, pois, às vezes, experimentamos forte impressão física [...] de que o filme, aquela fina membrana transparente, na qual as imagens se fixam e se movimentam pode nos tocar diretamente [...]. Nossos olhos enxergam o que não está lá, nossos ouvidos deixam de escutar o que está lá; o sol passa a girar em torno da Terra; acabamos tendo o prazer da ilusão ${ }^{19}$.

Iludir-se é crer na ficção que está sendo mostrada - seja na tela ou no palco - à frente do público. Dolls é um filme que mostra o bunraku, ou seja, um filme ficcional em que é mostrada outra forma artística de ficção. Se o cinema possui a limitação da tela para onde o espectador deve olhar e, ao seu redor, tudo é escuro, no bunraku os subterfúgios são mais visíveis para o espectador, pois estão sobre o palco. Em Dolls, entretanto, a seleção do recorte da visão sobre os palcos é estabelecida pelo diretor do filme, e não por seu espectador.

Nesse filme, os subterfúgios do teatro são selecionados pela câmera para serem mostrados ao espectador, muito embora os do filme não apareçam. $\mathrm{O}$ espectador não se depara com câmeras, microfones, etc., mas a filmagem deixa que ele por vezes veja o narrador, o músico, os manipuladores e mesmo a platéia da apresentação de teatro bunraku que abre o filme.

\footnotetext{
${ }^{18}$ CARrière, J. A Linguagem Secreta do Cinema. op. cit., p. 52.

${ }^{19}$ CARriÈre, J. A Linguagem Secreta do Cinema. op. cit., p. 56. Grifos do autor.
} 
A encenação mostrada em Dolls chama-se Mensageiro do inferno, obra consagrada de Chikamatsu, escrita em 1711. Antes de o espetáculo ter início, o espectador é apresentado aos bonecos: um casal à frente, Umekawa e Yamato, protagonistas da história que será mostrada, e duas bonecas femininas atrás. Os manipuladores não aparecem nesta cena inicial, os bonecos estão parados e não se pode ver que são titereados - eles parecem ter vida, existência e história pessoal próprias.

Logo em seguida se mostram os subterfúgios do bunraku: sentados sobre uma plataforma, no escuro, de pernas cruzadas, estão o músico, que toca o shamisen e o narrador, que é quem pronuncia as primeiras palavras do filme: "estamos prontos, vamos começar". Prontos estão o narrador, o músico e os manipuladores dos bonecos, assim como pronto está o espectador do filme, já apresentado aos personagens principais do teatro.

A plataforma na qual estão sentados o narrador e o músico se vira, e ao espectador é mostrado outro subterfúgio - a platéia. Todos os assentos do teatro estão ocupados, mas o espectador do filme parece convidado a sentar-se junto, para assistir ao teatro - e ao filme.

Começa a música da apresentação e o espectador pode ver, pela primeira vez, que os bonecos são manipulados por pessoas que ficam atrás deles: são três manipuladores para cada boneco, todos vestem preto. O principal tem o rosto descoberto, os outros dois usam capuz. A fala do casal de títeres protagonista, que está à frente do palco, tem início, partindo da mulher:

UMEKAWA: Eu lhe imploro, acalme seu coração. Não seja escravo de tantos sentimentos tristes. Quem o deixou nesse estado? Ninguém mais. Ninguém mais além de mim. Eu, Umekawa. Eu sou culpada de tudo. Eu devo me arrepender? Ou devo me lamentar? Eu não sei.

Em um rápido corte, surge na tela o narrador da apresentação. Ele aparece justamente no momento em que Umekawa chora, ou seja, um subterfúgio da apresentação é mostrado ao espectador do filme em um momento de grande dramaticidade. Antes que o espectador se emocione, envolto pelo drama em cena, o filme insiste em lembrá-lo que se trata de uma ficção, dificultando assim sua ilusão. Esse mecanismo acabará por dotar o filme de maior credibilidade para a entrega do espectador: o fará crer que, se no teatro há irrealidade, no cinema não há, pois que os subterfúgios da linguagem fílmica não são mostrados, contrariamente aos do bunraku. 
Umekawa finaliza sua fala: "veja meu coração prostrado de tanta angústia". Sua fala - na qual ela se culpa por ter feito seu amado sofrer, e lhe pede perdão - prenuncia o tema das histórias que se seguirão com personagens humanos. Nessas serão mostrados três casais cujas histórias são marcadas por acontecimentos trágicos, culpa e espera, produto de fatos irreversíveis.

Uma narração em terceira pessoa conta ao espectador o sofrimento de Umekawa, e a câmera deixa o espectador ver outra boneca movimentar-se atrás dela, levando-o a crer que é esta quem fala:

NARRAÇÃO: Ela chorou lágrimas angustiadas sobre pepitas de ouro. As moedas logo se transformaram em lindas e radiantes flores 'kenia', todas recobertas de orvalho, banhadas em suas lágrimas. As moedas resplandeceram brilhantes. Honra, glória e fortuna.

As lágrimas de Umekawa acabaram por gerar belas flores, o que dá ao espectador sensação de esperança - após muito sofrimento, Umekawa parece colher felicidade resplandecente. Encerra-se o ato com pausa na fala e na música. Logo a plataforma se vira e começa um novo ato. Vê-se a platéia, de novo, agora percorrida rapidamente pela câmera. Há uma aceleração no ritmo da música, tal qual da narração.

NARRAÇÃO: São pequenos grãos de areia passageiros. Seus vestígios tornaram-se poeira, espalhados pelos caminhos para Yamato, para serem pisados para sempre.

Os bonecos principais dançam, aproximam-se, caminham para a esquerda e finaliza-se o ato. O que se tem até aqui é um erro cometido por Umekawa, um pedido de perdão aparentemente bem-sucedido, no qual as lágrimas originaram flores resplandecentes, e por fim a atribuição de uma "efemeridade duradoura" a essa história ("pequenos grãos de areia passageiros" que serão "pisados para sempre") - a crise conjugal é superada com o pedido de perdão, mas suas marcas continuam, ainda que sob a volátil forma de poeira, presentes no caminho de Yamato, que para sempre caminhará sobre seus grãos. 

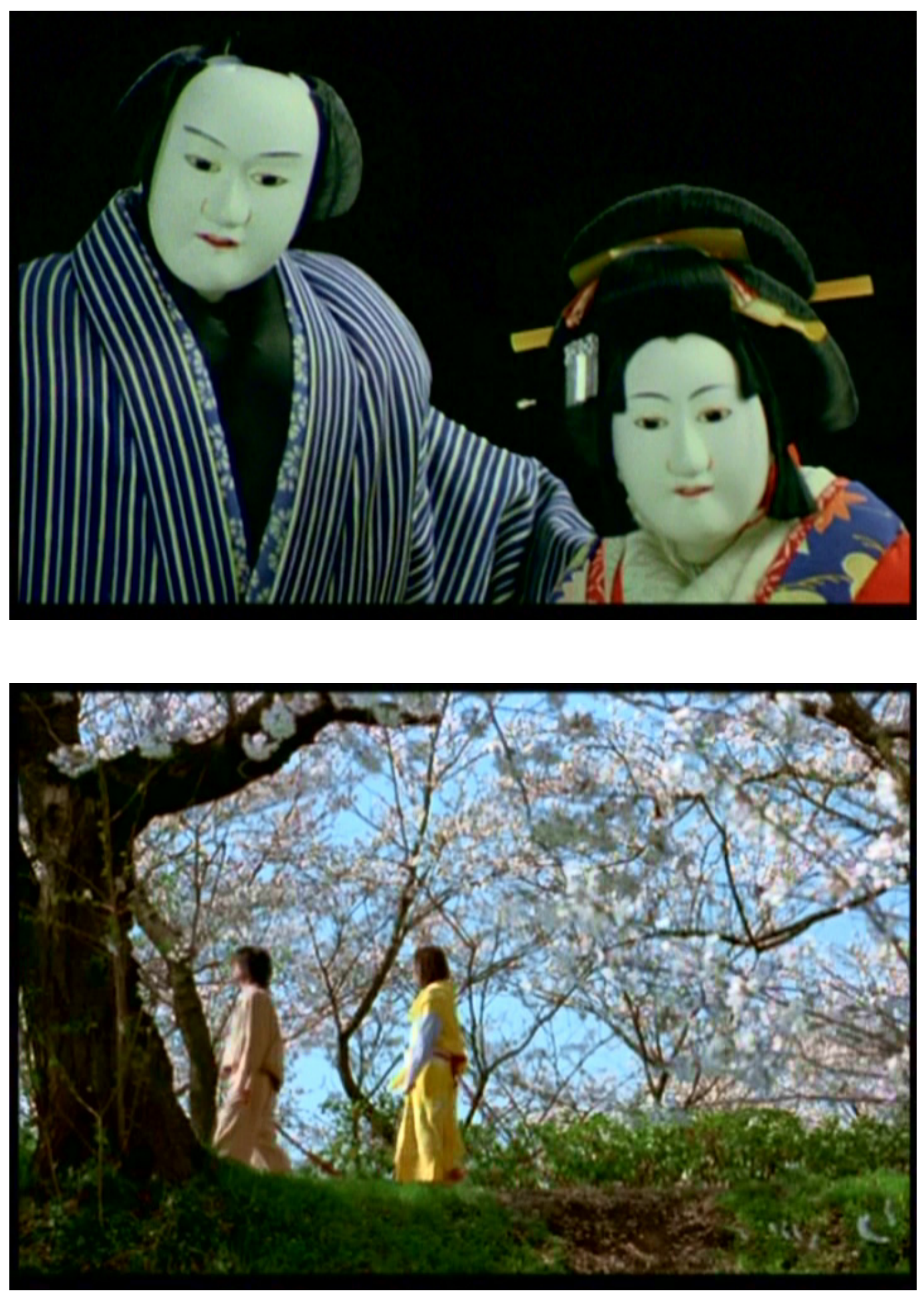
Após essa introdução - à tradição bunraku, a um pedido de perdão, à resolução de um acontecimento traumático que passa então a existir em forma de grãos de areia vem à tela o início formal do filme, seus créditos escritos em letras vermelhas sobre fundo preto, com a música principal, cujo ritmo é lento. Umekawa e Yamato aparecem novamente como se não precisassem das mãos dos homens para comandá-los; parecem flutuar sobre um fundo preto, ele cochicha no ouvido dela, em gesto de cumplicidade, e se viram para frente. Há um close em seus rostos, e olham para baixo. Assim é que, de protagonistas do bunraku, Yamato e Umekawa se voltam para as histórias que estão por vir na condição de espectadores. Igualam-se aos espectadores que assistem ao filme, lembrando-lhes que, como eles, também já viveram histórias de amor, perdão, dor e perda.

\subsection{Primavera}

A introdução pelo bunraku fora encerrada com uma cena na qual os bonecos olhavam para baixo, e a primavera começa com uma corda se arrastando pelo chão, em uma tomada que se movimenta pela paisagem de modo ascendente. Esse recurso reforça a impressão de que, antes atração no palco do teatro, os bonecos agora se tornam espectadores da história que está por começar - como se o espectador tivesse a mesma visão que os bonecos. Antes espectador do bunraku, o espectador do filme agora se une aos bonecos para ver a trama que se inicia.

Segundo Merleau-Ponty, o espectador toma como referência para a leitura de uma imagem, em um filme, aquelas que a precedem e o todo fílmico que com ela se compõe:

O sentido de uma imagem depende, então, daquelas que a precedem no correr do filme e a sucessão delas cria uma nova realidade, não equivalente à simples adição dos elementos empregados. ${ }^{20}$

Assim, o encadeamento das imagens em um filme influi diretamente no modo como o espectador o compreenderá. Desse modo, todo o conteúdo fílmico visto até aqui, ou seja, imagens de uma tradição que mostraram da ascensão do sofrimento de Umekawa às flores originadas por suas lágrimas, deverá guiar a leitura das imagens seguintes.

\footnotetext{
${ }^{20}$ Merleau-Ponty, Maurice. "O Cinema e a nova psicologia”. In: XAVIER, Ismail (org.). A experiência do cinema. $3^{\mathrm{a}}$ edição. Rio de Janeiro: Graal, 2003, p. 111.
} 
A primeira relação com personagens animados mostrada por Dolls é a do casal protagonista, Matsumoto e Sawako. Eles caminham em um parque cujas cerejeiras estão repletas de flores brancas. Tais flores são tradicionalmente associadas à primavera no Japão porque nascem apenas uma vez ao ano - assim que esta estação tem início.

A primavera é comumente associada à esperança - essa estação representa 0 início de um ciclo do qual logo engendrarão novos frutos. O sentimento de esperança é reforçado pelo espectador que, acostumado a filmes com finais felizes, não espera as tragédias que estão por vir na tela. Há mais um elemento operando para que o sentimento de esperança evocado por essas cenas primaveris se fortaleça: a bagagem fílmica que o espectador carrega, ou seja, o trecho do filme visto até aqui. As flores que antes nasceram originaram-se do choro, mas logo resplandeceram e foram associadas a honra, glória e fortuna. Por esses três fatores, o espectador é levado a associar a paisagem florida da primavera à possibilidade de mudança pela chegada de um novo ciclo, à esperança, portanto.

Depois de abertas, as flores das cerejeiras logo perdem suas pétalas e caem das árvores. A efemeridade das flores equivale à transitoriedade da esperança que o espectador vem atribuindo ao filme - tão logo as tragédias tenham início, esse sentimento perderá sua intensidade.

A aparente ruptura entre o bunraku e a trama com personagens humanos que se vê em seguida é compensada por elementos de continuidade. A corda que une Sawako a Matsumoto remete o espectador às cordas usadas para manipular os títeres. Os trajes que eles vestirão em todo o filme também se parecem com os do bunraku.

Há ainda outra aproximação entre o casal Matsumoto e Sawako e o bunraku. Embora em suas peças se contasse, inicialmente, histórias de feitos heróicos - os chamados "dramas históricos" -, em 1703, Chikamatsu baseou-se em uma história ocorrida à época para escrever Os amantes suicidas de Sonezaki ${ }^{21}$. Com essa obra, criou-se um novo gênero - o “drama doméstico". A trama dessa peça tem como protagonistas Tokubei e sua amada, a cortesã Ohatsu. O tio de Tokubei, para quem ele

\footnotetext{
${ }^{21}$ Embora a trama tenha sido adaptada ao português com o título Os amantes de Sonezaki (CHIKAMATSU et ONO, Claudio Mitsuhiro (trad.). Os amantes de Sonezaki. São Paulo: FTD, 2005), no site da Embaixada do Japão no Brasil a peça é nomeada Os amantes suicidas de Sonezaki (http://www.br.embjapan.go.jp/cultura/downloads/bunraku.htm, acessado em 29/06/2006), tradução que mais se aproxima da americana: nos Estados Unidos, a obra recebe o título The love-suicides at Sonezaki (CHIKAMATSU et REIS, Siri Von (trad.). The love-suicides at Sonezaki and other poems. Omaha: Zoo Press, 2001). Por esse motivo, optou-se por essa tradução, Os amantes suicidas de Sonezaki.
} 
trabalha, pede-lhe que se case com a sobrinha de sua esposa. Apaixonado por Ohatsu, ele recusa tal casamento, e a trama caminha de modo que a honra de Tokubei é ferida e o casal protagonista, para provar sua inocência, opta pelo suicídio. Tokubei então corta uma parte da faixa de seu quimono e a utiliza para atar-se a Ohatsu, para que morram unidos. Amarrados, ele apunhala a sua amada, e depois a si mesmo ${ }^{22}$.

A corda vermelha dos amantes de Dolls faz referência à faixa do quimono de $O S$ amantes suicidas de Sonezaki. Amarradas pela cintura, essas cordas referem-se também a uma relação entre os casais que é umbilical - fruto de uma ligação muito intensa. Se nessa peça o casal se atava nas cenas finais, isolado em um bosque, o que causa estranhamento em Dolls é o fato de o casal protagonista estar atado por uma corda em um parque de uma grande cidade, por onde circulam pessoas, e sem que nenhuma explicação prévia tenha sido dada ao espectador.

Ao olhar Sawako e Matsumoto unidos pela corda vermelha, tem-se a impressão de que ainda se tratam de bonecos, impressão que perpassará todo o filme, e que é consagrada por seu título, que então aparece sobre a imagem do casal, até aqui visto de costas: Dolls. Saem da tela e o espectador vê a corda arrastando-se pelo chão.

O casal segue caminhando, há um mecanismo de errância automatizado que os faz parar somente quando há empecilhos: em um primeiro momento, a corda enrosca em um pequeno tronco de árvore preso ao chão, e é quando os transeuntes do parque começam a comentar a estranha cena do casal atado: "eles são mendigos amarrados", diz um senhor. Há então outro impedimento na corda, e o casal interrompe seu trajeto mais uma vez. Sawako pára de caminhar, Matsumoto olha para trás. Entre eles, há três garotos em idade escolar, com mochila nas costas, e um deles segura a corda e reproduz a fala anteriormente dita a respeito do casal: "mendigos amarrados!” Larga a corda e os três meninos saem correndo.

A referência que o espectador tinha até essa cena era o bunraku, antiga tradição japonesa. Quem ousa desafiá-la são as crianças, que puxam a corda para fazer uma brincadeira. Como na modernidade, é o novo que provoca as tradições instauradas. Essa atitude causa, entretanto, constrangimento aos mais velhos que observam a errância de Matsumoto e Sawako, ou seja, eles observam a tradição com estranhamento, mas se

${ }^{22}$ Cf. Bunraku - teatro de bonecos. Texto disponível online no site da Embaixada do Japão no Brasil: http://www.br.emb-japan.go.jp/cultura/downloads/bunraku.htm. Acessado em 29/06/2006. 
constrangem quando a novidade a provoca, sem entretanto intervir nessa situação. Errante, o casal parte para longe da civilização sem o penar dos que ficam.

Aqui já está dada a relação temporal que será o centro da história deste casal, a principal história amorosa a compor o filme. Trata-se de uma temporalidade que não se aproxima daquele da modernidade - é, antes, o tempo de uma errância (que de início já está associado a uma tradição, o bunraku); da busca por algo que talvez não se saiba o que é, e que portanto não será encontrado; e da busca dos personagens por um perdão que, ainda que se concretize, não é capaz de mudar o rumo trágico que as histórias acabam por assumir.

A primavera é simbolizada por flores que rapidamente caem das cerejeiras, mas tal efemeridade não é a da modernidade, e tampouco com ela se parece. A efemeridade moderna decorre da valorização do novo - que vem sempre suplantar o que estava então estabelecido, tornando portanto os feitos abreviados e olvidando o passado por sua suplantação. A efemeridade dessa primavera refere-se apenas à rápida obsolescência da esperança que o espectador atribui ao filme. Se, nas cenas iniciais, a possibilidade de algum tipo de salvação para as histórias é esperada e plausível, essa possibilidade vai sendo abandonada a cada nova tomada. E não pela imposição moderna das novidades, mas pelo trágico rumo que a saída desse "tempo do incessantemente novo" acaba por tomar.

Construída a relação temporal que comandará o casal central, o filme traz explicações para a situação que levou Sawako e Matsumoto a essa errância, e o passo-apasso de seu abandono da vida moderna. Isso ocorre pelo mecanismo de "volta ao tempo": o espectador é levado à igreja onde Matsumoto se casaria com a filha de seu chefe e a conversa entre dois de seus colegas de trabalho opera como narração.

Colega 1: Oi, me diga. Sawako não é a noiva de Matsumoto?

COLEGa 2: De jeito nenhum.

Colega 1: Quando recebi este convite, achei que finalmente tinham se amarrado. Mas eu me enganei.

COLEGA 2: Ele vai se casar com a filha do presidente da nossa empresa.

COLEGA 1: Está brincando?

COLEGA 2: A família o escolheu.

Colega 1: Então é o "garoto Cinderela". Ele está fora de nosso grupo agora. Mas o que ele fez com Sawako?

COLEga 2: Deve ter dado um pé nela. 
Colega 1: Nunca achei que Matsumoto fosse desse tipo.

COLEGA 2: Qualquer um aproveitaria a oportunidade.

Colega 1: Provavelmente. É um atalho para o sucesso.

COLEGA 2: Em dois anos, estaremos nos curvando a ele.

A opção de Matsumoto revela um choque entre dois conceitos: a honra, que é social, o impele a casar-se com a filha do presidente de sua empresa; e a dignidade, pessoal, o leva a desejar Sawako. Berger et alli ${ }^{23}$ apontam para a obsolescência do conceito de honra e a emergência da dignidade como fator importante na determinação da "consciência moderna",24.

O que muda com o declínio da honra é que, se esse conceito implicava em que a identidade estivesse fortemente ligada aos papéis institucionais, a dignidade implica que a identidade seja essencialmente independente desses papéis. Isso porque, com a modernidade, passou-se a atribuir aos indivíduos, por debaixo dos disfarces sociais, uma dignidade fundamental, ligada aos diretos inalienáveis de todos os seres humanos. É nesse eu solitário que a dignidade aponta para uma humanidade intrínseca ao homem, despojada de todos os papéis e normas impostos pela sociedade. Trata-se de uma dignidade ligada ao eu enquanto tal, ou seja, ao indivíduo considerado independentemente de sua posição social. ${ }^{25}$ A perda da dignidade, tal qual a perda da honra, pode ocorrer e ocorre. O principal diferencial entre esses conceitos está na individualidade da dignidade, contraposta ao caráter social e ligado aos papéis sociais da honra.

A honra era atribuída aos homens de acordo com a força que as instituições às quais pertenciam tinham sobre eles. Com a perda da força dessas instituições na modernidade, o indivíduo viu-se como um eu solitário no qual a consciência moderna colocou a dignidade humana e os direitos inalienáveis do homem.

O homem moderno é Dom Quixote em seu leito de morte, despojado das bandeiras multicoloridas que anteriormente envolviam o eu e demonstrando não

\footnotetext{
23 Berger, Peter; Berger, Brigitte; Kellner, Hansfried. "Sobre la obsolescencia del concepto de honor". In: Un mundo sin hogar - modernización y consciencia. Santander: Editorial Sal Terrae, 1979, pp. 81-93 e Berger, P., BerGer, B. et KELLNER. “On the obsolescence of the concept of honor". In: The Homeless mind - modernization and consciousness. New York: Vintage Books, 1973, pp. 83-96.

${ }^{24}$ Cf. Berger, P. et ALLI. "Sobre la obsolescencia del concepto de honor". op. cit., p. 82. Isso não significa, vale ressaltar, que todos os homens sejam dignos - assim como ocorria com a honra, a dignidade pode ser perdida. A diferença é que, se antes ao homem era atribuída honra de acordo com as instituições que ocupava, a ele passou a ser atribuída dignidade em decorrência dos direitos inalienáveis atribuídos a todos os homens.

${ }^{25}$ Cf. Berger, P. et ALLI. “Sobre la obsolescencia del concepto de honor”. op. cit., pp. 86-87.
} 
ser nada mais que um homem [...]. Por trás do "simples brasão" está o rosto do homem moderno, o homem desprovido do consolo dos protótipos, o homem e só o homem. ${ }^{26}$

Esse processo, entretanto, não ocorre sem resistência, sobretudo no Japão, onde a tradição resiste fortemente em determinados papéis sociais, como o trabalho e o casamento $^{27}$. Casar-se com a filha do presidente é uma questão de honra, ele fora o escolhido e deveria seguir esse "destino", compactuando inclusive com a tradição do trabalho, honrando o peso do papel desempenhado em sua empresa.

O filme, entretanto, não mostra apenas o processo de resistência da honra à sua flexibilização para a entrada da dignidade, mas também características modernas que decorrem desse mesmo processo, como a possibilidade de inversão de papéis advinda da cidadania moderna, que permite ao funcionário Matsumoto ser noivo da filha do presidente de sua empresa e, em seguida, abandoná-la e se transformar em um "mendigo amarrado". É o mesmo processo que permite a Hiro, protagonista da segunda história, passar de operário a mafioso, e a Haruna, cantora que aparecerá na terceira ficção, tornar-se uma pop star - e passar do auge de sua carreira para o isolamento solitário afastado das câmeras.

Quando Matsumoto é escolhido para se casar com a filha do presidente da empresa onde trabalha, a imposição social para que aceite o pedido se torna uma questão de honra. Ele não consegue romper com as instituições em jogo e optar por Sawako, como sugeriria o cenário de emergência do conceito de dignidade, no qual o indivíduo tem maior poder de escolha. Ele apenas opta por acompanhar Sawako quando sente sua honra abalada, ao saber que ela tentara cometer suicídio. Nesse caso, opta por abandonar sua noiva na igreja e voltar para Sawako. Os custos sociais disso, entretanto, são altíssimos: têm o preço de sua vida social.

O comunicado da tentativa de suicídio de Sawako é feito a Matsumoto como forma de cobrança ética:

\footnotetext{
${ }^{26}$ BERGER, P. et ALLI. "Sobre la obsolescencia del concepto de honor". op. cit., pp. 85-86. (Grifos dos autores). Tradução livre de "El hombre moderno es Don Quijote en su lecho de muerte, despojado de las banderas multicolores que anteriormente envolvían el yo y demostrando no ser nada más que un hombre [...]. Detrás del "simple blasón" está el rostro del hombre moderno, el hombre desprovisto del consuelo de los prototipos, el hombre y sólo el hombre”.

${ }^{27}$ BERger, P. et ALLI situam essa tendência de substituição da honra pela dignidade sobretudo nas sociedades ocidentais, já apontando para esse maior enraizamento do mundo oriental na tradição. Cf. BERGER, P. et ALLI. "Sobre la obsolescencia del concepto de honor". op. cit., p. 83.
} 
AMIGA DE SAWAKO: Escolher o sucesso foi mais importante? Sawako escolheu o suicídio.

MATSUMOTO: Ela morreu?

Amiga de SAWAKO: Não, ela sobreviveu. Mas perdeu a memória. Nem mesmo me reconhece. Era melhor estar morta.

MATSUMOTO: Onde ela está?

Amiga DE SAWAKO: No hospital.

MATSUMOTO: Em qual?

AMIGA DE SAWAKO: Ela não reconhecerá você.

Esse breve diálogo dá início ao arrependimento de Matsumoto - e à inversão de atribuição de sua honra - que agora o faz procurar Sawako.

O elemento da saída de Sawako da temporalidade moderna foi a sua perda de memória, que a fez perder a dimensão do passado e implicou em um forte isolamento ao torná-la incomunicativa. Já o primeiro elemento de modernidade do qual Matsumoto se livra para ir atrás de Sawako é seu telefone celular - cujo toque é uma versão simplificada da música da Haruna que se ouvirá no filme, mais adiante. Dentro do carro em movimento, Matsumoto atira o aparelho pela janela.

No hospital, Sawako não se move, parece não notar a presença de Matsumoto. Ela observa, no chão, uma borboleta cor de rosa, e pisca seus olhos vagarosamente.

Graça e ligeireza, a borboleta é, no Japão, um emblema da mulher [...]. Ligeireza sutil: as borboletas são espíritos viajantes; sua presença anuncia uma visita ou a morte de uma pessoa próxima. ${ }^{28}$

Essa borboleta para a qual Sawako olha simboliza uma mulher que está dilacerada - porque logo o inseto sairá voando e $1 / 4$ de sua asa ficará no chão do hospital, os 3/4 restantes da borboleta logo serão atropelados pelo carro de Matsumoto. Sawako, a mulher que esse inseto simboliza, está dilacerada em sua memória, ou seja, na dimensão passada da sua vida. Após essa sua união com Matsumoto, será dilacerada também a dimensão futura da vida de Sawako, e eles viverão em uma temporalidade que se resume a um mesmo presente constante, preso em si.

Uma morte se configura com a união do casal - a morte de sua vida social. Uma morte simbólica, marcada pelo abandono do convívio deles com a cultura e, sobretudo, com os bens materiais, morte essa que já estava prefigurada no simbolismo das cerejeiras:

${ }^{28}$ Chevalier, Jean et Gheerbrant, Alain. Dicionário de símbolos. Rio de Janeiro: José Olympio, 2006, p.138. 
A flor de cerejeira, efêmera e frágil, que o vento não tarda a levar, simboliza também, no Japão, uma morte ideal, desapegada dos bens deste mundo, e a precariedade da existência. ${ }^{29}$

Efêmera como as flores da cerejeira, a esperança primaveril desaparece ainda na primavera. Nessa estação, o espectador pode ver a transformação que leva o "garoto Cinderela" a tornar-se um "mendigo amarrado". A imagem do carro amarelo de Matsumoto estacionado frente à empresa onde trabalha, rapidamente intercalada pela imagem desse mesmo carro, sujo, estacionado frente ao varal de corda vermelha (como a que os unia no início do filme) explicita essa transformação de Matsumoto.

Sawako, sem memória, perde o acesso à dimensão do passado, e assim parece adentrar uma nova infância, como uma criança que não tem história de vida acumulada. Ela age infantilmente ao pegar flores e brinquedos - sobretudo de cor rosa - dos locais por onde passa. Sua relação com Matsumoto também é infantilizada, uma vez que perde a dimensão erótica.

A frase que Matsumoto ouve de seu amigo em uma conversa telefônica, a respeito de Sawako, faz referência ao abandono social que já está se concretizando: “Parece que [Sawako] está em outro mundo. É verdade?" Matsumoto não responde, desliga o telefone.

"Estar em outro mundo" significa, aqui, partilhar outras regras e outra temporalidade que as socialmente predominantes. Matsumoto, arrependido da escolha que levou Sawako a perder a memória e a capacidade de expressão de sentimentos, decide deixar para trás a sociedade em cujos valores ele se baseou para optar por casarse com a filha do presidente de sua empresa. Abandona, assim, os planos que havia feito para seu futuro. Carrega consigo Sawako, que reafirma seu equívoco e que não tem a dimensão do passado, já que abandonou a interação social devido aos danos cerebrais decorrentes da ingestão de remédios. Esse casal passará o resto do filme vagando sem destino - um casal que não pode ter por completo a dimensão do passado, e nem a do futuro.

\footnotetext{
${ }^{29}$ Chevalier, J. et GheErbrant, A. Dicionário de símbolos. op. cit., p.222. Verbete: Cerejeira.
} 

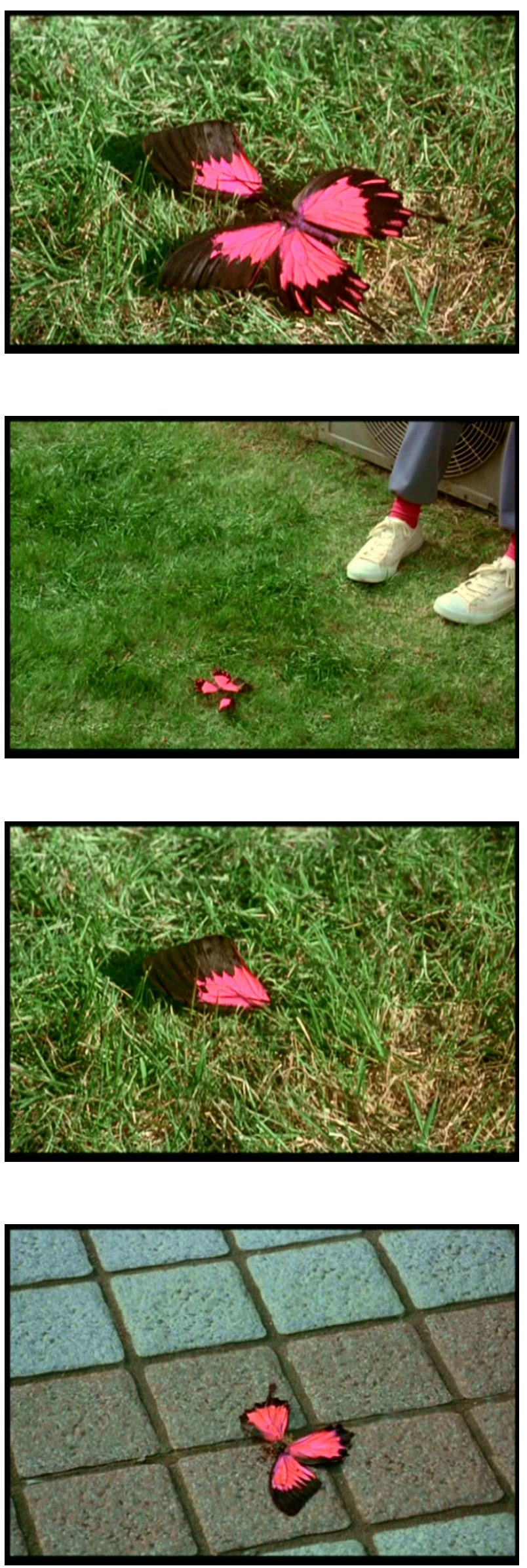
Esse abandono de regras e convívio social também é entendido como idiotice e loucura, “cuidado, seus idiotas! Vocês são loucos?”, diz o motorista de um carro após desviar de Sawako, que estava no meio da rua. Ela "está em outro mundo", eles são "mendigos amarrados", e agora também "loucos", o que os reposiciona fora de um mundo regular - o dos "normais", hegemônico na modernidade.

Um joguete cor-de-rosa com o qual Sawako brincara aparece atirado no chão do carro de Matsumoto, que está sujo, estacionado frente a um varal. Dentro do carro há lixo e embalagens plásticas. O cabelo de Matsumoto está comprido, marcando a passagem temporal. Ele observa Sawako. Não dormem mais em hotéis, mas dentro do carro. Matsumoto remexe uma lata de lixo, provavelmente à procura de comida.

Matsumoto amarra Sawako, pela cintura, a uma corda cuja outra extremidade é amarrada no banco de trás do carro. Ela tenta andar para frente, a corda a impede, ela volta, e faz esse movimento repetidamente. Depois de observá-la, Matsumoto a abraça e chora. Então diz: "Me perdoa".

É um pedido de perdão como o fora aquele de Umekawa para Yamato. A forma que Matsumoto encontra para fazer com que Sawako o perdoe, ou para que ele mesmo se perdoe é, juntamente a ela, anular a temporalidade moderna corrente em sua vida e entregar-se a essa errância sob a lenta temporalidade do perdão - ou, antes, da espera por esse perdão.

A opção de Matsumoto é solidificada na cena seguinte: dois carregadores retiram móveis da casa de seus pais. Sua mãe chora dentro do quarto vazio, e o pai a consola: "ele quis assim". Aqui, é um tempo sem volta. Para os que ficam, é um tempo em que não há retorno. É o tempo da espera pelo filho, que não voltará.

Matsumoto amarra-se à outra extremidade da corda. É quando os dois abandonam o carro - o que ainda os ligava à dimensão temporal em que viviam antes do início dessa errância. O primeiro elemento tecnológico abandonado por Matsumoto fora seu telefone celular; o carro, cuja função estava restrita à habitação, será o último. Após o pedido de perdão, Matsumoto e Sawako, atados pela corda, saem vagando ao léu, sem destino e sem metas.

Se Matsumoto já havia abandonado seu futuro com sua então noiva, e Sawako havia perdido seu passado ao esvaziar-se de memória, o casal agora segue caminhando sob uma temporalidade suspensa, na qual não há ação além da errância, na qual não se constrói história, e tampouco se rememora - na qual o passado aparece apenas em 
alguns breves momentos de flashback, sem que seja elaborado o conteúdo revisto. Matsumoto assume, assim, a descrença da volta da memória e da comunicabilidade de Sawako e, desse modo, entra na lógica dessa garota que perdeu a memória e não parece ao menos reconhecê-lo. Se ela estava numa temporalidade sem passado (sem memória), assume então uma temporalidade sem futuro: eles, assim, "saem do tempo".

Com a cena desses personagens caminhando amarrados por entre as cerejeiras, como na cena em que apareceram no filme pela primeira vez, acaba a espécie de flashback que explicou ao espectador como teve início a errância desse casal. Uma errância marcada e surgida pela tentativa de retomada de uma honra ferida em decorrência de uma escolha feita por Matsumoto. Uma errância talvez marcada pela expectativa de um perdão (mesmo que não pronunciado), errância essa que finda com a primavera.

\subsection{Verão}

A primavera fora marcada pela efemeridade das flores de cerejeira, o verão é marcado pela efemeridade da passagem das águas. Nessa estação, vêm à luz outras duas histórias que compõem o filme - em sua primeira cena, o espectador já é introduzido à segunda história (de amor e de espera).

A relação do homem com a água inclui sua utilização nos afazeres domésticos e nos cuidados com o corpo. José Carlos Bruni credita à água caseira teor de limpeza e conforto, e também a associa fundamentalmente à alimentação - porque os alimentos a possuem em sua composição, mas também porque ela é utilizada em seu cozimento ${ }^{30}$.

Não é essa água doméstica, pura, confortante e alimentícia, entretanto, que banha as cenas de Dolls (inclusive porque as cenas do filme são majoritariamente externas). As águas que passam por Dolls não saem de torneiras e chuveiros. A água nesse filme opera como componente da paisagem - na chuva, no rio e no mar. Elemento vital ao ser humano, sem a qual ele não vive, a água que aparece no filme não tem essa função prática.

\footnotetext{
${ }^{30}$ Cf. BRUNI, José Carlos. "A água e a vida”. In: Tempo Social - Revista de Sociologia da USP. São Paulo, 5 (1-2), 1993, pp. 54-55.
} 
Desde os fins do século XVIII, a água deixou, para a nossa cultura, de ser um elemento, uma substância primordial, qualitativamente diferenciada, para tornar-se $\mathrm{H}_{2} \mathrm{O}$ [...] Depois que a água tornou-se objeto de razão científica, passou a ser um corpo entre os outros, muito importante, é certo, mas sem alma, sem sentido, uma coisa morta ${ }^{31}$.

Com a verve cientificista advinda no Renascimento, quando as os sentidos no/do mundo passaram a se basear em pressupostos científicos, o simbolismo da água foi aos poucos substituído por sua composição. A água não deixou, entretanto, de possuir caráter simbólico - para além de sua composição química -, e essa dimensão pode ser resgatada em Dolls. De acordo com Bruni, “é na dimensão simbólica que a água diz respeito mais profundamente à vida e ao homem." 32 Diz ele ainda que "nada da natureza escapa de representação e da ação humanas, da atribuição de sentido e de significado. Não existe a natureza em si, fora das representações e dos atos de atribuição de sentido" 33 , o que instiga a buscar essa representação simbólica da água e o sentido que ela desperta no espectador de Dolls.

Para que se possa compreender o simbolismo da água, não se deve, entretanto, pensá-la como $\mathrm{H}_{2} \mathrm{O}$,

[...] mas como elemento fundamental indissociável de suas formas concretas: os mares, os oceanos, os rios, os lagos, os regatos, os riachos, as torrentes, as chuvas, as fontes, as nascentes, as praias, as quedas d'água, as cascatas, o gelo, o orvalho, onde se podem distinguir as águas claras, as águas correntes, as águas primaveris, as águas profundas, as águas dormentes, as águas mortas, as águas compostas, as águas doces, as águas violentas, as lágrimas. ${ }^{34}$

Aparecem no filme águas correntes, que remetem o espectador ao inevitável fluxo no qual ele, bem como os personagens do filme, está imerso, simbologia que retoma Heráclito - para quem a água do rio servia como "símbolo por excelência da mobilidade, do caráter passageiro de todas as coisas", já que nas mesmas águas um

\footnotetext{
${ }^{31}$ BRUNI, J. “A água e a vida”. op. cit., p. 57.

${ }^{32}$ BRUNI, J. "A água e a vida”. op. cit., p. 57.

${ }^{33}$ BRUNI, J. “A água e a vida”. op. cit., p. 58.

${ }^{34}$ BRUNI, J. “A água e a vida”. op. cit., p. 59.
} 
homem não se banhará mais que uma vez. "Como rio, a água faz ver concretamente o tempo, que tudo leva, que impede a permanência e a fixidez." 35

Bruni se refere a essa idéia para tratar a simbologia da água em relação à morte:

[...] o tempo simbolizado pelo rio, o caráter passageiro da existência, indica a morte das coisas. As coisas não só se dissolvem na água, elas também nela desaparecem. A purificação é a anulação do impuro, do pecado e do mal; é a anulação do passado. A água é símbolo de vida e de morte. ${ }^{36}$

Essa água que representa a vida, mas paradoxalmente também a morte, aparece em Dolls após a esperança inicial do florescimento das cerejeiras, que também simbolizavam a efemeridade dessa esperança pela queda das flores. Se havia, nas flores da primavera, a esperança de bons frutos, ela se perde e o verão vem com suas águas mostrar que o tempo passou e segue passando, de modo a tornar os fatos todos irreversíveis.

É interessante notar que, ao contrário da pressa com que a vida acontece na modernidade, a impressão que causa Dolls é que a temporalidade da natureza (representada pelas estações do ano) passa mais rapidamente do que a da vida de seus personagens. A vida dos personagens parece pouco mudar, ao passo que a paisagem vegetal e climática se modifica de forma considerável.

Com a chegada do verão, novos personagens aparecem no filme. $\mathrm{O}$ primeiro deles é Hiro, senhor pertencente à máfia japonesa - conhecida como yakuza ${ }^{37}$. A yakuza tem sofrido um processo de decadência, e isso fica expresso no filme pelo personagem escolhido para representá-la: protagonista nessa segunda história, Hiro é um senhor rico, porém senil e doente; tem discurso saudosista e refere-se nostalgicamente à "velha

\footnotetext{
${ }^{35}$ BRUNI, J. “A água e a vida”. op. cit., p. 59.

${ }^{36}$ BRUNI, J. “A água e a vida”. op. cit., p. 62.

${ }^{37}$ Assim como o bunraku, a yakuza já viveu seu tempo áureo, tendo sofrido forte abalo no final do século XX - sobretudo pelo colapso da bolha econômica japonesa em 1989-90 e pela aprovação, em 1991, de uma legislação mais rigorosa contra a máfia, que geraram perdas especialmente nos ganhos da yakuza referentes aos mercados imobiliário e financeiro. (Cf. HiLl, Peter. "Heisei Yakuza: burst bubble and Bôtaihô". In: Social Science Japan Journal. Tóquio, 6 (1), 2003, p.1. Disponível online em: http://ssjj.oxfordjournals.org/cgi/reprint/6/1/1. Acesso em 16/08/2006).

Entre 1991 e 1995, houve uma queda de 13\% no número de pessoas pertencentes à yakuza, o que significa uma diminuição de 91.000 para 79.300 membros, ou seja, uma perda de 11.700 membros. Em 1995 esse número passou a subir um pouco, chegando a 84.400 no final de 2001, quando foi filmado Dolls - mas isso não indica que a atividade voltará a ter a força de outros tempos. (Cf. HILL, Peter. "Heisei Yakuza: burst bubble and Bôtaihô". op. cit., p. 11).
} 
escola" da yakuza. O processo de decadência da yakuza é outro sinal da perda de tradições antes arraigadas no Japão (como o conceito de honra).

Hiro dá dinheiro a um deficiente físico que tem os membros do corpo encurtados e move sua cadeira-de-roda elétrica pela boca, sempre seguido por um ajudante. Hiro diz que ele é filho de um "irmão" seu, indicando que ele também possui relações com a yakuza. Então as histórias se cruzam de maneira muito sutil: pelo rapaz que recebeu o dinheiro, passam Matsumoto e Sawako, e ele pergunta para seu acompanhante "Qual o problema deles? São estranhos”. Essa fala, dita pelo personagem que, fisicamente, é o que está mais fora dos padrões estéticos no filme, aponta para uma falta de visão crítica e reflexiva da máfia japonesa - como se estranhos fossem apenas os outros, e não a perduração da yakuza em um ambiente de hostilidade.

$\mathrm{Na}$ conversa com seu novo guarda-costas, Hiro manifesta em suas afirmações a lembrança saudosa de um passado de glória: "antigamente, conseguíamos o que queríamos, à força", diz. Ele descreve sua lembrança de um dia em que ocorreram muitas mortes, inclusive a de um "irmão" da máfia que ele ordenou a seu antigo guardacostas que matasse. Sobre ele, Hiro comenta: "uma pena. Éramos muito amigos", deixando subentendido que se tratava do pai do rapaz a quem ele dá dinheiro. Nesse momento, vê-se um laguinho com muitas carpas e algumas plantas aquáticas. A água se mexe com o movimento das carpas. Embora ainda discreta, a água é um elemento que começa a ganhar força, lembrando o espectador da irreversibilidade de alguns fatos que ocorrem como o fluxo das águas de um rio - sem que haja possibilidade de retorno.

Essa sua rememoração de tempos de maior poder é interrompida pela chegada de um médico, fato que reforça a melancolia desse saudosista representante da yakuza. A máfia, desse modo, não aparece no filme por sua força ativa, mas por suas fraquezas e memórias de outros tempos. Fraquezas que são confirmadas pela fala de Hiro após a consulta com o médico: "eu acho que não vou durar muito".

A desconfiança de que sua vida terminará logo leva Hiro a relembrar seu passado - e ele se recorda de uma antiga namorada que deixara porque abandonaria seu trabalho. Ela prometera esperá-lo: "Hiro! Vou esperar por você! Vou trazer seu almoço! Estarei aqui todo sábado!" Hiro então vai ao parque onde a vira pela última vez, décadas antes. Nessa busca ao passado ele encontrará, entretanto, o fim de sua vida. 

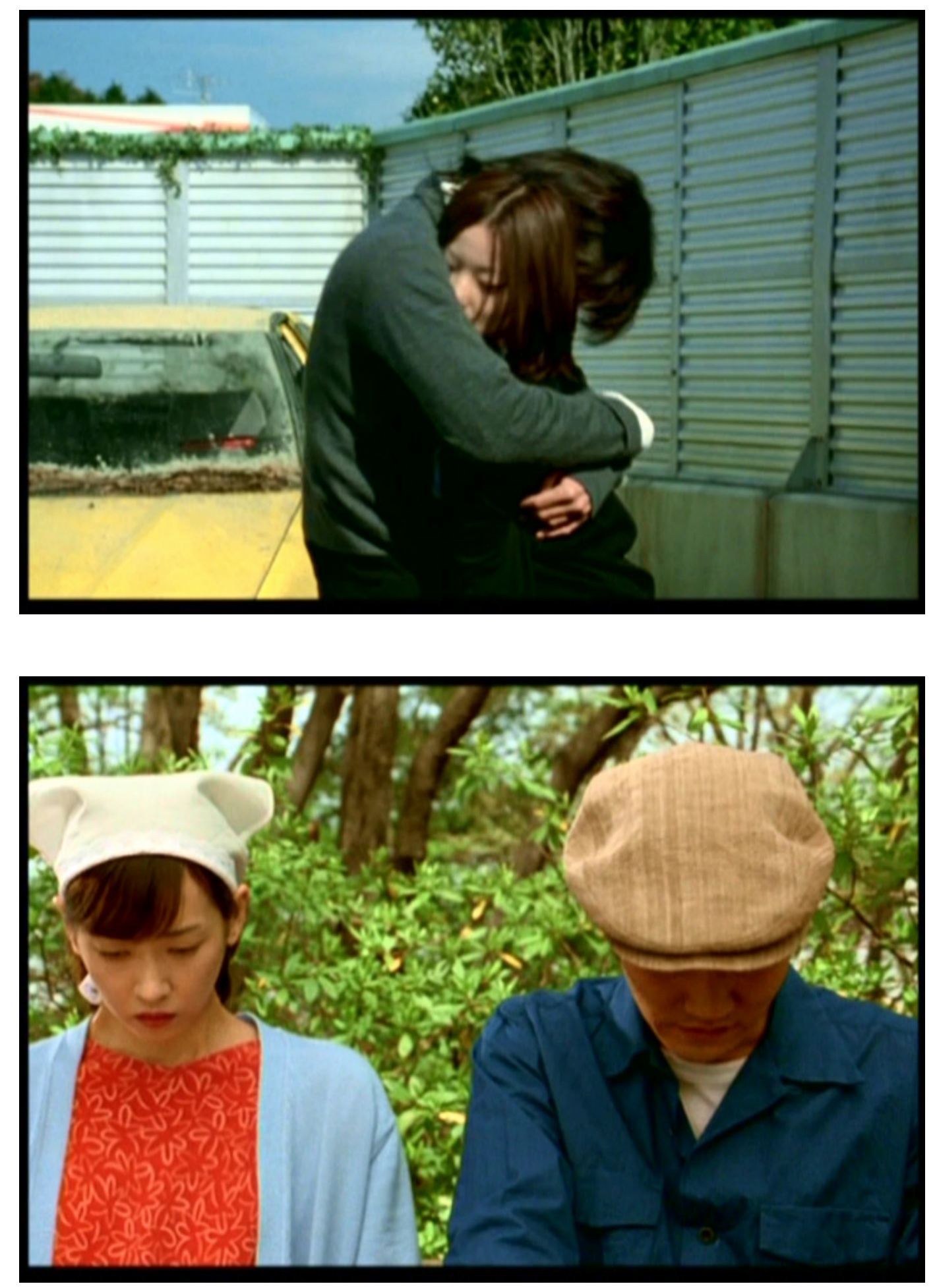
Hiro e Matsumoto deixaram suas namoradas apostando na busca por um encaminhamento de vida que mergulha em uma tradição ligada à dimensão profissional (o ingresso na yakuza e o casamento por indicação do presidente da empresa). As mulheres, por sua vez, acabaram por imobilizar-se diante da situação de abandono: Sawako perdeu a memória e o discernimento, a antiga namorada de Hiro insistiu por anos em uma espera que se esvaziou de objeto. Assim como a errância de Matsumoto e Sawako se sustenta como um mecanismo autônomo, sem objetivo, a mulher dessa segunda história vive sob a temporalidade de uma espera sem objeto.

Hiro vai ao parque (sem guarda-costas) para se esbaldar em sua lembrança e encontra lá sua antiga namorada. Essa senhora já não espera mais seu namorado - que namoro perduraria a tão longa distância temporal? - ela espera cada sábado para ir ao parque para esperar. E não sente constrangimento algum nessa atitude - a duas garotas que pedem para se sentar no banco em que ela está, explica: “estou esperando meu namorado. Tenho um encontro para almoçarmos juntos. Pode deixar o lugar para ele? Desculpe". Seguindo o título do filme, a ex-namorada de Hiro pode ser pensada como uma boneca titereada pela espera.

O espectador então é levado às águas de um rio canalizado. Quando anoitece, pode-se ver um abrigo formado por uma grande telha apoiada na estrutura da ponte sobre o rio, dentro da qual Matsumoto está sentado de pernas cruzadas, observando Sawako dormir.

Sawako então tem um sonho, e é somente nesse sonho que ela sai de uma vivência infantil para adentrar em um espaço onde há lugar para a sexualidade. Isso ocorre, entretanto, de forma velada: tem-se a impressão de que se trata de um estupro, apesar da imprecisão que uma cena mostrada com tal distância gera.

Também no sonho, Sawako e Matsumoto caminham atados pela corda. Perpassam fileiras de cata-ventos, que rodam e lembram que os ventos, passageiros como as águas do rio, podem ter sua direção modificada. A vida de Sawako, desesperançada, aparentemente sem que ela se dê conta do que se passa, deixa, desse modo, transparecer em seu sonho a possibilidade de mudança de rumos metaforizada em ventos - uma mudança que, entretanto, não ocorrerá.

Em seu sonho, ao ser carregada sobre um pano, assustada, Sawako acaba conduzindo Matsumoto que, amarrado a ela pela corda, é arrastado pelo chão, 
desacordado. Mas, se nesse momento Sawako conduz Matsumoto, o faz apenas porque está sendo conduzida por outros - não possui, portanto, liderança alguma.

Alguns elementos do sonho de Sawako invadem suas visões no dia seguinte, e a fronteira entre sonho e realidade fica nublada. Embora pareça assustada pela presença desses elementos, Sawako nada diz, apenas volta a andar, olhando para trás e, quando vê o mesmo homem de seu sonho, trajando apenas uma espécie de cueca vermelha, acelera seus passos em uma reação bastante instintiva e, pela primeira vez em sua andança, caminha à frente de Matsumoto.

Algumas lembranças do tempo em que o casal não possuía toda essa passividade, quando estava inserido na vida social e, sobretudo, na temporalidade corrente da modernidade, aparecem na tela. Lembram o espectador de que algo os motivou a ter esse comportamento tão peculiar, mas que parece já "naturalizado".

Tem início a última história a compor o filme: fazendo referência expressa ao título do filme, Dolls, Haruna é a personificação da metáfora de uma boneca pop star na mídia. Sua música está muito distante da tradição japonesa, a letra não tem profundidade poética, repete estrofes e tem um fundo instrumental que parece feito por máquinas, e não instrumentos. Ela canta e dança como uma boneca, tem a beleza e a perfeição física de uma boneca. É manipulada como uma boneca. Quando perde o vigor de sua forma, é esquecida como uma boneca jogada no fundo de um baú de brinquedos.

Nukui, fã de Haruna, já cego e acompanhado por uma mulher que lhe indica o caminho, segurando-o pelo braço, passa pelo casal Matsumoto e Sawako: assim tem início essa terceira história. É uma praia tranqüila, vazia, com um mar de águas calmas. Haruna está sentada na praia, voltada para o mar, com um curativo sobre o olho esquerdo. O mar vai ampliando a presença da água no filme.

É um mar calmo e com poucas ondas, uma praia na qual Haruna se instalou em busca de isolamento e sossego. A água desse mar calmo tem sentido de purificação e regeneração. Com o rosto marcado por um acidente de carro, Haruna afasta-se da mídia e do convívio social intenso que possuía, à espera de uma cura que pode não ocorrer. Ela se recusa a receber visitas para que não notem a imperfeição de seu rosto. Se antes olhava para as lentes das câmeras, olha agora para si mesma, abandona uma vida fundamentalmente voltada para o exterior para dar lugar a um olhar voltado para si, refletido sobre o mar, um espelho de calmas águas marinhas que a convida à reflexão. Nesse exílio, Haruna busca a purificação do encontro com as águas e as rosas. Espera a 
regeneração - de sua pele ferida, coberta por um lenço, e de si, cuja superficialidade de antes se deixa contrapor à profundidade do oceano à sua frente.

Sua superficialidade se concretiza na cena em que Haruna está no exercício de sua profissão anterior - a gravação de um vídeo-clipe de música pop cuja primeira estrofe diz: “As garotas ficam tão bonitas quando estão apaixonadas. Será verdade? Espero que sim". É uma música de baixa qualidade, que se dirige ao efêmero mercado fonográfico adolescente, no qual as canções e seus intérpretes encontram rápido sucesso, mas logo saem da mídia e são esquecidos. São artistas que criam músicas sem qualidade, com excessiva repetição de acordes, refrões e ritmos, e são adorados por fãs de não mais que uma geração - seguem, portanto, a lógica moderna da produção do novo que será logo superado pela produção de algo mais novo, sem que se estabeleçam cânones. Isso se explicita pela crítica que os produtores de Haruna, junto a ela no carro, fazem aos fãs mais antigos, a quem julgam ser "perigosos".

No palco, luzes coloridas piscam enquanto Haruna canta e dança. A cor que predomina é a rosa, expressando uma referência ao universo infantil feminino. Ela parece uma boneca sobre o palco, com movimentos mecânicos e repetitivos. Embora cercada de luzes, sobre o palco está apenas Haruna, e quando a câmera se afasta, ela parece extremamente só em um palco tão grande, cantando apenas para as câmeras, sem platéia.

Nukui disputa com Aoki a posição de principal fã e seguidor de Haruna. Seu trabalho é, com um bastão luminoso, fazer a sinalização de um desvio de tráfego em uma avenida, em função de obras na pista. Em seu uniforme há um broche com a foto de Haruna, apenas mais uma imagem em meio a tantas (a tantos estímulos) da metrópole onde ele mora e trabalha.

A imagem inicial de Nukui e Haruna em uma praia desabitada - na qual ela tem um lenço tampando o curativo em seu rosto, e ele está cego - é bastante contrastante com essas cenas urbanas. Há uma diferença fundamental na temporalidade das duas situações e no número de estímulos a que estão subjugados em ambas. Contrapõe-se uma situação tipicamente moderna (o trabalho com iluminação no trânsito de uma avenida, por parte de Nukui, e a vida agitada sob as luzes do palco de Haruna), e toda a efemeridade que isso pode trazer, a uma situação de espera (a espera de Haruna pelo tempo de sua cura ou esquecimento, e a espera de Nukui que, embora ainda não saiba, aguarda sua breve morte). 
O quarto de Nukui mostra ao espectador o grau de seu fanatismo em relação à cantora - as paredes estão cobertas por pôsteres com sua imagem. No contraste entre a vida moderna e a vida de isolamento, a vida de estímulos luminosos e a vida da escuridão da cegueira, há um corte e o espectador é levado à história de Hiro. Sua antiga namorada vai à casa de um vizinho e lhe dá o almoço que seria de seu namorado, que não apareceu: "tenho esse almoço sobrando", diz. Tem-se aqui a confirmação de uma espera que já virou hábito. Ela não espera um namorado, já que a probabilidade de ele aparecer seria quase nula, e quando Hiro aparecer ela não o reconhecerá. Ela vive sob essa temporalidade da espera, uma espera que perdeu seu objeto. Perde também seu objeto a espera de Haruna pela cura, e a errância de Sawako e Matsumoto. São saídas da temporalidade moderna que ocorrem por diferentes razões, mas que terminam por se autonomizar em esperas.

A memória do passado que Haruna viveu volta à tela, como volta sua reflexão a cada movimento do mar, a cada oscilação do vento. Haruna aparece autografando seu álbum de fotos, lançado como livro - como fosse ela de fato uma boneca que se vende por um catálogo fotográfico. Nukui e Aoki, os fãs mais antigos de Haruna, disputam a liderança dessa alcunha com tamanha rivalidade que fica subentendido que quem assassinará Nukui é Aoki.

Os principais seguidores de Haruna, que serão fiéis mesmo após o afastamento da cantora, são, não por acaso, os dois mais velhos. Nesse conflito entre a tradição e o moderno, entre a honra e a dignidade, os fãs mais novos, adolescentes, são os que demonstram menos fidelidade à adoração e, tão logo Haruna deixa de aparecer na mídia, a esquecem.

Nukui trabalha: distraído, com muitos estímulos ao seu redor marcando bem o espaço-tempo em que está inserido, seu chefe o olha, luzes piscam em todos os lugares, ele mesmo segura um bastão luminoso para sinalizar o tráfego, à sua frente há um painel luminoso que mostra notícias. Enquanto isso, Haruna sofre o acidente de carro: vê-se sangue no chão, a porta traseira esquerda do carro no qual ela estava ao deixar o estúdio aberta e, perto do sangue, um sapato cor-de-rosa com a ponta azul, feminino, jogado ao chão. Esse sapato remete novamente ao infantil, à inocência de uma valorização incondicional ao que é novo (os fãs mais antigos de Haruna o são há quatro anos). 

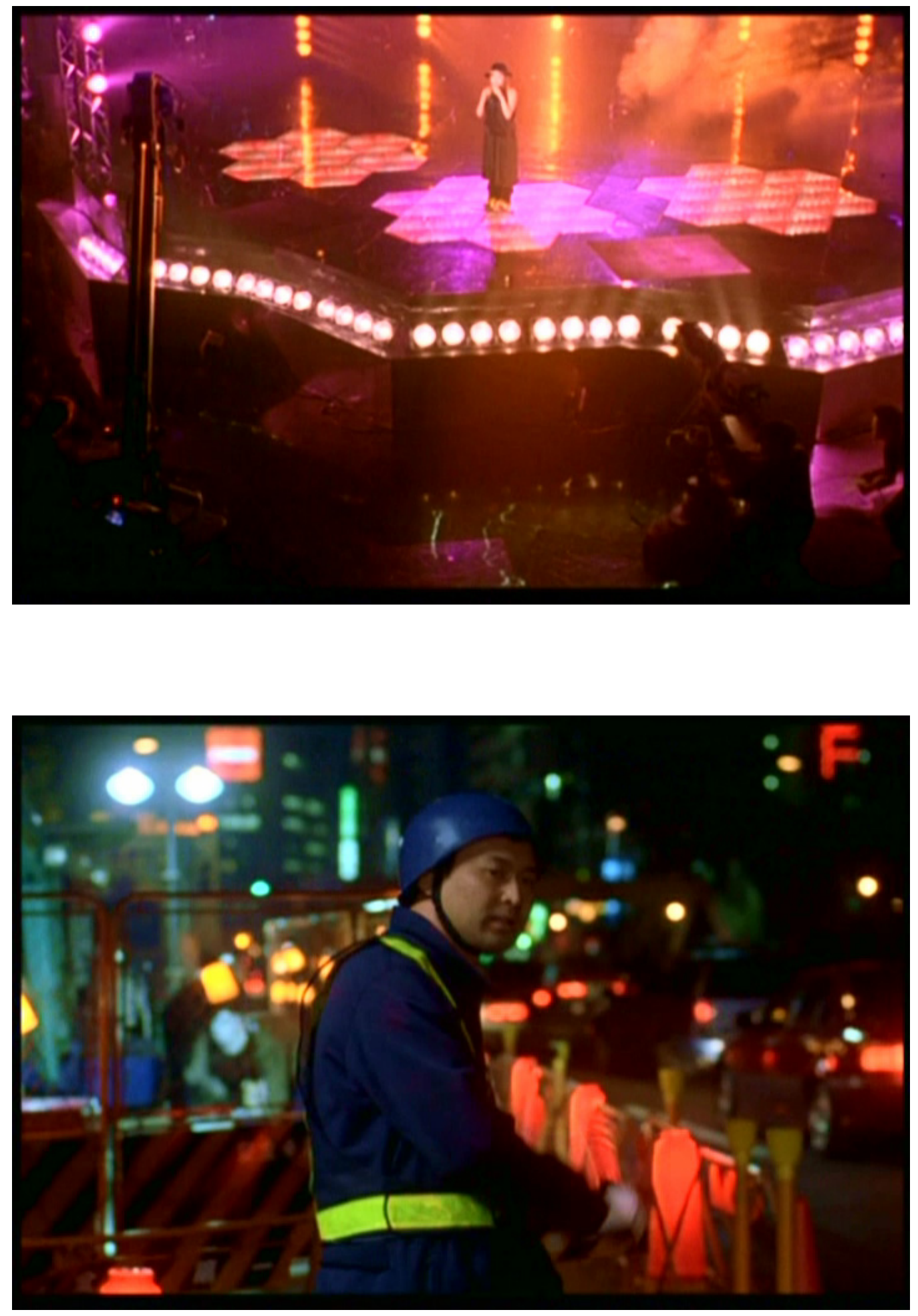

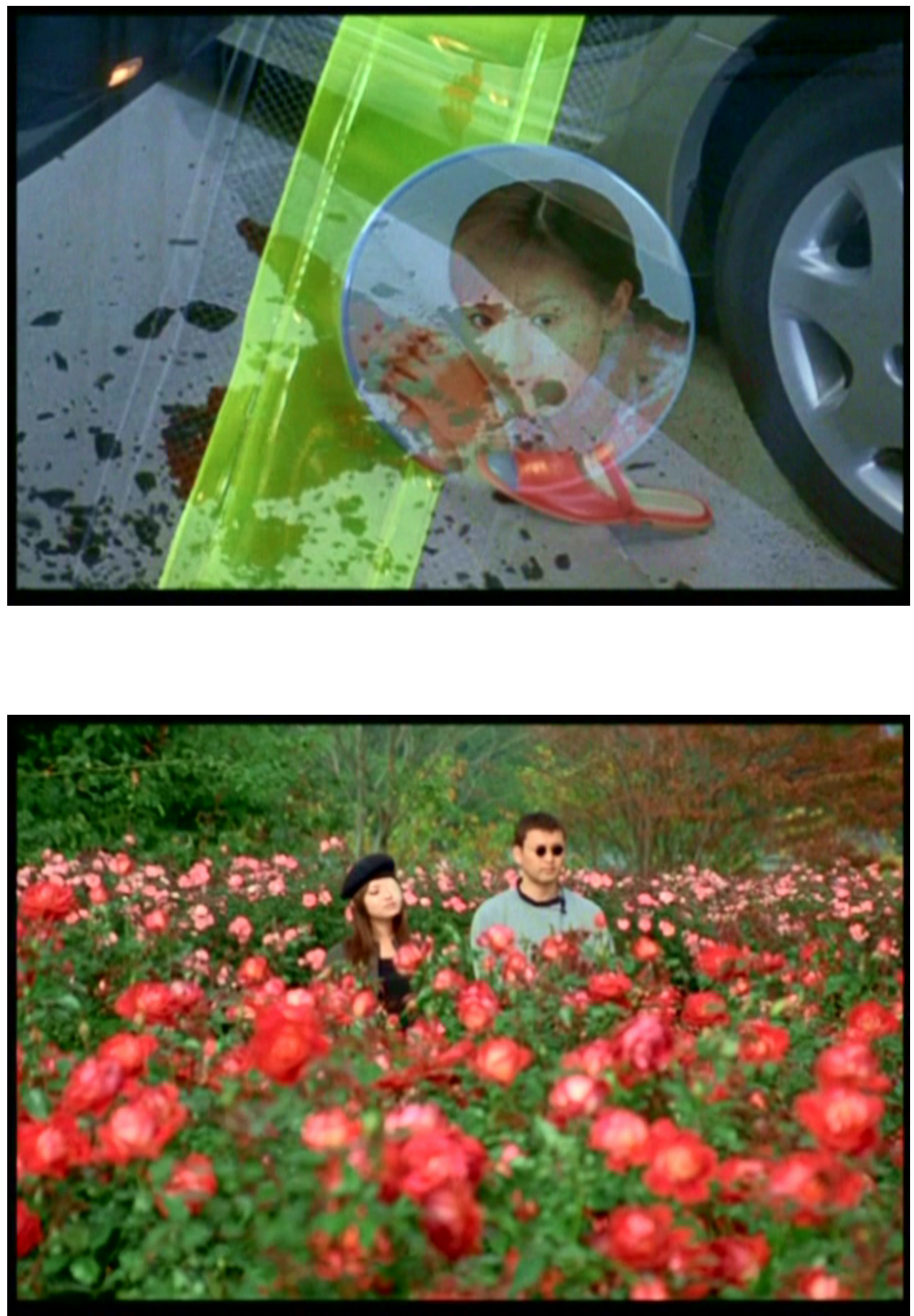
A imagem do acidente de Haruna é rapidamente intercalada pela imagem do broche de Nukui no qual está estampado o rosto da cantora, preso sobre seu uniforme, em uma das faixas que refletem luz que ele tem contornando seu corpo. Esse recurso de intercalação é semelhante ao que mostrou a imagem do carro de Matsumoto, limpo, estacionado à frente de sua empresa, intercalada à de seu carro sujo, como fora abandonado. Aqui se trata, entretanto, da forma invertida desse mesmo recurso: primeiro é mostrada a tragédia, aquilo que se tornará a temporalidade distendida, e essa imagem é intercalada à de uma fotografia em um broche sobre faixas luminosas, que remete à temporalidade moderna.

O acidente de Haruna é expresso como mais um estímulo na vida de Nukui - o painel luminoso que mostra notícias, para onde ele olhava, anuncia: "a pop star Haruna Yamaguchi sofre um acidente de carro". O abandono da vida de temporalidade moderna e estímulos de Nukui se concretiza na cena que se segue: o bastão que ele usava para desviar o trânsito cai no chão, ao lado de seus pés, e ele corre, observado por seu chefe. As conseqüências desse abandono o impedirão de voltar a esse trabalho e, no limite, de seguir vivendo.

O afastamento de Haruna é mostrado pela mídia: um jornal diz que a cantora nada comentou a respeito de seu retorno, “aposentadoria precoce?", indagam os escritos, o que indica que algum tempo já se passou, mas Haruna segue reclusa da vida dos holofotes. Quando Nukui vai à casa de Haruna (onde está também Aoki), sua mãe confirma o exílio da filha: "minha filha não está em casa. Ela se afastou do mundo. Não vai receber ninguém”. Tem-se, assim, novamente a idéia de alguém que se afasta do mundo, um mundo que é a vida da modernidade, como se viver em uma praia por onde poucas pessoas passam não significasse ainda estar imerso em valores que construíram o ser que depois se reclusa - mesmo no caso de Sawako, ainda que ela tenha sido destituída de sua memória e de grande parte desses valores ao tentar suicídio, algo ainda resta, que a faz caminhar, seguindo Matsumoto, que a faz sonhar, que a dota de postura corporal, mostrando que, por mais que a memória dos fatos não permaneça, ao menos a memória do corpo, socialmente adquirida, persiste nessa "saída do mundo".

O amigo de Matsumoto disse que Sawako estava "em outro mundo". A mãe de Haruna diz que ela "se afastou do mundo". O mundo, nessa concepção moderna, inclui apenas o que está subjugado à sua temporalidade dominante. O que à temporalidade 
moderna não pertence, por mais que essa temporalidade pertença ao mundo, não é considerado mais parte dele.

Chegando em casa, Nukui decide igualmente "sair do mundo" - pela impossibilidade de olhar para as luzes que o cercavam em seu trabalho, de ler o letreiro eletrônico que lhe deu a notícia sobre o acidente. Ele opta por memorizar uma imagem fotográfica da cantora que idolatra e ter apenas essa imagem dentro de si. Depois de observá-la continuamente, pega um estilete. Na cena seguinte, caminha com uma bengala e usa óculos escuros, o que leva o espectador à constatação de que ele perfurou seus olhos. Tornar-se cego é uma possibilidade para que a imagem de Haruna seja sua última imagem vista em uma vida antes tão repleta de estímulos visuais. Por essa "saída do mundo" que ele poderá realizar o sonho do encontro com a cantora que tanto idolatra. E tornar-se cego é, sobretudo, a única forma que Nukui encontra para poder ficar próximo a Haruna. Ela aceita vê-lo e, quando pergunta sobre o que se passou com seus olhos, ele confirma o grau a que chega sua devoção à cantora: "achei melhor não poder ver".

Após a explicação das histórias - que permitiu ao espectador ver, sob a luz do sol do verão e o reflexo das águas, como foi que os personagens das três histórias saíram de uma temporalidade corrente para ingressar em um tempo de espera - chega o outono.

\subsection{Outono}

Eis que chega o outono. Nessa estação, em que as histórias começam a ter um desfecho, o filme ganha uma coloração vermelha que bem representa o desenrolar trágico do que foi exibido até agora ao espectador. É a cor das folhas que caem no chão e que as imagens captam, mostrando ao espectador, por meio da mudança de estação, a passagem temporal. O outono é a preparação para o rígido inverno que virá em seguida, completando um ciclo de estações.

A cor vermelha é culturalmente associada ao sangue e, por extensão, ao perigo e à tragédia, mas também é associada ao amor e à paixão.

[...] não parece haver universais. É muito comum ver o vermelho sendo tratado como um signo de perigo, que pode derivar da associação vermelho-sangue. Mas 
o vermelho é também muito freqüentemente associado com prazer, podendo derivar de vermelho $=$ sangue $=$ vida $^{38}$

Os reencontros, nesse bloco outonal, entre Hiro e sua antiga namorada, e entre Haruna e Nukui, poderiam justificar a associação desse vermelho ao amor - a um amor incondicional, que beira a insanidade, mas que se mostra presente. Esse amor, entretanto, esvaiu-se rapidamente na trama do filme, perdendo espaço para o destino trágico e menos romântico que é a impossibilidade de amar. Uma vez que o espectador "lê" as novas cenas de um filme tendo em conta as anteriores, ele sabe que não se trata de um vermelho amoroso. Contrapõe, antes, esse vermelho em que as folhas caem à estação oposta a essa, a estação das flores: opõe o vermelho do outono à esperança branca da primavera.

[...] a questão mais geral é que os símbolos ocorrem em conjuntos e que o sentido dos símbolos particulares deve ser procurado antes no contraste com outros símbolos do que no símbolo como tal. [...] os símbolos assumem diferentes sentidos dependendo do que é contrastado com o quê. ${ }^{39}$

Assim, contrastando a simbologia desse vermelho do outono com folhas secas à estação oposta, a primavera, em que as flores resplandeciam em árvores, o vermelho é imediatamente associado a sangue/ tragédia. E o desenlace do filme confirma isso com a morte de dois personagens e o vermelho do sangue de Nukui exposto na tela.

Nesse princípio de outono, Hiro volta ao parque e senta-se no mesmo banco onde terminara o namoro. Lá se sentará também sua antiga namorada, que logo chega, trajando o mesmo vestido vermelho que usava no dia em que eles se encontraram pela última vez. Hiro não se identifica e ela tampouco o reconhece: “desculpe. Acho que meu namorado vai chegar logo. Quando ele vier, pode liberar esse lugar? Desculpe”.

O "namorado" que ela espera não é o homem que está ao seu lado e ela não consegue reconhecer. Ela espera o jovem Hiro, um garoto preso ao passado, que existe apenas em sua memória e, sobretudo, em sua promessa de que o esperaria. Um garoto que ela sabe que não existe mais, mas que insiste em esperar porque tornou essa espera - sem objeto - autonomizada em relação a seu fim (a chegada do que se aguarda). Com

\footnotetext{
${ }^{38}$ LEACH, Edmund Ronald. "Exemplos de códigos binários". In: Cultura e comunicação - a lógica pela qual os símbolos estão ligados. Rio de Janeiro: Zahar Editores, 1978, p. 70. Grifos do autor.

${ }^{39}$ LEACH, E. "Exemplos de códigos binários". op. cit., p. 71.
} 
a espera, ela acaba presa a um tempo ahistórico que, no limite, não existe, exceto talvez como possibilidade de rememoração. Ela vive, portanto, sob uma temporalidade que resulta da suspensão e mesmo da anulação da linha temporal corrente - um tempo no qual não se constrói, para o qual não há passado ou futuro, há apenas a espera passiva por algo que não virá.

A fala da antiga namorada de Hiro (única dentre os seis protagonistas que não é nomeada no filme) reforça essa autonomização de seu mecanismo de espera:

ANTIGA NAMORADA DE HIRO: Não importa mais. Não, já que você veio no lugar dele. Fico pensando se posso parar de esperar por ele. Quer almoçar comigo?

Em sua fala ela deixa transparecer, ao se questionar sobre sua espera e a não chegada do outro, o fato - lúcido - de que quem ela espera há tantas décadas não chegará mais. É um questionamento, entretanto, muito breve, e logo ela está almoçando com Hiro, o homem que poderia ter mudado de maneira radical a vida dessa mulher, caso tivesse aparecido muitos anos antes.

Se existe alguma possibilidade de que a temporalidade sob a qual ela vive seja abalada, ela reside na identificação de Hiro - que poderia lhe dar a percepção da passagem do tempo durante a espera, ou até mesmo ocasionar o fim da espera, caso ele fosse capaz de ocupar o lugar daquele operário que um dia fora, o rapaz preso ao passado por quem ela espera. Essa possibilidade abstrata - e que não se concretizará - é a chance que ela possui, na trama, de obter alguma saída para a sua constante temporalidade de exceção. A única identificação feita entre Hiro e seu antigo namorado, entretanto, diz respeito ao gosto culinário referente ao almoço que ela lhe ofereceu: "era o favorito dele também".

A breve esperança criada no espectador, de que Hiro seja reconhecido por ela, ou identifique-se, tem base na possibilidade de uma realização amorosa - que transformaria o vermelho do outono em símbolo romântico. Tal esperança, todavia, termina em seguida, com o assassinato de Hiro. O antigo chefe da yakuza, tratado no filme não como herói, mas como um senhor saudosista que se aproxima da morte, fica muito próximo da possibilidade de abalar o ciclo de espera de sua antiga namorada, mas não consegue obter seu título de herói: é exterminado com um tiro à queima-roupa antes de poder realizá-lo, reforçando a tragédia simbolizada pela cor vermelha. 
Sua morte é construída no filme por uma breve sucessão de imagens: o guardacostas e o motorista esperam por Hiro na entrada do parque. Hiro vem caminhando de volta ao carro. Ele tem uma expressão contente, está sereno. Um homem que estava sentado ao seu lado no parque, entretanto, caminha atrás dele. Abre o casaco, e dali saca um revólver. Quando olha em direção ao carro e aos rapazes, Hiro vira para trás com cara preocupada e lá está o homem apontando-lhe a arma. Não há escapatória para o que será esse tiro à queima-roupa. Ele é, portanto, assassinado. A mulher opera, nessa história, como o elemento que leva à morte do homem. Hiro havia dito que acreditava que uma mulher pode atrapalhar, mas dera a entender que reviu esse pensamento. $\mathrm{O}$ filme aqui, entretanto, confirma essa idéia - ele é assassinado justamente quando resolve ver sua antiga namorada.

Os outros personagens ligados a Hiro, o deficiente físico e o rapaz que sempre o acompanha, param novamente frente à casa de Hiro e gritam "chefe". Não há - nem poderá mais haver - resposta. "Ele deve ter saído", conclui o rapaz deficiente, e partem. A antiga namorada de Hiro então aparece - ela está novamente sentada no parque, de vestido vermelho e boina vermelha, à espera.

Encerrara-se com um tiro no personagem masculino a história de um amor preso a uma promessa, um amor romântico de dedicação (da mulher que espera toda a vida por seu amado) e sacrifício (do homem, que vai vê-la desprotegido e é assassinado). Encerra-se a possibilidade de concretização de um amor baseado na tradição, amor esse que não chega a se concretizar, mas pelo qual vive uma mulher e morre um homem. Encerra-se essa história, mostrando que a tradição da palavra e da dedicação não sobrevive à modernidade.

Não se encerram, entretanto, as tragédias. O vermelho também envolve Sawako e Matsumoto, cercados por árvores com folhagem dessa cor em sua primeira aparição nesse bloco: sobre um trilho de trem em meio à vegetação outonal, aparece a corda vermelha que os une sendo arrastada em primeiro plano. A corda passa por cima de uma pequenina flor amarela que ali nascera, fazendo sobrepor-se a cor vermelha nessa estação. 

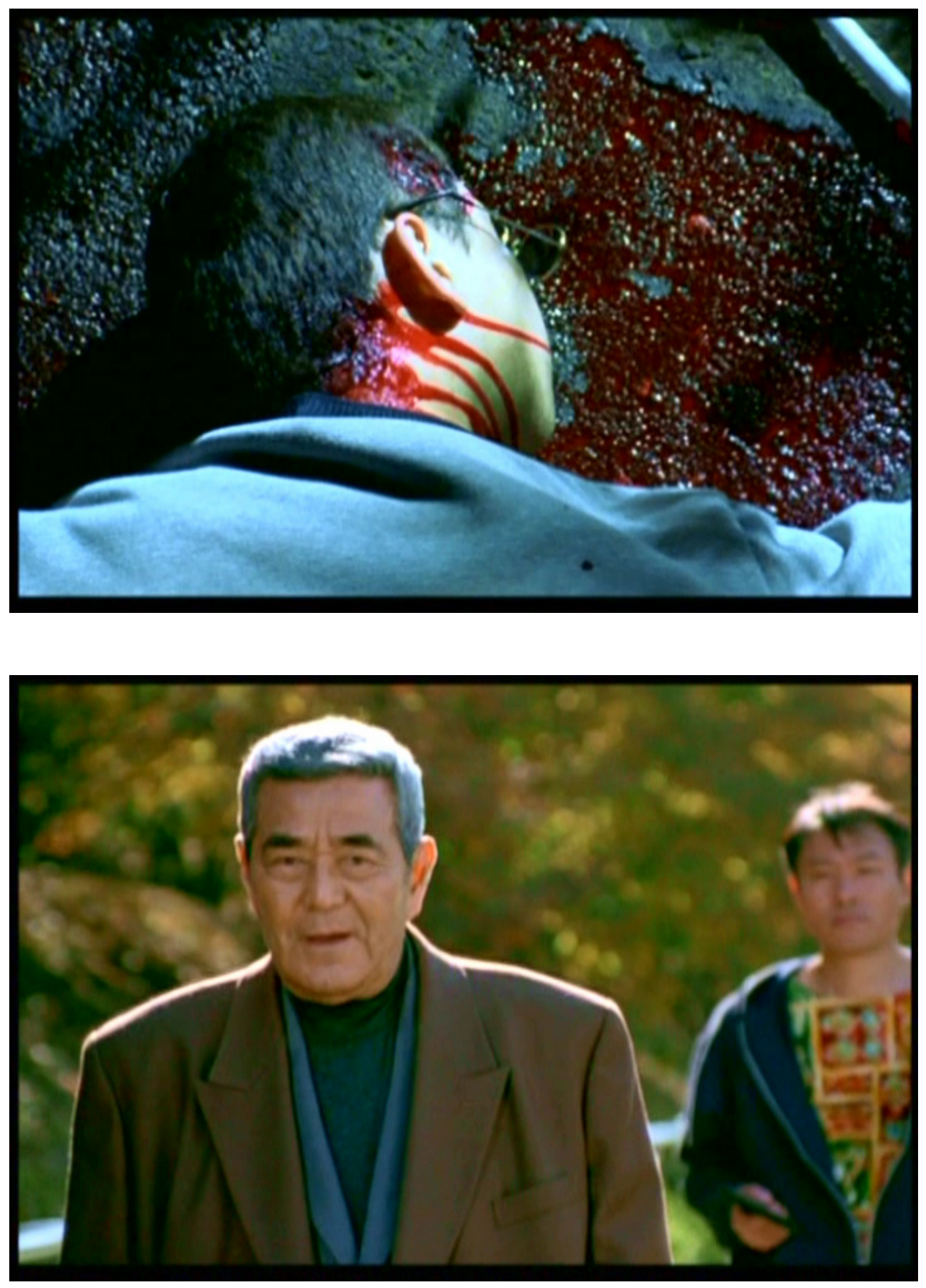
Seguem-se vidas construídas sobre a ausência de plausibilidade, sobre um objetivo inalcançável, de uma temporalidade, portanto, que não é a do progresso desenvolvimentista. Se a temporalidade moderna tem como objetivo um aperfeiçoamento técnico contínuo, que faz com que ela caminhe exclusivamente para frente, a temporalidade da espera, presente nas três histórias de Dolls, é a de quem "sai do mundo": uma temporalidade que não tem rumo definido, que está suspensa da linha temporal moderna.

Nesse outono em que as folhas - e os resquícios de esperança - caem uma a uma, planando até alcançarem o solo, há uma aceleração da intercalação entre as histórias. O ritmo dos cortes do filme é acelerado, de modo que uma imagem temporal distendida é tencionada por sua rápida edição. E o espectador transita, rapidamente, de uma história a outra.

E é por entre essas interposições das histórias que se têm os encontros de Nukui com Haruna e de Hiro com sua antiga namorada, que levam esses dois homens à morte. A morte é sintetizada pela imagem de uma folha vermelha, seca pelo outono, que cai no rio e vai seguindo o fluxo das águas em seu curso irreversível. O vermelho da folha se destaca em meio à água, e vai sendo levado por seu fluxo, assim como ocorre com o sangue de Nukui, lavado da estrada por policiais.

Matsumoto e Sawako observam, nesse outono, as águas dos rios que, como eles, vão sempre adiante, sem parar, e sem que se tenha qualquer elemento de progresso, sem que "ir adiante" signifique prosperidade ou avanço. Como as águas que correm, Sawako e Matsumoto vagam, como se fossem levados pela correnteza, como se fossem marionetes comandadas pelo destino e pela aparente ausência de salvação; vagam por uma vida sem pathos, vida de errância enquanto se espera.

Eles caminham por onde não há pessoas ou tempo que não seja o das estações. Caminham e observam esse mesmo tempo de espera sem objeto, parecem encaixar-se à paisagem, despidos de história, fala, ou contato com outrem. Seguem em seu estágio infantil, pré-sexual, aparentemente sem pulsão alguma.

Também isolados, "fora do mundo" estão Haruna e Nukui, em meio a um roseiral que Nukui não pode ver. Haruna o guia por essa realização de parte de seu sonho. Sonho esse, de Nukui, que poderia ser realizado pela concretização de uma relação amorosa - que novamente não ocorre. Ao sair dessa visita, Nukui de fato "sai do mundo": ele aparece caído no asfalto, morto, rodeado de sangue, com a gaita na qual 
tocava as músicas de Haruna e sua bengala ao seu lado. Indícios mostrados no filme anteriormente - a insistência na reprodução de um diálogo de Aoki com Haruna, a hostilidade existente entre os dois fãs e a fala de que fãs antigos são perigosos - criam nexos de significado no espectador, que associa esse assassinato à pessoa de Aoki.

Matsumoto e Sawako seguem caminhando, a despeito de toda a tragédia que os acometeu. Se a paisagem inicial do filme era marcada por flores brancas, agora se vêem as folhas avermelhadas caídas ao chão, sobre as quais o casal pisa em sua silenciosa caminhada.

Esse outono aniquila a esperança que os espectadores poderiam ainda projetar sobre as duas histórias que haviam começado no verão - esperança de que o vermelhotragédia se transfigurasse em vermelho-amor, de que a espera cessasse. Os protagonistas masculinos das duas histórias, depois de chegarem perto de proporcionar a "volta ao mundo" pela experiência amorosa, são assassinados violentamente. Suas "parceiras" continuarão abandonadas ao tempo da espera: Haruna seguirá isolada, na praia, esperando que seu acidente não tivesse ocorrido, e aquela que fora namorada de Hiro seguirá esperando a volta de um rapaz cuja existência tornou-se mítica. O que se espera? É um tempo de contemplação, cuja espera não se cristaliza em objetos específicos, que se autonomizou em relação a seu fim, deslocando-se do objeto inicial.

A corda que une Matsumoto a Sawako vai se arrastando pelo chão e carregando folhas secas avermelhadas, lembrando ao espectador que as marcas das grandes tragédias são carregadas por quem as vive. Retoma-se, assim, a história da apresentação de bunraku inicial, na qual o sofrimento de Yamato virara poeira espalhada para sempre em seu caminho.

O outono termina quando Sawako e Matsumoto cruzam uma ponte sobre um rio que corre. Corre como o tempo que carrega as tragédias dessa estação, que carrega o término de mais um outono e dá lugar ao inverno nesse tempo cíclico e previsível da natureza. 

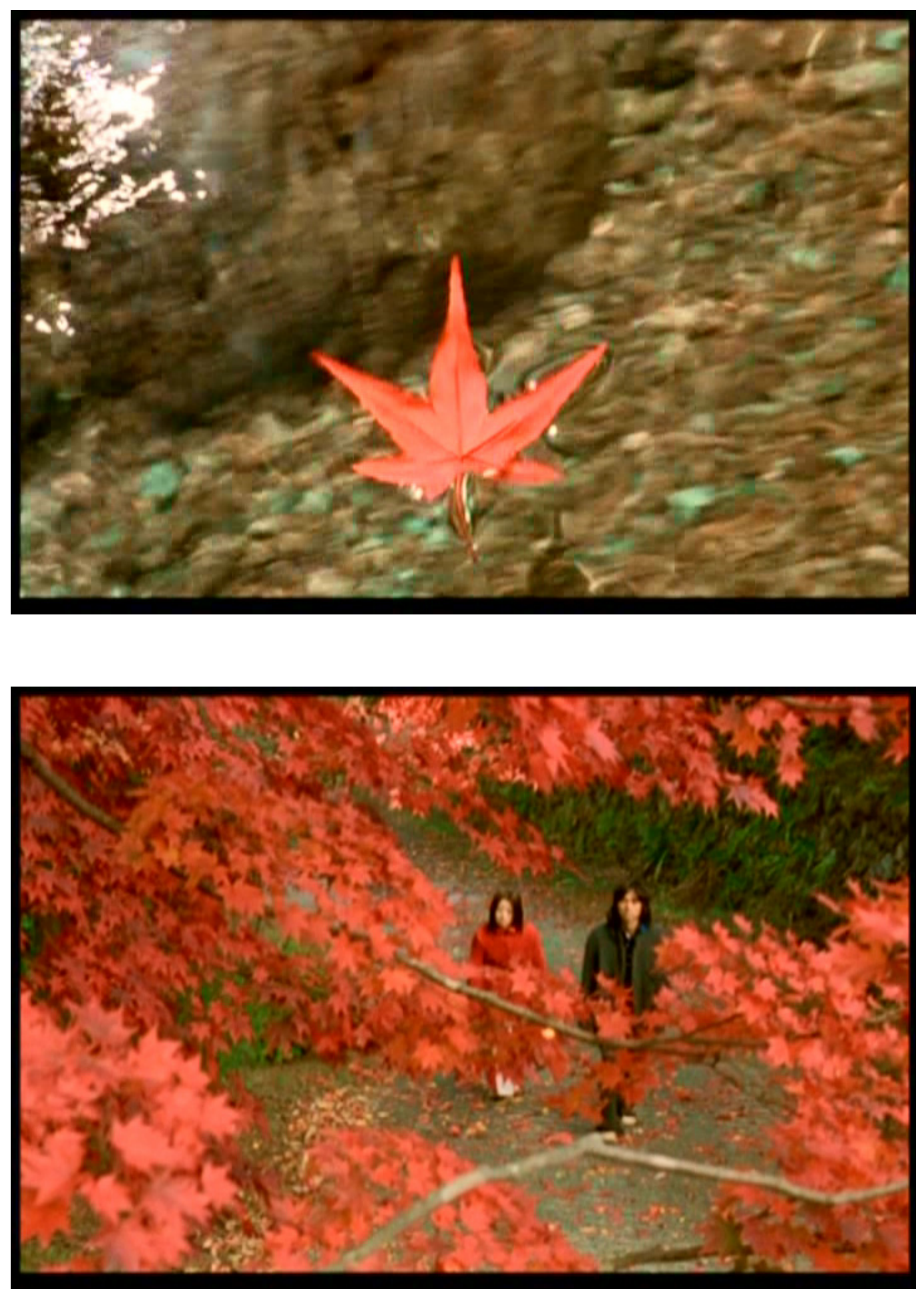


\subsection{Inverno}

No inverno, estação oposta ao verão, a água volta como elemento central. Está, entretanto, em forma de gelo, deixando transparecer a possibilidade de mudança de que esse elemento é capaz. A paisagem está tomada por um branco tão efêmero quanto o da primavera, pois tão logo termine o inverno o gelo derreterá e dará continuidade ao ciclo das estações. A única possibilidade de concretização amorosa que resiste no filme é a de Sawako e Matsumoto, já que Hiro e Nukui morreram. O casal segue caminhando, agora sobre a palidez do gelo.

A entrada no inverno se dá pela primeira imagem dessa estação: a corda vermelha, arrastando folhas secas em seu curso, passa sobre o gelo, onde deixa um rastro de folhas. A passagem entre uma estação e outra reforça no espectador o sentimento de continuidade, de que a natureza opera de forma cíclica - e que, portanto, após o inverno, (ainda que termine o filme) haverá sempre outra primavera, dando início a mais um ciclo.

As lembranças de Matsumoto e Sawako mostradas nesse bloco do filme referem-se a acontecimentos ocorridos no inverno, na época em que eles tornaram-se noivos. Quando o espectador percebe que uma dessas lembranças é de Sawako, crê que ela recuperou sua memória, há um último suspiro de esperança no filme - é como aquele momento de lucidez ou síntese que muitos moribundos têm antes da morte e que, quando a morte ocorria na presença dos outros, se contava uma anedota que originaria uma narrativa. Nesse inverno rigoroso o casal terá seu último momento de grande lucidez - expresso pela lembrança de Sawako - antes da tragédia final.

A associação entre o bunraku e a história desse casal errante é refeita nesse final de sua caminhada quando, ao lado de uma casa, sobre uma armação aparecem os bonecos do início do filme pendurados. Logo desaparecem, e restam apenas suas roupas penduradas na armação, balançadas pelo vento. Eis que na cena seguinte Matsumoto e Sawako caminham vestindo as roupas dos bonecos do bunraku e seguem amarrados eles agora parecem de fato dois bonecos, bonecos cuja errância deixa rastros de pegadas na neve. Matsumoto e Sawako estão inexpressivos e pálidos como os bonecos. E, como eles, são titereados, guiados não se sabe por quem nem para onde. Uma errância sem destino que em breve será uma espera pela morte. 
Atados pela corda, Sawako e Matsumoto retomam a semelhança com os amantes suicidas de Sonezaki. Se o espectador crê que a tragédia terminará como a destes amantes, surpreende-se com a lembrança que vem à tona em Sawako.

O casal se aproxima de um recinto que possui uma grande janela. A persiana está parcialmente levantada. Dentro dessa casa, há pessoas e luzes, mas só se podem ver vultos. Matsumoto mexe no lixo, à procura de comida, e Sawako fica atrás dele. Olham, então, para dentro da janela. Vê-se o casal pelo ângulo interno da construção. Eles têm expressão triste. Há silêncio.

O espectador é levado para dentro desse recinto (que possivelmente se trata de um restaurante), por uma lembrança. É o dia do noivado de Matsumoto e Sawako. Uma festa ocorre lá, há muitas pessoas bebendo e comendo, e um rapaz pede a atenção de todos: "tenho novidades. Matsumoto e Sawako decidiram se casar. Vão se casar!" A amiga de Sawako, a mesma que foi avisar Matsumoto da tentativa de suicídio de Sawako na igreja onde se realizaria seu casamento, está presente na festa e demonstra grande contentamento ao ouvir o comunicado. Todos os aplaudem.

O noivado fica simbolizado por um colar que Matsumoto coloca no pescoço de Sawako, sua suposta futura esposa. O amigo que havia anunciado seus planos diz: "Devia ter trazido um anel". O noivo the responde "Não deu, estou duro". Coloca o colar em Sawako e pergunta se ela está decepcionada. Sawako sinaliza que não com a cabeça, sorri, abaixa o rosto para olhar o colar. O pingente do colar dourado tem formato de anjo, o que remete ao início do filme, quando Sawako brincou com um anjinho de porcelana.

O filme volta ao presente narrativo, Matsumoto está olhando para dentro da casa. Um pouco atrás dele, Sawako toca em suas costas, chamando-o. Ele se volta para ela, triste e apreensivo e, olhando em seus olhos, Sawako segura o pingente (o anjo) em suas mãos, para que ele olhe o colar. Ela o encara seriamente, com o colar em mãos. Segue encarando-o, até sorrir. Ele não muda sua expressão e, no momento seguinte, ela começa a chorar, em silêncio. Ele também chora e a abraça fortemente.

Essa lembrança, se vista com relação às imagens que a antecedem, seria somente de Matsumoto, já que o espectador tem a informação de que Sawako perdeu a memória. Quando ela segura um objeto que se refere claramente à cena relembrada, entretanto, há uma re-significação do que foi visto - pode ter sido uma rememoração de Sawako e de 
Matsumoto, ou apenas dela, não mais necessariamente apenas de Matsumoto. A recuperação de sua memória passa a ser algo plausível.

O casal então é mostrado sentado frente a uma fogueira, apoiado no muro abaixo da janela do restaurante através da qual olhavam. Sawako dorme apoiada no ombro de Matsumoto. Um barulho de porta abrindo e uma luz vindo em sua direção faz com que ele olhe para o lado. Uma voz masculina lhes diz, acordando Sawako: "O que vocês estão fazendo aqui? Podiam provocar um incêndio! Caiam fora! Vocês ouviram, saiam."

Eles ainda estão vestidos com os trajes muito semelhantes aos dos bonecos. Matsumoto se levanta, ajuda Sawako a se levantar e eles saem de lá, caminhando sobre a neve de mãos dadas. A partir da lembrança do noivado, elementos como Sawako deitar-se no ombro de Matsumoto, eles caminharem de mãos dadas e chorarem abraçados denunciam a reconstrução de uma cumplicidade entre esse casal; parece haver uma reaproximação entre eles, como se resgatassem algo que estava preso ao passado - ou, antes, ao esquecimento. O fato de Sawako ter recuperado um elemento passado na lembrança simbolizada pelo anjo opera para estabelecer no filme a expectativa de alguma saída da temporalidade de espera pela concretização da relação amorosa.

Tal expectativa, entretanto, logo se encerra com a tragédia final - que se consolida como espera de tragédia, e não como tragédia em si, confirmando a temporalidade de espera que marcou a errância desse casal. Matsumoto e Sawako caminham rapidamente, de mãos dadas, em uma subida. Ao redor deles, há apenas neve. A imagem é intercalada por outra que mostra os bonecos que iniciaram o filme, Umekawa e Yamato, que, antes colocados na posição de espectadores, agora voltam a atuar, correndo no mesmo sentido que o casal humano. O casal de bonecos e o casal Sawako e Matsumoto se parecem bastante, vestem roupas muito semelhantes, de modo que o espectador é levado a associar, de modo quase didático, o casal errante do filme aos bonecos.

$\mathrm{Na}$ imensidão gélida que os cerca, surge uma árvore seca. Matsumoto e Sawako param ao seu lado e o espectador os vê virados de frente para a câmera. Eles escorregam, caem, e rolam sobre o gelo, descendo a montanha. Essa imagem é novamente intercalada pela de Yamato e Umekawa, movendo-se no mesmo sentido. Os bonecos se apóiam em uma coluna e Matsumoto e Sawako rolam, unidos pela corda, na neve. Ao espectador lhe resta a imagem do rastro do casal sobre a neve. 

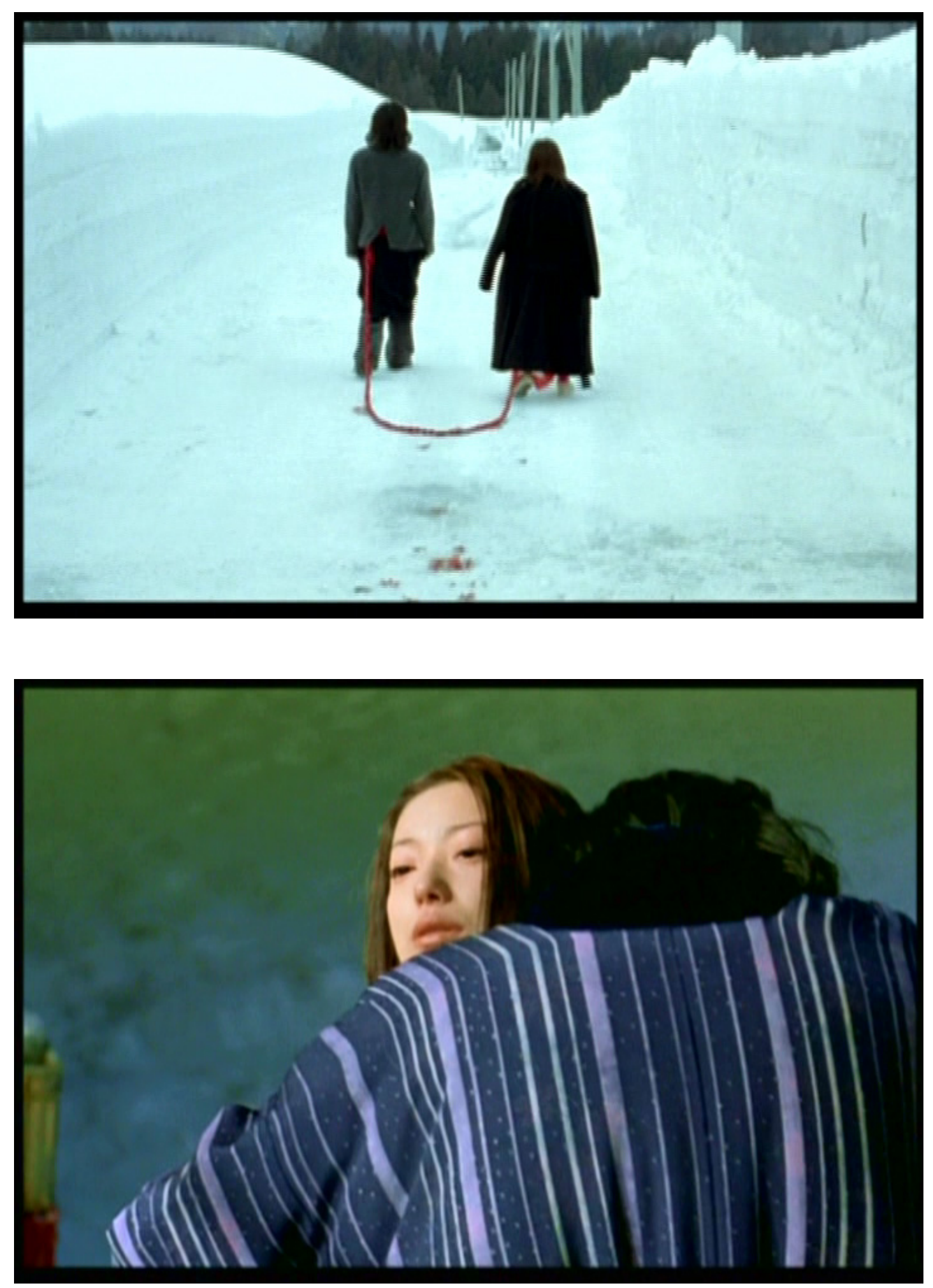
Esse rastro jamais será visto, pois o casal está em um lugar afastado, onde não há outras pessoas. Ele desaparecerá tão-logo neve mais ou derreta-se a neve, indicando uma nova primavera. Um rastro que serve de metáfora à vida do casal: uma existência sem rastros, uma existência que é o "desaparecimento do mundo", que não deixa corpos para serem velados, uma morte que encerra uma vida sem rastros, uma vida de errância e de desaparecimento, de espera.

O espectador pode ver, por fim, o resultado da queda do casal. Pela corda amarrada em suas cinturas, Matsumoto e Sawako estão pendurados em um tronco que os protege do abismo. Pela união, simbolizada pela corda, salvam-se da morte que é o abismo. Mas a corda também lhes condena à morte, pois não há como sair dali.

Nessa cena final, a corda metaforiza de modo paradigmático a união desse casal: a vida sob um tempo exclusivamente presente, que não possibilita a construção. É um presente de espera sem expectativas: eles não têm como sair da situação em que estão nem recorrendo ao passado - ao trajeto percorrido até chegarem ao tronco, pois não há como subir de volta à montanha -, nem ao futuro - se o tronco se quebrar eles completam o caminho que parecem estar seguindo, para o desconhecido percurso de um abismo no qual cairão. Assim, a possibilidade de saída dessa situação é a morte, não há salvação em vida.

Matsumoto está de olhos abertos, Sawako de olhos fechados, com o colar que simboliza o noivado pendurado em seu pescoço, caído sobre seu rosto. O espectador é afastado do casal pelas lentes da câmera, agora mais distantes. Pode-se perceber, assim, que o sol está nascendo. E que muitos dias nascerão até que eles saiam dali, pois a situação é de total aporia. O tempo de espera agora tem um objeto: trata-se da espera pela morte, é tempo de agonizar em silêncio. O abismo é a aporia de um caminho sem destino. O filme parece aqui mostrar que, embora seja possível anular a temporalidade da modernidade, não há chegada possível a um caminho sem destino - e que nem o amor é capaz de conduzir com rumo preciso quem está sob uma temporalidade de espera.

Seguindo-se a temporalidade cíclica das estações do ano, o inverno deverá findar com a chegada da primavera, quando a água do gelo será derretida e evaporará. Essa água em forma sólida, o gelo, que cobre a paisagem na qual o sol se reflete, condensa em si a possibilidade de regeneração da vida desse casal errante. 
Símbolo de regeneração: a infinitude das formas de água liga-se à infinitude das possíveis formas de vida. A passagem de uma forma de vida, tida como indesejável, decaída ou moribunda, a outra, tida como superior, melhor, desejável, é acompanhada pelo elemento líquido. ${ }^{40}$

Quando a efemeridade dessa água em estado sólido engendrar, com seu derretimento, um novo ciclo, esse tempo de espera que anula a concretização do amor deverá ser regenerado, possibilitando, quem sabe, um final menos trágico. Tem-se ao menos a certeza de que ao inverno seguirá a esperança de mais uma primavera.

Para finalizar o filme, Umekawa e Yamato aparecem novamente sem serem manipulados, como se tivessem existência própria, sobre fundo preto. E parecem, aos olhos do espectador, mais autônomos que os personagens humanos do filme. Títeres de uma espera por trágicos destinos.

O casal de bonecos olha para o espectador e se olha com a mesma cumplicidade de Matsumoto e Sawako ao lembrarem de seu noivado. Depois olha novamente para o espectador do filme, cúmplice da aporia que se viu. Desvia seu olhar ao solo. Sobre fundo preto, surgem os créditos do filme - como no início, em letras avermelhadas sobre fundo preto.

Termina assim a errância de uma espera que só cessa com a morte - ou melhor, com a espera pela morte, em uma situação aporética da qual não é possível escapar.

\subsection{Espera e errância}

Embora Dolls mostre ao espectador uma temporalidade que se diferencia daquela da modernidade, ela em nada se parece com a temporalidade que existia em períodos anteriores - e um simples argumento é necessário para afastar tal hipótese: o filme não contempla a dimensão do passado, exceto pelo uso escasso de flashback, que funciona mais como estratégia de narrativa fílmica do que lembrança dos personagens. O passado opera apenas como o tempo da situação traumática que levou à temporalidade de espera.

\footnotetext{
${ }^{40}$ BRUNI, J. “A água e a vida”. op. cit., p. 62.
} 
O filme mostra tentativas de fuga da modernidade e dá ao espectador a impressão de que o amor poderia coroar essa fuga, ser salvador, no sentido de despertar dimensões temporais que transcendessem o momento da espera e da errância, sem, entretanto, configurar um retorno à temporalidade moderna. A salvação pela concretização amorosa, todavia, não se consolida, embora as bases para isso tivessem sido construídas - pela visita de Nukui a Haruna, pelo encontro de Hiro e sua antiga namorada, pela lembrança de Sawako de seu noivado com Matsumoto.

A não-consolidação da saída dessa temporalidade de espera não opera, entretanto, como elemento de frustração (no sentido valorativo da palavra) - não é melhor estar sob a temporalidade de uma espera, ou sob a temporalidade moderna. Não há critério valorativo para julgar tais situações, e não haveria valia em fazê-lo. O que importa, no filme, é a possibilidade, própria do cinema, mas não exclusivamente, de mostrar temporalidades que se difiram daquela corrente na modernidade.

Os acontecimentos traumáticos que geram a "saída do mundo" de alguns dos personagens aconteceram sob o jugo da temporalidade corrente da modernidade e resultaram na saída dessa. Poderiam ter resultado em outras situações, mas esse modo de expressão dos eventos traumáticos em Dolls possibilita que o filme exiba uma temporalidade diferente da moderna, sob o jugo da qual já vive o espectador e a qual ele conhece bem.

Um elemento que fica presente nessa saída da temporalidade moderna é a busca de resistência a uma honra que parece fundamentada no arrependimento de uma decisão tomada anteriormente. Matsumoto chega mesmo a pronunciar um pedido de perdão a Sawako, desculpando-se por sua escolha.

Esse arrependimento que perpassa o filme pode ser simbolizado por uma frase que aparece na apresentação bunraku inicial, atribuída a Umekawa: "Eu sou culpada de tudo. Eu devo me arrepender? Ou devo me lamentar? Eu não sei”. A frase expressa o desejo de um perdão que só pode se concretizar na forma de morte. Morte que não deixa de ser, também, um modo de aniquilar a temporalidade moderna da qual "fogem" os personagens deste filme. ${ }^{41}$

A morte é, afinal, a única instância capaz de retirar, de fato, alguém "deste mundo". A vida individual, fincada em um aprendizado social, consegue se esvaziar por

\footnotetext{
${ }^{41}$ Muito embora a morte também seja elemento constante na modernidade, essa morte por suplantação do novo não encerra sentido e não é ao menos percebida.
} 
completo dos elementos culturais que nela se enraizaram e foram naturalizados apenas ao findar-se, ou seja, na morte.

Embora a mensagem fílmica final de Dolls mostre a ausência de uma saída para a temporalidade da espera, que não a contemplação de um abismo por quem está tão próximo de nele mergulhar - ou seja, a igual espera -, a idéia de uma temporalidade circular associada à natureza pode operar como indício para uma salvação. Se a morte de cada estação em Dolls não foi capaz de realizar as esperanças deixadas pelo ciclo anterior, o espectador encerra o filme com a idéia de um tempo cíclico para o qual a nova primavera que se seguirá poderá ser capaz de trazer novas esperanças. Essa é a possibilidade de salvação que resta em Dolls - uma possibilidade colocada fora do filme, que decorre da circularidade temporal nele atribuída à natureza.

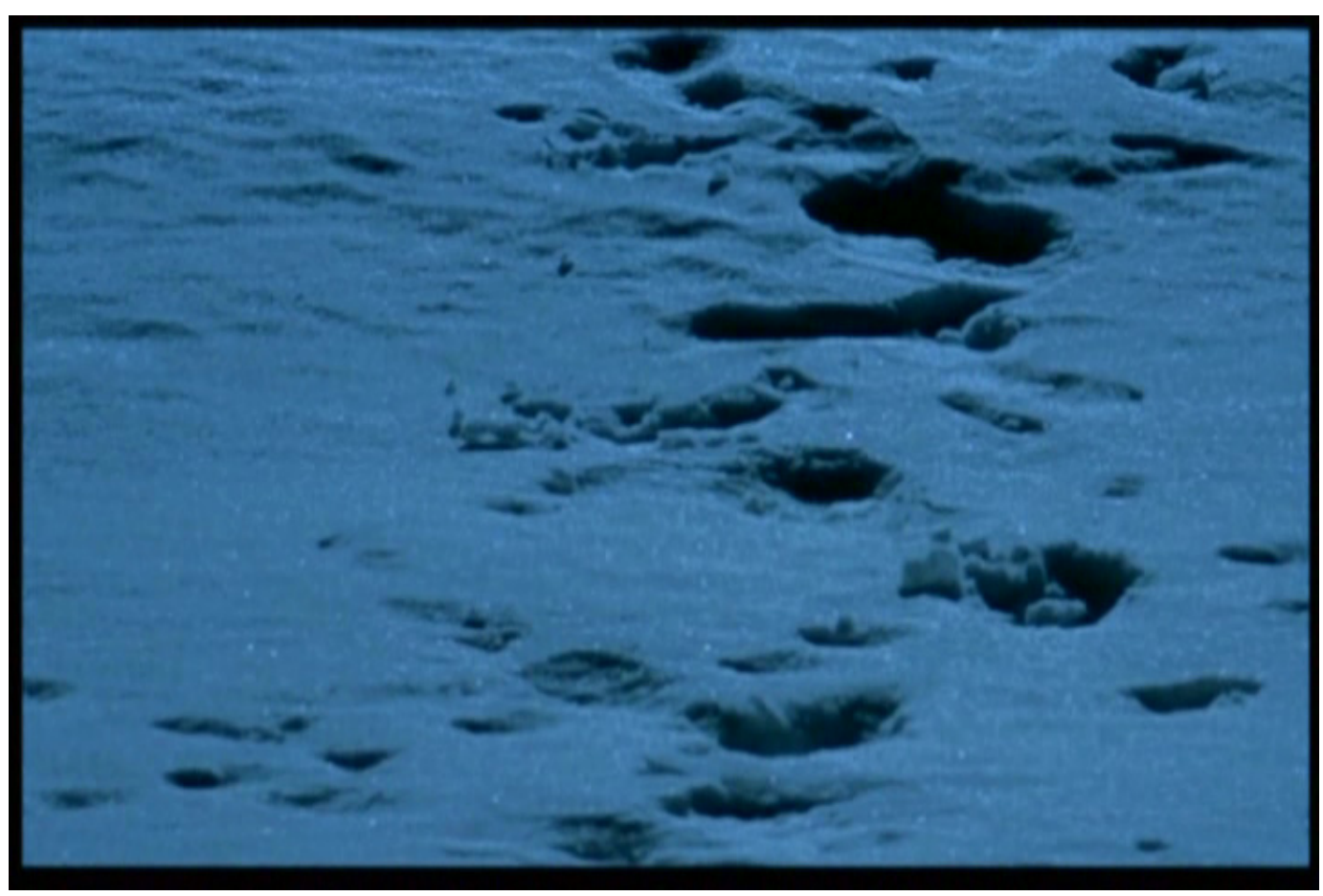



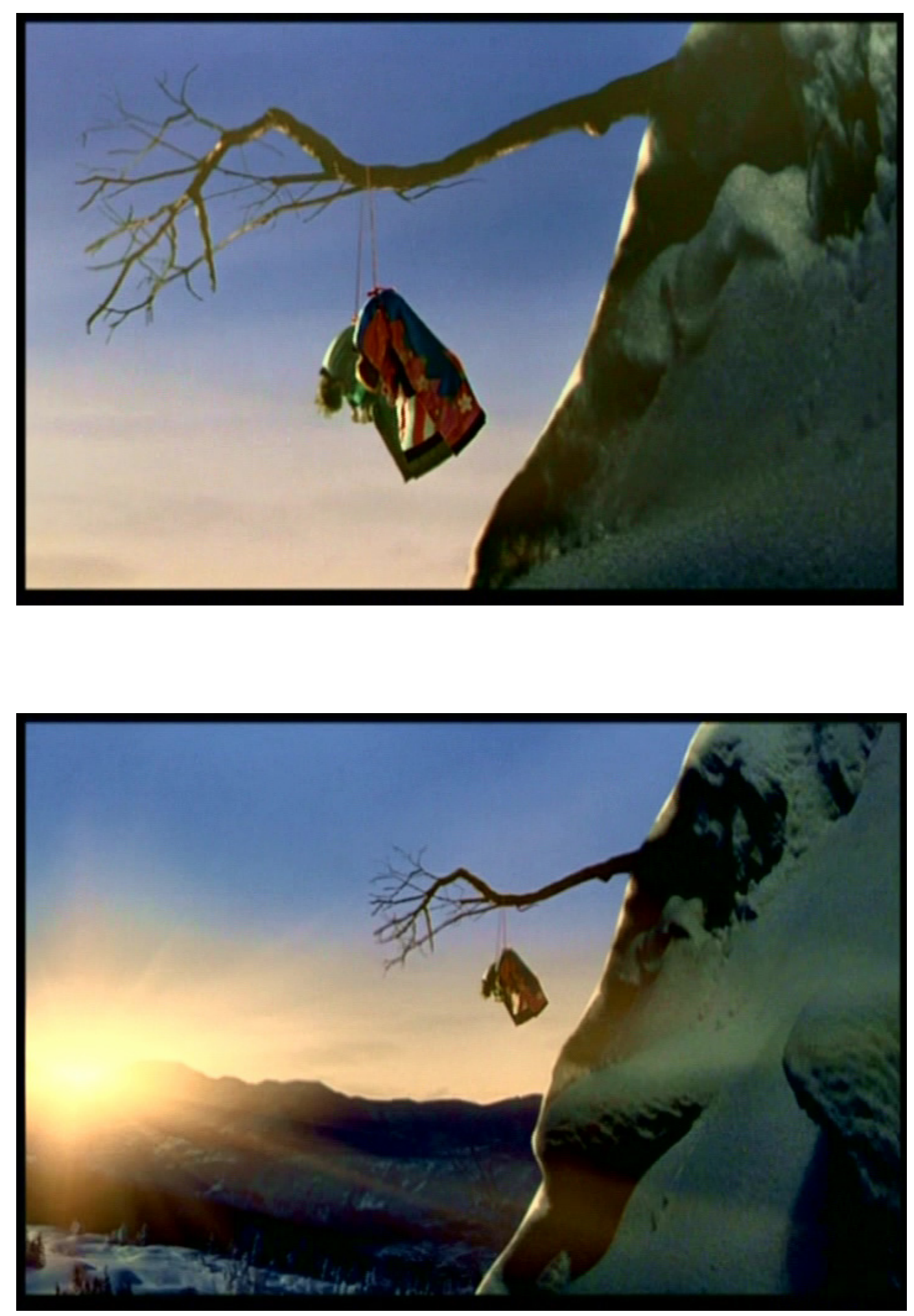


\section{Errância, itinerância, melancolia e silêncio: bem-vindo a} Paris, Texas.

Paris, Texas é uma co-produção da Alemanha Ocidental com a França. Foi filmado nos Estados Unidos, dirigido pelo alemão Wim Wenders. Lançado em 1984, o filme foi um sucesso de crítica e recebeu diversas premiações, sobretudo na Europa, incluindo Palma de Ouro em Cannes, festival no qual foi consagrado como melhor filme. Ry Cooder é responsável pela trilha sonora, Robby Muller por sua fotografia; o roteiro foi escrito por Sam Shepard ${ }^{1}$.

O protagonista de Paris, Texas é Travis, um homem melancólico que não consegue criar raízes, seja em um grupo ou um espaço físico. Após quatro anos de errância, ele é encontrado no deserto e levado para Los Angeles por seu irmão. Se, para Walter Benjamin, aquele que vinha de longe - no tempo ou no espaço - era um narrador em potencial, pois tinha sempre o que falar sobre conteúdos distantes ${ }^{2}$, em Paris, Texas, Travis, que passou quatro anos errando, é quem menos fala. Isso porque ele é fruto de uma época na qual a sabedoria acumulada na distância não desperta mais interesse. A comunicação no filme, quando ocorre, ora tem função prático-comunicativa ${ }^{3}$, ora é permeada pela técnica: fala-se por telefone, gravador, walkie-talkie; não se fala ao vivo, não há troca ou aconselhamento. O filme, com suas poucas falas, é assim capaz de mostrar ao espectador mais astuto (aquele que o consegue assisti-lo até o fim, sem se enfastiar), o quanto a comunicação está comprometida na sociedade moderna.

\footnotetext{
${ }^{1}$ Wim Wenders e Sam Shepard voltariam a trabalhar juntos em 2004, em A Estrela solitária (Don't come knocking), um longa-metragem cuja trama tem elementos que remetem a Paris, Texas, como a errância e o não-pertencimento.

${ }^{2}$ Cf. Benjamin, W. "O Narrador - Considerações sobre a obra de Nikolai Leskov". op. cit., pp. 198-199.

${ }^{3}$ Termo usado por Irene Cardoso para designar uma fala que é instrumental. Cf. CARDOSO, Irene. "A narrativa silenciada". op. cit., p.174 e 175.
} 


\subsection{Da errância à itinerância}

\subsubsection{Errância (interceptada)}

Um tema marcante no cineasta Wim Wenders é a errância masculina. Seus filmes se passam sobretudo em cenários amplos e abertos, por cujas paisagens circulam protagonistas desraigados. Em seus percursos, esses homens encontram outras pessoas, as quais poderão acompanhá-los por algum trecho de suas viagens. Esse encontro não será, entretanto, transformador, no sentido de que não abalará o principal elemento da vida desses personagens - a errância. É o que ocorre, por exemplo, em No Decurso do tempo ${ }^{4}$, Sob o céu de Lisboa ${ }^{5}$, Estrela solitária ${ }^{6}$ e em Paris, Texas.

Annie Goldmann caracteriza o universo cinematográfico de Wenders pela presença de três elementos: "personagens solitários, percursos indefinidos, encontros sem dia seguinte" ${ }^{\text {"7 }}$. Nesses percursos, os personagens encontram um mundo estranho a seus habitantes, por onde não circulam pessoas; uma paisagem composta por edifícios vazios, ruas desertas e trens partindo para lugares desconhecidos ${ }^{8}$.

Em Paris, Texas, a estrada é o elemento principal do cenário fílmico, o trânsito ocorre sobre ela. Embora o protagonista Travis seja um sujeito errante, a história vivenciada no filme corresponde essencialmente a uma pausa em sua errância, para a realização de viagens com um destino predeterminado - uma pausa que, entretanto, o mantém na estrada. De acordo com Goldmann, ainda que possa haver um objetivo nas viagens que empenham os heróis dos filmes de Wenders, o que realmente importa para eles é a viagem em si, ou seja, o trânsito, e não o que o motiva. Esse deslocamento só viria a confirmar o que já se sabe sobre a atuação de tais heróis: “[...] não existe nada a compreender, somente para olhar, mas olhar de maneira neutra, sem desejo de compreender ou de agir"'.

Para a autora, o mundo dos personagens de Wenders é uma superfície sem relevos, um mundo plano sobre o qual o olhar dos protagonistas não busca ir além do

${ }^{4}$ Im Lauf der Zeit, Alemanha Ocidental, 1975. Direção: Wim Wenders.

${ }^{5}$ Lisbon story, Alemanha, 1994. Direção: Wim Wenders.

${ }^{6}$ Don't come knocking, França, Alemanha, Estados Unidos, 2005. Direção: Wim Wenders.

${ }^{7}$ Goldmann, Annie. L'errance dans le cinéma contemporain. Paris: Henri Veyrier, 1985, p. 65. Tradução livre do original: "personnages solitaires, parcours indéfinis, rencontres sans lendemains".

${ }^{8}$ Cf. GoldmanN, A. L'errance dans le cinéma contemporain. op. cit., p. 65.

${ }^{9}$ Goldmann, A. L'errance dans le cinéma contemporain. op. cit., p. 65. Tradução livre de “(...) qu'il n'y a rien à comprendre, seulement à regarder, mais regarder de manière neutre, sans désir de compreendre ni d'agir". 
vazio que se vê. Viajar por esse mundo seria, assim, atravessar as aparências para encontrar, em todos os lugares, o mesmo, o idêntico ${ }^{10}$. Esses personagens de fato não possuem interesse em interferir ou agir sobre aquilo que vêem. A paisagem que observam pode sempre lhes parecer a mesma, mas se trata de uma paisagem que muda a cada instante, na qual a aparente repetição do mesmo tem como base uma contínua alternância de imagens - ou seja, a exaustiva troca de paisagens torna-se uma constância, a repetição de mudanças se traveste de sempre-igual para o personagem observador que está em trânsito, não importa o meio de transporte utilizado. Portanto, se os protagonistas errantes vivenciam estabilidade no conteúdo apreendido, essa advém da constância no fluxo da troca de paisagens por deslocamento espacial, ou seja, é uma estabilidade com base na mudança.

O deslocamento espacial já está proposto no título de Paris, Texas ${ }^{11}$, permeado por certo estranhamento: há Paris no Texas? As letras vermelhas que aparecerem sobre a tela preta no início do filme vêm confirmar a miscelânea espacial sugerida pelo título: ao som da trilha sonora feita pelo americano Ry Cooder, lê-se em inglês que o filme é fruto de uma coprodução entre a Alemanha Ocidental e a França. Wim Wenders, o diretor, é alemão. Logo surgem os nomes dos atores: Harry Dean Stanton (que protagonizará Travis) é americano; Nastassja Kinski (Jane), alemã; Dean Stockwell (Walter), americano; Aurore Clement (Anne), francesa; Hunter Carson (Hunter), americano; e Bernhard Wicki (Dr. Ulmer, o médico que atenderá Travis no Texas), austríaco. Por fim, surge o título do filme sobre a tela - escrito de forma americana, ou seja, o nome da cidade seguido de vírgula e nome do Estado - emoldurado por um retângulo de traços finos, como se fora uma placa de sinalização no trânsito: Paris, Texas.

A primeira imagem fílmica, uma tomada feita de um ângulo superior, capta a aridez de um dia de sol forte no deserto. A guitarra de Ry Cooder, seca como o clima, adentra junto ao espectador nesse ambiente quente. No deserto, um homem caminha só. Apesar do título sugestivo, nenhum elemento fílmico assegurou que se tratasse do deserto americano, até que a tela mostra, sobre uma falésia, o pouso de um falcão - ave simbólica dos Estados Unidos - e aumenta no espectador a suspeita de que se está nesse país.

O andarilho é um homem de meia idade. Suas roupas - terno, camisa e gravata desgastados e sujos pela poeira branca do deserto, e um boné que pouco o protege do sol

\footnotetext{
${ }^{10}$ Cf. Goldmann, A. L'errance dans le cinéma contemporain. op. cit., pp. 65-68.

${ }^{11}$ Assim como em Sob o céu de Lisboa, e tal qual um deslocamento temporal é sugerido em No Decurso do tempo.
} 
forte - condensam vestígios do tempo de sua errância. Seu olhar é distante, parece exausto e um pouco assustado. Leva à boca o galão de água que carrega mas, ao constatar a ausência de água, fecha-o e o joga no chão. A música segue. Ele olha para frente, e vê o mesmo que o espectador: uma repetição da mesma paisagem desértica. Se busca mais água, terá que caminhar muito para chegar a algum lugar onde possa obtê-la, já que não há sinal de habitação em um raio extenso ao seu redor. Ele então caminha em direção a esse vazio para o qual olha: o deserto, apenas.

Sob o mesmo céu azul, após muito caminhar, o andarilho surge próximo a um posto de gasolina. Ele ultrapassa um arame farpado e caminha em direção a uma torneira da qual tenta obter água, mas ela está seca como a paisagem ao seu redor. Com sede, adentra uma construção precária, sem acabamento: trata-se de um bar, escuro em oposição à claridade externa. A música que o acompanhava cessa para que o espectador possa ouvir a música do bar e o som ambiente. O homem caminha de modo desengonçado até o fundo do bar e tropeça em um banco - sem pronunciar uma palavra. Do lado direito, no escuro, é possível ver a silhueta de um homem sentado à parede, que bebe cerveja.

Andando em direção à geladeira, o caminhante do deserto passa por um cartaz manuscrito com letras em tamanho irregular (precário como o resto do local), onde o espectador pode ler: "A poeira veio para ficar. Você pode ficar, partir, ou o quer que seja" ${ }^{\prime 2}$. A poeira que lá chegou para ficar é a poeira do deserto que se expande do lado de fora da porta daquele bar, uma poeira aparentemente definitiva como as condições de vida locais, que induzem a pensar que jamais sofrerão abalo, independente de quem passe por ali. Essa placa dá a impressão de tratar-se de um lugar perdido no tempo e no espaço, um não-lugar, onde há poucos habitantes, dispersos, e algumas pessoas de passagem.

O andarilho, entretanto, passa pela placa sem notá-la - quem a nota é o espectador, que por ela obtém uma percepção melhor do lugar onde o protagonista está. Ele vai direto para a geladeira ao lado da placa, e abre sua porta. Como dentro há apenas cerveja, ele a fecha e abre outro refrigerador, de dentro do qual retira algumas pedras de gelo com as mãos, leva à boca e mastiga. É então que esse homem começa a cair, ouve-se o barulho de uma pessoa batendo no chão, e assim conclui-se que ele desmaiou por alguma espécie de choque térmico.

\footnotetext{
${ }^{12}$ Traduzido de: "The dust has come to stay. You may stay or pass on through or whatever".
} 

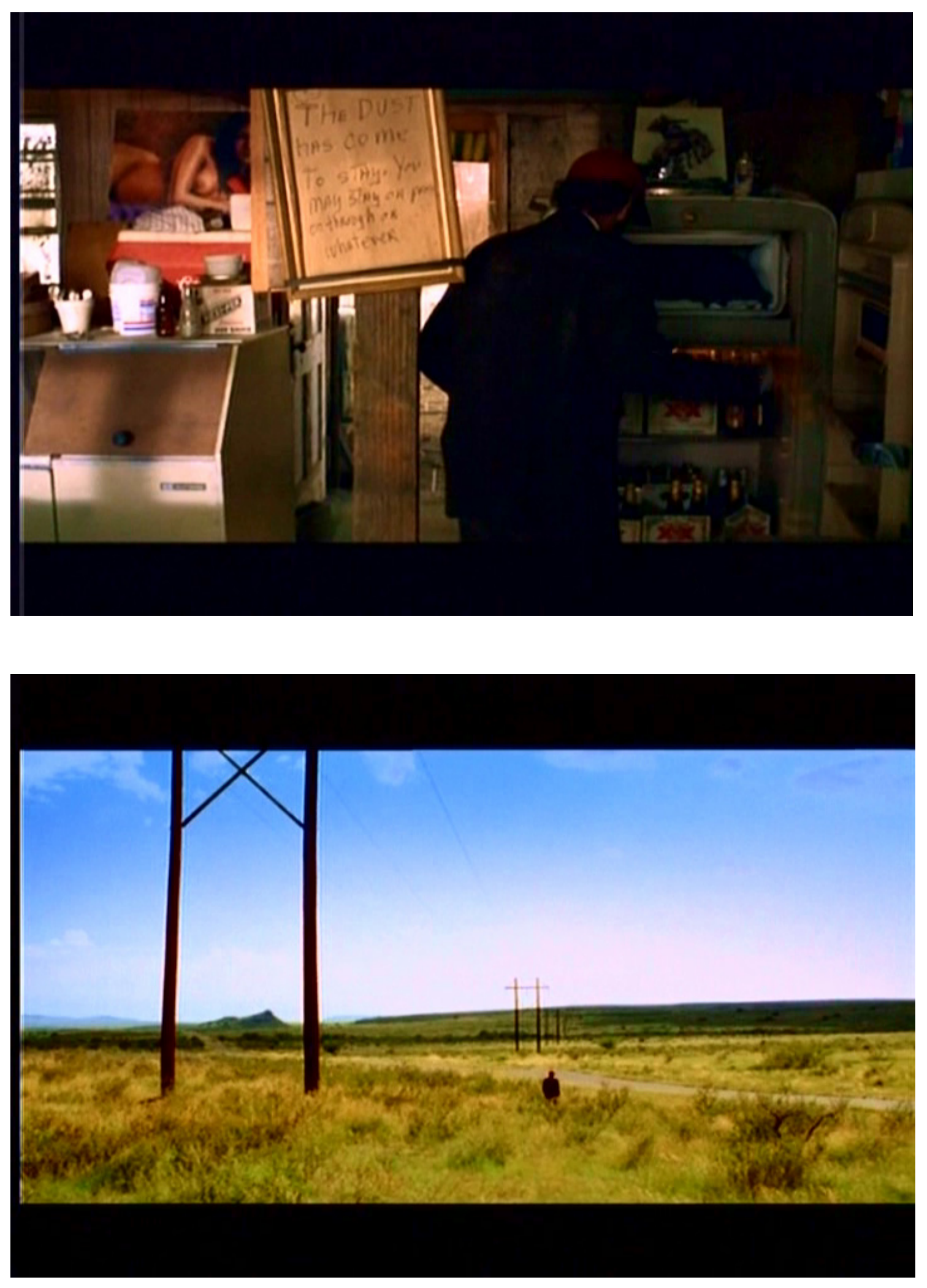
Não se vê a imagem dele de imediato, vê-se primeiramente a silhueta do homem que estava bebendo cerveja no bar. Ele pronuncia as primeiras palavras do filme, condensando nela um estranhamento que também é do espectador com relação ao andarilho e àquele lugar: "Que diabos..?"13 O espectador por fim pode ver o protagonista caído ao chão, o homem que estava sentado no bar tenta acordá-lo movendo-o com os pés, mas não há reação alguma.

$\mathrm{O}$ que se tem aqui é, portanto, um andarilho desmaiado em um bar de algum lugar no deserto, no qual apenas a poeira é definitiva de antemão, um lugar por onde passam pessoas estranhas ao meio social, os que vêm de fora, os estranhos/ estrangeiros já preconizados pela mixórdia de nacionalidades que compõe o elenco do filme. Há um corte, e enquanto o novo diálogo começa, o espectador é situado no tempo - o sol se põe, portanto já está anoitecendo - e no espaço - há uma placa indicando o nome de uma clínica (Terlingua MD. Clinic) e seu telefone. Além dessa clínica, poucos vestígios humanos podem ser vistos nesse cenário. A cidade de Terlingua fica nos Estados Unidos, no sul do Texas, próxima à fronteira com o México, e a confirmação sobre onde se passa o filme vem na pergunta - em inglês - de um médico que tem forte sotaque estrangeiro ao homem que desmaiara: "Sabe de que lado da fronteira você está?" O médico, que o examina, começa a provocá-lo, sugerindo que seu paciente queira esconder algo - por exemplo, que é um imigrante mexicano ilegal, o que certamente não é incomum naquela região fronteiriça: “Acho que alguém cortou sua língua. É isso ou então está escondendo alguma coisa".

Após examiná-lo - seus ouvidos e seus reflexos - de um modo bastante provocativo, o médico, com um charuto na boca (dentro da sala de exames) mexe nos poucos pertences do paciente, e encontra um papel, que lê em voz alta "Walter A. Henderson". O médico diz ao homem encontrado - que permanece imóvel, deitado na cama hospitalar, sem gravata e com a camisa um pouco aberta - que esta será sua última pergunta. Mostra-lhe o papel que estava em meio a seus pertences e pergunta se o nome que está no cartão é o dele ou de algum parente seu. O homem segue imóvel e calado. O médico então diz que telefonará para o número que está marcado no cartão porque lá "não há acomodações para mudos". A música recomeça, o médico sai da sala, o paciente levanta levemente a cabeça para olhá-lo, e logo se deita de novo. Ele ouve

\footnotetext{
${ }^{13}$ Traduzido de: "What the hell..?"
} 
enquanto o médico, de outra sala, pede à telefonista que faça uma ligação para Los Angeles. Então aparece o rosto do andarilho, que aparenta estar assustado por estar naquele lugar, e a música pára.

Do outro lado da linha está Walter: ele segura um telefone sem fio, usa boné amarelo e camisa listrada, tem um relógio no pulso, está à frente de um edifício alto, sob céu azul. Fica marcada assim a outra temporalidade que entrará em vigor no filme, com relógios e edifícios altos em grandes cidades. O prédio na frente do qual ele está, como será mostrado logo em seguida, não é mais que uma foto impressa em um painel atrás de Walter. Ou seja, Walter está frente a uma imagem de um ícone dessa era de paisagens repletas de construções, sem horizonte, na qual vive.

No telefone com o médico de Terlingua, a primeira pergunta de Walter é "o quê? Pode me dizer onde fica esse hospital?” Por fim, pede para avisarem ao seu irmão que está indo para lá. Já se sabe, portanto, que ele é irmão do homem que caminhava pelo deserto. Vê-se então a esposa de Walter, Anne, que aparece inicialmente de costas. Eles trabalham juntos em uma empresa responsável pela confecção de painéis publicitários. Nessa cena, Anne cuida do texto que acompanha um anúncio. Walter lhe diz que recebeu um "telefonema estranho" de Terlingua, no sul do Texas, no qual lhe disseram que encontraram Travis - seu irmão, o andarilho que por fim é nomeado no filme -, e que irá buscá-lo. Anne pergunta o que se passará com Hunter. Walter a abraça e aconselha "é melhor dizer a verdade". Anne é francesa, fato facilmente perceptível por seu sotaque. Parece perturbada com a viagem de Walter, mas ele parte mesmo assim.

Esse início de filme mostra ao espectador o incidente responsável pelo reencontro familiar que fundamentará a trama fílmica. E, desde já, os personagens são caracterizados da maneira como serão retratados no filme: se Travis parece uma pessoa muito simples, um andarilho do deserto, seu irmão, Walter, ao contrário, já é desde o primeiro momento construído no filme como aquele que mais compactua com o ritmo de vida moderna - vive de acordo com os padrões do American way of life. Esse início de filme aponta para quase toda a trama que virá - a guarda de Hunter, a errância não explicada de Travis, as estradas percorridas. 


\subsubsection{Itinerância e reencontro}

O cenário principal de Paris, Texas são as estradas. Sobre elas, o filme mostra uma clivagem entre errância e itinerância ${ }^{14}$. A "errância" pode ser definida como a "qualidade ou condição do errante"15, ou seja, daquele "que erra; erradio, vagabundo, errabundo, mulívago", palavra que etimologicamente vem do verbo errare, "andar sem destino, perder-se do caminho"16. A "itinerância" seria a qualidade ou condição do "itinerante", "que ou aquele que se desloca, que viaja"; "que se desloca de lugar em lugar no exercício de uma função"17. A diferença fundamental entre "errância" e “itinerância" seria, portanto, a inexistência de um objetivo na primeira. O errante é aquele que vaga sem destino, o vagabundo ${ }^{18}$; já o itinerante é aquele que viaja com objetivo(s) a cumprir (independente da qualidade desse objetivo, ou se ele será de fato cumprido).

Travis empregava uma errância, caminhava só e sem destino pelo deserto. Walter irá buscar seu irmão, fazendo um longo e solitário percurso de itinerância para reencontrá-lo, que começa dentro de um avião e continua em um carro alugado. Sobre seu capô, Walter observa um mapa enquanto carrega um copo de café. Atrás dele há um refrigerador com a inscrição "Ice" e o preço, "99c", lembrando ao espectador que o reencontro dos irmãos somente ocorrerá porque Travis levou um punhado de gelo à boca. O gelo opera também como elemento de diferenciação entre os irmãos: a água para Travis era vital, mas na forma de gelo o fez desmaiar. O gelo de Walter está valorado pelo preço, numericamente qualificado, e não é um artigo vital. Aliás, lhe é tão pouco importante, que ele toma um café quente sem ao menos olhar para o anúncio que está atrás de si.

Ao olhar os mapas e comentar seu itinerário em voz alta, Walter acaba por informar ao espectador sobre o quão longe irá para buscar Travis, situando mais precisamente onde fica Terlingua. Após já ter percorrido larga distância voando, ele dirigirá $15 \mathrm{~km}$ até Van Horn, $120 \mathrm{~km}$ até Alpina, e mais $180 \mathrm{~km}$ para o sul até chegar

\footnotetext{
${ }^{14} \mathrm{O}$ substantivo itinerância foi traduzido do neologismo francês "itinérance", usado por Goldmann (em Goldmann, A. L'errance dans le cinéma contemporain. op. cit., p. 103), ainda que ausente no dicionário LE PETIT Larousse Illustré. Paris: Larousse, 1995.

${ }^{15}$ Houaiss, Antonio; Villar, Mauro; et Mello-Franco, Francisco. Dicionário Houaiss da língua portuguesa. Rio de Janeiro: Objetiva, $1^{\text {a }}$ edição, 2001, p. 1190. Verbete: errância.

${ }^{16}$ HoUAISS, A., et ALli. Dicionário Houaiss da língua portuguesa. op. cit., p. 1190 . Verbete: errante.

${ }^{17}$ HouAiss, A., et ALLI. Dicionário Houaiss da língua portuguesa. op. cit., p. 1660. Verbete: itinerante.

${ }^{18}$ Embora muitas vezes associado a um significado pejorativo, o termo vagabundo aqui se refere àquele que erra; a saber, "que ou quem leva vida errante, perambula, vagueia, vagabundeia"; "indivíduo que não tem residência habitual, ou que emprega a vida em viagens, sem ter um ponto central de negócios" (HouAiss, A., et Alli. Dicionário Houaiss da língua portuguesa. op. cit., p. 2821. Verbete: vagabundo).
} 
em Terlingua. Walter fecha o mapa e entra no carro. É noite e eis que, de dia, ele dirige ainda mais e chega à clínica (o espectador vê a placa indicativa em primeiro plano).

MÉDICO: Você deve ser o irmão do mudo.

WALTER: Mudo?

MÉDICO: Ele não disse uma palavra. - senta-se enquanto fala. Sobre a mesa, há uma garrafa de bebida - Deve estar em encrencas. Não?

WALTER: Não sei de nada. Não o vejo há 4 anos.

MÉDICO: Em 4 anos muita coisa pode acontecer. Quero dizer... Todo tipo de encrenca. E encrencas custam caro.

WALTER: Como assim?

MÉDICO: Por essas bandas, pode-se dar muito mal. Demora para se livrar delas. Entende o que quero dizer? - leva à boca a garrafa que estava sobre a mesa, da qual bebe sem oferecer a Walter.

WALTER: Não, não entendo. Explique-se melhor, porque quero ver meu irmão.

MÉDICO (cospe a bebida no chão): Certo, mas antes quero fazer uma pergunta. Seu irmão já sofreu algum acidente de carro?

WALTER (senta-se): Acidente? Não que eu saiba.

MÉDICO: Então se meteu com vigaristas.

WALTER (visivelmente incomodado com as insinuações do médico): Quero ver meu irmão já, se não se incomoda.

MÉDICO: Ele sumiu!

WALTER: Ele não está aqui? Quer dizer que vim de tão longe à toa?

A última frase de Walter confirma o conteúdo itinerante de sua viagem: ele partiu para buscar Travis e voltar sem o irmão significa, como ele disse, ter se deslocado à toa, inutilmente. $\mathrm{O}$ médico lhe diz que Travis partiu de madrugada, mas deixou alguns pertences. Entrega-os a Walter, pedindo que acertem suas contas.

Há um corte e o espectador tem a visão de dentro do carro de Walter: pelo vidro frontal se vê o capô e uma longa estrada retilínea, um asfalto que cruza a região desértica cuja paisagem é composta por areia e poucos arbustos. Walter leva um cigarro à boca, parece estar em uma encruzilhada. Mexe nos pertences de Travis, onde encontra uma seqüência de fotos $3 \times 4$ nas quais Travis está junto a uma mulher e um menino. Walter dirige rumo à estrada de areia que corta o asfalto principal - sai da rota que seguiria para ir ao aeroporto (esta seria, supõe-se, a rota de asfalto, que liga as cidades), o que indica que ele está indo atrás de Travis, ou seja, que não se permitirá ter empregado tal viagem em vão. 
Travis surge caminhando paralelamente à estrada, em um trecho onde, além da poeira desértica, há uma vegetação rasteira que a cobre. Não há edificações, embora cabos de energia cruzem a estrada. Walter localiza Travis, estaciona o carro e o chama: "Travis! Hey...” Travis pára de andar, olha para o lado, aparenta estar perturbado, e Walter diz "Não me reconhece? Sou Walt." Então se aproxima mais de Travis e diz "Seu irmão Walt". Travis o olha, imóvel. Walter pergunta: "O que aconteceu com você? Parece mais um defunto."

Eles estão em um local de passagem (que poderia também ser caracterizado como um "não-lugar"), isto é, uma estrada que cruza o deserto, a região na qual apenas o que veio para ficar de modo definitivo é a poeira. Não é usual que se vá para lá, mas sim que se passe por lá, é um local de trânsito, que serve de ligação entre dois pontos. É interessante que o reencontro dos irmãos se dê aí, pois é essa a grande diferença entre eles: Walter pouco viaja, e para ele a estrada nada mais é que passagem e perda de tempo, por isso preferirá voltar de avião. Travis vive em trânsito, e o que deveria ser uma paisagem passageira é, para ele, uma constância.

Um vento brando levanta a lapela do paletó de Travis, que segue inexpressivo e olha para a frente, para onde seguiria não fosse a intervenção do irmão. Walter se aproxima, toca em seu ombro e diz "Vamos para o carro, vamos!" Eles caminham em direção ao veículo, Walter abre a porta do passageiro para Travis, mas ele abre a porta de trás, entra, e senta-se no banco traseiro. Walter o observa, entra no carro e eles partem. Dentro do carro, Travis segue imóvel e sem falar, Walter lhe dá seus pertences pegos na clínica, e sobre esta comenta "Que lugar horrível. Não o culpo por ter fugido de lá."

Sentar-se no banco traseiro marca em Travis tanto o desejo de manter distância de Walter, quanto um sinal de sua infantilização, que seguirá presente até que o reencontro com seu filho ocorra. No carro, Walter é filmado como se estivesse sendo observado do banco traseiro, ou seja, o espectador tem a mesma visão de Travis - que vê Walter, e à sua frente o caminho da estrada que estão a percorrer. Já Travis é filmado em sentido oposto, o espectador o vê como o veria Walter - atrás dele está toda a estrada já percorrida. Essa filmagem deixa transparecer o papel dos irmãos no filme: Walter é mostrado à frente da estrada que está por vir, do futuro, que é o tempo forte a comandar sua vivência. Travis, por sua vez, é filmado à frente do passado, tempo onde se encerram seus traumas e relacionamentos mais intensos. O carro representaria, dessa forma, o presente, o local e tempo onde eles estão. 
Embora Travis aparente ter sofrido uma perda de memória, tem relação mais intensa com o passado do que com o futuro, posto que foi um acontecimento passado que determinou seu presente errante. Walter, ao contrário, está sempre ligado ao futuro e a um presente menos denso, que a ele aparece apenas como uma etapa para o futuro breve.

Walter chama seu irmão pelo apelido, Trav, demonstrando ter havido proximidade entre eles antes dos quatro anos em que ficaram separados. Walter, se comparado a Travis, parece bastante ansioso, lhe diz que a viagem será longa, e que se Travis não falar com ele durante o caminho, se sentirá só. Walter quer saber onde Travis esteve durante esses quatro anos, e se ele se encontrou com Jane. Travis não responde, Walter então lhe diz que ele e Anne chegaram a pensar que estivesse morto. Ainda silêncio.

Walter está inserido em um ambiente de trabalho no qual a comunicação é fundamental (ele usa a comunicação visual para gerar venda). Foi igualmente pela palavra que o médico lhe comunicou que encontrara seu irmão. Travis, ao contrário, esteve caminhando só. Ao reverem-se, os dois irmãos reproduzem seus papéis de interlocutores, como se o encontro não fosse capaz de mudar as condições que o precederam. Walter continua falando, e Travis segue calado.

Eles param o carro, ainda de dia, em um motel $^{19}$, para descansar. Walter sugere ao irmão que tome um banho enquanto vai à cidade comprar-lhe roupas. Pergunta qual é seu número de sapatos e, sem obter resposta, compara o tamanho dos seus pés. É quando se pode ver os pés de Travis, cujos sapatos estão gastos e esburacados de tanto caminhar. Walter olha para a cara de seu irmão, que está próximo a ele, e diz "Deixou a barba crescer. Ficou bem assim”. Avisa a Travis que irá à cidade e já volta. Quando diz "Você vai ficar bem", Travis dá, pela primeira vez, um tímido sorriso. Ouve-se a guitarra de Ry Cooder, Walter parte e deixa a porta do chalé aberta. Travis olha à sua volta.

A passagem do tempo da errância de Travis fica, assim, marcada pelo desgaste de seus sapatos e pelo crescimento de sua barba - fatos que asseguram ao espectador a sensação de que ele passou os quatro anos caminhando, vagando.

Enquanto Walter chega na loja de sapatos de uma cidade muito pequena e vazia, Travis vai ao banheiro do chalé, ainda segurando o saco plástico com seus pertences, e liga o chuveiro. Quando vai colocar suas coisas em algum lugar para poder banhar-se,

${ }^{19}$ Embora no Brasil o termo motel esteja associado a um "estabelecimento que aluga quartos para encontros amorosos; hotel de alta rotatividade", a palavra será aqui associada a seu sentido de origem (palavra estadunidense formada por aglutinação de motor e hotel), significando "hotel, localizado na beira das estradas de grande movimento, que aluga quartos ou apartamentos e tem relativa infra-estrutura como estacionamento para carros, restaurante, etc." (HouAISS, A., et ALLI. Dicionário Houaiss da língua portuguesa. op. cit., p. 1967. Verbete: motel). 
depara-se com um espelho. Ao ver o reflexo de seu rosto, desvia o olhar para baixo e suspira. Olha-se de novo e há um corte: ele então caminha para longe do motel, a pé, pela estrada, carregando apenas o saco plástico com seus pertences.

Até aqui, Travis estava se deixando guiar pelo irmão. Estava acomodado no motel e ligou o chuveiro para banhar-se, seguindo o conselho de Walter de modo natural. Ao olhar-se no espelho, entretanto, teve um movimento contrário à entrada nos planos do irmão. O espelho revelou-lhe uma imagem sua do presente que parece não estar de acordo com o modo como Travis se imaginava. A imagem de si que ele carregara durante a errância era a foto dentro da sacola com seus pertences, uma foto na qual ele, seu filho e sua então esposa aparentam estar muito felizes. Uma imagem de harmonia entre mãe biológica e filho que Travis logo buscará retomar. Nessa foto, ele estava sem barba, com bigode, e quatro anos mais jovem. Com ele estava também sua família.

Ao olhar-se no espelho, Travis vê-se mais velho, com a barba crescida, e sozinho. Não reconhece o homem das fotos instantâneas de seus pertences, então se agarra àquilo que possui: uma sacola com poucas recordações, onde está essa antiga foto, e sai do motel. Quando Walter retorna com as roupas novas acomodadas em caixas, ouve o som da água do chuveiro e caminha até o banheiro. Percebe, então, que Travis não está no chalé.

Travis caminha sobre o trilho do trem, Walter o encontra e lhe pergunta: "Importa-se de me dizer aonde vai?" Walter olha para frente, onde não há construção alguma (exceto o trilho do trem), uma paisagem composta por um longo horizonte com vegetação rasteira sobre a areia, e lhe diz, como se dissesse a uma criança: "O que há lá? Não há nada lá. Não confia em mim?" Com a mão sobre as costas de Travis, continua: "Só quero ajudar você, Travis. Só isso." Travis olha para seu irmão, que o segue confortando-o: "Vamos, está tudo bem. Venha para o carro. Heim?" Eles caminham em direção ao carro, Walter novamente infantiliza Travis, reforça que o ajudará e lhe toca as costas, pedindo sua confiança.

O limpador de pára-brisa sobre o vidro frontal perpassa a tela. Embora chova, pode-se ver o sol se pôr. O céu está bastante nublado, exceto na parte baixa do horizonte, que se une à estrada - eles caminham rumo à claridade, como uma metáfora à luz no fim do túnel, à iluminação das consciências, resolução dos problemas. Gotas d'água caem sobre o vidro da frente, e o limpador as remove. Eles entram em outro motel. Se, quando Travis quis partir, nada havia no horizonte para o qual conduzia o trilho do trem, agora, no carro, eles caminham para a claridade. É finda a tarde. 
Há um corte e Travis está sentado sobre a cama do motel, sem barba, apenas com bigode e vestindo roupas novas, exceto o chapéu, que ainda é o mesmo boné vermelho, velho, e sujo que ele usou durante sua caminhada. Olha para o lado, onde há um espelho. Walter aparece, operando de novo como o homem que valoriza a novidade e a imputa a Travis - “É gostoso vestir roupa nova, não?” As roupas são de fato novas, mas o apego de Travis a determinados elementos, como o boné e seus pertences, foi mantido.

É então que Hunter, filho de Travis e Jane, que mora com Walter e Anne, adentra o filme - o faz de modo sutil, mas ganha cada vez mais destaque. Se as crianças em geral simbolizam o novo, pois são aqueles que chegaram ao mundo depois dos adultos, Hunter, todavia, não remete Travis à novidade, ao futuro, mas à reconstrução de seu passado. Mesmo as conversas que Travis terá com Hunter retomarão elementos de um passado - tópicos que enfocarão o bigue-bangue, os pais de Travis e, sobretudo, seu relacionamento com Jane. Hunter entra no filme primeiramente por via telefônica (em um exemplo de comunicação permeada pela técnica que logo se tornará recorrente no filme): Walter liga para o menino de uma cabine telefônica.

Walter se identifica como o "papai”, e logo diz a Hunter: "Adivinha quem vim ver no Texas? Seu pai. Está lembrado dele?” Hunter não demonstra surpresa pelo fato de ter dois pais, apenas lhe diz que não se lembra de seu (outro) pai. Após o telefonema, Walter fala sobre Hunter com Travis.

WALTER: Ele vive conosco desde que você sumiu. Não sabíamos o que fazer, então decidimos ficar com ele. Um dia ele apareceu em nossa porta. Disse que alguém o trouxera de carro. Não sabia o que tinha acontecido com você e Jane. Fizemos de tudo para encontrá-los, mas Jane também havia sumido. Não sabíamos o que fazer. Travis, não sei em que se meteu. Não sei o que aconteceu. Mas sou seu irmão, pode se abrir comigo. Estou cheio de falar sozinho.

Travis segue calado. Logo param em um posto de gasolina, e Walter novamente tenta falar com o irmão, que está sentado no banco de trás do carro: "Sabe, esse seu silêncio me deixa doente. Fale comigo. Também posso ficar calado. Não vou mais falar em toda a viagem". E parece que essa sua "pedagogia infantil" funciona, pois Travis pronuncia sua primeira palavra no filme: "Paris".

Walter, que estava no meio da repreensão, pára, vira-se para Travis e diz "o quê?" Travis repete, olhando para baixo, "Paris". E mais uma vez diz: "Paris". Walter lhe indaga: "Paris?", e Travis lhe pergunta: "Você já foi a Paris?" Dada a resposta negativa de Walter, Travis pergunta "Podemos ir lá agora?" e seu irmão lhe responde 
"Bem, fica meio fora de mão. Nem sequer fui à Europa". Travis sorri sutilmente e olha para baixo, há um mapa em suas mãos. Walter diz que Anne, sua esposa, é francesa, mas que eles nunca tiveram tempo de ir a Paris, porque sua empresa lhe dá muito trabalho.

Esse diálogo reforça mais uma vez a presença de Walter no filme como o rapaz do Novo Mundo: ele não conhece a Europa, teoricamente o berço de sua cultura. Ademais, vive nos Estados Unidos, trabalha com algo completamente fugaz - ter uma empresa que confecciona painéis publicitários significa refazê-los com freqüência, pois os anúncios têm duração bastante efêmera. Walter é filmicamente construído como aquele que tem apreço às novidades, ao contrário de Travis, que, a despeito do elogio às roupas novas feito por seu irmão, mantém seu antigo boné na cabeça.

Essa divergência entre os irmãos aparece novamente quando eles chegam ao aeroporto, e Travis finalmente pergunta aonde estão indo.

\author{
TRAVIS: Aonde vamos? \\ WALTER: Vamos para Los Angeles. Tem medo de andar de avião? \\ TRAVIS: Vamos sair do chão? \\ WALTER: Sim. \\ TRAVIS: Por quê? \\ WALTER: Porque é muito longe daqui. Levaríamos 2 dias, não tenho tempo. \\ TRAVIS: Por quê? \\ WALTER: De avião é mais simples e mais rápido. Vamos.
}

Esse diálogo denuncia a relação que os irmãos possuem com o tempo. Walter tem pressa em voltar para Los Angeles para trabalhar, diz não ter tempo (assim como nunca tivera tempo de ir à Europa) e lhe parece nitidamente óbvio que as pessoas façam todo o possível para "ganharem tempo". Ele tem, assim, uma vida apressada, típica da modernidade, contrária ao ócio. Se o curso irreversível e irrefreável do decorrer do tempo já gerava um sentimento que incomodava aos antigos ${ }^{20}$, foi na modernidade que o ócio se tornou inadmissível e a quantificação do tempo, então fragmentado, deixou a balança cair sobre o futuro; foi no século XIX que o ócio se tornou inadmissível, porque o tempo passou a ser um tempo partido, fragmentado, como o tempo de produção das fábricas. Estar em trânsito é estar em um “não-lugar”, é um tempo improdutivo e, como

${ }^{20}$ Como exemplo, tem-se Sêneca: “[...] O tempo presente é brevíssimo, tanto que a alguns parece não existir, pois está sempre em movimento; flui e precipita-se; deixa de ser antes de vir a ser; é tão incapaz de deter-se, quanto o mundo ou as estrelas, cujo infatigável movimento não lhes permite permanecer no mesmo lugar. [...]" (SÊNECA. Sobre a brevidade da vida - Tradução, notas e introdução de William Li. São Paulo: Nova Alexandria, 1993, p. 39.) 
tal, deve ser um período minimizado para que não se "perca" tempo. Para Walter, lhe parece óbvio que se economize tempo, assim ele terá mais tempo para o trabalho. Ele quer ir a Los Angeles de avião porque é "mais simples e mais rápido", sem que isso lhe evoque qualquer reflexão. Está presente nele, desse modo, uma racionalidade da rapidez já autonomizada.

Travis não entende por que devem sair do chão para chegar a Los Angeles - e tampouco entende a resposta de Walter, que apela para a rapidez. Eles entram no avião, mas desembarcam pouco antes da decolagem, quando Travis, muito nervoso, nega-se a seguir viagem, ignorando os apelos dos outros passageiros e comissários de bordo, que dizem que isso atrasará o vôo (ou seja, novamente usa-se o argumento temporal).

Do aeroporto, Walter telefona para Anne e explica o medo infantil de seu irmão: "Não sei, querida, ele apenas... entrou em pânico. Não adiantaria tomar outro avião, ele tem medo." E a comunica sobre o novo meio de transporte: "Temos que ir de carro. Vamos chegar em dois dias". Ou seja, Walter acaba se dobrando às necessidades de Travis para levá-lo a Los Angeles. Não foi perguntado a Travis, entretanto, se ele queria ir para Los Angeles. Walter vive de acordo com padrões modernos e os vai submetendo a Travis sem indagá-lo a esse respeito.

Esses padrões são hegemônicos como a temporalidade da modernidade, sobre a qual não se questiona, que é sobreposta a tudo sem que haja espaço - ou tempo - para reflexão. A explicação que Walter dá para Travis não ter entrado no avião é apenas a de que ele entrou em pânico, não se pensa a respeito dos motivos que o amedrontaram e tampouco há um olhar crítico para a escolha do avião como meio de transporte: é "melhor" por ser mais rápido; a rapidez é melhor, como se isso fosse um dado "natural".

Travis não apenas se recusa a voltar de avião, como faz questão de que voltem no mesmo carro utilizado para chegar ao aeroporto. No estacionamento da locadora de automóveis, a atendente pergunta "Por que quer o mesmo carro? São todos iguais". Pela visível parecença que há entre os carros, aos olhos dos indivíduos modernos, eles são de fato iguais. Iguais e substituíveis. Travis, entretanto, quer o exato mesmo carro em que andaram antes, e não um veículo que o possa substituir. Walter não revela à atendente a razão de seu pedido, diz a ela que esqueceu algo no interior do veículo. A sugestão da funcionária é que vão à seção de "Achados e Perdidos", símbolo aqui de uma burocracia organizativa, mostrando, além da fácil substituição, a fragmentação por setores e a burocracia do mundo empresarial. 
Walter tenta resolver essa questão para seu irmão de modo prático, não compreendendo seu desejo pelo mesmo carro, mas tampouco o indagando sobre seu pedido. Ele pede o número da placa do veículo utilizado, mas a recepcionista lhe responde "não posso deixá-lo entrar no estacionamento". É uma resposta tão padronizada, que não leva em conta a conjuntura em questão - eles já estão dentro do estacionamento. Ou seja, a atendente segue os procedimentos padrões que lhe foram ensinados, sem levar em conta situações que fujam das normas burocráticas, que devem ser seguidas sem questionamento ou exceções. Por fim, a atendente lhes revela a placa do veículo. Eles conseguem seguir viagem no mesmo carro, e logo já estão na estrada novamente.

Travis se apóia sobre o banco da frente, mais perto de Walter, segurando uma fotografia que diz ser de Paris.

WALTER: Isso aqui é Paris? Para mim, parece o Texas.

TRAVIS: E é!

WALTER: Paris, Texas?

TRAVIS (sinaliza que sim com a cabeça): Está no mapa.

WALTER: Um lugar chamado Paris, Texas?

Travis mostra a cidade no mapa, esclarecendo ao espectador que, para além do que fora sugerido pelo título do filme, quando ele propôs ao irmão que passassem por Paris, não se referia à capital da França, mas à cidade estadunidense de Paris que fica no Estado do Texas. Indagado sobre como obteve essa foto de Paris, Travis diz que lhe enviaram a foto quando comprou, pelo correio, um lote na cidade, "há muito tempo". Walter quer saber por que seu irmão comprou esse lote, mas Travis oscila e responde: "eu me esqueci".

O breve esclarecimento sobre Paris parece aproximar os irmãos: Travis aparece sentado no banco da frente, ao lado de Walter. A próxima conversa entre eles será também breve e relembrará algo: Travis pergunta se Walter se lembra do nome de solteira de sua mãe. "Sequine", diz Walter, lembrando que seu pai (avô deles) era espanhol.

Se Travis parecia ter perdido sua memória, ele agora tenta recuperar dados de seu passado. Eles param em uma lanchonete, e Walter tem a constatação de que Travis está entrando em seu ritmo de vida: "Eu não acredito! Até que enfim resolveu comer! Comer e falar! Logo vai estar de volta ao mundo dos vivos".

É de se questionar sobre o que seria esse "mundo dos vivos" a que se refere Walter. Não se trata de um mundo no qual as pessoas comem e bebem, mas de um 
mundo daqueles que têm os mesmos valores que ele - imersos na temporalidade corrente da modernidade. Travis estaria, então, mergulhando cada vez mais profundamente nesse mundo da cultura moderna, pois logo se oferece para dirigir. Quando Walter lhe pergunta se já está pronto para contar o que houve nesses quatro anos, Travis, que já falou sobre Paris e sua mãe, mas nada disse sobre sua errância, responde: "ainda não".

Walter cochila enquanto Travis dirige e, ao acordar, se vê sozinho no carro, estacionado em uma estrada de terra - que não é a principal. Travis está sentado sobre uma caminhonete antiga, com o capô aberto, organizando seus pertences em seu bolso. Walter quer saber onde estão e por que Travis saiu da estrada, mas ele diz que não sabe, "não tinha placa". Isso significa que Travis transformou, por algumas horas, essa itinerância em errância. "Que maravilha! Estamos no meio do Deserto de Mojave, num lugar sem nome!”, diz Walter, mas eles logo já estarão de volta à estrada.

De volta à itinerância terão, entretanto, que parar em dois cruzamentos e esperar o momento em que possam cruzar. Na primeira parada, enquanto esperam um trem cruzar a estrada, conversam:

WALTER: Quero falar sobre o Hunter.

TRAVIS: Que idade ele tem agora?

WALTER: Vai fazer oito anos em janeiro.

TRAVIS: Então ele tem sete.

WALTER: O que eu quero dizer é que... agora ele faz parte da família. Anne e eu somos os pais dele agora.

TRAVIS: Anne, sua esposa?

WALTER: Sim, lembra-se dela?

TRAVIS: Não. Hunter pensa que você é o pai dele?

WALTER: Bem, não. Anne contou a ele que você viria.

TRAVIS: Quem ele pensa que eu sou?

WALTER: Eu disse que você era pai dele. Mas você estava sumido por muito tempo, Travis.

TRAVIS: Por quanto tempo? Diga-me!

WALTER: Quatro anos.

TRAVIS: Isso é bastante tempo?

WALTER: Para um menino, sim. É metade da vida dele.

TRAVIS: Metade da vida de um menino.

Essa conversa breve, porém densa, mais uma vez enfatiza a diferença na relação que cada irmão tem com o tempo. Na errância que viveu durante os quatro anos 
anteriores, Travis não teve noção alguma do tempo cronológico que se passava: tanto é que pergunta por quanto tempo ficou afastado e, em seguida, se quatro anos é bastante tempo. É de se imaginar que quatro anos signifiquem um agregado maior de mudanças na vida de uma criança do que na vida de um adulto errante. Para falar sobre a duração que esse tempo designa, Walter se prende exatamente à evolução de Hunter, para quem metade de sua existência se deu no decorrer de quatro anos. Quando Travis pergunta a idade de Hunter, Walter não responde no tempo presente - diz que ele fará oito anos, e não que ele tem sete. A vida de Travis parece, aqui, muito mais calcada no tempo presente do que a de Walter, focada no futuro. Travis não se preocupa com a passagem do tempo, não o nota “correr”. Já Walter poupa tanto tempo quanto lhe é possível (por isso a necessidade do avião), e busca, ainda, presentificar o futuro, entrando na lógica de uma temporalidade apressada.

O trem que passa enquanto esse diálogo ocorre faz lembrar uma linha do tempo como aquela à qual o indivíduo moderno está habituado - uma linha reta, sobre a qual se segue sempre na mesma direção.

A rede de estrada de ferro evoca espontaneamente a imagem de um intenso tráfego de trens rápidos, expressos ou ônibus, de filas de carros de passageiros ou vagões de carga. Seus horários são inflexíveis e obrigam os usuários a submeter-se a eles. Seu funcionamento, minuciosamente dirigido, exige uma precisão de mecanismo de relojoaria. Põe a serviço do público uma organização pontual, que só pode funcionar impecavelmente se obedecer a uma ordem e a uma hierarquia inflexíveis, ignorando o sentimento. Sua rota é prioritária e as outras linhas de comunicação, ao cruzarem uma linha de estrada de ferro, verão seu tráfego interrompido logo que aparecer um trem: o transporte público é mais importante que os transportes privados. [...]

$[\ldots]$

O trem dos sonhos é a imagem da vida coletiva, da vida social, do destino que nos carregam. Evoca o veículo da evolução, que dificilmente tomamos, na direção certa ou errada, ou que perdemos; simboliza uma evolução psíquica, uma tomada de consciência que prepara a uma nova vida. ${ }^{21}$

Pois somente quando param o carro para que esse "veículo da evolução" - o trem - passe, de maneira inflexível, é que Walter consegue falar com Travis a respeito de Hunter. E isso gera, em Travis, uma "tomada de consciência que prepara a uma nova

${ }^{21}$ CheVhalier, Jean et GheERBRAnt, Alain. Dicionário de símbolos. Rio de Janeiro: José Olympio, 2006, pp.896-897. Verbete: Trem (estrada de ferro). Grifos do autor. 
vida". Ele retomará, a partir daí, seus laços familiares, relembrando seus pais primeiramente, e depois sua relação com a ex-mulher e o filho. A passagem do trem, portanto, permite uma comunicação que fez reaparecer alguma cumplicidade entre os irmãos. É quando estão submetidos a essa espera do trem (espera que Walter não pode adiantar, como tentou fazer com a espera pelo trajeto a ser percorrido, optando pelo avião), que por fim Walter consegue conversar com o irmão sobre esse assunto que incomodava a ele e a Anne já desde sua primeira conversa. Walter informa a Travis que Hunter vive com ele, mas nada discutem sobre a guarda do menino - mesmo porque nada foi dito sobre o destino do próprio Travis.

Pode-se ver o reflexo de Travis no espelho retrovisor, e à frente estão o vidro do carro e a estrada a ser percorrida. O trânsito, entretanto, é parado novamente em um cruzamento. Dessa vez, para a passagem de caminhões. É quando começa o diálogo que localiza a suposta origem de Travis:

TRAVIS: Eu me lembro agora.

WALTER: De quê?

TRAVIS: Porque comprei o terreno.

WALTER: Por quê?

TRAVIS: Mamãe me disse que foi lá onde ela e o papai fizeram amor pela primeira vez.

WALTER: Em Paris, Texas?

TRAVIS: Sim.

WALTER: Ela lhe contou isso?

Travis: Sim. Então... Pensei, lá é minha origem. Eu, Travis Clay Henderson. Deramme esse nome. Tudo começou lá.

WALter: Em Paris, Texas?

TRAVIS: Sim.

WALTER: Acha que foi concebido lá?

TRAVIS: Acho.

WALTER: Talvez tenha razão, Travis.

TRAVIS: Papai sempre fazia piada disso.

WALTER: Do quê?

TRAVIS: Dizia que conheceu mamãe em Paris. Daí ficava calado um tempo antes de dizer Texas. Era para que todos pensassem em Paris, França. Era engraçado, todos riam muito.

Após esse diálogo, pode-se entender melhor o significado da primeira palavra que Travis disse ao seu irmão: Paris. Ela poderia dizer respeito a uma relação quase umbilical de Travis com seu passado, poderia acolher seu senso de pertencimento. Mas 
Paris refere-se a um passado mítico de alguém que, errante, pertence a lugar nenhum (nowhere), e que logo questionará essa suposta origem natal.

Se Travis empenhou uma busca acerca de sua origem, ela parece ter precedido sua errância, pois ele comprou o lote em Paris, no Texas, antes de começar a vagar. A compra do lote foi feita pelo correio, o que demonstra certa insensatez de Travis (quem garante que aquela terra será mesmo sua?) A justificativa de Travis para eleger Paris como seu local de origem soa igualmente implausível - a história que ele conta á baseada em uma piada de seu pai e, ainda, desconhecida por seu irmão, que não se lembra ao menos da existência de uma cidade chamada Paris nos Estados Unidos.

Paris tem no filme uma conotação mítica, pois a cidade sequer aparece na tela, exceto na fotografia de Travis, sobre a qual ainda se pode perguntar: que grau de confiança se pode atribuir à imagem de um terreno vendido pelo correio? A fotografia não precisa ser de Paris, precisa apenas fazer com que o "proprietário" acredite se tratar de Paris, ou seja, precisa parecer ser Paris.

A proximidade de Los Angeles abala o cenário desértico das estradas: surgem mais pistas e placas. Aparecem os primeiros viadutos do filme, sob os quais os irmãos passam. Travis finalmente pergunta algo referente à vida do irmão, que explica a ele sua profissão: "Faço outdoors para publicidade".

Com a chegada à casa de Walter, termina a itinerância de Walter e Travis rumo a Los Angeles. Acaba assim a viagem na qual Travis deixou-se levar, sem saber ao certo seu destino, e através da qual Walter cumpriu com o dever de "resgatar" o irmão.

\subsection{Chegada e partida}

\subsubsection{Chegada pela estrada}

A casa de Walter fica no alto de uma colina. Tem como vista o aeroporto no qual teriam chegado, caso Travis não tivesse se recusado a voar. Após tanta estrada percorrida, tanta paisagem desértica, rodovias e trilhos de trem, compõe a vista desse "lar familiar" um aeroporto, (não-)lugar onde a maioria das pessoas está apenas de passagem - e onde Walter oferecerá um emprego para Travis.

No primeiro encontro com seu filho, Travis mantém uma postura infantil. É Hunter quem inicia o diálogo entre eles, a formalidade do cumprimento não parte, portanto, do adulto, mas de uma criança. Travis está infantilizado demais e Hunter está 
excessivamente maduro para sua idade. Essa situação apenas será revertida por completo na cena final do filme, quando Hunter encontrar sua mãe e Travis seguir sua errância.

No primeiro jantar "em família", o espectador tem uma visão não-usual, porém reveladora - não vê os rostos, mas os pés de cada um, por baixo da mesa. Há lá quatro pares de pés e uma mão. Em primeiro plano, à esquerda, estão os pés de Hunter, ele usa tênis azul marinho com faixas branca e vermelha e calça preta. Ele mexe os pés, irrequieto - o que não é de se estranhar, tratando-se de uma criança. À direita está Walter, ele veste calça jeans clara e tênis brancos com faixas prateadas. Cidadão americano típico, Walter também agita os pés, demonstrando ansiedade $\mathrm{e}$ transparecendo certa irritação com a reunião para a refeição. No segundo plano, à esquerda, está Anne (sentada na mesa ao lado de Hunter, portanto). Usa saia e sapatos bege com saltos, mostrando uma elegância comum à moda francesa. Tem as pernas cruzadas e passa as mãos sobre sua canela, acariciando-se com sua própria mão. À direita (portanto, ao lado de Walter e à frente de Anne, na mesa), está Travis. Ele usa jeans escuro e botas. Travis tem os pés imóveis.

Os pés parecem oscilar conforme o grau de ansiedade dessas pessoas, e quando o espectador tem acesso à parte superior da mesa, ouve um diálogo que demonstra a composição de cada personagem:

ANNE: Deve ter sido difícil suportar o calor no deserto.

TRAVIS: Sim, foi duro.

ANNE: Foi má idéia vir de carro. O que aconteceu?

WALTER: Travis não suporta avião.

ANNE: Eu entendo. Também não suporto mais aviões. Principalmente depois de morar aqui. Só ouvimos aviões.

HUNTER: Eu gosto dos aviões.

ANNE: Não costumava viajar de avião antes?

TRAVIS: Não.

ANNE: Desculpe! Lembro que você e Jane foram a Dallas de avião... - quando Anne fala Jane, Hunter se vira e olha para ela. - ... ou para outro lugar.

Travis vacila em responder, Anne olha para Walter e diz:

ANNE: Talvez eu esteja enganada.

Anne, a francesa, passa as mãos sobre sua perna e traz consigo a razão dos argumentos, aliada à polidez de suas palavras. Walter, americano que trabalha com publicidade em Los Angeles, exemplar típico do American way of life, balança as 
pernas, impaciente, e resolve a questão dizendo simplesmente que Travis não gosta de avião. Quando Anne ameaça discutir essa questão, Walter se cala. Hunter, o mais jovem americano, a criança, a novidade, balança os pés e diz simplesmente que gosta de avião: em geral, voar é uma aventura muito bem aceita no universo infantil. Travis, por sua vez, permanece tranqüilo, calmo, não balança os pés, e diz não se lembrar de já ter voado. Isso faz com que o espectador novamente se pergunte se Travis de fato perdeu a memória, ou se sua memória tem estado mais seletiva.

Até o fim do filme, essa dúvida sobre a memória de Travis não será esclarecida: pode-se induzir que sua errância foi marcada apenas pelo presente imediato, e sua memória começara a voltar, aos poucos, após o reencontro com seu irmão, culminando na lembrança do acontecimento que precede a errância, que contará a Jane no peepshow. Inicialmente, Travis recupera a memória emanada pelos pertences que carregava - que incluíam referência a Paris, Jane e Hunter (por meio de fotografias) e a Walter (seu nome completo e telefone anotados em um papel).

O tempo de errância de Travis não foi um tempo de busca por algo, mas um tempo de vivência de um presente intenso e imediato, um presente que é, portanto, desenraizado, descolado do passado. Por isso ocorre uma aparente perda de memória que seria mais uma suspensão de suas lembranças do que perda. Demora algum tempo para que Travis consiga reconstruir uma história de si, com lembranças e feitos, uma história que, ainda que possa estar suspensa, o constitui.

À noite, Travis não vai dormir, vai lavar louça, cantando em espanhol. Anne, sentada em sua cama, coberta apenas por um lençol, abre a porta para ouvir seu canto, deixando suas costas desnudas viradas para o espectador. Isso induz o espectador a incorporar a sedução nas intenções de Anne em relação a Travis - sem que ele a veja, ela o ouve cantar seminua - e a imaginar que a relação de Anne e Walter está abalada.

A cena seguinte tem início com um par de sapatos vermelhos femininos sobre o chão da sala. Travis, carregando o par de botas antes visto sobre a escada, recolhe esses sapatos de Anne, que em seguida aparecem colocados sob o sol, na varanda, para que seque a graxa que Travis utilizou para lustrá-los. Anne vai à busca de seus sapatos no terraço e, em agradecimento a Travis, o abraça. Ele está bastante infantilizado, embora, além da aparência maternal, Anne novamente demonstre uma sensualidade que extrapola o tipo de relação familiar que supostamente os une.

O barulho provocado pelos aviões é constante no terraço, e Travis os observa através das lentes de um binóculo. É a vez de Hunter ir buscar seu tênis, mas, ainda que 
seu pai diga “oi”, ele se vira e parte, mudo. Então Travis deixa de observar os aviões para olhar suas sombras no solo. Walter vai buscar seus sapatos e diz que pode conseguir-lhe um emprego de engraxate no aeroporto. Travis pede que suas botas novas sejam trocadas pelas botas velhas de Walter, e ele aceita. Calça as botas velhas enquanto Walter usa um par de tênis brancos.

Um desejo de fincar os pés no chão surge em Travis quando ele encontra Hunter, e fica expresso pelo deslocamento de seu interesse dos aviões que voam para as sombras no chão do aeroporto, e por sua vontade de calçar as botas usadas, já marcadas por passos e pegadas. Esse sentimento é despertado em Travis pela presença de Hunter, como uma obrigação da investida paterna: é a partir daí que Travis constrói uma relação com Hunter na qual procura agir de modo paternal. Corre à frente da casa, de onde Anne está partindo com o menino para levá-lo à escola, e sugere buscá-lo no colégio para que eles voltem juntos, caminhando, mas, apesar da aprovação de Anne, Hunter discorda, já que seus colegas voltam de carro. Ainda assim, Travis vai à saída da escola buscá-lo a pé, com o binóculo pendurado em seu braço. Em meio às crianças que correm e fazem barulho, ele acena para Hunter, que, ao vê-lo, discretamente pede carona a um amigo.

Ao chegarem, Hunter se esconde, e Travis diz que "para ele [Hunter] também não é fácil", reforçando assim um amadurecimento na relação com o filho. Walter encontra o menino na garagem, sentado no banco do motorista do carro. Não é de se estranhar que, para fugir da situação em que está, Hunter apele para uma hipotética viagem - diz estar dirigindo sem destino, "apenas dirigindo". Embora parado no lugar, remete-se ao trânsito, elemento marcante no filme, que trouxe Travis para sua vida e que compõe a paisagem de sua casa - cuja vista é um aeroporto.

\subsubsection{Reconstrução da família pela imagem}

É pouco provável que Travis conseguisse se fixar em Los Angeles, mesmo porque depois de quatro anos de errância é difícil que alguém se fixe em qualquer lugar, sobretudo em um local que não foi escolhido por si. O dispositivo que faz Travis partir é despertado tão logo ele vê a imagem de Jane em um filme que apresenta, antes de tudo, a imagem de uma família feliz e harmônica. Ver o filme não o leva à tentativa de reativar a união dessa família, mas o faz crer que Hunter deveria ficar com sua mãe, Jane. Algo é 
despertado em Travis após o filme - e sobretudo após a conversa na qual Anne diz saber qual é o paradeiro de Jane.

A idéia de assistir ao filme, gravado em Super-8 cinco anos antes, surge de Walter, e Travis parece aceitar a proposta sem se dar conta do que está por vir. Se sua memória não fora retomada por inteiro, durante a exibição do filme Travis demonstra reconhecer todos que lá aparecem. O filme em Super- 8 tem imagens fora de foco e tremidas, seu amadorismo e sua coloração o diferem das filmagens de Paris, Texas, reforçando, assim, o tom saudosista do filme amador. Esse filme é mudo, mas a trilha que acompanha sua projeção é mais animada nos outros momentos, menos dramática que a usual guitarra de Ry Cooder; é uma música ritmada e alegre como o dia de sol que a acompanha na tela.

O filme mostra, pela primeira vez, uma imagem móvel de Jane, que antes aparecera apenas na fotografia, com Hunter e Travis. Não por acaso o dono da câmera é Walter, aquele que tem maior apreço por novidades técnicas. Travis e Jane têm uma relação bastante carinhosa e cúmplice no filme. Eles estão em uma praia e, junto a Hunter, aparecem mais do que Anne e Walter.

Ao ver no filme as imagens em que aparece com Jane, Travis abaixa a cabeça, desviando seu olhar. Hunter, que no começo do filme não o assistia, mas olhava para um aquário, olha para Travis, cúmplice. Quando, no filme, Travis dirige com Hunter no seu colo, o garoto pergunta "Era eu que estava dirigindo?", Travis responde "Sim, você levava jeito". Anne, que estava sorrindo durante a projeção, fica séria. Parece não gostar da proximidade entre os dois. Jane e Travis se beijam e trocam carinhos, e nesse momento Travis aparece no presente narrativo novamente cabisbaixo e com o rosto voltado para baixo, sem olhar o filme. Quando volta a vê-lo, ele e Jane estão brincando de dar tapas um no outro. No presente narrativo, Hunter olha para Travis, que está sério, mas sorri para Hunter e olha para a frente de novo. No filme, Travis anda dançando por um cais, e Hunter tenta imitá-lo. Quando o filme acaba, acendemse as luzes. Travis está sério, olhando para a frente. Percebe que Hunter está parado do seu lado, próximo a ele. Hunter então caminha e fica próximo de sua mãe.

ANNE: Hora de dormir, Hunter.

HUNTER: Ah, mãe!

ANNE: Não discuta, já é tarde.

HUNTER: Boa noite, papai. - diz para Walter.

WALTER: Boa noite, Hunter.

HUNTER: Boa noite, papai. - então diz para Travis, olhando em seus olhos. 

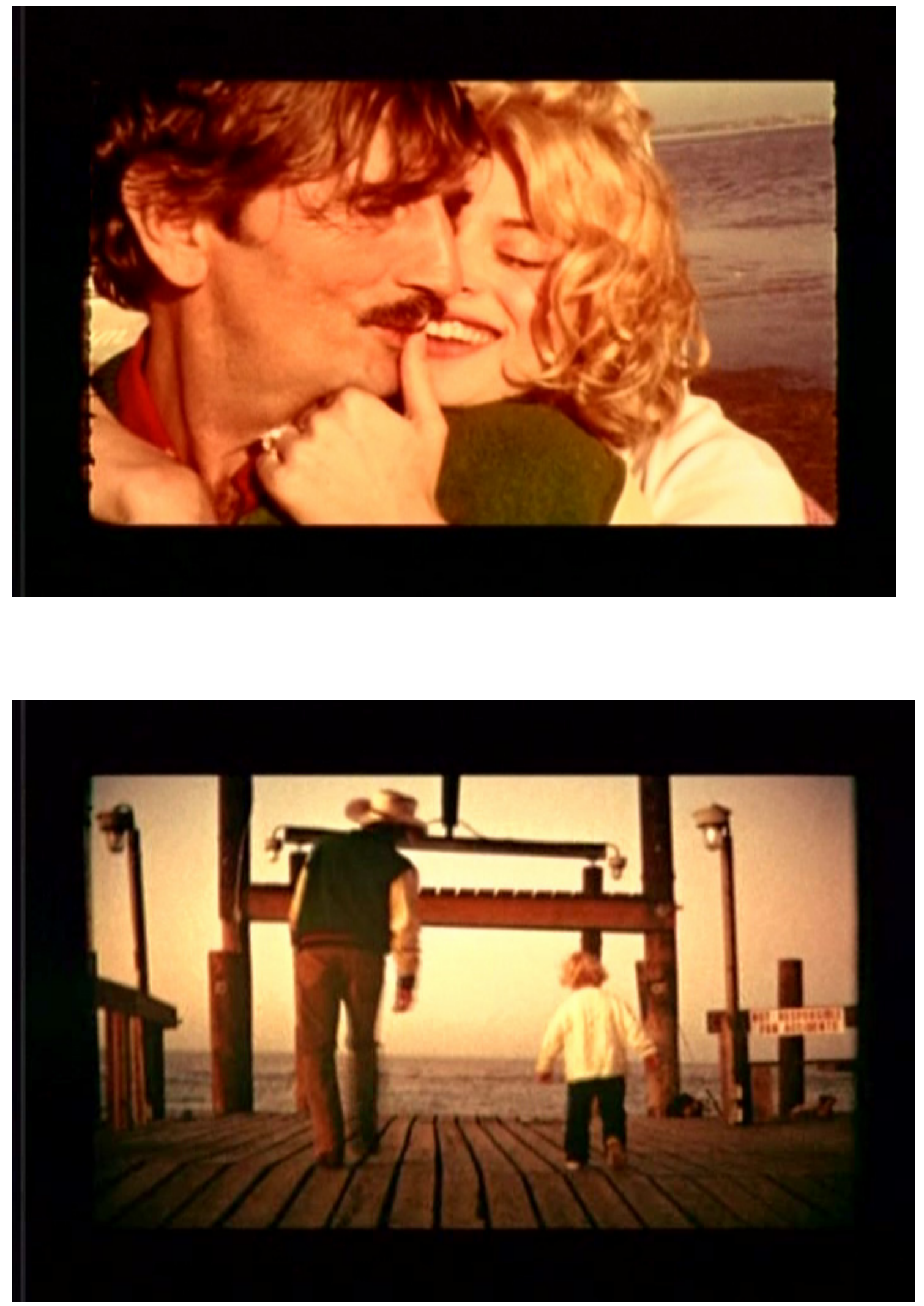
Walter o olha surpreso, mas nada diz. Ele e Travis observam Hunter partir. Conversando cm Anne, em seguida, Hunter tem uma posição bastante adulta: é a percepção (aparentemente obscura para uma criança de sete anos) de que Travis ama Jane, e de que isso é dedutível pelo modo como ele a olha. Hunter observa ainda que no filme não aparecera Jane, mas apenas uma imagem dela, "há muito tempo, numa galáxia muito, muito distante". Jane aparecera em Paris, Texas inicialmente em uma seqüência de fotografias $3 \times 4$. Aparece, agora, em movimento - nos dois casos não é Jane, mas sua imagem, o que se refere a uma metalinguagem que pode levar o espectador a pensar no filme mesmo como uma junção de imagens.

Se todos os personagens são imagens, Travis decide construir uma imagem de si como pai. Na cena seguinte, está sentando no sofá, folhando revistas à procura de um "pai". A faxineira lhe ajuda, perguntando se ele quer parecer um pai rico ou pobre, ele diz que "entre um e outro". "Isso não existe. Tem que ser um pai pobre ou rico", responde a faxineira. Ele então decide que quer ser um pai rico. Ela separa algumas roupas de Walter e lhe dá dicas posturais: "Lembre-se de uma coisa, Sr. Travis. O rico anda com a cabeça erguida, nunca olha o chão". Ele ensaia como caminhar ereto, "com respeito", "com dignidade".

Seguindo os conselhos da faxineira, Travis veste um terno cinza claro, com colete e chapéu da mesma cor, e na postura que ela lhe ensinou vai buscar Hunter na escola. Hunter o vê e sorri. Seu amigo lhe pergunta:

AMIGO DE HUNTER: Quem é aquele cara? Você o conhece?

HUNTER: É o irmão do meu pai. São dois irmãos. Não, são dois pais. Não, deixa pra lá. AMIGO DE HUNTER: Pais de quem?

HUNTER: Meus pais.

AMIGO DE HUnTER: Como pode ter dois pais?

HUNTER: Acho que tive sorte.

Apesar de ter demonstrado felicidade com a surpresa de Travis, Hunter mantémse distante, e não atravessa a rua para encontrá-lo, caminha pelo lado da via em que está, enquanto Travis segue pelo outro. Quando passa atrás de um caminhão, Travis começa a andar de costas, Hunter o imita, o que remete o espectador ao filme que eles assistiram, no qual o mimetismo entre os dois estava presente. Travis brinca - salta, tropeça, etc., Hunter o imita, sempre do lado oposto da rua. Quando estão quase chegando em casa, Travis atravessa a rua e caminha junto a Hunter, lado a lado. 
Essa é uma tentativa de Travis assumir seu papel paterno: ele é quem serve de modelo a ser seguido por Hunter, que o imita. Travis se desliga da passividade que possuía inclusive em relação a seu filho, de quem começa a se aproximar mais. Recuperando, pelo laço familiar com seu filho, sua memória familiar, Travis senta-se em uma poltrona e observa um álbum de fotografias enquanto Hunter lê, deitado no chão. Depois, olham juntos as fotografias de familiares.

A proximidade entre eles acaba revelando conflitos entre Anne e Walter. Ela diz ao marido que as coisas mudaram entre eles desde que Travis chegou, e tem medo do que possa acontecer se eles "perderem" Hunter. Ou seja, Hunter é quem tem mantido essa relação estável, já que a possibilidade da ausência do garoto poderia abalar a estabilidade do casal drasticamente. Walter evita a discussão, dizendo apenas que isso não acontecerá, pois eles não perderão Hunter. Anne pergunta por que Walter aproxima Hunter e Travis, sugerindo que o faz porque quer que Hunter vá embora. Walter eleva a voz e diz que Travis é seu irmão e pai de Hunter, e que sempre souberam disso; "quer fingir que somos os pais do filho meu irmão? Acha que Hunter aceitará isso?” Hunter ouve toda a discussão, acordado em seu quarto.

Após a discussão, Anne vai ao terraço e revela a Travis o paradeiro de Jane, uma informação que despertará nele a vontade de reencontrá-la. Jane costumava ligar para saber de seu filho, mas pediu que Anne não contasse a ninguém. Travis quer saber se Jane perguntava por ele, Anne diz que sim, no início, e que Jane decidiu que Hunter ficaria com Anne e Walter depois do que aconteceu entre ela e Travis, pois "disse que não poderia mais ser mãe dele". "Ela deixou de ser mãe muito tempo antes disso", diz Travis, e se levanta. O espectador pode ver Hunter, na janela do quarto, observando-os e provavelmente ouvindo também essa conversa.

Não ficam claros os objetivos de Anne, se ela disse isso para que Travis fosse à procura de Jane, ou porque concordou com Walter sobre não evitar que Hunter e Travis se aproximem. O diálogo gera mais curiosidade no espectador sobre o misterioso acontecimento que separou essa família, aparentemente tão unida. Que fato tão terrível teria separado Jane e Travis?

Travis diz sobre Jane: "Ela era jovem. Queria alguma coisa, mas eu não sabia o que era. Eu não conseguia perceber a raiva que me dominava.” Anne conta que Jane parou de ligar há um ano, mas que deposita algum dinheiro para Hunter todo dia cinco, desde então. Quantia que varia de valor, podem ser 5, 50 ou 100 dólares, mas que ela não deixa de depositar. É um banco em Houston, e Anne se propõe a anotar seu 
endereço para Travis, que pergunta "Que dia é hoje?" e Anne responde: "Primeiro de novembro".

Em seu quarto, Hunter, já deitado, brinca de luta com dois bonequinhos. Logo atrás dele está seu abajur, um globo terrestre iluminado - Hunter tem um mundo iluminado em seu quarto, mundo que ele logo percorrerá, em suas futuras viagens.

\subsubsection{Partida pelas pontes}

Apesar de tantas particularidades observáveis no mundo exterior, há uma idéia de que, na natureza, as ininterruptas transformações sofridas pela matéria e pela energia compõem um cosmos. Um cosmos no qual, entretanto, mantém-se uma distância espacial entre todos os objetos, uma vez que dois corpos não podem ocupar o mesmo espaço ao mesmo tempo. Se um homem separa dois objetos, é porque antes estavam unidos e ele os selecionou para separá-los, e se os une, é porque antes estavam separados. ${ }^{22}$ Cabe ao homem, portanto, unir o que está separado, e separar o que está unido: "Em um sentido tanto imediato como simbólico, tanto corporal como espiritual, somos a cada instante aqueles que separam o ligado e ligam o separado". ${ }^{23}$

Unir lugares pela construção de um caminho, diz Simmel, é um feito especificamente humano. Os animais podem unir distâncias, mas não constituem um caminho porque o começo e o fim ficam desligados. Essa realização especificamente humana atinge seu ponto culminante na construção da ponte - quando a vontade humana de ligar dois pontos se opõe à resistência passiva da distância espacial e à resistência ativa de uma configuração específica. Superando esse obstáculo, a ponte simboliza a extensão da esfera da vontade sobre o espaço, pois por meio dela o homem une, de forma visível, o que antes estava separado ${ }^{24}$.

Ao observar-se uma ponte, a ênfase da correlação entre separação e unificação recai sobre a união. Mas, aponta Simmel, separação e unificação são duas faces de um mesmo ato, e para isso lança mão de outro objeto conceitual: a porta. A porta é responsável pela articulação entre o espaço do homem e tudo o que está fora dele, superando, desse modo, a separação entre o dentro e o fora. Uma vez que a porta pode

\footnotetext{
${ }^{22}$ Cf. SiMMEL, Georg. "Puente y puerta". In: la cultura. Barcelona: Ediciones Península, 2001, pp. $45-46$.

${ }^{23}$ Simmel, G. "Puente y puerta". op. cit., p. 46. Tradução livre de: "En um sentido tanto inmediato como simbólico, tanto corporal como espiritual, somos a cada instante aquellos que separan lo ligado o ligan lo separado".

${ }^{24}$ Cf. Simmel, G. "Puente y puerta". op. cit., p. 47.
} 
ser aberta, seu fechamento provoca uma forte impressão de isolamento. É essencial para o homem que ele mesmo se ponha uma fronteira, mas com liberdade, isso é, de modo que ele também possa superar novamente essa fronteira, situar-se além dela - fazendo-o toda vez que abre a porta ${ }^{25}$.

Como a porta, a ponte manifesta o poder, especificamente humano frente à natureza, de recortar uma parcela da continuidade e da infinitude do espaço, ligando duas porções do espaço entre si e separando-as de todo o mundo restante. Se a porta estabelece a fronteira entre o limitado e o ilimitado (não como um muro divisório, mas como possibilidade de constante troca - pela sua abertura ou fechamento), a ponte, por sua vez, une o finito ao finito, unifica aquilo que fora selecionado ${ }^{26}$, e "[...] a direção na qual se cruze a ponte não implica nenhuma diferença para o que faz ao sentido, enquanto que a porta, com o dentro e o fora, indica uma diferença completa de direção"27.

Assim, cruzar uma ponte para um lado ou outro pouca diferença faz. O que importa no ato de atravessá-la é a autenticação da junção de duas parcelas do espaço que, na ausência da ponte, estariam separadas - e que primeiramente foram identificadas como objetos separados, para então serem unidos. Se, para Simmel, o homem é o "[...] ser que liga, que sempre deve separar e que sem separar não pode ligar", ele deve, portanto, considerar a existência de duas margens de um rio como uma separação, para poder ligá-las pelo intermédio de uma ponte. Já a porta é aquela que torna visível a separação entre o espaço específico e delimitado de alguém e toda a imensidão do mundo exterior, ou seja, a porta torna perceptível a possibilidade de sairse a cada instante de uma delimitação para a liberdade ${ }^{28}$.

A liberdade da errância por um espaço ilimitado surge em Paris, Texas uma vez que se abre uma porta. Errando sem residência fixa, Travis abdicou de sua delimitação espacial para, durante quatro anos, vagar sem destino pela imensidão infinita de sua liberdade $^{29}$. Quando o encontra, entretanto, Walter quer levá-lo à sua casa.

\footnotetext{
${ }^{25}$ Cf. Simmel, G. "Puente y puerta". op. cit., pp. 48-49.

${ }^{26}$ Cf. SimMeL, G. "Puente y puerta". op. cit., pp. 48-50.

${ }^{27}$ SiMMEL, G. "Puente y puerta”. op. cit., p. 50. Tradução livre de: “[...] la dirección en la que se cruce el puente no implica ninguna diferencia por lo que hace al sentido, mientras que la puerta, con el adentro y el afuera, indica uma diferencia completa de dirección."

${ }^{28}$ Cf. Simmel, G. "Puente y puerta". op. cit., p. 53. O trecho reproduzido foi traduzido livremente de: "[..] ser que liga, que siempre debe separar y que sin separar no puede ligar".

${ }^{29}$ É evidente que não há liberdade completa; trata-se, aqui, de uma liberdade de circulação por um espaço infinito que tem cunho teórico, e não de uma total liberdade de circulação na prática. Não há liberdade que vislumbre uma infinitude espacial no sentido prático quando há, por exemplo, a existência de propriedade privada. Trata-se, antes, de um espaço infinito quando comparado ao espaço restrito de uma casa, mais especificamente, de um espaço restrito pela existência de uma porta fechada.
} 
O filme que Travis assistiu o fez relembrar sua antiga família - a antiga casa cuja porta se podia fechar. E dentro dela estariam ele, Jane e Hunter. Uma vez tendo saído dessa casa, Travis não pode mais, entretanto, retornar a ela e fechar sua porta - o infinito o atrai de modo tão mais instigante, que a demarcação fixa de um terreno não lhe é possível. Ele não se sente arraigado a essa casa, a esse lar.

Na casa de Walter, após ver o filme, Travis seleciona objetos e os constrói como elementos separados. Constata em sua família uma separação essencial entre mãe (Jane) e filho (Hunter). Decide, então, uni-los, e para isso é preciso que se construam pontes. A partir desse momento, as pontes ganham mesmo forma imagética visível no filme. Cada nova decisão e cada possibilidade de caminho surgem para Travis fisicamente como um novo viaduto, uma nova junção.

Antes Travis percorria estradas, a estrada representava a infinitude do espaço do lado de fora da porta. Ele agora cruza pontes, unindo espaços na sua missão de unir pessoas. O avião no qual Travis se recusou a entrar representava a possibilidade de cruzar uma ponte invisível, mas ele preferira a estrada. Uma vez levado para a casa de Walter, tem a possibilidade de escapar do espaço limitado (pela porta) de dentro dessa casa para percorrer pontes, ligar espaços.

Travis sai para caminhar à noite, anda rápido pela cidade, com as mãos nos bolsos do casaco. Surge a primeira ponte, que une dois lados de uma estrada bastante larga (que, por sua vez, une cidades), na qual o tráfego de veículos é intenso. Sobre essa ponte, Travis depara-se com um homem que grita aos carros que passam embaixo dela. Seus gritos são um aviso para uma situação que ele acredita que acontecerá: "eles" virão buscar todos e levá-los para uma terra sem regresso, que fica em lugar nenhum ("Nenhum lugar estará seguro. Não haverá zona de segurança. Será apagada do mapa. Sereis levados para a terra sem regresso. Uma passagem para lugar nenhum ${ }^{30}$ ”). Isso ocorrerá em breve, e o mentor do discurso afirma não ser louco. Ele grita para pessoas que estão de passagem, e que certamente não podem ouvi-lo, pois passam em alta velocidade, dentro de seus carros, sob a ponte. Ele acredita que, do alto da ponte, pode gritar tão alto que podem ouvi-lo mesmo a quilômetros de distância. Embora tenha suas bases fixas nas margens da estrada, essa ponte, para ele, é sua união com o mundo. Um mundo do qual fora antes separado ("Talvez eu seja um verme. Mas acreditais que sei do que estou falando. Não sou louco"), e no qual quer agora entrar e alertar sobre os perigos vindouros.

\footnotetext{
${ }^{30}$ No original: "It's a navigation to nowhere".
} 
O que importa, para o homem que discursa, não é tanto a ligação que a ponte estabelece entre as duas margens da estrada, mas sua altura. É do alto da ponte que o homem grita, como se a altura (que o faz ter um campo de visão mais amplo) o fizesse ser ouvido por mais pessoas. Travis também atribuirá à altura uma visão mais precisa de seus problemas, e de um patamar acima da estrada dirá ter mais clareza sobre os fatos, e decidirá ir atrás de Jane.

Ele sobe em uma estrutura alta para falar com Walter, que está acompanhando o processo de troca de um grande e elevado outdoor. Sai o desenho de um escudo preto para entrar a fotografia de uma mulher vestida com trajes de ginástica, deitada ao lado de uma garrafa de água à qual refere-se a propaganda. $\mathrm{O}$ enquadramento mostra apenas uma parte da mulher, pois falta $1 / 3$ de sua imagem, que ainda está sendo colocada. Ao lado do painel publicitário está Walter - ele é menor que o antebraço da imagem dessa mulher.

É interessante notar, para além da pequenez relacionada ao homem ao lado de uma imagem tão grande, o quão fluido é o processo de mudança de imagem em um outdoor: ela é sempre trocada, pode-se sobrepor a imagem nova à antiga ou fazer uma substituição. No caso de sobreposição, o que acaba se constituindo é um palimpsesto de medidas exuberantes, que guarda imagens mostradas por um período de tempo muito breve, pois mensagens publicitárias - material com o qual trabalha Walter - têm uma duração absolutamente efêmera.

Essa troca de cartazes traz à tona um elemento tipicamente moderno: o excesso de imagens a que estão submetidos os indivíduos. Há uma diferença fundamental entre a paisagem do deserto cujas estradas Travis e Walter percorreram e as outras paisagens mostradas no filme: a quantidade de imagens conflitantes, não harmônicas, mostrada em cada uma. Olhar a paisagem de uma estrada composta por um trilho de trem contínuo, vegetação rasteira, poeira e montanhas significa ter uma visão ampla de um todo hegemônico. Nas estradas iniciais de Paris, Texas não há túneis, as pistas não cortam montanhas, foram construídas sobre terrenos planos. Ao redor da estrada, tem-se uma vista horizontal sem fim, há continuidade nos elementos observados - por exemplo, uma montanha começa a se erguer, tem seu cume, diminui e termina. Assim se forma uma paisagem harmônica, de poucos elementos. Nas grandes cidades, entretanto, o excesso de imagens é elemento marcante.

[...] ao longo do tempo, as imagens mudaram completamente de natureza, passando dos exemplares únicos da pintura aos clones numéricos. Elas cresceram 
numa velocidade incrível e se multiplicaram com a mesma rapidez. Somos bombardeados de imagens como jamais ocorrera na história da humanidade. E este bombardeio não vai parar; ao contrário, se intensificará ainda mais. Nenhuma administração, nenhuma instituição, nenhum governo poderá impedir que o reino das imagens continue a se estender $\left[\ldots . . .^{31}\right.$

O painel publicitário, cuja imagem Walter troca, é apenas mais um indício desse excesso de imagens presente nas grandes cidades (como as que aparecem em Paris, Texas: Los Angeles e Houston), nas quais o espaço é todo preenchido, ocupado além do nível do solo, mas sem a continuidade imagética de uma montanha, que forma uma curva - ainda que imperfeita - harmônica. Nas cidades, as construções são tão grandes que, estando o observador próximo a um prédio, não consegue ver senão uma pequena parte dele. Vê-lo de um ponto horizontalmente mais distante tampouco é possível, pois não há a distância necessária em terreno plano para fazê-lo. Caso se deseje observar a paisagem de uma grande cidade, a saída é buscar uma distância vertical - subir a uma altura como a da casa de Walter, da qual se vê Los Angeles, a uma altura que distancie o observador dos prédios a ponto de eles tornarem-se pequenos e, portanto, apreensíveis $^{32}$.

A quantidade de imagens conflitantes presente em uma cidade faz com que ela seja visivelmente mais apreensível à distância: quanto maior a distância, mais a visão torna-se clara e completa para quem queira observar a cidade, para o homem que gritava sobre a ponte, para Travis. É no alto da estrutura na qual Walter supervisiona a instalação do novo painel publicitário que Travis conversa com o irmão, de um lugar tão alto que permite a eles verem a cidade como horizonte distante, a estrada com pequenos carros que se movimentam.

TRAVIS: Daqui, as coisas não são como vistas no chão.

WALTER: O que quer dizer?

TRAVIS: Daqui de cima tudo fica claro. Pode ajudar a esclarecer as coisas.

\footnotetext{
${ }^{31}$ Wenders, Wim. "A Paisagem urbana". In: Revista do Patrimônio Histórico e Artístico Nacional. Rio de Janeiro, n.23, 1994, p. 183.

${ }^{32}$ Pode-se, mais facilmente, ver a imagem de um prédio reproduzida em uma fotografia. O prédio estará lá por inteiro, entretanto não haverá prédio algum, haverá apenas uma reprodução miniatural de sua imagem: “[...] Cada um de nós pode observar que uma imagem, escultura e principalmente um edifício são mais facilmente visíveis na fotografia que na realidade. [...] Em última instância, os métodos de reprodução mecânica constituem uma técnica de miniaturização e ajudam o homem a assegurar sobre as obras um grau de domínio sem o qual elas não mais poderiam ser utilizadas.” (BENJAMIN, Walter. "Pequena história da fotografia". In: volume I. São Paulo: Brasiliense, 1985, p. 104).
} 
É dessa altura esclarecedora que Travis comunica a Walter que partirá à busca de Jane - e que terá êxito nessa empreitada. Walter fica nervoso, pede para Travis contar o que houve entre ele e Jane, parar com o mistério, dizendo que o tem tratado como um menino mimado desde que o buscou no deserto. Mas logo se controla e muda o tom nervoso de sua fala. Travis nada menciona sobre o ocorrido, ele apenas avisa a Walter que precisará de dinheiro e cartão de crédito, e Walter se compromete a providenciá-los, ou seja, segue tratando o irmão como um garoto mimado, atendendo aos seus desejos ainda que não concorde com eles. O novo anúncio colocado sobre o painel pode ser lido: "estou no meu pico" ${ }^{33}$, mostrando ao espectador que, se para Travis tudo fica mais claro quando se está mais alto, a decisão de reencontrar Jane ocorre quando ele está no seu pico - ele não poderia, portanto, ter maior clareza, maior lucidez.

Com a decisão tomada, Travis estaciona uma caminhonete frente à escola de Hunter para buscá-lo, e então se consolida a possibilidade de escolha. Logo depois, pára o carro embaixo de um cruzamento que abrange cinco viadutos que, somados à pista de baixo, resultam em 6 vias - considerando-as duas mãos, isso corresponde a 12 possibilidades de caminhos distintos expressas na tela, pontes que unem os mais distintos espaços.

Eles estão sentados na parte traseira da caminhonete, comendo um queijo sobre o qual Hunter diz "Anne nos dá isso todo dia" e pronuncia em francês, ensinando a Travis, "La vache qui rit". Hunter chama Anne por seu nome (e não de "mãe") e em seguida chama Travis de "papai” (“daddy"). Pergunta a Travis por onde andou durante todo esse tempo, e ele diz que foi ao México porque "não sabia aonde ir". Ele pergunta pela sua mãe (“mammy”), Jane. Travis diz vai a Houston encontrá-la, e Hunter, que diz já ter sido encontrado, pede para ir junto. Eles partirão naquele mesmo momento. Travis diz que precisam comprar algumas coisas, e Hunter, preparando-se para uma grande aventura, diz que precisam de jaquetas, camisetas, escovas de dente e walkie-talkies.

Hunter colocara-se na posição de adulto e fora tratado como tal novamente. Quem decide se ele, um garoto de sete anos, viajará (em pleno período letivo!) é ele mesmo. Essa união entre Travis e Hunter, entretanto, fará com que, a partir daqui, Travis não esteja mais infantilizado. A relação com seu filho o fará amadurecer cada vez mais.

Eis que começa mais uma itinerância no filme, a busca de Hunter e Travis por Jane.

\footnotetext{
33 "I'm at my peak", no original.
} 

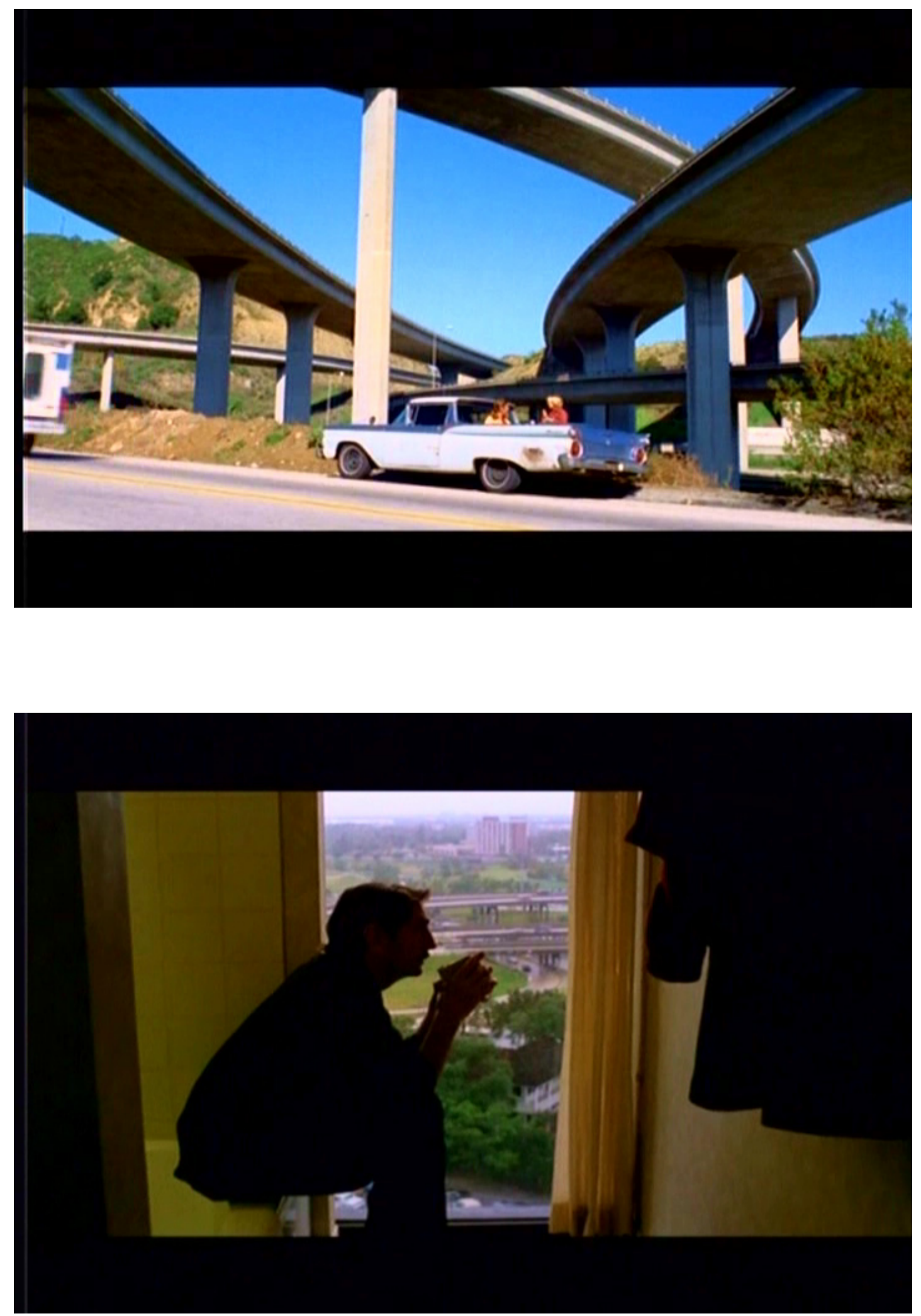


\subsubsection{Melancolia em trânsito}

Travis e Walter não voltarão a se encontrar no filme. Travis não contou a seu irmão o que ocorreu nesse tempo em que esteve errando. É provável que sua vida estivesse suspensa, sem acontecimentos muito marcantes. Mas ele sequer disse por onde andou. E tampouco o que motivou sua separação de Jane. Travis nem ao menos falava o que quer que fosse - no início. Com a intimidade, disse algumas poucas palavras, mas nada contou de sua viagem errante ocorrida no período em que, por conta mesmo da viagem, estiveram afastados.

Na casa de Walter, Travis visivelmente sentia-se incomodado. Ele estava sempre do lado de fora, na varanda que tinha vista para a cidade, para o aeroporto. A porta - à qual se refere a metáfora de Simmel - pode estar aberta ou fechada, mas Travis não apenas a abria, como estava sempre do lado de fora. Após esses poucos dias em que esteve em uma casa, logo se entregou por inteiro à liberdade do lado de fora da porta, na qual já havia vivido durante sua errância. Uma liberdade que se tornou regra e, justamente por isso, acabou tornando-se uma obrigação.

Parece ter se configurado uma situação de estranhamento entre Travis e o meio em que está. Seu irmão viajou quilômetros para buscá-lo, mas Travis não demonstrou qualquer prazer - ou raiva - ao revê-lo. Ao contrário, deixou o hotel em que estavam para partir só, caminhando por sobre o trilho do trem. Apesar do parentesco, Travis nutre com Walter uma relação de estranhamento, e não de familiaridade. Há algo que incomoda Travis não apenas na casa de Walter, mas em qualquer casa, algo que o impede de formar um lar - Travis não cria raízes. Ele prefere manter as portas abertas e caminhar para a infinitude da liberdade do lado de fora da casa (ainda que essa liberdade exagerada possa conter em si seu oposto, a obrigação da liberdade, surgida no momento em que não se é possível criar raiz alguma).

Travis não consegue ficar do lado interno ao fechar a porta. Aberta ou fechada a porta, ele fica fora da casa. Uma vez que partiu por quatro anos, já não pode mais entrar. Tampouco pode narrar o infinito que há do lado de fora dela. Travis voltou de sua vivência mudo, tal qual os combatentes da Primeira Guerra ao retornarem a seus países $^{34}$. Ele passou por uma vivência baseada em um presente que não se projetava para o futuro, e tampouco para o passado.

\footnotetext{
${ }^{34}$ Cf. Benjamin, W. "O Narrador - Considerações sobre a obra de Nikolai Leskov". op. cit., p. 198.
} 
Se o antigo narrador apontado por Benjamin era aquele que transmitia, por meio de um relato oral (a narrativa), um conhecimento que vinha de longe ${ }^{35}$, Travis parece seu oposto. Ele passou quatro anos viajando, mas nada diz. É alguém que vem de longe, mas que não fala nem para ceder ao pedido de seu irmão - cuja fala tem, majoritariamente, função prática. Walter não quer ouvir uma história e tampouco obter conselhos da fala de Travis. Quer saber, na prática, o que aconteceu entre ele e Jane, quer saber dos fatos, para assim saber qual será o futuro de Hunter. Travis, que nada diz, permanece mudo como se seguisse em sua errância solitária.

Sobre os quatro anos em que ficaram sem contato, Travis não dirá uma palavra para Walter. Durante todo o filme, sobre sua errância dirá apenas que correu por cinco dias, e depois desapareceu ${ }^{36}$. A ausência de acontecimentos narráveis, os sapatos gastos e a solidão desraigada de Travis é que induzem o espectador a pensar que, durante sua errância, ele encontrou-se mais com um vazio que lhe é constitutivo do que com outras pessoas e outras paisagens.

O narrador evocado por Benjamin ${ }^{37}$ era marca de uma sociedade na qual a comunicação ocorria - entre os coetâneos e entre as gerações, uma sociedade para a qual a experiência era fundamental. Com a modernidade e a perda de uma história comum e identitária entre os grupos, a comunicação sofreu fortes abalos. Paris, Texas mostra essas transformações de modo quase paradigmático: pela mudez seca de Travis.

Nos poucos momentos em que a comunicação ocorrerá em Paris, Texas, ela será permeada pela técnica ${ }^{38}$. Ou seja, as principais falas que aparecerão no filme não ocorrerão ao vivo, frente a frente - não haverá gestos, reciprocidade, troca de olhares. Nada haverá de especificamente humano na comunicação. A voz será submetida a um microfone para chegar aos ouvidos do outro interlocutor ${ }^{39}$. A comunicação não se dará cara a cara, mas será permeada por objetos tecnológicos. Com Walter, Travis não chegara a conversar. Com Hunter e Jane, terá uma fala mediada pela técnica.

Predomina no filme o silêncio, muitas vezes acompanhado pela trilha sonora de Ry Cooder, um silêncio que advém de uma ausência de palavras, ligada a um estranhamento que permeia os personagens. Um estranhamento deles mesmos e deles

\footnotetext{
${ }^{35}$ Cf. BenJAmin, W. “O Narrador - Considerações sobre a obra de Nikolai Leskov”. op. cit., pp. 198-199.

${ }^{36}$ Isso será dito, em terceira pessoa, quando Travis encontrar-se com Jane.

${ }^{37}$ Em BENJAMIN, W. “O Narrador - Considerações sobre a obra de Nikolai Leskov”. op. cit., pp. 197-221.

${ }^{38}$ Se se pode dizer "comunicação" para uma troca de falas permeada pela técnica, o termo aqui não é empregado em seu sentido forte.

${ }^{39}$ Haverá um diálogo direto entre Hunter e Travis a respeito da origem de ambos. O diálogo ocorrerá ao vivo, mas Travis estará bêbado, ou seja, a comunicação estará igualmente comprometida (por sua semi-consciência).
} 
para com os outros, pois há nos personagens do filme um desenraizamento marcante. Se há um elemento de desarraigamento expresso pelo estrangeirismo de Anne (que é francesa), pela inserção de Hunter em uma família nuclear que ele descobre não ser a sua e em Walter pelo apreço às novidades, esse desenraizamento se manifesta sobretudo e inegavelmente em Travis.

Travis não consegue transpor o enorme afastamento que sente em relação à família na qual tenta se reinserir, ou melhor, na qual tentam inseri-lo. Ele já sabe, de antemão, que lá não encontrará suas raízes. Nem poderia, já que ele sofre de um profundo e crônico desenraizamento. Travis sente-se confortável apenas no espaço do lado de fora da porta, na tentativa de abarcar todo esse espaço, em movimento, portanto: ele se sente em casa no que é errante - ou itinerante, que seja - e não na fixidez. Travis não se fixa, não pertence a lugar nenhum - tampouco pertence à sua origem mítica em Paris, no Texas.

Embora não tenha se fixado durante os quatro anos em que passou errando, Travis não é um estrangeiro nos moldes como a Sociologia concebe essa figura, na perspectiva de Simmel. Para esse autor, o estranho/ estrangeiro ${ }^{40}$ é alguém de fora de um grupo social, que passa a pertencer-lhe. Não é, portanto, alguém - um viajante - que chega a uma terra diferente da sua em um dia e parte em outro, mas alguém que aí chega e, no outro dia, aí permanece. É alguém que se fixa em um grupo social, embora nesse grupo sua posição esteja fundamentada no fato de ele não pertencer a esse grupo desde o início ${ }^{41}$, ou seja, o estranho/ estrangeiro tem uma mobilidade que o permite entrar em contato com cada elemento singular do grupo, "mas [ele] não é com nenhum deles organicamente ligado através da fixidez do parentesco, do local e da profissão". ${ }^{4}$

Sua posição, portanto, "é a daquele que, inserido em um círculo, permanece sempre exterior a ele, porque seus atributos não são os mesmos daqueles que caracterizam o círculo" ${ }^{, 43}$. E, por essa distância, o estrangeiro recebe confidências de outros membros do grupo com uma franqueza surpreendente ${ }^{44}$. Como diz Benjamin,

\footnotetext{
40 Seguiu-se preferencialmente a tradução proposta por WAIZBORT, Leopoldo. “'Jude', entre a ‘emancipação' e a 'assimilação"’. In: 2000, pp. 535-567.

${ }^{41}$ Cf. SimMEL, Georg. "O Estrangeiro". In: As Aventuras de Georg Simmel. São Paulo: Editora 34,

- Sociologia. São Paulo: Editora Ática, 1983, MorAes FILHO, Evaristo de (org.). Georg Simmel saber, SIMMEL, Georg. "Digresión sobre el extranjero". In: formas de socialización. Buenos Aires: Espasa-Calpe Argentina, 1939, pp. 273-296.

${ }^{42}$ SimMEL, Georg. Apud: WAIZBORT, L. “'Jude', entre a 'emancipação' e a 'assimilação””. op. cit., p. 541.

${ }^{43}$ WAIZBORT, Leopoldo. “'Jude', entre a 'emancipação' e a 'assimilação””. op. cit., p. 542.

${ }^{44}$ SIMMEL, G. "O Estrangeiro”. op. cit., p. 184.
} 
Nem sempre proclamamos em voz alta o que temos de mais importante a dizer. E, mesmo em voz baixa, não o confiamos sempre à pessoa mais familiar, mais próxima e mais disposta a ouvir a confidência. Não somente as pessoas, mas também as épocas, têm essa maneira inocente, ou antes, astuciosa e frívola, de comunicar seu segredo mais íntimo ao primeiro desconhecido ${ }^{45}$.

Além de ouvir os segredos alheios, pois que tem uma visão mais exterior ao grupo, o estranho/ estrangeiro deveria ser aquele que narra seus conhecimentos advindos de uma distância espacial. O desaparecimento da narrativa significa, entretanto, a cessação dessas histórias e mesmo o término do aconselhamento ${ }^{46}$. Embora tanto viaje, Travis não é um estrangeiro porque nele não há um elemento fundamental: a fixação em uma nova terra. Diferente do estrangeiro, Travis não se fixa. Ele chega em um dia e no outro (ou quiçá no mesmo dia), ele parte.

Se não um estrangeiro, Travis poderia ser considerado um "viajante"? Viajante é o estranho/ estrangeiro que não chega a constituir laços no local para onde vai, pois ele chega, e parte em seguida. O viajante observa. Hosokawa baseia-se em Jankélévitch para falar sobre esse viajante: é aquele que parte pelo prazer que sente no regresso, é mais turista que viajante, como um aventureiro para o qual a aventura está mais ligada à chegada que ao acontecimento ${ }^{47}$ :

O retorno turístico aniquila a ida, espacial e temporalmente: o turista não envelhece no entretempo. Ele é como era. Ele se move rapidamente, guiado por sua curiosidade ou pelo programa determinado. Em contrapartida, o verdadeiro viajante congela-se, sem querer, num lugar estranho, desloca-se lenta, imovelmente. ${ }^{48}$

Travis evidentemente tampouco é um viajante - ele parte, mas não retorna, mesmo porque ele não tem um ponto de partida. E tampouco um destino, ou um plano de viagem. Ele erra, simplesmente, e se não retorna jamais, é também porque não teria para onde retornar.

Em contraposição a esse viajante que é turista, estaria o viajante nostálgico. Se o viajante turista era aventureiro, o nostálgico é aventuroso, aquele para quem só há um

45 Benjamin, Walter. "A imagem de Proust". In: escolhidas, volume I. São Paulo: Brasiliense, 1985, p. 40. . Magia e técnica, arte e politica - Obras

${ }^{46}$ Cf. BENJAMIN, W. "O Narrador - Considerações sobre a obra de Nikolai Leskov”. op. cit., pp. 197-221.

${ }^{47}$ HosoKAWA, Shuhei. "Por um bom Viajante Nostálgico - Tarkovski visto pelas lentes de Jankelevitch". Imagens. Campinas, $\mathrm{n}^{\circ}$ 2, agosto de 1994, pp. 96-97.

${ }^{48}$ HosoKawA, S. "Por um bom Viajante Nostálgico". op. cit., p. 100. 
futuro próximo e imediato, para quem há uma novidade a cada passo, para quem não há previsão ${ }^{49}$. "A finalidade do viajante nostálgico não é voltar ao ponto de partida, mas derivar sempre, partir perpetuamente" ${ }^{, 50}$ :

A verdadeira viagem nostálgica é também um "exercício de lentidão", como diz o poeta e crítico japonês Hisaki Matsuura. Esse exercício está ligado à fadiga absoluta e à ociosidade involuntária, que se opõem à ordem capitalista da eficiência e do rendimento, assim como à velocidade esquizofrênica. [...] A fadiga absoluta [...] é um estado puro, do qual não existe saída para recuperar o vigor, nem para retomar a vitalidade: não se sabe por que alguém se cansa, nem o que causa o cansaço, nem mesmo se esse alguém se cansa. Uma coisa é certa: nada se faz, e o tempo passa lentamente, muito lentamente. Conhecemos bem a relação que existe entre o langor, a fadiga e a lentidão, quando deixamos nosso país natal ou seguimos viagem. $\mathrm{O}$ tempo transcorre noutro ritmo. Ou não passa: congela. Isso não nos incomoda, pelo contrário: ficamos contentes porque, por um lado, mergulhamos em devaneios de repouso que têm íntima relação com a Terra e possuem uma lentidão cálida, quase sensual; por outro lado, gostamos de deixar o tempo passar, de nos entregarmos ao seu sabor. Simples ociosidade? Simples preguiça? Não. É difícil viver a vida verdadeiramente lenta [...]. ${ }^{51}$

Embora agora mais próximo de Travis, essa categoria tampouco o abarca. $\mathrm{O}$ viajante nostálgico é aquele que faz um exercício de contemplação de uma temporalidade diversa da original. Mas, além de não possuir uma temporalidade que lhe sirva como referência original, Travis não se daria conta de uma possível mudança temporal, pois não percebe quão lento ou veloz o tempo transcorre - tanto é que reencontra seu irmão após quatro anos e não sabe quanto tempo se passou. Quando é informado de que foram quatro anos, pergunta se isso é muito tempo. Se o pergunta, é porque não sentiu o tempo vivido na errância com uma duração tão intensa quanto a que possui a temporalidade da nostalgia. O tempo para ele não estava congelado, mas suspenso, envolto por um presente forte e amparado por pouquíssimas lembranças - apenas os pertences que ele carregava. O nostálgico possui uma sensação de harmonia com o passado enquanto tal, que Travis não possui. Seu passado anterior à errância é o momento do trauma ao qual ele não se refere, do acontecimento que ele não chega a contar, a não ser para Jane, a única pessoa que estava presente no momento mesmo do trauma.

\footnotetext{
${ }^{49}$ Cf. HosokawA, S. "Por um bom Viajante Nostálgico". op. cit., pp. 96-97.

${ }^{50}$ HosokawA, S. "Por um bom Viajante Nostálgico". op. cit., p. 97.

${ }^{51}$ HosoKaWA, S. "Por um bom Viajante Nostálgico". op. cit., pp. 98-99.
} 
O exilado costuma ser um nostálgico, um nostálgico que tem como idealização sua terra natal, da qual foi obrigado a partir. O retorno a esse local, entretanto, costuma vir banhado pelas águas da decepção.

[...] "A nostalgia", escreve Jankelevitch, "não é somente um mal que precisa de remédio, é também a inquietação causada pela insuficiência desse remédio. Nesse sentido, o mal-do-retorno chama-se 'decepção'. No dia seguinte ao retorno, a decepção já terá suplantado a nostalgia. A nostalgia faz frente à amargura do fracasso" [...] A nostalgia, uma utopia que se projeta para o passado, é extremamente dilacerante, mas sem ela não é possível sobreviver. Neste sentido, dizemos que é um remédio amargo e incompleto. É o efeito da irreversabilidade: a nostalgia se encaixa na fluidez de mão única do tempo ${ }^{52}$.

O exilado seria aquele que

[...] se sente moralmente presente e, ao mesmo tempo, realmente ausente de seus lugares queridos. Ele partiu, mas ao mesmo tempo ficou. Este é o fundamento essencial de seu dilaceramento, de sua separação de si mesmo. Não é mais o espaço que estará aqui em jogo, mas a percepção de que se está em um outro espaço, não mais a consciência do deslocamento, mas a sensação de se estar em outro lugar distante e estranho, por mais perto e reconhecível que ele possa $\operatorname{ser}^{53}$.

$\mathrm{Na}$ nostalgia do exilado está presente uma desproporção entre o pouco significado que seu local de origem tinha quando ele estava lá e a enorme importância que passa a ter depois que ele parte. A terra de origem não importa tanto por suas qualidades próprias, mas simplesmente porque é sua, porque pertence ao exilado ${ }^{54}$. Quando esse exilado nostálgico chega à sua terra natal, entretanto, ele se dá conta de que o tempo lá também passou: o lugar e as pessoas não são como o que ele imaginara, ele não se reconhece mais ali, o que lhe provoca o sentimento de decepção ${ }^{55}$ : "Nem bem chegou, o nostálgico já quer novamente partir. O retorno passa a ser o desejo secreto de partir, de novo." 56 O nostálgico "gostaria de reencontrar não só o lugar de sua origem, mas reencontrar-se a si mesmo naquele momento distante,

\footnotetext{
${ }^{52}$ HosoKawA, S. "Por um bom Viajante Nostálgico". op. cit., p. 102. Grifos do autor.

${ }^{53}$ Menezes, Paulo. À meia-luz - Cinema e sexualidade nos anos 70. São Paulo: Editora 34, 2001, p. 90. Grifos do autor.

${ }^{54}$ Cf. Menezes, P. À meia-luz - Cinema e sexualidade nos anos 70. op. cit., p. 91.

${ }^{55}$ Cf. Menezes, P. À meia-luz - Cinema e sexualidade nos anos 70. op. cit., pp. 91-92.

${ }^{56}$ Menezes, P. À meia-luz - Cinema e sexualidade nos anos 70. op. cit., p. 92.
} 
ver-se a si mesmo como era antes" ${ }^{„ 57}$. O que, obviamente, lhe é impossível, e daí advém sua decepção.

Ainda que tenha se configurado o abandono da terra onde habitava, Travis não é um exilado. Sua terra natal é desconhecida, ele disse que foi concebido em Paris, no Texas, mas logo dirá, quando bêbado, que isso não passa de uma piada de seu pai. Ele não fala de sua origem, porque não tem uma origem definida - tem, antes, uma inquietação que lhe faz vagar, mas cujo objeto de busca se transforma. Ele vagava sem destino, seu destino passou a ser Los Angeles, de onde decidiu ir a Houston, à procura de Jane, para, no fim, voltar à errância sem destino, sem procurar realizar objetivo algum na viagem. Não há objeto a se buscar, portanto não há busca em sua errância. Há errância porque Travis não tem sensação de pertencimento a nenhum lugar ou pessoa. A nostalgia implica na idealização de um lugar como origem, e por isso está ligada ao exílio. Quando Walter encontrou Travis, o andarilho sequer lembrava-se de Paris, ele precisou reconstruir sua memória para lembrar-se das histórias ligadas à cidade - sua origem, o terreno que ele comprara, a piada de seu pai.

Embora tenha alguns traços da nostalgia, Travis não tem a busca por um objeto idealizado, que ele acredite ser capaz de findar sua angústia. Ele não busca algo concreto, melhor dito, ele não credita a algo concreto sua busca. Travis é, portanto, acima de tudo, um melancólico.

Tanto na nostalgia como na melancolia estão presentes uma relação com o passado e com a memória. O que as diferenciaria é justamente a percepção ou não daquilo que ficou para trás, preso na irreversibilidade do tempo. $\mathrm{Na}$ melancolia, o olhar para trás parece ser feito de olhos vendados, pois não se consegue encontrar os motivos de sua apreensão. [...]

Mas, se a nostalgia funda-se na esperança do retorno, a melancolia parece abandonar-se numa desesperança, ou na impossibilidade de toda esperança. [...] Ao ser privado de sua esperança, mesmo que seja esta "esperança” pouco esperançosa, o ser nostálgico dissolve-se completamente em sua melancolia. ${ }^{58}$

Assim,

A nostalgia está ligada à questão da origem ou, no limite, do reconhecimento da origem como tal, colocados como referência de sua própria

\footnotetext{
${ }^{57}$ Menezes, P. À meia-luz - Cinema e sexualidade nos anos 70. op. cit., p. 92.

${ }^{58}$ Menezes, P. À meia-luz - Cinema e sexualidade nos anos 70. op. cit., pp. 95-96. Grifos do autor.
} 
identidade, de sua localização no mundo e da percepção dos lugares de sua própria dor. Nesta aproximação, o tempo de então se contrapõe com ao tempo de antes, que reaparece depurado de seus desastres e de suas dores. A perda definitiva é a perda ou a dissipação deste lugar. ${ }^{59}$

A melancolia, por sua vez,

[...] fixa um lugar que não é mais perceptível como tal e portanto envolve o melancólico em uma dor que por sua própria indefinição toma conta de seu ser de uma maneira a um só tempo irrevogável e indelével. ${ }^{60}$

Assim, tem-se que o viajante é aquele que chega, e parte. O estrangeiro é aquele que chega, e permanece. O exilado seria aquele que chega, não pode partir e deposita suas esperanças no reencontro com o local (ou tempo) do qual está privado. Travis é, entretanto, um melancólico, e por isso um errante ${ }^{61}$.

Pela constituição da indeterminação de seu passado, o melancólico vai perder suas ligações com o presente e, a partir de então, parecerá viver uma vida que não é a sua, ou que não é mais a sua. Sua busca é fadada ao fracasso, pois ele nem mesmo tem mais as referências do que procurar. Mas ele procura assim mesmo, revira sua memória (que memória é esta?), incessantemente, no sentido de tentar determinar alguma coisa que lhe devolva pelo menos algumas referências. Assim, se podemos pensar o nostálgico como um exilado, que participa de diferentes espaços e de diferentes tempos, sendo um estrangeiro que não tem mais o poder de retornar, o melancólico experimenta o exílio dentro de si mesmo, não existindo diferentes espaços nem diferentes tempos que pudessem ser recobertos. É um errante, pois é um estrangeiro em seu próprio lugar. Sua desesperança advém justamente do fato de não ter mesmo para onde voltar, como o nostálgico, pois o melancólico, no limite, nunca saiu do mesmo lugar. Ou, o que é ainda pior, privado da relação com suas raízes, ele é um estranho em qualquer lugar. Portanto, na melancolia, o dilaceramento é acompanhado da impossibilidade do retorno, pois o seu lugar é aquele mesmo em que ele está,

\footnotetext{
${ }^{59}$ Menezes, P. À meia-luz - Cinema e sexualidade nos anos 70. op. cit., p. 96.

${ }^{60}$ Menezes, P. À meia-luz - Cinema e sexualidade nos anos 70. op. cit., p. 96.

${ }^{61}$ Freud também menciona a ausência do elemento que se perdeu no melancólico: "[...] Ainda em outros casos nos sentimos justificados em sustentar a crença de que uma perda dessa espécie ocorreu; não podemos, porém, ver claramente o que foi perdido, sendo de todo razoável supor que também o paciente não pode conscientemente perceber o que perdeu."; "a inibição do melancólico nos parece enigmática porque não podemos ver o que é que o está absorvendo tão completamente." (FrEUD, Sigmund. "Luto e melancolia". In:__. Edição standard brasileira das obras psicológicas completas de Sigmund Freud (Vol. XIV). Rio de Janeiro: Imago, 1974, p. 277; p. 278).
} 
como tempo e origem, mas ao mesmo tempo ele não se sente lá. O melancólico, nesta acepção, não experimenta nem desejo nem decepção: afinal, para onde voltar se estou aqui e se daqui eu nunca saí? ${ }^{62}$

Travis, é claro, tem uma origem. Mas sua origem não é reconhecida, e por isso não há nostalgia, mas uma busca na memória sobre seu pertencimento. Ele comprou um lote em Paris, pelo correio, mas nunca se mudou para lá. Por mais que queira acreditar que sua origem é Paris, quando bebe fala para Hunter que o pertencimento de sua mãe a Paris era uma piada, tão corriqueira, que seu pai acabou acreditando nela - e ele também.

Travis não idealiza Paris, mesmo porque ele teria apenas sido concebido lá, não seria, portanto, um retorno pós-exílio. Não há exílio, pois, ao contrário, Travis vive na estrada constantemente. Ele busca referências, mas não as encontra nem na origem de sua mãe, tampouco na família de seu irmão, em seu filho, ou em sua ex-mulher. Sua origem não está nos outros, tampouco em uma terra natal - ele não chega a dizer onde nasceu. Travis caminha para procurar sua origem - mas dentro de si mesmo.

\subsection{Nova itinerância: a busca por Jane}

O objeto momentâneo de busca do melancólico Travis será Jane. Ele não quer encontrá-la para tê-la de volta, mas para que Hunter fique com ela. Travis deseja, desse modo, unir mãe e filho por meio de uma busca temporária em cujo objetivo final ele não está incluso. Ele opera, portanto, apenas como realizador: participará dos meios, mas não dos fins dessa união, não sendo, assim, contemplado pelo objetivo de sua itinerância.

Goldmann vê o período abrangido por Paris, Texas como o contorno de uma errância contínua de Travis, pois o filme exibe itinerâncias temporárias que têm rumo bem definido. O filme mostraria, assim, uma pausa na errância de Travis, que o permitiria retornar à fonte de sua dor, retomar suas "origens". Para isso Travis precisaria passar por um processo de infantilização, uma regressão responsável por sua perda de autonomia, inércia e necessidade de ser guiado pelos outros. Esse refúgio na infância o faria retornar às origens de sua própria família, buscar raízes que, frágeis, não existiriam senão na forma de simulacro: uma foto do terreno onde ele talvez tenha sido concebido. Ainda segundo Goldmann, essa regressão seria um processo de conhecimento, e daí decorreriam os medos e obstinações infantis de Travis, como o receio de andar de avião

\footnotetext{
${ }^{62}$ Menezes, P. À meia-luz - Cinema e sexualidade nos anos 70. op. cit., p. 97. Grifos do autor.
} 
e a exigência de seguir viagem no mesmo carro; além de sua desconfiança em relação aos adultos que tentam ajudá-lo. O reencontro com seu filho, entretanto, acabaria por deslanchar um movimento de reconquista de sua autonomia - uma vez aceito como pai, Travis teria deixado, paulatinamente, de ver-se a si mesmo como uma criança. ${ }^{63}$

Que o filme seja uma pausa na errância de Travis, é de se concordar, mas vale explicitar que essa pausa é igualmente marcada por uma não-fixidez, ou seja, não se trata exatamente de uma pausa na errância, mas da transformação temporária dessa errância em itinerância. Ainda que tenha um objetivo definido, Travis segue na estrada, no não-lugar, em circulação, e isso lhe é fundamental. Infantilizado no início, desligado de questões práticas em sua vida, Travis é ingênuo a ponto de pensar que seu irmão faz todos os painéis publicitários que ele vê. O reencontro com seu filho coincide com um processo de amadurecimento de Travis, e é mesmo provável que, de certo modo, Hunter seja responsável por tal processo. Em todo o caso, o refúgio na infância não faz Travis retornar a suas origens. O terreno em Paris (ou, mais precisamente, a foto desse terreno) havia sido comprado antes da separação de Jane. Não é a busca de uma origem, mas a dissolução do mito de uma família feliz - composta por Travis, Jane e Hunter - que o faz errar. Errando, Travis se perde de suas raízes familiares, ele não as busca. Tanto é que passa quatro anos sem ter contato com seu irmão e seu filho, e após a errância não lembra ao menos o nome de solteira de sua mãe, ou por que comprara o terreno. Quando Travis parte em sua errância, o mito da felicidade em Paris já está esgotado, ele já é um melancólico, não tem objeto no qual se projete alguma esperança de arraigamento.

Se Travis aparece no filme infantilizado, Hunter, ao contrário, comporta-se como um adulto desde o início - é ele quem decide ver a sua mãe, quem escuta a confissão de um homem bêbado, quem guia as relações iniciais com Travis. Hunter seguirá adulto até o encontro final com sua mãe, nos braços de quem se entregará sem oscilar, como a criança que de fato ele é. ${ }^{64}$ Essa será a grande busca de "Hunter" (“o caçador", em inglês) no filme: a volta a sua família de origem, na qual seu papel é aquele apropriado a sua idade. ${ }^{65}$

Essa busca fica expressa como metáfora na explicação da teoria científica do bigue-bangue que Hunter dá a seu pai:

HuNTER: Toda a galáxia e o universo estavam comprimidos num pontinho bem pequeno. Sabe o que aconteceu?

\footnotetext{
${ }^{63}$ Cf. Goldmann, A. L'errance dans le cinéma contemporain. op. cit., p. 106.

${ }^{64}$ Cf. Goldmann, A. L'errance dans le cinéma contemporain. op. cit., p. 107.

${ }^{65}$ Também é de se notar a semelhança entre o nome "Travis" e o verbo "to travel", "viajar".
} 
TRAVIS: O quê?

HUNTER: Ele explodiu e as fagulhas se espalharam por todas as partes. Daí o espaço se formou. Só havia gás.

TRAVIS: E a Terra?

HUNTER: A Terra também era parte desse gás. Daí, o sol se formou, e era tão quente que a Terra virou uma grande bola coberta pelo oceano. Havia animais marinhos, centenas de vulcões submarinos entraram em erupção. Em contato com a água, as lavas formaram as rochas e surgiu a Terra.

Nas palavras de Hunter, o bigue-bangue se parece com seu núcleo familiar: há uma união primeira que é rompida, fazendo com que se espalhem partículas (fagulhas ou pessoas) que originam planetas individuais. Tal qual esse universo, a família de Hunter está dispersa, e seus pedaços ele tenta reunir junto a Travis. A busca por Jane aparece como um modo de voltar a um estágio inicial, mítico e irrevogável - que precedeu a explosão inicial, causadora da desintegração.

Quando Hunter telefona para Anne e Walter, a pedido de Travis, e os comunica que está "viajando", fica comprovada a hipótese de que Hunter seria afastado do casal pela presença de Travis, e Anne e Walter agora terão que enfrentar seus próprios conflitos - que Anne temia serem incontornáveis quando se questionou sobre a possibilidade do casal seguir unido sem Hunter. Walter fuma um cigarro no jardim, nervoso e triste, enquanto Anne se deita na cama de Hunter e cantarola uma música - a distância entre eles nesse momento de tristeza mostra que a partida de Hunter deverá realmente desagregar o casal.

Em um quarto de hotel, Travis dá a Hunter a fotografia que carregava, o que fortalece a idéia de que ele é, acima de tudo, um melancólico, e não um nostálgico. Travis se desfaz da fotografia que carregava porque ele não parte à busca dessa família harmônica que só existe enquanto mito. É provável que ele fosse nostálgico, idealizando essa vida feliz com sua família em Paris, no Texas. Mas, se isso ocorreu, perdeu-se antes do início de sua andança. Ele não erra à procura de uma família mítica; apresenta, antes, um abandono paulatino do ideal de família, e mesmo de felicidade. O passado é igualmente objeto do qual Travis se desfaz pouco a pouco. Recupera algumas lembranças, mas não insiste nelas. Após realizar a missão auto-atribuída de entregar o filho à mãe, Travis desprender-se-á de qualquer ideal de vida em família - ele partirá só, viverá só.

Antes de chegarem a Houston, Hunter e Travis conversam via walkie-talkie. Hunter está na caçamba da caminhonete e, mais uma vez, explica ao seu pai uma teoria científica. 
HUNTER: Pai, se um cara abandona um bebê e viaja à velocidade da luz, se viajar à velocidade da luz e voltar, uma hora depois, ele seria uma hora mais velho, mas o bebê seria um velho.

TRAVIS: E quanto tempo levaria até Houston?

HunTER: Acho que... levaria 3 segundos.

TRAVIS: Câmbio, não entendi o fim.

HunTER: Bastariam 3 segundos para ir da Califórnia a Houston à velocidade da luz.

Quando ele fala "à velocidade da luz", aparece na tela o letreiro de um motel em que a oscilação de luzes que piscam dá a impressão de que cavalos estão correndo. São cavalos de neon vermelho. Essa cena mostra ao espectador uma velocidade de luz (que pisca rapidamente) plausível e palpável na vivência humana - pelo menos, até aquele momento do desenvolvimento técnico.

A chegada a Houston é marcada pela aparição de grandes prédios e pelo tráfego intenso de veículos, até então inédito. Travis e Hunter conversam, mas o espectador vê apenas imagens da cidade, uma paisagem bastante diferente daquela do deserto. O banco ao qual vão à procura de Jane tem uma estrutura metálica grande, sob a qual é possível realizar operações sem sair do carro. É manhã e, nessa paisagem urbana, o sol surge no horizonte por entre os arranha-céus. Hunter e Travis se separaram para procurar por Jane, e se comunicam pelo walkie-talkie, pelo qual Hunter, que foi quem sugeriu comprar os aparelhos, diz: “eu disse que não eram só brinquedinhos, câmbio". Travis utiliza seu par de binóculos, e através de suas lentes o espectador pode ver, como se fosse Travis, primeiramente Hunter, e então um percurso que capta janelas espelhadas de um edifício comercial e, no alto de um guindaste, uma bandeira dos Estados Unidos que tremula, tendo o céu como fundo. O espectador percebe que, além de um ritmo diferente do usual da modernidade, Travis tem um olhar pouco usual. E a bandeira coroa essa aventura que ocorre sobre o solo americano.

O sol ainda mais forte marca a passagem do tempo, e Hunter dorme. Quando acorda, olha para cima e vê o pouso de um helicóptero sobre um edifício altíssimo, e o mesmo guindaste que ergue a bandeira estadunidense. Quando Hunter olha para frente, lá está a mulher loira, ouvindo walkman, que ele acredita ser Jane. Pelo walkie-talkie ele acorda Travis, e seguem o carro vermelho no qual, supostamente, ela estaria.

Para encontrar Jane, Hunter e Travis, que chegaram em Houston há pouco, voltam à estrada. A perseguição se dá por grandes vias e viadutos, as pontes que 
reunirão um filho à sua mãe. Nessa grande cidade, há muitos carros, mas Hunter (o “caçador”) é bastante instintivo, e diz ter certeza sobre qual deles é o de Jane.

A perseguição termina no subúrbio da cidade, onde Travis pára seu carro atrás do qual acreditam ser de Jane. O carro é vermelho, e Hunter e Travis vestem vermelho. O filme ganha essa coloração avermelhada, que se intensificará, até ser substituída pela predominância de tons esverdeados.

A Estátua da Liberdade surge no filme, pintada em uma parede, e atrás dela está a silhueta de uma cidade (de Nova York, supõe-se). Embora conhecida como Estátua da Liberdade, tal obra, vale lembrar, chama-se A Liberdade Iluminando o Mundo. "A partir da Revolução Francesa foram feitas várias tentativas de traduzir em linguagem visual os ideais de liberdade, igualdade e fraternidade" ${ }^{\circ 6}$, explica Peter Burke. Liberdade guiando o povo, de Delacroix, é possivelmente a pintura mais conhecida com esse objetivo, e nela se consolidou a simbolização da liberdade como uma mulher ${ }^{67}$. Na Estátua da Liberdade, presente francês aos Estados Unidos, essa corriqueira representação da Liberdade com feições femininas se repete. Ela carrega uma luz na mão, fortalecendo a idéia de seu nome original. Na outra mão, carrega uma tabuleta onde está escrito "4 de julho de 1776 "68. É justamente onde deveria estar a Constituição Americana que, na representação da estátua feita na parede do local onde Jane e Travis se encontrarão, há uma porta.

Como mostrou Simmel em seu ensaio, a porta é responsável pela separação entre o limitado e o ilimitado ${ }^{69}$, entre o privado e a liberdade do mundo. O ideal de liberdade está representado em uma parede externa do local onde trabalha Jane, e no lugar onde deveria haver regras (as leis da Constituição), está a porta que representa, ela sim, o acesso à liberdade. No lado de dentro da porta não se encontrará um ambiente familiar, mas um local de prostituição, pelo qual circulam mulheres vestidas de enfermeira, faxineira, ao agrado dos fetiches do público. É nesse local que Travis e Jane se encontrarão. Ele a vê, primeiramente, de costas, vestindo um pulôver vermelho com

\footnotetext{
${ }^{66}$ Burke, Peter. Testemunha ocular. Bauru: EDUSC, 2004, p.76.

${ }^{67}$ Sobre Liberdade guiando o povo, consultar: BURKE, Peter. Testemunha ocular. op. cit., pp.76-78; p. 228.

${ }^{68}$ Sobre a mensagem política implícita na Constituição que a Liberdade carrega, consultar BURKE, Peter. Testemunha ocular. op. cit., pp.76-79, onde se pode ler: "A mensagem política da estátua torna-se explícita, para aqueles que conseguem lê-la, pela tabuleta que ela segura, onde se lê '4 de julho de 1776'. Quaisquer que tenham sido as idéias do escultor francês, os indícios iconográficos levam à conclusão de que a Revolução Americana está sendo publicamente celebrada, antes que a Francesa. O halo, substituindo o barrete frígio, confere à Liberdade a feição de uma santa, de tal forma que é tentador especular se imigrantes italianos ou poloneses aproximando-se da ilha de Ellis, onde eram 'processados' antes de entrar nos Estados Unidos, não podem ter pensado que estavam observando a Virgem Maria, patrona dos marinheiros, 'A Estrela do Mar'” (BURKE, Peter. Testemunha ocular. op. cit., pp. 78-79).

${ }^{69}$ Em Simmel, G. "Puente y puerta". op. cit., p. 49.
} 
decote nas costas. Ela conversa com um homem, que diz a Travis "Senhor? Senhor, não devia estar aqui. É muito cedo, as garotas estão embaixo”. Ele sai sem que Jane o veja quando ela se vira, ele já está de costas. É aí que o espectador tem certeza de que se trata de Jane, de que os viadutos - as pontes - que Hunter e Travis percorreram eram aqueles que reuniriam mãe e filho.

Travis entra em uma das cabines do andar inferior, onde se senta à frente da vitrine que, até aqui, funciona como espelho. Pelo telefone, diz querer "uma loira, baixinha, de cabelos lisos, uns 25 anos". Quando a luz se acende na cabine, e Travis pode ver o outro lado - quem está lá não é Jane, mas a enfermeira Bibs, com quem ele já havia encontrado no andar superior. Enquanto ela fala, ele se mexe para ver se ela pode vê-lo, mas ela olha sempre na mesma direção. À vontade naquele ambiente, a enfermeira Bibs diz que já trabalhou demais, não parece estar muito animada. Ela servirá como demonstração do quão inábil é Jane com sua imagem nesse ambiente, do quão constrangida ela se sente. Travis vai a outra cabine.

\subsubsection{Reencontro}

O lugar onde Jane e Travis se encontram é expressivo, para não dizer paradigmático, da época em que vivem. É um lugar aonde os homens vão para falar porque na vida cotidiana não há mais tempo para isso. Da primeira vez, entretanto, Jane não sabe que fala com Travis. O encontro ocorre sem que Jane o veja, ou mesmo saiba de sua presença. A comunicação é, nesse lugar aonde se vai para falar, de qualquer modo, incompleta, pois o homem vê a mulher, mas ela não o vê. Ela fica ao dispor do usuário, tendo portanto que conversar sobre o que interessa a ele - como o lugar é parte do prostíbulo, imagina-se que se trate de uma espécie de "sexo verbal". Além disso, a fala só chega ao receptor após passar por uma aparelhagem técnica.

$\mathrm{O}$ modo como se dá o encontro entre os dois, inclusive por se contrapor à postura da enfermeira Bibs, mostra a inabilidade que Jane possui para lidar com o aparato técnico ao qual está submetida, e mesmo uma dificuldade de encarar sua imagem refletida no vidro pelo qual Travis a vê. Travis está com o telefone na mão. Uma voz feminina diz, fraca, “Oi”, e pigarreia. Jane logo expõe seu constrangimento com aquela situação: “Tem alguém aí? Bem, se a lâmpada está acesa, então deve ter. Hum? Se não quiser falar, tudo bem. Isso também me acontece. Às vezes também gosto de ficar calada. Posso me sentar?" Só então Travis a olha e constata: é mesmo Jane. 
Ela pergunta novamente: "se importa se eu me sentar?" E Travis diz sua primeira palavra para ela, após quatro anos: "não". Enquanto conversam, Jane olha para um espelho, e Travis olha para ela. Jane, tímida com sua própria imagem, muitas vezes desvia o olhar de seu reflexo no espelho, olhando para os lados ou para baixo. Ela pergunta se é a primeira vez que ele (que ela não sabe quem é) vai lá, quando Travis diz que sim, Jane ri e diz que leva um tempo para se acostumar ao fato de que ele pode vêla, mas ela não o vê. Travis está chorando em silêncio - saem lágrimas de seus olhos, mas ele sorri ao vê-la. Jane se diz "uma boa ouvinte". Travis permanece em silêncio, e quando Jane propõe tirar seu suéter, ele pede que não o faça. Ela se desculpa, diz que não sabe o que ele quer, “eu não quero nada”, diz Travis. "Então por que veio aqui?", Jane lhe pergunta. "Quero falar com você”, ele responde. Jane diz que está lá para ouvir e falar. Ela tenta conduzir a conversa entre eles de maneira natural, mas está igualmente constrangida. É um ambiente frio, permeado todo pela técnica - presente no vidro que de um lado é transparente, do outro é espelho, no telefone através do qual eles conversam, e mesmo nos objetos dessa sala onde ela está, que imita um quarto de hotel: há lá uma televisão fora de sintonia, um telefone, um abajur e um rádio-relógio.

Travis não se identifica. Quer saber sobre a vida de Jane, e para isso demonstra uma agressividade mesclada a ciúmes que dá pistas da intensidade da briga que os separou:

TRAVIS: Então, o que mais você faz?

JANE: Na verdade, nada. Não temos permissão para ver clientes fora daqui.

TRAVIS: E onde os vêem? Vai para casa com eles?

JANE: Não, de jeito nenhum. Não podemos ter relações com os clientes fora daqui.

TRAVIS: Nem se quiserem? Quero dizer, é o que acontece em todas essas casas. Quanto dinheiro ganha com isso? Quero dizer, quanto ganha por fora?

JANE: Desculpe-me, senhor, talvez queira falar com outra moça.

TRAVIS: Não! Não, não! Por favor, por favor. Não vá embora, por favor.

Travis se desculpa, Jane permanece na sala. Ele, no entanto, tira o fone de seu ouvido, o coloca sobre a bancada, fora do gancho, e parte. Jane não percebe, e continua falando com ele: "Sei que é difícil falar com uma estranha às vezes. Relaxe. Relaxe e diga-me o que lhe preocupa. Vou ouvir você. Sou uma boa ouvinte. Faço isso o tempo todo".

O espectador pode ver o espelho no qual Jane se olha. Em volta dele, há um isolamento acústico precário, com forro à mostra. Jane, como disse, está lá para falar e 
ouvir. Mas, nesse diálogo no qual o olhar recai sobre uma só pessoa - ela -, não há troca de olhares, aliás, muito pouco se pode verdadeiramente trocar nesse ambiente, já que inclusive os diálogos estão subordinados aos desejos de apenas um dos interlocutores. Através do vidro, o olhar trafega em um único sentido. As mulheres que estão nas vitrines não sabem ao menos com quem falam, já os homens fabricam as personagens com quem desejam conversar. Nessa relação em que não há toque ou troca de olhares, a fala é essencial. É uma fala, entretanto, que não chega a se constituir como uma comunicação efetiva, pois a voz perpassa um telefone e a troca entre os interlocutores é toda permeada pela técnica, além de estar limitada às vontades masculinas ${ }^{70}$.

$\mathrm{Na}$ cena seguinte ao encontro de Travis e Jane, ele está novamente dentro do carro em movimento. Hunter pergunta “ela estava lá, não é?" e Travis acena que sim com a cabeça. Breca a caminhonete bruscamente, anda de ré e vira em uma rua onde há apenas casas e construções precárias, típicas do subúrbio. De todas as possibilidades de caminhos expressas em ruas, pontes, estradas, e viadutos, Travis vira em uma rua pela qual passam poucos carros, quase sem cruzamentos, e estaciona lá, pois não quer seguir em trânsito. Travis encontrou o local de trabalho de Jane, e assim terminará sua itinerância, ele poderá então viajar rumo a si, na tranqüilidade de um lugar sem cruzamentos que convidam, a todo tempo, o motorista a desviar seu rumo. A itinerância termina, mas seu objetivo ainda não foi cumprido.

Após ter encontrado a mãe de Hunter, Travis se separa de modo mais brutal do universo infantil - à luz do dia, suas mãos seguram a foto de Paris, no Texas, sobre um balcão de madeira. Coloca um pequeno copo com bebida alcoólica do lado da foto e Hunter lhe pergunta “o que é isso?” Travis bebe cerveja diretamente da garrafa e responde:

Travis: Um lote vazio. Comprei esse lote quando estávamos todos juntos, com sua mãe. Pensei que um dia moraríamos lá.

HUNTER: Onde?

TRAVIS: Paris, Texas

HUNTER: Onde fica isso?

TRAVIS: Perto do Rio Vermelho. Você gosta?

HuNTER: Do quê, de viver no lixo?

Travis, que está visivelmente bêbado, bebe mais.

HUNTER: Por que você bebe essa porcaria? Isso fede!

\footnotetext{
${ }^{70}$ Uma fala que, evidentemente, em nada se parece com o aconselhamento existente nas antigas narrativas, descrito por Walter Benjamin. (O assunto foi discutido no Capítulo 1 deste trabalho. Ver também BENJAMIN, W. "O Narrador - Considerações sobre a obra de Nikolai Leskov". op. cit.).
} 
Hunter pega sua garrafa de refrigerante e caminha para fora do bar.

TRAVIS: Aonde você vai?

HUNTER: Para o carro.

Travis esvazia o copo e pede mais uma bebida.

Hunter, que sempre pareceu mais adulto que Travis, age como tal, demonstrando muita independência. Espera sozinho no carro, enquanto Travis, após ter confessado ao filho que teve, no passado, a esperança de viver com ele e Jane em Paris, se embriaga.

Até aqui, predominava no filme a cor vermelha - expressa sobretudo pela roupa de Jane, Travis e Hunter. Quando anoitece, eles caminham a pé por uma rua escura, onde folhas de jornal arrastam-se pelo chão, levadas pelo vento. A cena tem coloração esverdeada, tom que predomina quando Hunter assume sua infantilidade. Travis se apóia em Hunter, que o ajuda a caminhar. Nessa inversão de papéis, Hunter tem que cuidar de seu pai, alcoolizado, sem que isso signifique um reforço da infantilização de Travis ou o amadurecimento de Hunter, pois Hunter antes tomara um refrigerante, enquanto Travis se embriagava, ou seja, o estado de Travis é conseqüência de um ato bastante adulto, do qual Hunter não participou.

Em uma sala ao lado de uma lavanderia, onde há uma poltrona e um sofá muito precários, eles se instalam. Novamente o passado é evocado, e em uma conversa na qual Hunter pouco entende sobre o que Travis fala, há a predominância da cor vermelha: em suas roupas, na máquina de refrigerante no fundo da sala. Travis pronuncia novas confissões:

TRAVIS: Não é um lugar para se trazer uma mulher de classe. O que você acha? Se tivesse uma mulher de classe, a traria aqui?

HUNTER: O que é uma mulher de classe?

Travis deita no sofá e diz:

TRAVIS: Hãã... a minha mãe. Não a sua mãe. A minha mãe. Ela não era uma mulher de classe, ela era... Ela nunca quis ser uma mulher de classe. Nunca fingiu que era uma mulher de classe.

HUNTER: Então como ela era?

TRAVIS: Era simples, boa... Ela era muito boa. Mas meu pai... Ele tinha uma idéia na cabeça... que era como uma doença.

HUNTER: Que idéia?

TRAVIS: A respeito dela. Ele olhava para ela, mas não a via. Ele só via aquela idéia. Ele dizia às pessoas que ela era de Paris. Era uma grande piada. Mas ele falava tanto que acabou acreditando nisso. Acreditava mesmo. Ela... Ela ficava muito sem graça. Ela... Ela era tão tímida... 
Travis acaba a frase e dorme. A última parte de sua fala revela, por fim, que o pertencimento de Travis a Paris não passava de uma grande piada. Sua mãe não era de lá, fato que induz ao pensamento de que tampouco Travis fora concebido lá. Se Paris foi para Travis uma cidade mítica à qual ele atribuiu uma felicidade conjugal e familiar, e por isso comprou (a fotografia de) um terreno pelo correio, após o rompimento com Jane esse mito se desfaz. O encontro com Jane faz Travis lembrar-se de que Paris era apenas uma piada. Se Paris fosse um lugar ao qual (ainda) atribuísse uma promessa de felicidade, Travis teria ido a Paris, e não à busca de Jane. Se Paris é uma piada, ele realmente não tem raízes. E, sem raízes, ele se configura de fato como um melancólico, e não um nostálgico pois, afinal, se ele teve alguma nostalgia, ela foi baseada em um objeto completamente arbitrário: uma piada da qual não se podem emanar raízes.

E então, já sóbrio, mais uma vez Travis se comunicará por intermédio da técnica: ele grava uma fita para Hunter. Está sentado no banheiro de um hotel, sobre a banheira, frente a uma janela. Vê-se sua silhueta segurando o gravador, e, através da janela, a paisagem: três viadutos sobre uma quarta via. De novo, a cidade e suas pontes, avenidas e estradas simbolizam as possibilidades de traçar caminhos. Em um momento decisivo, aparecem inúmeras vias, e sobretudo aparecem pontes: que, nesse caso, unirão Hunter a Jane, mas separarão Travis deles.

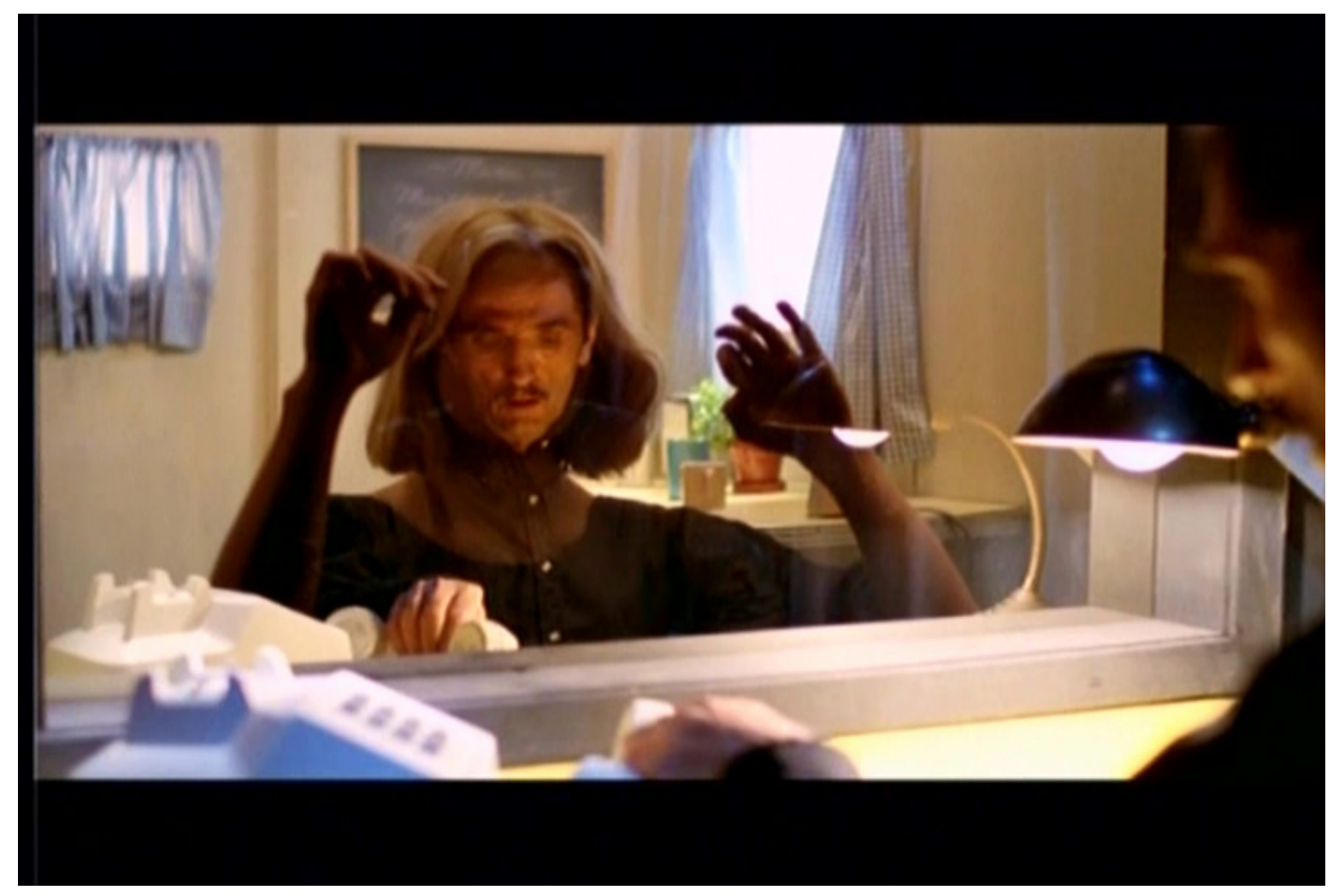



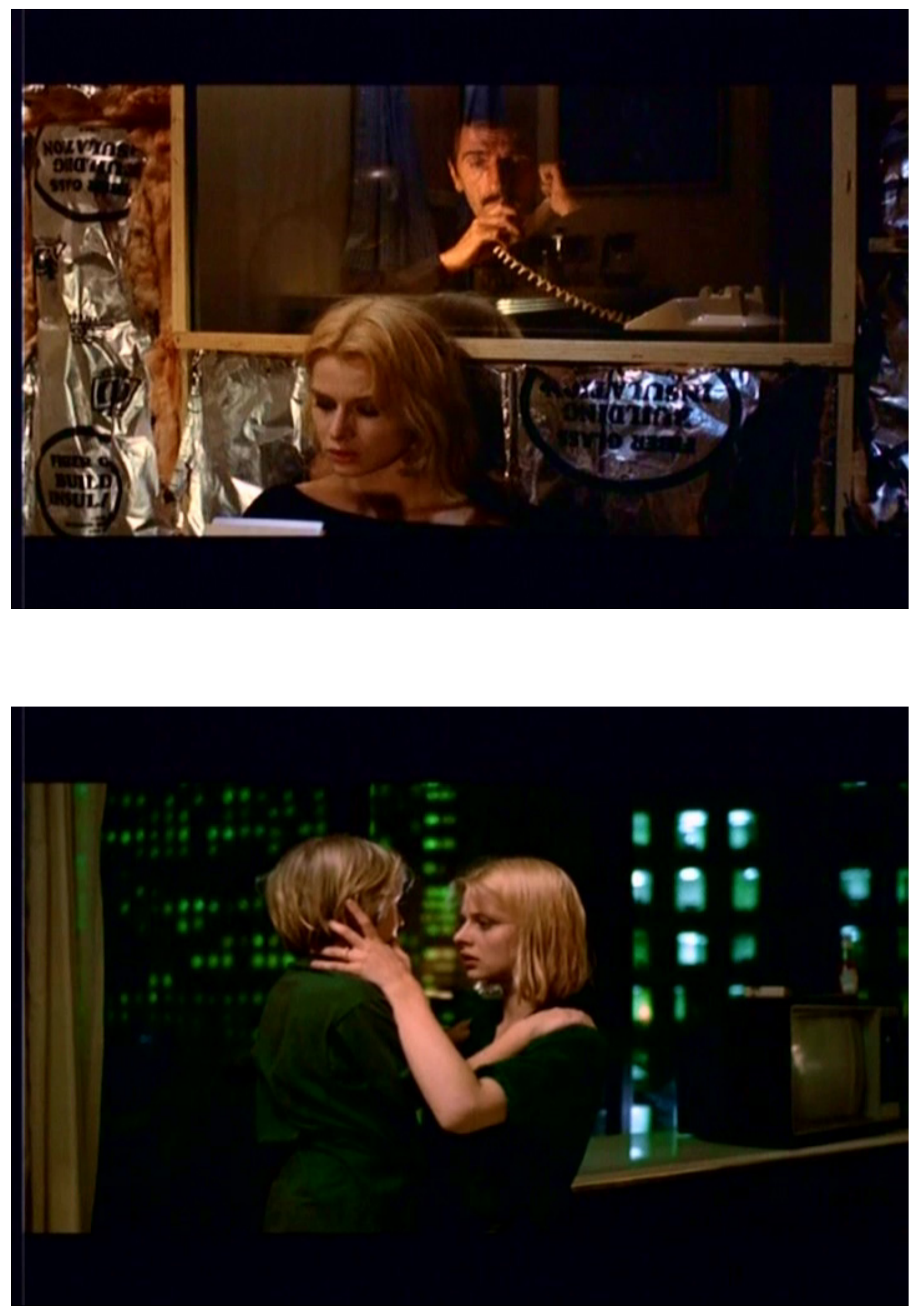


\subsubsection{Comunicação permeada pela técnica}

A fala que Travis grava para Hunter, permeada pela técnica, ganha uma dimensão temporal específica. Ela não ocorre ao vivo, não há conversa, mas um desabafo registrado em uma fita cassete pelo uso do gravador, que poderá ser reproduzido quantas vezes o queiram. Ao olhar para o gravador, Travis fala como se fosse a seu filho, pois somente assim lhe é possível estabelecer relações familiares.

TRAVIS: Hunter, sou eu. Estava com medo de nunca poder dizer isso a você pessoalmente. Então vou tentar desse jeito. Quando o vi pela primeira vez na casa do Walt eu esperava muitas coisas. Esperava mostrar-lhe que era o seu pai. E que me mostrasse quem você era. Mas minha esperança... não pôde se realizar. Agora eu tenho certeza. Seu lugar é junto da sua mãe.

Travis aparece dirigindo, ouvindo a reprodução de sua gravação, que segue:

TRAVIS: Seu lugar é junto da sua mãe. Eu separei vocês e é meu dever juntá-los novamente.

Quem ouve a gravação, então, é Hunter. Está sentado sobre a bancada do hotel, que tem janelas amplas e vista para os altos edificios da cidade. Ele olha para cima e o espectador acompanha sua visão: três prédios gigantescos, o do meio, mais alto, tem o topo cercado por neblina, e não se pode vê-lo por inteiro. A fala segue ininterrupta:

TRAVIS: Mas não posso ficar com vocês. Jamais poderei curar a ferida aberta. Mas é assim que deve ser. Não posso me lembrar do que houve. Ficou um vazio. Fez-me sentir tão só que não consegui me refazer. E, agora, tenho medo. Medo de fugir da realidade outra vez. Medo do que poderei descobrir. Mas o que mais temo é não enfrentar esse medo. Eu te amo, Hunter. Eu te amo mais do que minha própria vida.

Essa fala de Travis é típica de um melancólico, do modo como foi aqui caracterizado. Ele tem "um vazio" - ao contrário do nostálgico, ele não tem um ideal que o motive, e por isso empreenderá uma errância na qual mergulhará em si - daí o medo do que poderá encontrar, das memórias que podem vir a surgir ${ }^{71}$, medo mesmo do reencontro consigo. Antes de partir, entretanto, Travis vai até Jane e reconstrói a história de seu trauma, retoma isso de seu esquecimento, mas sem garantias de que será fixado em sua memória.

É esse o célebre diálogo do filme, entre Travis e Jane - um diálogo que, vale lembrar, é permeado pelo vidro espelhado e telefone -, o diálogo que revela ao espectador o que separou o casal e motivou a errância de Travis. Ele vai ao local onde ela trabalha, pega o telefone e fala com ela sem se identificar inicialmente, e sem que

\footnotetext{
${ }^{71} \mathrm{Ou}$, dito de outra forma: um medo de ter que, de alguma forma, lidar com seu esquecimento.
} 
ela possa vê-lo ${ }^{72}$. Os dois vestem preto, dotando esse reencontro de um caráter de despedida, honrando o luto de uma relação que terá aqui sua última etapa.

JANE: Oi!

TRAVIS: Oi. Posso lhe dizer uma coisa?

JANE: Claro, o que quiser.

TRAVIS: Vai demorar.

JANE: Tenho tempo de sobra.

Travis se movimenta para ver se Jane o vê, mas seu olhar segue intacto. Ela está sentada sobre uma bancada. Ele põe o fone sobre a mesa e se vira de costas para ela. Pega o fone e diz:

TRAVIS: Conheci essas pessoas.

JANE: Que pessoas?

TRAVIS: Duas pessoas. - pigarreia - Elas se amavam. A garota era... muito jovem, tinha uns 17 ou 18 anos, acho. O rapaz era... mais velho. Era bruto e rude. E ela era muito bonita, sabe?

JANE: Sei.

TRAVIS: E juntos eles transformavam tudo em aventura, e ela gostava disso. Uma simples ida ao mercado... já era uma aventura. Sempre riam de bobagens, ele adorava fazê-la sorrir. E... eles não se importavam muito com o resto, porque eles só queriam ficar juntos. Eles estavam sempre juntos.

JANE: Parece que eles eram muito felizes.

TRAVIS: Sim, eram. Eram felizes de verdade. E ele... ele a amava mais do que imaginava ser possível. Ele não suportava ficar longe dela durante o dia, quando ele ia trabalhar. Então, ele largou o emprego só para ficar em casa com ela. Aí ele arrumou outro emprego quando o dinheiro acabou, e largou de novo. Quando faltava dinheiro, ele arrumava outro trabalho, e depois se demitia novamente. Mas logo ela começou a se preocupar.

JANE: Com o quê?

TRAVIS: Dinheiro, eu acho. Não ter o suficiente, não saber quando chegaria o próximo cheque.

JANE: Sim, sei como é isso.

TRAVIS: Daí ele começou a ficar atormentado.

JANE: Como assim?

TRAVIS: Bem, ele sabia que tinha que trabalhar para sustentá-la... mas ele não suportava ficar longe dela.

JANE: Entendi.

TRAVIS: Quanto mais ele ficava longe dela, mais ele enlouquecia. Até que ele enlouqueceu de vez. Ele começou a imaginar todo o tipo de coisas.

JANE: Que coisas? ${ }^{72}$ Em alguns pontos desse diálogo, a tradução apresentada no filme foi refeita, tendo por base o inglês. A
transcrição do diálogo original e sua tradução conforme as legendas do filme estão disponíveis no Anexo 2. 
TRAVIS: Ele começou a achar que ela estava vendo outros caras secretamente. Ele voltava do trabalho e a acusava de ter passado o dia com outro. Ele gritava com ela e quebrava coisas no trailer.

JANE: No trailer?

TRAVIS: Sim, eles moravam num trailer.

JANE: Desculpe-me, senhor, mas não esteve aqui outro dia? Não quero ser intrometida.

TRAVIS: Não.

JANE: Oh... Por um minuto, pensei ter reconhecido a sua voz.

TRAVIS: Não, não era eu.

JANE: Sei... Por favor, continue.

TRAVIS: Então, ele começou a beber muito. E ele voltava tarde para casa para testá-la.

JANE: Como assim, "testá-la"?

TRAVIS: Para ver se ela sentia ciúmes. Ele queria que ela sentisse ciúmes, mas ela não sentia. Ela ficava preocupada com ele, mas isso o enfurecia ainda mais.

JANE: Por quê?

TRAVIS: Porque... ele pensava que, se ela nunca sentia ciúmes dele, era porque ela não se importava de verdade com ele. E os ciúmes seriam um sinal de que ela o amava. Então, uma noite, ela contou que estava grávida. De uns 3 ou 4 meses, e ele nem sabia. E, então, tudo mudou. Ele parou de beber e conseguiu um emprego fixo. Ele então ficou convencido de que ela o amava, pois carregava um filho dele. Ele ia se dedicar inteiramente a lhes dar um lar. Mas uma coisa estranha começou a acontecer.

JANE: O quê?

TRAVIS: No começo, ele não reparou, mas ela começou a mudar. Quando a criança nasceu, ela começou a ficar irritada com tudo. Até o bebê parecia uma injustiça para ela. Ele se esforçava para agradá-la: dava-lhe presentes, levava-a para jantar toda semana, mas nada parecia satisfazê-la. Durante dois anos, ele fez tudo para que voltassem a ser como eram quando se conheceram. Até que ele percebeu que isso seria impossível. Daí ele voltou a beber, e as coisas pioraram. Quando ele voltava tarde pra casa, ela não ficava mais preocupada, nem com ciúmes, só ficava furiosa. Ela o acusou de tê-la raptado só para fazer um filho. Dizia que sonhava em fugir, que só sonhava com isso. Via-se, à noite, correndo nua pela estrada. Cruzava os campos, os leitos dos rios, sempre correndo. E sempre que ela estava prestes a fugir, ele aparecia. Ele a impedia de algum modo. Ele sempre chegava para impedi-la. Quando ela lhe contava esses sonhos, ele acreditava. Ele sabia que, se não a impedisse, ela partiria para sempre. Então ele amarrou um guizo ao tornozelo dela para ouvir se ela tentasse se levantar da cama à noite. Mas ela aprendeu a abafar o som, colocando uma meia no sino, para sair da cama no meio da noite. Uma noite, a meia caiu e ele ouviu quando ela tentava fugir para a estrada. Ele pegou-a, a arrastou de volta para o trailer e prendeu-a no fogão com seu cinto. Deixou-a ali e voltou para a cama. Deitou-se e ouviu-a gritar. E ouviu seu filho gritar. Ele admirou-se porque não sentia mais nada, só queria dormir. E, pela primeira vez, ele queria estar bem longe, perdido num país enorme, onde ninguém o conhecesse, num lugar sem idioma ou ruas. Ele sonhou com esse lugar sem saber o nome. E quando ele acordou, ele 
estava num incêndio. Chamas azuis queimavam os lençóis da cama. Ele correu por entre as chamas atrás das únicas duas pessoas que ele amava. Mas eles tinham partido. Seus braços estavam pegando fogo, ele saiu de casa e rolou no chão molhado. Daí ele correu. Ele nunca olhou para trás para ver fogo, apenas correu. Correu até o sol nascer, até não poder correr mais. E quando o sol se pôs, ele voltou a correr. Ele correu assim por 5 dias... até que todo vestígio humano... desaparecesse.

Jane põe o rosto no espelho, tentando vê-lo.

JANE: Travis?

Ele olha para trás, a vê colada no vidro e vira a cadeira de frente para Jane. A imagem que o espectador vê é uma sobreposição da imagem de Travis e Jane.

TRAVIS: Se você apagar a luz, será que pode me ver?

JANE: Eu não sei. Nunca tentei - ela levanta e apaga a luz. Ele vira o abajur para seu rosto.

TRAVIS: Pode me ver?

JANE: Sim.

TRAVIS: Você me reconhece?

JANE: Oh! Travis!

TRAVIS: Trouxe Hunter comigo. Não quer vê-lo?

JANE: Sim. Quero tanto vê-lo que nem ouso mais imaginá-lo. Anne me mandava fotos dele, até que eu pedi que ela parasse. Não agüentava a dor de vê-lo crescer sem que eu estivesse lá.

TRAVIS: Por que não ficou com ele, Jane?

JANE: Eu não podia, Travis. Eu não tinha o que ele precisava. Não queria usá-lo para preencher meu vazio.

TRAVIS: Bom, ele precisa de você, Jane. E ele quer te ver.

JANE: Quer?

TRAVIS: Sim. Ele está esperando por você.

JANE: Onde?

TRAVIS: No centro, em um hotel. Le Meridien, quarto 1520. 1520.

Travis põe o fone no gancho. Jane se levanta, bate no vidro para que ele a ouça, e diz:

JANE: Você não está indo, está?

Ele pega o fone, olha em sua direção, e diz:

TRAVIS: Não posso vê-la, Jane. - (o espelho fora invertido quando ela apagou a luz).

JANE: Não vá embora ainda, não vá ainda.

Jane pega um relógio, para o qual olha enquanto fala, senta-se no chão, virada de costas para o vidro, mas apoiada sobre a parede deste. Diz:

JANE: Eu... Costumava fazer longos discursos para você depois que você partiu. Eu falava com você o tempo todo, mesmo estando sozinha. Conversei com você por meses a fio. Agora eu não sei o que dizer. Era mais fácil quando eu só imaginava você. Eu até imaginava você respondendo pra mim. Nós dois tínhamos longas conversas. Era quase como se você estivesse lá. Eu podia te ouvir, te ver, sentir teu cheiro. Eu podia ouvir tua voz. Às vezes tua voz me acordava. Acordava-me no meio da noite, como se você estivesse lá no quarto comigo. Então... tudo foi desaparecendo. Já não podia mais imaginar você. Tentei falar em voz alta com 
você, como costumava fazer, mas foi em vão. Eu não podia te ouvir. Então... eu desisti. Tudo parou. Você... simplesmente desapareceu. Agora eu estou trabalhando aqui... eu ouço sua voz o tempo todo. Todo homem... tem a sua voz.

Há um breve silêncio, Jane suspira e enxuga suas lágrimas. Travis diz:

TRAVIS: Direi ao Hunter que você vai vê-lo.

JANE: Travis?

TRAVIS: O quê?

JANE: Eu vou sim.

TRAVIS: Ótimo!

JANE: Hotel Le Meridien?

TRAVIS: Sim. Quarto 1520.

Travis desliga o telefone e parte. Jane segue sentada, chorando. Levanta-se, guarda o relógio, acende a luz e sai da sala. Assim acaba o encontro entre eles, com o acordo de entregar seu filho à mãe. Ele ainda verá, pela janela do hotel, o encontro dos dois, mas não terá contato com nenhum - o contato de Travis, agora, será consigo mesmo.

Nessa conversa, Travis reconstrói o ocorrido entre ele e Jane no momento mesmo em que conta a ela sua versão da história. Essa reconstrução, entretanto, abrange apenas fatos, não constitui uma rememoração. Ele não narra a história, mas a conta. Ele não retira os acontecimentos do passado no qual se encerram, simplesmente os evoca por uma fala perpassada pela técnica, mantendo em relação a Jane toda a impessoalidade já contida no ambiente em que estão. Travis conta a história em terceira pessoa, com distanciamento, como se fosse uma história de outrem, ele não permite se envolver, e por isso é que não revive os fatos. Jane, por sua vez, demora a entender que a história também lhe pertence, já que não pode ver quem é o homem que lhe fala - afinal, para ela, todo homem tem a voz de Travis, ou seja, em toda voz que ouve ela projeta a imagem dele.

O reencontro não é transformador, ele serve, antes, para comunicar a Jane que Hunter está lá, e ela deve buscá-lo. Um acontecimento rememorado se abre temporalmente. Mas esse foi apenas evocado, e, assim, em nada muda a vida do casal protagonista. O que poderá ser de fato transformador é o que está por ocorrer: o reencontro maternal de Hunter e Jane, no qual a preponderância de tonalidades esverdeadas é marcante.

$\mathrm{O}$ verde, valor médio, mediador entre o calor e o frio, o alto e o baixo, eqüidistante do azul celeste e do vermelho infernal - ambos absolutos e inacessíveis - é uma cor tranqüilizadora, refrescante, humana. $^{73}$

\footnotetext{
${ }^{73}$ Chevalier, J. et Gheerbrant, A. Dicionário de símbolos. op. cit., pp. 938-939. Grifos do autor.
} 
O encontro maternal virá mesmo a tranqüilizar o filme, será a concretização do objetivo de Travis, que é unir mãe e filho, e permitirá que ele siga sua errância. Um encontro que, ainda, libertará Hunter de sua busca (expressa mesmo em seu nome) e de seu amadurecimento precoce, e permitirá que se aflore a sua infância.

Parado em um estacionamento, quando o sol ainda termina de se pôr ao fundo do horizonte, está Travis. As luzes do estacionamento, já acesas, o iluminam e têm cor esverdeada, pela qual transmitem um sentimento de humanidade, uma tranqüilidade de quem encerrou uma itinerância com êxito. Travis observa, através das altas janelas do hotel, alguns metros acima, o reencontro entre Hunter e Jane.

Jane entra no quarto em que está Hunter. Por suas amplas janelas, é possível ver os prédios ao lado e uma privilegiada paisagem da cidade. É um andar alto, tem a distância vertical necessária para que tudo se torne claro - a cidade, o reencontro. Jane caminha devagar até Hunter, que brinca no chão. Fica parada a aproximadamente um metro de distância dele, que nota sua presença e se levanta. Veste uma camiseta grande, de adulto, que deve ser de Travis. Jane usa aliança, mas, se está casada, isso pouco importa. Importa seu reencontro com o filho, apenas. Não importa ao menos como viverão Hunter e Jane, ou se ela continuará em seu emprego, mas só o fato mesmo do reencontro. Hunter caminha até Jane e a abraça. Ela veste blusa e saia escuras, igualmente com tom esverdeado. Ambos têm o cabelo loiro na altura do pescoço e a pele bastante clara, têm uma fisionomia parecida. Jane então o abraça e acaricia. Ajoelha-se e olham-se nos olhos. Ele pega no cabelo de Jane e diz “Seu cabelo. Está molhado!” Eles se abraçam fortemente, ela sorri, levanta-se e gira com Hunter em seus braços.

A observação de Hunter e seu comentário de que os cabelos de Jane estão molhados são bastante infantis. Na presença materna, ele volta a ser criança. Uma infantilidade que se deixa libertar sobretudo no modo como Hunter se joga aos braços de sua mãe.

Do estacionamento, lá embaixo, Travis olha para esse abraço - a realização da "missão" que o levara à itinerância. Ele entra no carro e parte. Ouve-se a guitarra estridente de Ry Cooder. A luz do estacionamento, esverdeada, envolta pela aura do reencontro materno é substituída, tão logo Travis parte, por uma forte luz vermelha que ilumina seu rosto enquanto ele dirige. $\mathrm{O}$ espectador pode ver o carro do lado de fora, o farol do veículo também tem cor avermelhada. Travis está em uma estrada e a cidade, com seus altos edifícios iluminados, vai ficando para trás. Com Travis novamente errando pelas estradas, e a música que segue ininterrupta, surge na tela um fundo preto, sobre o qual se lê, com títulos em alemão, a dedicatória do filme e os créditos finais. 


\subsection{Volta à errância}

Annie Goldmann tributa à obra de Wenders a pouca valorização das personagens femininas (o que restringiria seu aparecimento à figura materna, anulando o lado mais propriamente feminino da mulher) e a predominância de personagens nos quais opera uma enorme cisão entre o indivíduo e o mundo ${ }^{74}$. Em Paris, Texas (como em No Decorrer do Tempo), a destruição do universo familiar seria a fonte principal de um abandono das raízes, da saída de alguém de seu meio original ${ }^{75}$. Entrecruzando tais características, poder-se-ia pensar que a destruição do ambiente familiar é tão forte, que gera um choque entre o indivíduo e o mundo. Ou, antes, que a pré-existência de uma tensão nesse âmbito acaba gerando a ruptura familiar.

O conflito amoroso não é, entretanto, característica específica desses sujeitos, mas elemento intrínseco aos relacionamentos. Estabelecer uma relação direta de causa e efeito entre a ruptura do ambiente familiar e a desilusão amorosa não é tarefa simples.

No estágio de primeira paixão, as relações eróticas rejeitam energicamente qualquer idéia de generalização: os amantes acham que nunca houve um amor como o deles; que nada pode se comparar, nem à pessoa amada, nem aos sentimentos por essa pessoa. Uma desavença - se é causa ou conseqüência, é difícil dizer - vem usualmente no momento em que este sentimento de singularidade desaparece da relação. Um certo ceticismo em relação a seu valor, em si mesmo e para eles, recai sobre a própria idéia de que sua relação, apesar de tudo, apenas realiza um destino genericamente humano; que, se não tivessem encontrado por acaso este companheiro em particular, teriam dado a mesma importância a outra pessoa. ${ }^{76}$

É difícil saber, também no caso de Travis, se esse abalo é o elemento que gera a cisão entre o indivíduo e o mundo, ou se a cisão é que gera o abalo na relação. O que Travis tem de específico, tal qual Robert de No Decurso do tempo, é que, a partir desse choque, ambos abandonam sua família e partem em uma errância. A ruptura, para Travis, não é algo ordinário, representa a quebra de um mito de felicidade em família que ele construíra com tal vigor que idealizara inclusive um local de origem que ele, de antemão, sabia ser parte de

${ }^{74}$ Cf. Goldmann, A. L'errance dans le cinéma contemporain. op. cit., pp. 69-70. À página 70, lê-se: "Indivíduo, mundo, como reconciliar os dois? [...] Em Paris, Texas, esse divórcio será mais pleno e beirará a loucura". Tradução livre de: "Individu, monde, comment réconcilier les deux? [...] Dans Paris, Texas, ce divorce sera plus total et aboutira à la demi-folie".

${ }^{75}$ Cf. Goldmann, A. L'errance dans le cinéma contemporain. op. cit., p. 88.

${ }^{76}$ SIMMEL, G. "O Estrangeiro". op. cit., p. 186. 
uma piada. A ruptura amorosa, entretanto, leva Travis a perder suas raízes. Se havia um pertencimento nostálgico, ele se dissolve em melancolia - é o desfalecimento de um local ideal(izado) onde Travis poderia conviver harmonicamente com sua família; trata-se da perda de uma utopia que tinha como foco a harmonia projetada em Paris.

A melancolia de Travis, que leva a seu rompimento com o mundo, é antes uma sensação de não-pertencimento, são cacos de algo que lhe era precioso, mas se quebrou. É uma ruptura com um futuro mítico em Paris, no Texas, mas também com o passado - ele pode enxergar, então, que não foi concebido em Paris, que seu pertencimento era apenas uma piada. Ele sabe que Paris era uma piada na vida de seus pais, e provavelmente sabe que à foto que carrega de seu lote não corresponde terreno algum. Tão profundo é o sentimento de desarraigamento, que Travis não consegue mais se fixar, seja temporal ou espacialmente. Por isso ele volta à errância, volta ao trânsito, volta-se à sua própria companhia, e por isso diz na gravação a Hunter que teme o que pode descobrir dentro de si.

A dificuldade de Travis em se fixar espacialmente reflete-se em uma dificuldade de fixação temporal e, errante, ele vive em um presente em suspensão, um tempo que roda sem destino, em uma ausência de linha temporal. E por isso é que Travis, embora não viva sob a temporalidade que predomina na modernidade, tampouco é capaz de seguir construindo uma história de si mesmo - ele participa desse presente em suspensão de modo passivo, não planeja nem rememora, apenas vive, sem que consiga, assim, construir algo - algo que se tornaria, ao menos, seu passado.

Não há história a contar. E tampouco há ouvintes. A rara comunicação que existe em Paris, Texas é permeada pela técnica, não há diálogos diretos. Travis fica quatro anos sem ver o irmão e nada tem a lhe contar. Walter tampouco tem algo a dizer, exceto sobre seu trabalho (e o diz de maneira genérica e rápida) e quanto pagara pela casa que comprou.

Dirá Goldmann que não é casual o fato de Travis e Jane se encontrarem em um peep-show no qual a mulher que fica atrás da vitrine não vende ao cliente seu corpo, mas sua conversa ${ }^{77}$ : "os clientes precisam menos de sexo do que de comunicação",78. Isso é representativo de uma sociedade que perdeu a narrativa, que não recupera histórias, que não tem tempo para conversar. A conversa que se obtém no peep-show é, entretanto, permeada pela técnica - a voz passa pelo telefone, a imagem por um vidro que, se de um lado é transparente, do outro é espelhado.

\footnotetext{
${ }^{77}$ Cf. Goldmann, A. L'errance dans le cinéma contemporain. op. cit., p. 107.

${ }^{78}$ Goldmann, A. L'errance dans le cinéma contemporain. op. cit., p. 107. Traduzido livremente de: "Les clients ont moins besoin de sexe que de communication".
} 
A conversa de Travis com Hunter tem a mesma característica - seja pelo walkietalkie, seja pelo gravador, a técnica a permeia e ela não ocorre em um momento presente. Hunter não diz a Walter e Anne que quer encontrar Jane, ele parte e os comunica depois, por telefone, que está “viajando". Após quatro anos sem se verem, ninguém relembra, ninguém conta o que se passou - o que retoma o passado são apenas as imagens do filme em Super-8, sobre o qual não há conversa, mas certo incômodo.

O encontro entre Jane e Travis não recupera o que ocorreu durante o tempo em que estiveram separados, apenas mostra rapidamente ao espectador como fora $o$ momento da separação e o subjacente a esse, sem que haja qualquer rememoração. Travis conta a Jane a história deles, e ela conta como viveu sem Travis, mas não há diálogo, não há troca, não há o que Benjamin chamava de aconselhamento ${ }^{79}$, mesmo porque não há senão a evocação de um acontecimento que segue preso ao passado, ou seja, o acontecimento passado é lembrado apenas como tal, factualmente, e ainda com o distanciamento que uma história de si adquire quando narrada em terceira pessoa, sem grande envolvimento ou senso de propriedade sobre o que está sendo contado.

Goldmann dirá que o que permite a comunicação entre Travis e Jane é o $\operatorname{artifício~}^{80}$. Mas poder-se-ia perguntar: que tipo de comunicação é essa? Será que se consolida uma comunicação, com tanto aparato técnico a permeá-la, e sem a troca de olhares? A comunicação é tão interceptada pela técnica que acaba se esvaziando de conteúdo. Não há troca. A fala situa o espectador mais do que mobiliza as reminiscências do casal. Ocorrem discursos, mas não há diálogo, a não ser aquele de função prática, no qual Travis diz a Jane que Hunter a espera no quarto do hotel - uma fala que poderia facilmente ser trocada por um bilhete. Não há acerto, após a fala, Travis segue vagando. Ele parece não se deixar penetrar pelo encontro - já perdeu suas raízes, e a conversa com Jane, embora o faça chorar, não o mobiliza à mudança.

Travis, dirá Goldmann, não é um errante autêntico durante o filme, mas o é antes e depois. A história que se passa na tela durante o tempo de projeção é um parêntese de sua vagabundagem, ela permite a resolução de um problema, mas não do problema ${ }^{81}$. Ou seja, com exceção dos minutos iniciais e finais do filme, nos quais se configura a errância, Paris, Texas abrange uma história de duas breves itinerâncias que têm lugar dentro da errância de Travis. Itinerâncias que, como se disse, poderiam ser transformadoras (sobretudo a que o

\footnotetext{
${ }^{79}$ Cf. BENJAMIN, W. "O Narrador - Considerações sobre a obra de Nikolai Leskov”. op. cit., p. 200.

${ }^{80} \mathrm{Cf}$. GoldmanN, A. L'errance dans le cinéma contemporain. op. cit., p. 108.

${ }^{81}$ Cf. GoldmanN, A. L'errance dans le cinéma contemporain. op. cit., p. 103.
} 
leva a Jane), mas não o são - não há a decepção do nostálgico que encontra o objeto idealizado, mas uma resignação melancólica e um tal sentimento de desenraizamento pessoal que não permite qualquer transformação em Travis. Ele leva seu filho à mãe porque acredita que seu lugar é próximo a ela. O lugar de Travis, entretanto, continua inalcançável, e ele segue na estrada, errando por essa instabilidade, pelas contínuas mudanças de cenário, andança de paisagens efêmeras, de impossível enraizamento.

Para finalizar sua análise de Paris, Texas, Goldmann destaca do filme duas seqüências e as comenta de um modo que vale a pena retomar:

Duas seqüências espetaculares balizam dois momentos contraditórios do filme. A primeira é a projeção do filme das férias nos tempos felizes de amor entre Travis, Jane e Hunter. A inabilidade, os erros de enquadramento, as improvisações não são devidos somente ao amadorismo em super-8, eles são sinais de um tempo anti-tecnológico, quando o êxito não dependia de técnicas sofisticadas. Em oposição, o encontro de Travis e Jane, após quatro anos, ocorre em um local altamente tecnológico, mas onde o pulôver cor-de-rosa de Jane não é suficiente para aquecer as cores frias e azuladas do vidro e do plástico. Entre as duas cenas, anos-luz se passaram. ${ }^{82}$

A tecnologia utilizada no peep-show hoje, mais de 20 anos depois, está claramente ultrapassada. Porque assim corre a técnica, aperfeiçoando-se de maneira irrefreada e fragmentada, mais veloz do que as patas dos cavalos que se moviam sobre a tela.

Após a conversa permeada pelo vidro (diria Benjamin, essa superfície tão lisa sobre a qual não se podem deixar $\operatorname{rastros}^{83}$ ), Travis parte de novo à errância. Ele é um melancólico e assim o será onde quer que esteja. Se Travis chegou a ir à busca de sua origem mítica em Paris, Texas, lá nada encontrou. Por outro lado, tampouco se sentira abrigado na casa de seu irmão, em Los Angeles, ou na companhia de Jane. Seu lugar é o trajeto, é o caminho, pois ele encontra fixidez no que é volátil, na paisagem que muda a cada instante. Um caminho que tem como tempo forte o momento mesmo em que se dá a errância.

\footnotetext{
${ }^{82}$ GoldmanN, A. L'errance dans le cinéma contemporain. op. cit., p. 110. Tradução livre de: "Deux séquences spectaculaires jolonnent deux moments contradictoires du film. La première est la projection du film de vacances aux temps heureux de l'amour entre Travis, Jane et Hunter. La maladresse, les erreurs de cadrage, l'improvisation ne sont pas dus seulement à l'amateur de super 8; ils sont les signes d'um temps ante-technologique où le bonheur ne se préoccupait pas de techniques sophistiquées. En opposition, la rencontre de Travis e Jane, quatre ans après, se fait, lui, dans um endroit hautement technologique mais où le pull-over rose de Jane ne suffit pas à réchauffer les couleurs froides et bleutées $d u$ verre et du platique. Entre les deux scènes, des années-lumière ont passé".

${ }^{83}$ Cf. BENJAMIN, W. "Experiência e pobreza". op. cit., p.117.
} 
Uma errância que, entretanto, ficará guardada em Travis, ainda que em seu esquecimento pois, se Robert disse, em No decorrer do tempo, "eu sou minha história", o mesmo vale para Travis. Ainda que ele se sinta absolutamente desraigado, ao mesmo tempo em que sua história o abrange, a cada minuto vivido, seu esquecimento é preenchido. Travis é sua história.
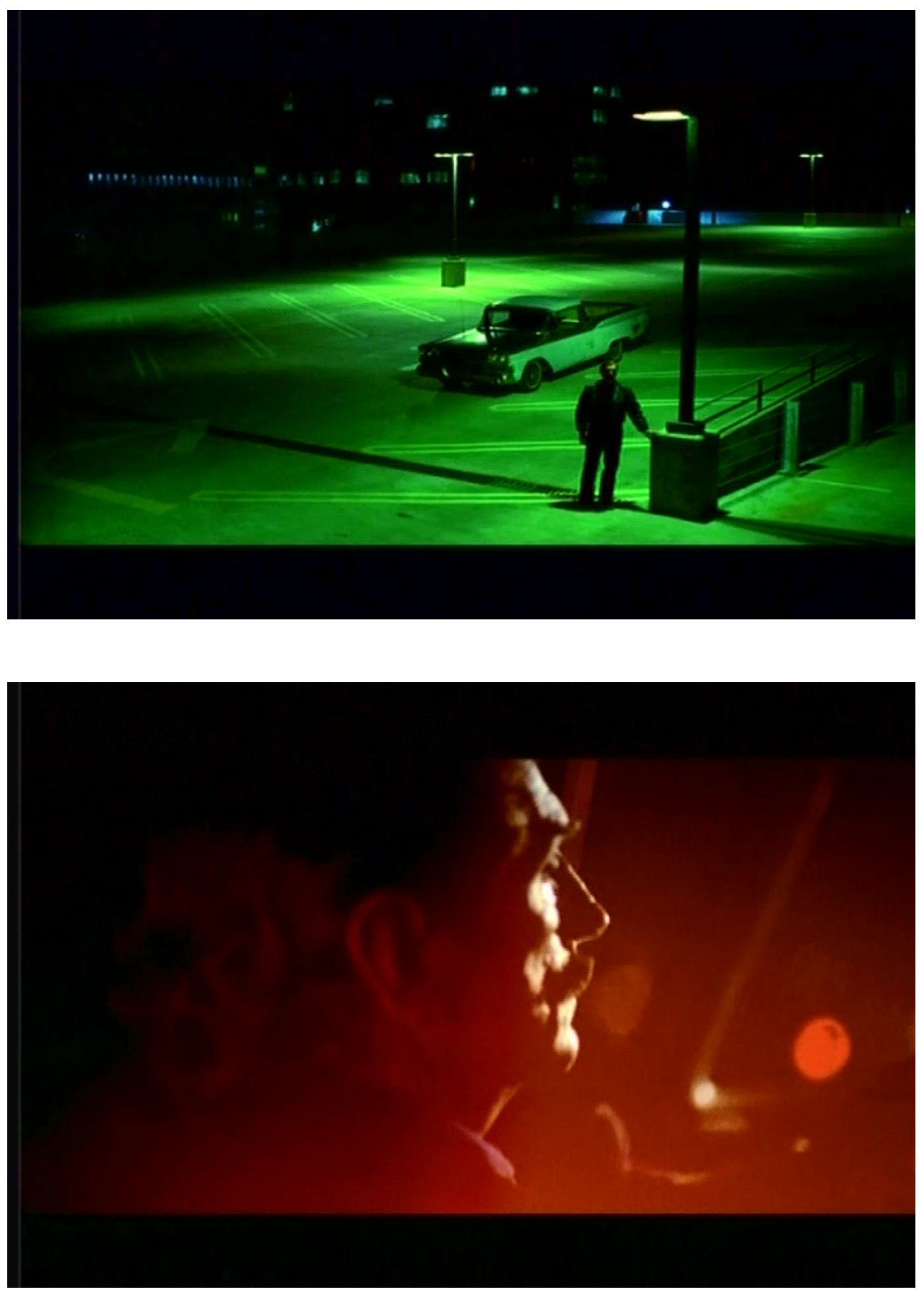


\section{Luto sob a areia}

\subsection{Trilogia da morte}

Sob a areia ${ }^{1}$, de 2000 , é o primeiro filme de uma trilogia proposta pelo diretor francês François Ozon, cujo tema é a morte ${ }^{2}$. Houve um intervalo de seis meses entre a filmagem da primeira parte, que se passa no verão, em Landes, e a segunda parte do filme, que ocorre sobretudo em Paris, no inverno. Esse intervalo representa, além da mudança climática, uma ruptura narrativa no filme.

A morte aparece em Sob a areia logo na primeira parte do filme, no afogamento de Jean. A segunda parte tratará do pós-morte, ou seja, do luto de sua esposa, Marie ou, antes, da impossibilidade de se viver um luto em situações nas quais a morte não vem acompanhada por um corpo a velar. Ozon dirá que a primeira parte funciona como uma espécie de prólogo para a segunda, na qual o espectador entraria "na cabeça de Marie", "um terreno de areias movediças"

O segundo filme da trilogia é $O$ Tempo que resta ${ }^{4}$, produção de 2005 que tem como protagonista Romain, um jovem que se descobre vítima de câncer terminal e opta por não se tratar. Relata a doença apenas a sua avó, que logo morrerá, pois, por ser mais velha, ela teoricamente tem a mesma proximidade em relação à morte que ele. $\mathrm{O}$ filme mostra $\mathrm{o}$ fim da vida do protagonista, mas a morte surge propriamente na tela nas cenas finais, em uma praia, remetendo o espectador à clássica cena final de Morte em Veneza ${ }^{5}$. O terceiro filme da série ainda não foi lançado, mas terá como tema a morte de uma criança ${ }^{6}$.

\footnotetext{
${ }^{1}$ Sous le sable. França, 2000. Direção: François Ozon. Embora filmicamente isso não apareça, vale lembrar que, de acordo com Ozon, a idéia para Sob a areia surgiu da lembrança de uma vivência sua na infância: “Je me suis inspiré d'un évènement dont enfant j'ai été le témoin. J'avais 9-10 ans et j'étais en vacances dans les Landes avec mes parents. Sur la plage, nous croisions tous les jours un couple de Hollandais de 60 ans. Un jour, l'homme est parti se baigner et il n'est jamais revenu. On a alors vu l'hélicoptère arriver sur la mer, la femme qui discutait avec les maîtres nageurs sauveteurs. Cet évènement a été un choc pour moi et mes frères et soeurs, il a perturbé la fin des vacances. Plus personne ne voulait se baigner. Et l'image de cette femme qui repart seule chez elle avec les affaires de son mari m'a souvent hanté. Je me suis toujours demandé: que s'est-il passé après?" (OzON, François. "Entretien réalisé en septembre 2000". Dossier de Presse. Disponível online em: http://www.francoisozon.com/francais/entretiens/sous-le-sable.html. Acesso em 20/04/2007).

${ }^{2}$ Cf. Merten, Luiz Carlos. "Estréia O Tempo que resta, filme de François Ozon”. O Estado de São Paulo. São Paulo, 25/08/2006. Disponível online em: http://www.estadao.com.br/arteelazer/cinema/noticias/2006/ago/25/88.htm. Acessado em 03/02/2007.

${ }^{3}$ OzON, François. "Entretien réalisé en septembre 2000". op. cit.

${ }^{4}$ Le Temps Qui Reste, França, 2005. Direção: François Ozon.

${ }^{5}$ Morte a Venezia. Itália, França, 1971. Direção: Luchino Visconti.

${ }^{6}$ Cf. Merten, Luiz Carlos. "Estréia O Tempo que resta, filme de François Ozon”. op. cit.
} 
Tal qual ocorre com a temporalidade, as representações sociais da morte se transformam. Não apenas seus rituais mudam, mas a reação dos que a presenciam. O tema aparece nos filmes de François Ozon envolto pelo modo como se apresenta socialmente nos dias de hoje. Se, como se verá, o tema da morte hoje ocupa menos espaço na vida que outrora, Sob a areia lembra que o luto - ainda que abreviado - segue fundamental para que se possa romper com o tempo no qual se convivia com quem morreu.

Sob a areia mostra a convivência de Marie com o desaparecimento de seu marido (uma morte que só virá a ser comprovada no final do filme, e que ainda assim não será aceita por ela). Apresenta a impossibilidade de Marie realizar o luto; é fundamentalmente um filme que trata da relação dos sobreviventes com a morte alheia.

\subsection{A vida}

Começa o Sob a areia. Após rápidos créditos vermelhos sobre fundo preto, vê-se uma imagem de Paris. O rio Sena está em primeiro plano, sobre ele há as famosas pontes, à esquerda a Notre Damme. Acima, vão surgindo os outros créditos. Há uma música dramática, que contrasta com a paisagem tão romântica. A câmera se movimenta e, quando apenas as águas do rio compõem a tela, surge o nome do filme: Sob a areia. Aqui se tem a impressão de que o filme faz referência à areia do rio Sena - o que haverá sob ela?

Esse início de filme comunica ao espectador que se está em Paris, e a câmera se desloca do famoso cenário da cidade para a direita. À margem do rio, pessoas tomam sol - é verão. Mais à direita, está a estrada, e se verá que os protagonistas estão deixando Paris. A câmera se aproxima do parapeito de um carro, mostrando os personagens de modo intimista, como o fará durante todo o filme - tratam-se de Marie e Jean, um casal que tem em torno de $60 \operatorname{anos}^{7}$. Ela é magra, cabelos curtos, castanhos claros e tem um porte bastante elegante. Já Jean é um homem gordo, alto, com cabelos grisalhos. Eles ouvem ópera durante a viagem - ele descansa enquanto Marie dirige, e logo as posições se invertem - ele é quem dirige. Na parada que fazem, Marie vai ao banheiro, lava as mãos e passa batom; Jean boceja enquanto aguarda o preparo de café em uma máquina. Se pararam em um bar durante o trajeto, é porque a viagem é longa.

Marie sai do banheiro e dá uma tragada no cigarro de Jean. Dão-se um beijo, ela leva o cigarro à boca de Jean para que ele fume, e seguem viagem - parece haver

\footnotetext{
${ }^{7}$ Dirá Marie ao casal nudista: "Com licença, viu meu marido? Ele tem uns 60 anos, é alto”.
} 
muita cumplicidade nesse casal, um relacionamento aparentemente harmonioso. Juntos há 25 anos, tem-se a impressão de que Jean e Marie pouco precisam dizer para que se comuniquem. Assim começa o filme, mostrando a cumplicidade de um casal que vive em Paris no começo dos anos 2000 e que, evidentemente, está inserido na sociedade em que vive.

A viagem termina com a chegada à casa de veraneio, em Landes, que é cercada por árvores. Marie pega a chave da casa embaixo de uma pedra e abre as portas enquanto Jean carrega as malas. Junto, o casal dobra o pano que cobre o sofá. Marie propõe que acendam a lareira, e Jean aparece na cena seguinte colhendo madeira no bosque. Apalpa a cortiça de uma árvore, depois observa formigas circulando embaixo de um tronco. Ele demonstra, assim, um olhar curioso para o mundo, um interesse pelo contato com a natureza que só é possível quando se tem tempo para observá-la. $\mathrm{E}$, durante as férias, Jean pode parar por alguns minutos para observar as formigas caminharem. É uma curiosidade que não se parece com depressão - Jean não demonstra tristeza ou qualquer característica que poderia levá-lo ao suicídio, demonstra algum cansaço, porém um olhar bastante investigativo, de quem busca descobertas.

$\mathrm{Na}$ casa, Marie liga o fogão, cantando, e põe uma panela com água sobre o fogo. Insere o spaghetti na água fervente e o espectador pode ver Jean - sentado, com um olhar vago, cabeça apoiada sobre as mãos - esperando. É uma cena escura, com fundo preto, e ele usa camisa preta. Quando ela chega, Jean “acorda”. Ela põe a massa sobre a mesa e se senta. Ele serve vinho para ela, ela serve a refeição para ele.

O que se vê, até aqui, é um casal em férias, em uma casa de veraneio isolada. É um tempo de ócio, possível recompensa ao trabalho do outro período do ano. Jean tem um escritório em casa, Marie dá aulas de Literatura Inglesa em uma universidade. Nesse tempo de lazer - as férias de verão -, eles decidem o itinerário do dia seguinte: se o tempo estiver bom, irão à praia "dos alemães", onde "não tem muita gente", nas palavras de Marie.

Após o jantar, sentam-se à lareira, Jean bebe uma xícara de chá, olha para o fogo, e depois para Marie. Logo já estão no quarto - a edição marca o filme todo o tempo, são cenas rápidas, porém de situações que teriam ocorrido com longa duração cenas que mostram apenas trechos das ações, porém não tornam seu ritmo acelerado. É um filme de muitos cortes, porém de ritmo lento.

Antes de dormir, Marie se olha no espelho e se penteia. Com tempo para se olhar, encontra algumas rugas e passa um creme ao redor dos olhos. Jean lê na cama, virado 
para o lado oposto de Marie. Ela se senta sobre a cama e diz "finalmente férias". Pergunta se ele está muito cansado, Jean afirma que sim, então eles se dão um beijo e dormem.

O que se viu até aqui foi o cotidiano de um casal que dirigiu por muito tempo e chegou à casa de veraneio. Nada diz que Jean estivesse infeliz com a Marie, ou que algo corresse mal, como depois será questionado. Nenhum elemento fílmico demonstra depressão ou desajuste nos personagens, aparentando apenas cansaço após uma longa viagem de carro.

No dia seguinte, quando Jean e Marie vão à praia, há novos gestos de cumplicidade entre eles: Jean passa protetor solar sobre as costas de Marie delicadamente, e a massageia. Marie está deitada de bruços e Jean, sentado, olha o mar. A câmera mostra sua cabeça por trás - ele está sentado de frente para o mar, olhando-o, de modo que o mar forma na tela uma moldura ao redor da cabeça de Jean. Então, vê-se seu rosto de frente. Ele tira a camiseta e pergunta a Marie “quer entrar?", ela diz "Agora não. Quero descansar um pouco". A câmera próxima ao rosto de Jean é quase invasiva, constrangedora, intimidadora, é um ângulo pouco comum a homens da sua faixa etária no cinema. Isso não se confunde, entretanto, com um possível estado depressivo de Jean, ele parece apenas fatigado. Ele olha para o mar, movimenta seus olhos e se levanta. Marie fica deitada. Vê-se o mar mais de perto, a arrebentação das ondas, que não estão muito fortes, e Marie segue deitada sobre uma toalha azul, cochilando ao lado da toalha vermelha de Jean.

Com um grito de criança, Marie se levanta e olha para o lado - Jean não está. Ela se vira para o mar, o procura, mas parece nada encontrar. Pega uma garrafa de água na bolsa e a bebe olhando para o mar, onde algumas crianças brincam. Deita-se novamente e lê. 

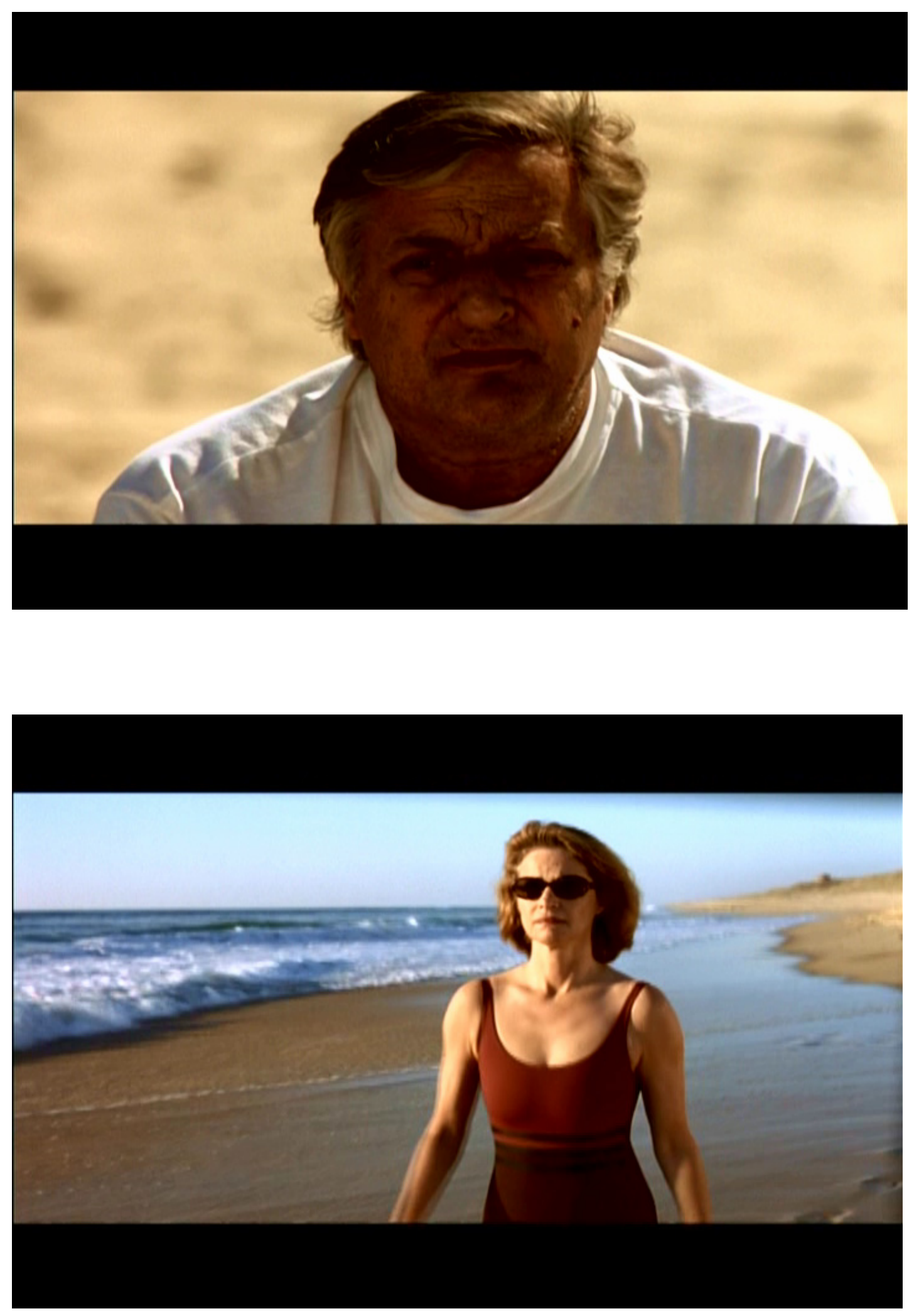
Na tomada seguinte, o sol já está mais baixo, marcando a passagem do tempo. Marie olha para seu relógio, larga o livro e se levanta. Já é fim de tarde, ela caminha em direção ao mar, de maiô e óculos escuros. A câmera roda em torno dela, que parece bastante só. Podem-se ver apenas mais duas pessoas nessa praia tão longa. Marie caminha à beira-mar em direção a essas pessoas - trata-se de um casal nudista - e lhes pergunta se viram seu marido, que ela não viu mais desde que entrou no mar. A resposta é negativa.

Marie então caminha com os pés na água, olhando para o fundo do mar, onde o sol se reflete. Ela está de costas, em primeiro plano, e atrás está o mar, de onde vem o som que acompanha essa imagem. De vestido vermelho, ela vai de carro a uma praia mais movimentada, onde há salva-vidas. Nervosa, diz que seu marido sumiu, tem um diálogo confuso com o oficial do corpo de bombeiros, mas no qual não há a negação do desaparecimento.

OFICIAL 1: Calma, senhora. Ele foi nadar?

MARIE: Acho que sim.

OFICIAL 1: Acha ou tem certeza?

MARIE: Tenho certeza.

OFICIAL 1: Não teria ido caminhar?

MARIE: Já disse que ele entrou na água.

OfICIAL 1: Nessa praia?

MARIE: Não, numa praia mais isolada.

OFICIAL 1: Sabe que não é nossa área?

MARIE (nervosa): Eu sei, mas, por favor, precisa fazer alguma coisa.

Na cena seguinte, o salva-vidas desconhecido (que depois será mostrado como aluno de Marie) está sentado sobre o jipe dos salva-vidas, na praia em que Marie e Jean estavam. Marie e o oficial também estão na caminhonete, olhando para o mar (ele com binóculos) à procura de Jean. Descem da caminhonete onde Marie deixara as toalhas estendidas para marcar o local do mergulho. As ondas estão mais fortes que antes. Eles comunicam à polícia, que traz um helicóptero para sobrevoar a área, provocando assim muito barulho. Embora esteja acompanhada pelos homens que procuram por Jean, Marie parece estar só, desesperada e desamparada. A câmera se gruda nela, e não a abandonará mais.

O relatório que Marie preenche para a polícia levanta uma suspeita de que Jean poderia ter fugido, e não se afogado. Suspeita essa que será de fato negada ao 
espectador quando seu corpo por fim for encontrado, mas hipótese da qual ela suspeitará quando a iminência de que Jean morreu afogado for muito forte.

OFICIAL 2: Seu marido tinha motivos pessoais ou profissionais para desaparecer?

MARIE: Não.

OFICIAL 2: Ou se suicidar?

(Marie olha para baixo, espantada, não responde).

OFICIAL 2: Notou um comportamento depressivo ou ele disse que queria morrer?

MARIE: Não.

OfICIAL 2: Muito bem. Vamos precisar, para a investigação, de uma descrição física exata do desaparecido, seu marido. (Marie leva as mãos ao rosto, fecha os olhos e baixa a cabeça.) Isso se não tiver notícias nos próximos dias. Também precisamos de detalhes médicos. Se fez alguma cirurgia, se fraturou algum osso.

$\mathrm{Na}$ cena seguinte, Marie está, de fato, só; isso fica expresso quando ela prepara um chá para beber. Como bem observou Schiller,

[...] Quando ela despeja a água dentro de um bule de chá, sentimos a ausência de Jean. Há duas xícaras sobre a bandeja e, enquanto ela se senta no sofá e bebe o chá, o suéter de Jean está logo atrás dela, sobre uma mesa. [...] ${ }^{8}$

Marie adormece no sofá, mas é acordada por um barulho no meio da noite. Levanta-se e chama pelo marido duas vezes, mas ninguém responde. Sai da casa, e pergunta se há alguém lá, mas não há ninguém, o som vinha de uma janela que batia, movida pelo vento. Ainda à noite, ela dirige o carro até a praia onde Jean sumira. A praia está escura e ela olha para o mar, destacado pela espuma branca que as ondas formam. Jean não está lá, ela está só e frágil, tão pequena frente a essa imensidão de areia e água quanto estará, para ela, Vincent, ao ser comparado a Jean. Ainda está com o vestido vermelho com o qual fora à praia, coberta por um casaco.

Na manhã seguinte, Marie tranca a casa, põe as malas no carro e parte. Ouvese uma música moderna, ritmada. Seu rosto sério, coberto por um par de óculos escuros, aparece sob o vidro do carro, no qual há o reflexo das árvores ao lado das

\footnotetext{
${ }^{8}$ SCHILLER, Britt-Marie. "A Memorial to mourning: Under the sand". Literature Film Quarterly, 2005. disponível online em: http://findarticles.com/p/articles/mi_qa3768/is_200501/ai_n15348553/. Acesso em 02/04/2007. Tradução livre de: "When she pours water into a teapot, we feel Jean's absence. There are two cups on the tray and as she sits on the sofa drinking tea, Jean's sweater is just behind her on a table."
} 
quais ela passa na estrada, e do céu. Se a ida à praia foi acompanhada, agora ela não tem com quem dividir a direção.

A primeira parte do filme, o verão, marcada por essa morte sem evidência (sem corpo), portanto não-comprovada, de Jean, acaba aqui. Uma morte que, como qualquer outra, deveria ser seguida por um luto. Perdeu-se algo. Pode ser momento de lembrar ou esquecer o que foi perdido, não importa. Importa, antes, que ocorra a fundamental percepção dessa perda.

\section{3. "Já não são as crianças que nascem dentro de repolhos, mas} os mortos que desaparecem por entre as flores" 9

O que a morte representa hoje? No que implica convalescer e morrer? Tal qual as condições de vida, a morte está envolta por uma série de rituais e manifestações do luto, que foram historicamente construídas.

A morte pode ser pensada como o encontro de um fenômeno que se chamaria "natural" - o término físico de uma vida, cessamento dos "processos vitais", inexistência de respiração, um coração que não bate, um cérebro que não responde (muito embora tanto se diga que cabelos e unhas seguem crescendo após a morte) -, com um fenômeno "social", que perpassa as formas de representação da morte, os rituais que a encerram e seu significado para aqueles que seguem vivos, ou seja, o modo de expressar a ausência de alguém com quem se convivia, os ritos fúnebres. As mudanças que ocorrem no aspecto "social" da morte parecem mais facilmente observáveis: as relações engendradas por seu acontecimento são perceptíveis mesmo em diferentes culturas coetâneas. Pois é também o aspecto "social" que determina as causas que se dizem "naturais" desse fenômeno - a causa mortis é variável de acordo com o grau de desenvolvimento científico de uma dada sociedade, de um dado período. Mesmo os critérios de autenticidade e legitimidade de uma morte variam. Como se tentou explicitar no Capítulo 1, a temporalidade corrente sofreu forte abalo com a instauração da modernidade. O mesmo ocorreu com a representação da morte.

Há práticas, entretanto, que não se abalam. Um hábito humano persiste desde os primeiros registros: já os homens de Neandertal davam sepultura a seus mortos ${ }^{10}$. Que

\footnotetext{
${ }^{9}$ ARIÈs, Philippe. História da morte no Ocidente: da Idade Média aos nossos dias. Rio de Janeiro: Francisco Alves, 1977, p. 147.
} 
se afirme ser o sepultamento uma questão de salubridade, isso será também um fator social, posto que as representações do que é pútrido se constituem social e historicamente $^{11}$. Os homens, ao contrário dos animais, têm consciência de que morrerão, e por isso os rituais fúnebres lhe são fundamentais. A sepultura (ou algum rito que envolva a morte) existe desde os agrupamentos humanos mais arcaicos: "Não há praticamente nenhum grupo arcaico ou 'primitivo', que seja, que abandone seus mortos ou que os abandone sem ritos"12. "Nas fronteiras do no man's land antropológico, o primeiro dado, fundamental, universal da morte humana, é a sepultura". ${ }^{13}$

O sepultamento e os ritos que acompanham a morte significam o encerramento da vida de um ser único; a morte é o término de uma vida individual, mas não da espécie humana. Se a natureza é pensada como um ciclo que se repete ad infinitum, a vida humana, todavia, é algo que sabidamente encerra um fim, e por isso o homem pode ser considerado imortal enquanto espécie, mas não enquanto um membro específico de uma espécie. Os gregos tinham o desejo de deixar suas vidas se contaminarem pela imortalidade do mundo, e isso apareceria na morte ${ }^{14}$ :

Para os gregos a mais dolorosa das experiências era o esquecimento, a "verdadeira morte"[,] e a rememoração era o modo de enfrentá-lo sem angústia, na perspectiva de um presente que se prolongaria num tempo sem limite, o da imortalidade $[\ldots]^{15}$

$\mathrm{Na}$ Idade Média, a morte costumava ser esperada no leito - havia, assim, uma cerimônia pública organizada pelo próprio moribundo em seu quarto (que então se tornava lugar público). Philippe Ariès observa que os "cavaleiros da gesta ou dos mais

${ }^{10}$ Cf. Morin, Edgar. "Aux frontières du no man's land”. In: L'Homme et la mort. Paris: Éditions du Seuil, 1970. p. 31.

${ }^{11}$ Uma pesquisa feita por Alain Corbin, por exemplo, demonstra as mudanças sofridas pela sociedade francesa no século XIX no que concerne ao olfato. A pesquisa serve como exemplo de que as características atribuídas aos odores são também determinadas histórica e socialmente. Ver: CORBIN, Alain. Saberes e odores. São Paulo: Cia. das Letras, 1987.

${ }^{12}$ Morin, Edgar. "Aux frontières du no man's land”. op. cit., p. 33. Tradução livre de: “Il n'existe pratiquement aucun groupe archaïque, aussi 'primitif', soit-il, qui abandonne ses morts ou qui les abandonne sans rites."

${ }^{13}$ Morin, Edgar. "Aux frontières du no man's land”. op. cit., p. 32. Tradução livre de: “Aux frontières donc du no man's land anthropologique, la donnée première, fondamentale, universelle de la mort humaine, est la sépulture."

${ }^{14}$ Como se pretendeu expor no Capítulo 1, se os gregos julgavam que os homens mortais, seus feitos e coisas podiam transcender tal qualidade, e então seus realizadores teriam a possibilidade de se contagiar de sua imortalidade. Isso era bastante desejado, pois era uma maneira de não se esvair por completo após a morte - ou seja, de não adentrar o indesejado mundo do esquecimento.

15 CARdoso, Irene. "História, memória e crítica do presente". In: Para uma crítica do presente. São Paulo: Editora 34, 2001, p.27. 
antigos romances medievais" só não previam sua morte em caso excepcional, por um motivo como peste ou morte súbita ${ }^{16}$. Ou seja, em geral, o homem sabia que ia morrer, fosse porque percebera, fosse porque o haviam advertido (vale lembrar que as enfermidades consideradas mais graves em geral resultavam em morte). A morte súbita era temida, pois nela não cabia o arrependimento, o homem ficava, assim, privado de sua própria morte ${ }^{17}$. Em contraposição à morte tal como é encarada hoje, quando "amedronta a ponto de não mais ousarmos dizer seu nome", Ariès chama a morte medieval de morte domada ${ }^{18}$. Ele diz ainda: "encontramos um sentimento muito antigo, duradouro e intenso de familiaridade com a morte, sem medo ou desespero, um meiotermo entre a resignação e a confiança mística" ${ }^{19}$.

Norbert Elias reconhece o impulso "instigante e bem documentado" de Ariès, mas questiona sua opinião quanto à domesticação da morte ${ }^{20}$; ele diz que "a vida nos Estados medievais era [...] apaixonada, violenta e, portanto, incerta, breve e selvagem”, e lembra do essencial fato de que havia menos possibilidades medicinais de se aliviar as dores que podem estar presentes na morte - o que dotava esse momento de maior dor e tormenta ${ }^{21}$. Norbert Elias ainda aponta outro fator contrário à pacificidade que Ariès tributa à morte na Idade Média: a retratação do inferno presente em quadros medievais, que certamente amedrontava os convalescentes como possível breve destino. "Com tais imagens aterrorizantes diante dos olhos", diz Elias, "uma morte pacífica não pode ter sido fácil",22. Assim, dirá Elias que o fato de a morte estar mais presente para os vivos não significa que ela fosse menos dura: "a morte naquela época [Idade Média] era, para jovens e velhos, menos oculta, mais presente, mais familiar. Isso não quer dizer que fosse mais pacífica"23. O grau de domesticação que a morte assumia na Idade Média, entretanto, não é aqui fundamental. Vale atentar, sim, à principal característica que a morte assumia na época, importante para contrapô-la ao modo como é pensada hoje: a morte era um fenômeno acompanhando coletivamente, "a participação dos outros na morte de um

\footnotetext{
${ }^{16}$ Cf. ARIÈs, P. História da morte no Ocidente: da Idade Média aos nossos dias. op. cit., p. 17.

${ }^{17}$ Cf. ARIÈs, P. História da morte no Ocidente: da Idade Média aos nossos dias. op. cit., p. 137.

${ }^{18}$ ARIÈs, P. História da morte no Ocidente: da Idade Média aos nossos dias. op. cit., p. 22.

${ }^{19}$ ARIÈs, P. História da morte no Ocidente: da Idade Média aos nossos dias. op. cit., p. 63. Grifos nossos.

${ }^{20}$ ELIAS, N. "A Solidão dos moribundos". op. cit., p. 20. A morte domesticada seria a morte "[...] ao mesmo tempo familiar, próxima e amenizada, indiferente [...]”.ARIÈs, P. Apud: ELIAS, N. "A Solidão dos moribundos". op. cit., p. 20.

${ }^{21}$ Cf. EliAs, Norbert. "A Solidão dos moribundos". In: A Solidão dos moribundos: seguido de "Envelhecer e morrer". Rio de Janeiro: Jorge Zahar, 2001, pp. 20-21.

${ }^{22}$ ELIAS, N. "A Solidão dos moribundos". op. cit., p. 23.

${ }^{23}$ ELIAS, N. "A Solidão dos moribundos". op. cit., p. 21.
} 
indivíduo era muito mais comum" ${ }^{24}$, e mesmo seu tema era mais freqüente nas conversas $^{25}$ e no cotidiano. A morte (tal qual o nascimento) era uma questão mais pública do que é hoje, mesmo porque era mais comum estar-se acompanhado - as pessoas ficavam menos tempo sozinhas ${ }^{26}$. O moribundo não era privado da sua morte, ele a presidia; nascia-se e morria-se em público $^{27}$.

Pode-se dizer, assim, que os ritos fúnebres eram mais extensos, uma vez que o processo fúnebre era acompanhado desde antes da morte, no quarto do agonizante. Ariès diz que, a partir do século XVIII, a morte foi cada vez mais considerada como "uma transgressão que arrebata o homem de sua vida quotidiana, de sua sociedade racional, de seu trabalho monótono para submetê-lo a um paroxismo e lançá-lo, então, em um mundo irracional, violento e cruel. [...]"28. Ainda no século XVIII, entretanto, e mesmo no início do XIX, "era costume que os vizinhos, amigos, padres viessem assistir o moribundo. A casa era aberta a todos" 29 . Mas isso logo se perdeu, e a morte foi se transformando em um fenômeno cada vez mais solitário e individual.

No século XIX, segundo Ariès, a assistência ao leito da morte foi tomada por paixão, choro e emoção; os sobreviventes passaram a demonstrar uma dor que aponta para uma nova intolerância com relação à separação. Para além da perturbação que a presença à cabeceira dos agonizantes promove, a simples idéia da morte passou a comover. ${ }^{30}$ No século seguinte, as modificações ocorreram na atitude frente à morte de modo veloz: “A morte, tão presente no passado, de tão familiar, vai se apagar e desaparecer. Torna-se vergonhosa e objeto de interdição."31

Elias destaca quatro características das "sociedades contemporâneas" e de suas "estruturas de personalidade" que seriam responsáveis "pela peculiaridade da imagem da morte e, portanto, pela natureza e pelo grau de recalcamento da morte em sociedades mais desenvolvidas" ${ }^{\prime 2}$. São elas: a) aumento da expectativa de vida, que gerou uma diminuição proporcional no período de vida em que se está próximo da morte; b) aumento da higienização e avanço das ciências médicas: com isso, a morte passou a ser

\footnotetext{
${ }^{24}$ ELIAS, N. "A Solidão dos moribundos". op. cit., pp. 23-24.

${ }^{25}$ Cf. Elias, N. “A Solidão dos moribundos”. op. cit., p. 21.

${ }^{26}$ Cf. EliAs, Norbert. "A Solidão dos moribundos". op. cit., p. 25.

${ }^{27}$ Cf. ARIÈs, P. História da morte no Ocidente: da Idade Média aos nossos dias. op. cit., p. 138.

${ }^{28}$ ARIÈs, P. História da morte no Ocidente: da Idade Média aos nossos dias. op. cit., p. 42.

${ }^{29}$ MANNONI, Maud. "O Homem diante da morte". In: palavra da vida. Rio de Janeiro: Jorge Zahar Editor, 1995, p. 41.

${ }^{30}$ ARIÈs, P. História da morte no Ocidente: da Idade Média aos nossos dias. op. cit., p. 43.

${ }^{31}$ ARIÈs, P. História da morte no Ocidente: da Idade Média aos nossos dias. op. cit., p. 53.

${ }^{32}$ ELIAS, N. "A Solidão dos moribundos". op. cit., p. 54.
} 
encarada como término de um processo natural, o que amenizou a angústia do vivo frente à morte, que virá não se sabe quando; c) aumento do grau de pacificação interna das sociedades contemporâneas: passou-se a imaginar uma morte pacífica, natural, pensando-se a morte violenta, especialmente pelas mãos de outrem, como criminal e excepcional; d) presença de um "alto grau e padrão específico de individualização" "33, que fez com que a imagem da morte na memória dos indivíduos passasse a ser associada à imagem de si mesmo, e não dos outros indivíduos da sociedade ${ }^{34}$.

Com base no ideal cientificista de progresso, cada vez mais novas técnicas foram levadas à medicina, e a vida prolongada ao máximo. Por isso, e porque à velhice deixou de ser atribuída sabedoria, os moribundos passaram a ser enviados a hospitais ou outras instituições, sendo afastados da família nos momentos em que a morte se aproxima. Passou-se a morrer higienicamente no hospital, e em situação de abandono: "Nunca antes as pessoas morreram tão silenciosa e higienicamente como hoje nessas sociedades, e nunca em condições tão propícias à solidão". ${ }^{35}$ Antes, envelhecimento e morte eram assistidos pela família extensa, e algumas vezes também pelos vizinhos. Com a modernidade, esses momentos ficaram afastados da vida social. Benjamin destaca tais mudanças:

No decorrer dos últimos séculos, pode-se observar que a idéia da morte vem perdendo, na consciência coletiva, sua onipresença e sua força de evocação. Esse processo se acelera em suas últimas etapas. Durante o século XIX, a sociedade burguesa produziu, com as instituições higiênicas e sociais, privadas e públicas, um efeito colateral que inconscientemente talvez tivesse sido seu objetivo principal: permitir aos homens evitarem o espetáculo da morte. Morrer era antes um episódio público na vida do indivíduo, e seu caráter era altamente exemplar: recordem-se as imagens da Idade Média, nas quais o leito de morte se transforma num trono em direção ao qual se precipita o povo, através das portas escancaradas. Hoje, a morte é cada vez mais expulsa do universo dos vivos. Antes não havia uma só casa e quase nenhum quarto em que não tivesse morrido alguém. [...]. Hoje, os burgueses vivem em espaços depurados de qualquer morte e, quando chegar sua hora, serão depositados por seus herdeiros em sanatórios e hospitais. [... $]^{36}$

\footnotetext{
${ }^{33}$ ELIAS, Norbert. "A Solidão dos moribundos". op. cit., p. 61.

${ }^{34}$ ELIAS, Norbert. “A Solidão dos moribundos”. op. cit., pp. 55-61.

${ }^{35}$ ELIAS, Norbert. "Envelhecer e morrer: alguns problemas sociológicos”. op. cit., pp. 97-98.

${ }^{36}$ BENJAMIN, Walter. “O Narrador - Considerações sobre a obra de Nikolai Leskov”. op. cit., p. 207.
} 
Já na segunda metade do século XIX, aqueles que cercavam o moribundo (um número cada vez menor de pessoas) tendiam a esconder dele a gravidade de seu estado. Os ritos da morte ainda não haviam mudado, ao menos em sua aparência, mas foram perdendo sua carga dramática. Foi entre 1930 e 1950 que o lugar da morte mudou: não mais em casa, mas no hospital. ${ }^{37}$ "Morre-se no hospital porque os médicos não conseguiram curar. Vamos ao hospital não mais para sermos curados, mas precisamente para morrer." ${ }^{38}$ Deve-se morrer sem fortes emoções, esconder as emoções seja no hospital ou na sociedade, "Só se tem o direito à comoção em particular, ou seja, às escondidas"39

A partir de então, a família e o médico escamoteiam do doente a gravidade de seu caso, ele nunca deve saber que vai morrer ${ }^{40}$ - mantém-se a ilusão de que a aplicação da ciência sempre dará conta de curar o doente ${ }^{41}$.

Elias acredita que esse processo no qual a morte é escamoteada da vida cotidiana, levada aos hospitais, individualizada e interdita representa um recalcamento da morte: "a morte parece estar recalcada - um recalcamento que é individual e social". ${ }^{42}$ Tal processo seria, de forma consciente ou não, a máxima resistência possível à idéia do próprio envelhecimento e da própria morte dos indivíduos. ${ }^{43}$

Além da quebra do caráter público da morte, as manifestações de luto sofreram mudanças. Desde o século XIII, a morte já vinha sendo clericalizada - nos ritos fúnebres, o padre passou a ocupar o papel principal, e não mais o morto, e o cadáver tornou-se cada vez mais insuportável aos olhos humanos ${ }^{44}$. Mesmo o procedimento fúnebre se modificou: sabe-se que, do século XVI ao XVIII, os médicos somente

\footnotetext{
${ }^{37}$ ARIÈs, P. História da morte no Ocidente: da Idade Média aos nossos dias. op. cit., pp. 53-54.

${ }^{38}$ ARIÈs, P. História da morte no Ocidente: da Idade Média aos nossos dias. op. cit., p. 54.

${ }^{39}$ ARIÈs, P. História da morte no Ocidente: da Idade Média aos nossos dias. op. cit., p. 55.

${ }^{40}$ Cf. ARIÈs, P. História da morte no Ocidente: da Idade Média aos nossos dias. op. cit., p. 139.

${ }^{41}$ Exceto no caso de poucas doenças, acredita-se que o tratamento médico poderá curar o enfermo. No caso de morte, ela é rapidamente associada a uma falha técnica ou à falta de socorro pronto. Mesmo no caso de morte instantânea por acidente, pensa-se nas falhas técnicas responsáveis pelo acidente. Como se acidente e morte fossem casualidades evitáveis cientificamente. Assim, é como se não se morresse por uma doença, mas porque não houve capacitação técnica para curá-la. No caso das doenças para as quais há poucos recursos técnicos de cura, usa-se culpar o doente por sua condição - como no caso de AIDS por contágio sexual e de câncer em fumantes.

${ }^{42}$ ELIAS, N. "A Solidão dos moribundos". op. cit., p. 15.

${ }^{43}$ ELIAS, N. "Envelhecer e morrer: alguns problemas sociológicos". op. cit., pp. 80-81.

${ }^{44}$ Cf. Bellato, Roseney et CARVAlho, Emília C. “O jogo existencial e a ritualização da morte". Revista Latino-Americana de Enfermagem. Vol. 13, n ${ }^{\circ}$ 1. Ribeirão Preto, jan/ fev. 2005. Disponível online em: http://www.scielo.br/scielo.php?script=sci_arttext\&pid=S0104-11692005000100016\&lng=en\&nrm=iso. Acesso em $15 / 04 / 2007$.
} 
atestavam a morte quando ocorria a decomposição do corpo. Assim, o embalsamento permitia, de certo modo, que se postergasse o término definitivo da vida. ${ }^{45}$

No século XIX, há um exagero nas manifestações do luto, que para Ariès significa que "os sobreviventes aceitam com mais dificuldade a morte do outro do que o faziam anteriormente. A morte temida não é mais a própria morte, mas a do outro". ${ }^{46} \mathrm{E}$, a partir da segunda metade do século, o processo fúnebre foi encurtado, pois o moribundo deixou de ser assistido no fim de sua vida e mesmo de ser informado de que morrerá:

[...] O doente sabe que vai morrer, mas ao seu redor finge-se ignorância. O doente se cala, pois recusa ser tratado como moribundo [...]. O médico, na maior parte do tempo, vê-se obrigado a mentir. Faz-se como se a morte não existisse. No entanto, o corpo está lá, precisando de cuidados, exalando odores e nem sempre belo de se ver. O doente assiste pouco a pouco a um espaçamento das visitas. Por decência, não se dá mais a ver um homem que agoniza. Não contentes em frustrá-lo de sua morte (o médico tende preferencialmente a fugir, tão logo se sinta impotente para curar), isolam, desde então, o "condenado a morrer" no hospital, único lugar onde se pode, de maneira decente, morrer em segredo. ${ }^{47}$

Dessa forma,

A "boa" morte de hoje corresponde, assim, à morte maldita de outrora (a morte que passava despercebida). A "má" morte é aquela que perturba o círculo, seja porque o doente se revolta, seja porque se retira dos vivos, antecipando sua hora. ${ }^{48}$

As anteriores demonstrações de luto, dessa forma, desapareceram; mantiveramse algumas formalidades, mas a sociedade deve perceber o mínimo possível que a morte ocorreu, a emoção deve ser tão discreta quanto possível, "As manifestações aparentes de luto são condenadas e desaparecem" 49 . Hoje, não só se enterra o corpo antes de sua decomposição, como antes da morte o moribundo já é afastado dos olhares alheios, tirado de casa e do convívio social. Mesmo após a morte, as manifestações de luto devem ser abreviadas, "As conveniências exigem que o enlutado volte a uma vida normal depois de passado algum tempo determinado pelos costumes. O recalcamento da

\footnotetext{
${ }^{45}$ MANNONI, M. "O Homem diante da morte". op. cit., p. 44.

${ }^{46}$ Cf. ARIÈs, P. História da morte no Ocidente: da Idade Média aos nossos dias. op. cit., p. 45.

${ }^{47}$ MANNONI, M. "O Homem diante da morte". op. cit., p. 45.

${ }^{48}$ MANNONI, M. "O Homem diante da morte". op. cit., p. 46.

${ }^{49}$ ARIÈs, P. História da morte no Ocidente: da Idade Média aos nossos dias. op. cit., p. 55.
} 
dor é exigido em lugar das manifestações outrora usuais" ${ }^{, 50}$; o choque da morte deve ter suas emoções controladas.

Uma dor demasiado visível não inspira pena, mas repugnância; é um sinal de perturbação mental ou de má-educação, é mórbida. [...] Só se tem o direito de chorar quando ninguém vê nem escuta: o luto solitário e envergonhado é o único recurso, como uma espécie de masturbação [...]. ${ }^{51}$

Isso significa a colocação de um interdito: "o que era antes exigido é agora proibido". ${ }^{52}$ Quando se percebe que o luto produziu um incômodo exacerbado em alguém, apela-se, por fim, à Medicina, para livrar tal pessoa dessa dor. O enlutado passa a ser tratado como doente - se o luto extrapola o prazo considerado "normal", logo se dirá tratar-se de depressão, e se buscará uma droga para a cura dessa dor que, antes, era regra e se legitimava por uma perda identificável.

Se, para os contemporâneos, o esquecimento "é condição da própria existência", e a memória e a história são consideradas irrelevantes ${ }^{53}$, a duração do luto (que é o reconhecimento de uma ausência, portanto o debruçamento sobre alguém que então existe apenas na memória) foi diminuída, a ponto de o luto, tal qual a morte, não dever ser notado. O processo fúnebre está, assim, reduzido - em seu início, pelo envio do moribundo a instituições "adequadas" e por seu isolamento; e em seu fim: "Uma vez esvaziada a morte, não há mais razão para visitar seu túmulo". ${ }^{54}$

Hoje em dia não há mais resquícios, nem da noção que cada um tem ou deve ter de que seu fim está próximo, nem do caráter de solenidade pública que tinha o momento da morte. O que devia ser conhecido é, a partir de então, dissimulado. O que devia ser solene, escamoteado. ${ }^{55}$

Não é por acaso que essas mudanças tão significativas na relação com a morte surgem na modernidade, afinal, foi quando da emergência desse período que as noções de "progresso, razão, produção, acumulação, liberdade, igualdade e singularidade" adquiriram forte ênfase, engendrando a idéia de que o mundo é construído por

\footnotetext{
${ }^{50}$ MANNONI, M. "O Homem diante da morte". op. cit., p. 43.

${ }^{51}$ ARIÈs, P. História da morte no Ocidente: da Idade Média aos nossos dias. op. cit., p. 55.

${ }^{52}$ ARIÈs, P. História da morte no Ocidente: da Idade Média aos nossos dias. op. cit., p. 56.

${ }^{53}$ Cf. CARDoso, I. "História, memória e crítica do presente". op. cit., p. 28.

${ }^{54}$ ARIÈs, P. História da morte no Ocidente: da Idade Média aos nossos dias. op. cit., p. 55.

${ }^{55}$ ARIÈs, P. História da morte no Ocidente: da Idade Média aos nossos dias. op. cit., p. 139.
} 
"indivíduos isolados, independentes de seu grupo familiar ou de localidade". Ou seja, na modernidade surge uma concepção de indivíduo (preenchida pela individualidade) que interfere diretamente nas representações da morte. ${ }^{56}$

Quando se fala de individualidade, está implícita, portanto, a possibilidade de autoreflexão, de crítica, de liberdade. Nesse sentido, o traçado da vida do indivíduo é, ao menos em parte, eleição. Seu destino não está fora dele, não é determinado, previa ou externamente: é seu destino, no sentido forte do termo. Como conseqüência, a realização individual exige que cada pessoa deixe marcas de sua passagem, marcas estas que caracterizarão a plenitude ou o vazio de uma existência. ${ }^{57}$

Surge, assim, a demanda pela constituição de uma história própria e que seja memorável, o que abala, certamente, a relação dos vivos com a morte e com o tempo:

A orientação para o futuro, que tende a prevalecer, e a ausência de liames com o passado que essa concepção envolve, estão vinculadas à forma pela qual a humanidade passou a encarar o destino: este não é algo derivado da vontade dos deuses, não lhe é impingido de fora, mas um resultado que decorre da própria ação humana [...]. Entretanto, a história única e irrepetível resultante desse processo só pode ser construída no interior de um período de tempo determinado: o tempo de vida de cada pessoa. Para que cada um possa traçar seu próprio caminho e deixar marcas em sua passagem, garantias de uma vida bem sucedida, existem balizas, que não podem ser transpostas. ${ }^{58}$

E assim o sentido da morte "deixa de ser o momento da passagem para outra existência, onde se terá o retorno - positivo ou negativo - da vida que se teve, e adquire o sentido de fim inexorável" 59 . O ócio não é mais desejado, é considerado "tempo perdido". Seria perda de tempo, também, velar um corpo por muito tempo, "perder-se" em lembranças do passado, esfera temporal que vai se tornando cada vez menos presente no cotidiano. Se há, hoje, a predominância de uma temporalidade que se projeta para o futuro, a lembrança daquele que morre passa a ser cada vez mais curta,

\footnotetext{
56 Augusto, Maria Helena Oliva. "O moderno e o contemporâneo: reflexões sobre os conceitos de indivíduo, tempo e morte”. op. cit., p. 94.

${ }^{57}$ Augusto, M. H. O. "O moderno e o contemporâneo: reflexões sobre os conceitos de indivíduo, tempo e morte". op. cit., pp. 94-95. Grifos da autora.

${ }^{58}$ Augusto, M. H. O. "O moderno e o contemporâneo: reflexões sobre os conceitos de indivíduo, tempo e morte". op. cit., p. 95.

${ }^{59}$ Augusto, M. H. O. "O moderno e o contemporâneo: reflexões sobre os conceitos de indivíduo, tempo e morte”. op. cit., p. 96.
} 
fator que vem também a diminuir a vivência do luto. Mas o luto, ainda que discreto, deve ser realizado, para que o rompimento com o ente perdido seja encarado como real.

\subsection{Luto}

Se a morte foi escamoteada da sociedade, o luto, entretanto, segue necessário, e o corpo e o rito fúnebre são fundamentais para o rompimento da relação de quem vive com quem morreu. O corpo sem vida é a prova da morte. O sepultamento - enterro, cremação - é o ritual de despedida do corpo. O sentido da morte foi alterado, e sobre ela pouco se fala. Mas, ainda que diminuído, e ainda que suas manifestações tenham sido bruscamente alteradas, a necessidade de realizar-se o luto persiste. Se na modernidade não se pode "perder" tempo, a duração do luto deve ser mais veloz do que fora anteriormente, mas ainda assim é essencial que ele seja realizado.

Mas o que é o luto? O processo de luto padrão ocorre quando se tem a constatação de uma perda (que, na morte, é a perda de uma presença mesmo física). O luto é a reação a essa perda, é o processo de rompimento com o objeto perdido, que o alocará no passado. Em "Luto e Melancolia”, Freud caracteriza esse processo:

[...] O luto, de modo geral, é a reação à perda de um ente querido, à perda de alguma abstração que ocupou o lugar de um ente querido, como o país, a liberdade ou o ideal de alguém, e assim por diante. [...]. Confiamos em que seja superado após certo lapso de tempo, e julgamos inútil ou mesmo prejudicial qualquer interferência em relação a ele. ${ }^{60}$

O luto seria, portanto, a reação de alguém à perda de um objeto estimado. Voltando a Sob a areia, no caso de Marie, o luto seria sua reação à perda de Jean. Faltalhe, entretanto, um elemento para que consiga passar por esse processo - o reconhecimento da perda. Ainda seguindo a definição de Freud, o luto realiza um trabalho importante:

Em que consiste, portanto, o trabalho que o luto realiza? Não me parece forçado apresentá-lo da forma que se segue. O teste da realidade revelou que o objeto amado não existe mais, passando a exigir que toda a libido seja retirada de suas ligações com aquele objeto. Essa exigência provoca

60 FreUd, Sigmund. "Luto e melancolia". In: . Edição standard brasileira das obras psicológicas completas de Sigmund Freud (Vol. XIV). Rio de Janeiro: Imago, 1974, pp. 275-276. 
uma oposição compreensível - é fato notório que as pessoas nunca abandonam de bom grado uma posição libidinal, nem mesmo, na realidade, quando um substituto já se lhes acena. $[\ldots]^{61}$

O trabalho do luto seria, assim, realizado após a percepção de que o objeto querido não existe mais. Sobre isso, comenta Mannoni:

O luto se situa no campo do princípio de realidade: existe separação do objeto a partir do momento em que este não existe mais. O trabalho do luto consiste, assim, num desinvestimento de um objeto, ao qual é mais difícil renunciar na medida em que uma parte de si mesmo se vê perdida nele. A nostalgia do objeto vem relembrar o apego ao ser amado desaparecido. [...]

Se o princípio de realidade exige do sobrevivente que ele se separe de um objeto que não existe mais, essa perda de objeto remete, todavia, no nível do vivido, a uma situação traumática. Foram as situações de satisfação que criaram o objeto que vai faltar quando de sua desaparição. Uma necessidade (do amado) abrindo-se para um desejo vai, no caso de uma perda, criar uma nova situação marcada pela dor, que é uma reação a essa perda (vivida às vezes sob o modo do abandono). A angústia se torna, então, por deslocamento, reação a um perigo proveniente do objeto perdido (a morte podendo trazer infelicidade ao sobrevivente). ${ }^{62}$

Desse modo, o luto ocorre após uma perda, e o trabalho de luto faz com que o enlutado desloque sua afetividade do objeto perdido. É, sabe-se, um processo doloroso, que engloba a parte ritual da morte. Tal qual as representações da morte, a vivência do luto é social e historicamente determinada, ambas foram construídas paralelamente.

Ainda no século XIX, os ritos de luto já tinham início quando do adoecimento do moribundo, com a assistência ao convalescente (pois isso significava sua provável breve morte, e não o início de uma - muitas vezes falsa - esperança de cura, como agora o é). Hoje, o processo de desligamento dos mortos, ou seja, o processo de luto, começa quando a morte é confirmada medicamente - não é mais a putrefação do corpo que a confirma, mas uma averiguação técnica. Um atestado é assinado precisando a causa do óbito. Para que haja um rito deve haver, entretanto, um cadáver. E hoje, mais do que nunca, é a presença do corpo que serve como evidência da morte, o óbito tem que ser atestado para que tenha legitimidade. E só pode ser atestado com a prova desse acontecimento - a presença do corpo. É interessante notar que esse corpo jamais

\footnotetext{
${ }^{61}$ FrEUD, Sigmund. "Luto e melancolia". op. cit., pp. 276-277.
}

${ }^{62}$ MANNONI, Maud. "O homem diante da morte". op. cit., p. 91. 
morrerá de forma "natural" - ninguém morre de velhice, morre, antes, por uma incapacidade técnica de se curar uma doença determinada.

Benjamin dissera que a informação, ao contrário da narrativa, precisa de verificação imediata ${ }^{63}$. Esse procedimento se estende para além das formas literárias com o crescimento do que poderia se chamar um espírito científico, a comprovação científica é uma demanda necessária. O corpo é a evidência cabal da morte. Se não há corpo, não há a comprovação empírica do falecimento de alguém.

Após o óbito, tal qual ocorrera com a morte, o luto é recalcado, ele deve ocorrer de maneira discreta e rápida, de modo que os outros não o percebam.

Hoje, à necessidade milenar do luto, mais ou menos espontâneo ou imposto segundo as épocas, sucedeu, em meados do século XX, sua interdição. [...] Não convém mais anunciar seu próprio sofrimento, e nem mesmo demonstrar estar sentindo-o. ${ }^{64}$

Mesmo a escolha de elementos que englobam o ritual fúnebre, como a do caixão e da lápide, tem sido afastada da família e dos que têm relações com o morto, para ser profissionalizada; cada vez mais, empresas se encarregam dessa tarefa. Uma vez enterrado, pode-se finalmente esquecer o morto, um corpo guardado à sepultura. Após o rito fúnebre - agora abreviado -, a vida dos que velaram retoma seu ritmo. A ausência do ente que "parte" é preenchida por outros elementos, sejam de lembrança ou de esquecimento. A sociedade exige dos parentes dos mortos "um autocontrole que corresponde à decência ou à dignidade que impõe aos moribundos. No caso destes, como no do sobrevivente, é importante nada dar a perceber de suas emoções. A sociedade inteira se comporta como a unidade hospitalar." 65

Se os moribundos são enviados aos hospitais, onde vivem seus últimos dias de vida, o velório também não é mais feito em casa, mas em locais apropriados, aos quais só se vai em caso de morte de alguém próximo ou querido.

[...] o velório, feito em ambiente próprio e não mais em casa, se apresenta como um momento pouco compartilhado socialmente, onde as manifestações de tristeza e choro são contidas para não constranger os presentes, os cemitérios mais se

\footnotetext{
${ }^{63}$ Cf. Benjamin, W. "O Narrador - Considerações sobre a obra de Nikolai Leskov”. op. cit., p. 203.

${ }^{64}$ ARIÈs, P. História da morte no Ocidente: da Idade Média aos nossos dias. op. cit., p. 146.

${ }^{65}$ ARIÈs, P. História da morte no Ocidente: da Idade Média aos nossos dias. op. cit., p. 151.
} 
parecem jardins, o período de luto se resume a poucos dias, sendo que logo a vida da família 'volta ao normal'. ${ }^{66}$

Assim, para que exista o hoje abreviado processo de luto, e por meio dele se possa consolidar o rompimento com aquele que morreu, o primeiro passo é justamente reconhecer que essa pessoa não existe mais. A primeira evidência dessa perda é o corpo sem vida, ao redor do qual será organizado o ritual fúnebre.

Se não há um corpo, o luto é prejudicado, não há evidência legal da morte e não é possível que se realizem os tradicionais ritos fúnebres que, ainda que cada vez mais apressados, encerram neles a morte, para poder afastá-la dos que vivem. Como pode haver o luto (ainda que breve) se não se pode fisicamente constatar o falecimento do corpo?

Aqui se volta a Sob a areia e a sua questão central, que foi aquela a instigar o debate acerca da morte: Marie não velou o corpo de Jean, pois ele não foi encontrado. Sem o corpo não houve enterro, e seu processo de luto ficou prejudicado. Percebe-se logo que algo vai mal com Marie. Não há a comprovação empírica da morte de Jean. Certamente o processo de luto de Marie não foi realizado, e isso porque ela não se dá conta da perda do marido. Dada a ausência do corpo, que operaria como prova empírica da morte, ela não vê o objeto perdido como tal, ou seja, não crê na morte do marido. E mesmo o espectador, em um primeiro momento, pode se indagar sobre essa morte.

\subsection{Retorno a Paris}

As ondas paravam e depois voltavam a erguer-se, suspirando como uma criatura adormecida, cuja respiração vai e vem sem que disso se perceba. ${ }^{67}$

A segunda parte do filme ocorre sobretudo em Paris. O retorno de Marie à capital, tal qual sua partida com Jean para Landes, é marcado pelo Sena. O rio, escuro pela noite, ocupa a tela inteira, o espectador mergulha nessas águas até que a tela lhe mostra, às margens do Sena, um prédio. A câmera logo já está dentro de um apartamento, onde há um jantar entre amigos. Conversam sobre ginástica e Marie, animada, sugere que o amigo Gérard vá à academia com ela. É quando Vincent demonstra interesse por ela, perguntando-lhe onde faz ginástica. Ela responde, sorrindo:

\footnotetext{
${ }^{66}$ Bellato, R. et CARvalho, E. C. "O jogo existencial e a ritualização da morte”. op. cit.

${ }^{67}$ Woolf, Virginia. As Ondas. Mira-Sintra: Publicações Europa-América, sem data, p. 7.
} 
MARIE: Numa academia pequena perto de casa. Vou de manhã antes de ir trabalhar. Meu marido sempre me diz que vai comigo, mas desiste. Ele é como você, Gérard. Não é grande esportista. (Gérard e Amanda ficam sérios e a olham com desconforto). Mas me prometeu que tentará ir aos sábados de manhã. E se viesse conosco, Gérard? Se sentiria menos sozinho. Os dois ficariam mais à vontade. Nessa idade e com tanto trabalho é bom ter uma atividade física.

A fala de Marie é natural, e faz crer que nada se passou. Seus brincos, entretanto, balançam, condensando a tensão da cena. Essa tensão fica nítida no incômodo gerado pelo olhar desconfortante entre Gérard e Amanda no momento em que Marie fala sobre "seu marido". Esse constrangimento mostra ao espectador que, apesar da fala de Marie, Jean não foi encontrado e ela tampouco se casou de novo. A câmera, a partir desse momento, ficará colada em Marie, e não fossem alguns sinais externos, nada faria perceber que Jean morreu - ou ao menos que ele não está mais lá, o que, de acordo com a teoria freudiana, já deveria gerar um luto. Marie age como se ainda vivesse com Jean.

Ela ainda insiste em falar sobre seu marido quando Vincent, interessado nela, e não incomodado com a situação, continua a conversa:

\section{VINCENT: Sempre praticou esporte?}

MARIE: Na Inglaterra, quando era jovem, fazia natação e até competia. Então conheci meu marido, um verdadeiro francês que adora uma boa comida, um bom vinho...

Para acabar com o constrangimento e interromper a fala de Marie, sua amiga diz:

AMANDA: Mais salada, Marie?

Ela aceita, e mudam de assunto.

Outro indício de que algo vai mal no processo de aceitação da perda do marido de Marie vem em seguida: na cozinha, com Amanda, Marie confessa que está um pouco bêbada. Arrumam as coisas enquanto conversam ora em francês, ora em inglês. É então que a amiga lhe pergunta se ela ligara para o psiquiatra que sugeriu, e Marie responde "não estou precisando". 

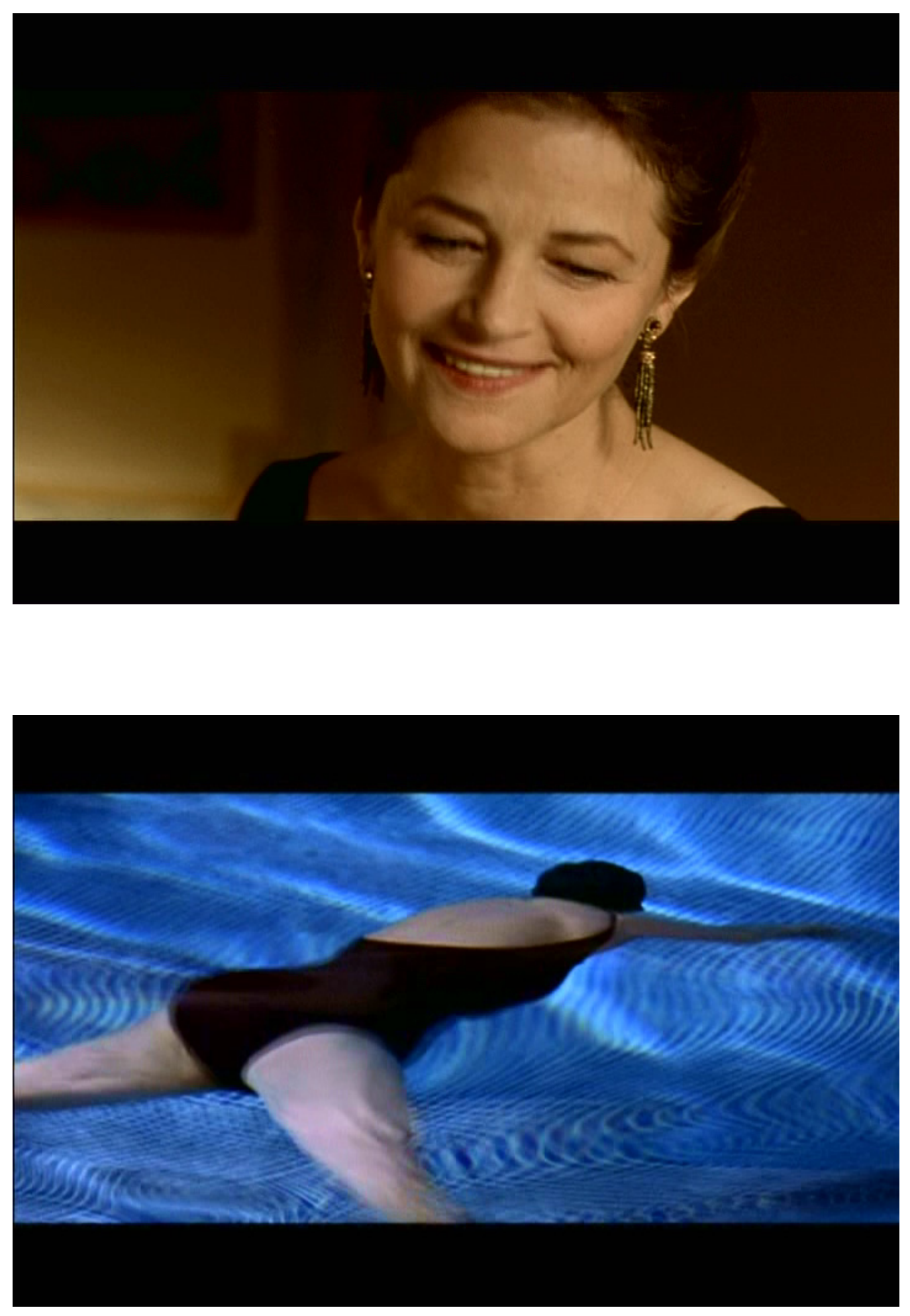
Voltando para casa com Vincent, Marie volta a falar de seu marido - com quem diz estar casada há 25 anos e não ter filhos - como se ele estivesse vivo. E se recusa a beijar Vincent. A surpresa filmica acontece após Marie entrar em casa, quando ela tira os sapatos e se deita no sofá, no escuro. Ao ouvir o som de passos, ela se vira e pergunta "Não dormiu ainda?", “Como vê, estava à sua espera", diz um homem que está à contra-luz. Marie acende o abajur, e o espectador por fim pode ver: esse homem é Jean, que se senta ao lado de Marie e conversa com ela. Quando ela vai dormir, ele está na cama, lendo. Marie lhe deseja boa noite e pergunta se ele ligou o despertador - "sim", responde Jean, sem ao menos desviar seus olhos do livro. Como na praia, ele põe o livro sobre o criado-mudo, tira os óculos e fecha os olhos para dormir. Marie apaga o abajur e pede para que Jean a abrace.

Na manhã seguinte, Marie prepara o café-da-manhã. Quando vai pegar a louça no armário (louça para quantas pessoas?), ela fecha os olhos, apreensiva, por alguns segundos. Abre os olhos e se vira. Sorri aliviada - Jean está ali, sentado à mesa. Marie enche a xícara de Jean e passa margarina sobre uma torrada, que então põe sobre o prato dele. Jean a observa, e a cena termina sem que ele toque na torrada. Jean continua presente na vida de Marie, mas sua imagem aparece de outro modo: ele não aparece mais de frente e nitidamente como antes; ele antes aparecera sempre muito iluminado, em cenas externas e com ângulos quase invasivos sobre seu rosto. Agora, Jean aparece sobretudo de lado, no escuro, ou é mostrado seu reflexo sobre o espelho - as tomadas são menos nítidas. Não é mais Jean quem se vê, mas a imagem dele na memória viva da solidão de Marie. Ainda assim, como diz Schiller, "Ele [Jean] nos parece tão real quanto Marie que, como muitos enlutados, encontra conforto na fantasia continuada de sua relação perdida" 68 .

Então a água, local onde Jean desapareceu, volta à tela na aula de natação de Marie. Antes de mergulhar na piscina, ela olha fixamente para a água, e o espectador tem a impressão de que, se não tem consciência da perda de Jean, Marie ao menos a sente por alguns instantes. A água se movimenta, impulsionada pelo nado de um senhor que Marie observa apreensiva. Quando ela mergulha, sua imagem se torna turva na tela. O espectador vê essa água que torna os corpos (visualmente) disformes, fluida como a que levou Jean fato que ela custa a aceitar, exceto em raros momentos de exceção, como esse.

Outro momento de oscilação (que faz o espectador crer que Marie notará a perda de Jean) ocorre em uma aula, quando ela lê um trecho de "As Ondas", de Virginia Woolf.

\footnotetext{
${ }^{68}$ SChILLER, B. M. "A Memorial to mourning: Under the sand". op. cit. Tradução livre de: "He seems as real to us as he does to Marie, who, as many mourners, finds comfort in the continued fantasy of her lost relationship."
} 
- E o tempo - disse Bernard - deixa cair a sua gota. A gota que se formou no topo da alma acaba por cair. No topo da minha mente, o tempo deixou cair a sua gota. Esta caiu a semana passada, quando me estava a barbear. De súbito, com a lâmina na mão, apercebi-me da natureza puramente mecânica do acto que desempenhava (era a gota a formar-se) e, não sem alguma ironia, dei os parabéns às minhas mãos por conseguirem levar as coisas até ao fim. "Barbeia, barbeia, barbeia", disse. "Continua a barbear". A gota caiu. Durante o dia, a intervalos regulares, sentia que o espírito como que viajava até esse espaço vazio, perguntando: “O que se perdeu? O que terminou?". Ainda murmurei: “Acabado e bem acabado, acabado e bem acabado", consolando-me com palavras. As pessoas repararam na expressão vazia do meu rosto e na inutilidade da conversa. As últimas palavras da frase foram-se apagando. E, quando apertava o casaco e me preparava para ir para casa, disse de forma dramática: "Perdi a juventude." ${ }^{69}$.

No momento em que lê "perdi minha juventude", Marie vê o rapaz que a ajudara a procurar o marido em Landes sentado no auditório. Ela pára de sorrir e tenta continuar sua leitura, mas gagueja.

É curioso que, quando ocorre uma crise, há uma frase que insiste em nos vir socorrer, mesmo nada tendo a ver com o caso - trata-se do castigo de viver numa civilização antiga e munido de um bloco-notas $[\ldots]^{70}$

Se frases sem sentidos podem salvar as pessoas em momentos difíceis, as que salvam Marie são as que ela pronuncia de modo natural, evocando Jean em um presente cotidiano e com isso fugindo do penoso enfrentamento de sua morte. Após a tentativa de leitura desse trecho, Marie se desculpa e termina a aula mais cedo do que o previsto.

Novamente, Marie demonstrou-se abalada pela perda do marido - portanto, se não reconheceu tal perda, parece ao menos tê-la sentido. Por que Marie interrompe a aula? Há a sensação melancólica de que perdeu algo? O reconhecimento do que se perdeu no rosto do salva-vidas? A leitura do texto que fala sobre a perda, o conhecimento da vida de Woolf, que se suicidou afogando-se? Seja o que for que a abalou - provavelmente mais de um fator - a oscilação pouco dura. O aluno que trabalhara como salva-vidas tenta cumprimentá-la do lado de fora da sala, dizendo que ajudou no caso de seu marido, em

\footnotetext{
${ }^{69}$ Marie cita Woolf no original, em inglês. Aqui, usou-se a tradução portuguesa de sua obra: WoOLF, Virginia. As Ondas. Mira-Sintra: Publicações Europa-América, pp. 115-116. Para ver a versão falada (em inglês) e a tradução brasileira apresentada nas legendas do filme, ver Anexo 3.

${ }^{70}$ Idem.
} 
Landes, no verão, mas Marie diz “Ouça, você se enganou. Nunca fui a Landes”. A negação da ida à praia denuncia, mais uma vez, sua recusa por aceitar a perda do marido.

A continuação do trecho lido por ela em aula seria:

[...] A gota que caiu nada tinha a ver com o facto de estar a perder a juventude. Esta gota mais não era que o tempo a atingir um certo ponto. $\mathrm{O}$ tempo, que mais não é que um pasto soalheiro coberto por uma luz trémula, o tempo, que se espalha pelos campos ao meio-dia, fica como que suspenso num determinado ponto. Semelhante a uma gota que cai de um copo cheio, assim o tempo cai. São estes os verdadeiros ciclos, os verdadeiros acontecimentos. Então, como se toda a luminosidade da atmosfera tivesse sido retirada, vejo-lhe o fundo vazio. Vejo aqui o que o hábito cobre. Deixo-me ficar na cama durante dias a fio. Janto fora e não paro de bocejar. Nem sequer me dou ao trabalho de concluir as frases, e as acções que pratico, por norma tão inconstantes, adquirem uma precisão mecânica. Foi numa destas ocasiões que, ao passar por uma agência de viagens e nela tendo entrado, comprei um bilhete para Roma com a compostura característica das figuras mecânicas. ${ }^{71}$

Esse tempo do qual fala Virginia Woolf é um tempo que está por trás do hábito no caso de Bernard, o hábito de se barbear -, um tempo que não se sente passar, que é quase sem duração, mecânico, o tempo das atividades cotidianas. O luto não é cotidiano, ele é exceção e deve ter uma duração na qual se esgote - é como o tempo que passa por trás do luto que Marie deveria estar realizando. Enquanto se vivencia um luto, envelhecese. O foco de pensamento do enlutado fica na lembrança de uma pessoa que então só existe no passado, embora o tempo passe como sempre, em seu curso irrefreável. Mas, com esse processo, realiza-se um rompimento que é fundamental. O tempo de um luto não-realizado é, entretanto, como o tempo do hábito: Marie simplesmente segue sua rotina, seu cotidiano, sem que a ausência de Jean seja construída, ou mesmo percebida; ela vive como se Jean estivesse com ela. Tal qual a gota faz Bernard perceber o correr do tempo, Marie se dá conta de mudanças decorridas no transcorrer do tempo durante breves instantes, que aqui se chamam de "oscilações" - mas que logo passam, sem deixar rastros.

E novamente Marie oscilará, abalando assim sua convicta negação da perda de Jean, mas logo retomará, com vigor, sua posição de rejeição ao luto. Em uma loja elegante, Marie decide comprar um vestido vermelho para si e duas camisas e uma gravata para Jean. Como seu cartão é recusado, opta por pagar utilizando cheque, desculpando-se com a vendedora e avisando que não levará mais as camisas e a gravata.

\footnotetext{
${ }^{71}$ WoOLF, Virginia. As Ondas. op. cit., p. 116.
} 
Aqui está mais uma oscilação. Parece que ela percebe, por um breve instante, que não teria a quem dar as camisas e a gravata, e se lembra de que não conta mais com o salário de Jean. Mas logo Marie se desculpa novamente com a vendedora, e diz que levará a gravata (que havia pedido em azul, a cor dos olhos de seu marido).

Quando chega em casa, Marie ouve o recado de Vincent na secretária eletrônica; ele se desculpa pelo beijo que lhe dera e a convida para jantar. Enquanto ouve, coloca as correspondências ainda fechadas em uma gaveta onde já há tantas outras. Anota o número de Vincent e, enquanto ri de seu recado cômico, uma voz grossa a assusta ao perguntar "Quem é esse Vincent?" - a voz é de Jean, que aparece primeiramente refletido no espelho da sala. Ela lhe dá a gravata e conversam rapidamente a respeito de Vincent.

Então Marie vai a um restaurante com Vincent, em uma cena que é ainda bastante reveladora da situação que ela tem vivenciado: eles se sentam ao lado de um aquário. A cena começa com o aquário em primeiro plano e eles atrás, vistos através das águas e dos peixes. No fundo do aquário há plantas verdes, e sobem bolinhas de oxigênio. Os peixes transitam, como se estivessem no mar no qual mergulhou Jean. Ainda a conversa retomará o tema marítimo. A tomada se inverte, o aquário vira o fundo da filmagem e, aparecendo em primeiro plano, eles conversam.

Marie cita $A s$ Ondas $^{72}$, o livro cuja leitura interrompera na aula anterior. Vincent diz que não se lembra muito bem do livro e ela cita, em inglês, o bilhete que Woolf deixou antes de cometer suicídio, afogando-se com pedras nos bolsos: "Tenho o sentimento de que posso enlouquecer. Ouço vozes, e não consigo me concentrar no meu trabalho. Tentei lutar, mas não posso mais lutar. Devo toda a felicidade da minha vida a você. Você tem sido tão perfeito, mas eu não posso continuar e estragar a sua vida" ${ }^{, 73}$. Essa nota suicida faz o espectador atribuir à Marie o que é dito: quem ouve vozes e não consegue se concentrar em seu trabalho é Marie, que tenta lutar, oscila, mas não tem forças, e logo se convence novamente de que Jean não morreu.

Vincent acha a morte por afogamento de Virginia Woolf assustadora, mas Marie a acha bonita. Acharia ela bonita também a morte de Jean? Logo Jean começará a desaparecer gradualmente de sua vida, sua imagem será cada vez menos presente para ela (e

\footnotetext{
${ }^{72}$ Vale lembrar que já o título do livro escrito por Virginia Woolf faz referência ao mar - às águas salgadas nas quais Jean se afogou.

${ }^{73}$ Tradução livre da fala de Marie, em inglês: "I have the feeling that I shall go mad. I hear voices and I cannot concentrate on my work. I've tried to fight, but I can't fight any longer. I owe all my happiness in my life to you. You've been so perfect, but I can't go on and spoil your life".
} 
para o espectador). E, nos raros momentos de oscilação, Marie então desconfiará não de que ele se afogou por acidente, mas de que pode ter cometido suicídio na água, tal qual Woolf.

Quando volta para casa, Marie convida Vincent para subir e beber algo, mas ele é quem recusa. Ela entra em casa e se deita. $\mathrm{O}$ espectador a vê no sentido oposto ao que está acostumado - de ponta-cabeça. As mãos de Vincent e Jean tiram seus sapatos e deslizam sobre seu corpo, acariciando-a. Marie se masturba com suas mãos enquanto as outras quatro mãos a tocam. Quando tem um orgasmo, as mãos de Jean e Vincent desaparecem, os homens que a acompanharam em suas fantasias sexuais a deixam, e então lá está Marie, inteiramente só em seu apartamento.

No dia seguinte, Marie tem que se haver com problemas burocráticos dessa morte que ainda não reconhece, do tempo do luto que ela não vivencia, da presença de alguém que não está lá. Marie vai ao escritório de Gérard, que lhe comunica as questões burocráticas que o desaparecimento do corpo de Jean implicam. Ela está sentada em uma cadeira forrada por cetim vermelho e contornada pela cor dourada, muito elegante. Igualmente elegante é a postura de Marie, que fuma e sorri enquanto fala, demonstrando firmeza em suas colocações, transmitindo uma segurança que Gérard não ousa questionar ou desafiar.

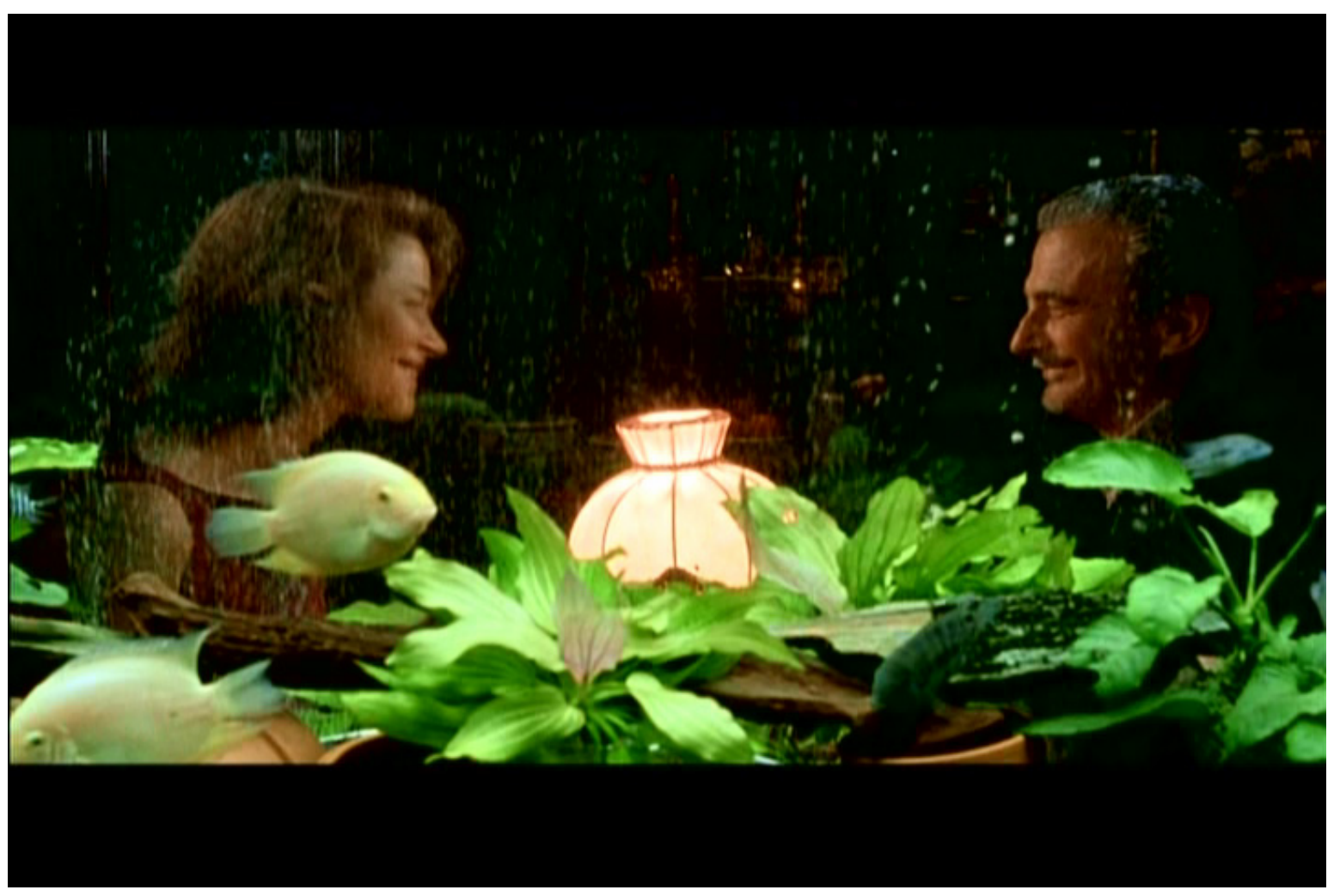



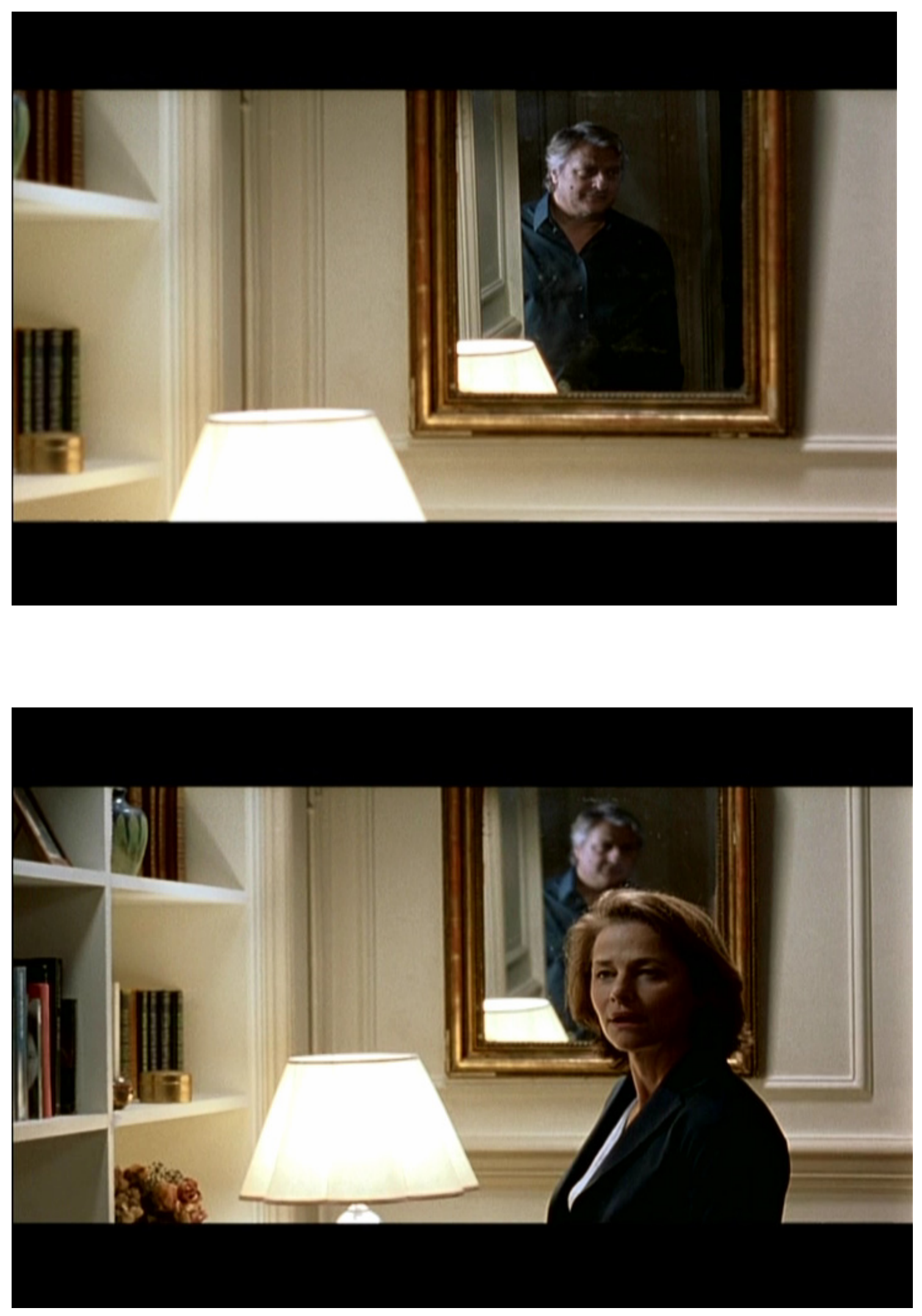
GÉRARD: Seu gerente me informou que ultrapassou o seu saldo e não pode mexer na conta de Jean.

MARIE: Ele te disse isso?

GÉRARD: Sim. Precisaria ter uma procuração dele. Como a morte não foi comprovada... A conta está bloqueada. Nesses casos, é preciso esperar 10 anos para que o testamento seja...

MARIE: Não se preocupe. Falarei com ele.

GÉRARD: Falar com quem?

MARIE: Com Jean. O que pensou? Só porque ele viaja e trabalha muito...

GÉRARD: Ouça, Marie, seja razoável. Só peço para não gastar demais. Tente viver com menos, enquanto as coisas...

MARIE: É gentil cuidar de mim. Não se preocupe. Vou resolver tudo bem depressa.

A não comprovação da morte, pela ausência do corpo, além de render à Marie a vivência de uma presença que se esvaiu, lhe causa esses transtornos burocráticos - sem o atestado do óbito, não há direito à herança. Burocraticamente, ela teria que esperar por dez anos para que pudesse ter acesso aos bens de seu marido "desaparecido". E quanto à espera pelo luto, também terá que perdurar por uma década?

Substituir Jean por Vincent seria um modo alternativo de lidar com a ausência do marido - ao invés da aceitação de uma perda, ocorreria uma substituição. Marie tentará fazê-lo, mas Vincent não pesará tanto quanto Jean. Ela é quem sugere que vão à casa de Vincent quando ele a busca em seu trabalho. Enquanto fazem sexo, Marie gargalha súbita e incontrolavelmente. Ele, que está deitado por cima dela, a olha e diz:

VINCENT: O que foi?

MARIE: Desculpe.

VINCENT: Deve saber por que está rindo, não?

MARIE: Não sei. É um negócio esquisito.

VINCENT: Um negócio esquisito?

MARIE: Desculpe, mas você é muito leve.

VINCENT: Leve? É a primeira vez que ouço isso.

MARIE: Não é uma crítica. Só preciso me acostumar. Pode fechar a cortina? 

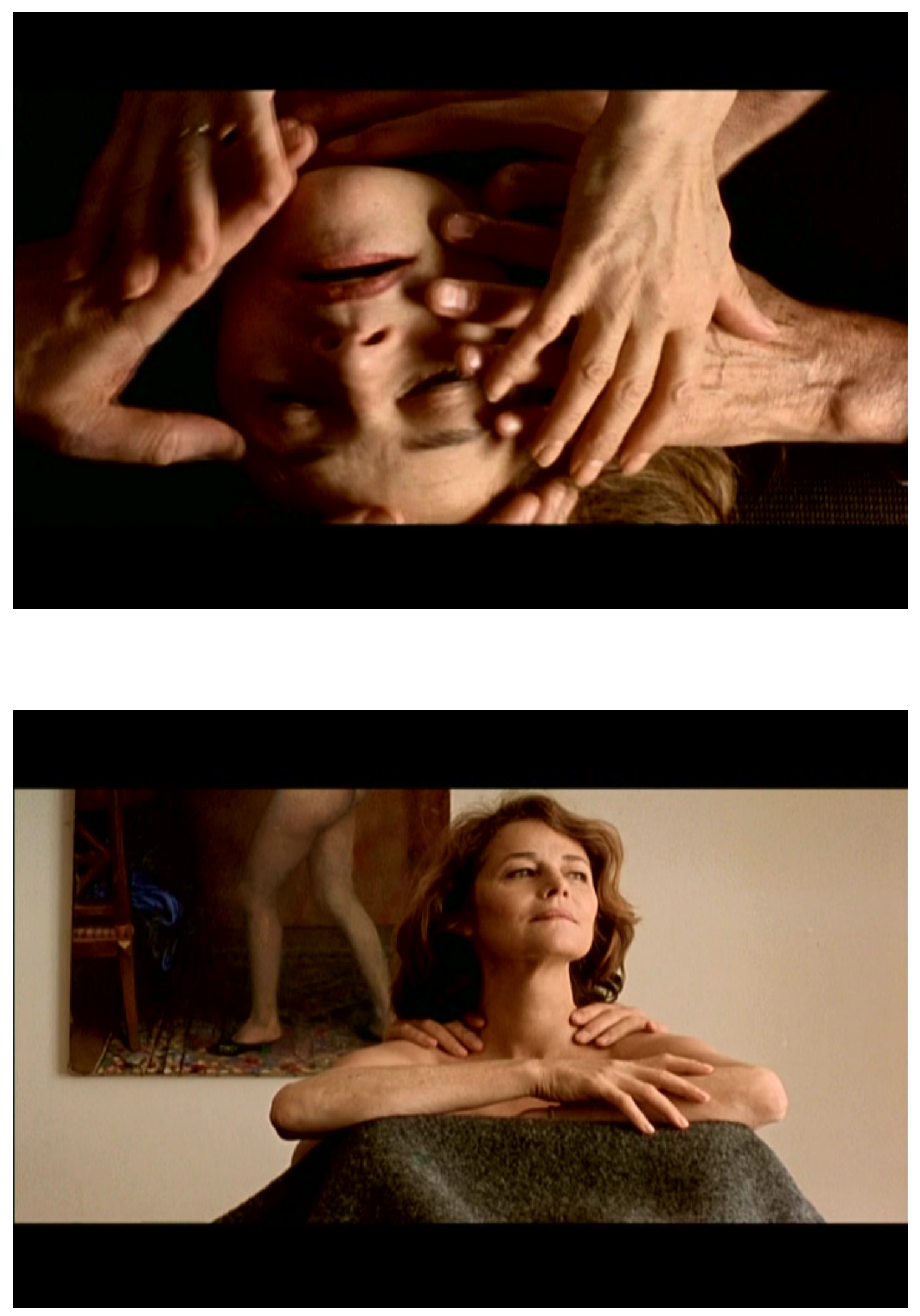
Marie não encarará Vincent como um novo amor, substituto a Jean, mas como um amante, um caso extraconjugal. Isso porque, para que Vincent pudesse substituir Jean, Marie teria que se dar conta do seu real desaparecimento - é com a percepção da perda do objeto que se pode substituí-lo, para isso Marie precisaria viver o tempo do luto, e ser capaz de mentalmente construir Jean como uma lembrança do passado. Mas, além da recusa de Marie em assumir a perda de Jean, ela não está apaixonada por Vincent, apenas o encara como um amante que é leve demais se comparado ao peso do homem com quem vivera por 25 anos.

Com o quarto mais escuro, eles voltam a fazer sexo. Marie pede para que Vincent feche seus olhos e diz onde quer que ele a acaricie. Diz que é a primeira vez que "trai" Jean. O espectador a vê, então, sentada, e atrás dela há um par de pernas, parte de um quadro que está na parede. Duas mãos surgem por trás de Marie, massageando seu pescoço - a presença dessas partes de corpo na tela se torna confusa. Marie é uma personagem solitária, tem um semblante impenetrável, ninguém a acusaria de demência. Fala de Jean demonstrando propriedade do conteúdo e convicção. Essas mãos que a tocam parecem vir, entretanto, mais de sua imaginação que da realidade. Uma imaginação que se manifesta fora de Marie - como quando vê Jean - uma imaginação que nega sua solidão. As pernas do quadro e as mãos finas nas costas de Marie, que parecem de Vincent, lembram o espectador de quando ela, só, imaginava estar com Vincent e Jean em sua casa. Se agora há a imagem de outro corpo no quadro, junto a ela está apenas Vincent, que logo aparece, confirmando serem suas as mãos, e conversa com Marie, respondendo a ela que, se fossem casados, ele não a trairia.

Vincent parte e Marie permanece em seu apartamento. Há uma ampla janela, pela qual se pode ver a chuva caindo sobre algumas plantas; ouve-se o som da água. Marie vai até o banheiro, olha-se no espelho e sorri para si. Caminha frente à estante de livros de Vincent, observando-os e passando a mão sobre eles, parecendo contente e aberta a uma nova paixão. Ela não está lá, entretanto, como esposa ou namorada de Vincent. O estranhamento que tem em relação ao apartamento - que a leva a desvendá-lo, apalpá-lo , é o estranhamento de uma nova amante que observa o apartamento de seu cúmplice, vestida apenas com uma anágua e coberta por um xale, caminhando languidamente. Tal é a sensação de que Marie é amante de Vincent, e não sua esposa, que a cena é encerrada com um zoom da câmera sobre uma fotografia, disposta em um porta-retratos, na qual Vincent aparece ao lado de outra mulher - essa, sim, adquirindo na cena o papel de sua 
esposa, ou ao menos de alguém que possui uma relação sólida e assumida com Vincent, muito embora ele tenha dito que não possui nenhum relacionamento sério.

Como amante, Marie está feliz e não parece tão só. Sua solidão virá ao chegar em casa e notar a ausência de Jean. Uma solidão intensa, e a sensação de que Vincent não ocupará seu lugar porque ele não pesa o suficiente, uma solidão aprofundada, ainda, pela alegria que aparece na cena precedente, pelo conforto que ela sente ao sair da casa de Vincent e ir às compras: no supermercado, ocorre o momento de maior descontração de Marie no filme, ela parece feliz como uma adolescente que se encanta por alguém. Age de acordo com o que dissera na conversa com Vincent - como se essa fosse sua primeira relação extraconjugal depois de 25 anos de matrimônio, mas um caso amoroso aceito por seu marido (afinal, ela já “conversou” com Jean sobre Vincent), ou seja, sem que haja culpa alguma, apenas a fruição do prazer hedônico.

Marie caminha pelo mercado empurrando seu carrinho de compras. Está calma e sorridente. Pela primeira vez desde o desaparecimento de Jean, expressa leveza. A música que a acompanha - Septembre (Quel joli temps) - é animada e dançante, sua letra celebra a beleza de uma época para se dizer adeus, versando sobre um amor que finda junto com o verão, um caso passageiro como o que parece se configurar entre Vincent e Marie. O verão cantado na música, ao qual se atribui beleza, seria oposto àquele vivido por Marie caso ela tivesse, de fato, realizado o luto pela morte de seu marido. (“Jamais o fim de verão pareceu tão bonito [...] Mas precisamos nos deixar, embora nos amemos/ Que linda época para dizer adeus/ Que linda noite para voltar aos vinte anos [...] O amor se vai, meu coração pára"74).

A felicidade dessa mulher que tem um novo amante, entretanto, dura pouco. Não porque dirá adeus a um amor de verão como na canção, mas porque a cena seguinte extinguirá qualquer leveza. Há um corte bruto e repentino, tanto na imagem como no som ouve-se o som de uma porta pesada se abrindo bruscamente, e já se está em outra cena, escura. É Marie entrando em casa. Ela acende a luz, ainda sorrindo. Pressiona o botão da secretária eletrônica para ouvir os recados enquanto tira seu mantô. Quando ouve a mensagem do delegado de Landes, fica séria e caminha em direção à secretária eletrônica.

DELEGAdo: Boa tarde. Esse é um recado para a Sra. Drillon da parte do delegado de Lit-et-Mix. Estou ligando porque encontramos no mar um corpo que pode ser o do seu marido. Poderia telefonar com urgência para 05-40-34-21-15? Obrigado e até logo.

\footnotetext{
${ }^{74}$ Trecho da música Septembre (Quel Joli Temps), cantada por Barbara. O trecho completo da música tal qual é cantado no filme, em francês, e sua tradução ao português encontram-se no Anexo 4.
} 
A câmera se aproxima de Marie, que está de costas. Ouve-se o bip telefônico soar após o delegado ter encerrado a ligação. A tensão da cena é reforçada por esse som pulsante, e o espectador não tem como prever a reação de Marie, pois não pode ao menos ver sua feição. Sua atitude é pressionar um botão na secretária eletrônica, como se assim apagasse da sua memória o recado que acabou de ouvir. Marie, então, vira-se, sorridente, e caminha pela casa chamando por Jean.

Não há resposta. Marie não encontra Jean, mas sua própria imagem refletida em um espelho. $\mathrm{O}$ espelho reflete sua solidão de forma tão escancarada que mesmo a câmera se constrange e faz um movimento descendente, mostrando não mais o rosto de Marie, mas a terça parte central de seu corpo. Tampouco ela suporta observar sua solidão, e logo está na rua, caminhando, à noite. A câmera se movimenta no ritmo de seus passos, marcados pelo som dos saltos batendo no chão. Marie parece oscilar novamente - ela observa o restaurante chinês em que esteve com Vincent pela janela, mas vai comer em uma rede fast-food, onde se senta só e observa as pessoas ao seu redor, desolada.

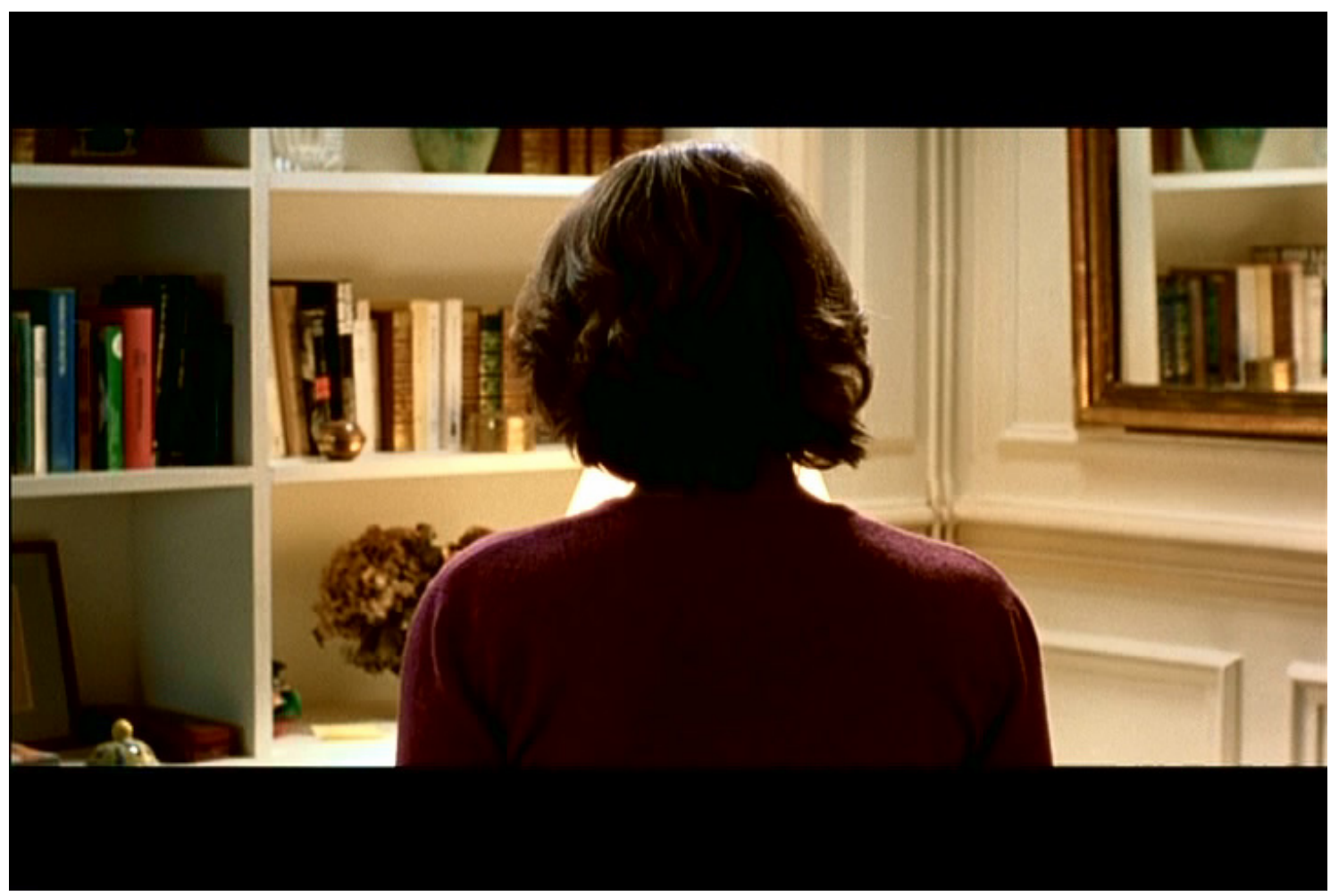


Parece que o recado deixado pelo delegado, comunicando que encontrara o corpo, fará com que Marie, por fim, reconheça a perda de Jean e realize o luto. Ela vai para casa, chega a despejar em suas mãos vários calmantes, mas toma apenas um comprimido e se deita para dormir, sozinha. Na manhã seguinte, Vincent, o caso "extraconjugal” que havia deixado Marie tão feliz, telefona, mas ela o trata de modo bastante grosseiro.

O filme gera um fortalecimento na crença de que Marie enfim percebera a perda do marido - ela desfaz o sorriso que estava em seus lábios, e busca alugar um novo apartamento, contendo assim seus gastos e saindo daquele no qual a presença de Jean é tão marcante. Na visita a um imóvel, diz à corretora que ele é perfeito, e pergunta quando podem assinar o contrato. A corretora lhe diz: “Tão rápido? Não quer que seu marido o veja antes?" Marie não lhe conta que seu marido morreu, mas tampouco diz que ele verá o apartamento, simplesmente responde "Não, não vale a pena. Ele vai gostar". Então, caminha até a janela e desfalece (cai rapidamente, a corretora a segura). Levanta-se e comunica que não quer mais o apartamento. Quando a câmera se aproxima da janela, é possível entender o que abalou Marie - a vista do apartamento é um cemitério, ou seja, o símbolo maior do ritual fúnebre, ritual esse que ela não realizou, e que seria fruto de uma perda que ela começava a aceitar, mas que será novamente obscurecida.

Marie então procura um médico, a quem diz que "às vezes" ouve "ruídos que não existem", "ruídos cotidianos", “algo como um zumbido". No momento de pagar a consulta, descobre que Jean esteve lá antes de partir, com ela, para a viagem de férias. Isso acanhará ainda mais a possibilidade de Marie reconhecer a morte do marido, de restringir a existência de Jean a um tempo passado. Ela tentará descobrir que mal-estar ele sentia para ter procurado um médico, como se uma entrada mais detetivesca em sua vida fosse lhe trazer respostas alternativas para algo que já foi respondido pelo tempo, e sobretudo pelo recado em sua secretária eletrônica: o afogamento acidental de Jean.

Ao chegar em casa, o espectador vê, pela primeira vez, Marie entrar no escritório de Jean. Não há saudosismo ou tristeza: ela busca as receitas médicas do marido com um empenho exclusivamente investigativo. Os pertences de Jean não a tocam como algo pertencente a alguém que se foi, não a levam ao passado, não lhe geram nostalgia ou saudade. Como Marie ainda sente a presença de Jean, seus objetos, que estariam presos a uma vivência passada e irrecuperável, nostálgica, portanto, são vistos por ela como objetos do cotidiano: o paletó de Jean sobre a cadeira, seus documentos, a caneta sobre a mesa. Nada a incomoda, ela entra no escritório somente para procurar a receita médica, e isso é o que faz - vasculha suas gavetas e tem o olhar 
focado em seu objetivo. Ao encontrar o que busca, Marie sai do escritório de Jean para descobrir a função dos remédios prescritos.

No almoço com Amanda, com quem conversa em inglês, embora conjugue os verbos referentes a Jean no presente e no futuro, Marie parece desconfiar de algo:

MARIE: E o Jean? Estou preocupada com ele.

AMANDA: O que quer dizer?

MARIE: Eu me pergunto se...

AMANDA: O quê?

MARIE: Estará pensando em suicídio.

AMANDA: Quer dizer que acha que Jean cometeu suicídio no verão passado?

MARIE: Não sei. Se soubesse de algo, você me contaria, não?

AMANDA: Claro que sim. É minha melhor amiga, Marie. Mas está na hora de esquecer. Não adianta ficar pensando. Precisa continuar sua vida, Marie, pensar em si mesma.

MARIE (fala agora em francês, como se com a mudança de idioma mudasse também o assunto, voltando a crer que ele não morreu): Acha que Jean é infeliz comigo?

AMANDA: (em francês) Pare com isso, Marie. Não fez nada de errado. Está me ouvindo? MARIE: Sim.

Quando Marie começa a aceitar, nesse diálogo, que Jean não está mais com ela, ainda assim conjuga os verbos no tempo presente. Cogita a possibilidade de que Jean tenha desaparecido por vontade própria ou suicídio - ou seja, oscilando, rapidamente aceita a falta de Jean -, mas logo volta a agir como se ainda vivessem juntos.

Marie então recebe Vincent em sua casa, e com ele vivencia uma repetição de seu cotidiano com Jean. Como na casa de praia, Marie põe o spaghetti na água que ferve em uma panela. Enquanto isso, Vincent põe lenha na fogueira. Em uma cena escura, com trajes escuros e o rosto iluminado, Vincent espera por Marie, já sentado à mesa, com um olhar perdido tal qual o de Jean na casa de praia. Depois de comer, Marie se olha no espelho e retira a maquiagem. Quando vai se deitar, Vincent já está na cama, lendo "um livro que achei ali". Ela lhe dá um beijo, diz "boa noite" e se deita. Vincent apaga o abajur, abraça Marie e ela pergunta "pôs o despertador?”. Tal qual Bernard, o personagem de Woolf, ao se barbear, Marie automatizou um hábito (perguntar pelo despertador, como o fizera por 25 anos com Jean), e o faz sem se dar conta. Mas nenhuma gota escorre para que ela perceba que o tempo passou, que o homem que está com ela não é o mesmo, que Jean não vive mais. 
Bernard, o personagem de Woolf, perdera sua juventude, Marie perdeu, embora não se dê conta, um tempo preso nos hábitos que tinha na vivência com Jean, o tempo da repetição do hábito, que finda com a morte de Jean. Sem seu marido, o tempo que a pergunta sobre o despertador levou para se tornar hábito se desprende da pergunta mesma, que então deixa de fazer sentido. Ainda que Vincent já tivesse ligado o despertador, e mesmo que ele pesasse tanto quanto Jean, haveria, para Marie, uma ausência - a ausência que se sente pela perda de alguém e que não é nomeada, muito embora se espalhe pela vivência de quem permanece, pela saudade contida em pequenas lembranças emanadas por objetos, ou em pequenos hábitos cotidianos que evocam essa falta.

O que se perde quando se perde alguém? Não perdi nesta ou naquela característica o ser amado. Não é porque minha mulher tinha aquele tom de cabelo ou de suavidade nas mãos que eu a amava. Por mais que faça a lista de seus atributos, sempre haverá um que resta a descrever. Por outro lado, cada elemento desta lista de atributos pode ser encontrado às dúzias no mundo. O que houve? Em uma primeira resposta, diremos que a morte levou consigo a possibilidade disso tudo estar reunido. Esta possibilidade acrescenta-se subtrativamente à série de traços, pois não é em si um atributo, mas pura suposição. [...] Em outros termos: o que se perdeu é sempre impossível de se esgotar com uma nomeação. ${ }^{75}$

Isso, que não se nomeia, era a presença de Jean, fruto de uma relação construída durante os vinte e cinco anos de convivência com Marie. E, ainda que Vincent tivesse muitos de seus atributos, ele jamais seria Jean.

Enquanto Marie e Vincent fazem sexo, Jean aparece na porta do quarto e os observa. Marie parece sentir prazer não por seu contato com Vincent, mas pela presença de Jean. E ela vai atrás dessa presença, no meio da noite, ao dormir no escritório do marido, onde Vincent a encontra na manhã seguinte, vestindo uma camiseta de Jean grande demais para seu corpo.

VINCENT: Era o escritório do seu marido?

MARIE: É o escritório do meu marido.

VINCENT: O que vai fazer com ele agora?

MARIE: Por que "agora"? Não entendi.

${ }^{75}$ VIEIRA, Marcus André. “Objeto e desejo em tempos de superexposição”. Ágora, vol. 8, no 1, Rio de Janeiro, jan/jun 2005. Disponível online http://www.scielo.br/scielo.php?script=sci_arttext\&pid=S1516-14982005000100002\&lng=en\&nrm=isso. Acesso em: 14/04/2007. 
VINCENT: Sei sobre seu marido. Esperava que me contasse. Sei que é duro.

MARIE: Você não sabe de nada.

VINCENT: Posso ajudá-la, Marie.

MARIE: Me ajudar? Quem é você pra mim? Nada! Então, por favor, cuide da sua vida!

Ela parte, e logo já estão à mesa, para tomar café da manhã, justamente como antes estiveram Marie e Jean.

MARIE: Mais café?

VINCENT: Não, obrigado. Achei que gostaria de conversar.

MARIE: Ah, é? Não. Não sou de falar pela manhã. Não é a minha hora. Engraçado que tenha me imaginado assim. (Põe uma torrada, na qual passou manteiga, sobre o prato dele, como fazia com Jean. Toma um gole de café). Bom, vou me vestir, tomar um banho. Feche a porta quando sair.

Ele se levanta, a segura pelo braço, e diz:

VINCENT: Escuta, Marie, já chega!

MARIE: Me solta.

VINCENT: Diga ao menos o que quer, o que pensa sobre nós. Um dia terá de esquecê-lo.

Ela se solta dele e diz:

MARIE: Quer a verdade? Você não chega aos pés dele ${ }^{76}$ - e vai para o banheiro.

Marie não nomeia os atributos que Jean possuía, e Vincent não tem, mas demonstra não estar interessada em uma nova relação - mesmo porque ainda está por inteira envolta na anterior. Se ela não assumiu para si a perda e Jean, não é para Vincent, com quem não estabelece uma relação de cumplicidade, que o fará. Marie aponta o fato de Vincent não conhecê-la - ele não sabe, por exemplo, que ela não gosta de conversar pela manhã, algo que certamente Jean sabia após os 25 anos de matrimônio. Por fim, Marie resume: Vincent não pesa como Jean, nem fisicamente e nem enquanto história vivida; seria mesmo injusto para Vincent concorrer com uma figura idealizada, alguém que supostamente ainda tem com Marie um relacionamento feliz, cúmplice, e uma longa história construída conjuntamente.

Resumindo a tentativa frustrada de construção de uma relação entre Vincent e Marie, diz Schiller:

[...] Vincent simplesmente não é capaz de preencher o espaço deixado pela morte de Jean. Isso se torna dolorosamente claro na manhã seguinte, quando Vincent procura por Marie vestindo uma camiseta muitas vezes maior que o

\footnotetext{
${ }^{76}$ O que se diz, em francês, é "tu ne fais pas le poids", expressão que literalmente significa "você não faz peso", mas que em português pode ser traduzida como no filme, "você não chega aos pés". A tradução literal mostra o duplo sentido dessa frase falada por Marie, que já havia dito a Vincent, quando estava deitado sobre ela, que era estranho o fato de ele ser leve demais (pois o comparara a Jean).
} 
tamanho dele. Vincent não é substituto para Jean, por quem Marie pode superar seu pesar, nem ela parece apta a amá-lo pela pessoa que ele é, um novo objeto amoroso, diferente do marido pelo qual ela está enlutada. ${ }^{77}$

Marie está confusa com as evidências de que Jean não a acompanha mais, fato que fora inclusive apontado por Vincent e, em determinados momentos de oscilação, desconfia de que ele possa ter se matado. Visita então Suzanne, sua sogra. No início, estão amistosas, mas quando Marie fala sobre Jean surge uma tensão. Nessa conversa, a dificuldade de realização do luto é estendida para a mãe de Jean, que tampouco pôde velá-lo e acredita que ele não morreu, mas foi atrás de seus sonhos. Ao saber que o corpo foi encontrado em uma rede de pescadores, o comentário de Suzanne, inesperado, é uma maneira de fugir dos elementos de realidade e continuar evitando o luto: “Jean sempre gostou de pescar".

Parece que alguns fatos empíricos começam a tornar-se claros para Marie - o telefonema anunciando a localização do corpo e a conversa com Suzanne, na qual reconhece a ausência de Jean. Marie então vai a Landes, sozinha. Na viagem, os mesmos elementos de seu solitário retorno de Landes a Paris: a mesma música e, sobre o vidro, o reflexo das árvores que perpassam Marie - mas agora ela não dirige, vai de trem e táxi. Em Landes, ela vai ao necrotério e conversa com o médico que fez a autópsia no corpo encontrado, acompanhada pelo delegado.

Em um ambiente claro, formado por azulejos brancos, frente a alguns órgãos acondicionados em potes de vidro com líquido, Marie conversa com o delegado e o legista. $\mathrm{O}$ médico lhe faz um relato médico sobre o corpo encontrado, expõe os dados técnicos do cadáver, que "morreu por submersão", "afogamento com encharcamento dos pulmões"; “o corpo [...] está em estado de putrefação avançada", "a putrefação provoca uma cor esverdeada e dilatação do corpo e da cabeça do cadáver”. Já o delegado lhe diz que encontrou as "provas materiais" - um calção azul e um relógio “em bom estado e identificáveis”. Propõe mostrá-las a Marie, mas ela pede para que antes possa ver o corpo. O médico insiste:

LEGISTA: Como lhe expliquei, não se pode falar propriamente de corpo. O cadáver está em parte mutilado e uma visão como essa pode ser traumatizante para a senhora.

\footnotetext{
${ }^{77}$ SCHILlER, B. M. "A Memorial to mourning: Under the sand”. op. cit. Tradução livre de: “[...] Vincent simply cannot fill the space left by Jean's death. This is made painfully clear the following morning when Vincent goes looking for Marie, wearing a T-shirt several sizes too large for him. Vincent is no substitute for Jean, through whom Marie can overcome her grief, nor does she seem able to love him as the person he is, a new love object, different from the husband she is mourning."
} 
MARIE: Sinto-me capaz de vê-lo.

LEGISTA: Tem certeza?

MARIE: É muito importante para mim.

Não foi dito, simplesmente, que o corpo de um homem que morreu afogado foi encontrado, mas se fez uma descrição técnica das causas da morte e do estado do corpo assim como não se diz que as pessoas morrem por velhice ou acidente, mas por doenças ou traumas específicos. Já o delegado transforma essa morte em caso policial, referindose às "provas materiais", e não aos pertences de Jean. Essa descrição técnica, entretanto, não é suficiente para Marie, ela precisa velar o corpo, e para isso precisa vê-lo.

Marie vai à geladeira acompanhada pelo delegado e pelo médico. Eles usam máscaras que lhes cobrem o nariz e a boca - o odor emanado pelo corpo em decomposição deve ser bastante desagradável. O médico legista retira uma maca com rodas, sobre a qual está o corpo, envolto por uma capa fechada por zíper, de um compartimento. Pergunta a Marie se quer ver apenas uma parte do corpo, mas ela diz que deseja vê-lo por inteiro.

O delegado vira-se de lado para não olhar o cadáver; o legista tampouco o olha. O espectador não pode vê-lo, mas vê a cara assustada de Marie, que certamente não reconhece, nesse corpo pútrido, seu marido. Ela olha o corpo inteiro, muito assustada e incomodada, respirando ofegantemente. Fecha os olhos e o legista pergunta se pode fechar a capa, ela o autoriza. Ainda que o espectador não possa ver o corpo em decomposição, ele é capaz de perceber, pela reação das três pessoas que estão lá e pela tomada intimista da câmera, que se trata de uma imagem muito desagradável. Em uma sociedade na qual os mortos são escondidos e pouco se fala sobre a morte, é ainda mais chocante ver um cadáver em decomposição.

A aceitação, por parte de Marie, da morte de Jean, fora apenas um lapso de enfrentamento da realidade. A descrição do médico legista não é suficiente para convencer Marie de que aquele corpo é o de Jean. Ela vê o cadáver, mas não é capaz de reconhecer seu marido, tão viril, naquele corpo esverdeado que passou tanto tempo no mar. Aquele corpo pútrido não poderá ser velado como seu marido. O luto será novamente adiado, e isso a despeito de toda a evidência técnica que mostra tratar-se mesmo de Jean. Isso é feito de uma maneira completamente desconcertante e constrangedora, ainda na sala de autópsia do necrotério. 
Marie está sentada, olhando para baixo. O legista caminha de um lado ao outro. O delegado chega à sala com os pertences do corpo encontrado. Entrega a Marie um saco plástico, dentro do qual está o calção de banho. Pergunta se ela o reconhece, ela diz "Acho que era azul, como esse", sem ao menos retirá-lo da embalagem. Ele então lhe mostra, também embrulhado em plástico, o relógio de pulso. Marie o segura, observa e começa a rir; gargalha. O legista põe a mão sobre suas costas e diz:

LEGISTA: Algum problema?

MARIE: Não, está tudo bem. Não é o relógio dele.

DELEGADO: Como assim? Ele corresponde exatamente à sua descrição.

MARIE: Mas não é esse. Eu sei, porque fui eu que dei a ele.

DELEGADO: Ouça, olhe bem.

MARIE: Tenho certeza. Não é esse. Não é Jean.

DELEGADO: Mas reconheceu o calção.

MARIE: Sou esposa dele e estou dizendo que não é ele.

Assim, quando Marie está prestes a aceitar as provas empíricas de que o corpo pútrido que viu é o de Jean, ela encontra um modo de negar essa constatação. O relógio era o último elemento a comprovar sua morte - não reconhecê-lo seria a última chance de negar a morte de Jean, portanto. E Marie justamente se aproveita do relógio para negar a perda do marido. O faz gargalhando, feliz por conseguir um motivo (ainda que totalmente implausível, pois que ela já havia descrito aquele relógio) para negar o reconhecimento de Jean naquele corpo. Seu riso fora de momento causa estranhamento nos homens que acompanham Marie; afinal, se todas as evidências apontam para a identificação de Jean naquele corpo, ela deveria reconhecer a morte do marido, e não negar o fato óbvio de que o relógio, tal qual o que ela descrevera, não é o dele.

Mesmo com a negação do fato claro e evidente, a ausência de Jean circunda Landes. Marie vai à praia na qual houve o (suposto) afogamento. Com roupas de inverno, caminha sobre a areia, em direção ao mar, deixando seu rastro onde pisa. Ouve-se o som do mar e do vento. Ela olha para o mar, e fica tão pequena e diminuída frente à imensidão da água quanto, para ela, estava Vincent frente a Jean. 


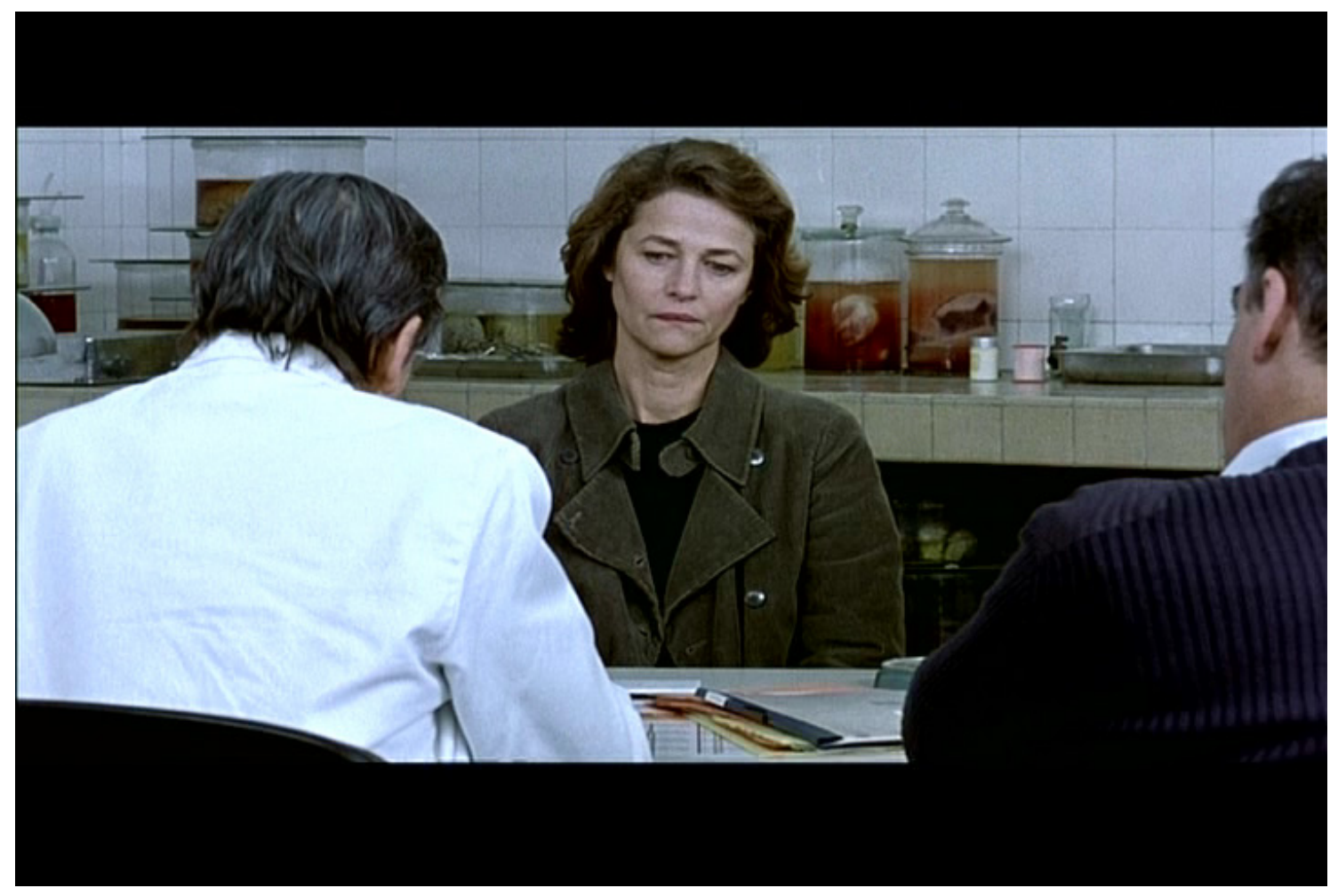

Sentada na praia, com a mão esquerda, na qual está sua aliança, Marie mexe na areia. Pela primeira vez no filme, ela chora. Chora com desespero, geme. Parece que por fim reconhece a morte de Jean, ali, frente à imensidão do azul do mar no qual seu marido se afogou. "E em Sob a areia, a mulher enlutada, Marie, é incapaz de chorar, até que ela vê os restos do corpo e simbolicamente enterra seu marido sob a areia." ${ }^{78} \mathrm{O}$ choro de Marie mostra que ela sofre pela ausência do marido, ela parece estar iniciando um processo de luto no qual alocará Jean no seu passado, lembra-se dele para poder esquecê-lo. Mas será que Marie chora por ele, ou simplesmente chora por uma ausência que ela não reconhece?

Marie olha para o lado. Há um homem com semblante como o de Jean, gordo e alto, parado, olhando o mar. Ela se levanta, como se o reconhecesse, como se de fato fora Jean e corre em direção a esse homem. Toca uma música suave. Não há mais ninguém na praia. Enquanto corre, Marie deixa um rastro mal-traçado e não retilíneo sobre a areia.

A música segue, o filme termina e surgem os créditos na tela.

Aonde vai Marie? - pergunta-se o espectador. De modo a não reconhecer seu marido naquele corpo pútrido que vira no necrotério, Marie por fim encontra um semblante que acredita ser o de Jean. Corre em direção à esperança de tê-lo ainda em

\footnotetext{
${ }^{78}$ SCHILLER, B. M. "A Memorial to mourning: Under the sand". op. cit. Tradução livre de: "And in Under the Sand the bereaved woman, Marie, is unable to weep until she sees the remains of the body and symbolically buries her husband under the sand."
} 
seu presente e em seu futuro (seus planos). Corre para fugir da solidão, do enfrentamento de uma nova condição em sua vida. Corre, e o público não pode ver o encontro dela com esse homem: haveria alguém lá, ou seria mais uma visão de Marie? Fica a dúvida, mas também a certeza, pelas evidências técnicas e policialescas, que Jean não é esse homem, e sim o cadáver encontrado na rede de pesca.

\subsection{Morte sem corpo}

Dada a ausência da evidência corpórea da morte de seu marido, Marie não pôde realizar o luto. Não pôde ao menos ter a certeza de que Jean estava morto. Essa situação não é exclusiva de Marie, é antes uma reação comum ao desaparecimento de alguém. Isso porque o desaparecimento significa a ausência dos anciões ritos que acompanham a morte.

O desaparecimento configura uma experiência de morte sem sepultura, ou seja, uma experiência de morte que se carrega em vida. A impossibilidade da realização do ritual do luto - a sepultura - configura uma situação de perda em que não se consegue renunciar ao objeto perdido, o que conduz à melancolia. ${ }^{79}$

Marie em poucos momentos sente melancolia, pois ela tende a agir como se não tivesse havido perda alguma, ela chega mesmo a ver seu marido, a dormir com ele. A melancolia apareceria nos momentos em que ela oscila, mas em tais momentos ela parece oscilar justamente porque reconhece o objeto que perdeu, porque sente a perda de Jean nesse caso, seria mais saudade ou nostalgia do que propriamente melancolia ${ }^{80}$. O que the falta é reconhecer a morte do marido, o que seria feito por meio do trabalho de luto. Marie, entretanto, não o faz porque não tem um corpo a velar; não aceita, assim, a morte de Jean.

[...] A mulher nesse filme [Sob a areia] é incapaz de realizar o luto até que haja um corpo para enterrar? Sabemos da importância de realizar os rituais de luto desde a Ilíada de Homero às seqüelas do 11 de setembro de 2001 em Nova Iorque. Um capitão dos bombeiros reformado que perdeu seu filho foi citado no New York Times como tendo dito: "Eu só quero levá-lo para casa. Estou tão cansado de vir para cá e sentir o cheiro da morte. (...) O que estamos procurando

\footnotetext{
${ }^{79}$ CARDOSO, Irene. "Os acontecimentos de 1968: notas para uma interpretação". In: crítica do presente. São Paulo: Editora 34, 2001, pp. 139-140.

${ }^{80}$ Como visto no capítulo sobre o filme Paris, Texas, a melancolia é entendida como um olhar para o passado no qual não se é capaz de localizar o objeto perdido (ver Capítulo 3). Para uma
} 
são seus restos" [...] Na Ilíada também encontramos um pai que busca pelos restos de seu filho nos campos de batalha de Tróia. ${ }^{81}$

Aquiles matou Heitor para obter o trono de Tróia, e deixou seu corpo à decomposição. O pai de Heitor, Príamo, desafiou o perigo do campo inimigo para pedir o corpo de seu filho a Aquiles. Disse-lhe "eu preciso ver meu filho com meus próprios olhos". ${ }^{82}$ Seu pedido foi atendido. Assim, desde os antigos, pode-se ver que o corpo é, e sempre foi, a evidência primeira de uma morte e, portanto, fundamental para que se possa constatá-la e iniciar o processo de luto (esse, como se viu, expresso de modos diferentes, de acordo com o contexto histórico-social em que se insere).

Em Sob a areia, o desaparecimento de Jean, essa morte sem corpo, não permitiu a Marie efetuar seu trabalho de luto. Ou seja, ela não vivenciou o tempo - cada vez mais breve - que é destinado a cada enlutado para romper com o ente querido; um tempo abreviado pelo recalcamento da morte. Um tempo de luto no qual a lembrança do ente perdido vem à tona, para que então, findo o processo, as imagens mentais dessa pessoa se encerrem na esfera do esquecimento, sendo trazidas à memória apenas ocasionalmente.

O luto é cada vez mais rápido na sociedade moderna, pouco se tem tempo para vivenciar a ruptura com aquele que se perde - porque é alguém que ficará encerrado na esfera do passado, porque são apenas lembranças, mas sobretudo porque se escamoteia a morte e, junto a ela, seus mortos. Hoje, tem-se menos tempo para vivenciar o processo de luto, e as lembranças foram minimizadas. Mas a ausência daquele que se perdeu segue, ainda que a lógica da substituição venha a preenchê-la. Grupos de auto-ajuda, por exemplo, preenchem o local dessa ausência de maneira rápida. O luto, entretanto, ainda que diminuído, é essencial, e Marie mostra isso. Os ritos fúnebres são fundamentais, e Sob a areia expressa a importância desses ritos (ainda que abreviados) e a dificuldade de, na ausência de um corpo, romper-se com um conteúdo que é compartilhado com alguém, mas que deverá ficar exclusivamente no passado quando findar o luto.

Sob a areia não traz rememorações, como $A$ Eternidade e um dia. Marie não traz Jean ao presente por rememoração, ela convive com ele porque não consegue encerrá-lo na

\footnotetext{
${ }^{81}$ SCHILLER, B. M. "A Memorial to mourning: Under the sand". op. cit. Tradução livre de: “[...] Is the woman in this film unable to mourn until there is a body to bury? We know about the importance of being able to carry out the rituals of bereavement from Homer's Iliad to the aftermath of 11 September 2001 in New York. A retired fire captain who lost his son was quoted in the New York Times as saying: "I just want to get him home. I am so tired of coming down here and smelling death. (...) What we are looking for are his remains" [...]. In the Iliad we also find a father looking for the remains of his son on the battlefields of Troy".

${ }^{82}$ Cf. SCHILler, B. M. "A Memorial to mourning: Under the sand". op. cit. Tradução livre de: "I must see my son with my own eyes".
} 
esfera do passado. Ela não tem acesso a seu passado com Jean, não relembra fatos vividos com ele. Marie convive com seu marido no presente cotidiano, como se ele ainda pertencesse a sua vivência rotineira - e, assim, livra-se da constatação de sua morte.

O luto, ou melhor, o prelúdio do luto, em Sob a areia é uma fuga ou negação. A fuga de Marie da dor da sua perda é manifestada no fato de ela continuar a viver fisicamente com seu marido morto, e sua negação é uma defesa maníaca, manifesta no sorriso que ela tem em seus lábios. ${ }^{83}$

Sob a areia começa nas águas do Sena. O acontecimento a partir do qual o filme se desenrola, a morte de Jean, ocorre no mar, em Landes, na mesma praia em que Marie estará na última cena do filme. Se, com a mão mexendo na areia, Marie por fim enterra Jean (sob a areia), ela logo interrompe seu luto para correr atrás de uma esperança - o homem que caminha na praia.

As praias são marcadas pela areia, que "abraça as formas que a ela se moldam", podendo prover, assim, repouso, segurança e regeneração ${ }^{84}$. É sobre a areia que morrem os protagonistas de O Tempo que resta e Morte em Veneza, na última cena dos filmes, por fim encontrando repouso e, quiçá, regeneração, passagem para uma outra vida. É sob a areia que, metaforicamente, Marie enterra Jean, e ensaia uma segurança que possa levá-la a assumir sua perda. Jean, por sua vez, não morre na areia, mas no mar.

Símbolo da dinâmica da vida. Tudo sai do mar e tudo retorna a ele: lugar dos nascimentos, das transformações e dos renascimentos. Águas em movimento, o mar simboliza um estado transitório entre as possibilidades ainda informes [e] as realidades configuradas, uma situação de ambivalência, que é a de incerteza, de dúvida, de indecisão, e que pode se concluir bem ou mal. Vem daí que o mar é ao mesmo tempo a imagem da vida e a imagem da morte. ${ }^{85}$

Marie se fixa na ambivalência do símbolo marítimo para se esquivar da morte de Jean. Como ele foi imerso por essas águas que vêm e vão, em constante movimento, ela transpassou tal mobilidade à própria morte de Jean, tornando-a dúbia. Quando, por fim, realizou o enterro metafórico para começar seu luto, o interrompeu e correu em direção

\footnotetext{
${ }^{83}$ SCHILLER, Britt-Marie. "A Memorial to mourning: Under the sand". op. cit. Tradução livre de: "The mourning, or rather the prelude to mourning, in Under the Sand is one of evasion and denial. Marie's evasion of the pain of her loss is manifest in her psychically continuing to live with her dead husband, and her denial is a manic defense, manifest in the smile that plays on her lips."

${ }^{84}$ Chevalier, Jean et Gheerbrant, Alain. Dicionário de símbolos. op. cit., p.79. Verbete: Areia.

${ }^{85}$ Chevalier, J. et GheERBrant, A. Dicionário de símbolos. op. cit., p.592. Verbete: Mar.
} 
ao homem que olhava para esse símbolo de vida e morte, o mar onde está sua esperança - de não ter que vivenciar o luto de Jean, de poder ainda se afastar da morte.

"Sinto que até mesmo para mim a onda se eleva. Incha; dobra-se. Tomo consciência de um novo desejo, de qualquer coisa que se ergue em mim como um cavalo orgulhoso, cujo montador esporeou antes de obrigar a parar. Que inimigo vemos avançar em direcção a nós, tu, a quem agora monto enquanto desço este caminho? É a morte. É ela o inimigo. É contra a morte que ergo a minha lança e avanço com o cabelo atirado para trás, tal como se este pertencesse a um jovem, ao Percival a galopar na Índia. Esporeio o cavalo. É contra ti que me lanço, resoluto e invencível, Morte!”

As ondas quebram-se na praia. ${ }^{86}$

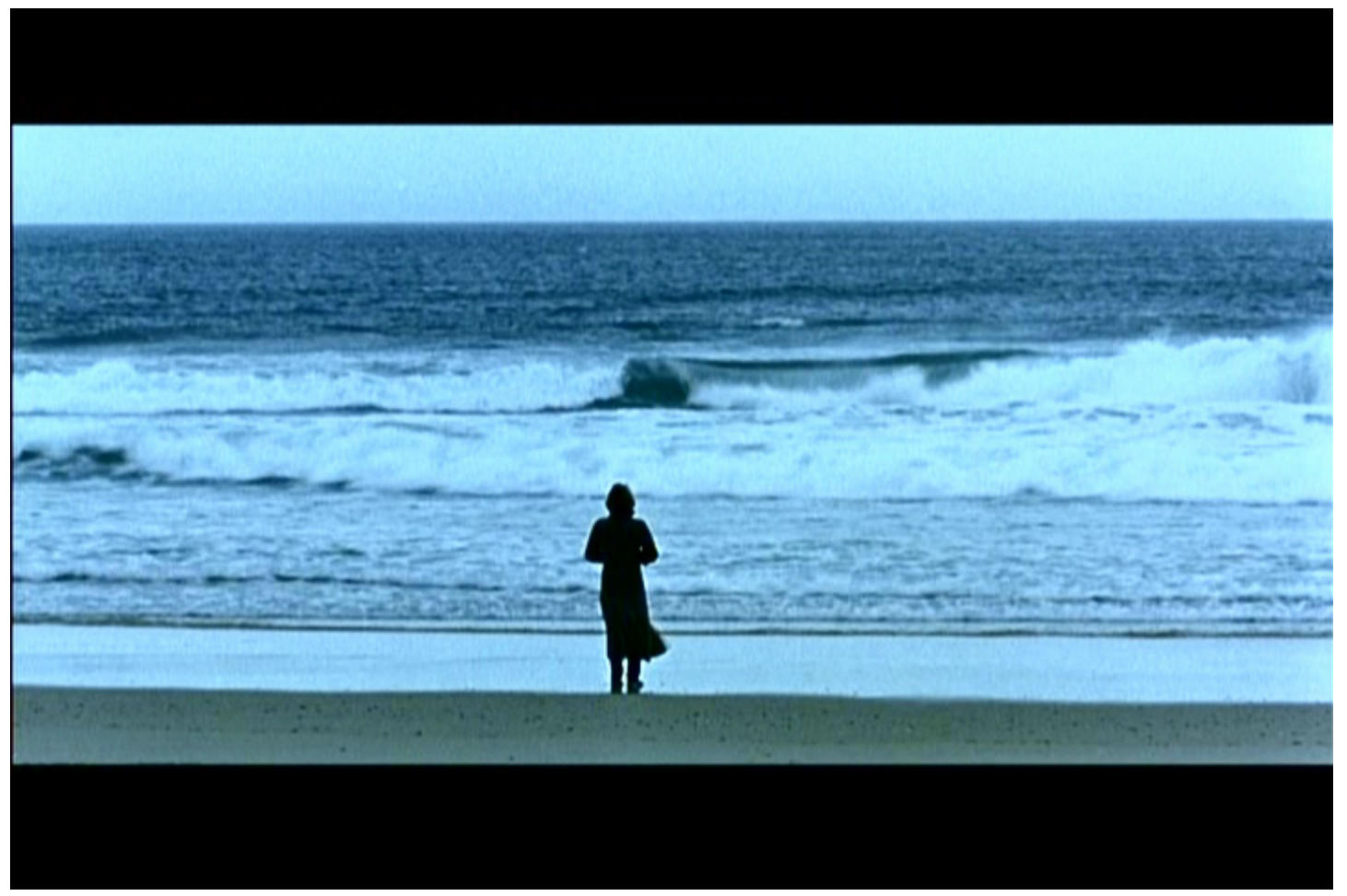

${ }^{86}$ Trecho final de As Ondas. Woolf, Virginia. As Ondas. op. cit., p. 185. 

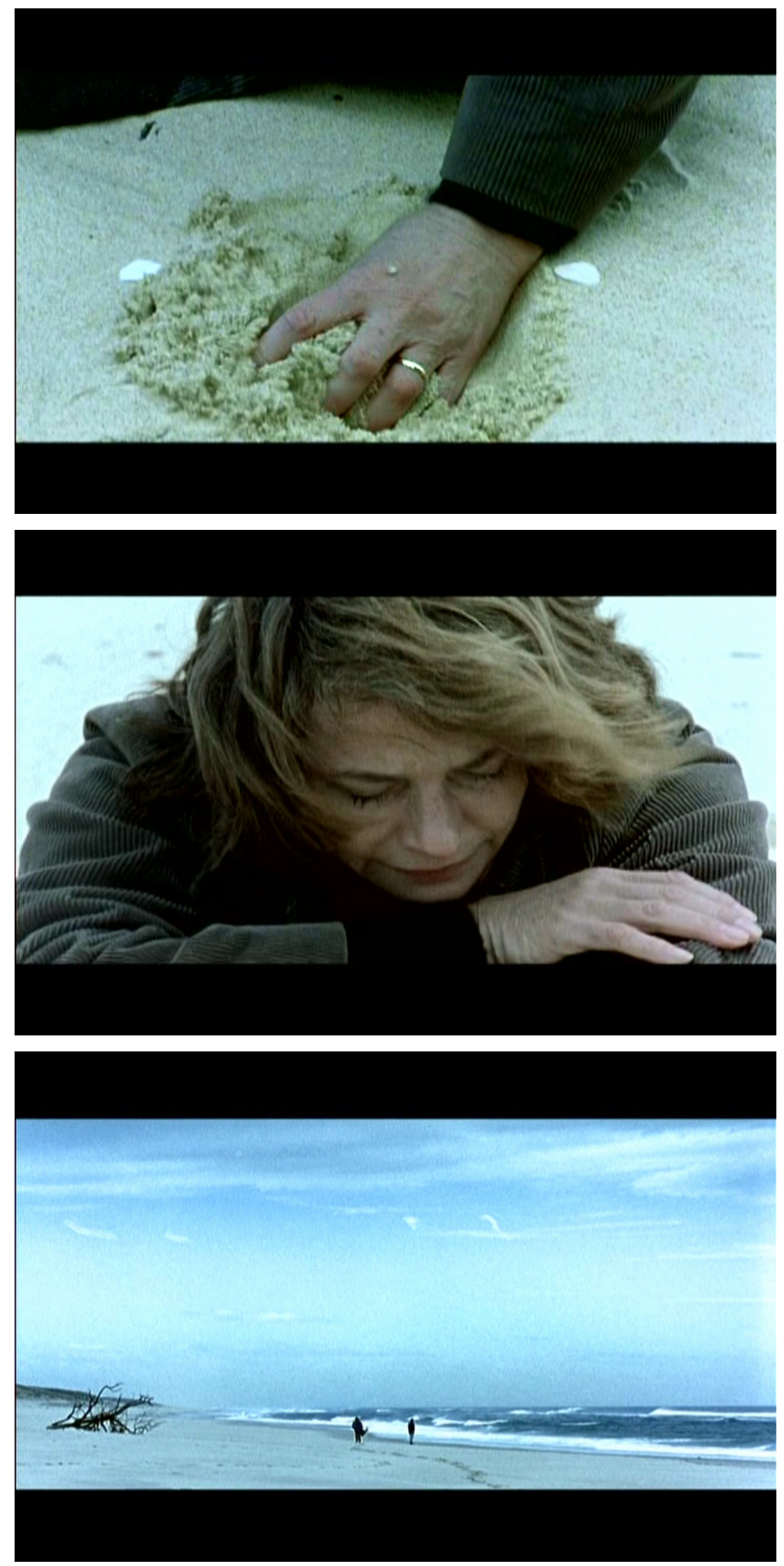


\section{A eternidade de um dia rememorado}

A língua tem indicado inequivocamente que a memória não é um instrumento para a exploração do passado; é, antes, o meio. É o meio onde se deu a vivência, assim como o solo é o meio no qual as antigas cidades estão soterradas. Quem pretende se aproximar do próprio passado soterrado deve agir como um homem que escava. Antes de tudo, não deve temer voltar sempre ao mesmo fato, espalhá-lo como se espalha a terra, revolvê-lo como se revolve o solo.

[...] E certamente é útil avançar em escavações segundo planos. Mas é igualmente indispensável a enxadada cautelosa e tateante na terra escura. E se ilude, privando-se do melhor, quem só faz o inventário dos achados e não sabe assinalar no terreno de hoje o lugar no qual é conservado o velho. ${ }^{1}$

Os filmes do diretor grego Theo Angelopoulos têm como característica a existência de longos planos-seqüência, com poucos cortes. A produção franco-ítalogrega A Eternidade e um dia, dirigida em 1998, carrega essas características. Mais que a forma, entretanto, o enredo do filme apresenta uma temporalidade pouco usual ao cinema contemporâneo.

Alexander, protagonista de A Eternidade e um dia, embrenha-se em suas lembranças, rememorando os acontecimentos vividos e, desse modo, entrando no domínio de uma temporalidade que se diferencia daquela corrente na modernidade. Como se tentou expor no Capítulo 1, a emergência da temporalidade moderna acaba excluindo do cotidiano do indivíduo o tempo da lembrança do passado.

Walter Benjamin aponta para a impossibilidade de transmissão da experiência coletiva na modernidade ${ }^{2}$. Em outros momentos ele menciona, entretanto, outro tipo de experiência, bastante diversa daquela coletiva e tradicional, mas ainda possível na modernidade: a experiência individual, ou seja, a possibilidade individual de estabelecer uma relação com o passado na qual se pode usufruir de uma temporalidade que não se limita ao tempo presente ou a sua extensão ao futuro (ou, ainda, à extensão do futuro ao passado, englobando-o).

Benjamin atribuiu a aquisição de uma temporalidade distinta da corrente ao romancista Marcel Proust, que a teria obtido por meio da rememoração. Ainda que isso

\footnotetext{
${ }^{1}$ BENJAMIN, Walter. "Escavando e recordando". In: São Paulo: Brasiliense, 1987, pp. 239-240.

Obras escolhidas II - Rua de Mao única.

${ }^{2}$ Cf. Benjamin, W. "O Narrador - Considerações sobre a obra de Nikolai Leskov". op. cit., pp. 197-221.
} 
tenha ocorrido individualmente, a experiência de Proust permitiu que a temporalidade por ele vivida ultrapassasse a rotina vazia e homogênea da modernidade - eternizandose, portanto.

O mecanismo de rememoração de Alexander será pensado aqui a partir da leitura de Benjamin sobre Proust. Para isso, primeiro se discorrerá brevemente sobre a experiência coletiva e a individual tal como Benjamin as entende, para então atribuir a aquisição de uma experiência ao protagonista do filme A Eternidade e um dia, Alexander, por meio de um processo de rememoração similar ao de Proust.

\subsection{Experiência}

Como se objetivou mostrar no primeiro capítulo, a modernidade acarreta o esvaecimento da experiência de caráter coletivo. Surge, em seu lugar, um cotidiano marcado por choques - como diz Benjamin ${ }^{3}$ - ou estímulos - nas palavras de Simmel $^{4}$. A expurgação da experiência é apontada por Benjamin, mas não se pode afirmar, entretanto, que o autor tem uma visão aporética da modernidade, muito embora algumas passagens possam sugerir isso, sobretudo em $O$ narrador. A saída para essa situação, tal como proposta em Experiência e pobreza, baseia-se na total expurgação da experiência, mas essa tampouco é a única saída a que induz a teoria benjaminiana: em suas teses Sobre o conceito da história e em A imagem de Proust, Benjamin aponta para outras alternativas, ou seja, para uma relação com a temporalidade que seja construída em igualdade com o tempo do passado.

Benjamin demonstra, portanto, que há meios de se viver sob uma temporalidade menos marcada pela intensificação do presente em sua relação exclusiva com o futuro (ou em sua relação com o passado apenas enquanto monumento, o que representaria uma relação com a barbárie ${ }^{5}$ ). Uma das possíveis saídas para essa temporalidade de um

\footnotetext{
3 "Quanto maior é a participação do fator choque em cada uma das impressões, tanto mais constante deve ser a presença do consciente no interesse em proteger contra os estímulos; quanto maior for o êxito de com ele operar, tanto menos essas impressões serão incorporadas à experiência, e tanto mais corresponderão ao conceito de vivência. Afinal, talvez seja possível ver o desempenho característico da resistência ao choque na sua função de indicar ao acontecimento, às custas da integridade de seu conteúdo, uma posição cronológica exata na consciência. Este seria o desempenho máximo da reflexão, que faria do incidente uma vivência. [...]" (BENJAMIN, Walter. "Sobre alguns temas em Baudelaire". In: . Obras escolhidas, volume III - Charles Baudelaire - Um Lírico no auge do capitalismo. São Paulo: Brasiliense, 1994, p. 111).

${ }^{4}$ Cf. SiMMEL, George. "A metrópole e a vida mental". op. cit., pp. 13-28.

5 "Nunca houve um monumento da cultura que não fosse também um monumento da barbárie" (BENJAMIN, Walter. "Sobre o conceito da História". In: Obras escolhidas, volume IMagia e técnica, arte e política. São Paulo: Brasiliense, 1994, p. 225. Tese 7).
} 
presente pouco denso, isolado ou superficialmente articulado - seja na relação com o passado, seja com o futuro - se viabiliza justamente pela extrapolação da duração imediatista dessa temporalidade - seja de modo coletivo, seja individual. Interessa para este trabalho, sobretudo, o método individual pelo qual Proust o fez, pois é muito semelhante ao utilizado por Alexander, protagonista do filme A eternidade e um dia. Para isso, aqui se pretende debruçar não sobre a obra de Marcel Proust, mas sobre a articulação temporal que Benjamin localiza no "método" utilizado pelo romancista ${ }^{6}$.

Se, como se pretendeu mostrar no Capítulo 1, a experiência declinou, esse fato não é suficiente para determinar uma situação de aporia, no sentido de que não se pode mais desfrutar de uma temporalidade eternizada, ou distendida. Uma síntese das propostas apontadas por Benjamin foi delineada por Douek:

Em Experiência e pobreza e $O$ narrador, Benjamin diagnostica a perda da experiência (Erfahrung), ou seja, da memória e da tradição, e a impossibilidade de contar, isto é, de transmitir uma palavra portadora de experiência. A experiência morreu, diz Benjamin; o que fazer deste luto? Esquecer o passado e começar do zero, como ele próprio propõe em Experiência e pobreza, ou então "chorar" esta perda, como sugere o tom nostálgico de $O$ narrador?

Nem uma coisa, nem outra, como Benjamin deixa claro em seu famoso e último texto, Sobre o conceito da história, aqui, perfila-se outra alternativa, alternativa que exige uma aliança entre a teologia judaica e o materialismo histórico e que consiste em "salvar" o passado, isto é, em recuperar as possibilidades nele contidas que não puderam se realizar. Se a narrativa é impossível, então a história, enquanto narrativa, também o é. Mas Benjamin propõe a escrita de uma outra história, história a contrapelo, ou ao avesso, que duvida da história oficial e quer dar voz à história dos vencidos e oprimidos. ${ }^{7}$

Essa possibilidade de articulação histórica existe porque o passado não está morto e tampouco deve ser esquecido ou enterrado. Mesmo o tom nostálgico que Benjamin assume nos ensaios Experiência e pobreza e $O$ narrador, sobretudo no

\footnotetext{
${ }^{6}$ Benjamin não organiza, vale notar, uma metodologia de análise prática e esquematizada da qual este trabalho se utiliza; propõe-se aqui uma aproximação entre a temporalidade vivida por Proust, do modo como Benjamin a analisa, e a temporalidade vivida por Alexander em $A$ eternidade e um dia. Que fique claro que não se pleiteia uma aproximação com a vida do escritor "como de fato foi" pois, tal como o passado, para Benjamin, essa instância da verdade original é inapreensível e, quiçá, inexistente. Trata-se, antes, de elaborar, a partir da obra de Benjamin, uma espécie de conceituação da "rememoração", independente de sua adequação ao processo vivido pelo romancista Marcel Proust.

${ }^{7}$ DoueK, Sybil Safdie. Memória e exílio. São Paulo: Escuta, 2003, pp. 16-17.
} 
segundo, não conclama a morte do passado, mas apenas um esfacelamento dessa dimensão temporal - seu esquecimento, portanto, e não o seu óbito. A perda da experiência ou da tradição não significam, em absoluto, a perda do passado. Ele pode ser deslocado para a dimensão do esquecimento, mas lá resiste, e essa é a possibilidade de abertura de temporalidade proposta por Benjamin em outros textos. ${ }^{8}$

Em suas teses sobre o conceito de história ${ }^{9}$, escritas em 1940, Benjamin discute a apreensão histórico-temporal da modernidade, criticando o historicismo e o conformismo da social-democracia alemã. Aponta a necessidade de articulação histórica do passado (a apropriação de sua reminiscência), método coletivo que encontra muitas similaridades na rememoração individual de Proust e, portanto, na possibilidade de construção de uma experiência na modernidade.

Em sua crítica à social-democracia alemã, cuja prática seria determinada por um conceito de progresso dogmático, Benjamin propõe que se rompa com a temporalidade da modernidade, na qual é marca característica o apelo incessante ao novo: "A idéia de um progresso da humanidade na história é inseparável da idéia de sua marcha no interior de um tempo vazio e homogêneo. A crítica da idéia do progresso tem como pressuposto a crítica da idéia dessa marcha"10.

A temporalidade da rememoração aparece, então, como possibilidade de rompimento com a temporalidade do progresso (na qual há a recorrente instauração do novo em substituição ao que fica imediatamente obsoleto):

\footnotetext{
${ }^{8}$ Douek diz que "[...] [Em Experiência e pobreza e $O$ narrador, ] Benjamin pensa a perda da experiência e da tradição na época atual e a impossibilidade de transmissão de uma palavra que se constitua em ponte entre passado e presente. O homem de hoje rompeu definitivamente com o passado, enterrou o passado, este está morto para sempre. Como viver esse luto? Esquecer os mortos e começar de novo, ou chorar melancolicamente sobre eles? [...]" Na frase seguinte, Douek voltará a mostrar que o homem de hoje não rompeu definitivamente com o passado, nem o enterrou, e que portanto o passado não está morto para sempre. Assim, não cabe aqui necessariamente um luto, mas talvez a salvação dessas reminiscências. Isso fica claro na continuação da escrita de Duoek, que de certa forma se contradiz com o que fora dito nas palavras anteriores: "[...] Nas teses Sobre o conceito da História, outra alternativa toma forma: "salvar" o passado, acordar os mortos. Alternativa que exige uma nova postura em relação ao passado, portanto, uma nova concepção de história e de tempo [...]." (DOUEK, S. Memória e exílio. op. cit., p. 69. Grifos nossos).

${ }^{9}$ BENJAMin, W. "Sobre o conceito da História". op. cit. Vale lembrar-se das observações de Jeanne-Marie Gagnebin a respeito das teses benjaminianas: "Publicado pela primeira vez em 1942, em um número especial em homenagem a Benjamin da Revista do Instituto de Pesquisa Social, esse texto póstumo não tem versão definitiva. Existem vários manuscritos com número variável de teses. Essa situação reflete o fato de que Benjamin nunca cogitou publicá-lo tal qual quando o escreveu. Ele sabia muito bem que essas 'teses' se prestariam a vários 'malentendidos entusiasmados', como escreveu em uma carta a Gretel Adorno: esses malentendidos não tardaram a aparecer quando foi finalmente editado. Para Benjamin, as 'teses' não têm nenhum caráter definitivo, não são um credo dogmático, mas oferecem, à ocasião, um balanço de pensamento e, mais ainda, umas 'hipóteses' de pensamento, para não desesperar". (GAGNEBIN, Jeanne Marie. "Seis teses sobre as 'Teses"'. In: Cult, no 106, ano 9, p. 50).

${ }^{10}$ Benjamin, W. "Sobre o conceito da história". op. cit., p. 229.
} 
Certamente, os adivinhos que interrogavam o tempo para saber o que ele ocultava em seu seio não o experimentavam nem como vazio nem como homogêneo. Quem tem em mente esse fato, poderá talvez ter uma idéia de como o tempo passado é vivido na rememoração: nem como vazio, nem como homogêneo. ${ }^{11}$

Esse tempo "vazio e homogêneo" foi descrito por Gagnebin como um "tempo indiferente e infinito que corre, sempre igual a si mesmo, que passa engolfando o sofrimento, o horror, mas também o êxtase e a felicidade."12 Como forma de romper com essa temporalidade uniforme, Benjamin propõe a rememoração.

A apropriação das reminiscências do passado seria, assim, um modo de retomada dos acontecimentos que ficam esquecidos, uma vez que a historiografia corrente se dedica a escrever uma história dos vencedores. Benjamin, ao contrário, propõe que se escreva uma história dos vencidos, de modo que possam emergir os acontecimentos relegados pela história oficial. Para isso, deve-se "escovar a história a contrapelo"13; é no e a partir do presente, portanto, que se deve "articular historicamente o passado" ${ }^{14}$. E, assim, o encontro com a reminiscência ocorrerá, pois "existe um encontro secreto, marcado entre as gerações precedentes e a nossa."15

É por meio da "verdadeira imagem do passado", que segundo Benjamin "perpassa, veloz", que surge a reminiscência e o passado se deixa fixar - desde que seja reconhecido ${ }^{16}$. A tarefa do historiador, de acordo com o autor, é justamente reconhecer o passado, para que então ele possa ser fixado: "Cabe ao materialismo histórico fixar uma imagem do passado, como ela se apresenta, no momento do perigo, ao sujeito

\footnotetext{
${ }^{11}$ Benjamin, W. "Sobre o conceito da História". op. cit., p. 232.

${ }^{12}$ GagneBIn, Jeanne-Marie. História e Narração em Walter Benjamin. op. cit, p. 96.

${ }^{13}$ Benjamin, W. "Sobre o conceito da História”. op. cit., p. 225. Sobre isso, explica Michael Löwy: "A exigência fundamental de Benjamin é escrever a história a contrapelo, ou seja, do ponto de vista dos vencidos - contra a tradição conformista do historicismo alemão cujos partidários entram sempre 'em empatia com o vencedor' [...].

É evidente que a palavra 'vencedor' não faz referência a batalhas ou guerras habituais, mas à 'guerra de classes', na qual um dos campos, a classe dirigente, 'não cessou de vencer' (Tese VII) os oprimidos [...]” (LöwY, Michael. "A filosofia da história de Walter Benjamin”. In: Estudos Avançados, 16 (45), 2002, p. 203. Disponível online em: http://www.scielo.br/pdf/ea/v16n45/v16n45a13.pdf. Acesso em 01 de julho de 2007).

${ }^{14}$ BenJAmin, W. "Sobre o conceito da História”. op. cit., p. 224.

${ }^{15}$ BENJAMIN, W. "Sobre o conceito da História". op. cit., p. 223.

${ }^{16}$ Diz Benjamin: "A verdadeira imagem do passado perpassa, veloz. O passado só se deixa fixar, como imagem que relampeja irreversivelmente, no momento em que é reconhecido". BENJAMIN, W. "Sobre o conceito da história”. op. cit., p. 224. Tese 5.
} 
histórico, sem que ele tenha consciência disso" ${ }^{17}$. Não se trata, pois, de uma imagem eterna, e tampouco da imagem do passado "como ele de fato foi"18; trata-se de uma imagem veloz que, em um momento de perigo, relampeja - e, tal como um relâmpago, se não for fixada, desaparece rapidamente. O historiador deve, portanto, registrar tal imagem, de modo que ela não se perca ${ }^{19}$. O instante do perigo é esse: o presente; tempo no qual o passado pode ser salvo.

[...] para Benjamin é o presente que ilumina o passado; porque os acontecimentos do passado ou seus fragmentos só ascendem a uma legibilidade em um espaço e um tempo determinado e não necessariamente no instante que os viu nascer. ${ }^{20}$

Assim, a imagem que relampeja virá sempre dotada de certa densidade temporal, pois será um conteúdo do passado que aparece no presente. Tal como o ouvinte da narrativa possuía uma relação temporal mais ampla, o espectador dessa imagem também é capaz de possuí-la, e isso ocorre porque “[...] a história não é acessível ao agente no momento da ação, mas ao espectador ou ouvinte" ${ }^{21}$, ou seja, ela precisa de uma maturação temporal. Esse passado esquecido surge na busca pelo detalhe, por aquilo que não aparece na história dominante, um conteúdo que se perderia caso não fosse acessado.

[...] Benjamin concorda com [...] esse cuidado pelo detalhe, pelo resto, pelos resquícios; sua preocupação, porém, não visa uma descrição exaustiva (a priori impossível, mas que tem o mérito de garantir emprego aos historiadores de todo calibre!), mas uma história "a contrapelo": não aquela dos vencedores, mas aquela que poderia ter sido outra, que foi sufocada, mas deixou interrogações, lacunas, brancos que são tantos sinais de alteridade e de resistência; esses sinais, cabe ao presente, justamente, reconhecê-los e, quem sabe, retomá-los e assumir suas promessas de alteridade e de resistência na luta histórica e política atual. Essa relação do presente ao passado não pode, então, seguir os moldes da

\footnotetext{
${ }^{17}$ BENJAMIN, W. "Sobre o conceito da história". op. cit., p. 224. Tese 6.

18 "Articular historicamente o passado não significa conhecê-lo "como ele de fato foi". (BENJAMIN, W. "Sobre o conceito da história". op. cit., p. 224. Tese 6).

${ }^{19}$ Diz ainda Benjamin: "O dom de despertar no passado as centelhas da esperança é privilégio exclusivo do historiador convencido de que também os mortos não estarão em segurança se o inimigo vencer. E esse inimigo não tem cessado de vencer". (BENJAMIN, W. "Sobre o conceito da história". op. cit., pp. 224225. Tese 6).

${ }^{20}$ MatTos, Olgária. "Memória e história em Walter Benjamin". In: São Paulo; Secretaria Municipal de Cultura; Departamento de Patrimônio Histórico. O direito à memória: patrimônio histórico e cidadania. São Paulo: Departamento do Patrimônio Histórico, 1992, p. 151.

${ }^{21}$ Mattos, Olgária. "A narrativa: metáfora e liberdade". In: NovAEs, Adauto (org.). O avesso da liberdade. São Paulo: Companhia das Letras, 2002, p. 317. Texto referente à nota 19.
} 
identificação afetiva ou empatia (Einfühlung) com os grandes heróis do passado, tais quais são descritos pela história oficial; pelo contrário, deve desconstruir a narrativa ronronante da "história dos vencedores" e indicar outras possibilidades narrativas e históricas, silenciadas, esquecidas ou recalcadas. ${ }^{22}$

É, por conseguinte, uma articulação entre o presente e o passado - que se dá no presente, pela fixação das imagens do passado que relampejam, sobretudo quando a história é escovada a contrapelo - que permite a salvação das reminiscências. A visão de história de Benjamin, portanto, tem como pressuposto uma articulação com o tempo do passado, do qual devem ser recuperadas reminiscências e lacunas que ficaram em aberto, ou seja, o autor propõe que o historiador recupere aquilo que usualmente é desprezado quando se escreve a "história dos vencedores". Assim, a história não deve ser entendida como um tempo "vazio e homogêneo"; a história deve ser pensada no registro de uma temporalidade não-linear e, sobretudo, heterogênea, composta por diferentes durações e temporalidades no interior de um mesmo tempo: "A história é objeto de uma construção cujo lugar não é o tempo homogêneo e vazio, mas um tempo saturado de 'agoras", 23 , de instantes.

$\mathrm{O}$ instante imobiliza esse desenvolvimento temporal infinito que se esvazia e se esgota e que chamamos - rapidamente demais - de história; Benjamin lhe opõe a exigência de um presente, que ela seja o exercício árduo da paciência ou o risco da decisão. Se o lembrar do passado não for uma simples enumeração oca, mas a tentativa, sempre retomada, de uma fidelidade àquilo que nele pedia um outro devir, a estes "signos dos quais o futuro se esqueceu em nossa casa" como luvas ou o regalo que uma mulher desconhecida, que nos visitou em nossa ausência, deixou numa cadeira, então a história que se lembra do passado também é sempre escrita no presente e para o presente. A intensidade dessa volta/renovação quebra a continuidade da cronologia tranqüila, imobiliza seu fluxo finito, instaura o instante e a instância da salvação. ${ }^{24}$

\footnotetext{
${ }^{22}$ GAGNEBIN, J. "Seis teses sobre as 'Teses"”. op. cit., p. 52.

${ }^{23}$ E Benjamin continua: "Assim, a Roma antiga era para Robespierre um passado carregado de "agoras", que ele fez explodir do continuum da história. A Revolução Francesa se via como uma Roma ressurreta. Ela citava a Roma antiga como a moda cita um vestuário antigo. A moda tem um faro para o atual, onde quer que ele esteja na folhagem do antigamente. Ela é um salto de tigre em direção ao passado. Somente, ele se dá numa arena comandada pela classe dominante. O mesmo salto, sob o livre céu da história, é o salto dialético da Revolução, como o concebeu Marx" (BENJAMIN, W. "Sobre o conceito da História". op. cit., pp. 229-230).

${ }^{24}$ GAGNEBIN, Jeanne-Marie. História e Narração em Walter Benjamin. op. cit., p. 97. A nota ao longo da passagem, aqui suprimida, sugeria que se conferisse a página 89 da mesma obra de Gagnebin, onde a referência aos signos "que o futuro esqueceu na nossa casa" é atribuída ao texto Infância Berlinense, de Walter Benjamin.
} 
Assim, o tempo linear deve ter descobertas suas porções de "agoras", que caso contrário ficariam presas ao passado. Escovar a história a contrapelo é permitir que as reminiscências sejam atualizadas, ou seja, que esperanças passadas sejam salvas no momento mesmo da fixação da imagem através da qual elas relampejam ${ }^{25}$.

[...] Em primeiro lugar, segundo Benjamin, a historiografia "burguesa" e a historiografia "progressista" se apóiam na mesma concepção de um tempo "homogêneo e vazio" (teses 13 e 14), um tempo cronológico e linear. Trata-se, para o historiador "materialista" - ou seja, de acordo com Benjamin, para o historiador capaz de identificar no passado os germes de uma outra história, capaz de levar em consideração os sofrimentos acumulados e de dar uma nova face às esperanças frustradas -, de fundar um outro conceito de tempo, "tempo de agora" ("Jetztzeit"), caracterizado por sua intensidade e sua brevidade, cujo modelo foi explicitamente calcado na tradição messiânica e mística judaica.

Em lugar de apontar para uma "imagem eterna do passado", como o historicismo, ou, dentro de uma teoria do progresso, para a de futuros que cantam, o historiador deve construir uma "experiência" ("Erfahrung") com o passado (tese 16). ${ }^{26}$

O encontro com o passado não revela fatos objetivos, pois o passado só emerge com a escavação de ruínas, e portanto só pode ser alcançado "através dos detalhes, ruínas - o que ficou pelo involuntário do tempo e da memória"27. Do passado, para Benjamin, "só nos restam fragmentos que nos vêm aos pedaços", diz Olgária Mattos, "recebemos uma tradição como herança mas uma herança sem testamento, não sabemos o que fazer dela, não existe um controle do tempo histórico segundo o qual o presente possa compreender em sua inteligibilidade o passado" ${ }^{28}$. Ela usa os termos de Hannah Arendt - "herança deixada sem testamento" - para se referir ao sentido de perda que um passado sem tradição provoca: encontram-se elementos, mas eles não podem ser reconhecidos. A proposta de Benjamin é, então, que se adentre no tempo do passado (atendendo assim ao seu apelo) para que se possa vê-lo por outro ângulo: "Benjamin diz ser possível reingressar numa verdade fechada do passado para contá-la de outra

\footnotetext{
${ }^{25}$ Como novamente será observado, esse processo de fixação/ atualização de uma reminiscência encontra paralelo com a fotografia, tal qual Benjamin a analisa.

${ }^{26}$ Gagnebin, Jeanne-Marie. "Prefácio - Walter Benjamin ou a história aberta". In: BenJAMIN, Walter. Magia e técnica, arte e politica-Obras escolhidas, volume I. São Paulo: Brasiliense, 1994, p. 8.

${ }^{27}$ MATTOS, Olgária. "Memória e história". op. cit., p. 6.

${ }^{28}$ MAtTos, O. "Memória e história em Walter Benjamin". op. cit., p. 152.
} 
maneira, porque o passado não é um continuum passado, presente, futuro". ${ }^{29}$ Ainda analisando Benjamin, Mattos diz que "O passado não é devir abstrato do tempo, o passado são fragmentos, do passado só nos resta um 'monte de tijolos", 30 , e cabe ao historiador construir a partir desses tijolos - segundo a análise de Gagnebin supracitada, construir uma "experiência" a partir do passado. Mas o que é essa experiência? É, sobretudo, uma relação com a temporalidade que ocorre de maneira mais qualitativa, uma relação mais densa.

[...] A experiência alia-se à idéia de viagem. Viagem, registram os dicionários, é "mudança de lugar", é deslocamento entre "lugares distantes" - com o que se insinua a ação do tempo - constituído de traumas, feridas, descontinuidades. Manter o passado em sua dispersão é demarcar os acidentes e ínfimos desvios e mesmo inversões completas que lhe deram nascimento. $[\ldots]^{31}$

Havia, no período anterior à modernidade, como se tentou apontar no Capítulo 1 , uma ligação mais intensa entre o homem e o passado, que ocorria de maneira coletiva: a tradição era retomada pela narrativa ${ }^{32}$, havia a sensação concreta de linearidade, o sentido do todo, de continuidade na vida. Em suas teses sobre a história, Benjamin não propõe que se retome essa experiência (mesmo porque ela se refere ao passado, e retomá-lo como de fato foi é por ele considerado impossível). Seu método propõe que se ouçam os apelos do passado, de modo que uma relação mais qualitativa com o tempo possa ser instaurada.

Estão em jogo, portanto, duas idéias distintas, mas traduzidas pelo mesmo termo em português: "experiência”. Para que se possa diferenciar essas duas espécies de experiência, elas serão aqui adjetivadas: experiência coletiva ou tradicional, e experiência individual. ${ }^{33}$

A experiência tradicional, Erfahrung, é aquela predominante no período da narrativa, quando uma tradição unia as gerações. Tal como a narrativa estava ligada à viagem, pois o narrador era alguém que vinha de longe - no espaço ou no tempo -, a

\footnotetext{
${ }^{29}$ MAtTos, O. "Memória e história em Walter Benjamin”. op. cit., p. 152.

${ }^{30}$ MAtTos, O. "Memória e história em Walter Benjamin". op. cit., p. 152.

${ }^{31}$ MAtTos, O. “A narrativa: metáfora e liberdade”. op. cit., p. 310. As notas escritas pela autora foram suprimidas por não serem relevantes à discussão aqui proposta.

32 "Experiência, memória e narração pertencem, para Benjamin, a um mesmo campo semântico". (MAtTos, O. “A narrativa: metáfora e liberdade”. op. cit., p. 303).

${ }^{33}$ Em alemão, os termos utilizados por Benjamin são Erfahrung e Erlebnis, respectivamente. (cf. GaGneBIN, Jeanne-Marie. Walter Benjamin: Os cacos da história. São Paulo: Brasiliense, 1982, pp. 67-68).
} 
experiência coletiva se liga à transmissão de um conteúdo ${ }^{34}$. Sobre a ligação entre experiência e viagem, esclarece Gagnebin: "Lembremos aqui que a palavra Erfahrung vem do radical fahr - usado ainda no antigo alemão no seu sentido literal de percorrer, de atravessar uma região durante uma viagem.",35

A experiência tradicional, portanto, viaja - se não através de uma superfície, através de sua relação temporal; ela tem duração intensa, possui uma profundidade temporal que permite a duração de uma tradição, a transmissão de um conhecimento pela narração.

A experiência (Erfahrung) diz respeito a um conhecimento transmitido de geração em geração e, portanto, vitalmente ligado a uma tradição que garante uma linguagem e uma memória comuns, a partir das quais as experiências podem ser compartilhadas. A experiência funda-se na tradição e ambas só encontram possibilidade de existência na esfera da comunidade, onde a unidade é dada a partir do comum, no compartilhar de um habitat, ou melhor, de uma palavra, comum a quem fala e a quem ouve. [...] ${ }^{36}$

Já a experiência individual, Erlebnis, a vivência, surge na modernidade, não é compartilhada, mas vivenciada pelo indivíduo isolado.

[...] Erlebnis: não mais um legado partilhado por todos os membros de uma comunidade, mas a vivência experimentada em sua privacidade e solidão, em que "cada um sabe de si. ${ }^{37}$

Com a perda da experiência coletiva, dada a instauração da modernidade, a possibilidade de vivência de uma dimensão temporal mais densa passa a ocorrer individualmente - por uma experiência individual e, marcadamente, pela psicanálise.

Com a hegemonia do indivíduo e da privacidade, assiste-se ao desaparecimento da comunidade; a tradição perde-se no caminho, e a experiência coletiva dá lugar à vivência privada e individualizada - Erlebnis. Aos indivíduos, só resta a possibilidade da vivência e da subjetividade. Tal processo, iniciado no século XVIII, pode ser observado na literatura (romance clássico), na arquitetura (valorização do interior da casa e dos objetos pessoais, privatização do espaço de cada membro da família), nas ciências (surgimento da psicologia e psicanálise -

\footnotetext{
${ }^{34}$ Vide Capítulo 1 deste trabalho.

${ }^{35}$ GAGNEBIN, J. História e Narração em Walter Benjamin. op. cit., p. 58.

${ }^{36}$ DoueK, S. Memória e exílio. op. cit., p. 64.

${ }^{37}$ DoueK, S. Memória e exílio. op. cit., p. 65.
} 
lugar privilegiado da subjetividade). O ponto de referência é agora o "euindivíduo" e não mais o "nós-coletivo". No vazio da experiência que diz respeito à comunidade, instala-se a vivência em que triunfa o indivíduo. O homem moderno fecha-se sobre si mesmo: o individualismo condenou o homem não somente ao esquecimento, mas também à solidão. ${ }^{38}$

Konder sumariza as duas formas de "experiência" de modo comparativo:

[...] Erfahrung é o conhecimento obtido através de uma experiência que se acumula, que se prolonga, que se desdobra, como numa viagem; o sujeito integrado numa comunidade dispõe de critérios que lhe permitem ir sedimentando as coisas com o tempo. Erlebnis é a vivência do indivíduo privado, isolado, é a impressão forte, que precisa ser assimilada às pressas, que produz efeitos imediatos. ${ }^{39}$

Ou seja,

[...] Para Benjamin, a verdadeira narração toma sua fonte de uma experiência no sentido pleno do termo (Erfahrung), progressivamente abolida pelo desenvolvimento do capitalismo. Essa experiência está ligada a uma tradição viva e coletiva, característica das comunidades em que os indivíduos não estão separados pela divisão capitalista do trabalho, mas onde sua organização coletiva reforça a vinculação consciente a um passado comum, permanentemente vivo nos relatos dos narradores. Nessas comunidades pré-capitalistas - que não são por isso forçosamente idílicas! - a experiência do trabalho e do passado coletivos (Erfahrung, no vocabulário de Benjamin) predomina sobre a experiência do indivíduo, isolado em seu trabalho e em sua história pessoal (Erlebnis). A obtenção de uma história comum, que se transmite através das histórias contadas de geração a geração, é hoje destruída pela rapidez e violência das transformações da sociedade capitalista. Agora, o refúgio da memória é a interioridade do indivíduo, reduzido à sua história privada, tal como ela é reconstruída no romance. ${ }^{40}$

A obtenção dessa experiência individual pode ocorrer, na modernidade, por meio da rememoração. Assim, ela se apresenta como uma possibilidade individual de salvação do passado, tendo como sua forma coletiva as idéias presentes nas teses de Benjamin sobre a história, que apontam para uma saída - a salvação do passado, que

\footnotetext{
${ }^{38}$ DOUEK, S. Memória e exílio. op. cit., p. 66.

${ }^{39}$ Konder, Leandro. Apud Benjamin, W. "Sobre alguns temas em Baudelaire". op. cit., p. 146, nota 12.

${ }^{40}$ Gagnebin, J. Walter Benjamin: Os cacos da história. op. cit., pp. 67-68.
} 
pode ocorrer à parte da perda da experiência. Essa recuperação do passado pode também ocorrer de maneira individual, e tal é o modo que Benjamin atribui ao romancista Marcel Proust e que aqui se pretende atribuir a Alexander. ${ }^{41}$

Em meio à perda da experiência coletiva, Benjamin aponta Proust como um sujeito que obteve, na vida moderna, uma experiência, ainda que individual. A experiência construída por Proust não é marcada pelos fatos por ele vividos, mas pela rememoração desses fatos, ou seja, é uma vida lembrada por quem a viveu. Importa, assim, o acontecimento tal como ele é rememorado no presente, em seu aspecto único e singular.

Em estado de constante atenção, o homem moderno não tem tempo para atribuir significado aos fatos observados no cotidiano, então as marcas do vivido ficam registradas em seu esquecimento. Em momentos semi-conscientes, entretanto, essas marcas inconscientes podem irromper, mas, assim como as imagens que possuem a duração de um relâmpago, logo se perdem se não forem registradas.

[...] Ele [Proust] está convencido da verdade de que não temos tempo de viver os verdadeiros dramas da existência que nos é destinada. É isso que nos faz envelhecer, e nada mais. As rugas e dobras do rosto são as inscrições deixadas pelas grandes paixões, pelos vícios, pelas intuições que nos falaram, sem que nada percebêssemos, porque nós, os proprietários, não estávamos em casa. ${ }^{42}$

É o progressivo abandono daquilo que ligava a consciência do homem à sua dimensão inconsciente que faz com que o indivíduo moderno tenha acesso, em geral, apenas às marcas visíveis de seu inconsciente - as rugas e dobras que se formam em seu rosto. Proust buscava as marcas mais profundas que a vivência imputava em seu inconsciente: buscava as marcas psicológicas de sua memória e de seu esquecimento, e rejuvenescia ao tirar o passado de sua dimensão temporal, abrindo-o em todos os tempos - exercício no qual o acontecimento vivido no passado ganha um novo significado e as vivências passadas são atualizadas, por meio de lembranças, no presente ${ }^{43}$.

[...] Na lembrança proustiana se abre, realmente, uma dimensão de infinito que ultrapassa a limitação da memória individual. Ela faz coincidir uma sensação perdida do passado com a evidência do presente, operando uma fusão entre um

\footnotetext{
${ }^{41}$ Vale salientar que, portanto, Benjamin virá a atribuir a Proust um tipo de experiência que em muito se diferencia da experiência tradicional, transmitida pelo narrador. A experiência de Proust é individual, a da narrativa era obrigatoriamente coletiva.

${ }^{42}$ Benjamin, W. "A imagem de Proust". op. cit., p. 46.

${ }^{43}$ Cf. Benjamin, W. "A imagem de Proust". op. cit., p. 46.
} 
tempo e outro. Essa fusão faz Proust feliz ao extremo, porque, como diz no final de seu livro, assim ele tem a impressão de poder escapar à fluência inexorável do tempo (e portanto à própria morte), graças a esse encontro efêmero do passado esquecido com a luminosidade do presente. ${ }^{44}$

Há muitas similaridades entre a rememoração proustiana e a proposição de Benjamin para a história. Ambos pressupõe alguma espécie de salvação pela atualização de elementos presos ao passado ${ }^{45}$. Uma entrada mais intensa no universo da rememoração de Proust poderá, por fim, clarear a saída benjaminiana para a temporalidade moderna e o procedimento utilizado por Alexander em A Eternidade e um dia.

\subsection{Rememoração em Proust ${ }^{46}$}

Tal qual cada época sonha a seguinte ${ }^{47}$, cada época deixa seus rastros, transmitindo seu segredo a qualquer desconhecido ${ }^{48}$. O romancista Marcel Proust foi quem ouviu, segundo Benjamin, as confidências do século XIX:

[...] no que diz respeito ao século XIX, [...] [foi] o jovem Proust, o esnobe sem importância, o trêfego freqüentador de salões, quem ouviu, de passagem, do século envelhecido, como de um outro Swann, quase agonizante, as mais extraordinárias confidências. Somente Proust fez do século XIX um século para memorialistas. ${ }^{49}$

\footnotetext{
${ }^{44}$ GAGNEBIN, J. Walter Benjamin: Os cacos da história. op. cit., pp. 70-71.

${ }^{45}$ Há também algumas diferenças, mas não cabe aqui enfatizá-las, apenas apontá-las brevemente: “[...] Como notou Peter Szondi, Benjamin se afasta de Proust exatamente nesse ponto. A coincidência do passado com o presente não deve, para ele, libertar o indivíduo do jugo do tempo, mas operar uma espécie de condensação que permita ao presente reencontrar, reativar um aspecto perdido no passado, e retomar, por assim dizer, o fio de uma história inacabada, para tecer-lhe a continuação. [...] Proust e Benjamin participam, realmente, da mesma convicção de que o passado comporta elementos inacabados; e além disso, que aguardam uma vida posterior, e que somos nós os encarregados de fazê-los reviver. Essas 'ressurreições da memória', como Proust as define, referem-se, em sua obra, ao passado individual e dependem de um acaso providencial, como aquele da madeleine [...], cujo gosto, misturado ao do chá, faz irromper toda uma cadeia de lembranças. Para Benjamin, essas ressurreições aludem ao passado coletivo da humanidade e não podem depender do acaso, mas devem ser produzidas pelo trabalho do historiador materialista." (GAGNEBIN, J. Walter Benjamin: Os cacos da história. op. cit., pp. 71-72).

${ }^{46}$ Vale lembrar, mais uma vez, que este trabalho não busca compreender a obra de Proust, mas se centra na leitura que Benjamin faz desse autor, como um sujeito que rememora, e a partir daí aplica esse "método" em Alexander. De modo algum, se pretende, aqui, analisar a obra de Proust. Busca-se analisar, antes, o pensamento de Benjamin sobre um autor que rememora, teoria essa retirada de sua análise do processo de escrita do romancista, que opera como uma espécie de "tipo ideal" de uma pessoa que rememora.

${ }^{47}$ Referência à frase de Michelet reproduzida por Benjamin: "Cada época sonha a seguinte". MichELET. Apud: BeNJAmin, Walter. "Exposés". In: Passagens. Belo Horizinte: Editora UFMG; São Paulo: Imprensa Oficial do Estado de São Paulo, 2006, p.41.

${ }^{48}$ Cf. Benjamin, W. "A imagem de Proust". op. cit., p. 40.

${ }^{49}$ Benjamin, W. "A imagem de Proust". op. cit., p. 40.
} 
No texto A imagem de Proust ${ }^{50}$, escrito em 1929, Walter Benjamin analisa a obra do romancista a partir do modo como era composto seu texto: uma articulação entre esquecimento e memória, na qual a memória involuntária tem papel fundamental. Para expressar esse processo de elaboração textual, Benjamin toma como metáfora o tear. Em termos literais, o trabalho da tecedura é realizado quando os fios que compõem a trama entrepassam os fios da urdidura, dispostos em um tear, e daí resulta algum tecido. Benjamin atribui à feitura do texto de Proust um processo artesanal análogo: "Se texto significava, para os romanos, aquilo que se tece, nenhum texto é mais 'tecido' que o de Proust, e de forma mais densa". ${ }^{51}$ No tear do romancista, por entre os fios do esquecimento (que formam a urdidura), passam os fios da recordação (compondo a trama). Esquecimento e recordação têm, portanto, movimentos simultaneamente complementares e opostos, mesclando-se e cruzando-se em um denso entrelaçamento que dá forma à rememoração proustiana.

Proust se entrega de tal forma às suas lembranças, que é capaz de extrapolá-las e libertá-las do tempo passado no qual estavam presas. Isso porque, diz Benjamin, "um acontecimento vivido é finito, ou pelo menos encerrado na esfera do vivido, ao passo que o acontecimento lembrado é sem limites, porque é apenas uma chave para tudo o que veio antes e depois" ${ }^{\text {52 }}$. A grandeza das lembranças de Proust não está, portanto, em seu conteúdo (a vida burguesa que ele descreve), mas em sua busca por analogias e semelhanças entre o passado e o presente. E, nessa busca, acredita Gagnebin,

[...] Proust não reencontra o passado em si - que talvez fosse bastante insosso -, mas a presença do passado no presente e o presente que já está lá, prefigurado no passado, ou seja, uma semelhança profunda, mais forte do que o tempo que passa e que se esvai sem que possamos segurá-lo. A tarefa do escritor não é, portanto, simplesmente relembrar os acontecimentos, mas "subtraí-los às contingências do tempo em uma metáfora",53.

Ou seja, o importante em Proust, destaca Benjamin, não são os fatos que ele viveu e relembra ao escrever, mas o tecido que constitui sua rememoração; "a unidade do texto está apenas no actus purus da própria recordação, e não na pessoa do autor, e

\footnotetext{
${ }^{50}$ Benjamin, W. “A imagem de Proust”. op. cit., pp.36-49.

${ }^{51}$ Benjamin, W. “A imagem de Proust”. op. cit., p. 37.

${ }^{52}$ Benjamin, W. “A imagem de Proust”. op. cit., p. 37.

${ }^{53}$ Gagnebin, J. "Prefácio - Walter Benjamin ou a história aberta". op. cit., pp. 15-16. À seleção de texto final, Gagnebin atribui a Marcel Proust, $A$ La Recherche du temps perdu, ed. Plêiade, vol. III, p. 889.
} 
muito menos na ação"54. Em Experiência e Pobreza ${ }^{55}$, Benjamin aponta que determinados homens buscavam se livrar de quaisquer fragmentos de experiência que aparecessem durante o sono. Proust fazia o oposto: tentava recolhê-los com tal afã que não dormia à noite. O romancista passava a noite tecendo, sentia medo de que o dia, com suas ações e reminiscências intencionais, desfizesse os ornamentos do esquecimento, desmanchasse seu trabalho. Isso porque o dia revela apenas algumas das franjas que o esquecimento tece na existência vivida.

Acordado à noite, Benjamin acredita que Proust encontrava, nessa "hora mais banal e mais efêmera, mais sentimental e mais frágil” ${ }^{56}$ de sua vida, uma significação que ele registra ao descrever esse momento, e

[...] o faz de tal maneira que cada um de nós reencontra essa hora em sua própria existência. Por pouco, poderíamos chamá-la de uma hora que se repete todos os dias. Ela vem com a noite, com um arrulho perdido, ou com a respiração na balaustrada de uma janela aberta. Não podemos prever os encontros que nos estariam destinados se nos submetêssemos menos ao sono. Proust não se submetia ao sono. [...] Submetendo-se à noite, Proust vencia a tristeza sem consolo de sua vida interior (que ele uma vez descreveu como "l'imperfection incurable dans l'essence même du présent”), e construiu, com as colméias da memória, uma casa para o enxame dos seus pensamentos. ${ }^{57}$

Por meio dessa tecedura, a qual permitia aos acontecimentos vividos no passado serem libertados dessa dimensão temporal, Proust foi capaz de construir uma experiência, no sentido moderno, individual, do termo (Erlebnis). Tal qual a proposição benjaminiana para a história, o processo de rememoração proustiano tem como base a atualização de uma lembrança, que permite a um acontecimento passado ser salvo no presente.

A temporalidade corrente na modernidade é aquela ligada a um tipo de memória, a "memória voluntária", tutelada pelo intelecto e sujeita aos apelos da atenção, que não guarda traços do passado. É a memória do cotidiano, dos hábitos diários, necessária à organização da vida. Pode ser acessada pelos esforços da inteligência humana que, no entanto, são inúteis para evocar o passado. Está ligada à consciência, instância que opera

\footnotetext{
${ }^{54}$ Benjamin, W. “A imagem de Proust”. op. cit., p. 37.

${ }^{55}$ BenJAMin, W. "Experiência e pobreza". op. cit., p.114-119.

${ }^{56}$ Benjamin, W. "A imagem de Proust”. op. cit., p. 38.

${ }^{57}$ Benjamin, W. "A imagem de Proust". op. cit., p. 38.
} 
no indivíduo moderno como uma proteção contra os incessantes estímulos (choques, diria Simmel ${ }^{58}$ ) que o subjugam - e que, por tal função, não registra traços mnemônicos ${ }^{59}$.

Nas rememorações de Proust irrompem, todavia, lembranças involuntárias, as quais ele nomeia "memória involuntária”, lembranças que se desprendem de um objeto por meio de seus sentidos. A rememoração proustiana não se baseia na memória corriqueira da modernidade (voluntária), mas na memória involuntária que, embora cada vez menos comum com o avanço da modernidade, persiste. A chave para acioná-la está em um objeto qualquer e desconhecido, situado fora da inteligência e de seu campo de ação. Ao encontrar tal objeto, sorte que depende do acaso ${ }^{60}$, irrompe a memória involuntária por meio de imagens que estão esquecidas, recalcadas. São imagens que condensam os significados da vida, processo a que Benjamin chama de galvanização ${ }^{61}$. Contendo a duração de um relâmpago, se não forem fixadas, tais imagens desaparecem.

Por meio das rememorações que partem da memória involuntária é que se pode atribuir a Proust a obtenção de uma experiência. Trata-se de uma experiência individual, que pouco se parece com aquela antes transmitida pelo narrador. Representa, entretanto, uma possibilidade de eternizar a temporalidade vivida por um sujeito, ainda que se esteja sob o jugo da modernidade. Proust mergulhava em uma temporalidade distinta daquela sobressalente na modernidade ao escrever romances, sozinho em seu quarto, a partir da rememoração de fatos que ele vivera.

O ambiente sintético que Proust criara para escrever buscava suprimir o presente marcado por memórias superficiais, corriqueiras e racionais (a memória que está sob o domínio do cotidiano), tornando mais freqüente o aparecimento das lembranças que normalmente aparecem em forma de devaneio, entre o sono e a vigília. Quando a lembrança se transformava em percepção, irrompia no autor a memória involuntária em forma de imagem. Assim, um tempo perdido no esquecimento podia ser redescoberto pela atualização do evento passado.

[...] Pode-se considerar a obra de Proust, Em Busca do Tempo Perdido, como a tentativa de reproduzir artificialmente, sob as condições sociais atuais, a experiência tal como Bergson a imagina, pois cada vez se poderá ter menos esperanças de realizá-la por meios naturais. [...] Ato contínuo, [Proust] confronta esta memória involuntária com a voluntária, sujeita à tutela do intelecto. As

\footnotetext{
${ }^{58}$ Cf. . Simmel, G. "A metrópole e a vida mental”. op. cit.

${ }^{59}$ Cf. Benjamin, W. "Sobre alguns temas em Baudelaire”. op. cit., p. 106.

${ }^{60}$ Cf. Proust, Marcel. Apud Benjamin, W. "Sobre alguns temas em Baudelaire”. op. cit., p. 106.

${ }^{61}$ Benjamin, W. "A imagem de Proust”. op. cit., p. 46.
} 
primeiras páginas de sua grande obra se incumbem de esclarecer esta relação. Nas reflexões que introduzem o termo, Proust fala da forma precária como se apresentou em sua lembrança, durante muitos anos, a cidade de Combray, onde, afinal, havia transcorrido uma parte de sua infância. Até aquela tarde, em que o sabor da madeleine (espécie de bolo pequeno) o houvesse transportado de volta aos velhos tempos - sabor a que se reportará, então, freqüentemente -, Proust estaria limitado àquilo que lhe proporcionava uma memória sujeita aos apelos da atenção. Esta seria a mémoire volontaire, a memória voluntária; e as informações sobre o passado, por ela transmitidas, não guardam nenhum traço dele. "E é isto que acontece com nosso passado. Em vão buscamos evocá-lo deliberadamente; todos os esforços de nossa inteligência são inúteis." Por isso Proust não hesita em afirmar, concludentemente, que o passado encontrar-se-ia "em um objeto material qualquer, fora do âmbito da inteligência e de seu campo de ação. Em qual objeto, isso não sabemos. E é questão de sorte, se nos depararmos com ele antes de morrermos ou jamais o encontrarmos".

Segundo Proust, fica por conta do acaso, se cada indivíduo adquire ou não uma imagem de si mesmo, e se pode ou não se apossar de sua própria experiência. Não é de modo algum evidente este depender do acaso. As inquietações de nossa vida interior não têm, por natureza, este caráter irremediavelmente privado. Elas só o adquirem depois que se reduziram as chances dos fatos exteriores se integrarem à nossa experiência. $[\ldots]^{62}$

Nas palavras de Proust:

[O passado] Está escondido, fora de seu domínio e de seu alcance, em algum objeto material (na sensação que este objeto material nos daria), que estamos longe de suspeitar. Tal objeto, depende apenas do acaso que o reencontremos antes de morrer, ou que não o encontremos jamais. ${ }^{63}$

\section{$\mathrm{Na}$ análise de Duoek:}

Odores, sabores, sons persistem e subsistem como almas encerradas em algum objeto, e quando o acaso nos coloca em contato com tal objeto, elas dele se despreendem, e nos oferecem o passado que ali estava preso. Esta memória, por assim dizer, corporal, memória inscrita nas sensações (o gosto de um bolinho mergulhado no chá, um passo dado em falso, o barulho de uma colher) traz repentinamente de volta um passado que parecia morto. O passado vem, libertado, ressuscita, com violência, com força, bruscamente ("E de súbito a

\footnotetext{
${ }^{62}$ BENJAMIN, W. "Sobre alguns temas em Baudelaire”. op. cit., pp. 105-106.

${ }^{63}$ Proust. Apud Douek, S. Memória e exílio. op. cit., p. 101.
} 
lembrança me apareceu."), ele vem quase sem ser chamado, sem convite, irrompe em nossa vida, no "tempo de agora", no solo de hoje, no presente, interrompendo o tranqüilo curso do tempo, salta para o presente, num instante que o salva. [...] Esse mágico instante destaca-se no tempo, interrompendo o fluxo contínuo dos acontecimentos: o tempo pára, imobiliza-se, e o passado invade o presente, que o ressuscita $[\ldots] .{ }^{64}$

A memória involuntária de Proust, que como qualquer memória costuma ser associada à lembrança, Benjamin aproxima do esquecimento ${ }^{65}$. Esse esquecimento, que produz franjas e ornamentos no tecido proustiano, embora fique disposto no tear, também atua ativamente na tecedura proustiana, como a recordação. E dele, a depender do acaso, irrompem as imagens da memória involuntária.

Além de só, Proust escrevia à noite, em seu quarto escuro, sem ser perturbado, sob luz artificial, abalado por suas crises de asma - ou seja, no ambiente sintético que criara em sua busca por suprimir o presente marcado pela memória voluntária e tornar mais freqüente o irrompimento da memória involuntária. Na tentativa de barrar as memórias superficiais, corriqueiras e racionais, Proust deixava caminho aberto para o aparecimento das lembranças que normalmente aparecem em forma de devaneio, entre o sono e a vigília. À noite, as imagens da memória involuntária pareciam mais propensas a aparecer e dar forma às suas rememorações. A memória involuntária irrompia, em forma de imagem, quando essa lembrança se transformava em percepção. Assim se dava a rememoração de Proust, de acordo com Benjamin, de modo que um tempo perdido no esquecimento podia ser redescoberto pela atualização do evento passado ${ }^{66}$.

Gagnebin $^{67}$, interpretando o ensaio de Benjamin sobre Proust, atribui à criação do ambiente artificial no qual o romancista escrevia uma busca pela experiência. ${ }^{68} \mathrm{E}$ essa experiência, que por fim Proust construía, não parte dos fatos por ele vividos, mas da rememoração desses fatos. Esse mecanismo traz o entrecruzamento de tempos à vida de Proust. A rememoração lhe permite experimentar uma temporalidade que não segue

\footnotetext{
${ }^{64}$ DoueK, S. Memória e exílio. op. cit., p. 102. Quando às expressões destacadas entre aspas pela autora, a primeira é atribuída a Proust e a segunda é a tradução para o termo benjaminiano Jetztzeit.

${ }^{65}$ Benjamin, W. "A imagem de Proust". op. cit., p. 37.

${ }^{66}$ Benjamin, W. "A imagem de Proust”. op. cit., p. 37.

${ }^{67}$ Idéia que percorre as seguintes obras: GAGNEBIN, J. "Prefácio - Walter Benjamin ou a história aberta". op. cit., pp. 7-19 e GAGNEBIN, J. História e Narração em Walter Benjamin. op. cit.

${ }^{68}$ Evidentemente, fala-se aqui de Erlebnis, a experiência individual que, embora rara, ainda não se perdeu por inteiro no mundo moderno; experiência essa bastante diferente de Erfahrung, experiência coletiva cuja perda Benjamin anunciava em O Narrador (BENJAMIN, W. "O Narrador - Considerações sobre a obra de Nikolai Leskov". op. cit., pp. 197-221).
} 
a linha temporal cronológica. Dessa linha, Proust retira os acontecimentos de modo que o passado, que poderia desaparecer no esquecimento, assume a forma de uma rememoração, e o presente se mostra como uma possível realização da promessa anterior, que poderia ter se perdido para sempre (e ainda pode), não fosse inscrita no presente ${ }^{69}$. Proust atualizava suas lembranças adicionando-as a seus romances.

Benjamin, assim, aponta em Proust uma temporalidade que se remete a um tempo entrecruzado, no qual interagem a reminiscência e o esquecimento. Ao mundo proustiano, um mundo em estado de semelhança, Benjamin se refere como o "universo dos entrecruzamentos" ${ }^{70}$. Ao rememorar os acontecimentos, Proust os retira da linha temporal cronológica, os retira do tempo; os torna, portanto, eternos ${ }^{71}$.

69 Aqui se encontra um ponto comum entre o rememorar proustiano e a fotografia na acepção de
Benjamin, no sentido de que ambos se baseiam em uma miscelânea temporal, na qual outro tempo se
sobressai no presente, pelo acaso. Embora as definições benjaminianas de inconsciente ótico e aura sejam
bastante complexas e mesmo inconstantes, apenas para apontar essa parecença, colocam-se aqui breves
definições de Benjamin a respeito das primeiras fotografias, imagens que mantinham sua unicidade: “[...]
a técnica mais exata pode dar às suas criações um valor mágico que um quadro nunca mais terá para nós.
Apesar de toda a perícia do fotógrafo e de tudo o que existe de planejado em seu comportamento, o
observador sente a necessidade irresistível de procurar nessa imagem a pequena centelha do acaso, do
aqui e agora, com a qual a realidade chamuscou a imagem, de procurar o lugar imperceptível em que o
futuro se aninha ainda hoje em minutos únicos, há muito extintos, e com tanta eloqüência que podemos
descobri-lo, olhando para trás"; "[...] Em suma, o que é a aura? É uma figura singular, composta de
elementos espaciais e temporais: a aparição única de uma coisa distante, por mais próxima que ela
esteja". (BENJAMIN, Walter. "Pequena história da fotografia". op. cit., p. 94 e 101, respectivamente).
Sobre o conceito de aura, ver PALHARES, Taisa. Aura - A Crise da Arte em Walter Benjamin. São Paulo: Barracuda, 2006. A autora se debruça sobre três significados distintos empregados à "aura" na escrita benjaminiana. Sobre a relação intensa entre Proust e a fotografia, ver BRASSAİ. Proust e a fotografia. Rio de Janeiro: Jorge Zahar Editor, 2005. O fotógrafo relata o entusiasmo com o qual Proust colecionava fotografias, e analisa a obra do romancista a partir da emergência de imagens fotográficas que seu texto provoca no leitor.

${ }^{70}$ Diz Benjamin: "A eternidade que Proust nos faz vislumbrar não é a do tempo infinito, e sim a do tempo entrecruzado. Seu verdadeiro interesse é consagrado ao fluxo do tempo sob sua forma mais real, e por isso mesmo mais entrecruzada, que se manifesta com clareza na reminiscência (internamente) e no envelhecimento (externamente). Compreender a interação do envelhecimento e da reminiscência significa penetrar no coração do mundo proustiano, o universo dos entrecruzamentos. É o mundo em estado de semelhança, e nela reinam as 'correspondências', [...] que Proust foi o único a incorporar em sua existência vivida". (BENJAMIN, W. "A imagem de Proust". op. cit., p. 45).

${ }^{71}$ Douek, baseada em Blanchot, diferencia a "extra-temporalidade" da "eternidade": "O 'fora do tempo' não pode ser assimilado unicamente à eternidade, mas também a um tempo puro, isto é, abolido, apagado, liberto de acontecimentos, um tempo pensado como espaço vazio. [...]"; "Se Blanchot foge assim de uma interpretação apressada que identificaria o extra-temporal com a eternidade, para Benjamin também o tempo proustiano não pode ser entendido como sinônimo de eternidade [...]" (DouEK, S. Memória e exílio. op. cit., p. 112; pp. 112-113). Como não se busca, aqui, a compreensão da obra de Proust, mas a noção benjaminiana de "rememoração" - noção essa que Benjamin aplica a Proust -, deixa-se apenas indicada a possibilidade de diferentes visões sobre essa questão. Acreditamos, entretanto, que o tempo que Benjamin atribui à rememoração proustiana é um tempo eterno (sem que isso signifique que eternidade e extra-temporalidade tenham, ou não, significados semelhantes). A última frase aqui citada por Douek não está suficientemente justificada para que julguemos necessário um diálogo maior com essa questão, por isso optamos por deixar apenas apontada a possibilidade de outros modos de apreensão da visão benjaminiana sobre a temporalidade da rememoração especificamente proustiana (ver DOUEK, S. Memória e exílio. op. cit., pp. 108-114). Quanto ao processo de rememoração, apreendido de Benjamin de modo geral, acreditamos que ele, sim, dota seu autor de uma temporalidade eterna, posto que extraída da 
O passado é salvo no presente de Proust porque o autor percebe a semelhança que transforma esses dois tempos; o passado, que poderia desaparecer no esquecimento, assume a forma de uma rememoração, e o presente se mostra como uma possível realização da promessa anterior que poderia ter se perdido para sempre (e ainda pode) se não fosse inscrita no presente. $\mathrm{O}$ tempo assume, aqui, uma dimensão qualitativa.

A infinitude da obra de Proust se expressa inclusive no desejo que o autor possuía de fazer um livro sem parágrafos, em volume único. Para o romancista, as interrupções da ação de sua tecedura (sua escrita) representavam o avesso do continuum da recordação, e por isso seu livro deveria ser contínuo, tal qual seu tecer:

Podemos mesmo dizer que as intermitências da ação são o mero reverso do continuum da recordação, o padrão invertido da tapeçaria. Assim o queria Proust, e assim devemos interpretá-lo, quando afirmava preferir que toda a sua obra fosse impressa em um único volume, em coluna dupla, sem um único parágrafo. ${ }^{72}$

Benjamin propõe que se analise Proust segundo suas fraquezas ${ }^{73}$ : ele era um estranho ao mundo. Sua inexperiência era tamanha para os feitos práticos e ações mecânicas a que se sujeitam os indivíduos, que permitiu a ele escrever sua obra, mas que também o matou, pois ele não sabia como alterar suas condições de vida.

Embora os médicos tenham ficado impotentes frente à doença de Proust, Benjamin acredita que ele soube usá-la a seu favor. A presença constante da morte, a falta de fôlego, a dificuldade ao respirar, suas crises de asfixia, a ameaça e a sensação de sufocamento que a asma lhe causava teriam feito com que Proust escrevesse sua obra. “[...] Sua sintaxe imita o ritmo de suas crises de asfixia. Sua reflexão irônica, filosófica, didática, é a sua maneira de recobrar o fôlego quando se liberta do peso de suas reminiscências", diz Benjamin ${ }^{74}$. E Proust parece concordar: "O ruído de minha respiração abafa o da minha pena, e o de um banho, no andar de baixo."75

linha temporal corrente, aquela do progresso. O que importa em Proust e Benjamin é aquilo a que Douek se referenciará depois: o mesmo desejo de "salvar" o passado por meio da sua reatualização no presente (cf. DOUEK, S. Memória e exílio. op. cit., p.122).

${ }^{72}$ Cf. Benjamin, W. "A imagem de Proust". op. cit., pp. 37-38.

73 "É assim, em sua fraqueza, que precisamos vê-lo, para compreender a maneira feliz com que Jacques Rivière procurou interpretá-lo, a partir dessa fraqueza: 'Marcel Proust morreu por inexperiência, a mesma que lhe permitiu escrever sua obra. Morreu por ser estranho ao mundo, e por não ter sabido alterar as condições de vida que para ele se tinham tornado destruidoras. Morreu porque não sabia como se acende um fogo, como se abre uma janela'. E morreu, naturalmente, de sua asma nervosa." (BENJAMIN, W. "A imagem de Proust". op. cit., pp. 47-48).

${ }^{74}$ Benjamin, W. “A imagem de Proust”. op. cit., p. 48.

${ }^{75}$ Proust, M. Apud: Benjamin, W. “A imagem de Proust”. op. cit., p. 48. 
De acordo com Benjamin, o sofrimento gerado pela doença de Proust "estava destinado a encontrar seu lugar no grande processo da [sua] obra, graças a um furor sem desejos e sem remorsos"76. Sem esse sofrimento, certamente a tecedura de Proust cessaria e, em seu tear, encostado em um canto qualquer de sua casa, que não seu quarto, restaria apenas a urdidura - os fios do esquecimento. Os fios da memória, não mais trançados aos do esquecimento, trariam em si lembranças daquela época em que, esquecendo-se do mundo, Proust concentrava-se em si mesmo, em seus fios; lembranças de uma época na qual ele tecia e assim entrecruzava o tempo, podendo constituir, pela rememoração, uma experiência (individual) na modernidade.

\subsection{A eternidade e um dia}

A narrativa se constituía de um entrecruzamento de tempos; a memória formava a trama da vida junto a um esquecimento que, diferente daquele da modernidade, é produtivo e reflui da memória para ser narrado novamente. Como se tentou apresentar no primeiro capítulo, isso se perdeu na modernidade, na qual a temporalidade predominante se baseia em eventos que se sucedem em uma linha contínua que caminha para a frente. Se a experiência tradicional se perdeu, na modernidade é ainda possível que um determinado tipo de experiência seja alcançado: a experiência individual, vivida por Proust e - pode-se dizer - por Alexander, o protagonista do filme $A$ eternidade e um dia.

A obra mostra um personagem que, tal como Proust, rememora e mergulha em seu passado, retirando-o da esfera fechada na qual estava. $\mathrm{O}$ espectador já nota de início duas características filmicas fundamentais: a mistura temporal nele presente e a sobreposição de diferentes tempos históricos, que acaba por definir sua (não)linearidade.

Além da rememoração, outros elementos coincidem na trajetória de Alexander e no propósito literário de Proust. Ambos são escritores, o que significa não apenas uma ocupação em comum, mas uma atividade que, como a da figura do artesão, exige uma temporalidade diferenciada daquela dos princípios de produção capitalista.

Para que se possa obter um conhecimento de causa pleno da literatura proustiana, Benjamin propõe a seu leitor mergulhar na camada mais profunda da memória involuntária - onde os momentos de reminiscência aparecem informes, de modo não-visual, infinito e denso, e não na forma como ela irrompe (por meio de

\footnotetext{
${ }^{76}$ Benjamin, W. “A imagem de Proust”. op. cit., p. 49.
} 
imagens isoladas) $)^{77}$. Benjamin constrói, assim, outra metáfora para Proust, na qual essa camada aparece em estado líquido. O filme A Eternidade e um dia, oportunamente, também traz o mar como metáfora - logo em seu primeiro diálogo.

$\mathrm{Na}$ figura de linguagem benjaminiana, em um oceano, um pescador joga sua rede no mar. Percebe que capturou uma presa ao sentir o peso da rede, então a puxa para fora da água, fazendo bastante esforço físico. Esse trabalho realizado pelo pescador é artesanal, assim como a tecedura, outra figura de linguagem usada por Benjamin.

Resolvendo essa metáfora, como Benjamin o faz, tem-se o mar como representante da camada onde se internalizam as memórias involuntárias, o "oceano do temps perdu" ${ }^{78}$. Lançando a rede nas águas do tempo perdido, o pescador sente seu peso, tal qual Proust sente um odor característico que desperta seu rememorar. Esses são os sinais de que foi capturada parte da camada especial do oceano onde os momentos da reminiscência aparecem sem forma, indefinidos e densos, constituindo um todo. Para retirar do oceano a rede com presa tão densa, Proust faz, com suas frases, um esforço indizível, como aquele que o pescador realiza para erguer uma rede cheia de peixes. É exatamente a alta densidade do material pescado que permite sua captura, pois ainda que a presa forme um todo, ela está diluída no oceano da memória involuntária ${ }^{79}$.

O primeiro diálogo de A Eternidade e um dia, uma espécie de prefácio ao filme, apresenta esse mesmo processo metafórico. Após os créditos iniciais, vê-se a imagem de uma casa branca, ampla, com varandas. O mar ainda não apareceu, mas é possível escutar o som das ondas e de pássaros. A imagem se aproxima lentamente da casa, e ouve-se um menino que sussurra.

AMIGO (voz off): Venha, Alexander, iremos à ilha.

ALEXANDER (voz off): Onde?

AMIGO (voz off): À ilha. Iremos mergulhar e observar a velha cidade. Depois subiremos o penhasco e gritaremos pros navios.

ALEXANDER (voz off): O que você sabe sobre a velha cidade?

AMigo (voz off): Meu avô diz que era uma cidade muito alegre, foi submersa depois de um terremoto, agora está no fundo do mar... há séculos. Ela aparece de tempos em tempos, só por um momento, quando a estrela da manhã está com saudades da terra e a contempla lá de longe. Então tudo pára.

\footnotetext{
${ }^{77}$ Cf. Benjamin, W. “A imagem de Proust”. op. cit., pp. 48-49.

${ }^{78}$ BENJAMIN, W. "A imagem de Proust". op. cit., p. 49.

${ }^{79}$ Vale lembrar que as águas desse oceano também banham o esquecimento, já que não há memória sem que tenha havido, antes, esquecimento.
} 
AlEXANDER (voz off): E quando isso acontece?

AMIGo (voz off): Meu avô disse que é quando algum garoto estiver jogando "jack" na praia. Você vem?

A velha cidade, submersa no oceano como os fatos do passado na memória - ou no esquecimento -, aparece esporadicamente, sempre que irrompe a memória involuntária. E então tudo pára, pois a temporalidade corrente é anulada e o tempo se eterniza. Esse é o mesmo processo de retirada do mar da densa presa da reminiscência que Benjamin localizou em Proust.

A memória involuntária aparece quando um elemento do acaso a desperta, "de tempos em tempos, só por um momento"; quando algum elemento do passado, portanto distante (“a estrela da manhã"), vem ao encontro do presente. E, se "então tudo pára”, é porque a rememoração que daí pode surgir abala a temporalidade corrente.

Essa introdução à memória involuntária funciona como prelúdio ao início formal do filme. Surge então o título escrito em letras brancas sobre a imagem da casa na praia que servirá de cenário para as rememorações. A câmera se aproxima de uma das varandas da casa lentamente, até que o espectador adentra a casa, onde um garoto deitado sobre a cama desperta ao ouvir assobios.

Ele, já vestido com jardineira e camiseta, pega seus calçados e caminha na ponta dos pés em direção à porta do quarto. A câmera o segue pela casa, ele olha para os lados, conferindo se alguém nota sua saída. O espectador percebe a presença de outras pessoas ao ouvir o som de adultos rindo e ouvindo música. Quando o garoto chega à escada, a câmera pára de acompanhá-lo. Assim é introduzida a casa da praia que será o cenário das rememorações de Alexander - já com a lembrança de um garoto que brinca.

$\mathrm{Na}$ cena seguinte esse garoto aparece correndo, com as sandálias nas mãos, até o mar. Na praia já estão seus amigos. Ao atravessar uma tenda montada sobre a areia, o menino olha para trás rapidamente, mas logo volta a correr em direção a seus amigos, ao mar - de águas calmas, onde há poucas ondas. A câmera o acompanha, ainda que em ritmo mais lento que o garoto. Ele tira a jardineira e se junta aos amigos na água nadam em direção ao alto mar. O garoto é Alexander, que nada rumo à velha cidade, submersa após o terremoto. Nada em direção às suas memórias, afogadas pelo oceano do esquecimento, às suas lembranças de Ana, sufocadas após sua morte, e que serão despertas pela leitura de suas cartas. Ele nada até que uma voz feminina o chama e a paisagem muda. 
Há o som de uma buzina e a imagem se funde com outra, feita do alto, cada vez mais distante do observador. Surge um barco e logo se pode perceber que se tratam de outras águas - esse mar é apenas a vista do local onde está Urania, que, abrindo a porta de uma varanda, comenta "Você dormiu aqui? E não tocou na comida".

Dada a descontinuidade entre as cenas e devido às roupas antigas que usava o garoto, tem-se a impressão de que o conteúdo visto até então era um flashback. Urania, vestida de preto, se agacha diante de um homem reclinado sobre uma cadeira de balanço, um homem com barba branca, vestindo capa, de olhos fechados e com a mão no pescoço: é Alexander, que pela primeira vez aparece no presente narrativo. Ele diz a ela: "Há um gosto de sal do mar na minha boca". É então que se pode perceber Alexander relembrava sua infância, e o fez de modo tão profundo que sentiu em sua boca o gosto do sal do mar no qual mergulhara quando criança.

A lembrança de Alexander é feita de modo tão intenso que ele chega a vivenciar uma sensação física do passado - o gosto do sal. Não se trata ainda de uma rememoração, e sim de uma lembrança, porque ele não mergulha no passado com sua fisionomia do presente, ele se lembra do passado do modo como o vivera naquele tempo. O estímulo sensorial que poderia ter acionado sua memória involuntária - o gosto de sal na boca - aparece depois da lembrança e como conseqüência dela (na rememoração, vale lembrar, o estímulo sensorial costuma ser o acaso que desperta a memória involuntária, que levará à rememoração, portanto ele ocorre antes de qualquer lembrança, diferente do que ocorre inicialmente no filme).

Após comentar sobre o gosto de sal, Alexander parece centrar-se novamente no presente narrativo, ele olha para Urania e se senta lentamente. Então comenta "É meu último dia". Mais uma confusão temporal surge assim - após uma cena que evocava o passado de Alexander, ele aparece no presente narrativo e comenta que não tem perspectivas para o futuro (afinal, é seu último dia, o fim de qualquer vivência temporal em sua vida).

Quando Urania sugere acompanhá-lo ao hospital no dia seguinte, Alexander pede que não piorem as coisas e levanta-se da cadeira de balanço falando "Não é assim o fim de todos?" Ela lhe entrega um molho de chaves, fala que o café está na sala de estudos e que já fez a mala dele. "Espero que não tenha colocado muita coisa. Não precisarei", diz Alexander. Ele a chama pelo nome e agradece por ter permanecido três anos com ele naquele apartamento, diz que sem ela não teria chegado até ali. Urania sai sem falar nada, volta para dizer que tratou do cachorro e parte novamente. Então se 
ouve a porta bater e Alexander volta para a sala inicial, onde toma seu café. O cachorro que foi citado na fala de Urania aparece sentado na varanda (cuja porta está aberta), voltado para a paisagem.

Logo nos primeiros minutos do filme já fica apontado que o fim da vida de Alexander se aproxima. Sua doença, não nomeada, é responsável por despertar nele um desencadeamento de rememorações que, no limite, o levarão de uma posição conformista à vontade de seguir vivendo, proclamada no final do filme.

Antes das rememorações terem início, Alexander se despede de alguns hábitos rotineiros que logo não existirão mais. Liga um aparelho de som para, ao desligá-lo, obter a resposta do vizinho pela varanda:

ALEXANDER: Nos últimos anos, meu único contato com o mundo é este estranho vizinho que me responde com a mesma música. Quem é ele? Como se parece?

Há então um corte imagético - até aqui, toda a tomada do presente narrativo havia sido feita com movimentos lentos e sem cortes. Embora haja esse corte na imagem, a fala de Alexander segue sem interrupções. Ele passeia na beira do cais que se via pela sua janela, com o cachorro.

AlEXANDER: Um dia saí à sua procura. Mas mudei de idéia. É melhor não saber, assim fico imaginando. Um solitário como eu... Talvez seja uma garota em busca do desconhecido antes de ir pro colégio.

Ele solta a coleira do cachorro, que sai correndo - em busca do desconhecido? - e desaparece da cena.

AlEXANDER: Tudo aconteceu tão rápido. A suspeita da doença, minha persistência em descobrir o que era... Então veio a escuridão e o silêncio em volta... o silêncio. Tudo dizia que antes do inverno estava acabado, juntamente com a silhueta dos navios no horizonte, contornados pela névoa do horizonte... Amantes passeando pela praia ao entardecer, e a decepção pela promessa da primavera. Tudo dizia que antes do inverno estava acabado.

A neblina da paisagem e a capa que Alexander veste indicam que é inverno. Atrás dele, surge um navio em meio à névoa do horizonte.

AleXANDER: Meu único arrependimento... Ana. Este é meu único arrependimento? É que eu nunca termino as coisas. Meus planos permaneciam como as palavras que se espalham pelo vento.

Ele então caminha para fora da abrangência do quadro imagético e a cena termina. 
No monólogo acima reproduzido, a fala de Alexander é permeada pela descrição de imagens visuais e está em sincronia com os acontecimentos da cena. Sua fala não segue uma ordem cronológica, mas revela pensamentos - ou imagens - que se seguem uns aos outros, conforme irrompem em Alexander.

É a fala de alguém que se despede do cotidiano, que vive nele seu último dia, que fecha um ciclo e, nesse processo, questiona-se sobre o que poderia ter sido diferente. Seu arrependimento é sua mulher, Ana, certamente não o fato de ter se casado com ela mas, como logo dirá, o fato de não ter dado o que ela lhe pedia - um dia, como aparecerá logo aparecerá no filme. Alexander se arrepende de não terminar o que começa, e em uma nova metáfora diz que seus planos se espalham como folhas impulsionadas pelo vento, ou seja, se dispersam, não se realizam.

A ausência de comunicação com o mundo que o protagonista revela ter vivenciado deve tê-lo aproximado de um isolamento que, segundo Benjamin, Proust experimentou como condição necessária para o irrompimento de sua memória involuntária. Seu arrependimento - Ana, ou nunca terminar o que começou - está ligado a uma incapacidade prática que também acometia Proust. Ambos os escritores dedicavamse mais a seus livros do que à esfera prática de suas vidas. Assim como, segundo Benjamin, Proust consegue rememorar o que vivera devido a um "esforço indizível”, sem dormir, anulando a corrente temporalidade do presente, Alexander conseguirá, rememorando, dar a Ana - e a si mesmo - um dia inteiro de convivência, dedicará um dia a ela, já que durante a vida de Ana ele não teve tempo para dedicar-se senão aos livros.

$\mathrm{Na}$ cena seguinte, ocorrerá o primeiro encontro entre Alexander e o garoto com quem ele passará o dia. Em seu carro, abre a porta para que o menino que limpava o vidro entre, pois a polícia o persegue. Esse garoto loiro, que aparenta ter dez anos, vivenciará com Alexander seu último dia, dando-lhe ainda um sentido de futuro Alexander partirá no dia seguinte, mas o menino, cujo nome não é revelado no filme, seguirá uma vida toda.

É após esse encontro que, na casa de sua filha, Alexander terá a primeira rememoração. A reação de Katerina ao ver o pai com seu cachorro magro e esguio, atado a uma coleira, em seu apartamento, é perguntar o que o leva lá em um domingo. Diz que tem telefonado para ele há duas semanas, mas ele não atende o telefone. Denuncia, assim, o isolamento do pai, sobretudo nos dias recentes. Mas ele nada responde, apenas pede para que ela fique com o seu cachorro, já que "estará fora por alguns dias". Ela recusa, alegando que seu marido não quer animais em casa. É então que Alexander entrega a 
Katerina as cartas que sua mãe, Ana, escrevera para ele. Katerina sai da cena - vai buscar algo para beber, enquanto Alexander caminha com o cachorro em direção à sala. Lá, há na parede um relógio projetado. A filha conversa com seu pai:

\section{KATERINA: Como vai seu trabalho?}

ALEXANDER: Meu trabalho?

KATERINA: "Assédio Livre" de Salomo. - (enquanto diz isso, passa frente à projeção do relógio, fazendo sombra sobre a parede, tendo o relógio projetado em seu corpo.) - O rascunho do terceiro poema. Não é isso que tem feito desde que mamãe morreu? Acho que nunca entenderei como um escritor com a sua reputação de repente abandona tudo para terminar um poema do século 19. Não me diga que abandonou isso também.

ALEXANDER (sozinho na sala, com o relógio projetado ao seu lado): Não sei. Talvez eu não consiga achar as palavras.

KATERINA (que volta à sala, com as cartas na mão): Esta não tem envelope. Por quê? Posso abrir?

Então ocorre a primeira rememoração do filme, que trará uma confusão temporal já prenunciada pela projeção do relógio na parede. Katerina lê a carta que se refere ao dia de seu nascimento, 20 de setembro de 1966, em voz alta:

KATERINA (lendo a carta de Ana): Você ainda dormia quando eu acordei. Olhei pra você, deitado ao meu lado. Estava sonhando, Alexander?

ANA (a leitura da carta prossegue com a voz de Ana): Estava sonhando, Alexander? Sua mão se moveu, procurando por mim, seus olhos abriram, mas logo voltou a dormir. Uma gota de suor percorreu seu rosto até desaparecer. O bebê ao nosso lado chorava baixinho, a porta rangeu, fui até a varanda e chorei.

Alexander vai à varanda de Katerina, e se pode ver, por trás do tecido translúcido da cortina, que há alguém lá. Ele abre a cortina, e há um corte: o espectador é levado ao lado externo da varanda, onde está uma mulher com cabelos cacheados, trajando um vestido branco com bolinhas pretas, decotado. Ela olha para fora da varanda. Logo que Alexander abre a cortina e diz: "Bom dia, Ana. Tive uns sonhos muito estranhos", dialogando com o que ela antes lhe perguntara (“está sonhando, Alexander?”)

Alexander dissera que seus arrependimentos eram Ana e nunca terminar o que começa. Não por acaso, sua primeira rememoração começa quando Katerina pergunta se ele abandonou "também" o poema de Solomo. A série de rememorações que ele terá 
ocorre para que ele perceba os motivos pelos quais se arrepende: não ter dedicado a Ana a atenção que ele gostaria, e não ter por hábito terminar aquilo que começa.

Alexander dialoga com Ana do modo como estava quando foi até a varanda da casa de sua filha, mas a varanda (assim como o tempo narrativo) já não é a mesma. Estão na casa de praia que aparecera no início do filme e Ana está viva.

ALEXANDER: Está chorando, Ana? - e se movimenta para secar suas lágrimas.

ANA: Não é nada. - diz, retira a mão de Alexander e se afasta dele.

A narração em off da carta, retomada, mostra o que preocupa Ana - ela pensa que Alexander se dedica tempo demais aos livros e pouco tempo a ela. E diz "se eu pudesse parar o tempo..." A leitura da carta é interrompida com a chegada da família, que veio conhecer Katerina, então recém-nascida.

Enquanto Ana recepciona os convidados, ouve-se novamente a narração da filha. Sua voz se mescla ao que está sendo vivido por Ana e Alexander.

ANA (voz off): Estou escrevendo de frente para o mar, deitada, como se não pudesse me mover. Escrevo para você, falo com você. Agora me sinto mais perto de você do que imaginava. Eu ameaço o seu mundo, Alexander? Eu ainda sou uma mulher apaixonada.

Katerina selecionara a carta que estava sem envelope para ler - provavelmente a carta estava aberta porque Alexander já a havia lido muitas vezes, e sua rememoração já havia sido refeita diversas vezes, tal como fazia Proust ao reler as provas de seu livro. Sempre que as relia, o romancista rememorava os mesmos fatos de um modo diferente.

Dentro de casa, a família festeja o nascimento de Katerina e novamente fica evidente o comportamento de Alexander: ele vive isoladamente, é introspectivo e possui poucos laços sociais.

ANA (voz off): À noite eu olhava para você, não sabia se você estava dormindo ou em silêncio. Tinha medo do que você pudesse estar pensando, tinha medo de interromper o seu silêncio, então comecei a mostrar como eu era vulnerável, com o meu corpo, porque assim você não se sentia em risco. Sou apenas uma mulher apaixonada, Alexander.

Mais pessoas chegam à casa para ver o bebê, que está sob uma tenda construída na praia. Todos os personagens, a família do casal, usam roupas claras, exceto a mãe de Alexander, que está com Katerina e usa um vestido escuro, mostrando o quanto a morte 
de seu marido a abalou. Enquanto observam o bebê, Ana se afasta da família e caminha em direção ao mar.

ANA ( $v o z$ off): Eu caminhei nua pela areia sentindo o vento. Um navio passava, você já havia acordado, eu ainda sentia o calor de seu corpo. Não nego que gostaria que você sonhasse comigo. Ah, Alexander! Se eu pudesse acreditar por um momento... eu me desmancharia em lágrimas.

Durante essa cena, Ana anda em direção à areia, o espectador a vê caminhando de costas, com o mar à sua frente. Essa cena se parece com o caminhar de Marie na praia em Sob a areia, após o sumiço de Jean, seu marido. Nas duas cenas, a imensidão do mar se equipara à ausência que elas sentem do marido, essas águas que avançam o limite da visão humana demonstram uma grandeza que as faz parecer extremamente frágeis face à solidão na qual mergulham.

A primeira fase da rememoração de Alexander termina com Ana frente ao mar e a volta ao presente narrativo, quando ele diz a Katerina "Eu não tinha percebido..." e logo é interrompido por seu genro, que lhe diz que venderam a casa da praia e entregarão a chave ao novo dono no dia seguinte. Fica evidente que os dois não têm uma boa relação e que Alexander não queria que a casa fosse vendida. Katerina tenta consolar seu pai, mas ele ainda insiste nas memórias, dizendo a ela:

ALEXANDER: Lembra da primeira viagem que fizemos juntos? Quantos anos você tinha? 15? Nós dois em Yannena para o maldito campeonato de tênis. Você perdeu e desatou a chorar.

Ela não parece interessada em lembranças, e responde justificando a venda da casa:

KATERINA: O que poderíamos fazer, papai? Nikos e eu... naquela casa enorme, com rachaduras dos terremotos e cercada de edifícios.

ALEXANDER: Caminhamos de mãos dadas pelo lago, tentei em vão, mas você estava inconsolável.

Alexander partirá no mesmo dia em que a casa será entregue ao novo dono. Essa antiga casa da praia, tão viva na memória de Alexander, está tomada por rachaduras. As memórias de Alexander, por outro lado, estão cada vez mais vivas embora também tenham fissuras, afinal a rememoração não traz o acontecimento como ele foi de fato vivenciado. 
Nessa rememoração de Alexander há uma mistura temporal que engloba gerações de uma mesma família, tempos históricos distintos e uma imagem pictórica que reforça tudo isso - o relógio projetado na parede da sala de Katerina. Ele opera como prelúdio à distensão temporal que está por vir, introduz o espectador à confusão temporal que logo ocorrerá. Na imagem do relógio, a rigidez do tempo cronometrado dos minutos se confunde com a impalpabilidade de uma projeção na parede, formada por um jogo de luzes.

Na rememoração de Alexander, Ana aparece em cena para lhe fazer um pedido que ele dedique um dia de sua vida a ela. Ana tem a mesma forma física do passado, de quando Katerina nascera. Alexander, por sua vez, "entra" no passado com sua forma física do presente - a partir do presente narrativo, ele rememora fatos do passado, onde há pessoas tão jovens como o eram naquele tempo.

O pedido de Ana, expresso na leitura da carta, indica projeções futuras que foram feitas em um tempo passado. Sua vontade seria realizada em um tempo futuro àquele em que fora pronunciada - e acaba se realizando no tempo presente da narrativa, com uma série de rememorações no mesmo dia. Esse entrecruzamento de tempos, análogo ao de Proust (segundo a concepção benjaminiana), é o que garante a Alexander ser sujeito de uma rememoração, ou seja, obter uma experiência individual.

As rememorações de Alexander têm como cenário a casa de praia cuja venda fora comunicada por seu genro. É a mesma casa do início do filme, onde Alexander, criança, acordara e mergulhara no mar e, adulto, ao lembrar-se desse dia, sentiu gosto de sal em sua boca. A notícia da venda da casa, palco de suas rememorações, faz com que Alexander, ao sair da casa da filha, sinta-se mal.

Sua entrada em uma farmácia mostra que Alexander de fato está doente, esclarecendo melhor qual o sentido de sua partida - anunciada por Urania, mas não comunicada a Katerina. Ele toma remédios na própria farmácia, de onde vê o garoto que ajudara ser capturado por dois homens e levado para dentro de um carro.

Devido a esse reencontro, a partida de Alexander não ocorrerá sem que antes haja uma grande aventura. Ele se envolve na vida de alguém que, não por acaso, é uma criança. Ou seja, ao mesmo tempo em que rememora sua vida, posto que irá deixá-la, Alexander passa a se relacionar com a temporalidade do futuro - não do seu, que está por findar, mas a de um garoto que conhece ao acaso. É, portanto, antes de partir definitivamente para o hospital, que Alexander se envolve nessa relação intensa com o passado, tentando realizar suas esperanças por meio da rememoração, e com o futuro, 
tentando salvar o menino (de quem não se saberá o nome) de uma situação de imigração ilegal - socialmente determinada, e que sabidamente não será resolvida por meio de uma ação individual.

Alexander segue o carro que leva o menino, em uma estrada coberta por neblina ${ }^{80}$, até uma construção desabitada. Lá estaciona um ônibus de onde saem pessoas elegantes (homens de terno e gravata), que seguem um homem de jaqueta de couro que claramente se diferencia deles. Alexander se une às pessoas elegantes para adentrar o galpão junto a eles, mas visivelmente não pertence ao grupo desses homens, pois é o único que veste uma capa.

Dentro do galpão, torna-se claro que os meninos capturados serão "vendidos" para a adoção ilegal. Um casal de idosos fica parado frente aos organizadores com um menino, enquanto um deles confere o dinheiro recebido. $\mathrm{O}$ ambiente é sombrio, fica às escondidas e tudo é negociado com dinheiro em espécie.

No meio desse cenário bastante improvisado, algumas cadeiras de plástico estão dispostas entre duas colunas, e o homem que conduziu o grupo até aquele local pede que eles se sentem. Essas pessoas, tão elegantes, destoam do lugar desprovido em que estão. Alexander é estranho tanto aos que operam o lugar, quanto aos freqüentadores. E ele reforça essa constatação ao não se misturar com nenhum dos grupos - ele caminha, só, por esse ambiente onde o chão é coberto por cacos de vidro e outros detritos de construção civil.

Como um dos elegantes casais aponta para um garoto e o descreve em inglês, fica mais claro que se trata não apenas de uma adoção ilegal, mas que esse esquema, aparentemente tão mambembe, tem dimensões internacionais. Os garotos ficam dispostos lado a lado, encostados na parede, atuam de acordo com o papel que estão sendo forçados a representar: como mercadorias dispostas em uma prateleira. $\mathrm{O}$ garoto que Alexander busca está também nessa fila, é o mais baixo, e provavelmente o mais novo de todos. Isso reforça ainda o grau de intervenção no futuro que Alexander acarreta por sua ação, pois ele se engaja em mudar a vida de alguém que, teoricamente, terá muitos anos para viver e, conseqüentemente, para vivenciar sua intervenção. Ao ver Alexander, o garoto dá um passo à frente, mas o homem que vigia as crianças o manda recuar, e ele o obedece.

Os garotos, entretanto, não aceitam passivamente o papel em que foram colocados à força e, quando um deles atira uma pedra na vidraça lateral, ocorre uma

\footnotetext{
${ }^{80}$ A referência a outro filme de Angelopoulos, Paisagem na neblina, está, aqui, não apenas no cenário nublado, mas também no percurso de uma busca aparentemente descabida e intangível.
} 
grande confusão, na qual Alexander por fim se agarra ao menino. Quando eles tentam sair, caminhando com naturalidade, de mãos dadas, o ambiente se silencia; eles passam pelas cadeiras que já estão vazias e três dos homens organizadores aparecem. Alexander percebe os códigos que regem o local e não diz nada, apenas coloca algum dinheiro sobre um galão, mostra a carteira então vazia, e parte, caminhando com o garoto. $\mathrm{O}$ risco que Alexander correra ali era bastante evidente, o que reforça seu afã em, de algum modo, salvar o garoto.

Toda a tomada que ocorre dentro dessa construção inacabada é feita sem cortes. A câmera se movimenta lentamente, sempre seguindo Alexander. As poucas palavras ditas são faladas em inglês. Sem cortes, a cena forma um todo. Tem um ritmo lento, a câmera percorre esse ambiente vagarosamente, contraposta à tensão que predomina no local. A incursão dessa tomada é mais no espaço que no tempo, ela é ambientada em um espaço estranho, no qual se fala outra língua, que tem códigos próprios; um espaço excêntrico a todos que estão ali, um espaço de exceção ao qual as pessoas foram com um objetivo muito específico.

A cena seguinte é de ruptura - não apenas é aberta, mas mostra uma estrada pela qual passa um caminhão-cegonha, produzindo muito ruído. É uma ruptura pois, a partir de então, Alexander estará com o garoto, terá essa missão de zelar não por seu próprio futuro, mas pelo futuro desse garoto - cedendo inclusive aos apelos do menino, não conseguindo abandoná-lo, exceto no final daquele seu último dia.

Um dos carros que passam por essa estrada nublada é o de Alexander, que o estaciona e conversa com o atendente do trailer onde compra um sanduíche. Então o menino fica menos estranho ao espectador - seu nome continuará sendo uma incógnita, mas sua nacionalidade albanesa é revelada. O conselho do atendente é que Alexander não dirija por duas horas sob neve, mas que peça ao motorista de um ônibus para levar o menino à fronteira com seu país de origem. Mas o garoto já demonstra que não tem interesse no retorno, pois ele tenta partir a pé ao ver Alexander conversando com o motorista do ônibus. Os homens que comandavam a adoção passam pela estrada, lembrando ao garoto o perigo que corre estando só na Grécia. Sobre seu passado, ele diz que tem uma avó que vive em seu país. Alexander comunica ao garoto que o ônibus irá para perto da fronteira, para onde planeja que o menino irá. 
ALEXANDER: Não posso te deixar depois disso tudo. Entende? Estarei viajando amanhã. Não terei tempo. Lá o motorista encontrará um táxi que o levará à fronteira. Não quer voltar para sua avó? - Alexander pusera dinheiro no bolso do menino durante sua fala. O ônibus buzina.

MENINO (cantando enquanto caminha rumo ao ônibus): Meu pequeno pássaro exilado passando por estranhos lugares, alguns com muita sorte por tê-lo enquanto eu anseio por você. O que você me diz, "Korfoula", minha florzinha...

ALEXANDER (o interrompendo): Você disse Korfoula... florzinha? - E pede para que o menino cante novamente, mas ele permanece calado. Quando chegam ao ônibus, Alexander passa a se desculpar - Eu não podia te deixar. Tinha que fazer algo.

$\mathrm{O}$ menino entra no ônibus e olha para Alexander através da janela. $\mathrm{O}$ ônibus parte, mas logo pára e o menino desce. Alexander conversa com ele, que está do outro lado da estrada:

AleXANDER: Eu sei o que quer! Mas não posso te deixar. Não posso!

Essa incapacidade de Alexander em abandonar o garoto significa que ele não o deixará como antes estava - vivendo ilegalmente na Grécia, sujeito a ações como a dos homens que tentaram "vendê-lo". Isso porque Alexander, de alguma forma, sente-se preso ao futuro do menino e quer intervir nesse tempo, ele projeta nessa criança todo o tempo de vida que logo lhe faltará. Ele parece bastante convicto de que o menino deve voltar para o seu país, e por isso dirige rumo a um clima cada vez mais coberto por neve, em direção à Albânia.

Mesmo quando o garoto tenta fugir novamente, dessa vez temendo militares em um bar, Alexander, fiel à sua missão auto-atribuída de levar o menino à Albânia, persegue o garoto e o localiza ao ouvi-lo cantar:

MENINO: Eu te mando uma maçã e ela apodrece, mando uma flor e ela murcha, mando uvas, mas elas estragam com o tempo.

AlEXANDER: O que foi? Está tremendo. A polícia o assusta? - O garoto devolve o dinheiro, mas Alexander o recusa, colocando-o de volta no bolso do garoto. - É seu. Lembra da palavra que usou na estrada? A palavra "Korfoula"? Você sabe o que é um poeta? Se eu tivesse tempo de te explicar o que era... Eu entendo... Vamos, você irá congelar. Vamos!

A primeira palavra já fora comprada por Alexander, sem que ele tivesse tido tempo de explicar esse "comércio" ao garoto. A próxima parada ocorre próxima à fronteira com a Albânia, onde Alexander estaciona e eles descem do carro, em meio à 
neve. O garoto lhe conta sobre como foi sua partida e os horrores que o esperam caso volte a seu país de origem. Se antes se sabia a sua nacionalidade, a partir de então o espectador passa a conhecer também uma parte de sua história de vida, que é a história de um país em guerra.

MENINO: Gangues armadas, tiros a noite toda em direção às casas das pessoas, bebês chorando, a cidade vazia... A passagem é por ali [olha para o outro lado da fronteira]. Selim sabia disso porque fez isso antes. Os adultos deixaram a trilha para nos guiar, sacos plásticos amarrados. Se você não sabe, se perde... a neve cobre você. De saco a saco acaba chegando num lugar plano, sem árvores. Selim começou a gritar porque eu não sabia e comecei a me mover... “têm bombas escondidas, seu idiota!" Ele disse. "Sente-se!” Eu sentei. Ele pegou uma pedra bem grande, jogou a pedra na nossa frente e se abaixou antes dela atingir a neve. Nada aconteceu, então andamos até a pedra. Me empurrou pra baixo, pegou a pedra e a jogou novamente. Eu estava com medo, com frio. Andamos mais um pouco, jogamos a pedra de novo. Fizemos isso de outro lado, vimos muitas luzes de longe.

Ainda com o cenário descrito pelo garoto, Alexander insiste em mandá-lo para a Albânia, acreditando que ele reencontrará sua avó. Levá-lo a seu país de origem significaria, para Alexander, resolver os problemas do menino.

Mas a fronteira surge na tela por uma imagem bastante impressionante: em meio à neblina, podem-se notar espécies de corpos pendurados sobre as grades que dividem os países. Após a história de migração recém-contada pelo garoto, tem-se a impressão de que se tratam de pessoas que tentaram sair da Albânia para ir à Grécia ilegalmente e foram mortas na fronteiras. Como conseqüência, seus corpos teriam ficado expostos, mostrando os perigos dessa tentativa de migração.

Nublada e tenebrosa, a fronteira fica colocada como lugar de horror, não se sabe o que há do outro lado, mas há certeza de que é algo ruim. A imagem dos corpos sobre a grade remete à metáfora de Benjamin - o mar profundo no qual Proust captura uma presa densa e pesada corresponde à neblina densa na qual os corpos se dissolvem, à espera de serem capturados.

Apenas quando o portão se abre e o oficial da fronteira vai em direção a eles é que o menino diz que mentira, pois não possui ninguém. Alexander reafirma que viajará no dia seguinte, mas corre junto ao menino, ignorando o grito que o aduaneiro lhes dirige. Por fim, Alexander desiste de enviá-lo à Albânia, e aproveita junto com o garoto o seu último dia: fica decidido que ele acompanhará Alexander até o fim desse dia, dando-lhe a dimensão do futuro, que certamente faltaria a um homem que, no fim da vida, rememora. 

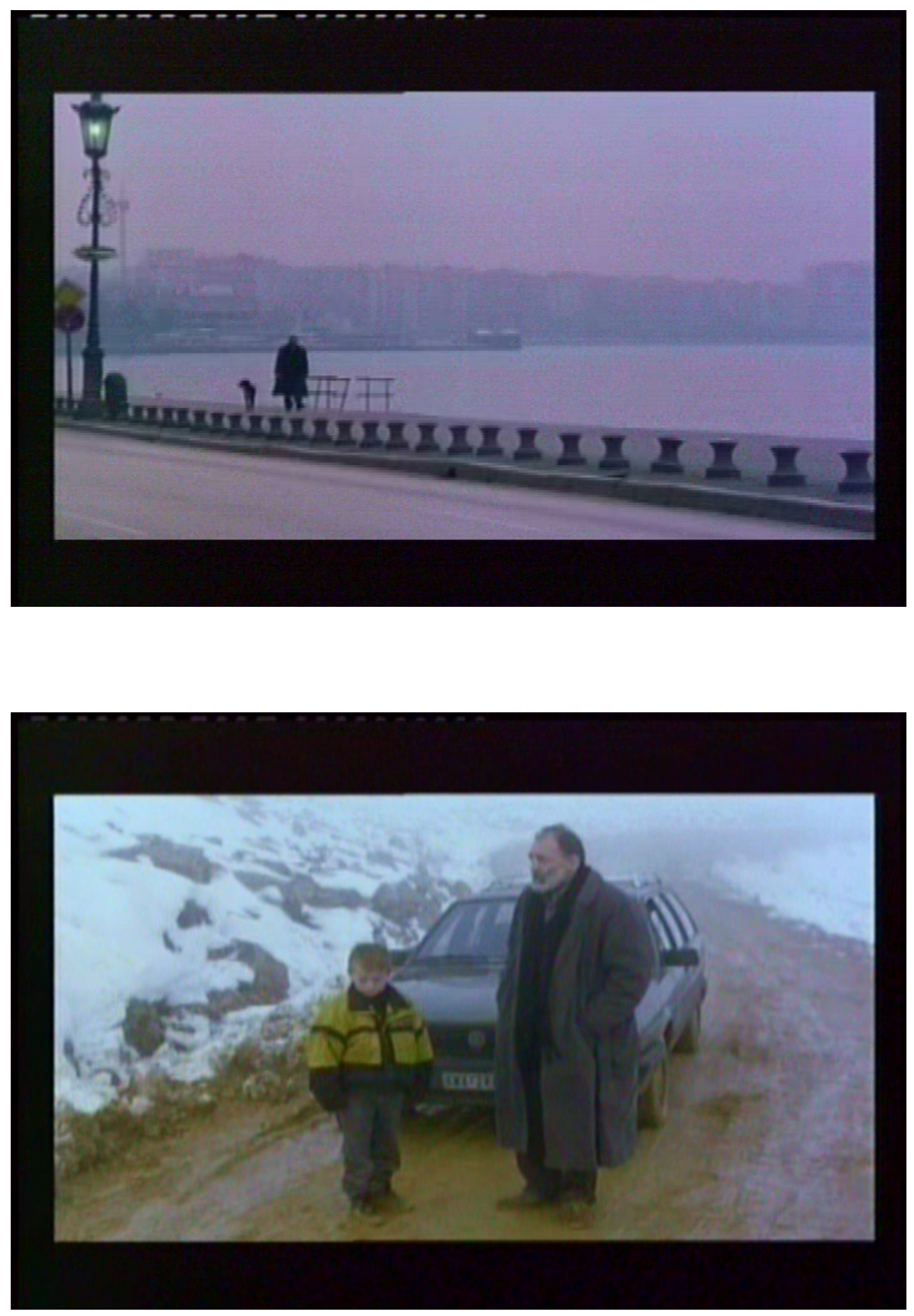
Esse limiar entre a vida e a morte que a doença carrega, limiar que era coletivamente assistido antes da modernidade, de onde surgiam as narrativas, é um ponto em comum entre Proust e Alexander. Além dessa convivência com a perspectiva de um futuro breve, uma morte que se aproxima, ambos são escritores e têm profunda inabilidade com os fatos práticos. Marcel Proust não sabia como acender o fogo ou abrir uma janela ${ }^{81}$. Alexander se esquece de comer, e quando o garoto the pergunta se ele nunca come, responde: "às vezes".

Tal era a inabilidade de Alexander com os fatos cotidianos da vida, que adentra seus relacionamentos sociais. Como Katerina se recusou a ficar com o cachorro, ele interrompe o casamento do filho de Urania para pedir que ela fique com o animal. A cerimônia ocorre na rua, é alegre e dançante. A música é paralisada quando Alexander se aproxima de Urania.

ALEXANDER: Eu trouxe o cachorro, Urania. Não tinha onde deixar.

URANIA: Meu filho está se casando.

ALEXANDER: Desculpe. Não queria atrapalhar. Não tinha onde deixar. Me desculpe. URANIA: Deixe-me ir com você amanhã.

ALEXANDER: A noiva está linda! Sabia que minha filha e Nikos venderam a casa de praia? Eu queria que... - lhe dá a coleira - Ele deve estar com fome...

Alexander olha para trás e parte, deixando Urania com o cachorro durante o casamento, que então é retomado, com a música e o casal de noivos dançando. Sobre a grade, há pessoas debruçadas - sobretudo crianças -, como havia corpos na fronteira. Mas essas pessoas são nítidas, toda a imagem é mais clara. A despedida final de Urania e Alexander termina assim, ele parte e a deixa com o cachorro.

Se Alexander é inábil para os afazeres práticos e sociais, tal qual o era Proust, na sua escrita e no que a ela se refere ele se demonstra, igualmente como Proust, bastante competente. E isso pode ser percebido quando o garoto pede que explique o que é um poeta.

MENINO: Sabe o que é um poeta?

ALEXANDER: Sim. Eu te digo. Existia um poeta no século passado, um grande poeta, ele era grego, mas cresceu e viveu na Itália. Um dia ele ouviu que os gregos que viviam como escravos em Ottomans tinham aceitado armas. Então a memória de sua pátria esquecida brotou dentro dele. Sua infância na ilha, o rosto de sua mãe que viveu por lá. Não podia descansar, andava aturdido, sonhava todas as noites com sua mãe, uma noiva, vestida toda de branco, o chamando.

\footnotetext{
${ }^{81}$ Cf. RiviÈRE. Apud: Benjamin, W. “A imagem de Proust”. op. cit., pp. 47-48. Ver nota 73 neste capítulo.
} 

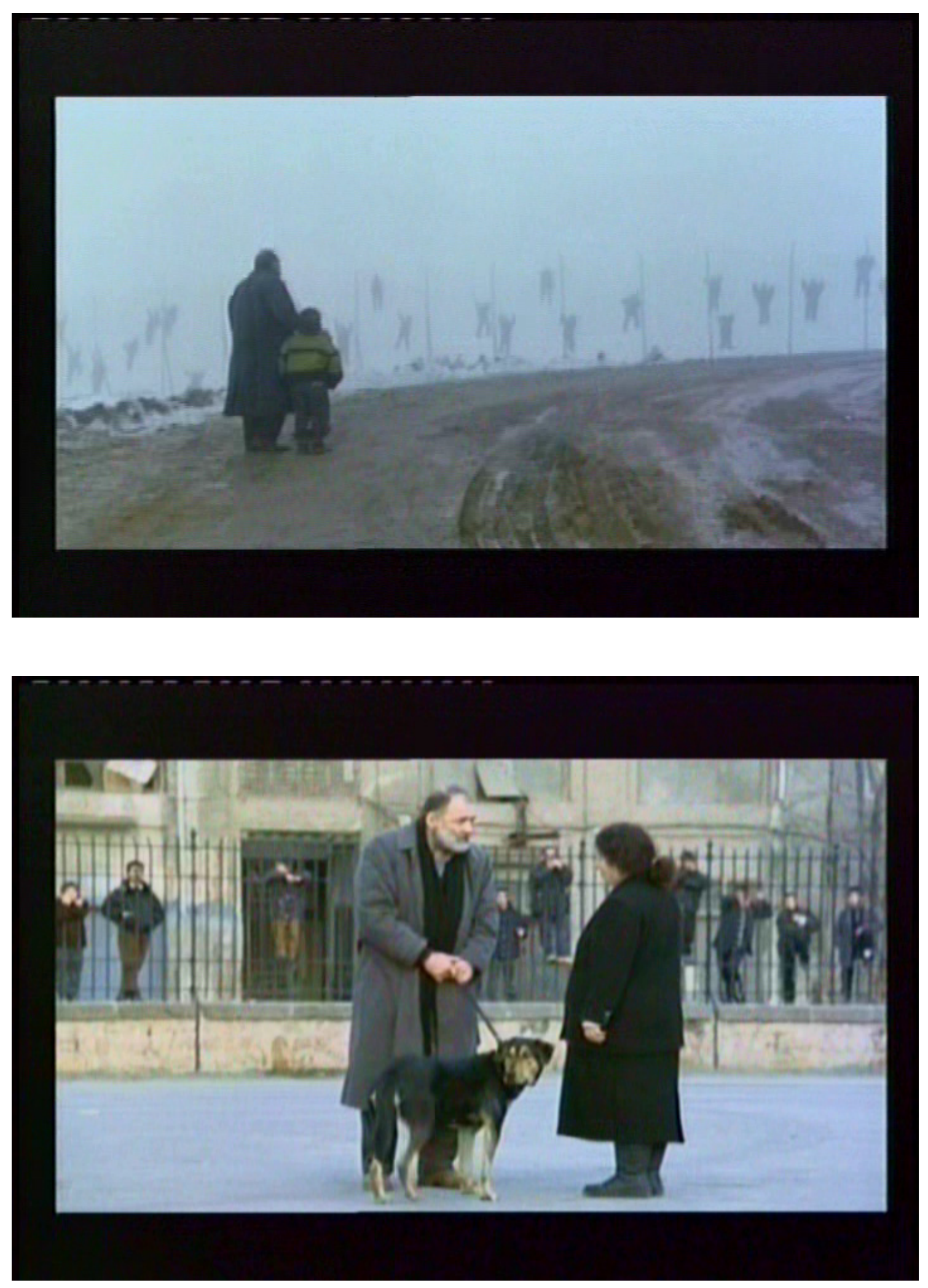
Então o filme apresenta a versão imagética desse poeta - Alexander faz uma pausa em sua fala, e a imagem os abandona, percorrendo o rio até encontrar um poeta na margem. A história que Alexander estava contando passa a ser imageticamente exibida. O espectador ouve primeiro uma ópera, e então vê o poeta, que veste uma capa e cartola pretas. Ouve-se sua fala, em italiano, em off:

PoETA: Eu mudei de idéia. Estou partindo pra Grécia. Não posso ficar aqui. Depois de séculos, os gregos estão aceitando armas. O que pode um poeta fazer? Celebrar a revolução numa canção, lamentar pelas mortes, invocar a face perdida da liberdade.

Alexander, como lembrou sua filha, é um escritor consagrado. Sua função é, então, essa mesma? O poeta sobe em uma carruagem e parte, ouve-se a ópera. Começa a narração de Alexander, e tem-se na tela as imagens desse poeta em um tempo passado.

ALEXANDER: No dia seguinte ele pegou um barco de Veneza e retornou para Zante, sua cidade natal. Ele encontrou de novo os rostos, as cores, o cheiro, sua casa, mas não sabia a língua. Ele queria celebrar a revolução, mas não sabia falar sua própria língua. Então começou a vagar pela vizinhança, pela vila de pescadores, escrevendo as palavras que ouvia. As manchetes anunciaram: "O poeta que compra palavras". Daquele momento em diante, onde quer que fosse, pessoas pobres se reuniam por toda ilha, milhares deles, para vender-lhe palavras.

É curioso que o poeta volte para um dos berços da civilização ocidental, a Grécia, sem conseguir se comunicar. Não podia "celebrar a revolução numa canção" sem saber falar a língua do lugar. Como saída, ele opta por comprar palavras, o que significará compor poemas junto aos habitantes nativos, uma revolução coletivamente celebrada. Esse processo remete certamente à narrativa, mas não se trata, aqui, de uma forma de narração espontânea; é, antes, uma comunicação mediada (porque depende disso) por uma troca financeira.

O poeta acumula, desse modo, uma cultura local, pois compõe poemas em conjunto com as pessoas que lhe "vendem" palavras. Alexander diz ao garoto que esse poeta foi quem escreveu "Assédio Livre", "um longo e interminável poema”, que ele passou "o resto de sua vida tentando terminar. Mas perdeu a noção do tempo... faltaramlhe palavras...". Pois foi justamente a esse poema inconcluso que, dissera Katerina, Alexander dedicou seus últimos anos de vida.

Depois que Alexander conta isso ao garoto, eles começam a comercializar palavras. O foco não é tanto o dinheiro pago, mas a possibilidade de conhecer novas 
palavras, de intensificar a troca entre essas duas pessoas de origem distinta, que por acaso se encontraram. A próxima palavra que Alexander compra do menino é "desconhecido". Enquanto ele busca mais palavras - desconhecidas -, Alexander se levanta e caminha em direção ao rio dizendo “Onde, na ilha, Ana?" É o início de mais uma etapa de sua rememoração, que começa em um barco onde se pode ouvir música animada e ver a família do casal dançar.

Alexander veste as roupas de inverno e tem a idade do presente narrativo. Ana e os outros que estão no barco, entretanto, são jovens e usam roupas de verão. Todos se sentam quando tem início uma canção lenta. Alexander, no barco, conversa com sua mãe, que lhe confessa a ausência de seu marido:

MÃE DE AleXander: Tenho sonhado com seu pai esses dias. Toda noite. Como sinto sua falta! Ele nos deixou tão cedo! Você estava numa de suas viagens...

ALEXANDER: Meu primeiro livro estava sendo lançado na França.

MÃE DE AleXANDER: Nunca esteve muito perto. Você sempre duvidou dele. Isso o magoou muito.

ALEXANDER: Mas eu retornei imediatamente.

Nessa fala há a cobrança da mãe de Alexander, incomodada pela escassa presença do filho. Como Ana, ela reclama de sua ausência, inclusive no momento da morte de seu pai. Essa cobrança dá início à rememoração de Alexander, mas a conversa é interrompida pela chegada de Ana, com quem ele se deita na proa do navio. O casal conversa, e a voz de Ana, em off, narra mais uma das cartas escritas para ele, paralelamente ao que é mostrado na imagem fílmica.

ANA: Estou tentando te seqüestrar de dois livros. Você vive uma vida paralela à nossa, à nossa filha, mas não conosco. Sei que um dia você nos deixará. O vento levará seu olhar pra longe, mas me dê este dia como se fosse o último. Me dê este dia!

O pedido de Ana é aqui exclamado, e Alexander parece disposto a concretizá-lo, ainda que isso ocorra em um tempo posterior ao desejo, ainda que ele só possa ser realizado enquanto exercício de memória. Sua lembrança, então, inclui toda a família, reunida na mesma praia que parece ter marcado tão profundamente a sua vida. Os familiares decidem nadar perto das pedras, Ana vai buscar uma mesa e Alexander diz que irá "subir". Ana o chama de traidor e se aproxima do mar, Alexander responde: "Por que está tão brava? Por favor, não vou demorar! Por favor... não vou demorar..." a abraça e 
parte, mas Ana o chama de traidor mais uma vez. Além de dedicar esse dia a Ana, Alexander tem outros fatos para relembrar: ele passeia sobre as pedras, onde encontra seu nome e os de seus amigos gravados em uma pedra, com a inscrição "verão de 1939".

A ruptura que leva de volta ao presente narrativo ocorre por imagens da praia - a câmera mostra o mar, e se desloca para o céu. Um avião passa, carregando uma faixa, e, quando a imagem se desloca para baixo, aparece o rio com a margem urbanizada. A rememoração de Alexander se mescla com o presente. Pessoas se amontoam na beira do rio, de sua margem alguém recolhe uma criança. Alexander está de pé, frente a isso, quando encontra seu médico, que o lembra de que aquele será seu último dia, e situa o espectador a respeito da doença que o acomete.

MÉDICO: Estava preocupado com você... Estava com medo de que...

ALEXANDER: Que tivesse progredido. O corpo que não obedece, a mancha do contorno familiar do corpo vira a sombra de si mesmo. Irei amanhã, disse que quando a dor piorasse...

MÉDICO: Olhe, eu não sabia o que fazer. Estava numa situação muito difícil. Sempre te admirei. Nossa geração cresceu lendo os seus livros e versos. Tenho que ir agora. Eles estão me esperando. - e parte.

É então que ocorre a primeira morte no filme - não a de Alexander, como imaginara o médico, mas a de Selim, o garoto que havia ajudado os meninos albaneses a deixarem seu país por melhores condições de vida. Alexander se deixa envolver pelo drama que esse acontecimento representa na vida dos meninos, e ajuda o garoto com quem passa o dia a entrar escondido no necrotério e olhar o corpo de Selim pela última vez, na sala de autópsia. O garoto pega as roupas do amigo, e parte. Em uma construção, crianças e jovens refugiados se apóiam nas grades de cada andar, formando novamente uma cena parecida com a da fronteira e do casamento.

O que há de comum nas três ocasiões é a presença de um limiar: primeiramente, na divisa com a Albânia, uma fronteira que representaria a volta do menino para seu país, e, portanto, uma mudança radical em sua vida. Na segunda ocasião, o casamento se apresenta igualmente como um limiar na vida dos noivos, um importante rito de passagem para a vida adulta. $\mathrm{Na}$ terceira cena, a morte de uma criança é também um evento que abala a estrutura vigente, especialmente quando vivenciada de perto por seus amigos. Esse é o sentido das fronteiras nesse filme, fronteiras que já estão dispostas previamente pela situação do protagonista: um homem que vive seu último dia, que está na fronteira entre a vida e a morte e tem consciência disso. 
As roupas de Selim são usadas pelas crianças para ritualizar sua morte. À fogueira que se forma, os garotos gritam frases como "Estou com medo!"; "O mar é grande"; "Como é aí do outro lado?"; “Como será pra onde iremos?”; "E se tiver montanhas, barrancos, soldados... nunca iríamos pra lá. Afora eu vejo o mar e não existe um fim. Vejo a minha mãe à noite, em pé na porta, triste na noite de Natal. Neve na montanha, os sinos tocando"; "só você podia nos falar sobre os portos, sobre Marselha, Nápoles, e esse grande mundo.”; “É, Selim. Fale, fale conosco sobre esse mundo!”.

O menino chora enquanto as roupas são queimadas. Selim era o homem que lhes dava possibilidade de ruptura, que lhes contava como são os outros países, que lhes protegera no momento de fuga da Albânia e que provavelmente os levaria para a Itália. Alexander assiste ao ritual um pouco distante.

Depois da despedida de Selim, Alexander vai ao hospital ver sua mãe pela última vez. Desculpa-se por não tê-la visitado antes e lhe comunica: "Mamãe, vim para dizer adeus. Estou partindo". Ela, muda, levanta-se, caminha até a janela e grita "Alexander! Alexander! O jantar está pronto! Alexander!" e ele diz: "estou indo", se levanta e já aparece na praia, descendo da colina na qual estava na última cena de sua rememoração.

Ao lado de sua mãe, ele rememora novamente, sempre com a forma física do presente narrativo, enquanto os outros têm a forma do passado. Alexander diz que o mundo visto do alto da colina é "mágico" - esse é mundo da rememoração: mágico, pois capaz de trazer de volta os fatos resguardados no passado. Como, em sua memória, Alexander se atrasa para o almoço, sua mãe lhe diz "Você não cresce. Sempre desaparece, feito criança. O jantar está pronto". Começa a chover, ele sai à procura de Ana e a encontra. Beijam-se e entra a voz da Ana, em off, seguindo a leitura da carta e, dessa forma, criando uma continuidade com relação à rememoração anterior.

ANA (voz off): Longe, em mar aberto, sua ilha viaja além. Uma de suas camisas esquecida na varanda, você que mente escondido na sombra de um quarto acompanhado pelas vozes da noite. Olho pra você com meus olhos fechados. Te ouço com meus ouvidos tapados. Sem falar, eu imploro a você.

$\mathrm{Na}$ leitura da carta, Ana mostra mais um hábito comum entre Alexander e Proust: ouvir as vozes da noite, em um quarto, e transpô-las para as páginas de seus livros. E Ana lhe implora: ela quer um dia. 

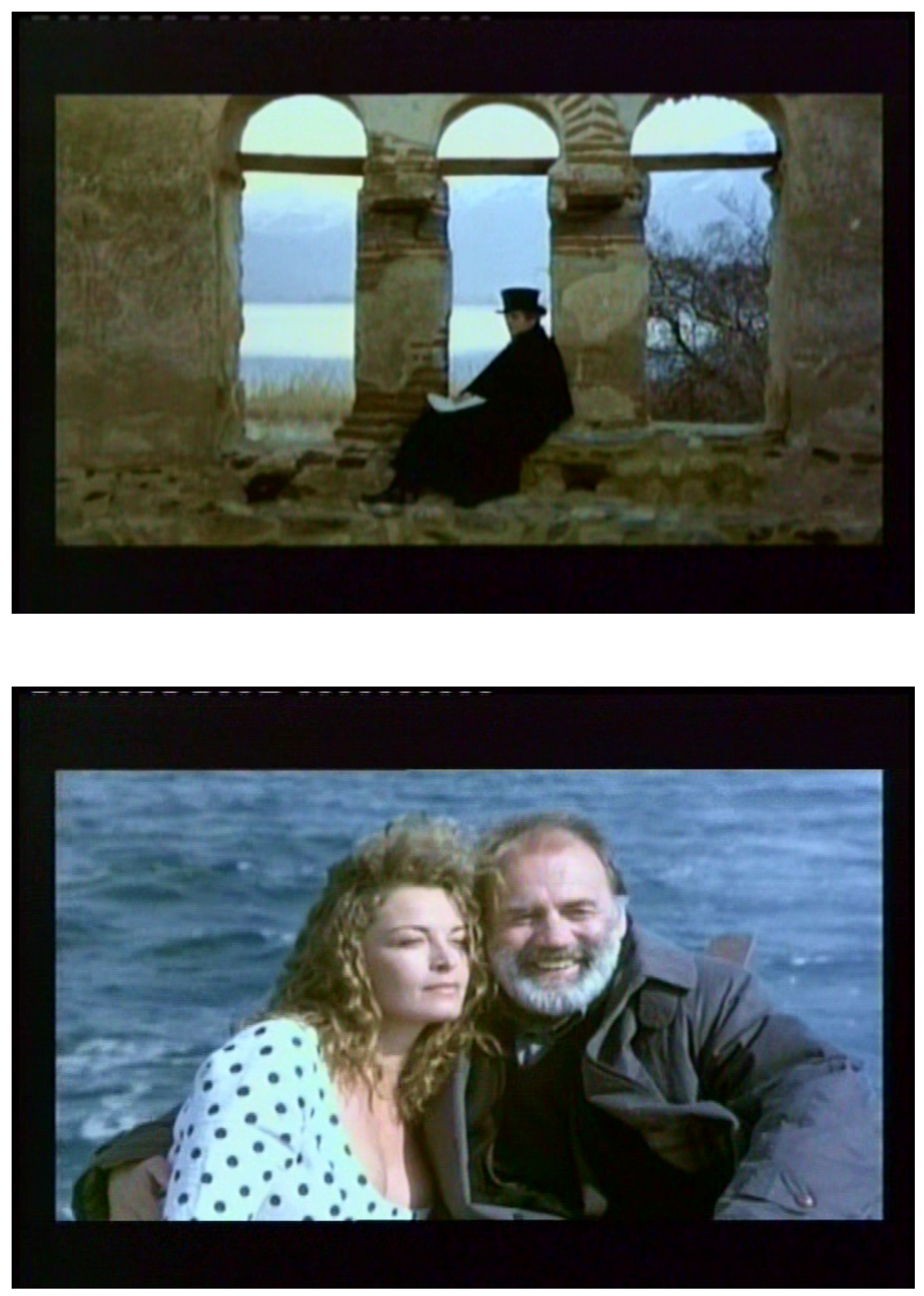
De volta ao presente narrativo, a mãe de Alexander está na janela, como se pudesse ver a rememoração de seu filho.

MÃe DE AleXAnder: Os talheres de prata, meus dotes, onde os colocou? Estavam todos aqui ontem... - Começa a cair, desmaiada. Alexander a segura e a deita sobre a camaOntem... Eles estavam aqui...

AleXander: Por que, mamãe? Por que nada é como desejamos? Por quê? Por que temos que apodrecer sem poder fazer nada entre a dor e o desejo? Por que vivi minha vida em exílio? Porque me senti em casa somente em raros momentos onde conceder a graça da minha língua, minha própria língua, onde eu ainda podia recuperar as palavras perdidas ou reaver palavras esquecidas do silêncio. Por que a única coisa que pude ouvir foram os meus próprios passos? Por quê? - ele beija sua mãe, que parece dormir, apaga a luz e, quando já está na porta, lhe pergunta - Diga, mamãe, por que não aprendemos como amar?

$\mathrm{O}$ encontro de Alexander com o médico, somado pela visita à sua mãe, leva a crer que, de fato, ele está enfermo, tem uma doença hereditária que é o motivo de ausência no dia seguinte - e, por conseqüência, de levar seu cachorro para Urania, ver sua filha, e rememorar. A doença de Proust o teria ajudado a criar sua obra através da rememoração, diz Benjamin ${ }^{82}$. É também a proximidade da morte que leva Alexander a rememorar, mostra o filme.

As perguntas que Alexander faz a sua mãe antes de partir mostram que, apesar de dedicar-se à família nas rememorações, Alexander se culpa por ter ficado ausente durante tantos anos, quando ainda podia ter o contato direto com seus parentes. Mas ainda assim não abandona o recurso de responder a esses pedidos em um tempo que é outro. Fora do hospital, ele tem uma nova despedida a fazer: o garoto partirá também.

ALEXANDER: Estará partindo esta noite, no meio da noite... Eu pensei... Quer que eu acredite que...

MENINO: Você também está partindo, não terei mais ninguém...

ALEXANDER: Você terá... Breve você terá uma grande jornada. Os portos, o mundo todo...

MENINO: Adeus. - e caminha.

AlEXANDER (agachado, implora): Fique comigo! Ainda tem duas horas antes do navio partir. Eu tenho somente esta noite. Fique comigo.

MENINO: Estou com medo.

ALEXANDER: Eu também. - se abraçam - Fique comigo, fique comigo.

\footnotetext{
${ }^{82}$ Cf. Benjamin, W. "A imagem de Proust". op. cit., p. 48.
} 
Se antes o garoto precisava da ajuda de Alexander, fosse para fugir da polícia ou dos homens que queriam "vendê-lo", agora é o escritor quem, percebendo sua partida solitária, precisa da companhia do menino. Alexander esteve distante de sua família durante muito tempo, quando esteve só. No seu último dia, pretendia ficar igualmente só, e por isso dispensou a companhia de Urania. Mas foi então que, por meio de suas rememorações, Alexander percebeu a falta que ele fazia para sua família, e, provavelmente pela reciprocidade desse sentimento, não quis mais ficar só. Ainda que lhe restem apenas poucas horas, não quer passá-las sozinho, quer a companhia desse menino que, se antes representava o futuro, alguém em cujas condições de vida futuras ele queria intervir, agora está atrelado de modo profundo ao seu presente. $\mathrm{O}$ garoto concorda em acompanhá-lo e, sem rumo em meio à cidade, Alexander e o garoto não têm senão um ao outro antes de partirem.

Juntos, entram em um ônibus que anda paralelamente a um navio no mar. Atrás do ônibus, passam três bicicletas cujos ciclistas vestem capas de chuva amarelas - que aparecem também em Paisagem na neblina. O percurso que o ônibus realiza se parece com uma retrospectiva da vida de Alexander, sobre a qual o espectador tem poucos dados. Pessoas entram e saem do ônibus. A primeira parada tem seu nome apresentado pelo cobrador do ônibus: “Todas as Almas”. Lá ocorre uma manifestação, ouvem-se vozes, e um homem portando uma bandeira vermelha adentra o coletivo. Entra também um casal brigando, a mulher joga um buquê de flores no chão, que é pego por outro homem. Eles saem do ônibus e nele ficam Alexander, o menino e o militante com sua bandeira, que agora dorme, além do cobrador e do motorista.

Em seguida, adentram o ônibus três jovens carregando instrumentos - um violoncelo, um violino e uma flauta doce. Eles tocam uma música que se mistura com a música-tema do filme, que a ela se sobrepõe. Na parada chamada "Conservatório", a pequena orquestra desce do ônibus e sobe o poeta que aparecera antes, novamente vestindo capa preta e cartola. Ele se senta à frente de Alexander e do garoto e lhes declama:

POETA: O orvalho da última alvorada anunciou a vinda do sol radiante. Nenhuma névoa ou sombra desafiou o mar, a perfeição do céu, sem nuvens, acariciando as faces lá embaixo, como se sussurrasse no esconderijo do coração. A vida é doce e... a vida é doce. 

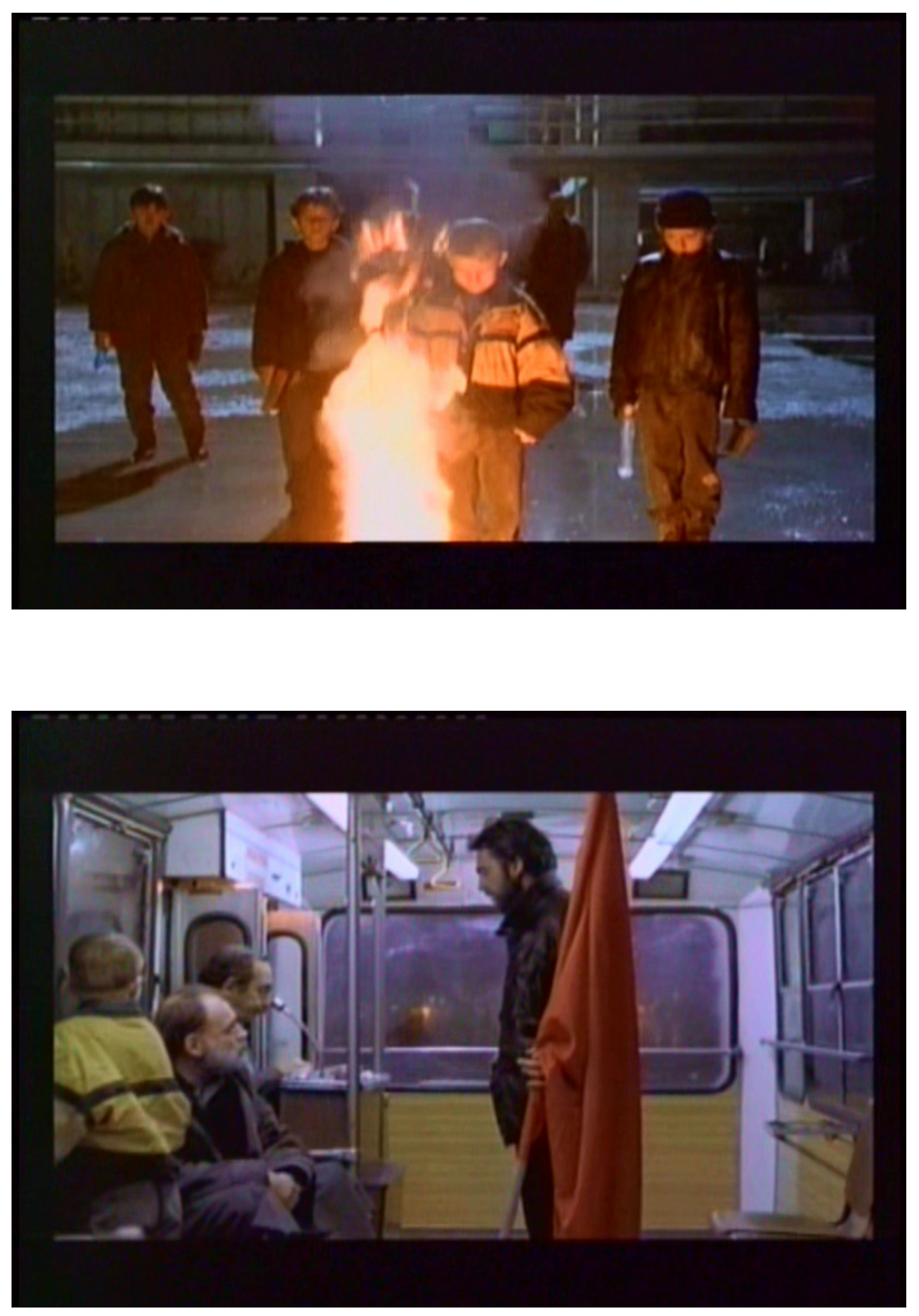
O poeta desce do ônibus. Alexander vai até a porta e grita: "Diga! Quanto tempo tem o amanhã?" Não há resposta, mas um corte na imagem. Eles descem do ônibus no mesmo local onde haviam subido, e por eles passam, mais uma vez, os ciclistas que vestem amarelo, atribuindo uma noção de circularidade a esse passeio que fizeram, mas também aos filmes de Angelopoulos.

Como um antigo moribundo que, tendo a morte assistida, se confessava e, aos próximos, dava um conselho baseado em sua experiência de vida; como Proust que, doente, rememorava sua vida e a escrevia; como se diz hoje em dia ao sobreviver - que a vida toda perpassa a mente de uma pessoa em situação de perigo -, a morte iminente leva a percorrer as lembranças da vida, mesmo que se retomem apenas rápidas imagens sem reflexão, sem aconselhamento. Como alguém que se aproxima da morte, Alexander retoma o que viveu ao entrar no ônibus.

Alguns elementos fílmicos mostram que esse ônibus circula por uma porção de memórias (ou fantasias) da vida de Alexander. Como ele dissera, um poeta pode "celebrar a revolução em uma canção, lamentar pelas mortes, invocar a face perdida da liberdade". Na primeira parada, quem entra no ônibus é um militante, como é provável que Alexander tenha sido, um militante tentando fazer a revolução coletivamente (para “Todas as Almas”), que se contrapõe à solidão de um poeta que celebra a revolução em uma canção. Em seguida, o casal que briga vem mostrar que também o pathos dos revolucionários recai sobre os pares amorosos.

O início do filme mostrou a relação intensa que Alexander tem com a música: toda manhã ele ouve uma música diferente, que seu vizinho reproduz. Possivelmente Alexander tocara algum instrumento, o que justificaria a entrada dos músicos no ônibus. No Conservatório eles descem, e quem sobe é o poeta, que representa a última - e provavelmente a mais longa - etapa da vida de Alexander.

O poema declamado fala sobre o prenúncio de algo belo, a vinda do "sol radiante". O início do filme servira como oposto disso, apontava a chegada da morte, o fim de uma existência, pois Alexander despedia-se de seu cotidiano - de Urania, da música que ouvia pela manhã, de seu vizinho, sua filha e seu cachorro. E a morte - seria bela, sem névoas? Ou assim seria a possibilidade de trazer Ana de volta para poder dedicar-lhe um dia? Alexander anunciara que seu único arrependimento era Ana, ou não concluir o que começa. Mas ele agora está próximo de concluir algo - de dedicar a Ana um dia, ainda que em rememoração. E, podendo realizar uma esperança passada, há de concordar com o poeta, que diz que "a vida é doce". Alexander quer saber dele "quanto 
tempo tem o amanhã", mas não obtém resposta - ele só poderá chegar ao "amanhã", o dia derradeiro, depois de passar pelo "hoje", o infinito do dia rememorado.

O ônibus chega ao lugar de onde partira, ou seja, é um ônibus circular, que completa um percurso e volta ao ponto inicial. É um giro panorâmico pela vida de Alexander, por aspectos de sua vida que não incluem Ana. São fatos que ele observa junto ao garoto, como espectador, sem interferir - no único momento em que tenta perguntar algo ao poeta, não obtém resposta -, e, por isso mesmo, sem rememorar.

Após mostrar ao menino fases da sua vida em uma espécie de "prosa visual" que ocorre dentro do ônibus em movimento, eles vão, de carro, ao local de onde partirá um navio que levará o garoto rumo a outra migração ilegal. É lá que eles se despedem:

ALEXANDER: Chegou a hora, certo?

MENINO: Argadini

ALEXANDER: O que disse?

MeninO: Argadini. Significa "muito tarde".

AlEXANDER: Muito tarde... Muito tarde mergulhado na noite - tira uma moeda do bolso e lhe entrega. Comprara sua palavra. Eles sorriem.

Menino: Eu tenho que ir. Adeus. - diz e logo sai do carro.

Ouve-se o ruído de um caminhão acelerando, o espectador supõe, portanto, que o garoto se escondeu dentro da boléia do caminhão para, como os outros meninos, partir para outro país. Tal qual o poeta, o garoto deve ir para a Itália, o país cujas cidades foram citadas no ritual de despedida de Selim. E, talvez, um dia ele voltará - se não para a Grécia, para a Albânia - e possivelmente precisará também comprar palavras. Em todo o caso, o que se sabe é apenas que o menino parte, e que logo partirá também Alexander, que desce do carro para observar o caminhão entrar em um navio e se despedir desse garoto com quem viveu o seu "último dia".

Alexander rompe, desse modo, com essa referência ao futuro (o menino), mas ainda lhe faltam algumas etapas de rompimento com o passado, para que então ele possa partir sem pendências. É noite - muito tarde mergulhado na noite - e Alexander pára seu carro porque o semáforo está vermelho. O limpador de pára-brisas está ligado, garoa. A câmera se aproxima dele vagarosamente. Ele está imóvel, com olhar perdido. Os outros carros o ultrapassam, alguns buzinam e sinalizam com farol alto. Ele continua parado. Quando amanhece, o espectador pode ver seu carro pelo ângulo inverso, o vê por trás. Em cima dele, o semáforo está vermelho. Repentinamente, Alexander acelera e parte. 
Essa seqüência mostra uma inversão da seqüência corrente esperada. Após tanto tempo parado no semáforo, Alexander se locomove justamente quando o farol está vermelho. Ele age fora de qualquer regulamentação de trânsito, assim como a temporalidade por ele vivida contraria qualquer relógio com funcionamento mecânico ajustado.

Alexander vai à casa da praia, onde terminará o ciclo de sua rememoração. Entra na casa vazia, na qual se pode ouvir o barulho de muitos carros - não fosse a conversa com Katerina, o espectador estranharia as mudanças que sofreu essa casa outrora tão silenciosa e habitada. Não há móveis. Começa uma música e a conversa de muitas pessoas ao fundo - um som como o das rememorações de Alexander, que vai se sobrepondo ao dos carros, até que ele desapareça. Então surge a voz de Ana, em off:

ANA: Estou escrevendo de frente para o mar novamente. Escrevo para você, falo com você. Quando... quando de repente você recordar este dia, lembre-se como se eu fosse somente olhos acariciando, como se fosse somente mãos, e parada esperando você, trêmula. Me dê este dia!

Essa fala introduz a última rememoração de Alexander, que tem início quando uma das portas para a varanda se abre e lá está sua mãe, jovem, balançando um carrinho de bebê. Na praia, que está frente à varanda, os parentes de Alexander e Ana tocam música, cantam e dançam. Ana anda sobre um caminho de madeira que une a casa à praia, já bastante destruído pelo tempo. Ela veste branco e, enquanto caminha, a música, que havia parado com a chegada de Alexander, volta a ser tocada - agora, toca-se a música-tema do filme. Toda a família, que usa roupas claras, se volta ao casal. A capa de Alexander está molhada nas costas, tal qual seu cabelo - como estavam no presente narrativo do filme, no qual chovia. Alexander se aproxima de Ana e a chama. Ela responde: "Vamos dançar? Sei que não gosta, mas hoje é o meu dia" - eles dançam, a família toda se agrupa em pares, dança ao redor deles. A câmera se aproxima dos dois, o mar que se une ao céu compõe o cenário da dança. Quando já não se pode mais ver os outros casais, e a câmera está bastante próxima deles, Alexander diz:

ALEXANDER:Ana, eu não vou para o hospital. Não vou para o hospital. Não vou. - Eles se abraçam e caminham rumo ao mar - Quero fazer planos para amanhã. O estranho responderá com a mesma música. E sempre haverá alguém para me vender palavras. Amanhã... O que é o amanhã, Ana? - A câmera filma seus corpos inteiros e ela, lânguida, ainda se movendo pela 
dança, caminha. Alexander a segue, a cerca - Uma vez te perguntei quanto tempo havia o amanhã e você disse...

ANA (passa a mão sobre o rosto de Alexander e diz): Uma eternidade e um dia $-e$ começa a se afastar.

AlEXANDER: Eu não te ouvi... O que disse? - Ana sai de cena.

ANA (gritando): Uma eternidade e um dia!

AlEXANDER: Ana! - E então, parado, sozinho, frente ao mar, diz para Ana, ou para si mesmo - Minha passagem para o outro lado será hoje. Eu trouxe você de volta com palavras e você está aqui. É tudo verdade e tudo que esperei foi pela verdade... pela verdade. - Ele se vira para o mar e repete as palavras que havia "comprado" - Minha "florzinha" [korfula]... desconhecido... eu estou "muito atrasado" [argadini]... - passa a gritar - Minha florzinha... desconhecido... eu estou muito atrasado... Minha florzinha... Minha florzinha...

Uma voz feminina o chama, ao fundo, por três vezes:

VOZ OFF: Alexander... Alexander... Alexander...

Assim termina o filme, com um final que remete ao seu início - ou seja, com a mesma voz chamando por Alexander, convidando-o para rememorar.

Alexander dissera que Solomo, o poeta que ele estuda, não terminou seus poemas porque não conseguia encontrar as palavras. Tampouco ele, Alexander, conseguia achar as palavras para terminar os poemas, e por isso as comprou. São essas palavras que repete nesse final de filme, após ter obtido de Ana a resposta que o poeta do ônibus (ele mesmo?) não lhe dera: a duração do amanhã que é, aqui, a duração de um dia rememorado.

Quanto tempo dura o amanhã? "Uma eternidade e um dia", a eternidade de um dia rememorado e mais um dia para que se chegue ao amanhã. E esse exercício de rememoração de Alexander lhe foi tão satisfatório, que ele comunica Ana de que não deseja mais partir, que não irá mais para o hospital. A rememoração permitiu a Alexander ser sujeito de sua existência por meio de uma experiência através da qual ele atribuiu sentido à vida. Uma experiência individual, solitária, como a de Proust, mas por meio da qual se adentra uma esfera então aparentemente inabalável, morta: pelo presente, se adentra o passado, de onde se retira elementos futuros.

Assim como Proust, Alexander torna os acontecimentos por ele vividos eternos, posto que rememorados. O dia rememorado se torna eterno. Assim como Proust conseguia entrecruzar o tempo passado a outras formas temporais, Alexander consegue realizar, na cena final do filme, um desejo que estava preso no passado: finalmente 
dedica um dia à sua finada esposa, por meio da rememoração. Um dia, quando articulado aos outros períodos temporais, torna-se eterno. $\mathrm{O}$ entrecruzamento eterniza o dia, retira-o da linha temporal vigente.

Esse mecanismo de eternização do tempo por meio de seu entrecruzamento possibilita a Alexander, e também a Proust, a realização de expectativas futuras que estavam presas no passado. Ou seja, permite a obtenção da experiência individual.

Um dos apostos usados por Gagnebin para a "rememoração" é "retomada salvadora pela palavra de um passado que, sem isso, desapareceria no silêncio e no esquecimento" ${ }^{\prime 3}$. Proust desenvolve suas rememorações a partir da escrita; Alexander o faz pela leitura das cartas de Ana. Há uma óbvia correspondência entre o valor que os dois conferem às palavras (Alexander chega mesmo a comprá-las) e sua profissão: dois escritores renomados, no fim de suas vidas.

A doença de ambos os escritores traz à tona o fato de que algum elemento teoricamente preso ao passado pode voltar inconscientemente e iluminar algo no presente. A madeleine faz com que esse elemento seja desperto em Proust, em Alexander é a leitura das cartas de Ana que o ativa. Não é, portanto, a densidade da situação anterior que faz com que ela seja relembrada, mas são as ações triviais do presente que levam a imagem do passado a emergir - sempre ao acaso.

A lembrança em si, que emerge por um evento trivial, não é geradora de felicidade, pois pode ser um evento igualmente trivial (como um passeio de barco). Mas há, no próprio mecanismo da rememoração, uma chave positiva e benéfica, que é o que leva Alexander a desistir de ir para o hospital, e faz com que Proust continue escrevendo. A felicidade, portanto, não vem da experimentação (de comer o bolinho, de ler uma carta), e tampouco da própria lembrança. A chave para a felicidade está na própria rememoração, nessa fortuita conjunção entre o passado e o presente, na qual não se segue uma linha cronológica, na qual se ilumina tanto o que estava perdido no passado, quanto o presente e o futuro.

A modernidade apresenta, como característica social, uma desvinculação do indivíduo, dada a perda da tradição. Isso significa desenraizamento, que pode atingir os mais diversos graus - como o altíssimo grau de desarraigamento vivido por Travis em Paris, Texas. O passado fica esquecido, e a tradição não é transmitida de geração em geração, como o era antes. Obter uma relação mais densa com o passado não é de todo

\footnotetext{
${ }^{83}$ GAgnebin, Jeanne-Marie. História e Narração em Walter Benjamin. op. cit., p. 03.
} 
impossível, mostram Alexander e Proust. Esse processo de junção de cacos sem sentido, entretanto, tem que ser feito individualmente.

[...] Para Benjamin o passado não permanece tal como gostaríamos que permanecesse, como dele só nos restam fragmentos que nos vêm aos pedaços, recebemos uma tradição como herança mas uma herança sem testamento ${ }^{84}$, não sabemos o que fazer dela, não existe um controle do tempo histórico segundo o qual o presente possa compreender em sua inteligibilidade o passado. Benjamin diz ser possível reingressar numa verdade fechada do passado para contá-la de outra maneira, porque o passado não é um continuum passado, presente, futuro. O passado não é devir abstrato de tempo, o passado são fragmentos, do passado só nos resta um "monte de tijolos". [...] O enraizamento numa tradição significa nosso pertencimento a pontos de origem, porque só podemos saber quem somos hoje se reconhecermos nosso ponto de partida. O que significa, pois, a perda da tradição ou a dissolução da tradição? Antes de mais nada, significa desenraizamento, expatriamento. $[\ldots]^{85}$

Se não é possível a recuperação dessa tradição perdida, isso não configura uma situação de total aporia: Benjamin mostra que, por meio da rememoração, é possível restabelecer uma relação com o passado que seja fortuita. Ele aponta duas formas distintas de relacionamento com o passado: por meio de uma identificação, "uma repetição do passado e [que] resulta sempre nas catástrofes históricas"; ou por meio de uma relação de construção ${ }^{86}$, como o fazem Proust e Alexander. A rememoração, tal qual a proposição de Benjamin, é uma construção que, individual ou coletivamente, resgata outras esferas temporais.

Sobre Benjamin, diz Gagnebin:

\footnotetext{
${ }^{84}$ Referência a Hannah Arendt: “[...] nossa herança foi deixada sem testamento algum. O testamento, dizendo ao herdeiro o que será seu de direito, lega posses do passado para um futuro. Sem testamento ou, resolvendo a metáfora, sem tradição - que selecione e nomeie, que transmita e preserve, que indique onde se encontram os tesouros e qual seu valor - parece não haver continuidade consciente no tempo, e portanto, humanamente falando, nem passado nem futuro, mas tão-somente a sempiterna mudança do mundo e o ciclo biológico das criaturas que nele vivem. O tesouro foi sim perdido, não mercê de circunstâncias históricas e da adversidade da realidade, mas por nenhuma tradição ter previsto seu aparecimento ou sua realidade; por nenhum testamento o haver legado ao futuro. [...] O ponto em questão é que o 'acabamento' que de fato todo acontecimento vivido precisa ter nas mentes dos que deverão depois contar a história e transmitir seu significado deles se esquivou, e sem este acabamento pensado após o ato e sem articulação realizada pela memória, simplesmente não sobrou nenhuma história que pudesse ser contada." In: ARENDT, Hannah. Entre o Passado e o Futuro. op. cit., pp. 30-31.

${ }^{85}$ MAtTos, O. "Memória e história em Walter Benjamin". op. cit., p. 152.

${ }^{86}$ MATtos, O. "Memória e história". op. cit., p. 6.
} 
[...] o motivo essencial de sua filosofia da história, desde o livro sobre o barroco até o texto póstumo das "Teses": a saber, que a exigência de rememoração do passado não implica simplesmente a restauração do passado, mas também uma transformação do presente tal que, se o passado perdido aí for reencontrado, ele não fique o mesmo, mas seja, ele também, retomado e transformado. ${ }^{87}$

As teses de história benjaminianas propõem que se faça uma apropriação coletiva da rememoração, tendo uma história comum a todos como objeto de resgate para a atualização. Enquanto isso não ocorre (ocorrerá?), a possibilidade de rememorar os fatos ocorridos na própria vida já significa uma ampliação elevada da dimensão temporal do homem moderno. Porque, para além do resgate do passado, há a libertação do futuro que estava nesse tempo e, sobretudo, uma possibilidade de mudança do e pelo presente.

Como mostrou A Eternidade e um dia, essa abertura temporal, ainda que individual, tem um significado muito intenso para quem a experimenta, e por isso é que Alexander, então conformado com a sua partida, sente um desejo profundo de continuar vivendo. A despeito de toda a tristeza que ver a casa de praia naquelas condições poderia lhe causar, ele diz a Ana que não irá mais para o hospital.

Embora a experiência individual possa ter o preço do isolamento social daquele que rememora, ela é transformadora. A ampla abertura temporal que a rememoração proporciona faz com que o sujeito que a experimenta encontre, imerso nas condições de vida moderna, uma relação intensa com cada um dos tempos - passado, presente e futuro -, de forma que ele pode atribuir sentido aos acontecimentos vividos - e, portanto, à sua vida.

O indivíduo, então, não se encontra imerso em uma situação de aporia com a temporalidade moderna, mas, antes, diante da possibilidade de construção de uma relação temporal intensa. Custosa, é fato. Mas, ainda assim, possível.

\footnotetext{
${ }^{87}$ GagneBin, J. História e Narração em Walter Benjamin. op. cit., p. 16.
} 

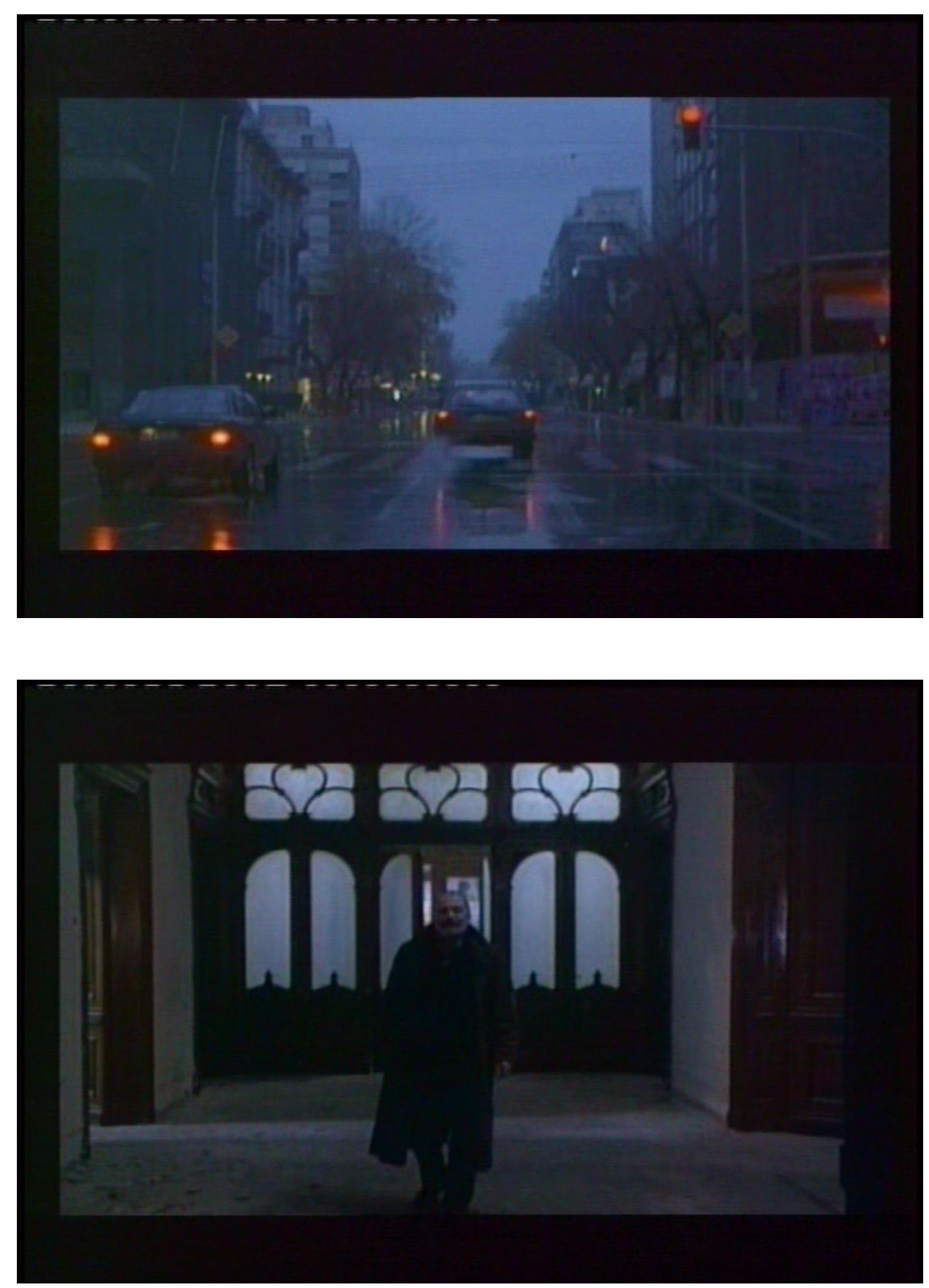

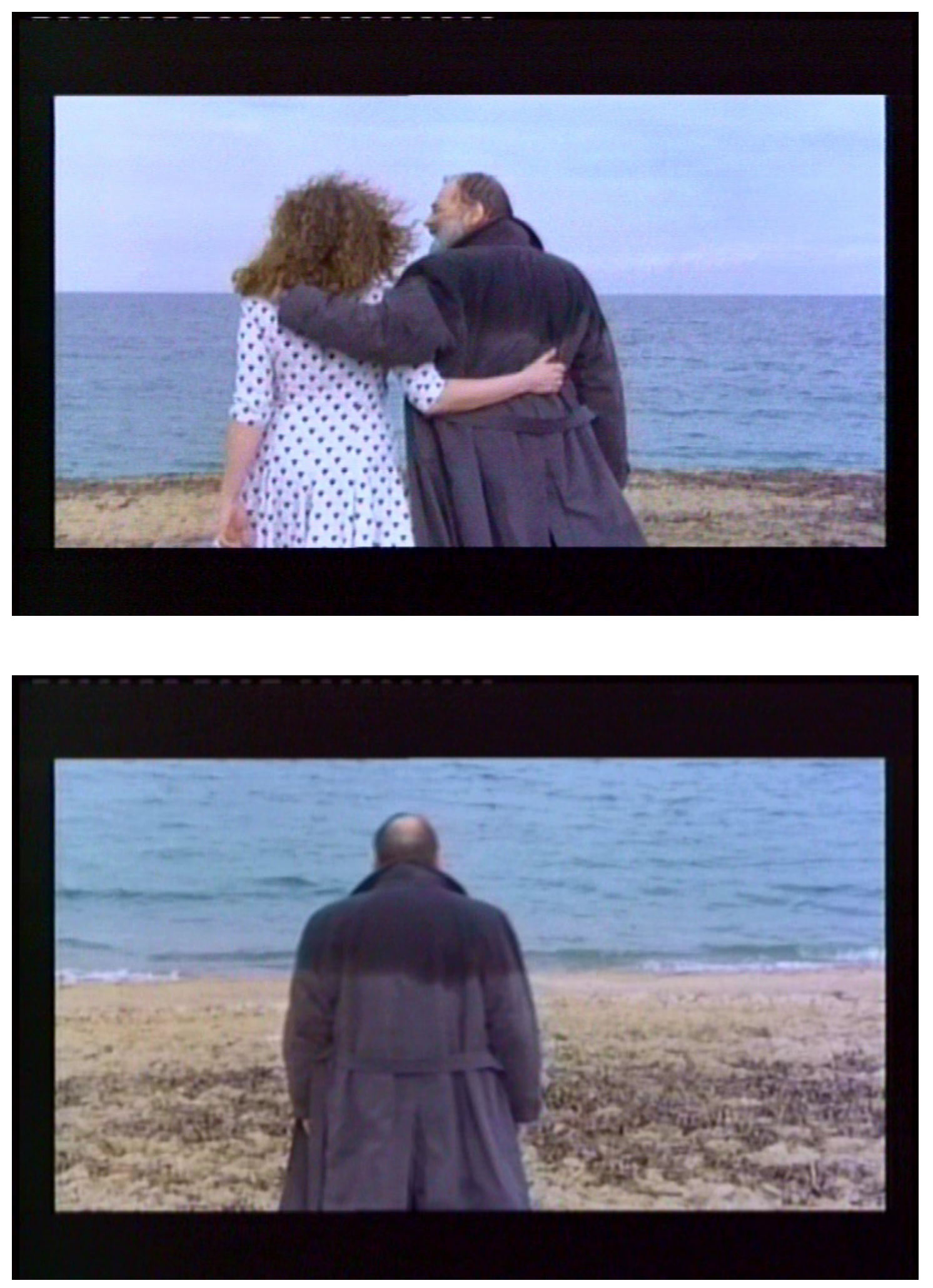


\section{Considerações finais}

Uma imensa quantidade de filmes é produzida anualmente em todo o mundo. A escolha de uma amostra costuma ser tarefa árdua. Com esta pesquisa não foi diferente. Certamente, tanto a escolha do objeto a ser analisado nos filmes - uma temporalidade que se distingue da corrente - quanto a seleção dos filmes perpassaram critérios de escolha subjetivos. Mas assim o é qualquer recorte sociológico, e acreditamos que parte do mérito dos estudos da cultura está justamente em sua não-objetividade, que remete a um não-acabamento como aquele atribuído à narrativa. Isso porque nem todos os eventos são previsíveis ou mensuráveis, embora sociologicamente os abordemos a partir de critérios determinados. Diz Weber:

Não existe nenhuma análise científica totalmente "objetivada" da vida cultural, ou - o que pode significar algo mais limitado, mas seguramente não essencialmente diverso, para nossos propósitos - dos "fenômenos sociais", que seja independente de determinadas perspectivas especiais e parciais, graças às quais estas manifestações possam ser, explícita ou implicitamente, consciente ou inconscientemente, selecionadas, analisadas e organizadas na exposição, enquanto objeto de pesquisa. Isso se deve ao caráter particular da meta do conhecimento de qualquer trabalho das ciências sociais que se proponha ir além de um estudo meramente formal das normas - legais ou convencionais - da convivência social.

A ciência social que pretendemos exercitar é uma ciência da realidade. Procuramos entender na realidade que está ao nosso redor, e na qual nos encontramos situados, aquilo que ela tem de específico; por um lado, as conexões e a significação cultural das nossas diversas manifestações na sua configuração atual e, por outro, as causas pelas quais ela se desenvolveu historicamente de uma forma e não de outra. Acontece que, tão logo tentamos tomar consciência do modo como se nos apresenta imediatamente a vida, verificamos que ela se nos manifesta "dentro" e "fora" de nós, sob uma quase infinita diversidade de eventos que aparecem e desaparecem sucessiva e simultaneamente. E a absoluta infinitude dessa diversidade subsiste, sem qualquer atenuante do seu caráter intensivo, mesmo quando voltamos a nossa atenção, isoladamente, a um único "objeto" - por exemplo, uma transação concreta - e isso tão logo tentamos descrever de forma exaustiva essa "singularidade" em todos os componentes individuais, e, ainda muito mais, quando tentamos captá-la naquilo que tem de casualmente determinado. Assim, todo o conhecimento da realidade infinita, realizado pelo espírito humano finito, 
baseia-se na premissa tácita de que apenas um fragmento limitado dessa realidade poderá constituir de cada vez o objeto da compreensão científica e de que só ele será “essencial” no sentido de “digno de ser conhecido". [... $]^{1}$

Assim, como qualquer recorte para um tema que será objeto de um estudo científico, a escolha dos filmes para esta pesquisa foi valorativa. Mas nesses filmes foram buscados temas universais, e por isso mesmo selecionamos obras de diferentes nacionalidades. E nessa universalidade da cultura dominante consiste o empenho sociológico na seleção dos filmes, que teve como critério objetivo a busca de temporalidades que se diferenciem daquela marcante na modernidade.

Se hoje dizemos que o tempo "voa" com tanta constância, é porque a temporalidade que vivenciamos tem uma importância fundamental. O recorte dessa questão nos sobressaiu em meio a outras tantas questões importantes - e, por isso, esse tema foi escolhido frente à infinitude de temas existentes, e contraposto à finitude do homem ou de um estudo.

No primeiro capítulo, procuramos abordar como, historicamente, formou-se a temporalidade dominante na modernidade, sufocando uma dimensão temporal mais densa. Buscamos, dessa forma, localizar o processo que gerou uma "naturalização" da nossa vivência temporal cotidiana. Uma vez identificada a temporalidade hegemônica da modernidade, fomos aos filmes buscar formas de resistência a essa temporalidade predominante.

Debruçando-nos sobre a amostra de filmes que abarcava essa questão, percebermos as diferentes temporalidades que existem ainda que a sociedade esteja submetida a uma temporalidade hegemônica. Embora o empenho desta pesquisa seja sobretudo sociológico, não partimos diretamente da análise da sociedade empírica, mas das formas de representação presentes em seu imaginário. Esse imaginário, de cunho igualmente social, é abarcado aqui pela forma que assume no cinema.

Pois foi justamente esse o elemento sociológico desta empreitada: a percepção de um mundo social tal qual está inserido em seu imaginário. Podem-se localizar objetos sociológicos na própria obra de arte, ou fora dela. A Sociologia da Arte que se buscou aqui é aquela da obra de arte, ou seja, aquela que se debruça sobre o objeto

\footnotetext{
${ }^{1}$ WeBER, Max. "A 'objetividade' do conhecimento na ciência social e na política". Metodologia das ciências sociais - parte 1. São Paulo: Cortez; Campinas: Editora da Universidade Estadual de Campinas, 1992, p. 124.
} 
artístico para nele buscar elementos de expressão social - no caso desta pesquisa, elementos de resistência à temporalidade moderna. ${ }^{2}$

Nesta pesquisa, portanto, buscaram-se elementos sociológicos que estão presentes nos filmes e neles podem ser percebidos. Dentre tais elementos, internos ao filme ou presentes como desdobramento da relação que o espectador estabelece com a obra, privilegiaram-se aqueles que dizem respeito aos modos de representação de uma temporalidade distinta da hegemônica na modernidade.

A esse empenho da Sociologia da Arte, Pierre Francastel denomina Sociologia das obras, e a coloca em uma das grandes sub-categorias propostas em sua metodologia, aquela que “[...] corresponde ao desejo de explorar os critérios de coerência interna dos objetos e seu relacionamento com outros valores teóricos em voga na sociedade [...]"3

A opção por buscar elementos no próprio filme vem da opinião de que a obra cinematográfica apresenta, em si, concepções de um mundo social que são transmissoras de valores e revelam características dessa mesma sociedade. Assim, após o primeiro capítulo, no qual procuramos mostrar como, histórica e sociologicamente, estabeleceu-se a temporalidade específica da modernidade, as análises fílmicas empenharam tentativas de apontar como outras temporalidades resistem dentro das obras. E, se elas aparecem nos filmes, é porque persistem no imaginário social.

"A arte é o reino das satisfações imaginárias", diz Francastel, e a Sociologia da Arte “[...] será essencialmente uma problemática do imaginário [...]”. ${ }^{5}$ Assim, se outras temporalidades podem ser encontradas nos filmes selecionados para esta pesquisa, é porque, a despeito da tendência à hegemonia que a temporalidade moderna apresenta ocupando tanto espaço quanto possível -, ela não se estabelece como exclusiva. Ou seja, o imaginário social apresenta resistências à temporalidade moderna que podem ser vistas em algumas das obras de arte que o expressam - nos filmes aqui analisados, por exemplo.

\footnotetext{
${ }^{2}$ Assim, os objetos sociológicos que se localizam fora da obra, como a política de financiamento para os filmes, as relações sociais engendradas pelos realizadores dos filmes, etc., não foram os elementos privilegiados nesta análise, muito embora não se negue sua importância na opção por outro recorte.

${ }^{3}$ Francastel, Pierre, "Problemas da Sociologia da Arte". In: Velho, Gilberto. Sociologia da Arte, II. Rio de Janeiro: Zahar Editores, 1967, p. 37.

${ }^{4}$ Francastel, P., "Problemas da Sociologia da Arte". op. cit., p. 17.

${ }^{5}$ Francastel, P., "Problemas da Sociologia da Arte". op. cit., p. 17.
} 
Partiu-se da idéia, portanto, de que o filme possui um conteúdo social em si, que não é redutível ao contexto em que o filme foi produzido, posto que se expressa na obra. Isso porque, vale lembrar, a arte

[...] é uma atividade material e simbólica que não se limita à elaboração de objetos não-usuais, mas que se associa às modalidades as mais diversas de ação. Não podemos reduzi-la nem ao personalismo nem ao simbolismo. [...] É criadora, ao mesmo tempo, de técnicas, de representações e de instituições. ${ }^{6}$

Ou seja, a arte não deve ser reduzida a um simplismo personalista ou simbólico, mas pensada enquanto uma atividade material e simbólica ligada à ação, e que é responsável pela criação de técnicas, representações e instituições. Desses três elementos, é destacada aqui a criação de representações, pois diz respeito ao modo de expressão dos elementos simbólicos do imaginário. Assim, a arte cria representações para temas do imaginário - como uma forma de temporalidade não-usual, representada seja pela errância, seja pela rememoração.

As representações sociais, tal qual aparecem no imaginário - e, conseqüentemente, nas expressões artísticas -, são peças fundamentais para que a sociedade possa se caracterizar:

As representações compartilhadas pelos membros de uma sociedade são de fundamental importância para caracterizá-la, para darem conta do seu verdadeiro perfil e possibilitarem, ao mesmo tempo, por parte de seus integrantes, reconhecerem-se como participantes dela.

Isso significa dizer que as visões que os homens e as mulheres portam sobre sua sociedade são formas através das quais ela permanece, para cada um individualmente e também para o conjunto. Trata-se da maneira pela qual a sociedade se representa diante de seus membros, criando significações que lhe são específicas. Os membros de uma dada sociedade tornam-se seres sociais através da incorporação dessas mesmas representações/ significações. [... $]^{7}$

Assim, uma tensão expressa em um filme pode ser representativa das tensões presentes em uma sociedade - um conflito entre o modo como ela se caracteriza internamente e as formas de representação que se deixam expressar por outros meios -

\footnotetext{
${ }^{6}$ Francastel, P., "Problemas da Sociologia da Arte”. op. cit., p. 20.

7 Augusto, M. "O moderno e o contemporâneo: reflexões sobre os conceitos de indivíduo, tempo e morte”. op. cit., p. 91.
} 
como seu imaginário. Em Paris, Texas, por exemplo, a tensão entre os modos de vida de Travis e Walter não pode ser expressa senão filmicamente. É preciso não apenas que o filme seja sociologicamente analisado, mas também percebido, como propõe MerleauPonty ${ }^{8}$, para que se possa entender qual é a temporalidade sob a qual vive Travis. Essa temporalidade representa um conflito frente à temporalidade predominante, e é preciso mesmo que o espectador vivencie a duração do filme para que entenda a densidade sutil dessa tensão entre a temporalidade moderna e a do indivíduo desraigado, que aparece no filme, e não fora dele.

Paulo Menezes propõe duas perspectivas de análise fílmica: uma na qual “[...] privilegia-se o modo de produção e reprodução dos filmes, centrando-se a análise, portanto, no que se convencionou chamar de a indústria cinematográfica" ${ }^{9}$; e outra na qual:

[...] a análise propriamente fílmica coloca-se em primeiro plano, transformando as imagens do filme no material analítico primordial, do qual devem decorrer as interpretações e as proposições significativas sobre a construção do filme como parte da constituição de um imaginário social, como expressão das formas nas quais uma sociedade concebe-se visualmente. Esta realidade não existiria em outro lugar [...], pois existem informações que só lá estão, que só nelas podem ser encontradas. Exprimiria, portanto, valores, relações, concepções que só existem e se expressam nela. Portanto, seria uma dimensão e não apenas um reflexo de um processo social. ${ }^{10}$

Os filmes foram aqui tomados como material primordial. É partindo dessa dimensão do processo social que se chega aos valores que fazem parte do imaginário social. Para alcançar tal dimensão, como dissemos, o caminho foi a análise da obra mesma, ou seja, a análise propriamente filmica. Sorlin, em seu livro Sociologia del cine, propõe esse mesmo caminho: "[...] nosso trabalho consiste precisamente em rechaçar o que é exterior ao filme e não reter mais que as indicações apresentadas na tela."11

\footnotetext{
${ }^{8}$ Merleau-PONTy, Maurice. "O Cinema e a nova psicologia”. op. cit., p. 115.

${ }^{9}$ MenEZES, P. "O Cinema documental como representificação - Verdades e mentiras nas relações (im)possíveis entre representação, documentário, filme etnográfico, filme sociológico e conhecimento". In: NovaEs, Sylvia C. et Alli (orgs), Escrituras da imagem, São Paulo: Edusp, 2004, pp. 21-22.

${ }^{10}$ Menezes, P. "O Cinema documental como representificação - Verdades e mentiras nas relações (im)possíveis entre representação, documentário, filme etnográfico, filme sociológico e conhecimento", op. cit., p. 22. Grifos do autor.

${ }^{11}$ Sorlin, Pierre, Sociología del Cine: La Apertura para la Historia de Mañana, Ciudad de México: Fondo de Cultura Econômica, 1992, p. 148. Tradução livre de: "[...] nuestro trabajo consiste precisamente en rechazar lo que es exterior al filme y no retener más que las indicaciones presentadas en la pantalla."
} 
O que aparece na tela do cinema, evidentemente, não é uma reprodução do que se vê no mundo exterior. No que diz respeito aos filmes, Francastel nos lembra que “[...] convém nunca perder de vista que se trata de uma linguagem e de uma arte de ilusão, e não da transposição mecânica do mundo exterior para o écran"12 ; “[...] O que se materializa no écran, não é nem o real nem a imagem que se formou no cérebro do cineasta, nem a imagem que se forma no nosso cérebro, mas um signo [...]"13 que, como tal, configura uma gramática.

Trata-se, antes, da articulação desses signos dentro do filme e de elementos construídos no e pelo imaginário social, que se articulam de forma específica na obra - e por isso é fundamental que se olhe para ela. Para ler os signos do imaginário, é preciso um empenho sociológico sobre a obra, e optamos, aqui, por um empenho que leva em conta as condições sócio-históricas gerais nas quais a obra foi produzida do modo como aparecem dentro da obra, e não apenas as condições individuais dos realizadores dos filmes.

Ao ler esses signos que compõem os filmes, procuramos localizar, nos próprios filmes, personagens que romperam com a temporalidade moderna e o estranhamento do olhar a eles dirigido. A partir dessa ruptura, podemos estabelecer parâmetros para um rompimento com essa mesma temporalidade na qual vive o espectador padrão.

Um filme não se resume à anedota presente nele, e a amostra aqui selecionada deixa isso bastante evidente. Interessa mais, em Dolls, Paris, Texas, Sob a areia e $A$ eternidade e um dia, o modo de articulação da temporalidade do que a história contada em cada um deles. O que buscamos nos filmes certamente não foi a anedota (muito embora seja sabido que "Um filme começa a nascer quando alguém propõe um assunto. A anedota não é o filme, mas lhe serve de pretexto [...].”) ${ }^{14}$ Pouco importa, nesses filmes, o motivo que leva à ruptura com a temporalidade corrente - o rompimento de uma relação amorosa, ou a lembrança de uma relação passada. Importa, antes, a temporalidade que os personagens assumem após essa ruptura, pois ela condensa a tensão presente em cada filme.

Quando o enredo não é central, o "roubo da bicicleta" deixa de ter importância, disse o cineasta Michelangelo Antonioni após o neo-realismo:

\footnotetext{
${ }^{12}$ FranCASTEL, Pierre. "Espaço e ilusão". In: 70, 1987, p. 166.

${ }^{13}$ FranCASTEL, Pierre. "Espaço e ilusão"op. cit., p. 173.

${ }^{14}$ Sorlin, Pierre. Sociología del Cine: La Apertura para la Historia de Mañana. op. cit., p. 174. Tradução livre de: "Un filme empieza a nacer cuando alguien propone un asunto. La anécdota no es el filme, pero si le sirve de pretexto". Imagem, visão e imaginação. Lisboa: Edições
} 
[...] não me parece mais importante hoje fazer um filme sobre um homem de quem roubaram a bicicleta. Quer dizer, sobre um personagem cuja importância provém do fato de que roubaram sua bicicleta (sobretudo e exclusivamente). [...]

Agora, que nós eliminamos o problema da bicicleta (eu falo por metáfora, procurem me compreender para além de minhas palavras), é importante ver o que há no espírito e no coração desse homem de quem roubaram a bicicleta, como ele se adaptou, o que restou nele de todas as experiências passadas da guerra, do pós-guerra, de tudo isso que se passou no nosso país, um país justamente que, como tantos outros, vem de uma aventura tão importante e tão grave. ${ }^{15}$

A esses cineastas lhes pareceu importante fazer um filme sobre uma outra forma de temporalidade, que não a predominante, porque no imaginário social essa forma resiste. Eles não a criaram sozinhos, mas refletiram em suas obras feições do imaginário social que eles compõem, mas que também se compõe por meio deles.

Quando o "roubo da bicicleta" começa a desaparecer dos filmes, a errância vem surgindo. Não importa a anedota, mas o caminho dos personagens, que parecem vagar sem destino. Além da temporalidade divergente da predominante, é característica comum dos filmes aqui analisados a errância de seus personagens - diz-se errância porque eles se movimentam com uma dimensão temporal diferente da hegemônica, para a qual não importa tanto o tempo vivido durante o filme. Em Paris, Texas, Sob a Areia e Dolls vive-se o tempo do pós-trauma, em A Eternidade e um dia vive-se a reconstrução de uma história. Os personagens principais desses filmes não se envolvem em tramas complexas, mas desenvolvem suas vidas presos a dimensões para as quais o futuro não é o tempo forte.

$\mathrm{Na}$ errância, não há um acontecimento central, o elemento fundamental é o trânsito. Embora nada de extraordinário ocorra aos personagens desses filmes de errância, diz Annie Goldmann, eles

\footnotetext{
${ }^{15}$ Antonioni, Michelangelo. "L'Auteur et le sujet". Cinéma d'aujoud'hui 2, Paris: Éditions Seghers, p. 94. Tradução livre de: "[...] il ne me semble plus important aujoud'hui de faire un film sur un homme à qui on a volé sa bicyclette. C'est-à-dire sur un personnage dont l'importance provient du feit qu'on lui a volé sa bicyclette (sourtout et exclusivement). [...]

Aujourd'hui, que nous avons éliminé le problème de la bicyclette (je parle par métaphore, essayez de me comprendre au-delà de mes paroles), il est important de voir ce qu'il y a dans l'espirit et le coeur de cet homme à qui on a volé sa bicyclette, comment il s'est adapté, ce qui est resté en lui de toutes ses expériences passées de la guerre, de l'aprés-guerre, de tout ce qui est arrivé dans notre pays, un pays justement qui, comme tant d'autres, est sorti d'une aventure si importante et grave."
} 
[...] atraem-nos e nos fascinam porque revelam a nossa angústia escondida, o nosso desejo de unidade nunca realizado. Eles são o contrário dos nossos sonhos e de nossa aparência, a imagem escondida da nossa desesperança secreta. [... $]^{16}$

Em nossa amostra, a vontade secreta é aquela de viver sobre outra temporalidade, na qual há tempo para a errância, na qual o trabalho marcado pela infinita divisão do tempo não é obrigatório. Não por acaso, a errância surge no cinema justamente quando as queixas a respeito da falta de tempo aparecem enquanto questão social.

Goldmann aponta Carlitos (personagem de Charles Chaplin) como o primeiro errante da história do cinema, mas ele seria um errante diferente dos que surgiram depois, por estar inserido em um mundo bastante "real" ". O errante dos anos 60-80, por outro lado, seria como os que vemos aqui: para eles, "o mundo perdeu sua realidade; não é nem hostil nem acolhedor: é apenas uma imagem, uma representação esvaziada de sentido, uma simples evidência." 18

Ou seja, o que está por trás dessa errância é um desenraizamento, uma concepção de mundo na qual o indivíduo está segregado do todo social, tal qual se apresenta na modernidade. Para os indivíduos representados nos filmes da nossa amostra, o desarraigamento em relação ao mundo no qual vivem é extenso ao ponto de não se relacionarem propriamente com o mundo, não terem uma participação ativa. Eles se isolam - em sua errância, em sua lembrança - e vivem assim sob o jugo de uma temporalidade que não é a da modernidade; apresentam um afastamento essencial do mundo concreto e dos elementos desse mundo.

Assim, o que Goldmann diz sobre os heróis dos filmes que ela analisa ${ }^{19}$ pode também ser transposto aos protagonistas dos filmes que analisamos:

[...] [nesses heróis,] a consciência não é mais um sujeito ativo; ela está esvaziada de qualquer conteúdo afetivo, cognitivo e, por conseguinte, incapaz de ação.

16 Goldmann, A. L'errance dans le cinéma contemporain. op. cit., p. 9. Tradução livre de: “[...] ils nous attirent et nous fascinent parce qu'ils révèlent notre angoisse cachée, notre désir d'unité jamais accompli. Ils sont l'envers de nos rêves et de notre paraître, l'image cachée de notre désespérance secréte."

${ }^{17}$ Cf. Goldmann, A. L'errance dans le cinéma contemporain. op. cit., p. 11.

18 Goldmann, A. L'errance dans le cinéma contemporain. op. cit., p. 11. Tradução livre de: “[...] le monde a perdu sa réalité; il n'est ni hostile ni accueillant: il n'est qu'une image, une représentation vidée de sens, une simple évidence. [...]"

${ }^{19}$ Goldmann analisa: Le Camion. França, 1977. Direção: Marguerite Duras. Movimento em falso (Falsche bewegung). Alemanha Ocidental, 1975. Direção: Wim Wenders. No decurso do tempo (Im Lauf der Zeit), Alemanha Ocidental, 1975. Direção: Wim Wenders. Paris, Texas, Alemanha, França, Estados Unidos, 1984. Direção: Wim Wenders. Stranger than paradise. Alemanha Ocidental, Estados Unidos, 1984. Direção: Jim Jarmusch. 
Resulta que não há mais vínculos possíveis entre o sujeito e o mundo, nem ação possível sobre o mundo. ${ }^{20}$

Assim, tal qual Antonioni e Sorlin, Goldmann aponta para a ausência da anedota. Isso porque os personagens não buscam um sentido no mundo, mas vagueiam. ${ }^{21}$ Como primeiro errante desraigado, Goldmann aponta Michel Poiccard, protagonista de $A \operatorname{cossado} o^{22}$, de Godard. Ele seria a prefiguração de um tipo de herói que será um verdadeiro protótipo nos vinte anos seguintes: um personagem masculino marginal, desprendido do real, do ambiente social e familiar, sem um lar, sem trabalho, sem vínculos. ${ }^{23}$

$\mathrm{Na}$ amostra de Goldmann, os heróis vão evoluindo, historicamente, de um filme ao outro, reforçando sua distância em relação ao mundo, endurecendo suas barreiras sociais. Eles vão de um lugar a outro, passam por cidades, pela natureza, pegam trens ou aviões, conhecem pessoas, mas sem que ninguém marque de fato sua existência. Sua indiferença se torna mais radical, sua sensibilidade se fecha cada vez mais, e ao mesmo tempo a aceitação de seu destino se dilui com uma indiferença a tudo. Esses são os errantes solitários, os viajantes sem estrelas, que não crêem em nada: nem no êxito social, nem na criação, nem nas relações humanas. ${ }^{24}$

$\mathrm{Na}$ vida errante, a preocupação principal desses heróis seria evitar todo contato com os outros. "Sem ideologia contestatória, sem esperança de felicidade, eles têm a segurança tranqüila daqueles que terminaram o caminho antes mesmo de tê-lo começado" 25 . Vazios de toda interioridade, diz Goldmann, sua forte presença na tela provém de uma ausência de consciência, de um vazio que conduz seja à morte, seja à solidão absoluta. $^{26}$

Os heróis de Goldmann não são contestatórios nem revolucionários. Eles não querem mudar o sistema social nem por uma ação, nem pelo discurso. ${ }^{27}$ Os nossos

\footnotetext{
${ }^{20}$ Goldmann, A. L'errance dans le cinéma contemporain. op. cit., p. 14. Tradução livre de: “[...] la conscience n'est plus um sujet actif; elle est vidée de tout contenu affectif, cognitif et, par conséquent, incapable d'action. Il s'ensuit qu'il n'y a plus de liens possibles entre le sujet et le monde, ni d'action possible sur le monde."

${ }^{21}$ GoldmanN, A. L'errance dans le cinéma contemporain. op. cit., p. 16.

${ }^{22}$ A bout de souffle. França, 1959. Direção: Jean-Luc Godard.

${ }^{23}$ Goldmann, A. L'errance dans le cinéma contemporain. op. cit., p. 17.

${ }^{24}$ Goldmann, A. L'errance dans le cinéma contemporain. op. cit., p. 17.

${ }^{25}$ Goldmann, A. L'errance dans le cinéma contemporain. op. cit., p. 17. Tradução livre de: "[...] Sans idéologie contestataire, sans espoir de félicité, ils ont la tranquille assurance de ceux qui ont fini le chemin avant même de l'avior commencé".

${ }^{26}$ GoldmanN, A. L'errance dans le cinéma contemporain. op. cit., pp. 17-21.

${ }^{27}$ Goldmann, A. L'errance dans le cinéma contemporain. op. cit., p. 24.
} 
tampouco. Alexander é o único que atua de forma construtiva, mas a transformação é individual. Pode-se então dizer que apenas a vida interior interessa aos protagonistas dos filmes que analisamos, suas emoções, seus afetos? Não, isso não ocorre pelo fato essencial de que há um abandono desses indivíduos no mundo. Se vivenciam uma temporalidade distinta, é porque estão, de alguma forma, descolados do universo social hegemônico e inclusive de suas relações com os outros.

A análise de Goldmann empenha uma abordagem que é sobretudo espacial - o deslocamento físico de seus personagens. Nossa abordagem, por outro lado, tem um elemento essencial que a difere da leitura de Goldmann: o enfoque temporal. Tal opção baseia-se na percepção da temporalidade acelerada e da necessidade do incessantemente novo como questões fundamentais para a modernidade.

Em cada um dos filmes, opera uma relação temporal distinta. Na ordem em que foram aqui expostos, configuram um aumento progressivo em sua relação com a dimensão do passado: Dolls, Paris, Texas, Sob a areia e A eternidade e um dia.

Em Dolls, a temporalidade está presa a uma espera e a uma errância que engendram a vivência em um presente no qual não se constrói, e que exclui passado e futuro. Ela decorre de um acontecimento traumático na vida de cada um dos casais. A relação amorosa, que aparece inicialmente como possibilidade de fuga da situação aparentemente aporética de aprisionamento no presente mesmo, não se concretiza. Matsumoto apenas decide viver com Sawako quando ela perde sua memória e se infantiliza, ou seja, quando já não há possibilidade de construção de uma história a dois. Hiro encontra sua antiga namorada, mas ela nem ao menos o reconhece, e segue esperando o homem que existe apenas em suas lembranças. Haruna esperará por Nukui, assassinado após vê-la.

Essa temporalidade, que se mistura com a das estações do ano, emerge também de uma ausência de relação com o mundo. Matsumoto e Sawako erram para longe do contato com outras pessoas. Eles estão completamente desgarrados do mundo - e apenas não se separam um do outro porque uma corda os une.

O filme apresenta a temporalidade de um presente preso a uma espera. Matsumoto e Sawako não têm um passado a relembrar ou rememorar - ela perdeu a memória e ele resignou-se. O casal erra após a desilusão amorosa que levou Sawako a desistir de viver. Sua tentativa de "sair do mundo" pelo suicídio não se concretizou, mas operou uma saída da vida social. 
Hiro percebe que sua morte está próxima, e o desejo de ir atrás do seu passado no parque onde encontrou sua antiga namorada pela última vez, sem guarda-costas - é o que leva à sua morte. Ele parte sem dizer a ela quem ele é, e é assassinado, de modo que o futuro dessa relação amorosa é aniquilado, para ambos, pela impossibilidade de encontrarem-se novamente. E ela seguirá aguardando seu antigo namorado.

Haruna, por sua vez, após isolar-se do mundo em uma praia, a mirar a imensidão do mar, aceita a visita de Nukui apenas porque ele igualmente se desligou do mundo apagando sua visão de tantos estímulos conflitantes. Mas tampouco essa realização amorosa se concretiza, pois é também por ir atrás de uma mulher que Nukui morre, assassinado ao voltar para casa.

Assim, se a relação amorosa pode inicialmente aparecer em Dolls como modo de resgatar os personagens de sua temporalidade de espera, seja fazendo-os abrir sua vivência temporal para o passado, seja para o futuro, ela não se realiza. Todos os protagonistas que sobrevivem permanecem presos a sua espera, e não erram mais: apenas esperam. A antiga namorada de Hiro o espera no parque com duas refeições, Haruna espera por Nukui - ou pela sua improvável cura - olhando para o mar, Matsumoto e Sawako esperam pela resolução de sua situação tão aporética: quando ela demonstrou uma lembrança do passado, logo essa possibilidade foi anulada, e eles esperam a morte pendurados no penhasco. Não chegam a morrer, apenas esperam por seu fim.

Em Paris, Texas, a errância também marca a narrativa do filme. Travis vive, nessa errância, um presente constante. No início ele perdera sua memória, mas ela vai sendo reconquistada a cada nova cena, e manifestada a cada nova fala. Assim ele vai dialogando com seu passado - por breves lembranças, sem que isso mude algo em sua vida. O único efeito dessa relação que estabelece com o passado é a substituição de sua errância por uma itinerância que é abordada pelo filme.

A localização do trauma que fez Travis errar vai se clareando conforme estímulos externos atuam de forma a remetê-lo ao seu passado: o encontro com Walter, depois com Hunter, o filme em Super 8 e, por fim, a interação com Jane. Mas esse trauma só é de fato relembrado quando posto em palavras - ainda que permeado pela técnica e contado em terceira pessoa, anonimamente.

A intervenção de Travis no peep-show, entretanto, não faz com que o trauma seja trabalhado, no sentido que a psicanálise poderia atribuir à fala. A enunciação do trauma não muda a condição errante de Travis. Sua melancolia representa um desenraizamento tão profundo que nada parece capaz de abalar suas condições de vida. 
O mundo externo, tal qual o interno, não é capaz de abalar Travis, que parece descolado de todo conteúdo social.

Se Dolls se resumia a uma vivência do presente imediato, Paris, Texas apresenta uma abertura um pouco maior ao tempo do passado, recuperando um acontecimento que deixou marcas que influem ainda no presente, muito embora seja incapaz de transformar seus resultados. Travis se lembra do rompimento com Jane, mas é incapaz de com isso transformar seja seu presente, pela enunciação do trauma, seja seu passado, pela rememoração. É, portanto, uma lembrança factual do passado, e sobre ele não opera nenhuma construção.

Dolls e Paris, Texas apresentam uma situação na qual o passado não é capaz de transformar o presente, e tampouco o presente pode transformar o passado. Ainda que esteja localizada no passado a desilusão amorosa responsável pelo afastamento social de seus protagonistas - seja por uma errância ou por uma espera -, não há um adensamento temporal. Como não há expectativas transformadoras nesses dois filmes, o futuro opera apenas como provável repetição do presente imediato no qual vivem. Se, no início dos filmes, o espectador ainda é capaz de creditar ao enredo alguma espécie de esperança de que o futuro dos protagonistas será o tempo da transformação de suas condições de prisão ao presente, isso logo desaparece. Não há expectativas quando o presente aparece como tempo único da temporalidade vivenciada.

Assim terminam os dois filmes, com a constatação de que nada mudou, porque nada pode ser mudado. A espera de Dolls, marcante no presente dos personagens, se materializa na aparição final de Matsumoto e Sawako - eles não morrem, mas ficam esperando a morte, pendurados no penhasco. Em Paris, Texas, o final mostra, também, que o encontro com Jane não foi transformador - que a tentativa de Travis voltar ao foco de sua dor não faz com que o passado possa ser rememorado ou re-significado. $\mathrm{O}$ filme aborda um desvio na vida de Travis: uma pausa em sua errância, quando ela é substituída pela itinerância, e termina com o retorno à errância solitária, que não carrega traços do passado e nem expectativas do futuro.

Em Sob a areia, a temporalidade vivida por Marie após o desaparecimento de Jean é aquela de um presente que não se atualiza em um aspecto, que segue vinculada a um elemento do passado - Jean. Marie não é capaz de se desvincular desse elemento do passado para aceitar uma perda concreta do presente.

Assim, o presente não pode ser vivenciado propriamente, pois há dados da realidade atual que Marie não é capaz de perceber. Sem uma constatação da perda, não há 
a atualização de sua condição presente e, portanto, o futuro fica igualmente prejudicado, pois aparece também como um tempo marcado por essa vinculação ao passado - a Jean.

Diferente de Dolls e Paris, Texas, não é a desilusão amorosa que coloca Marie nessa situação, mas a perda da pessoa amada, seu desaparecimento. Assim, não se trata da necessidade de uma re-significação de seu passado para que ela abandone seu estado atual, mas de uma atualização de seu presente pela percepção dos dados concretos. Com a percepção desses dados que ela não é capaz de ver em seu presente, Marie conseguiria abandonar a força que o passado tem em sua vida, e construir um presente e um futuro com base nos fatos observáveis em sua vivência.

Em $A$ eternidade e um dia, a origem do deslocamento temporal também não está na desilusão amorosa, mas em uma ruptura. O que desperta em Alexander o adensamento da sua relação temporal com o passado é a percepção de sua morte. No dia anterior a sua partida, ele tem sua memória ativada pela leitura das cartas de Ana. E, ao ouvi-las, sua memória involuntária é ativada de modo que ele é capaz de construir uma relação intensa com seu passado, a partir do presente. Essa relação, fruto da rememoração, é capaz de transformar o passado e o futuro, tanto é que Alexander decide não ir mais ao hospital.

Ou seja, é por meio da construção de seu passado que Alexander consegue se libertar da temporalidade da modernidade, abrindo as esferas temporais de forma a experimentá-las intensamente. Alexander estava preso a um tempo sem futuro, pois era seu último dia. Pela rememoração, entretanto, ele é capaz de abrir a temporalidade vivida em todos os tempos, e transformar todos eles: o passado, porque adentra suas lembranças, o presente, porque se atualiza, e o futuro - tanto aquele futuro que estava preso ao passado, e dele se liberta, quanto o futuro do presente que ele vive - que se esgotaria no dia seguinte.

Não há, em $A$ eternidade e um dia, uma desilusão amorosa. Tampouco a perda do objeto de amor. Ocorre um movimento oposto: é por meio da rememoração que a relação de Alexander com Ana é construída e intensificada. E é pela rememoração também que essa relação cria expectativas futuras - e Alexander desiste de aniquilar seu futuro com sua partida.

O que marca os protagonistas dos quatro filmes estudados nesta pesquisa é a presença de um sentimento de profunda solidão. Eles se desprendem da temporalidade moderna e, assim, desatam-se de um elemento que é fundamental para sua vinculação com o mundo exterior. Descolados da inserção na modernidade enquanto forma temporal, eles encontram, no isolamento social, um mundo frente ao qual se tornam quase 
insignificantes. A existência desses personagens, individual e solitária, é minúscula quando comparada à imensidão do mundo e da "natureza", o palco do isolamento social mais radical. É pequena como a imagem de um indivíduo frente ao mar ou à ampla vegetação, recorrente nos filmes aqui analisados, um indivíduo que muitas vezes está de costas para nós, pois são espectadores da imensidão do mundo à sua volta.

Mas esse desarraigamento solitário presente em Dolls, Paris, Texas, Sob a areia e A eternidade e um dia não nos é estranho, ainda que vivamos sob o jugo da temporalidade moderna. Nossa desvinculação das esferas temporais mais abrangentes afrouxou os laços que poderíamos ter com nossos antepassados, mesmo aqueles mais próximos. A ausência de referências que poderiam nos dar um senso de pertencimento no mundo é marca desse tempo apressado em que vivemos. E, quando não conseguimos localizar nossas origens, o sentimento que nos acomete é mesmo de uma solidão intensa.

Ainda que estejamos inseridos na temporalidade moderna, temos dificuldade em nos enraizarmos, pois os paradigmas, assim como os fatos observáveis no mundo exterior, mudam com muita rapidez. É difícil estabelecer fixidez sobre uma base em constante mutação e, ainda que estejamos inseridos na temporalidade corrente, temos a impressão de que não estamos efetivamente ligados a nada. Daí decorre o sentimento de abandono e falta de sentido na vida; além da impressão constante de que o tempo corre autonomamente - quando o tempo, de fato, somos nós quem construímos.

Mas vale lembrar o fato fundamental abarcado por esta pesquisa: embora a temporalidade moderna se imponha, hoje, como hegemônica, nos resta a possibilidade de alterá-la. Afinal, somos fundamentalmente seres errantes, caminhando em um destino sem sentido - deixados ao sabor da nossa própria liberdade. 

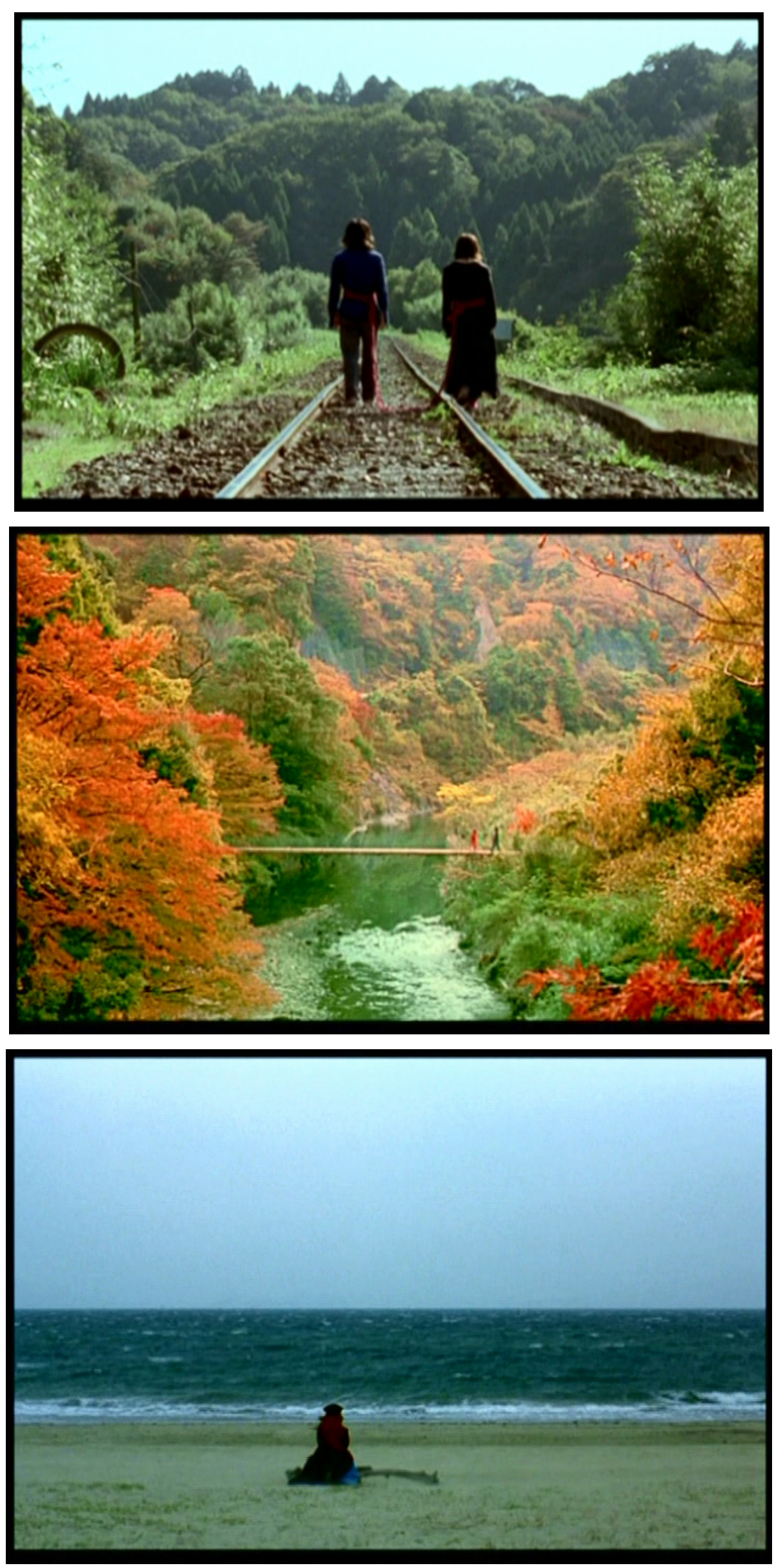

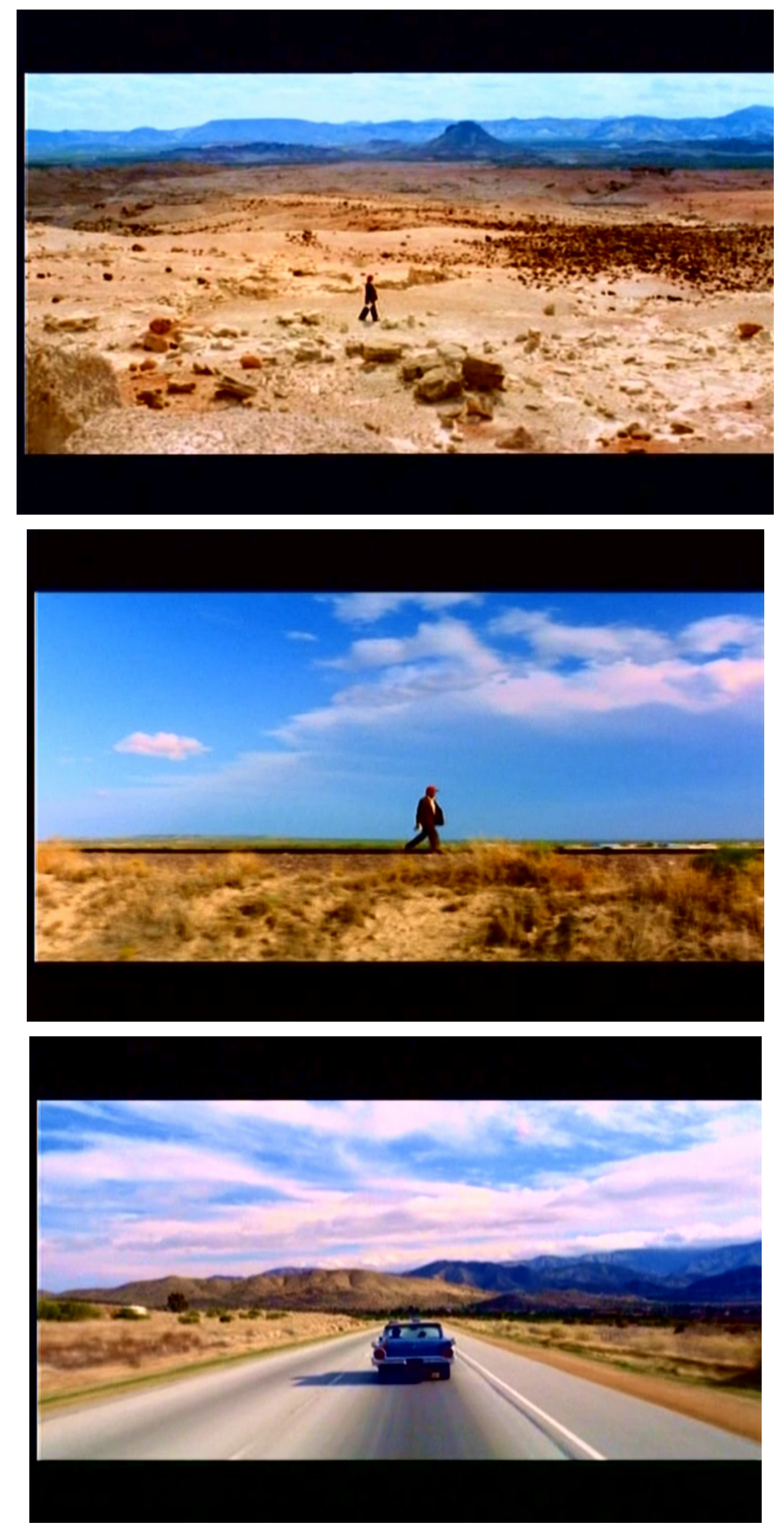

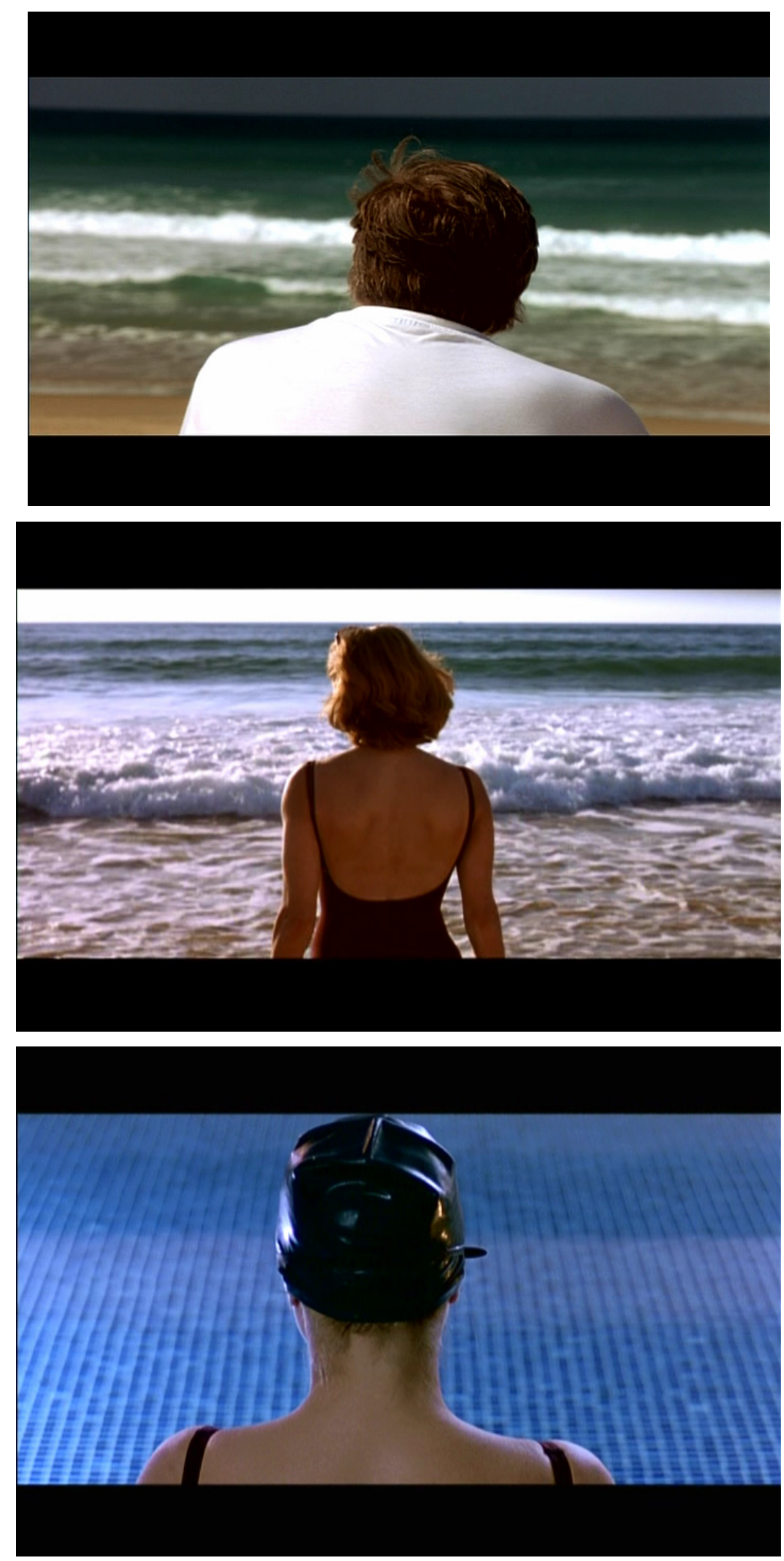

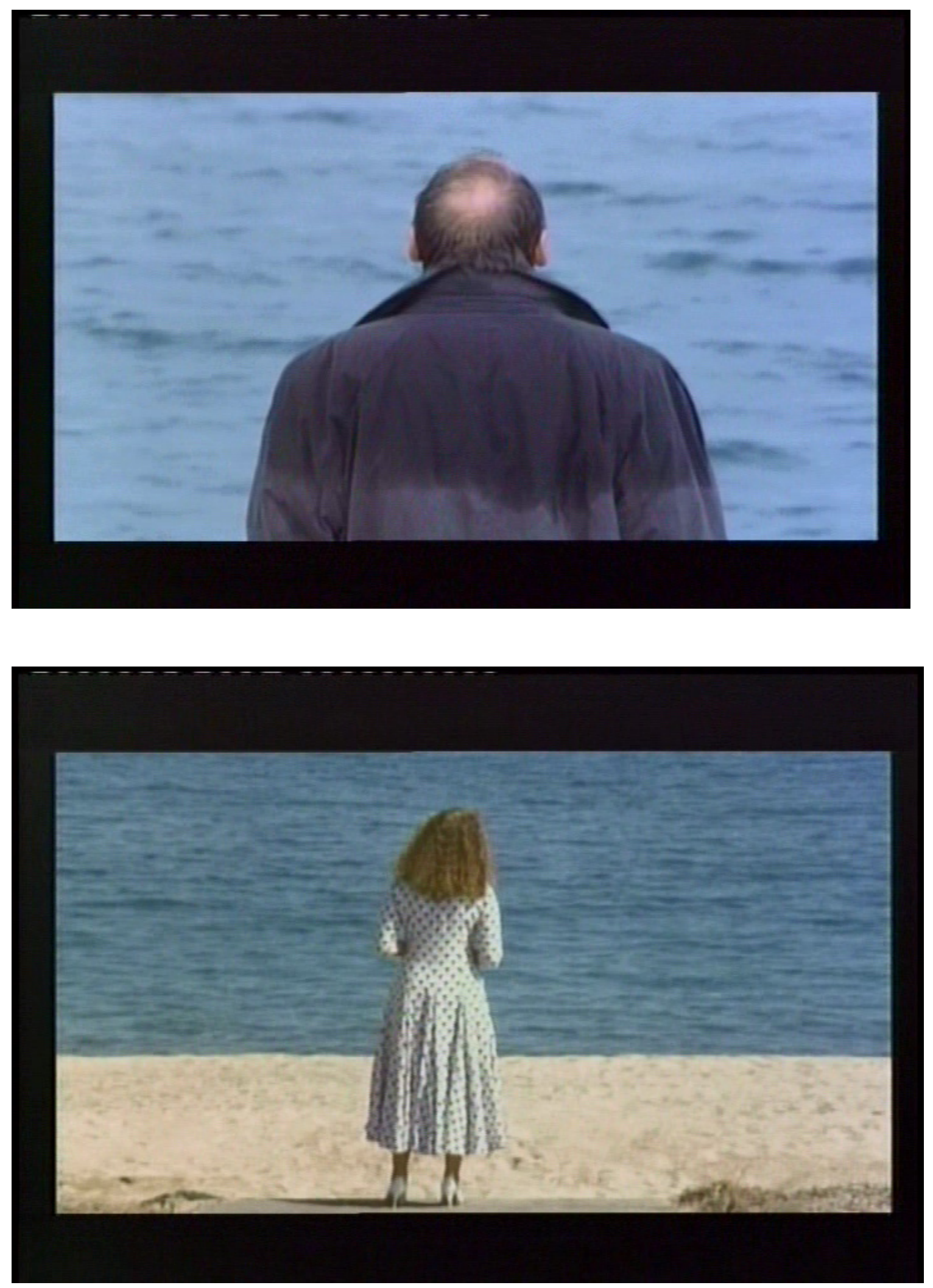


\section{Referências bibliográficas}

Antonioni, Michelangelo, “L'Auteur et le sujet", Cinéma d'aujoud'hui 2, Paris: Éditions Seghers, pp. 91-94.

AREndt, Hannah. A Condição humana. Rio de Janeiro: Forense-Universitária; Rio de Janeiro: Salamandra; São Paulo: Edusp, 1981.

AREndt, Hannah. Entre o Passado e o Futuro. São Paulo: Perspectiva, $5^{\text {a }}$ edição, 2000.

ARIÈs, Philippe. História da morte no Ocidente: da Idade Média aos nossos dias. Rio de Janeiro: Francisco Alves, 1977

Augusto, Maria Helena Oliva. "O moderno e o contemporâneo: reflexões sobre os conceitos de indivíduo, tempo e morte". In: Tempo Social - Revista de Sociologia da USP. São Paulo, 6 (1-2), 1994 (editado em jun. 1995), pp. 91-105.

BAudelaire, Charles. As Flores do Mal. Rio de Janeiro: Nova Fronteira, 1985.

BAUdelAIRE, Charles. Les Fleurs du mal. Paris: Booking International, 1993.

Baudelaire, Charles. Pequenos poemas em prosa. Rio de Janeiro: Nova Fronteira, 1980.

BAudelaire, Charles. Sobre a modernidade. Rio de Janeiro: Paz e Terra, 1996.

Bellato, Roseney et CARvalho, Emília C. "O jogo existencial e a ritualização da morte". Revista Latino-Americana de Enfermagem. Vol. 13, no 1. Ribeirão Preto, jan/ fev. 2005. Disponível online em: http://www.scielo.br/scielo.php?script=sci arttext\&pid=S0104-

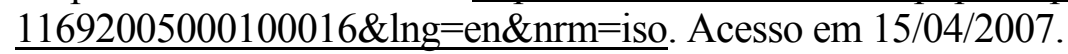

Benevolo, Leonardo. "Haussmann e o plano de Paris". In: arquitetura moderna. São Paulo: Perspectiva, 1976, pp. 91-128. . História da

BENJAMIN, Walter. "A Doutrina das semelhanças". In: - Magia e técnica, arte e política-Obras escolhidas, volume I. São Paulo: Brasiliense, 1985, pp. 108-113.

Benjamin, Walter. "A imagem de Proust". In: - Magia e técnica, arte e política-Obras escolhidas, volume I. São Paulo: Brasiliense, 1985, pp.36-49. 
BENJAMIN, Walter. "Escavando e recordando". In: Obras escolhidas II -

Rua de Mao única. São Paulo: Brasiliense, 1987, pp. 239-240.

BENJAMIN, Walter. "Experiência e pobreza". In: - Magia e técnica, arte e política - Obras escolhidas, volume I. São Paulo: Brasiliense, 1985, p.114-119.

BENJAMIN, Walter. "Exposés". In: . Passagens. Belo Horizinte: Editora UFMG; São Paulo: Imprensa Oficial do Estado de São Paulo, 2006, pp.35-67.

BENJAMIN, Walter. "O Narrador - Considerações sobre a obra de Nikolai Leskov". In: . Obras escolhidas, volume I - Magia e técnica, arte e política. São Paulo: Brasiliense, 1994, pp. 197-221.

BENJAMIN, Walter. "O Narrador - Observações sobre a obra de Nikolai Leskow". In: Benjamin, Horkheimer, Adorno et Habermas. Textos escolhidos. Coleção "Os pensadores". São Paulo: Abril Cultural, 1975, pp. 63-81.

BENJAMIN, Walter. "Paris, capital do século XIX". In: . Kothe, Flávio R. (org.). Walter Benjamin - Sociologia. São Paulo: Editora Ática, 1985, pp. 30-43.

BENJAMIN, Walter. "Pequena história da fotografia". In: . Magia e técnica, arte e política - Obras escolhidas, volume I. São Paulo: Brasiliense, 1985, pp. 91-107.

BENJAMIN, Walter. "Sobre alguns temas em Baudelaire". In: . Obras escolhidas, volume III - Charles Baudelaire - Um Lírico no auge do capitalismo. São Paulo: Brasiliense, 1994, pp. 103-149.

BENJAMIN, Walter. "Sobre o conceito de história". In: . Magia e técnica, arte e política-Obras escolhidas, volume I. São Paulo: Brasiliense, 1994, pp. 222-232.

BENJAMIN, Walter. "Tiergarten". In: . Obras escolhidas II - Rua de Mao única. São Paulo: Brasiliense, 1987, pp. 73-75.

Benjamin, Walter et Bolle, Willi (org.) Passagens. Belo Horizonte: Editora UFMG e São Paulo: Imprensa Oficial do Estado, 2006.

Berger, Peter; Berger, Brigitte; Kellner, Hansfried. "On the obsolescence of the concept of honor". In: The Homeless mind: modernization and consciousness. New York: Vintage Books, 1973, pp. 83-96. 
Berger, Peter; Berger, Brigitte; Kellner, Hansfried. "Sobre la obsolescencia del concepto de honor". In: Un mundo sin hogar - modernización y consciencia. Santander: Editorial Sal Terrae, 1979, pp.81-93.

BoRGES, Jorge Luis. "Las Mil y una noches". In: . Obras Completas III.

Barcelona: Emecé Editores, 1989, pp. 232-241.

BRASSAÏ. Proust e a fotografia. Rio de Janeiro: Jorge Zahar Editor, 2005

Bresciani, Maria Stella M. Londres e Paris no século XIX: o espetáculo da pobreza. São Paulo: Brasiliense, 2004.

BRUnI, José Carlos. “A água e a vida”. In: Tempo Social - Revista de Sociologia da USP, São Paulo, 5 (1-2), 1993 (editado em nov. 1994), pp. 53-65.

Bruni, José Carlos. "Tempo e trabalho intelectual". In: Tempo Social - Revista de Sociologia da USP. São Paulo, 3 (1-2), 1991, pp. 155-168.

Buck-Morss, Sandra. Dialética do olhar - Walter Benjamin e o Projeto das Passagens. Belo Horizonte: Editora UFMG; Chapecó/SC: Editora Universitária Argos, 2002.

BUNRAKU - teatro de bonecos. Texto disponível online no site da Embaixada do Japão no Brasil: http://www.br.emb-japan.go.jp/cultura/downloads/bunraku.htm. Acessado em 29/06/2006.

BURKE, Peter. Testemunha ocular. Bauru: EDUSC, 2004

CALABI, Donatella. "O Papel de Paris na urbanística italiana do século XIX: o mito da modernidazação". In: SAlgueIRO, H. A. (org.). Cidades Capitais do século XIX. São Paulo: Edusp, 2001 pp. 103-134.

CARdoso, Irene. "A narrativa silenciada". In: CARdoso, Irene et Silveira, Paulo (orgs.). Utopia e mal-estar na cultura: perspectivas psicanalíticas. São Paulo: Hucitec, 1997, pp. 169-196.

CARdoso, Irene. "História, memória e crítica do presente". In: crítica do presente. São Paulo: Editora 34, 2001, pp. 15-40. . Para uma 
CARDOSO, Irene. "Os acontecimentos de 1968: notas para uma interpretação". In: . Para uma crítica do presente. São Paulo: Editora 34, 2001, pp. 133-146.

CARrière, Jean-Claude. A Linguagem Secreta do Cinema. São Paulo: Nova Fronteira, 1995.

Chevalier, Jean et GheERBrant, Alain. Dicionário de símbolos. Rio de Janeiro: José Olympio, 2006.

CIA - Central Intelligence Agency. The World Factbook 2006. E.U.A., 2006. Publicação anual disponível em: https://www.cia.gov/cia/publications/factbook/geos/ja.html\#Econ. Acesso em 13/09/2006.

Columbia Encyclopedia, The. Sixth Edition, 2006. Verbete "Chikamatsu, Monzaemon" consultado online em http://www.encyclopedia.com/doc/1E1Chikamat.html. Acesso em 07/06/2006.

Corbin, Alain. Saberes e odores. São Paulo: Cia. das Letras, 1987.

DouEK, Sybil Safdie. Memória e exílio. São Paulo: Escuta, 2003.

ELIAS, Norbert. "A Solidão dos moribundos". In: A Solidão dos moribundos: seguido de "Envelhecer e morrer”. Rio de Janeiro: Jorge Zahar, 2001, pp. 7-77.

ELIAS, Norbert. "Envelhecer e morrer: alguns problemas sociológicos". In: A Solidão dos moribundos: seguido de "Envelhecer e morrer". Rio de Janeiro: Jorge Zahar, 2001, pp. 79-103.

ELIAS, Norbert. Sobre o Tempo. Rio de Janeiro: Jorge Zahar Editor, 1998.

ENGELS, Friedrich. A Situação da classe trabalhadora na Inglaterra. São Paulo: Global, 1985.

FerreIrA, Aurélio B. H. Novo Aurélio Século XXI: o dicionário da língua portuguesa. Rio de Janeiro: Nova Fronteira, $3^{\text {a }}$ edição, 1999.

FRANCASTEL, Pierre, "Espaço e ilusão", Imagem, visão e imaginação. Lisboa: Edições 70, 1987, pp. 157-174. 
Francastel, Pierre, "Problemas da Sociologia da Arte". In: Velho, Gilberto. Sociologia da Arte, II. Rio de Janeiro: Zahar Editores, 1967, pp. 12-41.

FREUD, Sigmund. "Luto e melancolia". In: . Edição standard brasileira das obras psicológicas completas de Sigmund Freud (Vol. XIV). Rio de Janeiro: Imago, 1974, pp. 275-291.

FundaÇão Japão. Página da web. São Paulo, disponível online em http://www.fjsp.org.br/bunraku/\#bunraku. Acessado em 18/06/2006.

Gagnebin, Jeanne-Marie. História e Narração em Walter Benjamin. São Paulo: Editora Perspectiva, 1999.

GaGneBIN, Jeanne-Marie. "Prefácio - Walter Benjamin ou a história aberta". In: BENJAMIN, Walter. Magia e técnica, arte e política - Obras escolhidas, volume I. São Paulo: Brasiliense, 1994, pp. 7-19.

GaGnEBIn, Jeanne-Marie. "Seis teses sobre as 'Teses"”. In: Cult, n' 106, ano 9, pp. 5053.

GAgneBIN, Jeanne-Marie. Walter Benjamin - os cacos da história. São Paulo: Brasiliense, 1982.

Goldmann, Annie. L'errance dans le cinema contemporain. Paris: Henri Veyrier, 1985.

HADDAD, Jamil Almansur. Interpretações das Mil e Uma Noites. In: Collatio, $\mathrm{n}^{\circ}$ 6. São Paulo: Centro de Estudos Árabes da FFLCH-USP, junho/1986. Disponível online em http://www.hottopos.com/collat6/jamyl.htm, acesso em 07/08/2006.

HiLl, Peter. "Heisei Yakuza: burst bubble and Bôtaihô". In: Social Science Japan Journal. Tóquio, 6 (1), 2003. Disponível online em: http://ssjj.oxfordjournals.org/cgi/reprint/6/1/1. Acesso em 16/08/2006.

HosoKawA, Shuhei. "Por um bom Viajante Nostálgico - Tarkovski visto pelas lentes de Jankelevitch”. Imagens. Campinas, no 2, agosto de 1994, pp. 96-103.

Houaiss, Antonio; Villar, Mauro; et Mello-Franco, Francisco. Dicionário Houaiss da língua portuguesa. Rio de Janeiro: Objetiva, 1ª edição, 2001. 
LAS MIL Y UNA NOCHES. Autor anônimo. "Traducción directa y literal del árabe: Dr. J. C. Mardrús”. León: Editorial Everest, sem data.

Laurel, Maria Herminia A., "Le Spleen de Paris, Petits poèmes en prose: "crise de vers', crise de prose". In: Máthesis, 10, 2001, 137-152. Disponível online em: www4.crb.ucp.pt/Biblioteca/Mathesis/Mat10/mathesis10 137.pdf. Acesso em $11 / 08 / 2006$.

LEACH, Edmund Ronald. “Cronos e Crono". In: Repensando a Antropologia. São Paulo: Perspectiva, 1974, pp.192-209.

LEACH, Edmund Ronald. "Exemplos de códigos binários”. In: Cultura e comunicação a lógica pela qual os símbolos estão ligados. Rio de Janeiro: Zahar Editores, 1978, pp. 67-77.

LEPETIT, Bernardo. "Das capitais às praças centrais. Mobilidade e centralidade no pensamento econômico francês". In: SALgUeIRO, Heliana Angotti (org.). Cidades Capitais do século XIX. São Paulo: Edusp, 2001, pp.41-63.

LöWY, Michael. “A filosofia da história de Walter Benjamin”. In: Estudos Avançados, 16 (45), 2002, pp. 199-206. Disponível online em: http://www.scielo.br/pdf/ea/v16n45/v16n45a13.pdf. Acesso em 01 de julho de 2007.

Mannoni, Maud. "O Homem diante da morte". In: - O Nomeável e o inomeável - a última palavra da vida. Rio de Janeiro: Jorge Zahar Editor, 1995, pp. 3997.

MAtTos, Olgária. “A narrativa: metáfora e liberdade". In: NovAES, Adauto (org.). $O$ avesso da liberdade. São Paulo: Companhia das Letras, 2002, pp. 303-317.

Mattos, Olgária. "Memória e história". A Terceira idade - Revista do SESC-SP. Ano 4, núm. 6, out/1992, pp. 5-15.

Mattos, Olgária. "Memória e história em Walter Benjamin". In: São Paulo; Secretaria Municipal de Cultura; Departamento de Patrimônio Histórico. O direito à memória: patrimônio histórico e cidadania. São Paulo: Departamento do Patrimônio Histórico, 1992, pp. 151-156.

Menezes, Paulo. À meia-luz - Cinema e sexualidade nos anos 70. São Paulo: Editora 34,2001 
Menezes, Paulo. "O Cinema documental como representificação - Verdades e mentiras nas relações (im)possíveis entre representação, documentário, filme etnográfico, filme sociológico e conhecimento". In: NOVAES, Sylvia C. ET ALLI (orgs), Escrituras da imagem, São Paulo: Edusp, 2004, pp. 21-48.

MERleau-PonTy, Maurice. "O Cinema e a nova psicologia”. In: XAVIER, Ismail (org.). A experiência do cinema. $3^{\mathrm{a}}$ edição. Rio de Janeiro: Graal, 2003, pp. 101-117.

Merten, Luiz Carlos. "Estréia O Tempo que resta, filme de François Ozon”. O Estado de São Paulo. São Paulo, 25/08/2006. Disponível online em: http://www.estadao.com.br/arteelazer/cinema/noticias/2006/ago/25/88.htm. Acessado em 03/02/2007.

MisSAC, Pierre. Passagem de Walter Benjamin. São Paulo: Iluminuras, 1998.

MORIN, Edgar. “Aux frontières du no man's land”. In: Paris: Éditions du Seuil, 1970. pp. $31-47$. . L'Homme et la mort.

OrTIZ, Renato. Cultura e Modernidade - A França no século XIX. São Paulo: Brasiliense, $1^{\text {a }}$ edição, 1991.

Ozon, François. "Entretien réalisé en septembre 2000”. Dossier de Presse. Disponível online em: http://www.francois-ozon.com/francais/entretiens/sous-le-sable.html. Acesso em 20/04/2007.

Palhares, Taisa. Aura - A Crise da Arte em Walter Benjamin. São Paulo: Barracuda, 2006

PICON, Antoine. "Racionalidade técnica e utopia: a gênese da haussmannização". In: SAlgueiro, H. A. (org.). Cidades Capitais do século XIX. São Paulo: Edusp, 2001 pp. 65-101.

SAlgueIro, Heliana Angotti. "Introdução: Da Temática, dos autores e de suas idéias". In: (org.). Cidades Capitais do século XIX. São Paulo: Edusp, 2001, pp.1940 .

SAlgueIro, Heliana Angotti. "O Pensamento francês na fundação de Belo Horizonte: das representações às práticas". In: São Paulo: Edusp, 2001, pp.135-181. (org.). Cidades Capitais do século XIX. 
SARlo, Beatriz. Siete ensayos sobre Walter Benjamin. Buenos Aires: Fondo de Cultura Económica de Argentina, 2000.

SÊNECA. Sobre a brevidade da vida - Tradução, notas e introdução de William Li. São Paulo: Nova Alexandria, 1993

SCHILLER, Britt-Marie. "A Memorial to mourning: Under the sand". Literature Film Quarterly, 2005. disponível online em: http://findarticles.com/p/articles/mi_qa3768/is_200501/ai_n15348553/. Acesso em $02 / 04 / 2007$

SCHWARZ, Roberto. "Nacional por subtração". In: Cultura e politica. 1 a edição. São Paulo: Paz e Terra, 2001, p. 108-135.

SILVA, Franklin Leopoldo. "O mundo vazio: sobre a ausência da política no contexto contemporâneo". In: SILVA, Doris Accioly e MARRACH, Sonia Alem (orgs.). Maurício Tragtenberg - Uma vida para as Ciências Humanas. São Paulo: Ed. Unesp, 2001, pp. 239-250.

SiMMEL, George. "A metrópole e a vida mental”. In: Velho, Otávio Guilherme (org.). O fenômeno urbano. Rio de Janeiro: Zahar Editores, 1967, pp. 13-28.

SiMMEL, Georg. "Digresión sobre el extranjero". In: Sociología - Estudios sobre las formas de socialización. Buenos Aires: Espasa-Calpe Argentina, 1939, pp. 273-296

SIMMEL, Georg. "O Estrangeiro". In: . Moraes Filho, Evaristo de (org.). Georg Simmel - Sociologia. São Paulo: Editora Ática, 1983, pp. 182-188.

SiMMEL, Georg. "Puente y puerta". In: . El individuo y la libertad-Ensayos de crítica de la cultura. Barcelona: Ediciones Península, 2001, pp. 45-53.

Sorlin, Pierre, Sociología del Cine: La Apertura para la Historia de Mañana, Ciudad de México: Fondo de Cultura Econômica, 1992

VIEIRA, Marcus André. “Objeto e desejo em tempos de superexposição”. Ágora, vol. 8, $\mathrm{n}^{\mathrm{o}}$ 1, Rio de Janeiro, jan/jun 2005. Disponível online em: http:/www.scielo.br/scielo .php $\quad$ script $=$ sci arttext\&pid=S1516- $14982005000100002 \& \quad$ lng=en\&nrm=isso. Acesso em: 14/04/2007. 
WAIZBORT, Leopoldo. “'Jude', entre a 'emancipação' e a 'assimilação””. In: As Aventuras de Georg Simmel. São Paulo: Editora 34, 2000, pp. 535-567.

WEBER, MAX. “A Ciência como vocação”. In: . Ciência e política: duas vocações. São Paulo: Cultrix, 1993, pp. 15-52.

Weber, Max. "A 'objetividade' do conhecimento na ciência social e na política". Metodologia das ciências sociais - parte 1. São Paulo: Cortez; Campinas: Editora da Universidade Estadual de Campinas, 1992, pp. 107 - 154.

Wenders, Wim. “A Paisagem urbana". In: Revista do Patrimônio Histórico e Artístico Nacional. Rio de Janeiro, n.23, 1994, pp. 181-189.

Woolf, Virginia. As Ondas. Mira-Sintra: Publicações Europa-América, sem data 


\section{Anexo 1}

Ficha técnica dos filmes analisados

\section{Dolls}

Título original: Dolls

Direção: Takeshi Kitano

Produção: Japão

Ano: 2002

Roteiro: Takeshi Kitano

Duração: 109 min.

Idioma: Japonês

Atores principais: Miho Kanno, Hidetoshi Nishijima, Tatsuya Mihashi, Chieko Matsubara, Kyôko Fukada, Tsutomu Takeshige, Nao Omori, Hawking Aoyama, Ren Osugi, Kayoko Kishimoto

Música (trilha sonora): Jô Hisaishi

\section{Paris, Texas}

Título original: Paris, Texas

Direção: Wim Wenders

Produção: França, Alemanha Ocidental

Ano: 1984

Roteiro: Sam Shepard

Duração: 148 min.

Idioma: Inglês

Atores principais: Harry Dean Stanton, Nastassja Kinski, Dean Stockwell, Aurore Clement, Hunter Carson

Música (trilha sonora): Ry Cooder 


\section{Sob a Areia}

Título original: Sous le sable

Direção: François Ozon

Produção: França

Ano: 2000

Roteiro: Emmanuèle Bernheim, François Ozon, Marcia Romano e Marina de Van

Duração: 95 min.

Idioma: Francês

Atores principais: Charlotte Rampling, Bruno Cremer, Jacques Nolot, Alexandra Stewart, Pierre Vernier, Andrée Tainsy

Música (trilha sonora): Philippe Rombi

\section{A Eternidade e um dia}

Título original: Mia aioniotita kai mia mera

Direção: Theodoros Angelopoulos

Produção: Grécia, França, Itália

Ano: 1998

Roteiro: Theodoros Angelopoulos, Tonino Guerra, Petros Markaris e Giorgio Silvagni Duração: 132 min.

Idioma: Grego

Atores principais: Bruno Ganz, Achileas Skevis, Isabelle Renauld.

Música (trilha sonora): Eleni Karaindrou

OBS: As imagens usadas nesta dissertação foram reproduzidas a partir desses filmes. 


\section{Anexo 2}

\section{A. 2.1. Diálogo entre Jane e Travis em inglês}

JANE: Hey.

TRAVIS: Hey. Can I tell you something?

JANE: Sure, anything you like.

TRAVIS: It's kind of long.

JANE: I got plenty of time.

TRAVIS: I knew these people...

JANE: What people?

TRAVIS: These two people. They were in love with each other. The girl was ... very young, about seventeen or eighteen, I guess. And the guy was ... quite a bit older. He was kind of ragged in, wild. She was very beautiful, you know?

JANE: Yeah.

TRAVIS: And together they turned everything into a kind of an adventure, and she liked that. Just an ordinary trip down the grocery store was ... full of adventure. They were always laughing at stupid things. He liked to make her laugh. And ... they didn't much care for anything else, because all they wanted to do was be with each other. They were always together.

JANE: Sounds like they were very happy.

TRAVIS: Yes, they were. They were real happy. And he, he loved her more than he ever felt possible. He couldn't stand being away from her, uh ... during the day when he went to work. So, he quit. Just to be home with her. Then he got another job when the money ran out, then he quit again. But pretty soon, she started to worry.

JANE: About what?

TRAVIS: Money, I guess. Not having enough. Not knowing when the next check was coming in.

JANE: Yep. I know that feeling.

TRAVIS: So he started to get kind of ... torn inside.

JANE: How do you mean?

TRAVIS: Well he knew he had to work to support her, but he couldn't stand being away from her, either.

JANE: I see.

TRAVIS: And the more he was away from her, the crazier he got. Except now, he got really crazy. He started imagining all kinds of things.

JANE: Like what?

TRAVIS: He started thinking that she was seeing other men on the sly. He'd come home from work and accuse her of spending the day with somebody else. He'd yell at her, break things in the trailer. 
JANE: The trailer?

TRAVIS: Yes. They lived in a trailer home.

JANE: Excuse me, sir. But were you in to visit me the other day? I don't mean pry.

TRAVIS: No.

JANE: Oh. I thought I recognized your voice for a minute.

TRAVIS: No. Wasn't me.

JANE: Mm-hmm. Please go on.

TRAVIS: Anyway, he started to drink real bad. And he'd stay out late to test her.

JANE: What do you mean "test her"?

TRAVIS: To see if she'd get jealous.

JANE: Ha. Mm-hmm.

TRAVIS: He wanted her to get jealous, but she didn't. She just worried about him, but that got him even madder.

JANE: Why?

TRAVIS: Because ... he thought if she never got jealous of him, she didn't really care about him. Jealousy was a sign of her love for him. And then one night, one night, she told him she was pregnant. She was about three or fourth month pregnant, and he didn't even know. And then suddenly everything changed. He stopped drinking, he got a steady job. He was convinced that she loved him now, because she was carrying his child. And he was going to dedicated himself to making a home for her. But funny thing started to happen.

JANE: What?

TRAVIS: He didn't even notice at first. She started to change. On the day the baby was born, she began to get irritated with everything around her. She got mad at everything. Even the baby seemed to be an injustice to her. He kept trying to make everything all right for her. Buy her things. Take her out to dinner once a week. But nothing seemed to satisfy her. For two years, He struggled to put them back together like they were when they first met. Finally, he knew that it was never gonna work out. So, he hit the bottle again. But this time, it got mean. This time when he came home late at night, she wasn't worried about him, or jealous, she was just enraged. She accused him of holding her captive, by making her have a baby. She told him that she dreamed about escaping. That was all she dreamed about: escape. She saw herself at night, running naked down a highway. Running across fields, running down riverbeds, always running. And always, just as she was about to get away, he'd be there. He would stop her somehow. He would just appear and stop her. And when she told him these dreams, he believed them. He knew she had to be stopped, or she'd leave him forever. So he tied a cowbell to her ankle, so he could hear it at night if she tried to get out bed. But she learned how to muffle the bell by stucking a sock into it and inched her away out bed and into the night.

He caught her one night, when the sock fell out and he heard her trying to run out to the highway. He caught her, dragged her back to the trailer and tied her to the stove with his belt. He just left her there, he went back to bed and lay there and listening to her scream. And he listened to his son scream. He was surprised at himself because he didn't feel anything anymore. All he 
wanted to do was sleep. And for the first time, he wished he were far away. Lost in a deep, vast country where nobody knew him. Somewhere without language or streets. And he dreamed about this place without knowing its name.

And when he woke up, he was on fire. There were blue flames burning the sheets of his bed. He ran through the flames towards the only two people he loved. But they were gone. His arms were burning. And he threw himself outside, and rolled on the wet ground. Then he ran. He never looked back at the fire. He just ran. He ran until the sun came up, then he couldn't run any further. And when the sun went down, he ran again. For five days he ran like this ... until every sign of man ... had disappeared.

JANE: Travis.

TRAVIS: If you turn the light off in there, will you be able to see me?

JANE: I don't know. I never tried.

TRAVIS: Can you see me?

JANE: Yeah.

TRAVIS: Do you recognize me?

JANE: Oh, Travis.

TRAVIS: I brought Hunter with me. Don't you want to see him?

JANE: Yeah. I wanted to see him so bad that I didn't even dare imagine him anymore. Anne kept sending me pictures of him, until I asked her to stop. I couldn't stand the ... pain of seeing him grow up and missing it.

TRAVIS: Why didn't you keep him with you, Jane?

JANE: I couldn't, Travis. I didn't have what I knew he needed. I didn't want to use him to fill all my emptiness.

TRAVIS: Well, he needs you now, Jane. And he wants to see you.

JANE: He does?

TRAVIS: Yes. He's ... he's waiting for you.

JANE: Where?

TRAVIS: Downtown. In a hotel. The Meridian. Room 1520. 1520.

JANE: You are not going, are you?

TRAVIS: I can't see you, Jane.

JANE: Don't go yet. Don't go yet. I ... I used to make up long speeches to you after you left. I used to talk to you all the time, even though I was alone. I walked around for months talking to you. Now, I don't know what to say. It was easier when I just imagined you. I even imagined you talking back to me. We'd have long conversations, the two of us. It was almost like you were there. I could hear you, I could see you, smell you. I could hear your voice. Sometimes your voice would wake me up. It would wake me up in the middle of the night, just like you were there in the room with me. Then ... it slowly faded. I couldn't picture you anymore. I tried to talk out aloud to you like I used to, but there was nothing there. I couldn't hear you. Then ... I just gave up. Everything stopped. You ... just disappeared. Now I'm working here. I hear your voice all the time. Every man ... has your voice. 
TRAVIS: I'll tell Hunter that you're coming.

JANE: Travis,

TRAVIS: What?

JANE: I will be there.

TRAVIS: Good.

JANE: Meridian Hotel?

TRAVIS: Yeah. Room 1520.

\section{A. 2.1. Diálogo entre Jane e Travis em português, de acordo com}

\section{as legendas}

\section{JANE: Olá!}

TRAVIS: Oi. Posso the dizer uma coisa?

JANE: Claro, diga o que quiser.

TRAVIS: Vai demorar.

JANE: Tenho tempo de sobra.

TRAVIS: Conheci umas pessoas.

JANE: Que pessoas?

TRAVIS: Duas pessoas. Elas se amavam. A garota era muito jovem, tinha uns 17 ou 18 anos, acho. $\mathrm{O}$ rapaz era mais velho. Era bruto e rude. E ela era muito bonita, sabe?

JANE: Sei.

TRAVIS: Eles faziam de tudo uma aventura, ela adorava isso. Uma simples ida ao mercado já era uma aventura. Sempre riam de bobagens, ele adorava vê-la sorrir. Não se importavam com o resto, porque só queriam uma coisa. Ficar sempre juntos.

JANE: Parece que eram muito felizes.

TRAVIS: Sim, eles eram felizes. E ele... a amava mais do que... julgava ser possível. Não podia ficar longe dela enquanto trabalhava. Então ele largava o emprego. Só para ficar com ela em casa. Quando faltava dinheiro, ele arrumava ouro trabalho. Depois ele se demitia novamente. Mas daí ela começou a se preocupar.

JANE: Com o quê?

TRAVIS: Com a falta de dinheiro. Por não saber quando chegaria o outro cheque.

JANE: Sim, sei o que é isso.

TRAVIS: Daí ele começou a se atormentar.

JANE: Como assim?

TRAVIS: Por ter que trabalhar para sustentá-la, mas não suportava ficar longe dela também.

JANE: Entendi.

TRAVIS: Quanto mais ele ficava longe dela, mais enlouquecia. Até que ele enlouqueceu de verdade. Ele começou a imaginar todo o tipo de coisas.

JANE: Que coisas? 
TRAVIS: Que ela começara a sair com outros caras quando ele não estava em casa. Quando voltava, ele a acusava de ter ficado com outros. Ele gritava e quebrava tudo no trailer.

JANE: No trailer?

TRAVIS: Sim, eles moravam num trailer.

JANE: Desculpe-me, senhor, mas não esteve aqui ontem? Não quero ser intrometida.

TRAVIS: Não

JANE: Oh... Pensei ter reconhecido sua voz.

TRAVIS: Não, não era eu.

JANE: Sei. Continue.

TRAVIS: Então ele começou a beber muito. Passou a voltar tarde para casa para testá-la.

JANE: Como assim, testá-la?

TRAVIS: Para ver se ela sentia ciúmes. Ele queria que ela sentisse ciúme, mas ela não sentia. Só se preocupava com ele, o que o enfurecia ainda mais.

JANE: Por quê?

TRAVIS: Porque pensava que se ela não sentia ciúmes, não se importava com ele. E os ciúmes seriam um sinal de que ela o amava. Então numa noite ela contou que estava grávida. De uns 3 ou 4 meses. Ele não sabia. E, então, tudo mudou. Ele parou de beber e conseguiu um emprego fixo. Ele se convenceu do amor, pois ela levava um filho dele. Ele ia se dedicar inteiramente a lhes dar um lar. Mas aconteceu uma coisa estranha.

JANE: O quê?

TRAVIS: No início ele não reparou, mas ela havia mudado. Desde que a criança nasceu, tudo em volta a deixava irritada. Até o bebê parecia uma injustiça para ela. Ele se esforçava para agradá-la. Dava-lhe presentes, levava-a para jantar toda semana, mas nada a satisfazia. Durante dois anos ele fez tudo para que voltasse a ser como era. Finalmente, acabou entendendo que isso seria impossível. Daí ele voltou a beber e as coisas pioraram. Quando voltava tarde, ela não ficava mais preocupada, nem com ciúmes. Ela só ficava furiosa. Ela o acusou de tê-la raptado só para fazer um filho. Dizia que queria fugir, que só sonhava com isso. Via-se correndo à noite nua pelos campos, sempre a correr. Sempre que estava prestes a fugir, ele aparecia e a impedia. Ele sempre chegava para impedi-la. Quando ela lhe contava esses sonhos, ele acreditava. Sabia que se não a impedisse, ela fugiria para sempre. Daí ele amarrou um guizo ao tornozelo dela para ouvir se ela tentasse se levantar da cama à noite. Mas aprendeu a abafar o som com a meia para sair no meio da noite. Um dia a meia caiu quando ela tentava fugir pela estrada. Ele a pegou e a prendeu no fogão com um cinto. Deixou-a ali e voltou a se deitar. Ouviu-a gritar sem se mexer. Depois ouviu o filho aos gritos. Ele admirou-se de não querer saber de mais nada. Ele só queria dormir. E pela primeira vez, ele quis ficar bem longe dela. Perdido num país enorme onde ninguém o conhecesse. Num lugar sem idiomas... e sem ruas. Ele sonhou com esse lugar sem saber o nome. E quando acordou, ele estava nem incêndio. Chamas azuis queimavam os lençóis da cama. Correu para acudir os únicos dois que ele amava. Mas eles tinham sumido. Seus braços estavam pegando fogo. E ele saiu de casa e rolou-se no chão molhado. Daí ele correu. Ele nunca olhou para trás 
para ver fogo. Só correu. Correu até o sol nascer. Até não poder correr mais. E quando o Sol se pôs, ele tornou a correr. Ele correu por 5 dias. Até que, sem deixar sinais, ele desapareceu.

JANE: Travis?

TRAVIS: Se apagar a luz, será que pode me ver?

JANE: Eu não sei. Eu nunca tentei.

TRAVIS: Pode me ver?

JANE: Sim.

TRAVIS: Você me reconhece?

JANE: Oh! Travis!

TRAVIS: Trouxe Hunter comigo. Não quer vê-lo?

JANE: Sim. Quero vê-lo tanto que nem posso mais imaginá-lo. Anne me mandava fotos dele. Eu pedi que parasse de mandar. Não agüentava mais vê-lo crescer e me culpar.

TRAVIS: Por que não ficou com ele?

JANE: Eu não podia, Travis. Eu não tinha o que ele mais precisava. Não queria usá-lo para preencher meu vazio interior.

TRAVIS: Ele precisa de você, Jane. Ele quer vê-la.

JANE: É mesmo?

TRAVIS: Sim. Ele está esperando por você.

JANE: Onde?

TRAVIS: No centro, no hotel Le Meridien, quarto 1520. 1520.

JANE: Posso ir com você?

TRAVIS: Não posso vê-la, Jane.

JANE: Não vá embora ainda. Não vá embora ainda. Eu... Costumava conversar a sós com você depois que partiu. Eu falava sempre com você, mesmo quando eu estava sozinha. Conversava com você por meses a fio. Agora não sei o que dizer. Era mais fácil quando eu só o imaginava. Eu até imaginava que você me respondia. Conversávamos longamente. Só nós dois. Era como se você realmente estivesse comigo. Eu o via, sentia seu cheiro... eu podia ouvir sua voz. Às vezes sua voz me acordava. Acordava-me no meio da noite, como se estivesse comigo. Depois... tudo foi acabando. Já não podia mais imaginar você. Tentei falar com você como sempre fazia, mas foi em vão. Já não podia mais ouvi-lo. Então... Eu apenas desisti. Tudo acabou. Você... simplesmente desapareceu. Agora estou trabalhando aqui. Ouço sua voz o tempo todo. Todo homem tem a sua voz.

TRAVIS: Direi ao Hunter que você vai vê-lo.

JANE: Travis?

TRAVIS: O quê?

JANE: Eu vou sim.

TRAVIS: Ótimo!

JANE: Hotel Le Meridien?

TRAVIS: Sim. Quarto 1520. 


\section{Anexo 3}

\section{A. 3.1. Leitura do trecho de "As Ondas" ("The Waves") como é feita em inglês}

"And time," said Bernard, "lets fall its drop. The drop that has formed on the roof of the soul falls. On the roof of my mind time, forming, lets fall its drop. Last week, as I stood shaving, the drop fell. I, standing with my razor in my hand, became suddenly aware of the merely habitual nature of my action (that is the drop forming) and congratulated my hands, ironically for keeping at it. 'Shave, shave, shave', I said. 'Go on shaving'. The drop fell. All through the day's work, at intervals, my mind went to an empty place, saying, 'What is lost? What is over?' And 'Over and done with', I muttered, 'over and done with', solacing myself with words. People noticed the vacuity of my face and the aimlessness of my conversation. The last words of my sentence tailed away. And as I buttoned on my coat to go home I said more dramatically, 'I have lost my youth."”

It is curious, it's curious how, it's curious how at every crisis, some phrase which does not fit insists upon coming to the rescue — the penalty of living in an old civilization with a notebook....

\section{A. 3.1. Leitura do trecho de "As Ondas" ("The Waves"), de acordo com as legendas}

"O tempo permite que a gota caia", disse Bernard. A gota que se formou na beira da alma cai. O tempo faz cair a gota que se formava. Semana passada, enquanto me barbeava, senti a gota cair. De pé, com a lâmina na mão, de repente, percebi que meu gesto era um hábito”. Isso era a gota se formando. "Então, parabenizei minhas mãos por aceitar a rotina. 'Continue, continue, não pare de se barbear', eu disse. E a gota caiu. Durante todo o dia meu espírito vagou dizendo: 'O que foi perdido?' 'O que acabou?' 'Acabou, e fim', disse a mim mesmo. as pessoas notaram o vazio no meu rosto e a insensatez das minhas palavras. As últimas palavras se perderam. E, enquanto eu me preparava para partir, disse: 'Perdi minha juventude'.

É estranho, é estranho como nas situações difíceis algumas frases que não fazem sentido nos salvam. $\mathrm{O}$ castigo de viver numa civilização antiga com um caderno de anotações. 
Anexo 4

\section{A. 4.1. Letra do trecho da música Septembre (Quel joli temps), interpretada por Barbara e tocada em Sob a areia}

Jamais la fin d'été n'avait paru si belle,

Les vignes de l'année auront de beaux raisins,

On voit se rassembler, déjà les hirondelles,

Mais il faut se quitter, pourtant l'on s'aimait bien.

Quel joli temps pour se dire au revoir,

Quel joli soir pour jouer ses vingt ans,

Sur la fumée des cigarettes,

L'amour s'en va, mon coeur s'arrête.

\section{A. 4.1. Tradução do trecho conforme as legendas de Sob a areia}

Jamais o fim de verão pareceu tão bonito,

As vinhas desse ano darão belas uvas,

Já vemos se reunindo as andorinhas,

Mas precisamos nos deixar, embora nos amemos.

Que linda época para dizer adeus,

Que linda noite para voltar aos vinte anos,

$\mathrm{Na}$ fumaça dos cigarros,

O amor se vai, meu coração pára. 